\title{
UNIWERSYTET EKONOMICZNY W POZNANIU
}

\section{Marcin Soniewicki}

Rola orientacji na wiedzę w kształtowaniu przewagi konkurencyjnej przedsiębiorstwa $\mathrm{w}$ procesie internacjonalizacji

Rozprawa doktorska

Promotor:

prof. dr hab. Krzysztof Fonfara, prof. zw. UEP

Poznań 2014 
1. WIEDZA A PRZEWAGA KONKURENCYJNA PRZEDSIĘBIORSTWA 15

1.1. Charakterystyka pojęcia wiedza __ 15

1.1.1. Definicja _ 15

1.1.2. Rodzaje wiedzy___ 17

1.2. Gospodarczy wymiar wiedzy __ 20

1.2.1. Znaczenie wiedzy w gospodarce industrialnej ___ 20

1.2.2. Zmiana roli zasobu wiedzy we współczesnych procesach gospodarczych - transformacja w kierunku gospodarki opartej na wiedzy ___ 22

1.3. Przewaga konkurencyjna przedsiębiorstwa ___ 36

1.4. Wiedza a przewaga konkurencyjna przedsiębiorstwa: ujęcie statyczne oraz dynamiczne___ 47

1.5. Podsumowanie i wnioski___ 49

\section{ISTOTA DYNAMICZNEGO PODEJŚCIA DO ZASOBU WIEDZY}

PRZEDSIĘBIORSTWA

2.1. Dynamiczne koncepcje w obszarze wiedzy i uczenia się w przedsiębiorstwie.___ 51

2.1.1. Zarządzanie wiedzą _ 51

2.1.2. Organizacyjne uczenie się (organizational learning)___ 56

2.1.3. Organizacja ucząca się (learning organization) __ 57

2.1.4. Pozostałe koncepcje w zakresie wiedzy ___ 60

2.1.5. Różnice i relacje pomiędzy poszczególnymi koncepcjami w zakresie wiedzy i uczenia się __ 61

2.1.6. Dynamiczne koncepcje w zakresie wiedzy - ujęcie integracyjne___ 63

2.2. Zarządzanie wiedzą w przedsiębiorstwie

2.2.1. Modele i strategie zarządzania wiedzą. __ 64

2.2.2. Społeczno-kulturowe oraz organizacyjne elementy zarządzania wiedzą __ 74

2.2.3. Rola technologii informacyjnych i komunikacyjnych w zarządzaniu wiedzą __ 77

2.2.4. Kompleksowe podejście do zarządzania wiedzą ___ 85

2.3. Procesy zarządzania wiedzą _ 87

2.3.1. Pozyskiwanie i kreacja wiedzy ___ 88

2.3.2. Zachowywanie i rozpowszechnianie wiedzy __ 92

2.2.3. Wykorzystywanie wiedzy____ 97

2.2.4. Ochrona wiedzy ___ 98

2.2.5. Podsumowanie podejścia procesowego __ 101

2.3 Podsumowanie i wnioski ___ 103

3. ORIENTACJA NA WIEDZE A KSZTALTOWANIE PRZEWAGI KONKURENCYJNEJ PRZEDSIĘBIORSTWA _ 105

3.1. Orientacja rynkowa przedsiębiorstwa __ 106

3.2. Charakterystyka orientacji przedsiębiorstwa na wiedzę___ 117

3.3. Modelowe ujęcie roli orientacji na wiedzę w ksztaltowaniu przewagi konkurencyjnej przedsiębiorstwa 


\section{ORIENTACJA NA WIEDZE A PRZEWAGA KONKURENCYJNA} PRZEDSIĘBIORSTWA W PROCESIE INTERNACJONALIZACJI

4.1. Proces internacjonalizacji przedsiębiorstwa

4.2. Modelowe ujęcie roli orientacji na wiedzę w ksztaltowaniu przewagi konkurencyjnej przedsiębiorstwa w procesie internacjonalizacji

\section{ZALEŻNOŚĆ POMIĘDZY ORIENTACJĄ NA WIEDZE PRZEDSIĘBIORSTWA W PROCESIE INTERNACJONALIZACJI A JEGO PRZEWAGA KONKURENCYJNĄ - WYNIKI BADAŃ EMPIRYCZNYCH}

5.1. Metodologia

5.2. Wyniki badań ilościowych

5.2.1. Charakterystyka respondentów

5.2.2. Poziom orientacji na wiedzę przedsiębiorstw działających lokalnie oraz podmiotów zaangażowanych zagranicznie

5.2.3. Poziom orientacji na wiedzę przedsiębiorstw na poszczególnych etapach procesu internacjonalizacji.

5.2.4. Rola orientacji na wiedzę $\mathrm{w}$ procesie kształtowania przewagi konkurencyjnej przedsiębiorstwa $\mathrm{w}$ procesie internacjonalizacji.

5.3. Wyniki badań jakościowych - studia przypadku

5.3.1. Netguru Sp. z o.o.

5.3.2. Trepko Sp. z o.o.

SPIS TABEL

ANEKS

Załącznik 1. Wyjaśnienie najważniejszych terminów i kategorii wykorzystywanych w pracy.

Załącznik 2. Szczegółowa charakterystyka poszczególnych sekcji kwestionariusza ankiety wykorzystywanego w badaniach ilościowych

Załącznik 3. Charakterystyka systemu ankietowania elektronicznego oraz tradycyjnego kwestionariusza papierowego.

Załącznik 4a. List wprowadzający do kwestionariusza ankiety. 266 
Załącznik 5. Źródła pytań wykorzystanych w kwestionariuszu ankiety.

Załącznik 6. Zdjęcia systemu ankietowania elektronicznego.

280 


\section{Wstęp}

Pod koniec XX wieku zauważono wyraźne zmiany w procesach gospodarowania. Mają one związek ze znacznym wzrostem ogólnego znaczenia zasobu wiedzy w tworzeniu wartości dodanej. Skala zaobserwowanych zmian spowodowała pojawienie się szeregu określających ten fenomen terminów, wśród których dominującym, lecz nie jedynym, jest gospodarka oparta na wiedzy ${ }^{1}$.

Zdaniem Kahina i Foray [2006, s. 17] rola zasobu wiedzy jako czynnika wyjaśniającego wzrost gospodarczy, a także bogactwo regionów znacząco wzrosła. W literaturze podkreśla się również wyraźne różnice pomiędzy gospodarkami tradycyjnymi i gospodarką opartą na wiedzy oraz zauważa, iż nie wszystkie tradycyjne (klasyczne) modele i prawa mogą nadal być aktualne i właściwie funkcjonować w zmienionych realiach [Neef, Siesfeld i Cefola 1998, s. 5].

Przemiany makroekonomiczne wywarły duży wpływ na sposób działania poszczególnych podmiotów gospodarczych. Wymuszają one na firmach czynności przystosowawcze związane z intensyfikacją działań w obszarze wiedzy. Widoczną reakcją na poziomie mikroekonomicznym jest również pojawianie się kolejnych teorii działań organizacyjnych w zakresie wiedzy. Wśród nich dominującą pozycję, prawdopodobnie z uwagi na swoje aspekty praktyczne, zajmuje koncepcja zarządzania wiedzą. Innymi znaczącymi teoriami w tym obszarze są m.in. organizacyjne uczenie się czy organizacja ucząca się.

Działania w zakresie wiedzy w przedsiębiorstwie są jednak bezcelowe, jeżeli właściwie nie określimy ich kierunku. Obecnie jest to szczególnie ważne w związku ze współczesnymi zmianami gospodarczymi - skróceniem cyklu życia produktów, szybkimi zmianami preferencji nabywców, a także coraz bardziej intensywną konkurencją. Kierunek działań w zakresie wiedzy nie może być statyczny, musi zmieniać się dynamicznie, zgodnie $\mathrm{z}$ rozwojem potrzeb rynkowych. W związku $\mathrm{z}$ tym coraz większego znaczenia nabiera zagadnienie orientacji rynkowej, postrzeganej w ujęciu dynamicznym i związane z nią stałe działania przedsiębiorstwa w obszarze śledzenia trendów rynkowych oraz preferencji nabywców.

Kolejną tendencją, którą można zaobserwować w ostatnich dekadach jest postępujący proces globalizacji gospodarek, w związku z którym coraz większa liczba przedsiębiorstw

\footnotetext{
${ }^{1}$ Dokładne wyjaśnienie kluczowych terminów wykorzystywanych $\mathrm{w}$ niniejszej pracy zostało zawarte w załączniku 1.
} 
decyduje się na zaangażowanie na rynkach zagranicznych. Heterogeniczne warunki działania, różnorodni, silni, często nieznani konkurenci oraz przede wszystkim niepewność związana z nieprzewidywalnymi zmianami środowiska gospodarowania sprawiają, że kształtowanie przewagi konkurencyjnej tego typu podmiotów odbywa się w inny sposób niż w przypadku firm działających lokalnie. Zapotrzebowanie na wiedzę, w każdym aspekcie aktywności, tego typu przedsiębiorstw jest znaczące $\mathrm{z}$ uwagi na ich określoną charakterystykę i dynamizm środowiska działania.

W związku z wymienionymi, możliwymi do zaobserwowania w dzisiejszym świecie tendencjami, można podejrzewać, iż istotną rolę w kształtowaniu przewagi konkurencyjnej przedsiębiorstw $\mathrm{w}$ procesie internacjonalizacji mają odpowiednio ukierunkowane procesy systemowego pozyskiwania, tworzenia, transferu, magazynowania, wdrażania, jak i ochrony wiedzy ${ }^{2}$.

$\mathrm{O}$ ile transfer (jeden $\mathrm{z}$ aspektów działań $\mathrm{w}$ zakresie wiedzy podmiotów gospodarczych) jest omawiany w literaturze kompleksowo, to procesowe podejście do tematu działań przedsiębiorstw w obszarze wiedzy, szczególnie w kontekście procesu internacjonalizacji firmy, jest rzadkością.

Brak badań w zakresie wpływu rynkowo ukierunkowanych działań w zakresie wiedzy na przewagę konkurencyjną podmiotów zaangażowanych zagranicznie, tworzy lukę badawczą. Jej wypełnienie było motywacją dla podjęcia tematu prezentowanej pracy doktorskiej.

Badania dotyczące działań przedsiębiorstw w zakresie wiedzy koncentrują się najczęściej wokół jednej teorii w tym obszarze np. zarządzania wiedzą czy organizacji uczącej się. Niniejsza praca ma na celu integrację szeregu ujęć, choć uznaje dominację na tym polu koncepcji zarządzania wiedzą i traktuje ją jako podstawową bazę rozważań. Inną kwestią jest fakt, iż badania aktywności przedsiębiorstw w zakresie wiedzy są najczęściej prowadzone we względnie ogólnej perspektywie. W ramach rozprawy zawężono podmiotowy obszar badawczy do specyficznego typu firm, jakimi są odznaczające się wyjątkowymi charakterystykami oraz potrzebami przedsiębiorstwa zaangażowane $\mathrm{W}$ proces internacjonalizacji. Kolejnym bardzo ważnym zagadnieniem, które niestety rzadko jest podejmowane $\mathrm{w}$ kontekście działań firm $\mathrm{w}$ obszarze wiedzy jest ukierunkowanie tych

\footnotetext{
${ }^{2}$ Autor celowo nie wykorzystuje $\mathrm{w}$ tym miejscu, oraz w wielu miejscach niniejszej pracy, nazwy żadnej teorii w zakresie działań organizacji $\mathrm{w}$ obszarze wiedzy, a ogranicza się do ogólnego, parasolowego terminu: „orientacja na wiedzę" lub równie neutralnego „procesy w zakresie wiedzy”. Jest to związane z faktem, iż niniejsza praca stara się wykorzystywać dorobek różnych teorii w zakresie wiedzy co zostanie dokładnie omówione w dalszych częściach rozprawy.
} 
procesów. Nawet najlepsze posunięcia w tym zakresie będą bezcelowe i nie umożliwią podmiotowi osiągnięcia pożądanych celów, jeżeli nie będą odpowiednio prowadzone. W obliczu istniejących uwarunkowań gospodarczych rynkowe ukierunkowanie procesów w zakresie wiedzy jest najbardziej zasadne.

W odpowiedzi na zidentyfikowaną lukę badawczą, problemem badawczym niniejszej rozprawy doktorskiej jest ustalenie roli rynkowo ukierunkowanych działań w zakresie wiedzy przedsiębiorstw zaangażowanych zagranicznie w kontekście kształtowania przewagi konkurencyjnej tego rodzaju podmiotów.

Nie należy zapominać, iż naczelnym celem istnienia przedsiębiorstwa jest maksymalizacja jego wartości. Sytuacją temu sprzyjającą jest osiągnięcie i ugruntowanie przez przedsiębiorstwo przewagi konkurencyjnej. Biorąc pod uwagę wcześniej nakreślone uwarunkowania, jakimi charakteryzuje się dzisiejsze środowisko gospodarowania, zdaniem autora można stwierdzić, iż proces tworzenia relatywnie stabilnej, długoterminowej przewagi konkurencyjnej zmienia się i nabiera bardziej złożonego charakteru.

W związku z próbą wypełnienia nakreślonej luki badawczej, przedmiotem niniejszej rozprawy jest charakterystyka i kierunek działań w zakresie wiedzy przedsiębiorstw $\mathrm{w}$ procesie internacjonalizacji, a także proces kształtowania ich przewagi konkurencyjnej.

Praca dąży do wniesienia wartości w ramach zidentyfikowanej luki badawczej zarówno poprzez rozważania teoretyczne, jak i badania empiryczne. Rozważania teoretyczne są oparte na aktualnych publikacjach naukowych (zarówno polskich, jak i zagranicznych) zostały ujęte $\mathrm{w}$ rozprawie $\mathrm{w}$ formie kompleksowego modelu kształtowania przewagi konkurencyjnej przedsiębiorstwa. Z uwagi na swoją treść został on określony przez autora mianem „modelu dynamicznej orientacji na wiedze”. Rozważania ogólne w tym zakresie zostały zawarte w rozdziale trzecim, zaś uszczegółowienie niniejszego modelu w kontekście procesu internacjonalizacji przedsiębiorstwa zostało zamieszczone w rozdziale czwartym.

Celem rozprawy jest wyjaśnienie roli orientacji na wiedzę, czyli rynkowo ukierunkowanych działań w obszarze zasobu wiedzy, w przedsiębiorstwach $\mathrm{w}$ procesie internacjonalizacji w kontekście kształtowania ich przewagi konkurencyjnej. W związku ze złożonością celu głównego ustalono cele szczegółowe pracy:

- porównanie intensywności i charakterystyki procesów $\mathrm{W}$ zakresie wiedzy oraz poziomu orientacji rynkowej przedsiębiorstw działających lokalnie oraz podmiotów w procesie internacjonalizacji,

- określenie intensywności i charakterystyki procesów dotyczących wiedzy oraz poziomu orientacji rynkowej przedsiębiorstw na poszczególnych etapach 
zaangażowania zagranicznego ( $w$ aspekcie czasu, formy internacjonalizacji, a także udziału sprzedaży zagranicznej w sprzedaży ogółem firmy),

- ustalenie, w jakim stopniu intensywność procesów w zakresie wiedzy wraz z poziomem orientacji rynkowej przedsiębiorstw zaangażowanych na rynkach zagranicznych wpływają na kształtowanie przewagi konkurencyjnej tego typu podmiotów.

Niniejsza rozprawa powszechnie wykorzystuje termin „orientacja na wiedzę”. Pojęcie to jest w pracy definiowane jako intensywność, charakterystyka i ukierunkowanie działań przedsiębiorstwa w zakresie wiedzy. Jego użycie jest przejawem chęci poznania wszelkiego rodzaju działań w obszarze wiedzy mających miejsce w przedsiębiorstwach. Nie bazuje ono wyłącznie na wybranej czy wybranych teoriach dotyczących wiedzy. Zdaniem autora firmy powinny korzystać $\mathrm{z}$ szeregu różnorodnych koncepcji $\mathrm{w}$ tym zakresie, gdyż każda $\mathrm{z}$ nich niesie ze sobą unikalną wartość. W kontekście ukierunkowania działań w zakresie wiedzy autor niniejszej pracy podziela pogląd J. Mazur, M. Rószkiewicz i M. Strzyżewskiej [2008, s. 23-24, 2011, s. 14-15] oraz J. Darroch i R. McNaughtona [2003, s. 573], iż pełnia orientacji na wiedzę, w przedsiębiorstwie działającym w warunkach rynkowych, osiągnięta jest w momencie uzyskania wysokiej intensywności procesów w zakresie wiedzy oraz wysokiej orientacji rynkowej, która odpowiednio ukierunkowuje działania firmy w obszarze wiedzy.

Ważnymi terminami wykorzystywanymi w niniejszej pracy są pojęcia pozycji i przewagi konkurencyjnej, które wymagają wyjaśnienia. Pozycja konkurencyjna jest rozumiana jako relatywna różnica wyników firmy, wyrażona zarówno miernikami finansowymi jak i niefinansowymi, w porównaniu do najbliższych konkurentów podmiotu. Przedsiębiorstwo zdobywa przewagę konkurencyjną w momencie, gdy na podstawie szeregu wskaźników można stwierdzić jego nadrzędną pozycję względem najbliższych konkurentów ${ }^{3}$ [Fonfara 2007, s. 3-4].

Wspomniane na początku wstępu uwarunkowania działalności przedsiębiorstw zaangażowanych na rynkach zagranicznych (powszechne luki wiedzy w wielu obszarach,

\footnotetext{
${ }^{3}$ Tego rodzaju podejście jest zgodne z opinią K. Obłoja, który zauważa, iż „...przewaga konkurencyjna jest podstawą procesu tworzenia i zawłaszczania wartości w większym stopniu, niż się to udaje konkurentom” [Obłój 2007, s. 409]. M. Gorynia [2000, s. 49, 52, 53] również odnotowuje potrzebę odniesienia mierników stosowanych do pomiaru pozycji konkurencyjnej do rywali przedsiębiorstwa. Wykorzystywane w niniejszej pracy narzędzie pomiaru pozycji konkurencyjnej firmy było $\mathrm{w}$ przeszłości $\mathrm{z}$ powodzeniem stosowane w realizacji szeregu projektów przez zespół Katedry Marketingu Międzynarodowego na Uniwersytecie Ekonomicznym w Poznaniu w tym m.in. K. Fonfara [2009, 2012], M. Ratajczak-Mrozek [2008, 2010] czy Ł. Małys [2012, 2013].
} 
dynamiczne środowisko funkcjonowania, intensywna konkurencja, wzrost znaczenia zasobu wiedzy w procesach gospodarczych) sprawiają, że można oczekiwać, iż przedsiębiorstwa w procesie internacjonalizacji muszą wykształcić systemowe działania w zakresie pozyskiwania, kreacji, magazynowania i wykorzystania wiedzy, które także, aby były użyteczne, muszą być rynkowo ukierunkowane. Można więc przypuszczać, że podmioty przejawiające wymienione tendencje na niskim poziomie nie będą w stanie rozpocząć i utrzymywać działalności na rynkach zagranicznych. Na tej podstawie można więc sądzić, że ważnym czynnikiem w funkcjonowaniu podmiotów prowadzących działalność zagraniczną jest wysoka intensywność procesów związanych z wiedzą - wyższa niż w przypadku podmiotów działających lokalnie, których uwarunkowania działalności sąmniej skomplikowane. W związku z powyższymi rozważaniami została sformułowana następująca hipoteza 1:

H1: Przedsiębiorstwa działające na rynkach zagranicznych sq przeciętnie bardziej zorientowane na wiedzę w porównaniu do przedsiębiorstw działających lokalnie.

Heterogeniczność form działalności przedsiębiorstwa $\mathrm{w}$ procesie internacjonalizacji wiąże się z różnorodnym zaangażowaniem firmy na rynkach zagranicznych, zróżnicowaną złożonością procesów zachodzących w przedsiębiorstwie, a także potrzebą coraz szybszego przystosowywania do zmieniających się warunków i stawiania czoła coraz groźniejszym konkurentom. Można przypuszczać, że większe zaangażowanie w proces internacjonalizacji (rozumiane w aspekcie czasu, formy, a także udziału sprzedaży zagranicznej w sprzedaży firmy ogółem) może sprzyjać osiąganiu przez podmiot wyższych poziomów orientacji na wiedzę. Dłuższy okres zaangażowania przedsiębiorstwa w proces internacjonalizacji może wpływać na wzrost orientacji przedsiębiorstwa na wiedzę ze względu na większe doświadczenie firmy i świadomość wagi tego czynnika. Można oczekiwać, iż wyższy udział sprzedaży przedsiębiorstwa na rynkach zagranicznych w porównaniu do jego sprzedaży ogółem implikuje większą koncentrację firmy na procesie internacjonalizacji i stwarza większe możliwości pozyskiwania oraz wykorzystywania zasobu wiedzy. Można również podejrzewać, że w zależności od wykorzystania mniej lub bardziej zaawansowanej formy sposobu działalności przedsiębiorstwa na rynku zagranicznym - istnieją różnice w poziomie badanych procesów. W związku z tym została sformułowana hipoteza 2: 
H2: Przedsiębiorstwa wraz $z$ większym zaangażowaniem $w$ proces internacjonalizacji sa przeciętnie bardziej zorientowane na wiedzę.

Z uwagi na wcześniej przedstawione i omówione charakterystyki przedsiębiorstwa zaangażowanego na rynkach zagranicznych (powszechne luki wiedzy w wielu obszarach, dynamiczne środowisko funkcjonowania, intensywną, najczęściej mniej znaną konkurencję, wzrost znaczenia zasobu wiedzy w procesach gospodarczych) można podejrzewać, że wysoka intensywność rynkowo ukierunkowanych, systemowych działań w zakresie wiedzy (orientacji na wiedzę) może pozytywnie wpływać na pozycję konkurencyjną podmiotu zaangażowanego na rynkach zagranicznych. Stąd została sformułowana hipoteza 3:

H3: Wyższy poziom orientacji na wiedze przedsiębiorstw $w$ procesie internacjonalizacji wpływa pozytywnie na ksztaltowanie przewagi konkurencyjnej podmiotów zaangażowanych zagranicznie.

Poziomem analizy niniejszej pracy jest przedsiębiorstwo, choć ze względu na wybraną tematykę, w niektórych miejscach rozprawy, w celu pokazania charakterystyki zjawisk ogólnogospodarczych i ich wpływu na przedsiębiorstwa, analiza przenosi się na poziom makroekonomiczny - gospodarki kraju lub gospodarki światowej. W przeważającej mierze w rozprawie jest wykorzystywane podejście dedukcyjne.

Praca ma charakter teoretyczno-empiryczny. W zakresie teoretycznym posłużono się literaturą polską, jak i zagraniczną. Dzięki środkom z uzyskanym przez autora w ramach grantu Narodowego Centrum Nauki (szczegóły w zakresie finansowania niniejszej pracy szerzej opisano w dalszej części wstępu) możliwym było wykorzystanie najnowszego i najbardziej aktualnego dorobku literaturowego w badanym obszarze. Znaczący wkład, zwłaszcza wśród pozycji zwartych, wniosły poszukiwania literatury w bibliotekach Freie Universität Berlin oraz Uniwersytetu w Genewie. Studia literaturowe publikacji obcojęzycznych oraz polskich wydanych w ostatnich dziesięciu latach stanowiły podstawę krytycznej analizy literatury.

Wątki empiryczne pracy obejmują badania ilościowe, jak i jakościowe. Wartym podkreślenia jest szczególnie pierwszy rodzaj badań, który został przeprowadzony wśród relatywnie dużej grupy firm. Badanie ilościowe wykorzystywało kwestionariusz udostępniany w formie elektronicznej oraz rozsyłany pocztą tradycyjną. Otrzymano prawie 1300 wypełnionych kwestionariuszy ankietowych. Uzyskane dane zostały następnie 
przeanalizowane (m.in. z wykorzystaniem programu SPSS). Zaobserwowane zależności szczegółowo przeanalizowano w badaniu jakościowym przeprowadzonym w formie studiów przypadku. W pracy zdecydowano się na wykorzystanie wymienionych, różnorodnych typów badań, aby zrozumieć i jak najdokładniej przedstawić relatywnie złożone działania przedsiębiorstw w procesie internacjonalizacji. Zakres czasowy badań obejmował drugi i trzeci kwartał 2012 roku oraz początek 2013 roku. Studia przypadku zostały przeprowadzone w okresie od czerwca do września 2013 roku. Badania dotyczyły podmiotów gospodarczych $\mathrm{w}$ procesie internacjonalizacji zlokalizowanych na terenie Polski. Szczegółowe informacje dotyczące metodologii badań zostały zamieszczone w rozdziale piątym.

Podsumowując, niniejsza rozprawa obejmuje następujące teoretyczne oraz empiryczne zadania badawcze:

Teoretyczne:

1. Rozpoznanie zagadnienia i terminu ,wiedza”.

2. Rozpoznanie współczesnych trendów makroekonomicznych w zakresie roli wiedzy w gospodarce (gospodarka wiedzy, gospodarka oparta na wiedzy).

3. Rozpoznanie głównych teorii w zakresie kształtowania przewagi konkurencyjnej przedsiębiorstwa.

4. Analiza roli zasobu wiedzy $\mathrm{w}$ gospodarce $\mathrm{w}$ kontekście kształtowania przewagi konkurencyjnej przedsiębiorstwa.

5. Przygotowanie wstępnego, statycznego modelu w zakresie roli zasobu wiedzy w kształtowaniu przewagi konkurencyjnej przedsiębiorstwa.

6. Uporządkowanie dorobku literaturowego w zakresie głównych teorii odnoszących się do dynamicznych działań przedsiębiorstw w zakresie wiedzy (zarządzanie wiedzą, organizacja ucząca się, organizacyjne uczenie się).

7. Konfrontacja różnych teorii literaturowych obejmujących działania przedsiębiorstw w zakresie wiedzy w celu ich wykorzystania pod wspólnym, jednolitym terminem „orientacja na wiedzę”.

8. Rozpoznanie dorobku literaturowego w zakresie orientacji rynkowej przedsiębiorstwa oraz jego konfrontacja $\mathrm{z}$ teoriami dotyczącymi działań $\mathrm{w}$ zakresie wiedzy przedsiębiorstwa w celu poszukiwania teoretycznych synergii obu obszarów działań. 
9. Stworzenie kompleksowego, dynamicznego modelu kształtowania przewagi konkurencyjnej przedsiębiorstwa bazującego na orientacji rynkowej podmiotu oraz działaniach w zakresie wiedzy $\mathrm{z}$ wykorzystaniem różnego rodzaju teorii (m.in. zarządzania wiedzą, organizacji uczącej się i organizacyjnego uczenia się) „model dynamicznej orientacji na wiedzę”.

10. Analiza literatury w zakresie internacjonalizacji.

11. Teoretyczne odniesienie „modelu dynamicznej orientacji na wiedzę” do sytuacji podmiotu w procesie internacjonalizacji.

12. Sformułowanie hipotez badawczych oraz stworzenie modeli badawczych na podstawie modelu teoretycznego.

Empiryczne (ogólne):

13. Weryfikacja empiryczna hipotez badawczych poprzez przeprowadzenie ilościowych badań empirycznych z wykorzystaniem kwestionariusza udostępnianego w formie elektronicznej oraz rozsyłanego pocztą tradycyjną.

14. Szczegółowa analiza zaobserwowanych zależności poprzez przeprowadzenie jakościowych badań w formie studiów przypadku.

15. Analiza danych i wnioskowanie.

Rozprawa składa się z pięciu rozdziałów. Pierwsze cztery z nich tworzą jej część teoretyczną. Zawierają one kompleksową, krytyczną analizę literatury. Mają na celu przedstawienie teoretycznych uwarunkowań $\mathrm{i}$ tendencji związanych $\mathrm{z}$ zasobem wiedzy zarówno na poziomie mikro- jak i makroekonomicznym. Prezentują również stan wiedzy W wybranym temacie.

Rozdział pierwszy przedstawia statyczne zależności pomiędzy zasobem wiedzy a przewagą konkurencyjną przedsiębiorstwa. Sprecyzowano i scharakteryzowano w nim istotę zagadnienia wiedzy. Przedstawiono zmieniającą się rolę wymienionego zasobu w kontekście makroekonomicznym ze szczególnym uwzględnieniem kontekstu przemian gospodarczych, których byliśmy świadkami w ostatnich dziesięcioleciach - rozwój gospodarki opartej na wiedzy. W rozdziale zaprezentowano również obecne w literaturze teorie związane z kształtowaniem przewagi konkurencyjnej przedsiębiorstwa, które zostały skonfrontowane $\mathrm{z}$ wcześniej wspomnianymi zmianami gospodarczymi związanymi ze wzrostem znaczenia wartości niematerialnych. Na tej podstawie przedstawiono wstępną, 
statyczną wersję modelu kształtowania przewagi konkurencyjnej przedsiębiorstwa z wykorzystaniem zasobu wiedzy.

Rozdział drugi, koncentruje się na dynamicznych teoriach działań przedsiębiorstw w zakresie wiedzy, ze szczególnym uwzględnieniem dominującej koncepcji w tym obszarze zarządzania wiedzą. Jest on logiczną konsekwencją konkluzji rozdziału pierwszego związanej z potrzebą dynamicznego ujęcia zagadnień związanych $\mathrm{z}$ wiedzą w przedsiębiorstwach. Omawiany rozdział zawiera szczegółową, dokonaną na podstawie literatury, charakterystykę przede wszystkim zagadnienia zarządzania wiedzą, lecz także organizacji uczącej się oraz organizacyjnego uczenia się. Ta część pracy przedstawia teoretyczne koncepcje w zakresie wiedzy nakreślając różnice pomiędzy nimi. Innym ważnym jej elementem jest usystematyzowanie działań przedsiębiorstwa $\mathrm{w}$ zakresie wiedzy $\mathrm{w}$ formie serii uporządkowanych procesów głównie na podstawie dorobku teorii zarządzania wiedzą.

Rozdział trzeci wprowadza kolejne ważne i nieodzowne zagadnienie związane z kształtowaniem przewagi konkurencyjnej przedsiębiorstwa - rynkowe ukierunkowanie działań firmy $\mathrm{w}$ zakresie wiedzy. W związku $\mathrm{z}$ tym przedstawiona zostaje koncepcja orientacji rynkowej przedsiębiorstwa. Jest ona następnie integrowana $\mathrm{z}$ teoriami działań firmy w zakresie wiedzy na podstawie dorobku szeregu koncepcji z tego obszaru. W ostatniej części rozdziału wszystkie rozważania zostają ujęte w autorski model dynamicznej orientacji na wiedzę.

Celem rozdziału czwartego jest analiza modelu, będącego konkluzją wcześniejszego rozdziału, w sytuacji zaangażowania przedsiębiorstwa na rynkach zagranicznych. Przedstawia on teorię internacjonalizacji podmiotu gospodarczego oraz wyjaśnia zasadność zastosowania wcześniej opisanego modelu kształtowania przewagi konkurencyjnej przedsiębiorstwa w warunkach procesu internacjonalizacji.

Rozdział piąty prezentuje metodologię oraz wyniki ilościowych badań empirycznych przeprowadzonych przez autora celem weryfikacji zależności modelowych zaprezentowanych we wcześniejszych rozdziałach pracy. Zawiera on również szczegółową analizę zaobserwowanych zależności w formie badań jakościowych - studiów przypadku.

Zakończenie podsumowuje rozważania teoretyczne i empiryczne zawarte w niniejszej rozprawie i przedstawia wnioski końcowe pracy oraz nakreśla dalsze kierunki badań.

Integralną częścią niniejszej rozprawy jest aneks. Zawiera on m.in. wzór kwestionariusza w wersji tradycyjnej (papierowej) oraz zdjęcia kwestionariusza w wersji elektronicznej. 
Praca została przygotowana $w$ ramach projektu sfinansowanego ze środków Narodowego Centrum Nauki przyznanych na podstawie decyzji numer DEC2011/03/N/HS4/00429, uzyskanych w ramach konkursu Preludium 2. Tytuł projektu: „Rola orientacji na wiedzę $\mathrm{w}$ procesie kształtowania przewagi konkurencyjnej przedsiębiorstwa w procesie internacjonalizacji”, okres realizacji: 08.2012-08.2014r. Autor niniejszej rozprawy pełnił funkcję kierownika projektu, zaś funkcję promotora pełnił prof. dr hab. Krzysztof Fonfara, prof. zw. UEP. 


\section{Wiedza a przewaga konkurencyjna przedsiębiorstwa}

\subsection{Charakterystyka pojęcia wiedza}

\subsubsection{Definicja}

Od tysięcy lat ludzie próbowali zdefiniować wiedzę. Platon uważał, że posiada wiedzę ten, kto potrafi uzasadnić swoje zdanie. Arystoteles twierdził, że wiedza to nieustające dążenie do zgłębienia doświadczenia człowieka. Według Kanta wiedza jest ograniczona poprzez dostępność doświadczeń, zaś Locke uważał, że jest ona dostrzeganiem związków pomiędzy ideami [Jashapara 2006 s. 51, 55-57]. Dziś wiedza jest pojęciem nadal trudnym do zdefiniowania. Wśród autorów nie ma zgody, co do jednej, uniwersalnej, definicji. Można jednak wyróżnić kilka głównych ujęć, często spotykanych w literaturze. Wielka Encyklopedia PWN [2005, tom 29, s. 96] w najogólniejszym sensie definiuje wiedzę jako rezultat wszelkich możliwych aktów poznania. Najbardziej popularnym ujęciem jest jednak koncepcja postrzegania wiedzy jako formy wyższej w stosunku do danych i informacji, zaś niższej do mądrości. Dane są określane jako niepowiązane fakty. Informacje oznaczają dane, które zostały w pewien sposób poddane kategoryzacji lub w inny sposób uporządkowane. Wiedza jest zaś określana jako uporządkowane, a także wyselekcjonowane informacje ujęte w określonym kontekście. Ma ona charakter intuicyjny i przez to jest trudniejsza do zdefiniowania w przeciwieństwie do danych i informacji [Kijewska 2005, s. 12]. W celu przekształcenia informacji w wiedzę potrzebny jest proces myślenia, który jest wyłącznie domeną człowieka. Informacja może także redukować niepewność, innymi słowy może zwiększać wiedzę [Fazlagić 2006, s. 44]. Charakter wiedzy jest dynamiczny, jest to pojęcie subiektywne. Dane oraz informacje mają charakter statyczny, ich celem jest obiektywne odzwierciedlenie stanu faktycznego [Sopińska 2010, s. 86]. Zdaniem Baruka z większości przeanalizowanych przez niego definicji wiedzy wynika, że jest ona zdolnością do przekształcania informacji. Stąd wymieniony autor postrzega wiedzę jako umiejętność do interpretowania danych $\mathrm{i}$ informacji w procesie nadawania im znaczenia w kontekście rozwiązywania określonego problemu czy zadania [Baruk 2006, s. 23].

Należy zaznaczyć, że w literaturze można spotkać zamienne użycie pojęcia informacji i wiedzy. Zdaniem autora pracy, istnieje jednak wyraźna różnica. Brak rozróżnienia w zakresie informacji i wiedzy może prowadzić do sprzeczności. Wielu światowych badaczy 
wskazuje na znaczącą dysproporcję pomiędzy ilością dostępnej informacji a ilością zakumulowanej wiedzy. Wzrost zasobu informacji nie musi koniecznie oznaczać wzrostu zasobu wiedzy. Społeczeństwa dobrze poinformowane, gdzie istnieje szeroki dostęp do zasobu informacji, nie zawsze muszą wykorzystywać dostępne możliwości przetwarzając informacje w wiedzę [Materska 2007, s. 46]. Interesującym przykładem egzemplifikującym tę różnicę jest sieć kasyn Harrah Entertainment. Firma próbując uruchomić program lojalnościowy stworzyła obszerną bazę danych swoich klientów i ich preferencji. Pomimo porażki programu, wnikliwa analiza zebranych danych przez kluczowe osoby w przedsiębiorstwie umożliwiła ujęcie ich w określonym kontekście, co stało się podstawą do uczynienia firmy najbardziej zyskowną w swojej branży [Loveman 2004, s. 84-88]. Jest to bardzo jaskrawy przykład pokazujący różnice pomiędzy wiedzą, a jej formami pierwotnymi. Pokazuje on, że baza danych może być potencjalnie bardzo cenna, lecz bez procesów myślowych, które w odpowiedni sposób przekształcą dane lub informacje w wiedzę, może być ona także bezużyteczna.

Istnieją też innego rodzaju definicje terminu wiedza. Turban uważa, że wiedza składa się szeregu składowych takich, jak: przekonania, prawda, osądy, przewidywania, pomysły, oczekiwania, metodologia oraz know how [Kłak 2010, s. 17]. McDermott [1999, s. 106] określa wiedzę jako efekt zastosowania zdobytych doświadczeń i informacji. Zdaniem Grudzewskiego i Merskiego [2004, s. 205] wiedzę można określić jako narzędzie, które umożliwia człowiekowi sprawne korzystanie ze zbioru posiadanych przez niego informacji. Davenport i Prusak definiują wiedzę jako płynną mieszaninę kontekstowych doświadczeń, informacji oraz wartości, która tworzy ramy dla przyswajania oraz rozumienia nowych doświadczeń. W organizacjach jest ona odzwierciedlona nie tylko w dokumentach oraz bazach danych wiedzy, ale także w jej praktykach i zwyczajach [Davenport i Prusak 1998, s. 5]. Firma Alcatel postrzega wiedzę jako ,informację, która została zrozumiana, wzbogacona o osąd i wykorzystana w działaniu" [Jemielniak i Koźmiński 2008, s. 13]. Zdaniem Brdulaka [2005, s. 14] wiedzę wyróżnia sześć cech:

a) podmiotowość - wiedza jest $\mathrm{w}$ dużym stopniu zależna od doświadczeń jej użytkownika oraz kontekstu, w jakim jest stosowana,

b) transferowalność - wiedza może być pozyskana z jednego miejsca i aplikowana z korzyścią w innym,

c) osadzenie - wiedza najczęściej znajduje się w ludzkim umyśle, stąd jej transfer, choć do pewnego stopnia możliwy jest często bardzo trudny, 
d) samozasilanie - wiedza nie zużywa się w miarę jej wykorzystywania, a wręcz często jej przybywa, gdy jest stosowana,

e) nietrwałość - wiedza szybko się dezaktualizuje,

f) spontaniczność - wiedza rozwija się najczęściej w niekontrolowanym procesie.

W niniejszej pracy autor przyjmuje, zgodnie z dominującym poglądem panującym w literaturze, że wiedza jest informacją ujętą w określonym kontekście, która może zostać efektywnie użyta do wykonania określonego zadania.

\subsubsection{Rodzaje wiedzy}

Istnieje wiele podziałów wiedzy. Jednym $\mathrm{z}$ najpowszechniejszych jest podział na wiedzę jawną i ukrytą. Pierwszą z nich można zapisywać w formie instrukcji, książek, przechowywać w bazach danych. Drugiej z nich - wiedzy ukrytej - nie można przekazać w łatwy sposób. Przykładowo, dana osoba może wiedzieć jak prowadzić samochód lub pilotować samolot, lecz nie jest w stanie całościowo tej wiedzy przekazać w formie pisemnej [Tiwana 2003, s. 63]. Istnieją różnego rodzaju szacunki przeciętnych proporcji poziomu wiedzy jawnej do poziomu wiedzy ukrytej w przedsiębiorstwie. W zależności od źródła wynoszą one od 1 do 4-5. W literaturze można nawet znaleźć nawet stwierdzenia, że ma tu zastosowanie zasada Pareto 20/80 gdzie 80\% oznacza wiedzę ukrytą, zaś 20\% wiedzę jawną [Brdulak 2005, s. 16]. Szczegółowe porównanie charakterystyk wiedzy jawnej i ukrytej zostało przedstawione w tabeli 1 .

Można odnieść wrażenie, że wiedza ukryta - przekazywana osobowo jest ważniejsza, ze względu na większy potencjał, jaki ze sobą niesie, lecz zdaniem Fazlagića gwałtowny rozwój cywilizacji atlantyckiej w dużej mierze był zdeterminowany rozwojem wiedzy skodyfikowanej zawartej w książkach. Dzięki wynalezieniu druku wiedza mogła zostać przekazana bez udziału jej twórcy. Potocznie mówi się, że książki i innego rodzaju dokumenty pisane zawierają wiedzę. Zawierają one jednak tylko informacje, w których drzemie potencjał generacji wiedzy. Wiedza jest kwestią interpretacji i zrozumienia danych oraz informacji. Jakość przekazywania wiedzy poprzez dokumenty pisane jest więc zdeterminowana jakością odczytania intencji twórcy wiedzy poprzez dane i informacje zawarte w danym dokumencie [Fazlagić 2006, s. 45]. 
Tabela 1. Porównanie charakterystyk wiedzy jawnej i ukrytej.

\begin{tabular}{|c|c|c|}
\hline Cecha & Wiedza jawna & Wiedza ukryta \\
\hline Charakter & $\begin{array}{c}\text { Zbliżona do informacji, } \\
\text { racjonalna, teoretyczna }\end{array}$ & $\begin{array}{c}\text { Nienamacalna, doświadczalna, } \\
\text { praktyczna }\end{array}$ \\
\hline $\begin{array}{c}\text { Miejsce } \\
\text { przechowywania }\end{array}$ & $\begin{array}{c}\text { Dokumenty pisane, książki, } \\
\text { instrukcje itp. }\end{array}$ & Doświadczenie osób i ich zdolności \\
\hline $\begin{array}{c}\text { Stopień } \\
\text { trudności } \\
\text { komunikowania }\end{array}$ & Relatywnie niski & Bardzo wysoki \\
\hline $\begin{array}{c}\text { Metody } \\
\text { transferu }\end{array}$ & Formalny język & Socjalizacja \\
\hline $\begin{array}{c}\text { Możliwość } \\
\text { przetwarzania } \\
\text { za pomoca } \\
\text { technologii } \\
\text { informacyjnych }\end{array}$ & Praktycznie nieograniczona & Bardzo ograniczona \\
\hline
\end{tabular}

Źródło: opracowanie własne na podstawie: [Tiwana 2003, s. 65; Piech 2009, s. 193; Nonaka i Takeuchi 2000,

$$
\text { s. 84]. }
$$

Z punktu widzenia przedsiębiorstwa interesujący jest podział na wiedzę indywidualną oraz grupową. Pierwsza $\mathrm{z}$ nich jest przechowywana $\mathrm{w}$ umysłach indywidualnych osób (pracowników firmy). Charakteryzuje się ona dużą specjalizacją oraz jest relatywnie ograniczona zakresowo. W przypadku tej wiedzy istnieje problem jej akumulacji i zatrzymania w przedsiębiorstwie. W momencie odejścia pracownika z firmy wiedza zostaje utracona, stąd z punktu widzenia interesu przedsiębiorstwa nie jest korzystne, aby pracownicy posiadali wiedzę, która nie jest zapisana w innym miejscu. Niestety, jest to w praktyce niemożliwe, stąd przedsiębiorstwo powinno dążyć do minimalizacji ilości wiedzy będącej wyłącznie w posiadaniu pojedynczych pracowników, a nie kompletnej eliminacji tego zjawiska. Drugim typem wiedzy wyróżnionej w omawianej klasyfikacji jest wiedza grupowa. Jest ona zawarta w procedurach, działaniach, regułach oraz zwyczajach przedsiębiorstwa. W literaturze można odnaleźć opinie, że może być ona zarówno czymś więcej lub mniej niż sumą wiedzy indywidualnych osób. Poprzez udział wiedzy każdej z indywidualnych osób (pracowników firmy) może stać się unikatowym, stąd trudnym do naśladowania zasobem przedsiębiorstwa [Materska 2007, s. 166-167]. Podobną, lecz nieco bardziej rozbudowaną 
klasyfikację, zaproponowali Kowalczyk i Nogalski [2007, s. 24-25]. Wyróżnili oni, na podstawie dorobku literatury, cztery rodzaje wiedzy [Kowalczyk i Nogalski 2007, s. 24-25]:

a) wiedza zewnętrzna znajdująca się w systemie międzyorganizacyjnym - dotyczy ona sytuacji otoczenia przedsiębiorstwa - wpływa na funkcjonowanie przedsiębiorstwa, gdyż na jej podstawie firma podejmuje strategiczne decyzje np. perspektyw danego sektora; pozwala ona też oceniać ogólne trendy występujące w gospodarce czy branży,

b) wiedza na poziomie przedsiębiorstwa - jest sumą indywidualnej wiedzy pracowników przedsiębiorstwa oraz umiejętności jej wykorzystania; jej ogólny poziom może być wysoki, ale o jej faktycznej wartości ekonomicznej decyduje także umiejętność praktycznego jej zastosowania; wiedza tego rodzaju jest najważniejszym czynnikiem sukcesu przedsiębiorstwa,

c) wiedza na poziomach zespołów - jest ona częścią wiedzy przedsiębiorstwa, oraz ma duże znaczenie w powstawaniu nowej wiedzy w organizacji,

d) wiedza indywidualnych jednostek (pracowników przedsiębiorstwa) - jest ona podstawą całościowej wiedzy przedsiębiorstwa oraz każdego systemu zarządzania wiedzą.

Innym podziałem, promowanym przez OECD, jest podział na cztery typy wiedzy [Clarke 2001, s. 190]:

a) wiedzieć co (know-what) - jest to zbiór faktów, ten typ wiedzy jest bliski informacjom oraz jest podzielny,

b) wiedzieć dlaczego (know-why) - jest to wiedza naukowa dotycząca m.in. praw natury czy rozwoju technologicznego,

c) wiedzieć jak (know-how) - jest to umiejętność do wykonania danej rzeczy, jest to typowa wiedza rozwijana w przedsiębiorstwach; przedsiębiorstwa formują różnego rodzaju sieci w celu dzielenia się tego typu wiedzą,

d) wiedzieć kto (know-who) - jest to informacja kto co wie, oraz kto wie jak daną rzecz wykonać, jest związana ze stosunkami społecznymi, które umożliwiają dostęp do ekspertów w określonych dziedzinach, a także jest szczególnie ważna w dzisiejszych czasach ze względu na zwiększające się tempo zmian.

Zdaniem Clarke'a niektóre ze wspomnianych typów wiedzy są towarem rynkowym, zaś inne np. wiedzieć jak czy wiedzieć kto są związane osobowo i znacznie trudniej je zmierzyć czy przekazać, lecz są one uważane za najcenniejsze [Clarke 2001, s. 190]. 


\subsection{Gospodarczy wymiar wiedzy}

\subsubsection{Znaczenie wiedzy $w$ gospodarce industrialnej}

Często pomijanym w literaturze zagadnieniem jest zmiana znaczenia słowa wiedza na przestrzeni wieków. Należy zwrócić uwagę na różnice pojmowania wiedzy w czasach starożytnych i obecnie. Wiedza w przeszłości nie oznaczała umiejętności robienia czegoś. Posiadanie umiejętności wykonania czegoś było określane jako zdolność, nazywana przez Greków techne. Przyczyną rozróżnienia między techne a wiedzą był brak ogólności tego pierwszego. Techne miało zastosowanie tylko do określonych sytuacji, a sposobem jego pozyskiwania było przede wszystkim doświadczenie. Nie było możliwości wyjaśnienia go w słowach czy języku pisanym. Do 1700 roku w Anglii nie mówiono o wiedzy rzemieślniczej, ani o rzemiosłach, istniało wyłącznie wtajemniczenie, a posiadacze umiejętności byli zobowiązani do zachowania tajemnicy [Drucker 1999, s. 28]. Korzystając z dzisiejszej terminologii można stwierdzić, że w przeszłości pojęcie wiedza odpowiadało dzisiejszej wiedzy jawnej, zaś dzisiejszy termin wiedza ukryta jest odpowiednikiem ówczesnego techne.

Zmiana podejścia do wiedzy rozpoczęła się w XVII wieku. Wymyślono wtedy termin technologia jako połączenie techne ze słowem logy oznaczającym systematyczną, zorganizowaną i ukierunkowaną wiedzę. W połowie XVII wieku powstały pierwsze uczelnie techniczne, rolnicze i górnicze. Na początku XVIII wieku zmianom uległa edukacja medyczna. Medycynę także przekształcono w systematyczną technologię. Symbolem przejścia od techne do technologii można określić Encyclopédie ou Dictionnaire raisonné des sciences, des arts et des métiers (Encyklopedia albo słownik rozumowany nauk, sztuk i rzemiosł). Była ona próbą zebrania wiedzy o wszystkich rzemiosłach w jednym miejscu, aby można było nauczyć się ich wykonywania bez odbywania stażu u rzemieślnika. Produkcja dóbr, która wcześniej była domeną rzemiosła i rzemieślników, została oparta na technologii. Opisane przemiany, czyli przede wszystkim zmiana rozumienia i znaczenia wiedzy (co skutkowało przede wszystkim zdecydowanie większą jej powszechnością), miały ogromny wpływ na rozwój kapitalizmu [Drucker 1999, s. 28-29]. Encyklopedia oraz nowopowstałe szkoły wyższe były namacalną formą tego, o czym pisze Fazlagić [2006, s. 45] w kontekście znaczenia wiedzy jawnej w rozwoju cywilizacji europejskiej.

Zmiana znaczenia wiedzy oraz w konsekwencji zwiększony dostęp do niej, miały duży wpływ na rozkwit gospodarki industrialnej, gdyż stworzyły impuls do jej rozwoju. 
W tym sensie można pokusić się o określenie wiedzy, jako ukrytego czynnika produkcji, lecz różnego w swej charakterystyce od klasycznych: kapitału i pracy. Jest to spowodowane faktem, że do procesu produkcji w gospodarce industrialnej potrzebny był odpowiedni poziom wiedzy. W momencie jednak, gdy został on już osiągnięty, jego zwiększanie nie było aż tak potrzebne. Spowodowane to było faktem, iż technologia, szczególnie na początku okresu gospodarki instytucjonalnej nie zmieniała się aż tak szybko, a przedsiębiorstwa ze względu na brak dużej konkurencji nie miały motywacji do jej rozwoju. W przypadku klasycznych czynników produkcji - kapitału i wiedzy - każde zwiększenie wielkości produkcji wiązało się ze zwiększeniem zaangażowania najczęściej obu tych czynników.

Interesującym problemem w gospodarce industrialnej była produktywność. Pierwszym, który zainteresował się tym aspektem gospodarki był Frederick Winslow Taylor. Celem Taylora było osiągnięcie wyższej produktywności pracowników w celu poprawy ich warunków bytowych. Jego badania unaoczniły problem braku zainteresowania rozwojem zasobu wiedzy w przedsiębiorstwach, co uniemożliwiało wzrost produktywności. Jako egzemplifikacją problemu można się posłużyć sytuacją panującą w państwowych zakładach przemysłu obronnego oraz stoczniowego Stanów Zjednoczonych w pierwszej połowie XX wieku. We wspomnianych zakładach działały w omawianym okresie bardzo silne związki zawodowe, w których członkostwo było bardzo ograniczone. Żądały one stażu od pięciu do siedmiu lat, bez organizacji systematycznych szkoleń lub badania efektywności pracy. Uniemożliwiano nawet robienie notatek oraz zakazywano rozmów o pracy z osobami spoza związku. Był to w pewnym sensie powrót do przedindustrialnego myślenia o wiedzy, który uniemożliwiał rozwój. Dzięki temu rozwinął się mit, że w pracy robotnika tkwi jakieś misterium, co z kolei prowadziło przynajmniej do przekonania, że wykształcenie specjalisty rzemieślnika musi trwać dużo czasu. Właśnie to przekonanie wpłynęło na decyzję Hitlera o wypowiedzeniu w 1941 roku wojny Stanom Zjednoczonym, gdyż nie miały one odpowiednio rozwiniętego przemysłu zbrojeniowego, ani floty handlowej, a wykształcenie w krótkim czasie odpowiedniego przemysłu zdolnego konkurować z niemieckim wydawało się niemożliwe. Mimo to, dzięki implementacji badań nad pracą i jej produktywnością przeprowadzonych przez Taylora, Stany Zjednoczone mogły bardzo szybko opracować efektywny program szkoleń i wykształcić potrzebnych wykwalifikowanych robotników np. dokerów czy spawaczy oraz stworzyć przemysł produkujący wyroby nieraz jakościowo lepsze od niemieckich, co w konsekwencji wpłynęło na wynik wojny [Drucker 1999, s. 3536]. 
Podsumowując, sukces jaki odniosły Stany Zjednoczone był rezultatem nagromadzenia zasobów wiedzy w badaniach Taylora i odpowiedniego jej wykorzystania. Jak wynika $z$ historii, częstym hamulcem rozwoju krajów i przedsiębiorstw były problemy w przepływie i wykorzystaniu wiedzy, a skupienie się na tym zasobie prowadziło do sukcesów. Obecnie, zwiększona obfitość kapitału i pracy powiązana z mniejszym zapotrzebowaniem na te czynniki produkcji (m.in. ze względu na zwiększoną produktywność) sprawiły, że zasobem pozostającym w największym niedoborze stała się właśnie wiedza, co doprowadziło do powstania gospodarki opartej na wiedzy.

\subsubsection{Zmiana roli zasobu wiedzy we współczesnych procesach gospodarczych - transformacja w kierunku gospodarki opartej na wiedzy}

Od końca XX wieku ${ }^{4}$ wielu autorów zauważyło znaczącą zmianę w procesach gospodarowania związaną $\mathrm{z}$ rosnącą rolą zasobu wiedzy w procesie tworzenia wartości dodanej. Rola tego czynnika stała się do tego stopnia znacząca, iż w powszechnym użyciu pojawiły się pojęcia takie, jak gospodarka wiedzy (knowledge economy) czy gospodarka oparta na wiedzy ${ }^{5}$ (knowledge based economy). Celowym jest poznanie wymienionych przemian otoczenia przedsiębiorstw, gdyż ich charakter wpływa nieuchronnie na firmy modyfikując zasady gry rynkowej, implikując odpowiednie działania oraz metody, jakie powinny być przez te podmioty stosowane w celu osiągnięcia przewagi konkurencyjnej.

Pojęcie gospodarki opartej na wiedzy ${ }^{6}$ umożliwiło nazwanie zmian gospodarczych, które nastąpiły sferze ekonomicznej przede wszystkim najbardziej rozwiniętych krajów świata. Związane one były ze zwiększeniem znaczenia zasobu wiedzy. Zmiana roli wspominanego zasobu oraz wzrost jego pozycji był w pewnym sensie przeciwstawieniem się tradycyjnej gospodarce przemysłowej, wraz z jej materialnymi czynnikami wytwórczymi

\footnotetext{
${ }^{4}$ Zdaniem Karlssona, Johanssona i Sougha pierwsze oznaki gospodarki opartej na wiedzy można nawet odnaleźć w latach 60-tych i 70-tych, w momencie wzrostu popytu na usługi, który spowodował rozwój tego sektora [Karlsson, Johansson i Sough 2006, s. 1].

${ }^{5}$ Należy jednak zwrócić uwagę, że nie są to terminy do końca jednoznaczne. Gospodarka wiedzy jest terminem starszym wywodzącym się z lat pięćdziesiątych dwudziestego wieku, skupiającym się na proporcjach siły roboczej. Pojęcie gospodarka oparta na wiedzy jest zdecydowanie nowsze, jego początków należy upatrywać w końcu dwudziestego wieku [Cooke i Leydesdorff 2006, s. 5-15]. Rozpowszechnienie pojęcia gospodarki opartej na wiedzy można głównie zawdzięczać Organizacji Współpracy Gospodarczej i Rozwoju (OECD), która w 1996 roku opublikowała raport zatytułowany „Gospodarka oparta na wiedzy” [OECD, 1996, s. 1]. Komisja Europejska także użyła tego terminu podczas formułowania strategii konkurencyjności Unii Europejskiej w Lizbonie w 2000 roku (Strategia Lizbońska) [Leydesdorff, Dolfsma i Soete 2005, s. 1].

${ }^{6}$ Autor w niniejszej pracy jako dominującego używa pojęcia „gospodarka oparta na wiedzy”, mimo to, ze względów leksykalnych (unikanie powtórzeń) stosowane jest pojęcie „gospodarka wiedzy” używane w tym samym znaczeniu. Działanie to jest to umotywowane niewielkimi różnicami znaczeniowymi - oba pojęcia mają na celu podkreślenie powiększającej się roli wiedzy w gospodarce.
} 
[Gaczek 2009, s. 27]. Należy podkreślić, że gospodarka oparta na wiedzy nie stanowi negacji gospodarki rynkowej, tylko jej materialnej sfery [Kleer 2009, s. 74]. Według Nijkamp i Siedschlag [2011, s. 33] gospodarka oparta na wiedzy jest w dzisiejszym świecie bardzo istotną koncepcją. Zmiany przez nią wywołane są widoczne w wielu aspektach gospodarki np. w formie nowych miejsc pracy, nowych produktów czy nowych branż. Neef, Siesfeld i Cefola podkreślają, że większość ekonomistów zgadza się co do faktu, że procesy ekonomiczne gospodarki opartej na wiedzy bardzo się różnią w porównaniu z gospodarkami tradycyjnymi i zauważają, że nie wszystkie tradycyjne prawa i modele mogą nadal funkcjonować [Neef, Siesfeld i Cefola 1998, s. 5]. Opinię te podziela Welfe zaznaczając, że gospodarka oparta na wiedzy jest koncepcją, która zdecydowanie odróżnia się od poprzedzającej ją i dominującej przez dziesięciolecia gospodarki industrialnej. Zasób wiedzy, który jest podstawą działalności w gospodarce opartej na wiedzy, był co prawda przedtem także istotny ${ }^{7}$, lecz jego rola w procesach gospodarczych w ostatnich dziesięcioleciach stała się dominująca [Welfe 2007, s. 9]. Według Nijkamp i Siedschlag [2011, s. 15] jest to spowodowane faktem, że wpływ wiedzy na procesy ekonomicznie zmienił się fundamentalnie. Zdaniem Kahina i Foray [2006, s. 17] jej rola jako czynnika wyjaśniającego wzrost gospodarczy oraz bogactwo regionów zdecydowanie wzrosła. W przeszłości wiedza była postrzegana jako powszechnie dostępne dobro publiczne [Gaczek 2009, s. 21], nie ujmowano jej jednak w modelach ekonomicznych.

W gospodarce opartej na wiedzy jest ona zwykle dobrem powszechnie niedostępnym. Powstaje najczęściej w podmiotach prywatnych i jest ściśle chroniona [Gaczek 2009, s. 21, 24]. Zmieniło się też postrzeganie człowieka - w perspektywie przedsiębiorstw przestał być on odbierany zaledwie jako zasób pracy, lecz także, dzięki posiadanej wiedzy jako kapitał ludzki, czyli wartość dla organizacji [Nowakowska, Przygodzki i Sokołowicz 2011, s. 7]. Szromnik [2013, s. 9] podkreśla, że wiedza może być ujmowana w charakterze unikalnego czynnika wytwórczego przedsiębiorstwa. Podobnego zdania są Bratianu i Dinca [2010, s. 219], według których gospodarka oparta na wiedzy sprawiła, że wiedza stała się najistotniejszym zasobem, a potencjał mózgu człowieka głównym kapitałem przedsiębiorstw. Przejawem znaczenia wiedzy dla tworzenia przewagi konkurencyjnej jest fakt, że w dzisiejszych czasach najważniejszym motywem zakupu jednych firm przez drugie jest ich wiedza. Przykładem takiego działania jest przejęcie firmy Motorola przez Google. Jednym z motywów firmy z Mountain View w tym zakresie były patenty, w których posiadaniu była

\footnotetext{
${ }^{7}$ W opinii Kleera wiedza zawsze była stymulatorem postępu gospodarczego [Kleer 2009, s. 72].
} 
Motorola [Quest Means Business 2011]. Wzrost intensywności procesów związanych $\mathrm{z}$ wiedzą $\mathrm{W}$ gospodarce może być przedstawiony także za pomocą szeregu wskaźników statystycznych. Przykładowo w 1950 roku 80 procent wartości dodanej produkcji przemysłowej w Stanach Zjednoczonych stanowiło przetwarzanie surowych materiałów, a o 20 procentach stanowiła wiedza. W 1995 roku proporcje te praktycznie się odwróciły znaczenie materiałów spadło do 30 procent, a wiedzy wzrosło do 70 procent. Podobnie spadł udział aktywów materialnych w całkowitej wartości księgowej przedsiębiorstw. Od 1975 do 1990 roku w krajach OECD wydatki na badania i rozwój rosły trzykrotnie szybciej niż produkcja przemysłowa. Liczba rejestrowanych patentów w Stanach Zjednoczonych wzrosła w tym okresie o 48 procent, zaś w sektorach intensywnie wykorzystujących wiedzę wzrost w tym kontekście wynosił aż 182 procent [Cook 2002, s. 189]. Podobnie w Wielkiej Brytanii w 1970 roku inwestycje w środki niematerialne stanowiły zaledwie 40 procent inwestycji w środki materialne. W 2004 roku udział ten wzrósł do 130 procent [Brinkley 2009, s. 4]. Poprzez procesy tworzenia i wykorzystania wiedzy w centrum procesów ekonomicznych, dana gospodarka przekształca się w gospodarkę wiedzy. Wiedza staje się najważniejszym czynnikiem warunkującym długoterminowy wzrost. Ponadto, przeistacza się w główny czynnik przewagi konkurencyjnej takiej gospodarki [Nijkamp i Siedschlag 2011, s. 17].

W literaturze istnieje wiele, często bardzo różniących się, prób zdefiniowania zjawiska gospodarki opartej na wiedzy. Nie ma jednak jednej uznanej definicji [Karlsson, Johansson i Sough 2006, s. 12]. Zdaniem Brinkley [2006, s. 29] opracowanie definicji jest zadaniem wyjątkowo trudnym, gdyż podstawowe pojęcie i jednocześnie zasób, na którym się ona opiera (wiedza) jest również trudno definiowalny. Zdaniem Welfe [2007, s. 7] termin gospodarka oparta na wiedzy został stworzony w celu podkreślenia cech współczesnej gospodarki, która w coraz większym stopniu korzysta ze zgromadzonego zasobu wiedzy. Ogólnie charakterystyczną cechą gospodarki opartej na wiedzy jest rozwój dziedzin i branż związanych z nauką, przetwarzaniem informacji czyli przede wszystkim przemysłów wysokiej technologii, a także usług społeczeństwa informacyjnego [Moszkowicz i Kubiński 2010, s. 133-134]. Gaczek [2009, s. 31] zauważa, że mianem gospodarki opartej na wiedzy określa się także region na wysokim poziomie rozwoju gospodarczego, którego mieszkańcy cieszą się wysokimi dochodami i bardzo dobrym standardem życia. Rosati zauważa, że kraje rozwinięte są określane mianem gospodarek opartych na wiedzy. Istota tego typu systemu ekonomicznego tkwi jednak w istnieniu zaawansowanych mechanizmów pozwalających na wytwarzanie wiedzy, a także takich, które umożliwiają jej wykorzystywanie w procesie 
gospodarowania. Rezultatem tych działań są m.in. wysoki poziom zaawansowania technicznego wytwarzanych w danym kraju czy regionie dóbr i usług [Rosati 2007, s. 22]. Gospodarka oparta na wiedzy charakteryzuje się tym, że jest to gospodarka ludzi stale uczących się i posiadających wysokie kwalifikacje. Ważnym jej aspektem jest także organizacja instytucjonalna, która ułatwia absorpcję wiedzy oraz umożliwia późniejsze jej wykorzystanie np. w produkcji dóbr materialnych czy dostarczaniu usług. Analizy OECD i Eurostatu najczęściej przyjmują, że w tego rodzaju gospodarce duże znaczenie mają dziedziny wykorzystujące lub wytwarzające narzędzia wysokiej technologii. W wielu publikacjach gospodarkę opartą na wiedzy określa się jako innowacyjną milcząco przyjmując, że proces ten wymaga odpowiedniej wiedzy, jak i umiejętności jej wykorzystania [Gaczek 2009, s. 28, 29].

Kahin i Foray [2006, s. 18-22] opisują gospodarkę opartą na wiedzy za pomocą greckiej świątyni $^{8}$ (rysunek 1). Pierwszym, podstawowym elementem zaprezentowanego, obrazowego przedstawienia gospodarki opartej na wiedzy są fundamenty ekonomiczne ${ }^{9}$, które wspomniani autorzy definiują jako szereg czynników [Kahin i Foray 2006, s. 18-22]:

- stabilne polityki makroekonomiczne, które umożliwiają planowanie długoterminowe,

- dobrze funkcjonujące rynki produktowe i kapitałowe,

- efektywna polityka edukacyjna, dzięki której mniej wyedukowani członkowie społeczności mogą posiąść odpowiednie umiejętności; ma to na celu uniknięcie wykluczenia cyfrowego (knowledge divide),

- odpowiednie regulacje dotyczące konkurencyjności, które obniżają koszty technologiczne,

- liberalizacja polityki telekomunikacyjnej,

- otwarcie na handel i zagraniczne inwestycje bezpośrednie, co umożliwia napływ nowych pomysłów i idei.

\footnotetext{
${ }^{8}$ Bardzo podobnego podziału dokonuje Kukliński twierdząc, że podczas rozwoju gospodarki opartej na wiedzy należy uwzględnić cztery współzależne elementy. Pierwszym jest stworzenie odpowiedniego systemu, efektywnie promującego wykorzystanie wiedzy we wszystkich dziedzinach życia gospodarczego. Następnym elementem jest dążenie do zbudowania społeczeństwa ludzi dobrze wykształconych, potrafiących tworzyć nową i wykorzystywać istniejącą wiedzę. Niesie to za sobą potrzebę stworzenia dostępnego systemu edukacji wraz możliwościami przekwalifikowania się w dowolnym momencie. Trzecim elementem jest budowa infrastruktury informacyjnej, która jest podstawą przepływu wiedzy w gospodarce. Ostatnim jest budowa systemów innowacyjnych skupiających szereg różnych podmiotów takich, jak m.in. uczelnie wyższe, ośrodki badawcze i inne organizacje, które mogą czerpać z globalnych zasobów wiedzy, rozwijać ją, ale także adaptować do potrzeb lokalnych [Kukliński 2003, s. 14-15].

${ }^{9}$ Tę opinię podzielają Nijkamp i Siedschlag, którzy uważają, że fundamenty ekonomiczne wpływają w znaczący sposób na możliwości gospodarki w zakresie kreacji oraz wykorzystywania wiedzy [Nijkamp i Siedschlag 2011, s. 19].
} 


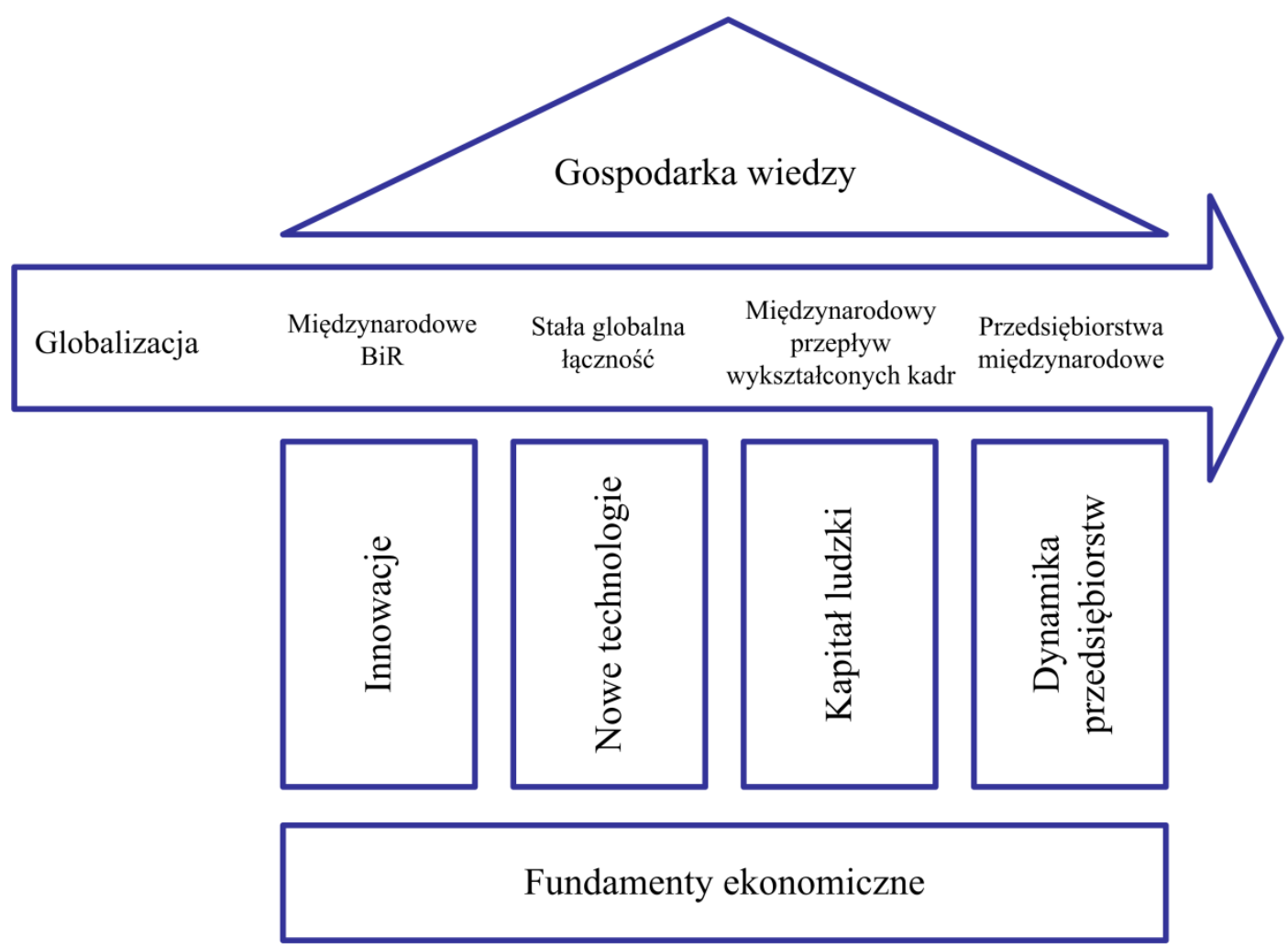

Rysunek 1. Czynniki kształtujące gospodarkę wiedzy.

Źródło: wersja zmodyfikowana rysunku z [Kahin i Foray 2006, s. 18].

Następnym elementem gospodarki opartej na wiedzy, są cztery filary reprezentujące różne jej sfery, które wymagają podjęcia odpowiednich działań. Pierwszym z nich jest innowacyjność. Jest ona ważnym elementem przewagi konkurencyjnej $\mathrm{w}$ dzisiejszej gospodarce. Przedsiębiorstwa powinny kreować wiedzę we własnym zakresie, lecz ważnym jest także, aby wykorzystywać inne metody jej pozyskiwania np. poprzez kontakty z uczelniami, alianse lub fuzje i przejęcia. Drugim filarem są nowoczesne technologie informacyjne i komunikacyjne ${ }^{10}$, które są podstawą działania nowoczesnej gospodarki. Bank Rezerwy Federalnej w Nowym Jorku przeprowadził badania, z których wynika, że największy skok produktywności zaistniał w sektorach gospodarki, w których technologie informacyjne i komunikacyjne są najintensywniej używane. Trzecim filarem jest kapitał ludzki, czyli umiejętności, wiedza i kompetencje pracowników. Znaczenie zasobów ludzkich jest kluczowe w procesie tworzenia gospodarki opartej na wiedzy z kilku względów. Po pierwsze, sukces przedsiębiorstwa jest w dużej mierze uzależniony od produktywności pracowników. Po drugie, oba wcześniej wspomniane filary nie mają większego znaczenia bez wysoko

\footnotetext{
${ }^{10}$ Nijkamp i Siedschlag podkreślają, że dziś dostęp do informacji jest nieodłącznie związany z technologiami informacyjnymi i komunikacyjnymi. Umożliwiają one transmisje informacji na duże odległości, lecz niezbędna jest odpowiednia infrastruktura [Nijkamp i Siedschlag 2011, s. 18].
} 
wykwalifikowanych zasobów ludzkich potrafiących je odpowiednio wykorzystywać ${ }^{11}$. W ostatnich dziesięcioleciach w krajach OECD udział populacji, która posiada przynajmniej wykształcenie gimnazjalne znacząco wzrósł. Było to spowodowane coraz większym zapotrzebowaniem na wykształconą kadrę pracowniczą. Ostatnim filarem zaprezentowanym na rysunku 1 jest dynamika przedsiębiorstw. Pojęciem tym określa się zmienność podmiotów na rynku przedsiębiorstw. Znaczenie tego czynnika jest uwarunkowane faktem, że nowopowstałe podmioty są często w dużej mierze źródłem innowacji. Ponadto, z badań prowadzonych w Stanach Zjednoczonych i innych krajach OECD wynika, że to właśnie one najczęściej inwestują duże środki w działalność badawczo-rozwojową oraz rejestrują dużą liczbę patentów. Zmienność podmiotów na rynku przedsiębiorstw pokazuje ponadto elastyczność, jaka panuje w danej gospodarce, łatwość zmian miejsca zaangażowania zasobów oraz dopasowania struktury produkcji do zmieniających się potrzeb nabywców. Innym ważnym czynnikiem mającym duże znaczenie w gospodarce wiedzy jest globalizacja, która wpływa na każdy z wcześniej omówionych filarów. Sprawia ona, że prace badawczorozwojowe mogą być prowadzone w porozumieniu z innymi krajami lub nawet na zlecenie w innych państwach, nowe technologie umożliwiają stałą łączność z każdym miejscem na świecie, umniejszając znaczenie czynnika lokalizacji, dając dostęp do niespotykanych dotąd zasobów. Współpraca między osobami odległymi geograficznie jest łatwiejsza niż kiedykolwiek [Kahin i Foray 2006, s. 18-22]. Dodatkowo, globalizacja zintensyfikowała rozwój przedsiębiorstw międzynarodowych. Wzbogacają one zasób firm istniejący w poszczególnych krajach, a także ułatwiają i usprawniają międzynarodowy przepływ wiedzy.

Zadaniem autora pracy, ważnym jest podkreślenie, że działania w wymienionych sferach będą skuteczne wyłącznie w momencie istnienia stabilnych ekonomicznych fundamentów $^{12}$. Potrzebna jest odpowiednia, kompleksowa polityka, która będzie dostosowana do specyficznych uwarunkowań istniejących w danym kraju ${ }^{13}$, obejmująca wszystkie cztery wymienione na rysunku sfery [Kahin i Foray 2006, s. 18].

\footnotetext{
11 Podstawowa edukacja jest ważna, gdyż zwiększa potencjał osób w zakresi uczenia się oraz umożliwia wykorzystywanie informacji. Znaczenie wyższej edukacji jest związane z produkcją nowej wiedzy, a także odpowiednią adaptacją oraz innowacyjnym zastosowaniem istniejącej już wiedzy. Odpowiednio wyedukowane społeczeństwo jest biegłe technologicznie, co zwiększa popyt na różnego rodzaju zaawansowane dobra i umożliwia rozwój firmom w tym sektorze [Nijkamp i Siedschlag 2011, s. 18].

12 Tę opinię podzielają Nijkamp i Siedschlag, którzy uważają, że fundamenty ekonomiczne wpływają w znaczący sposób na możliwości gospodarki w zakresie kreacji oraz wykorzystywania wiedzy [Nijkamp i Siedschlag 2011, s. 19].

${ }^{13}$ Sundać i Krmpotić także podkreślają, że budowanie i rozwój gospodarki opartej na wiedzy jest procesem bardzo zindywidualizowanym i zależy w dużej mierze od charakterystyk kraju czy regionu. Podejmowane w tym
} 
Podobnie jak wcześniej wspomniani Kahin i Foray także Dunning [2000, s. 10] podkreśla efekt wzrostu znaczenia kooperacji między przedsiębiorstwami w gospodarce opartej na wiedzy. Tego samego zdania jest Rooney, który zaznacza, że jedną z najważniejszych cech gospodarki opartej na wiedzy jest gwałtowny rozwój współpracy sieciowej między przedsiębiorstwami. Budowanie szerokiej sieci kontaktów stało się kluczowym elementem strategii przedsiębiorstw. Organizacje coraz częściej przyjmują strukturę sieciową lub nawet formę luźnych koalicji pomiędzy pojedynczymi jednostkami. Godnym podkreślenia jest fakt, że organizacje sieciowe stoją w sprzeczności z hierarchiami, które były podstawą tworzenia organizacji starego typu. Organizacje sieciowe są zdecydowanie bardziej elastyczne i do pewnego stopnia nawet chaotyczne, lecz jest to wyraz dostosowania do niepewnego, zmiennego i często nieprzewidywalnego środowiska gospodarki opartej na wiedzy. Ponadto, sieci są zdecydowanie bardziej efektywne w kontekście alokacji zasobów informacyjnych w porównaniu z hierarchiami [Rooney, Hearn i Ninan 2005, s. 167-171].

Głównym motorem gospodarki wiedzy jest popyt na wyrafinowane dobra o wysokiej wartości dodanej, który zgłaszają coraz lepiej wyedukowani i wymagający konsumenci oraz przedsiębiorstwa. Implikuje to potrzebę zmian priorytetów inwestycyjnych przedsiębiorstw w kierunku wytwarzania oraz wykorzystania wiedzy oraz innych aktywów niematerialnych, jako podstawy przewagi konkurencyjnej [Brinkley 2008, s. 5]. Powell i Snellman podkreślają, że w omawianych warunkach $\mathrm{w}$ procesie gospodarowania większe znaczenie ma wiedza i możliwości intelektualne, niż praca oraz zasoby naturalne ${ }^{14}$ [Powell i Snellman 2004, s. 199]. Firmy, zespoły, a także pojedynczy pracownicy muszą rozwijać określone umiejętności i kompetencje, aby być w stanie uczestniczyć w życiu gospodarczym, które jest obecnie w dużym stopniu oparte na efektywności działań związanych z wiedzą [Woodall, Lee i Stewart 2004, s. 165]. Gospodarka oparta na wiedzy charakteryzuje się odejściem od produkcji dóbr fizycznych w kierunku koncentracji na usługach, które z kolei opierają się na wysoko wykwalifikowanych zasobach ludzkich oraz firmach technologicznych [Neef, Siesfeld i Cefola 1998, s. 4]. Stąd jak zaznacza Runiewicz-Wardyn [2008, s. 7] bardzo istotnymi elementami dla gospodarki opartej na wiedzy są wydatki na badania i rozwój, edukację, technologie informacyjne i komunikacyjne, a także odpowiednia polityka

kierunku działania powinny być uzależnione od poziomu rozwoju gospodarczego danego obszaru [Sundać i Krmpotić 2011, s. 105-141].

${ }^{14}$ Niektórzy autorzy są nawet zdania, iż wiedza stanowi „uniwersalny substytut” [Śmigielska 2013, s. 36]. Zdaniem autora pracy jest to stwierdzenie dość ryzykowne, lecz po dokonaniu określonych założeń możliwe do obronienia. 
i instytucje, które skłaniają do implementacji istniejącej oraz nowej wiedzy. Ważną cechą gospodarki opartej na wiedzy jest także wysoka konkurencja. Hsu, Lin i Wei podkreślają, że daje ona napęd innowacyjnym wysiłkom przedsiębiorstw. Stąd bardzo istotnym zadaniem dla polityków jest stworzenie odpowiedniego ładu prawnego, który będzie wspierał uczciwą konkurencję między podmiotami [Hsu, Lin i Wei 2008, s. 826-832].

Inną ważną charakterystyką gospodarki opartej na wiedzy jest ciągła zmienność. Szybki rozwój technologiczny implikuje powstawanie coraz to nowszych produktów, pojawiają się nowego rodzaju przemysły [Powell i Snellman 2004, s. 199-220]. Cecha ta przejawia się także we wzroście znaczenia firm produkujących wiedzę i marginalizacją tych działających w branżach tradycyjnych. Zmienność dotyczy także podmiotów obecnych na rynku. Przykładowo w słynnym rankingu „Fortune 500” w 1955 większość stanowiły firmy opierające swoją działalność na zasobach naturalnych. Dziś 70 procent z nich już nie istnieje. Działalność gospodarcza oparta na wiedzy stale tworzy także nowe rynki. Zwiększa ona swój zakres poprzez kreację innowacji, nie będąc w dużej mierze ograniczona przez materialne czynniki produkcji, które były istotną przeszkodą w gospodarce tradycyjnej. Dobrym przykładem tego zjawiska jest przemysł informatyczny, który czerpie 70 procent swoich przychodów z produktów i usług, które dwa lata wcześniej w ogóle nie istniały [Neef, Siesfeld i Cefola 1998, s. 7].

Obecnie nie dysponujemy miarodajnymi narzędziami, które mogłyby zmierzyć rolę i znaczenie wiedzy w danej gospodarce. W literaturze możemy jednak spotkać narzędzia, które mogą dać nam choćby orientacyjny pogląd w tej kwestii [Welfe 2007, s. 9]. Najistotniejszym problemem jest fakt, że duża część zasobów wiedzy nie jest odzwierciedlona w oficjalnych statystykach i ma charakter niemierzalny. W szczególności wiedza ukryta, uważana przez wielu autorów za najważniejszą wiedzę podmiotów i jednostek jest całkowicie niemierzalna. Dodatkowym problemem jest powszechny brak zgody, co do jednej, dominującej definicji wiedzy. W takiej sytuacji często poszukuje się zmiennych, które są pozytywnie skorelowane z poziomem wiedzy, przy czym możliwy jest ich pomiar. Są one określane jako zmienne symptomatyczne. Takimi zmiennymi są m.in. poziom wykształcenia społeczeństwa, udział wydatków na naukę jako udział w PKB lub liczba zarejestrowanych patentów na np. milion mieszkańców. Takie podejście, mierzenie objawów wiedzy zamiast jej właściwego zasobu, jest zdaniem niektórych autorów wystarczające [Rosati 2007, s. 23-24]. Mimo to Nijkamp podkreśla, że wykorzystanie miar związanych z PKB ma znaczącą liczbę wad. Przede wszystkim tego rodzaju miary nie biorą pod uwagę korzystnych efektów zewnętrznych, które mogą wyniknąć z działań w zakresie wiedzy i edukacji. Po drugie, PKB 
mierzy tylko transakcje finansowe całkowicie pomijając procesy budowania zasobu wiedzy poza systemem rynkowym [Nijkamp i Siedschlag 2011, s. 19, 20]. Podobne wątpliwości ma Gaczek, który podkreśla, że określenie procesu tworzenia wiedzy w gospodarce np. jako funkcji produkcji, której surowcem są środki finansowe przeznaczane na prace badawczorozwojowe prowadzi do problemów związanych z określeniem efektywności tego rodzaju działania, gdyż efekty całego procesu trudno jest zmierzyć. Wykorzystując do pomiaru tego zjawiska wcześniej wspomniane zmienne symptomatyczne możemy poznać tylko liczbę wynikłych z danego procesu patentów, wynalazków czy publikacji naukowych [Gaczek 2009, s. 20-21]. Problemem jednak pozostaje ich jakość. Przykładowo w Chinach, w celu zachęcenia firm do inwestycji w działania badawczo-rozwojowe i zwiększania liczby rejestrowanych patentów stosuje się znaczące ulgi podatkowe, które są efektywne w momencie zgłoszenia przez przedsiębiorstwo określonej liczby patentów. Niestety, prowadzi to do wypaczenia całego procesu, gdyż firmy w pogoni za ulgami są skłonne do patentowania wszystkiego, co możliwe. Efektem tego są częste wątpliwości co do jakości oraz innowacyjności zgłaszanych do opatentowania rozwiązań [Kowalik 2011, s. 76-77]. Jest to przykład trudności pomiaru całego procesu kreacji wiedzy, którego wyniki mogą być do pewnego stopnia oceniane jak na razie wyłącznie w sposób subiektywny.

Problemem w przypadku traktowania wiedzy jako czynnika wytwórczego jest także jej wyjątkowa charakterystyka, zupełnie odmienna od tradycyjnych czynników wytwórczych. Powiększanie jej zasobu często nie następuje w sposób liniowy tylko zazwyczaj skokowy. Podobnie jej wykorzystanie nie jest liniowe - do zwiększenia skali produkcji nie potrzebujemy w ogólnym sensie większej ilości wiedzy, mimo to w gospodarce opartej na wiedzy do utrzymania poziomu konkurencyjności w czasie (i w konsekwencji do utrzymania produkcji) potrzebujemy coraz większych ilości tego zasobu. Fakt ten jest zdecydowanie mniej namacalny niż w przypadku tradycyjnych czynników produkcji, ale w dzisiejszym świecie jest coraz bardziej zauważalny.

W omawianym kontekście należy się także przyjrzeć zależnościom pomiędzy poziomem rozwoju gospodarczego kraju, a zasobem wiedzy. Można w tym przypadku dostrzec pozytywną korelację pomiędzy nimi - zasób wiedzy oraz stopień jego wykorzystania jest wyższy w zamożniejszych krajach. Dokładniejsze przyjrzenie się zależnościom pomiędzy omawianymi zmiennymi przedstawia tę relację w nieco innym świetle, nie jest ona aż tak oczywista, lecz zdecydowanie bardziej złożona [Rosati 2007, s. 23]. W bardzo dużym uproszczeniu można powiedzieć, że zasób wiedzy wpływa na poziom rozwoju gospodarczego na dwa sposoby. $Z$ jednej strony umożliwia udoskonalanie procesu produkcji lub świadczenia 
usług, dzięki czemu proces ten staje się bardziej efektywny. Z drugiej strony, zasób wiedzy wpływa na same produkty lub usługi, gdyż umożliwia zarówno tworzenie nowych jak i udoskonalanie już istniejących. Źródłem powstawania nowej wiedzy jest tak zwany sektor wiedzy. Nie jest on dokładnie określony, gdyż jego wyodrębnienie jest bardzo problematyczne. Najczęściej uznaje się, że obejmuje on dwa rodzaje obszarów - badań naukowych i rozwoju oraz edukacji. Podział ten niestety nie jest wyczerpujący, gdyż bardzo duża część wiedzy jest tworzona także w innych obszarach. Każde przedsiębiorstwo w mniejszym lub większym stopniu tworzy wiedzę [Rosati 2007, s. 25] (Rysunek 2).

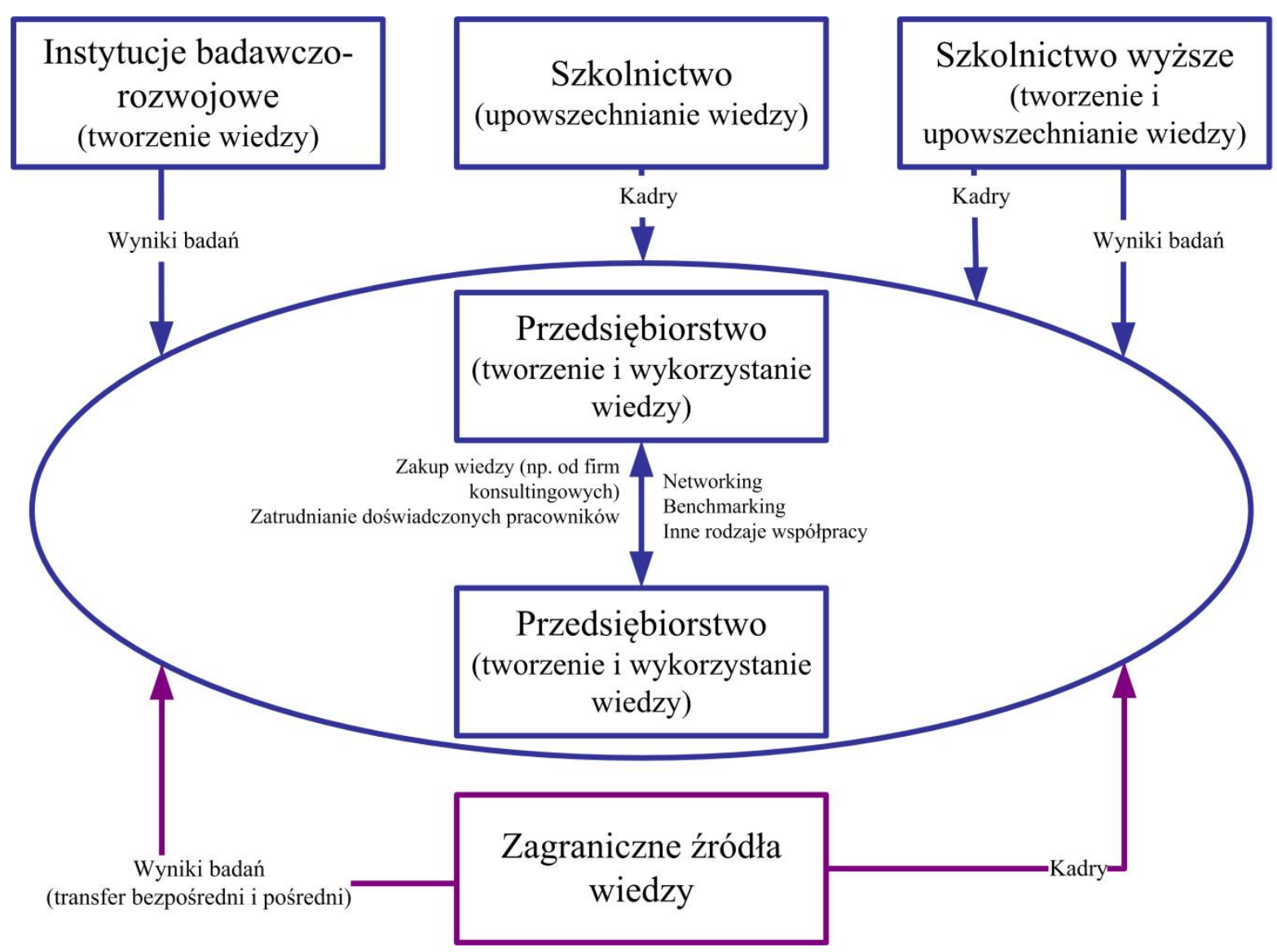

Rysunek 2. Ogólny schemat tworzenia, przepływu i wykorzystania wiedzy w gospodarce. Źródło: opracowanie własne na podstawie Rosati [2007, s. 32-33] oraz Welfe [2007, s. 9].

Proces kreacji wiedzy nie jest wyłącznie ograniczony do istniejących w przedsiębiorstwach działów badań i rozwoju. Nowa wiedza, choć może nie tak intensywnie, jest tworzona w każdym miejscu przedsiębiorstwa, a co istotne powstaje ona często przypadkiem i nierzadko nie jest odpowiednio zachowywana i w konsekwencji bywa tracona. Ostateczny wpływ poziomu procesów związanych $\mathrm{z}$ wiedzą na poziom wzrostu gospodarczego jest 
uzależniony także od systemowych procesów upowszechniania wiedzy w gospodarce [Rosati 2007, s. 25]. Jest to kompleksowy, wewnętrznie zależny system, który jest tak silny jak najsłabsze jego ogniwo.

Pomimo znaczących wad mierników gospodarki wiedzy opartych na zmiennych symptomatycznych zostało na tej podstawie stworzonych wiele wskaźników. Jest to spowodowane faktem, że są one jedynym w miarę skutecznym narzędziem dającym pogląd o poziomie gospodarki opartej na wiedzy w danym państwie czy regionie. Przykładowo Komisja Europejska w celu pomiaru gospodarki opartej na wiedzy stworzyła dwa złożone wskaźniki. Kryteria brane pod uwagę przez pierwszy z nich są związane najważniejszymi inwestycjami w gospodarce opartej na wiedzy takimi, jak np. zatrudnienie w nauce czy wydatki na badania i rozwój. Drugi z nich ocenia wydajność transformacji danej gospodarki do gospodarki opartej na wiedzy poprzez ocenę wyników produkcji wiedzy mierzonych przez liczbę zarejestrowanych patentów i wydanych publikacji naukowych [Nijkamp i Siedschlag 2011, s. 20]. Bardziej znaczące są w tym zakresie dokonania Banku Światowego. Dla celów związanych z programem Wiedza dla Rozwoju (Knowledge for Development Program K4D) stworzył on odpowiednią Metodologię Oceny Wiedzy (Knowledge Assessment Methodology - KAM). Ma ona na celu identyfikację szans i zagrożeń poszczególnych krajów lub regionów na drodze do stworzenia gospodarki opartej na wiedzy oraz wskazanie politykom dziedzin, które wymagają szczególnego zainteresowania. Indeks jest uaktualniany co roku. Metodologia Oceny Wiedzy Banku Światowego składa się z szeregu indeksów. Najczęściej cytowanym z nich jest Wskaźnik Gospodarki Wiedzy (Knowledge Economy Index - KEI), który jest ogólną miarą poziomu przygotowania danej gospodarki lub regionu do gospodarki wiedzy. Przedstawia on uśredniony poziom gospodarki mierzony przez 12 rodzajów zmiennych, które pochodzą z czterech filarów gospodarki wiedzy. Wartość indeksu stanowi znormalizowana średnia arytmetyczna wartości wspomnianych zmiennych, których zakres stanowi przestrzeń od 0 do 10 (wartość 10 jest maksymalna, zaś 0 jest wartością minimalną, którą może uzyskać dana gospodarka). Drugim, pod kątem popularności indeksem z omawianej grupy jest Indeks Wiedzy (Knowledge Index - KI). Różnica pomiędzy nim, a Indeksem Gospodarki Wiedzy polega na tym, że korzysta on tylko ze zmiennych pochodzących $\mathrm{z}$ trzech filarów: edukacja, infrastruktura informacyjna oraz innowacje [World Bank Institute 2008, s. 3-5]. Także OECD rozwinęło swój własny, złożony miernik inwestycji w wiedzę. Polega on na badaniu udziału szeregu wydatków w PKB, w skład, których wchodzą inwestycje w badania i rozwój, technologie informacyjne, oraz wyższą edukację [Brinkley i Lee 2007, s. 12]. 
Znaczenie innowacji dla gospodarki opartej na wiedzy jest tak duże, iż często w literaturze wykorzystuje się indeksy innowacyjności jako wskaźniki poziomu zaawansowania gospodarki opartej na wiedzy. Innowacje są namacalnym efektem inwestycji w procesy związane $\mathrm{z}$ wiedzą. W literaturze można odnaleźć trzy główne wskaźniki innowacyjności gospodarki, które mogą do pewnego stopnia zmierzyć zaawansowanie gospodarki w zakresie wiedzy. Pierwszym z nich jest Indeks Innowacyjności (Innovation Index) stworzony przez Portera i Sterna. Bierze on pod uwage m.in. wydatki na badania i rozwój, zatrudnienie w nauce, wydatki na edukację oraz siłę ochrony własności intelektualnej ${ }^{15}$. Kolejnym wskaźnikiem jest Sumaryczny Indeks Innowacyjność (Summary Innovation Index - SII). Korzysta on $\mathrm{z}$ oficjalnych statystyk Eurostatu $\mathrm{w}$ celu pomiaru możliwości innowacyjnych krajów Unii Europejskiej. Analizuje on dwadzieścia zmiennych w obszarach m.in. takich jak kreacja wiedzy, zasoby ludzkie, finansowanie innowacji, a także transmisja i wdrażanie nowej wiedzy. Ostatnim wskaźnikiem w omawianej kategorii jest stworzony przez Freudenberga Indeks Wydajności Innowacyjnej (Index of Innovation Pefromance - IIP). Korzysta on danych z trzech obszarów: kreacja nowej wiedzy (m.in. wydajność w zakresie badań i rozwoju, udział wydatków na badania w PKB, liczba obronionych doktoratów), powiązania pomiędzy biznesem a nauką (m.in. liczba publikacji i patentów) oraz innowacja przemysłowa (m.in. liczba naukowców i firm implementujących nową wiedzę) [Nijkamp i Siedschlag 2011, s. 20].

Interesującym miernikiem, choć zdaniem autora pracy także niedoskonałym, zaawansowania gospodarki opartej na wiedzy mogą być także wskaźniki postępu technologicznego. Jednym $\mathrm{z}$ takich wskaźników jest Indeks Zaawansowania Technologicznego (Technological Achievement Index - TAI), który ma na celu zmierzenie wydajności tworzenia i rozprzestrzeniania technologii $\mathrm{w}$ gospodarce. Korzysta on $\mathrm{z}$ ośmiu rodzajów danych m.in. tworzenie technologii (liczba patentów, licencji), rozpowszechnianie nowych innowacji, rozprzestrzenianie starych innowacji, oraz wykształcenie zasobów ludzkich. Kolejnym wskaźnikiem w tej kategorii jest Generalny Wskaźnik Nauki i Technologii (General Indicator of Science and Technology - GIST). Został on stworzony w celu oceny i międzynarodowego porównania japońskiej nauki i technologii. Indeks bierze pod uwagę 13 typów zmiennych [Nijkamp i Siedschlag 2011, s. 21].

\footnotetext{
${ }^{15}$ Brinkley podkreśla znaczenie tego czynnika w rozwoju gospodarki opartej na wiedzy zaznaczając, że polityka dotycząca ochrony własności intelektualnej w danym państwie lub regionie musi być dostatecznie silna, aby zachęcać podmioty do inwestycji w wiedzę oraz innowacje procesowe czy produktowe. Polityka ta musi być jednak wyważona, gdyż nie może także utrudniać dyfuzji wiedzy [Brinkley 2006, s. 5].
} 
Badania nad pomiarem gospodarki opartej na wiedzy, szczególnie w aspekcie wzrostu gospodarczego, przykładają dużą wagę do zagadnienia absorpcji wiedzy. Objawia się ona szczególnie w kontekście procesu produkcji poprzez m.in. zmniejszenie zużycia środków trwałych oraz kapitału pracy, a także w produkcji nowego rodzaju wyrobów oraz w zarządzaniu. Innymi istotnymi zagadnieniami w pomiarze gospodarki opartej na wiedzy są wytwarzanie wiedzy oraz jej transfer. Efekty wytwarzania wiedzy mogą być widoczne m.in. w formie licencji czy patentów. Bardzo duże znaczenie, szczególnie dla mniej rozwiniętych krajów, ma odpowiedni transfer wiedzy. Możemy przy tym wyróżnić różnego rodzaju metody transferu. Metody bezpośrednie - poprzez rożnego rodzaju nośniki informacji, oraz pośrednie - związane z importem np. materiałów czy dóbr inwestycyjnych zawierających nowe technologie. W kontekście transferu wiedzy duże znaczenie mają także procesy efektywnego magazynowania wiedzy w taki sposób, aby była ona odpowiednio szybko dostępna w razie potrzeby. Najczęściej jest to robione w formie baz wiedzy tworzonych przez różnego rodzaju podmioty, które gwarantują jej zachowanie oraz efektywny dostęp [Welfe 2007, s. 9].

Inną próbą pomiaru poziomu gospodarki opartej na wiedzy jest zestawienie wzrostu nakładu środków finansowych na badania i rozwój oraz edukację w porównaniu ze wzrostem nakładów inwestycyjnych na środki trwałe [Welfe 2007, s. 9]. Niestety, podobnie jak w przypadku pokrewnych wskaźników jego niedoskonałość tkwi w problemie odpowiedniego spożytkowania środków przeznaczanych na badania i rozwój czy edukację. Wyższe finansowanie wymienionych dziedzin niekoniecznie musi iść w parze z lepszymi wynikami dofinansowanych jednostek. Efektywność wydatkowania środków w przypadku tej miary jest pomijana.

W przypadku badania poziomu zaawansowania gospodarki opartej na wiedzy bardzo ważnym pojęciem jest granica technologiczna (technological frontier). Tym mianem określane mogą być przedsiębiorstwa, sektory gospodarki lub kraje, które wykorzystują najnowocześniejsze oraz najbardziej zaawansowane w danym czasie technologie. Uznaje się, że kraje, które są najbliżej granicy technologicznej wykorzystują wiedzę w największym stopniu [Rosati 2007, s. 22-23]. Jednak w przypadku krajów poniżej granicy technologicznej duże znaczenie powinno mieć wykorzystanie zarówno źródeł wewnętrznych - kreacji wiedzy, jak i zewnętrznych - absorpcji wiedzy zagranicznej [Gaczek 2009, s. 31]. Dobrym przykładem efektywnego wykorzystania zagranicznych transferów kapitału, ale także i wiedzy jest przykład Chin. Niski poziom rozwoju gospodarczego tego kraju, oraz zacofanie technologiczne umożliwiły osiągnięcie przez Chiny w wyniku takiego transferu bardzo wysokiego poziomu wzrostu gospodarczego. W dużym stopniu jest to zasługa dobrego 
wykorzystania transferów technologii i wiedzy ze zdecydowanie lepiej rozwiniętych części świata. Mając na uwadze zmniejszanie luki technologicznej między Chinami a krajami zachodu i związane z tym coraz mniejsze możliwości importu technologii, Chińczycy coraz intensywniej inwestują w rozwój technologii we własnym zakresie, co umożliwi im podtrzymanie opartego na wiedzy wzrostu gospodarczego. Można także zauważyć wysoki poziom inwestycji w edukację przez obywateli tego kraju - można ich spotkać na większości wyższych uczelni starego kontynentu. Działania tego typu są bardzo istotne, gdyż w miarę zbliżania się do granicy technologicznej, utrzymanie gospodarki opartej na wiedzy jest coraz bardziej związane z kreacją wiedzy w krajowych instytucjach badawczo rozwojowych oraz na uczelniach wyższych, a także stymulacją jej kreacji w przedsiębiorstwach i jej popularyzacją poprzez różnorodne przedsięwzięcia edukacyjne. W celu utrzymania wzrostu potrzebne jest prawdziwe społeczeństwo gospodarki opartej na wiedzy, które charakteryzuje się skłonnością do permanentnej nauki i rozwoju oraz co za tym idzie wysokim poziomem wykształcenia [Gaczek 2009, s. 31].

Coraz bardziej widoczny zwrot gospodarek wielu krajów w kierunku gospodarek wiedzy poza szeregiem korzyści niesie za sobą także pewne wyzwania, którym trzeba sprostać, aby omawiana transformacja przebiegała w odpowiednim kierunku [Cook 2002, s. 196-200]. Częstym problemem są braki w zasobie wiedzy, które są przyczyną niepowodzeń w kształtowaniu przewagi konkurencyjnej regionów. W kontekście społecznym braki w zasobie wiedzy mogą prowadzić w dzisiejszych czasach nawet do wykluczenia informacyjnego [Gaczek 2009, s. 19]. Powoduje to pogłębiające się różnice majątkowe pomiędzy określonymi regionami oraz migrację populacji do większych miast tworząc $\mathrm{z}$ nich swoiste klastry. Potrzebne są więc odpowiednie programy rządowe oraz zachęty do inwestycji w mniej rozwiniętych regionach. Podstawą gospodarki wiedzy jest ciągła kreacja nowych firm, stąd nieodzownym jest stworzenie skutecznego systemu wspierania powstawania nowych przedsiębiorstw zapewniającego im także odpowiednie zasoby finansowe. Odpowiednie inwestycje muszą być poczynione pod kątem zasobów ludzkich, gdyż liczba wysoko wykwalifikowanych specjalistów jest dziś niewystarczająca. Kluczowymi podmiotami umożliwiającym działanie i rozwój gospodarki wiedzy są także inwestycje wysokiego ryzyka w nowe, perspektywiczne firmy (venture capital) oraz inkubatory przedsiębiorczości. Muszą one zwiększyć swoją efektywność zapewniając poza środkami finansowymi wsparcie w zakresie wiedzy o zarządzaniu, gdyż jak wynika z badań, w dzisiejszych firmach intensywnie wykorzystujących technologie jest ona najbardziej potrzebna [Cook 2002, s. 196-200]. Przykładem skuteczności takiego działania jest firma 
Google. Stworzyli ją dwaj wybitni informatycy - Sergey Brin i Larry Page. Jednak na sukces firmy Google duży wpływ miał także Eric Schimdt. Jest on specjalistą od zarządzania, który potrafił odpowiednio sprzedać tworzone przez firmę innowacje i odpowiednio pokierować jej rozwojem. Umożliwił on twórcom większą koncentrację na czynnościach, które znają i lubią, co w konsekwencji przyniosło bardzo pozytywne rezultaty.

Dużym problemem w gospodarce opartej na wiedzy jest wycena aktywów firm. Dominującą ich część w tego rodzaju gospodarce stanowią aktywa intelektualne, które najczęściej są najważniejszym elementem w procesie tworzenia przez firmę wartości dodanej. Dodatkowo, systemy księgowe nie są w stanie pomóc w rozwiązaniu tego problemu, gdyż umożliwiają wycenę aktywów intelektualnych tylko w ściśle określonych okolicznościach (np.w przypadku ich zakupu). Sytuacja ta stwarza problem wysokiego ryzyka inwestycyjnego, gdyż inwestorzy nie są najczęściej w stanie ze stuprocentową pewnością wycenić wartości poszczególnych podmiotów. Jest to wysoce problematyczne, gdyż to właśnie inwestycje wysokiego ryzyka w nowe niesprawdzone pomysły i technologie są motorem gospodarki opartej na wiedzy [Dobija i Rosolińska 2008, s. 80].

\subsection{Przewaga konkurencyjna przedsiębiorstwa}

Zagadnienie przewagi konkurencyjnej przedsiębiorstwa od dziesięcioleci wzbudza wiele emocji zarówno wśród naukowców, jak i praktyków gospodarczych. Jak podkreśla Adamik, wypracowanie stabilnej przewagi konkurencyjnej jest najważniejszym zadaniem strategicznym każdego przedsiębiorstwa [Adamik 2008, s. 44]. W celu dokładniejszego omówienia tego problemu należy jednak wcześniej dokładniej sprecyzować szereg pojęć. Podstawową kategorią w tym zakresie wydaje się być zjawisko konkurencji. Źródeł konkurencji gospodarczej należy doszukiwać się w konflikcie interesów pomiędzy podmiotami - uczestnikami gry rynkowej ${ }^{16}$ (najczęściej pomiędzy przedsiębiorstwami), dążącymi do pozyskania określonych, ale ograniczonych wartości (np. popyt), które znajdują się w otoczeniu tych podmiotów. Mantura [2009, s. 22] definiuje konkurencję jako prowadzenie działań, przez co najmniej dwa podmioty, które wynikają z antagonizmu ich celów. Wielu ekspertów postrzega jednak to pojęcie jako ekonomiczną kategorię podstawową, która nie wymaga definiowania [Adamkiewicz-Drwiłło 2010, s. 18]. Zjawisko to ma duże znaczenie dla postępu, a także rozwoju cywilizacyjnego. Konkurencja wraz systemem potrzeb człowieka powinna być traktowana jako ważna siła napędowa gospodarki,

\footnotetext{
${ }^{16}$ Stosunki przedsiębiorstwa $\mathrm{z}$ innymi podmiotami na rynku (konkurentami) można określić jako konkurencyjne, przetargowe z dostawcami i klientami, oraz podporządkowania z podmiotami władzy [Mantura 2009, s. 22].
} 
oraz być odpowiednio stymulowana i chroniona. Ważną charakterystyką zjawiska, jakim jest konkurencja jest jego niejednorodność, stąd nie powinno być ono rozpatrywane dychotomicznie (w relacji występuje lub nie występuje). Istnienie konkurencji rynkowej jest podstawą do rozważań dotyczących konkurencyjności przedsiębiorstw [Mantura 2009, s. 21, $23,24]$.

Pojęcie konkurencyjności było na początku swojego istnienia używane w kontekście makroekonomicznym. Stworzono je jako abstrakcyjny rzeczownik od słowa konkurować, żeby podkreślić określoną cechę danej gospodarki [Świtalski 2005, s. 165]. Szerokie zainteresowanie tym zagadnieniem, zarówno w wymiarze mikro-, jak i makroekonomicznym pojawiło się w latach 70-tych XX wieku. W dzisiejszych czasach pojęcie to jest nieodłączną częścią analiz rynkowych. Termin ten stosuje się w odniesieniu do poszczególnych podmiotów rynkowych, sektorów, a także całych gospodarek. Należy zaznaczyć, że analiza konkurencyjności wymaga istnienia co najmniej dwóch podmiotów i jest ona określoną właściwością każdego przedsiębiorstwa [Adamkiewicz-Drwiłło 2010, s. 16, 67, 80]. Większość autorów postrzega konkurencyjność, podobnie jak w przypadku konkurencji, jako termin niewymagający definiowania [Świtalski 2005, s. 154]. Można jednak spotkać próby precyzyjnego określenia tego terminu. Mantura postrzega konkurencyjność jako cechę przedsiębiorstwa, która określa jego zdolność konkurowania, a także osiągania określonej pozycji konkurencyjnej [Mantura 2009, s. 25]. Przedstawiona definicja wykorzystuje w swojej treści kolejny istotny termin - pozycja konkurencyjna przedsiębiorstwa, którą można określić jako miejsce danego podmiotu w uporządkowanym szeregu konkurencyjności, przy czym pojęcie to ma charakter statyczny [Adamkiewicz-Drwiłło 2010, s. 80]. Należy również zaznaczyć, że konkurencyjność przedsiębiorstwa jest cechą złożoną i stopniowalną. Jej złożoność polega na możliwości jej rozłożenia na szereg elementów składowych, które mogą być badane, opisywane i mierzone. Stopniowalność konkurencyjności polega na możliwości wyznaczania poziomów tej cechy na podstawie odpowiedniej analizy i syntezy poziomów cech składowych [Mantura 2009, s. 25]. Konkurencyjność przedsiębiorstwa jest także bardzo ważnym elementem w momencie formułowania strategii rozwoju podmiotu [Adamkiewicz-Drwiłło 2010, s. 16].

Pojęcie konkurencyjności umożliwia zdefiniowanie terminu przewagi konkurencyjnej, który można określić jako umiejętność budowania nowych elementów konkurencyjności szybciej niż robią to rywale rynkowi [Adamik 2008, s. 10]. Nie ma jednak jednej, powszechnie akceptowalnej definicji przewagi konkurencyjnej przedsiębiorstwa [Adamik 2008, s. 6]. Zdaniem Barneya, o przewadze konkurencyjnej przedsiębiorstwa mówimy, gdy 
potrafi ono wygenerować więcej wartości ekonomicznej ${ }^{17} \mathrm{~W}$ porównaniu do firm konkurencyjnych [Barney 2011, s. 15]. Stankiewicz definiuje przewagę konkurencyjną jako konfigurację wszystkich elementów potencjału konkurencyjności, która składa się z zasobów materialnych i niematerialnych, które sprzyjają kształtowaniu przewagi konkurencyjnej i dają możliwości tworzenia skuteczniejszych instrumentów konkurowania w porównaniu do przedsiębiorstw konkurencyjnych [Adamkiewicz-Drwiłło 2010, s. 79-80]. Ponadto, przewaga konkurencyjna jest kategorią względną, gdyż można zmierzyć tę cechę przedsiębiorstwa tylko względem innego podmiotu [Adamik 2008, s. 9].

Tradycyjnie przyjmuje się, że przewaga konkurencyjna powinna być nietrwała na wysoko konkurencyjnych rynkach. Zgodnie $\mathrm{z}$ tym podejściem jakiekolwiek przewagi konkurencyjne uzyskane przez dany podmiot zostaną szybko zidentyfikowane oraz imitowane przez inne firmy, co będzie prowadzić do parytetu konkurencyjnego ${ }^{18}$ [Barney 2011, s. 17]. Jak podkreśla Obłój powiedzenie „nic nie trwa wiecznie” trafnie opisuje zagadnienie przewagi konkurencyjnej, która zdaniem wymienionego autora jest raczej deformacją rynku [Obłój 2002, s. 121]. Należy również pamiętać, że pozycja (i przewaga) konkurencyjna produktu (usługi) przedsiębiorstwa - nawet, gdy jest to jedyne dobro produkowane (świadczone) przez daną przez firmę - nie jest równoznaczna z pozycją (i przewagą) konkurencyjną przedsiębiorstwa. Dzieje się tak, gdyż nawet przedsiębiorstwo nieposiadające konkurencyjnego produktu może posiadać odpowiednią biegłość w innych sferach, przykładowo może to być zorganizowana dystrybucja przejawiająca się m.in. dobrymi kontaktami z detalistami, co implikuje skuteczniejsze dotarcie do klienta. Jak podkreśla Adamowicz-Drwiłło, w momencie badania konkurencyjności przedsiębiorstwa należy przede wszystkim rozpatrywać konkurencyjność podmiotu, a dopiero później konkurencyjność oferowanych przez niego produktów czy usług. Jest to spowodowane faktem, iż konkurencyjność przedsiębiorstwa jest pojęciem odrębnym i szerszym niż termin konkurencyjność produktu czy usługi, które ten podmiot oferuje [Adamkiewicz-Drwiłło 2010, s. 120]. Przykładem sytuacji, w której konkurencyjność produktów różni się od konkurencyjności podmiotu jest firma Nokia, której produkty utraciły przewagę konkurencyjną w Europie na rzecz m.in. Apple'a i innych marek pod koniec pierwszej dekady XXI wieku. Mimo to pozycja firmy Nokia słabła bardzo powoli, gdyż rozwinięte przez lata

\footnotetext{
${ }^{17}$ Barney definiuje wartość ekonomiczną jako postrzeganą przez nabywcę różnicę pomiędzy wartością, jaką otrzymuje wraz zakupem produktu (lub usługi) oraz pełnym kosztem ekonomicznym związanym z zakupem produktu (usługi) [Barney 2011, s. 15].

${ }_{18}$ Parytet konkurencyjny jest sytuacją, w które dwie lub więcej firm tworzą taką samą wartość ekonomiczną [Barney 2011, s. 16].
} 
kontakty z operatorami telefonów komórkowych sprawiły, że dystrybucja nowych produktów była bardzo skuteczna. Operatorzy włączali nawet produkty tej firmy do finansowanych przez siebie kampanii promocyjnych.

Bardzo istotnym aspektem, są źródła przewagi konkurencyjnej przedsiębiorstw, zwłaszcza ich umiejscowienie wewnątrz lub na zewnątrz podmiotu, ich charakter materialny lub niematerialny, oraz możliwości tworzenia i rozwoju przewag konkurencyjnych [Wysocki 2002, s. 11]. W przeszłości zagadnienie przewagi konkurencyjnej przedsiębiorstw nie miało tak dużego znaczenia, ze względu na rolę, jaką pełniły różnego rodzaju naturalne przewagi konkurencyjne, które stwarzały sytuację całkowitego lub częściowego monopolu. Do tego rodzaju przewag należy przede wszystkim lokalizacja. Brak lub ograniczona mobilność odbiorców usług oraz produktów, a także koszt z tym związany sprawia, że firmy z danej lokalizacji są uprzywilejowane. Podobnym przykładem jest przewaga związana z dostępem do zasobów. Przykładowo, dzięki tej możliwości kraje OPEK mogły stworzyć kartel, który w dużej mierze wpływa na ceny ropy poprzez regulację jej wydobycia [Obłój 2001, s. 3-6]. Innym przykładem źródła naturalnej przewagi konkurencyjnej mogą być określone regulacje prawne, a w szczególności patenty [Obłój 2002, s. 105]. Należy zwrócić uwagę, że wymienione czynniki w przeszłości były źródłami najczęściej względnie stabilnej, a także relatywnie długoterminowej przewagi konkurencyjnej. W dzisiejszych czasach mogą w pewnych, specyficznych okolicznościach także gwarantować długoterminową, stabilną pozycję firmy (np. rosyjski Gazprom - dostęp do zasobów oraz regulacje prawne), lecz poza nielicznymi wyjątkami obecne przedsiębiorstwa mają bardzo ograniczone możliwości korzystania $\mathrm{z}$ naturalnych przewag konkurencyjnych. Znaczenie lokalizacji jest coraz mniejsze ze względu na postęp logistyki, cyfryzacji oraz mobilności nabywców, a także dostawców. Uzyskanie wyłącznego dostępu do określonych kluczowych i rzadkich zasobów jest także w dzisiejszych czasach trudne. Patenty, choć nadal odgrywają bardzo znaczącą rolę, nie są już gwarancją zabezpieczenia pomysłu przed konkurencją. Prawa własności intelektualnej są też często lamane lub też prawo jest omijane poprzez proces naśladownictwa. Ze względu na wymienione tendencje przewaga konkurencyjna jest w dzisiejszych czasach zagadnieniem bardziej złożonym niż kiedykolwiek, musi być budowana na czynnikach mało trwałych i stabilnych. Nabiera ona stąd z pewnością bardziej dynamicznego charakteru.

W literaturze istnieją dwa główne podejścia do zagadnienia przewagi konkurencyjnej. Pierwsze z nich zapoczątkowane przez Portera (szkoła pozycyjna) koncentruje się, na unikalnych działaniach przedsiębiorstwa, które prowadzą do odpowiedniego pozycjonowania 
na rynku. Druga koncepcja - szkoła zasobowa, postrzega przedsiębiorstwo jako pakiet zasobów i zdolności. Dzięki ich posiadaniu i wykorzystaniu, podmiot osiąga przewagę konkurencyjną. Oba podejścia łączy element unikalności, stanowiący coś, co przedsiębiorstwo posiada, a jego konkurenci nie mają [Lechner 2001, s. 28; Szymura-Tyc 2006, s. 17-18].

Zdaniem Portera strategia konkurencyjności polega na wyszukiwaniu przez przedsiębiorstwa jak najlepszej pozycji konkurencyjnej $\mathrm{w}$ branży, czyli przewagi w najważniejszym obszarze z perspektywy konkurencji. Ma ona na celu wypracowanie przez firmę solidnej pozycji względem czynników decydujących w danej branży o charakterze konkurencji [Porter 2006, s. 27]. Ważnym elementem jest identyfikacja możliwości osiągania rentowności w danej branży oraz czynników, jakie na nią wpływają. Branże różnią się pod względem możliwości osiągania rentowności, stąd istotnym jest wyznaczenie charakterystycznej rentowności branży, w jakiej działa przedsiębiorstwo oraz czynników określających pozycję konkurencyjną firmy. Źródłem przewagi konkurencyjnej przedsiębiorstwa jest wartość, jaką jest ono w stanie wytworzyć dla swoich odbiorców. Wyraża się ona w cenie produktu lub usługi, jaką nabywcy są $\mathrm{w}$ stanie za nią zapłacić. Wspomniana wartość może się wyrażać w dwojaki sposób. Może to być niższa cena za produkty lub usługi o porównywalnej jakości do tych oferowanych przez konkurentów. Drugą możliwością jest produkcja towarów lub świadczenie usług o unikalnych, niespotykanych u konkurentów cechach, które w oczach odbiorców rekompensują z nawiązką ich cenę. W związku z tym można wyznaczyć dwie główne kategorie przewag konkurencyjnych przywództwo cenowe oraz zróżnicowanie. Z pomocą tych kategorii Porter określa trzy ogólne strategie umożliwiające osiągnięcie lepszych od przeciętnych wyników w danej branży, są to strategie przywództwa kosztowego, zróżnicowania oraz dwuwariantowa strategia koncentracji [Porter 2006, s. 27, 29, 38] (rysunek 3).

Przedsiębiorstwo realizujące strategię pierwszego typu - przywództwa kosztowego w celu osiągnięcia przewagi musi posiadać koszty niższe niż przedsiębiorstwa konkurencyjne. Źródłem tej przewagi konkurencyjnej może być wydajniejszy proces technologiczny, dostęp do tańszych surowców, korzyści skali, tańsza siła robocza, a także inne czynniki. Należy zauważyć, że w celu wykorzystania tej strategii produkt lub usługa przedsiębiorstwa musi oferować podobny lub zbliżony pod kątem zróżnicowania produkt (usługę). Jeżeli nabywcy będą postrzegać produkt lub usługę przedsiębiorstwa jako gorszą, wtedy podmiot ten będzie zmuszony do obniżenia ceny co zniweluje zakładane z przyjęcia przewagi kosztowej zyski. Druga strategia - zróżnicowania polega na unikalności. Firma 
koncentruje się na elementach najbardziej cenionych przez nabywców, sytuując się na pozycji jedynego przedsiębiorstwa zaspokajającego te konkretne potrzeby odbiorców. Trzecią strategią ogólną wyróżnioną przez Portera jest strategia koncentracji. Przedsiębiorstwo, które decyduje się realizować tę strategię, skupia się na jednym lub kilku segmentach w danej branży ignorując pozostałe. Firma koncentruje się na potrzebach nabywców z wybranych segmentów i nie dąży do uzyskania przewagi ogólnej [Porter 2006, s. 39-42].

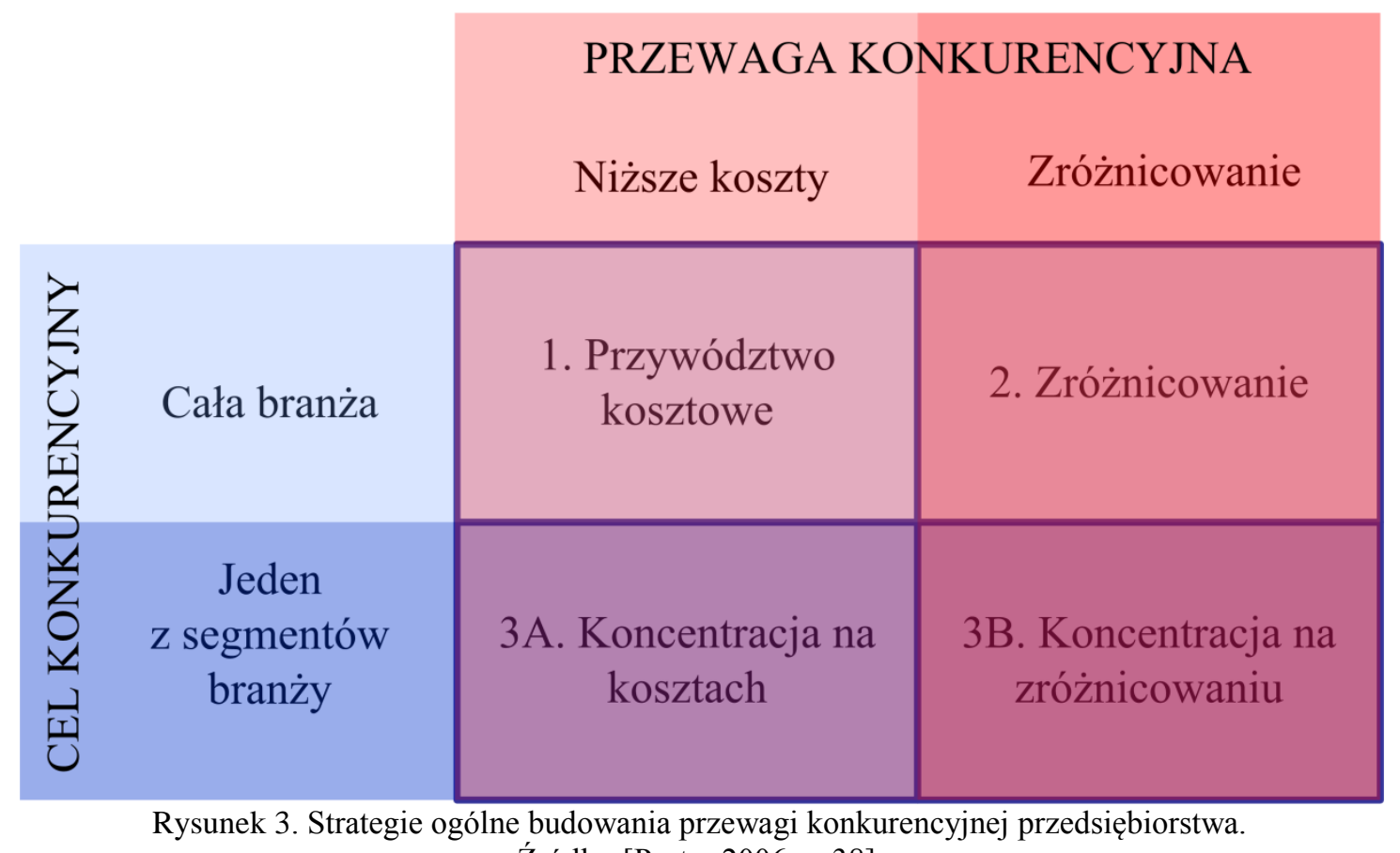

Źródło: [Porter 2006, s. 38].

Założenie leżące u podstaw ogólnych strategii przewagi konkurencyjnej wymaga od przedsiębiorstwa jasnego wyboru jednego rodzaju przewagi strategicznej, a także celu konkurencyjnego, któremu ma służyć wybrana strategia. Brak zdecydowanego wyboru w zakresie powyższych zagadnień najczęściej prowadzi do przeciętności oraz spadku wyników poniżej średniej dla przedsiębiorstw w branży, co jest jednoznaczne z brakiem przewagi konkurencyjnej takiego podmiotu [Porter 2006, s. 39].

Zdaniem Portera najgorszą dla firmy jest sytuacja, w której stosuje ona wszystkie wyróżnione przez wspomnianego autora strategie ogólne. Jest to oznaką braku właściwej strategii konkurencyjnej tego podmiotu oraz implikuje duże prawdopodobieństwo osiągania wyników poniżej przeciętnej dla branży, w jakiej działa firma. Według Portera niezbędnym warunkiem trwałości jest dysponowanie mechanizmem, który utrudnia innym podmiotom naśladownictwo jego działania. Mimo to uważa on, że zazwyczaj takie działania są nieskuteczne, stąd jedynym sposobem jest ciągłe inwestowanie w poprawę pozycji 
konkurencyjnej [Porter 2006, s. 43, 48]. W związku z tym ważnym elementem konkurencyjności jest dla przedsiębiorstwa pozostawanie „ruchomym celem” dla konkurentów [Fryzeł 2004, s. 70].

Szkoła pozycyjna koncentruje się głównie na dopasowaniu mocnych i słabych stron podmiotu do szans i zagrożeń otoczenia firmy [Moszkowicz 2000, s. 48]. Skupia się ona na aspekcie zewnętrznym sukcesu firmy, którego rezultatem są czynniki związane z otoczeniem, omijając zagadnienie wewnętrznych zasobów podmiotu, postrzegając ten element za nieistotny w kontekście kształtowania przewagi konkurencyjnej [Wysocki 2002, s. 17]. Pomimo rozmaitych zarzutów wysuwanych pod jej adresem, szkoła ta posiada także sukcesy. Przede wszystkim wypracowała narzędzia analizy otoczenia powszechnie stosowane do dziś [Wysocki 2002, s. 78-82]. Dużą zasługą Portera w zakresie konkurencyjności podmiotów było zwrócenie uwagi na potrzebę koncentracji na strategiach konkurencji przedsiębiorstw, na badaniu ich źródeł, przyczyn oraz sposobów utrzymania [Świtalski 2005, s. 170]. Istotną słabością tego podejścia jest milczące założenie, że kadra zarządzająca przedsiębiorstwem będzie w posiadaniu odpowiedniej wiedzy, która umożliwi stworzenie skutecznej strategii [Moszkowicz 2000, s. 45].

Główne założenie szkoły pozycyjnej mówiące o tym, że zasoby w każdej branży są jednorodne oraz mobilne $\mathrm{z}$ biegiem czasu okazywało się nieprawdziwe. Spowodowało to powstanie szkoły zasobowej, która koncentruje się na wnętrzu przedsiębiorstwa, gdzie poszukuje na informacji na pytanie dotyczące źródeł oraz trwałości przewagi konkurencyjnej podmiotu [Wysocki 2002, s. 19]. Lockett, Thompson i Morgenstern [2009, s. 9] podkreślają, że w okresie ostatnich 20 lat szkoła zasobowa zdominowała badania w zakresie strategii przedsiębiorstw. Jak zaznacza Oakes, nurt ten można opisać za pomocą trzech pytań, jakie jej przedstawiciele zadają [Oakes 2000, s. 4]:

1. Jakie zasoby przedsiębiorstwa są najważniejsze w osiąganiu przez podmiot przewagi konkurencyjnej?

2. Jakie istnieją bariery w duplikacji zasobów, które są tworzą przewagę konkurencyjną przedsiębiorstwa?

3. W jaki sposób przedsiębiorstwa powinny utrzymywać pozytywny wpływ zasobów nie tylko w krótkim okresie, ale także i w długim, skutecznie broniąc ich względem sił rynkowych?

Przedstawiciele szkoły zasobowej upatrują źródeł przewagi konkurencyjnej we wnętrzu przedsiębiorstwa. Ich zdaniem pozycja konkurencyjna jest uzależniona przede wszystkim od wewnętrznie posiadanych przez firmę zasobów (w szerokim tego słowa znaczeniu), a także 
metod ich wykorzystania. Według szkoły zasobowej, aby zrozumieć źródła sukcesu danego przedsiębiorstwa należy poznać konfiguracje unikalnych zasobów (materialnych i niematerialnych) oraz umiejętności (zdolności) tego podmiotu. Jest to fundamentalne założenie tego nurtu [Wysocki 2002, s. 15]. Drugim założeniem szkoły zasobowej jest istnienie odpowiedniego oddziaływania pomiędzy posiadanymi przez firmę zasobami oraz jej zamierzeniami. Umożliwia ono uzyskanie odpowiedniej stymulacji dalszego rozwoju oraz odpowiednią alokację zasobów. Innymi słowy, potrzebne jest odpowiednie przełożenie pomiędzy zasobami firmy, a jej celami i planowanymi działaniami [Moszkowicz 2000, s. 49]. Trzecie założenie szkoły zasobowej mówi o warunkach, jakie muszą być spełnione przez dane zasoby przedsiębiorstwa, aby określać je mianem strategicznych. Tego rodzaju zasoby powinny umożliwiać firmie wykorzystywanie szans rynkowych lub przeciwstawienie się zagrożeniom, nie powinny być łatwe do kopiowania lub imitacji, powinny także charakteryzować się brakiem możliwości substytucji przez inne zasoby a także odznaczać się rzadkością wśród konkurentów zarówno obecnych, jak i przyszłych [Stankiewicz 1999, s. 116-117]. Należy podkreślić, że każdy podmiot posiada unikalną kompozycję zasobów (materialnych i niematerialnych) oraz zdolności, które warunkują jego sukces [Collis i Montgomery 2008, s. 142].

Podejście zasobowe kładzie nacisk na dwa elementy strategii firmy. Po pierwsze, na programy mające na celu ulepszanie zasobów przedsiębiorstwa, które mają na celu rozwój obecnie posiadanych oraz dodawanie nowych zasobów. Po drugie na określenie luki zasobowej oraz perspektyw jej zniwelowania. Element definiowania luki zasobowej odróżnia podejście zasobowe od pozycyjnego [Moszkowicz 2000, s. 47].

W kontekście rozważań w zakresie szkoły zasobowej należy zwrócić uwagę na bardzo ważną rolę wiedzy związaną z podwójnym znaczeniem tego czynnika w domenie kategorii stosowanych w tym nurcie - zasobów i zdolności ${ }^{19}$. Zdolności można określić jako wiedzę typu: wiem, jak wykorzystać wiedzę (a także inny zasób materialny lub niematerialny). Nie są one zasobem, gdyż same w sobie nie umożliwiają stworzenia wartości, lecz są jedynie aktywatorem zasobów (np. wiedza, jak wykorzystać linie produkcyjne, których właścicielem jest przedsiębiorstwo). Według opinii wielu autorów np. Collis, Montgomery [2008, s. 145] zasoby podmiotu dzielą się na materialne, jak i niematerialne. Zasadnym jest, aby określone typy wiedzy, ze względu na swoją charakterystykę określić jako zasoby niematerialne

\footnotetext{
${ }^{19}$ Podział został zainspirowany rozważaniami Sidor-Rządkowskiej [2008] oraz Omerzel i Gulev [2011].
} 
przedsiębiorstwa. Tego typu wiedzę można opisać kategoriami podziału wiedzy promowanego przez OECD [Clarke 2001, s. 190]:

- wiem co,

- wiem kto,

- wiem jak i potrafię.

Należy zaznaczyć, że zasób niematerialny przedsiębiorstwa niekoniecznie musi być wiedzą (np. zasobem niematerialnym firmy niebędącym wiedzą jest licencja na wydobycie ropy $\mathrm{w}$ danej lokalizacji). Wiedza $\mathrm{w}$ formie zasobu niematerialnego jest cenna, lecz $\mathrm{w}$ tej formie nie zawsze może być wykorzystana w praktyce np. wiedza i umiejętność budowy elementu składowego danej maszyny są w praktyce bezużyteczne bez zdolności - wiedzy, jak je wykorzystać w kontekście przedsiębiorstwa (budowa całej maszyny) lub procesów rynkowych (sprzedaż elementu z zyskiem).

Według zwolenników szkoły zasobowej źródłem przewagi konkurencyjnej podmiotu mogą być wyłącznie umiejętności wykorzystania posiadanych przez firmę zasobów, a także głównych zdolności w sposób bardziej efektywny od konkurencji oraz dostęp do zasobów w większej mierze odpowiadających kluczowym umiejętnościom ${ }^{20}$, jakie są potrzebne w celu osiągnięcia sukcesu w danych warunkach rynkowych [Wysocki 2002, s. 15]. Ogólnie można stwierdzić, że szkoła zasobowa szuka przewagi konkurencyjnej przedsiębiorstwa w jego wyposażeniu w zasoby (w ich unikalności i wyjątkowości), a także w umiejętnościach lepszego, w porównaniu do konkurencji, ich wykorzystania. Dodatkowo należy zaznaczyć, iż każdy zasób ma inne znaczenie dla budowania przewagi konkurencyjnej podmiotu. Zdaniem Wysockiego najważniejszą różnicą pomiędzy szkołą zasobową a szkołą pozycyjną w postrzeganiu przewagi konkurencyjnej przedsiębiorstwa jest odmienne postrzeganie uwarunkowań tego zjawiska, które decydują o sukcesie rynkowym podmiotu [Wysocki 2002, s. 16]. Podejście pozycyjne koncentruje się na środowisku zewnętrznym, a podejście zasobowe według Hameeda [2009, s. 224] zakłada, że systematyczny rozwój kluczowych zasobów podmiotu umożliwi mu tworzenie przewagi konkurencyjnej bez względu na zmiany zachodzące w środowisku zewnętrznym.

\footnotetext{
${ }^{20}$ Wang, He i Mahoney [2009, s. 1265] podkreślają, że przedsiębiorstwa w celu budowania przewagi konkurencyjnej potrzebują specyficznych dla siebie zasobów, co jest szczególne ważne w zakresie zasobu wiedzy firmy.
} 


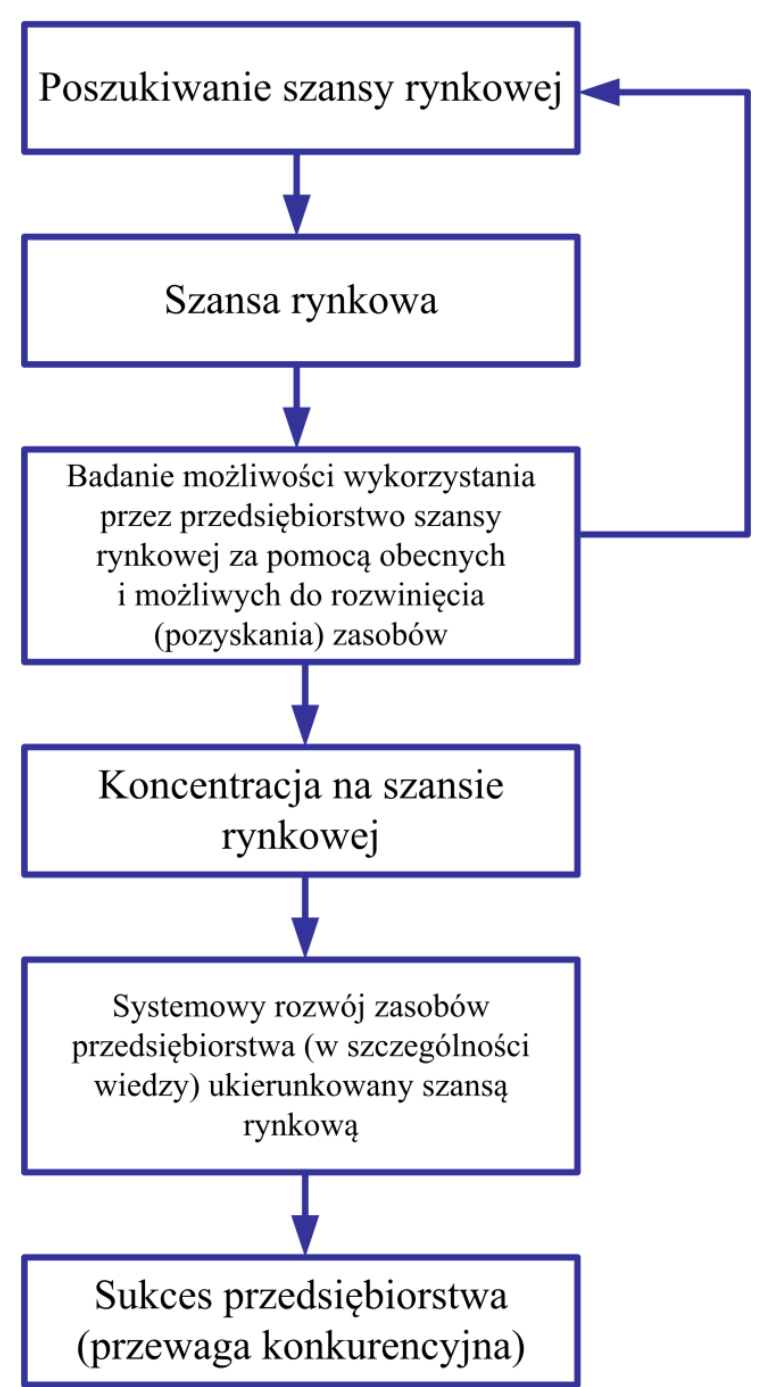

Rysunek 4. Ogólny schemat kształtowania przewagi konkurencyjnej przedsiębiorstwa. Źródło: opracowanie własne na podstawie rozważań [Faulknera i Bowmana 1996, s. 30].

Klasyczne szkoły wyjaśniające zjawisko przewagi konkurencyjnej - pozycyjna i zasobowa - zbudowały podstawy postrzegania tego zagadnienia i wyposażyły nas w narzędzia, które w zależności od szkoły umożliwiają sprawne rozpoznanie różnych elementów tego problemu. Szkoła pozycyjna dostarczyła instrumentów do badania elementów zewnętrznych, a zasobowa wewnętrznych przewagi konkurencyjnej. Zdaniem autora niniejszej pracy złożoność zagadnienia wymaga wykorzystania silnych stron obu ujęć. Jest to zgodne z opinią Faulknera i Bowmana, którzy uważają, że tworzenie strategii konkurencji przedsiębiorstwa wymaga zarówno uwzględnienia otoczenia zewnętrznego, jak i elementów wnętrza przedsiębiorstwa. Implikuje to wykorzystanie zarówno szkoły pozycyjnej, jak i szkoły zasobowej [Faulkner i Bowman 1996, s. 30]. Komplementarność wymienionych podejść podkreślają również w swoich rozważaniach M. Dzikowska i M. Gorynia [2012, s. 3, 26]. 
W opinii autora niniejszej pracy obecne tendencje gospodarcze związane ze wzrostem znaczenia elastyczności i dostosowania przedsiębiorstwa do zmieniających się warunków rynkowych sprawiają, że w dzisiejszych czasach punktem wyjścia dla rozważań w zakresie przewagi konkurencyjnej powinny być szanse rynkowe. Jak zaznaczają Faulkner i Bowman kolejność wykorzystania narzędzi (szkoły pozycyjnej lub zasobowej) ma bardzo duże znaczenie. Uważają oni, że rozpoczęcie analizy od zasobów przedsiębiorstwa może być podejściem bardzo ograniczającym, gdyż może przyczynić się do odrzucenia bardzo atrakcyjnych szans rynkowych [Faulkner i Bowman 1996, s. 30]. Przykładowo, firma Apple Computer przed założeniem serwisu iTunes nie była związana z przemysłem muzycznym, lecz zarządzający nią Steve Jobs zauważył lukę rynkową, jaka powstała po likwidacji serwisu Napster. Apple Computer nie miało wystarczających zasobów do zaangażowania się na tym rynku, lecz zdołało te zasoby pozyskać podczas pracy nad serwisem iTunes. Podobnie firma Nokia, która otrzymała zlecenie od rządu na zbudowanie telefonu bezprzewodowego. Wnioskiem z doświadczeń obu firm jest waga, jaką przedsiębiorstwa powinny przywiązywać do szans rynkowych oraz niekoniecznie do posiadanych w danym momencie zasobów, a jedynie perspektyw ich pozyskania. W dobie gospodarki opartej na wiedzy, która wiąże się z brakiem stabilności, potrzebą częstych oraz szybkich zmian, element rozwoju i dostosowania zasobów przedsiębiorstwa ma kluczową rolę.

W niniejszej pracy proces uzyskiwania przez przedsiębiorstwo przewagi konkurencyjnej będzie postrzegany na podstawie procesu opracowanego na podstawie rozważań Faulknera i Bowmana [1996, s. 30-31] (rysunek 4). Jest on próbą połączenia elementów oferowanych zarówno przez szkołę zasobową, jak i pozycyjną w taki sposób, aby wykorzystać najlepsze cechy obu. Jako punkt wyjścia przyjęte jest zewnętrzne podejście szkoły pozycyjnej w formie szansy rynkowej. Dzięki temu przedsiębiorstwo nie będzie odrzucać szans, na skorzystanie $\mathrm{z}$ których nie ma w danym momencie wystarczających zasobów $^{21}$. Kolejnym elementem procesu jest zapożyczona $\mathrm{z}$ drugiego nurtu analiza zasobów przedsiębiorstwa pod kątem potencjału wykorzystania danej szansy oraz co najważniejsze analiza możliwości pozyskania brakujących zasobów. W momencie, gdy zasoby potrzebne do wykorzystania szansy nie mogą być pozyskane wtedy podmiot musi zrezygnować z danej szansy. W przeciwnym wypadku powinien z niej skorzystać, ukierunkowując rozwój swoich zasobów w tym kierunku np. pozyskując odpowiednią wiedzę. Przedsiębiorstwo powinno

${ }^{21} \mathrm{Z}$ tym podejściem zgadza się Gajęcki, który w kontekście kluczowych kompetencji, wspomina, że decyzje w zakresie inwestycji dla dobra firmy powinny być podejmowane niezależnie od istniejących w danym momencie jednostek strategicznych w przedsiębiorstwie tzn. w oderwaniu m.in. od ich obecnych zasobów czy możliwości a także interesów [Bieliński 2005, s. 18-19]. 
stworzyć odpowiednie rozwiązania systemowe mające na celu ciągły rozwój potrzebnych do wykorzystania szansy zasobów, stale je udoskonalając. Właściwe wykorzystanie szansy prowadzi do uzyskania przez podmiot przewagi konkurencyjnej i sukcesu rynkowego.

\subsection{Wiedza a przewaga konkurencyjna przedsiębiorstwa: ujęcie statyczne oraz dynamiczne}

Zgodnie $\mathrm{z}$ przedstawionym $\mathrm{w}$ poprzednim podrozdziale modelem, kształtowanie przewagi konkurencyjnej przedsiębiorstwa jest zagadnieniem złożonym, na które wpływ ma duża liczba czynników, m.in. uwarunkowania rynkowe, a także kompozycja i umiejętność wykorzystania zasobów podmiotu (rysunek 5). W związku z tym celowym jest skupienie się na najważniejszych czynnikach w tym procesie. Współczesne tendencje ekonomiczne opisane we wcześniejszych podrozdziałach wskazują na wzrastające znaczenie zasobów niematerialnych, w szczególności wiedzy, w procesach gospodarczych. Rola wiedzy w kształtowaniu przewagi konkurencyjnej przedsiębiorstwa jest podkreślana w literaturze przez wielu autorów. Zdaniem Jacksona, Hitta i DeNisi sposób pracy ludzi zmieniał się w ostatnich czasach w kierunku większej pracy umysłowej - coraz bardziej wymaga się od ludzi, aby planowali, myśleli oraz podejmowali decyzje, a coraz mniej składali, podnosili czy budowali. Tego rodzaju działania wymagają posiadania różnorodnej wiedzy, a także umiejętności jej właściwego wykorzystania [Jackson, Hitt i DeNisi 2003, s. 9]. Wysocki podziela opinię, że w dzisiejszych czasach podstawę konkurowania przedsiębiorstw stanowią szczególnie ich zasoby niematerialne. Jest to spowodowane ich względną rzadkością oraz relatywnie trudniejszą imitacją w porównaniu do zasobów materialnych. Innym aspektem jest wpływ tych zasobów na możliwości wykorzystania innych zasobów firmy, zarówno materialnych, jak i niematerialnych [Wysocki 2002, s. 21]. Ten aspekt wiedzy podkreślają także Omerzel i Gulev, ich zdaniem wiedza jest sama w sobie bardzo ważnym zasobem, lecz jej rola jest ważniejsza, gdyż stanowi ona narzędzie aktywujące - umożliwia efektywną alokację i wykorzystanie pozostałych zasobów [Omerzel i Gulev 2011, s. 335] (rysunek 5). 


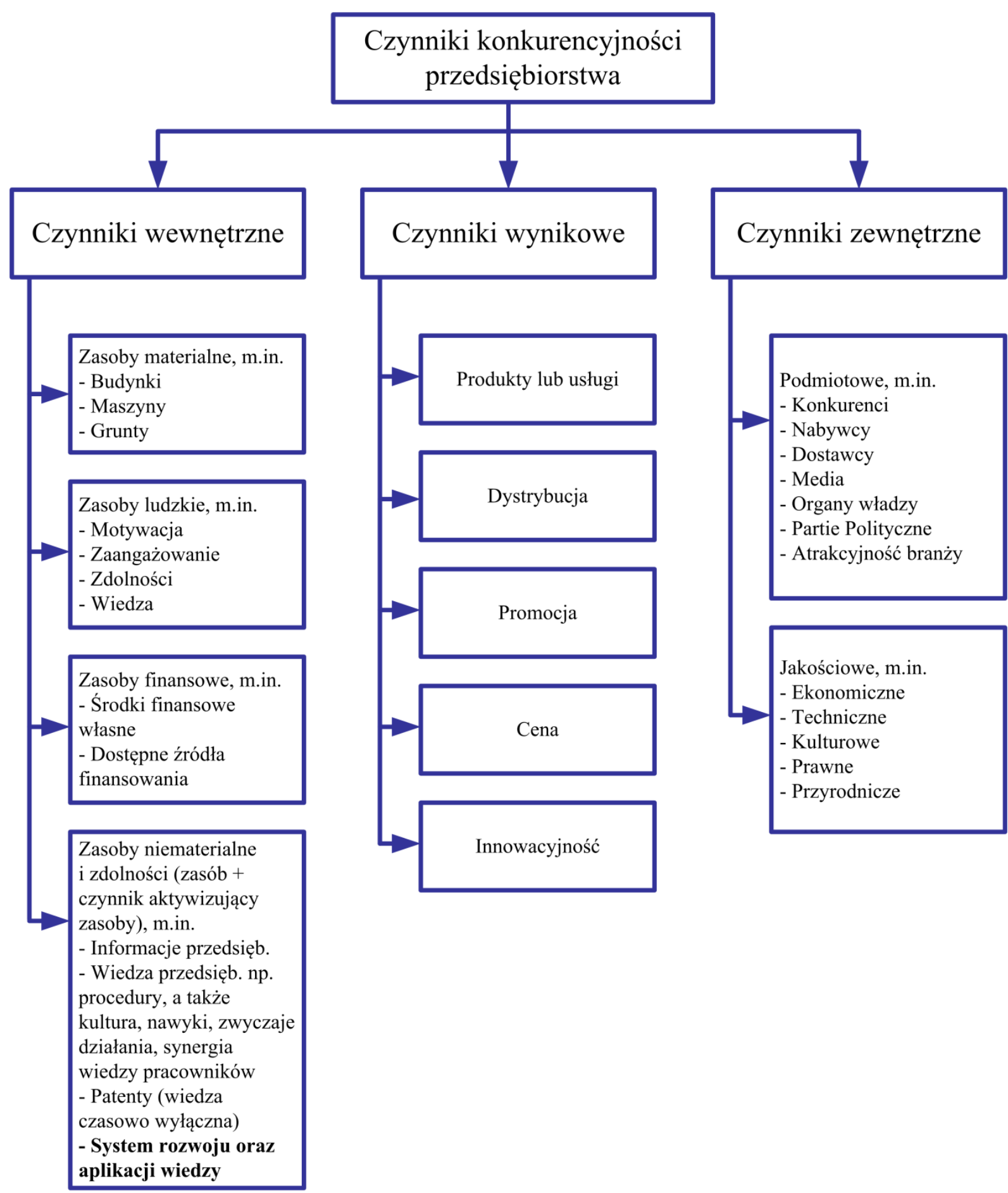

Rysunek 5. Czynniki konkurencyjności przedsiębiorstwa.

Źródło: na podstawie [Mantura 2009, s. 28; Omerzel i Gulev 2011, s. 335].

Zdaniem Rothberga i Ericksona [2005, s. 8] oraz Zacka [1999, s. 128] wiedza jest głównym elementem konkurencyjności przedsiębiorstwa. Przejawem znaczenia zagadnienia wiedzy jest koncentracja dziesiątek tysięcy firm wyłącznie na przetwarzaniu informacji [AdamkiewiczDrwiłło 2010, s. 332].

Przedstawiona do tej pory analiza znaczenia wiedzy ujmowała omawiany zasób wyłącznie w kontekście statycznym. Należy jednak zwrócić uwagę na znaczenie 
dynamicznego ujęcia tego zjawiska. Obecne tempo rozwoju i zmian gospodarczych napędzane przez wysoką konkurencję i procesy globalizacji sprawia, że postrzeganie przedsiębiorstwa $\mathrm{W}$ formie statycznej nie ma większego znaczenia dla procesów strategicznych. Podmioty, aby pozostać konkurencyjne muszą stale się rozwijać. Dotyczy to, w szczególności, zagadnienia wiedzy. Przykładowo, nie ulega wątpliwości, że obecna wiedza firmy Apple jest znaczna i bardzo cenna (jest to odzwierciedlone poprzez kapitalizację akcji przedsiębiorstwa). Należy jednak zauważyć, że wartość obecnej wiedzy tego podmiotu za dwa lata lub nawet wcześniej będzie znikoma. Z dużym prawdopodobieństwem już za rok konkurenci firmy Apple, np. Samsung będą posiadali w swojej ofercie zdecydowanie lepsze technologie niż firma z Cupertino obecnie. Z przedstawionego rozumowania wynika wniosek, że najcenniejszym elementem przedsiębiorstwa nie jest wiedza posiadana przez podmiot w danym momencie, lecz umiejętność systematycznego jej powiększania i stosowania.

Z powyższych rozważań można wywnioskować, iż w kontekście długofalowej przewagi konkurencyjnej przedsiębiorstwa, największe znaczenie będą miały skuteczne, kompleksowe działania organizacji w zakresie wiedzy. Zgodnie z tym faktem, przedstawiony wcześniej model kształtowania przewagi konkurencyjnej zostanie $\mathrm{w}$ dalszych rozdziałach pracy ukierunkowany $\mathrm{W}$ stronę wiedzy, a w szczególności procesów jej rozwoju. W literaturze zagadnieniem efektywności tego rodzaju działań w podmiotach gospodarczych zajmuje się szereg teorii, których wspólną cechą jest dynamiczne podejście do zasobu wiedzy przedsiębiorstwa.

\subsection{Podsumowanie i wnioski}

Rola zasobu wiedzy stała się pod koniec XX wieku do tego stopnia znacząca, iż w powszechnym użyciu pojawiły się pojęcia takie, jak gospodarka wiedzy (knowledge economy) czy gospodarka oparta na wiedzy (knowledge based economy). Przemiany makroekonomiczne wywarły duży wpływ na sposób działania poszczególnych podmiotów gospodarczych. Wymuszają one na firmach czynności przystosowawcze związane z intensyfikacją działań w obszarze wiedzy. W tym kontekście fundamentalną sprawą jest zdefiniowanie zagadnienia wiedzy. Autor przyjmuje, zgodnie z dominującym poglądem panującym w literaturze, że wiedza jest informacją ujętą w określonym kontekście, która może zostać efektywnie użyta do wykonania określonego zadania.

Kluczową kwestią w zakresie wpływu gospodarki opartej na wiedzy na podmioty gospodarcze jest zagadnienie przewagi konkurencyjnej. Zdaniem K. Fonfary 
przedsiębiorstwo zdobywa przewagę konkurencyjną w momencie, gdy na podstawie szeregu wskaźników można stwierdzić jego nadrzędną pozycję względem najbliższych konkurentów [Fonfara 2007, s. 3-4]. Klasyczne szkoły wyjaśniające zjawisko przewagi konkurencyjnej pozycyjna i zasobowa - zbudowały podstawy postrzegania tego zagadnienia i wyposażyły nas w różnorodne narzędzia, które w zależności od szkoły umożliwiają sprawne rozpoznanie różnych charakterystyk tego problemu. Wspomniane ujęcia są komplementarne, co podkreślają M. Dzikowska i M. Gorynia [2012, s. 3, 26]. Przykładowo, szkoła pozycyjna dostarczyła instrumentów do badania elementów zewnętrznych, a zasobowa wewnętrznych przewagi konkurencyjnej.

Zdaniem autora, w literaturze brakuje jednak teorii uwzględniających zarówno otoczenie, jak i wnętrze przedsiębiorstwa przy jednoczesnej koncentracji na zasobie wiedzy podmiotu. W związku z tym został opracowany przez autora model statyczny zakładający koncentrację przedsiębiorstwa na szansach tworzonych przez otoczenie, a następnie na obecnie najważniejszym zasobie firmy - wiedzy, który umożliwia wykorzystanie tych szans. Przywołano także przykłady potwierdzające zasadność takiego podejścia. Wspomniany model został określony jako statyczny, gdyż koncentruje się na tworzeniu wiedzy operacyjnej. Zaprezentowane ujęcie z uwagi na cechy gospodarki opartej na wiedzy - częste zmiany oraz nietrwałość zasobu wiedzy - jest jednak niewystarczające i nie umożliwi przedsiębiorstwu utrzymania długotrwałej przewagi konkurencyjnej. W związku z tym, autor zauważył potrzebę dynamicznego podejścia do zagadnienia wiedzy, które zostało szczegółowo przedstawione w rozdziale 2. 


\section{Istota dynamicznego podejścia do zasobu wiedzy przedsiębiorstwa}

Charakterystyka wiedzy związana z nietrwałością tego zasobu wymusza stały jego rozwój $^{22}$. Istnieje szereg koncepcji w tym obszarze koncentrujących się na działaniach, w zakresie wiedzy podmiotu gospodarczego oraz uczenia się organizacji. Ich wspólną cechą jest dynamiczne podejście do zasobu wiedzy przedsiębiorstwa. W praktyce obszary zainteresowania poszczególnych teorii często nieco się od siebie różnią, lecz również na siebie nachodzą. Niestety publikacje dotyczące jednych koncepcji nie zawsze odwołują się do innych. Kompleksowe ujęcia są relatywnie rzadkie, a jeśli nawet się pojawiają, to ich wzajemna konfrontacja ujawnia, iż relacje pomiędzy różnymi teoriami nie zawsze są jednolicie postrzegane przez poszczególnych autorów ${ }^{23}$.

\subsection{Dynamiczne koncepcje w obszarze wiedzy i uczenia się w przedsiębiorstwie.}

Autor niniejszej pracy, za najbardziej rozwiniętą, praktyczną i stąd w omawianym kontekście najbardziej użyteczną w obszarze wiedzy i uczenia się w przedsiębiorstwie, uważa ideę zarządzania wiedzą. W związku z tym niniejsza praca, w kontekście działań w zakresie wiedzy, jest w największym stopniu skoncentrowana właśnie na teorii tego obszaru. W zdecydowanie mniejszej skali wykorzystywany jest dorobek innych koncepcji np. organizacji uczącej się czy organizacyjnego uczenia, które również zostaną pokrótce omówione.

\subsubsection{Zarządzanie wiedzą}

Zarządzanie wiedzą jest bardzo złożonym zagadnieniem, którego zdefiniowanie, podobnie jak samego pojęcia wiedzy, jest niezwykle trudne [Geisler i Wickramasinghe 2009, s. 3; Karwowski 2010, s. 77]. Ma ono charakter multidyscyplinarny [Geisler i Wickramasinghe 2009, s. 5]. Centralnym punktem koncepcji zarządzania wiedzą jest wiedza organizacyjna, która istnieje „u zbiegu ludzi, procesów oraz technologii” [Bali, Wickramasinghe i Lahaney 2009, s. 1]. Zarządzanie wiedzą angażuje praktycznie wszystkie jednostki i obszary organizacji [Boughzala i Ermine 2006, s. 24]. Należy ono także do grona

\footnotetext{
${ }^{22}$ Simone, Ackerman i Wulf [2012, s. 109] podkreślają, iż każde organizacje, nie tylko komercyjne, są coraz bardziej świadome, że ich umiejętności w obszarze szerokiej gamy dynamicznych działań w obszarze wiedzy przekładają się m.in. na ich kompetencje w zakresie rozwoju i dostosowania do dzisiejszego, zmiennego środowiska działania i determinują również ich szanse na dalsze przetrwanie.

${ }^{23}$ Przykładowo: definicja organizacji uczącej się - w ujęciu Fazlagić [2004, s. 3] w porównaniu do perspektywy Vera i Crossan [2006, s. 122-124].
} 
koncepcji zarządzania, które nie mieszczą się w jego tradycyjnych funkcjach [Perechuda 2005, s. 61].

Sama idea nie jest jednak do końca nowa, lecz towarzyszy człowiekowi praktycznie od początku istnienia ludzkości. Najstarsze działania w zakresie przekazywania i zachowywania wiedzy bazowały przede wszystkim na pamięci ludzkiej oraz przekazie ustnym. W związku jednak $\mathrm{z}$ niedoskonałością pamięci oraz tendencją człowieka do eliminowania subiektywnie nieznaczących informacji, działania te nie były dość skuteczne, co zrodziło potrzebę wykorzystania innego narzędzia - pisma. Jego najdawniejsze, do tej pory poznane, ślady wskazują na 3000 rok p.n.e. [Jashapara 2006, s. 35-36]. W opinii Buscha właśnie w tym momencie - okresie rozwoju języka klinowego należy szukać początków zarządzania wiedzą [Busch 2008, s. 19]. Handel wiedzą w formie ręcznie pisanych zwojów przeżywał rozkwit w 400 roku p.n.e. w czasach Sokratesa, lecz prawdziwa rewolucja w tym obszarze nastąpiła dopiero w 1455 roku n.e. w związku z wynalezieniem druku przez J. Gutenberga. Prawdopodobnie wcześniej - w VIII wieku n.e. druk był już wykorzystywany przez Chińczyków. Następny przełom przyniosło, w XX wieku, skonstruowanie komputera [Jashapara 2006, s. 37-42].

Znaczenie zarządzania procesami w zakresie wiedzy w biznesie zostało zauważone w latach 80. XX wieku [Ahmed, Lim i Loh, 2002, s. 3]. Kowalczyk i Nogalski podają, iż oficjalnie koncepcja zarządzania wiedzą została zapoczątkowana w 1987 roku, kiedy odbyła się pierwsza konferencja: „Managing the Knowledge Assets into 21st Century” [Kowalczyk i Nogalski 2007, s. 41-42]. Pierwszy artykuł, posiadający w tytule termin ,zarządzanie wiedzą" (Knowledge Management: An Introduction) został opublikowany w 1990 roku przez Karla Wigga [Fazlagić 2006, s. 53], jednak działania firm konsultingowych w zakresie zarządzania wiedzą, miały miejsce już w latach 60-tych XX wieku [Kowalczyk i Nogalski 2007, s. 41-42]. Prawdziwie duże zainteresowanie zarządzaniem wiedzą pojawiło się w drugiej połowie lat 90. XX wieku, kiedy przedsiębiorstwa zdały sobie sprawę z posiadanych przez siebie zasobów intelektualnych, które nie były wcześniej w pełni wykorzystane. Badanie przeprowadzone w 1997 roku przez firmę Ernst \& Young wykazało, iż w opinii 94 procent ankietowanych osób, wiedza w ich firmach mogłaby być wykorzystywana efektywniej, zaś 40 procent przyznało, że ich organizacje prowadzą lub prowadziły działania w zakresie usprawnienia procesów w zakresie wiedzy [Ahmed, Lim i Loh 2002, s. 3-4].

W związku z przedstawioną genezą zarządzania wiedzą wielu autorów słusznie podkreśla, iż w każdym przedsiębiorstwie można zaobserwować działania w tym zakresie. 
Przykładowo szkolenia, ustanawianie procedur czy różnego rodzaju formy współpracy są aktywnościami, które mają na celu rozwój kapitału wiedzy przedsiębiorstwa [Boughzala i Ermine 2006, s. 35]. Różnica polega na określeniu celów oraz dotyczy świadomości znaczenia tych działań dla podmiotu [Perechuda 2005, s. 62]. Zarządzanie wiedzą w dzisiejszym rozumieniu wprowadza kompleksową organizację procesów w zakresie wiedzy. Jest to konieczne, gdyż jak podkreśla Leonard-Barton - w związku ze wzrostem ilości informacji wzrosła też skala zagadnienia oraz złożoność procesu [Kowalczyk i Nogalski 2007, s. 55]. Stąd można zgodzić się ze słowami Fazlagića, iż wkład omawianego zagadnienia „...polega więc przede wszystkim na budowie nowego rodzaju świadomości wśród decydentów" [Fazlagić 2006, s. 50].

Nie ma jednak jednej, powszechnie uznanej definicji zarządzania wiedzą [Ahmed, Lim i Loh 2002, s. 12; Stankiewicz 2006, s. 118]. Literaturowe definicje autorstwa szeregu badaczy oraz instytucji zostały zebrane w tabeli 2 .

Tabela 2. Definicje koncepcji zarządzania wiedzą.

\begin{tabular}{|c|c|}
\hline Definicja & Autor / autorzy \\
\hline $\begin{array}{l}\text { „Zarządzania wiedzą jest procesem przechwytywania, dystrybucji } \\
\text { oraz skutecznego wykorzystywania zasobu wiedzy.” }\end{array}$ & T. Davenport \\
\hline $\begin{array}{l}\text { „Zarządzanie wiedzą w organizacjach służy integracji wszystkich } \\
\text { znanych dotychczas podejść, takich jak zarządzanie informacją, } \\
\text { zarządzanie jakością, motywowanie pracowników, zarządzanie } \\
\text { strategiczne itp.” }\end{array}$ & J. Fazlagić \\
\hline $\begin{array}{c}\text { „Zarządzanie wiedzą można określić jako całościowy, określony } \\
\text { pomysł na zarządzanie.” }\end{array}$ & K. Perechuda \\
\hline $\begin{array}{l}\text { „Zarządzanie wiedzą jest koncepcją, dzięki której informacja jest } \\
\text { przekształcana w wiedzę, która jest następnie dostarczana w } \\
\text { przystępnej formie osobom, które mogą ją wykorzystać.” }\end{array}$ & Information Week \\
\hline $\begin{array}{l}\text { „Zarządzanie wiedzą jest działaniem, które poprzez koordynację } \\
\text { technologii, kultury i strategii przedsiębiorstwa, a także procesów } \\
\text { zarządczych oraz odpowiedniego wykorzystania potencjału wiedzy } \\
\text { ludzkiej umożliwia przedsiębiorstwu osiągnięcie zysku.” }\end{array}$ & $\begin{array}{l}\text { P. K. Ahmed., } \\
\text { K. K. Lim, } \\
\text { A. Y. E. Loh }\end{array}$ \\
\hline $\begin{array}{c}\text { „Zarządzanie wiedzą oznacza akumulację, ochronę oraz } \\
\text { wykorzystanie zasobu wiedzy.” }\end{array}$ & $\begin{array}{l}\text { B. Chakravarthy, } \\
\text { S. McEvily, } \\
\text { Y. Doz, D. Rau }\end{array}$ \\
\hline
\end{tabular}




\begin{tabular}{|c|c|}
\hline $\begin{array}{l}\text { „Zarządzanie wiedzą jest nową dziedziną, która koncentruje się na } \\
\text { różnego rodzaju technikach oraz metodach umożliwiających } \\
\text { efektywne wykorzystanie zasobu wiedzy organizacji.” }\end{array}$ & J. Brdulak \\
\hline $\begin{array}{c}\text { „Zarządzanie wiedzą oznacza konwersję informacji i aktywów } \\
\text { intelektualnych w trwałą wartość dla klientów i pracowników } \\
\text { organizacji." }\end{array}$ & $\mathrm{PwC}$ \\
\hline $\begin{array}{l}\text { „Zarządzanie wiedzą jest to system, którego celem jest pozyskanie, } \\
\text { analiza i wykorzystanie informacji w procesie podejmowania decyzji } \\
\text { umożliwiających osiągnięcie przewagi konkurencyjnej.” }\end{array}$ & Ernst and Young \\
\hline $\begin{array}{c}\text { „Zarządzanie wiedzą polega na stałej, jawnej, a także świadomej } \\
\text { budowie, odnawianiu oraz zastosowaniu wiedzy w celu } \\
\text { maksymalizacji wydajności przedsiębiorstwa.” }\end{array}$ & K. Wiig \\
\hline $\begin{array}{l}\text { Zarządzanie wiedzą jest „złożonym współgraniem ludzi i technologii } \\
\text { w innowacyjnych procesach oraz działaniach organizacyjnych dla } \\
\text { osiągnięcia celów biznesowych.” } \\
\text { (definicja stworzona przez wymienionych autorów na podstawie } \\
\text { analizy szeregu definicji literaturowych) }\end{array}$ & $\begin{array}{l}\text { M. Handzic } \\
\text { H. Hasan }\end{array}$ \\
\hline $\begin{array}{l}\text { „Sposoby i środki, za pomocą jakich firma używa zasobów wiedzy } \\
\text { dla generowania wartości ekonomicznej.” }\end{array}$ & IBM \\
\hline $\begin{array}{c}\text { „Dyscyplina, która promuje zintegrowane podejście do identyfikacji, } \\
\text { zarządzania oraz dzielenia się informacją.” }\end{array}$ & Gartner Group \\
\hline $\begin{array}{c}\text { „Zarządzanie wiedzą jest synergicznym połączeniem zarówno } \\
\text { kreatywnego potencjału człowieka z obszernym potencjałem } \\
\text { technologii informatycznych w zakresie przetwarzania informacji } \\
\text { i danych.” }\end{array}$ & Y. Malhorta \\
\hline $\begin{array}{c}\text { „Zarządzanie wiedzą jest procesem, które zakłada ciągły rozwój } \\
\text { i dążenie do doskonałości w zakresie tego co już istnieje } \\
\text { w przedsiębiorstwie.” }\end{array}$ & $\begin{array}{l}\text { I. Boughzala, } \\
\text { J. L. Ermine }\end{array}$ \\
\hline $\begin{array}{c}\text { „Ogół procesów umożliwiających tworzenie, upowszechnianie } \\
\text { i wykorzystywanie wiedzy do realizacji celów organizacji.” } \\
\text { (Definicja zaaprobowana podczas badań przez } 73 \text { procent } \\
\text { menedżerów) }\end{array}$ & $\begin{array}{l}\text { Cranfield School of } \\
\text { Management }\end{array}$ \\
\hline
\end{tabular}


„Zarządzanie wiedzą jest to przekrojowa koncepcja, która polega

na realizacji procesów związanych z wiedzą w dążeniu do

E. Tabaszewska

osiągnięcia celów organizacji."

Opracowanie własne na podstawie: [Fazlagić 2006, s. 50, 51; Perechuda 2005, s. 68, 74; Geisler

i Wickramasinghe 2009, s. 5; Ahmed, Lim i Loh 2002, s. 12; Chakravarthy i in. 2006, s. 305; Brdulak 2005,

s. 17, 19; Handzic i Zhou 2005, s. 4; Boughzala i Ermine 2006, s. 35; Tabaszewska 2012, s. 27; McInerney

i Koenig 2011, s. 1].

Przedstawione definicje na pozór są bardzo różnorodne, co pokazuje złożoność i wielowymiarowość koncepcji zarządzania wiedzą. Pierwszym, najpowszechniej dyskutowanym w literaturze i widocznym w definicjach podziałem jest sposób postrzegania zasobu wiedzy. Może być on utożsamiany z informacją lub traktowany wyłącznie jako domena ludzi. W szczególności definicje Information Week, PwC, Ernst and Young i Gartner Group (czyli stworzone przez praktyków gospodarczych) utożsamiają wiedzę z namacalnym tworem lub wprost z informacją. Zaś definicje Ahmed, Lim i Loh czy Malhorty podkreślają ludzki aspekt wiedzy. Paliszkiewicz podkreśla, iż skłaniający się ku jednej koncepcji zarządzania wiedzą (lub precyzyjniej - postrzegania wiedzy w zarządzaniu wiedzą) najczęściej „nie odwołują się do drugiej” koncepcji z uwagi na odmienne założenia [Paliszkiewicz 2007, s. 37]. Bardzo pozytywnym przejawem próby pogodzenia zwolenników dwóch przytoczonych frontów są definicje integracyjne, np. Malhorty, Ahmed, Lim i Loh, Fazlagića oraz do pewnego stopnia Handzic i Hasan. Podkreślają one zarówno rolę działań organizacyjnych czy społecznych, jak i wykorzystanie odpowiednich technologii informacyjnych.

Procesowe podejście do zagadnienia zarządzania wiedzą jest bardzo powszechne i również bezpośrednio podkreślane $\mathrm{w}$ niektórych $\mathrm{z}$ przytoczonych definicji np. Cranfield School of Management czy B. Chakravarthy, S. McEvily, Y. Doz, D. Rau. Można stąd wnioskować, iż zarządzanie wiedzą jest szeregiem następujących po sobie oraz powiązanych i wzajemnie na siebie wpływających procesów.

Część definicji bezpośrednio odnosi się do efektów, jakie może przynieść zarządzanie wiedzą np. Kowalczyk i Nogalski wśród szeregu dostępnych w literaturze definicji zarządzania wiedzą odnajdują pewne podobieństwa. We wszystkich eksponowane są działania w zakresie pozyskiwania, przechowywania, jak i wykorzystania zasobu wiedzy. Podkreślają one również wpływ omawianej koncepcji na sprawność działania, konkurencyjność oraz zdolności w zakresie podejmowania lepszych decyzji [Kowalczyk 
i Nogalski 2007, s. 43]. Podobnego zdania są Tranfield i in. [2012, s. 132], którzy podkreślają, że zarządzanie wiedzą zwiększa zdolność podmiotu do działania.

Perechuda biorąc pod uwagę charakterystykę wiedzy - jej indywidualność i różnorodną naturę, zastanawia się czy jej złożoność nie wymaga nawet do pewnego stopnia tworzenia przez każdy podmiot własnej teorii zarządzania tym zasobem [Perechuda 2005, s. 63]. W literaturze można znaleźć stwierdzenie iż ,wiedza podlega zarządzaniu podobnie, jak pozostałe zasoby w przedsiębiorstwie” [Szyjewski, Nowak i Grabara 2004, s. 393], lecz zdaniem autora jest to stwierdzenie ryzykowne, gdyż w przypadku zarządzania wiedzą mamy do czynienia $\mathrm{w}$ praktyce $\mathrm{z}$ zarządzaniem procesami związanymi $\mathrm{z}$ wiedzą, a nie faktycznie wiedzą jako zasobem.

Bez względu na użytą definicję, zdaniem Bali, Wickramasinghe i Lahaney istnieje zgoda, że zarządzanie wiedzą jest jedną z kluczowych oraz integrujących koncepcji naszych czasów [Bali, Wickramasinghe i Lahaney 2009, s. 1]. Przedstawiciele różnych nauk, w tym m.in. ekonomii, socjologii czy zarządzania zgodnie twierdzą, iż przy obecnych warunkach biznesu nieodzownym elementem rozwoju organizacji jest właśnie zarządzanie wiedzą [Ahmed, Lim i Loh 2002, s. 6]. Należy jednak pamiętać, iż różnorodność definicji pokazuje jak różne spojrzenia na omawiane zagadnienie można spotkać zarówno wśród badaczy, jak i w praktyce gospodarczej.

Pomimo dominującej pozycji, jaką zajmuje w literaturze koncepcja zarządzania wiedzą należy pamiętać, że istnieją również inne, pokrewne koncepcje w omawianym obszarze. Ich podejście do zagadnienia i spektrum zainteresowania jest najczęściej nieco inne niż w przypadku zarządzania wiedzą, lecz ich dorobek jest również wartościowy i warty docenienia oraz wykorzystania wraz dominującą koncepcją zarządzania wiedzą. Wśród ważniejszych tego rodzaju teorii należy wymienić m.in. organizacyjne uczenie się oraz organizację uczącą się.

\subsubsection{Organizacyjne uczenie się (organizational learning)}

Zagadnienie organizacyjnego uczenia się koncentruje się na badaniu, z naukowego punktu widzenia, procesów uczenia się w ramach organizacji [Easterby-Smith i Lyles 2006, s. 2]. Baloh, Desouza i Paquette [2011, s. 44] definiują tę teorię jako działania, których efektem jest pozyskanie wiedzy przez jakąkolwiek jednostkę organizacji, która może być dla podmiotu użyteczna. Koncepcja ta nie posiada zwartego dorobku naukowego. Nie istnieje 
w tym zakresie jednolity model (czy teoria), który łączyłby różnorodne koncepcje w tym obszarze [Jashapara 2006, s. 82]. Najważniejszą i najczęściej wspominaną w literaturze teorią jest koncepcja uczenia się jedno- i dwupętlowego stworzona przez Argyrisa i Schona, która również jest jedną ze znaczących inspiracji modelu będącego rezultatem niniejszej pracy.

Pierwszy typ - jednopętlowe uczenie się jest określane również jako zachowawcze czy adaptacyjne. Bazuje ono na stosowaniu w obliczu napotkanego przez organizację problemu sprawdzonych metod i działań. W przypadku uczenia się dwupętlowego (zwanego również poznawczym czy transformacyjnym) organizacja nie koncentruje się na utartych schematach działań, podważając stare założenia oraz zasady. Umożliwia to odkrywanie nowych metod i sposobów działania [Jashapara 2006, s. 89, 368].

Poza szeroko opisywanymi w literaturze koncepcjami uczenia się jednoi dwupętlowego można natrafić również na koncepcje deutero-dwu pętlowego (deuterodouble loop learning) czy uczenia się trzypętlowego ${ }^{24}$. Uczenie się deutero-dwu pętlowe zachodzi w momencie, gdy organizacja m.in. nauczy się stosować poprzednie dwa typy uczenia się. Najbardziej jednak interesującym w kontekście niniejszej pracy jest uczenie się trzypętlowe. Określane jest ono przez Sunassee, Haumant jako najbardziej wszechstronna metoda nauki opisana do tej pory. Dochodzi do niego w momencie, gdy organizacja kwestionuje swoje podstawy czyli wizję, misję kulturę czy pozycję rynkową [Sunassee i Haumant 2004, s. 265]. Przykładowo, Steve Jobs inwestując zasoby organizacyjne firmy Apple w pierwszego iPoda zakwestionował kierunek działań firmy, która od dwudziestu lat była skupiona na komputerach osobistych.

\subsubsection{Organizacja ucząca się (learning organization)}

Idea organizacji uczącej się, jak podkreśla Seebacher [2002, s. 144], powstała około roku 1988 w Wielkiej Brytanii i Stanach Zjednoczonych, ale wiele jej elementów pochodzi z lat 50. i 60. z teorii systemów [Perechuda 2005, s. 85]. Za twórcę tej koncepcji uznaje się Chrisa Argyrisa z Harvardu [Bali, Wickramasinghe i Lahaney 2009, s. 83]. Jej popularyzacja wśród praktyków, jak i naukowców nastąpiła jednak dzięki Peterowi Senge, który napisał słynną książkę „Piąta dyscyplina” [Easterby-Smith i Lyles 2006, s. 4]. Wymieniona pozycja

\footnotetext{
${ }^{24}$ Należy podkreślić, iż nie zawsze te dwie kategorie uczenia się (deutero-dwu pętlowe i trzypętlowe) są w literaturze ujmowane rozdzielnie. Przykładowo Markowski postrzega uczenie się deutero-dwu pętlowe również jako trzecią pętlę uczenia się, które odróżnia się od wcześniejszych typów (jedno- i dwupętlowego) tym, że proces uczenia jest celem, a nie skutkiem [Markowski 2009, s. 99].
} 
literaturowa przyczyniła się do trwałego zainteresowania się omawianym zagadnieniem szczególnie wśród szkół biznesu i firm doradczych [Jashapara 2006, s. 308-309].

Podstawową różnicą pomiędzy organizacją tradycyjną, a uczącą się jest według Perechudy świadome uczenie się, które wynika z przyjęcia założenia, iż podstawą tworzenia wartości i funkcjonowania podmiotu jest zasób wiedzy, nie zaś kapitał finansowy czy rzeczowy [Perechuda 2005, s. 87]. Zdaniem Senge kształtowanie organizacji uczącej się nie jest działaniem, które ma określony zakres czasowy, ale jest działaniem ciągłym [Senge 2012, s. 16]. Wspominany autor wyróżnił pięć dyscyplin ważnych dla istnienia organizacji uczącej się, które zostały ujęte w tabeli 3.

Tabela 3. Pięć dyscyplin organizacji uczącej się Petera Senge.

\begin{tabular}{|c|c|c|}
\hline & Dyscyplina & Charakterystyka \\
\hline 1. & $\begin{array}{l}\text { Myślenie } \\
\text { systemowe }\end{array}$ & $\begin{array}{l}\text { Polega na postrzeganiu przedsiębiorstwa jako systemu działań, } \\
\text { które są wzajemnie powiązane. }\end{array}$ \\
\hline 2. & $\begin{array}{l}\text { Mistrzostwo } \\
\text { osobiste }\end{array}$ & $\begin{array}{c}\text { Polega na stałym uczeniu się i rozwoju umiejętności zdobywania } \\
\text { wiedzy przez pracowników podmiotu. }\end{array}$ \\
\hline 3. & $\begin{array}{l}\text { Modele } \\
\text { myślowe }\end{array}$ & $\begin{array}{l}\text { Związane są z ludzkimi wyobrażeniami i zakorzenionymi } \\
\text { założeniami, które wpływają na postrzeganie świata } \\
\text { i w konsekwencji podejmowane działania. }\end{array}$ \\
\hline 4. & $\begin{array}{l}\text { Budowanie } \\
\text { wspólnej wizji }\end{array}$ & $\begin{array}{c}\text { Wspólna wizja inspiruje członków organizacji, umożliwia } \\
\text { bardziej efektywne działanie jednostek i wyzwala } \\
\text { długoterminową motywację. }\end{array}$ \\
\hline 5. & $\begin{array}{l}\text { Zespołowe } \\
\text { uczenie się }\end{array}$ & Wspólna inteligencja zespołu może być zarówno wyższa \\
\hline
\end{tabular}




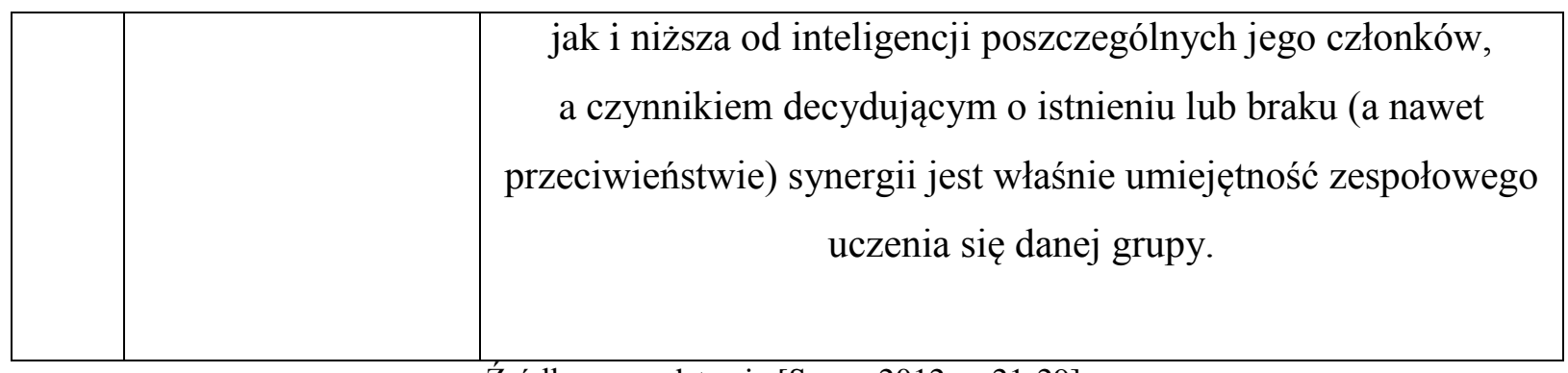

Źródło: na podstawie [Senge 2012, s. 21-29].

Senge podkreśla przede wszystkim znaczenie pierwszej z wymienionych dyscyplin myślenia systemowego, które określa mianem piątej dyscypliny umożliwiającej integrację pozostałych. Wspomniany autor podaje tu przykład samolotu DC-3 i pięciu technologii, których jednoczesne zastosowanie w jednym modelu samolotu umożliwiło zmiany - w tym przypadku zapoczątkowało lotnictwo komercyjne [Senge 2012, s. 28]. U podstaw modelu wykorzystywanego w niniejszej pracy leży również myślenie systemowe Senge, a także jednoczesne zastosowanie dwóch ważnych elementów w działaniach przedsiębiorstwa, które zostaną omówione w późniejszych etapach pracy.

Należy jednak podkreślić, iż wkład Senge do koncepcji organizacji uczącej się, choć najbardziej rozpowszechniony, nie jest jednym. Jashapara podkreśla również wkład brytyjski (Garratt, Revans) czy japoński (Nonaka) [Jashapara 2006, s. 311-317].

W kontekście niniejszej pracy i wypracowywania ostatecznego modelu duże znaczenie ma koncepcja organizacji uczącej się konkurencyjnie Jashapary. Oparta jest ona na spostrzeżeniu, iż sam proces uczenia się nie zapewni przedsiębiorstwu przewagi konkurencyjnej. Bardzo ważnym jest, aby nauka była odpowiednio ukierunkowana, gdyż uczenie się rzeczy niepotrzebnych nie przyniesie oczekiwanych rezultatów [Jashapara 2006, s. 318]. Zdaniem autora, wadą modelu Jashapary jest jednak relatywna abstrakcyjność co w konsekwencji sprawia, iż trudno w prosty sposób zbadać i zastosować to ujęcie w praktyce.

Pomimo faktu, iż modele w ramach koncepcji organizacji uczącej się wnoszą ważny wkład do rozwoju teorii w zakresie działań przedsiębiorstw w zakresie wiedzy to zdaniem Probsta, Rauba i Rombhardta oraz szeregu osób zajmujących się zarządzaniem, wiele publikacji dotyczących organizacji uczących się jest bardzo abstrakcyjnych i wynikające z nich wnioski nie nadają się do praktycznego zastosowania. Przedsiębiorstwa potrzebują koncepcji na niższym poziomie abstrakcji, które wskażą właściwy kierunek osobom decyzyjnym [Probst, Raub i Romhardt 2004, s. 39-40]. Część autorów postrzega organizację uczącą się jako swoisty i nieosiągalny stan idealny, do którego przedsiębiorstwo będzie 
zawsze dążyć [Jashapara 2006, s. 307]. Jashapara również podkreśla, iż rozważania w zakresie organizacji uczącej się, mają najczęściej charakter teoretyczny i rzadko poparte są wynikami badań empirycznych [Jashapara 2006, s. 307]. Problemem organizacji uczącej jest również przyjmowanie implicite założenia, iż samo stworzenie tego typu organizacji jest gwarantem i źródłem przewagi konkurencyjnej [Jashapara 2006, s. 317].

Podsumowując powyższe rozważania, koncepcja organizacji uczącej się pomimo swojego raczej abstrakcyjnego charakteru, uniemożliwiającego praktyczne wdrożenie tej idei w przedsiębiorstwie, dostarcza jednak cennych wniosków, które mają wpływ na kształt ostatecznego modelu opracowanego w niniejszej pracy. Przede wszystkim wyznacza ona kierunek, w którym powinno dążyć nowoczesne przedsiębiorstwo. Zakłada stałe zmiany związane ze zmieniającym się środowiskiem działania podmiotu. Dodatkowo podkreśla wagę ciągłego uczenia się firmy i doskonalenia procesów, co jest nieodzowne w czasach dużej konkurencji.

\subsubsection{Pozostałe koncepcje w zakresie wiedzy}

Autor niniejszej pracy jest świadom, iż w literaturze istnieje znaczna liczba koncepcji bezpośrednio lub pośrednio nawiązujących do zasobu wiedzy czy uczenia się. Nie wszystkie z nich zostały zaprezentowane w niniejszej pracy. Wśród nich należy wymienić ciągle zmieniającą się organizację inteligentną [Perechuda 2005, s. 93-105], która jest przez Mikułę definiowana jako wyższa forma organizacji uczącej się [Mazur, Rószkiewicz i Strzyżewska 2008, s. 14]. Easterby-Smith i Lyles [2006, s. 11-12] wyszczególniają również jako osobną koncepcję tzw. „wiedzę organizacyjną”. Wyróżnia się również koncepcję kapitału intelektualnego oraz zarządzania tym zasobem [Stankiewicz 2006, s. 119].

Należy również podkreślić, iż dorobek poszczególnych teorii w dużej mierze nakłada się na siebie. Intencją autora było umiejscowienie pracy oraz wypracowanego w ramach niej modelu w kontekście głównych koncepcji w zakresie wiedzy, które w związku ze swoją popularnością skupiają zdecydowaną większość dorobku literaturowego odnoszącego się do wiedzy i uczenia się. 


\subsubsection{Różnice i relacje pomiędzy poszczególnymi koncepcjami w zakresie wiedzy i uczenia się}

Trudnym zadaniem jest określenie różnic i relacji pomiędzy poszczególnymi koncepcjami w omawianym obszarze. Jedną z przyczyn problemu jest fakt, iż w literaturze w wielu sytuacjach brakuje wyraźnego rozróżnienia pomiędzy wiedzą, a uczeniem się [Chakravarthy i in. 2006, s. 306]. Zdaniem Very i Crossana zadanie dodatkowo utrudniają także sami badacze, gdyż często zdarza się, iż naukowcy koncentrujący się na „wiedzy” unikają pojęcia „uczenie się” i odwrotnie. Inni zaś używają pojęć „wiedza”, „zarządzanie wiedzą” oraz „uczenie się” jako synonimów [Vera i Crossan 2006, s. 123]. Brak istnienia jasnych relacji i zgodności pomiędzy tego rodzaju koncepcjami egzemplifikuje stwierdzenie Nonaki i Takeuchiego, którzy podkreślają, że teoria organizacji uczącej się Senge ma „coś wspólnego" z ich koncepcją tworzenia wiedzy, lecz wspomniany autor rzadko posługuje się pojęciem „wiedza” i nie wyjaśnia, jak tworzyć ten zasób [Nonaka i Takeuchi 2000, s. 68].

Wielu autorów oraz praktyków zajmujących się zagadnieniami uczenia się i wiedzy dostrzega potrzebę rozwoju jednej, konsekwentnej terminologii, która byłaby stosowana w obu obszarach [Vera i Crossan 2006, s. 122]. Wielu naukowców (m.in. Huber, Simon i Weick) już w latach 90-tych XX wieku podkreślało brak jednolitego, zwartego nazewnictwa w obszarach wiedzy oraz uczenia się [Vera i Crossan 2006, s. 122].

Swan i inni podkreślają, iż koncepcja organizacji uczącej się zyskała popularność jako pierwsza. Pojawienie się teorii zarządzania wiedzą spowodowało jednak spadek zainteresowania wcześniejszą tematyką [Jashapara 2006, s. 307]. Niestety również czołowi teoretycy $\mathrm{w}$ zakresie zarządzania wiedzą często nie uwzględniają koncepcji ani pojęć „organizacja ucząca się” czy „organizacyjne uczenie się” [Jashapara 2006, s. 307]. Sprawia to, iż cenny dorobek tych koncepcji nie zawsze jest wykorzystywany.

Poszczególne teorie niestety są również rzadko omawiane wspólnie [Vera i Crossan 2006, s. 122]. Sprawia to, iż brakuje jednolitej interpretacji zależności pomiędzy poszczególnymi koncepcjami. Kilka publikacji próbuje jednak zmierzyć się z tym problemem, z których najbardziej kompleksowym, zdaniem autora niniejszej pracy, jest ujęcie Easterby-Smitha i Lylesa [2006, s. 3] (rysunek 6). 


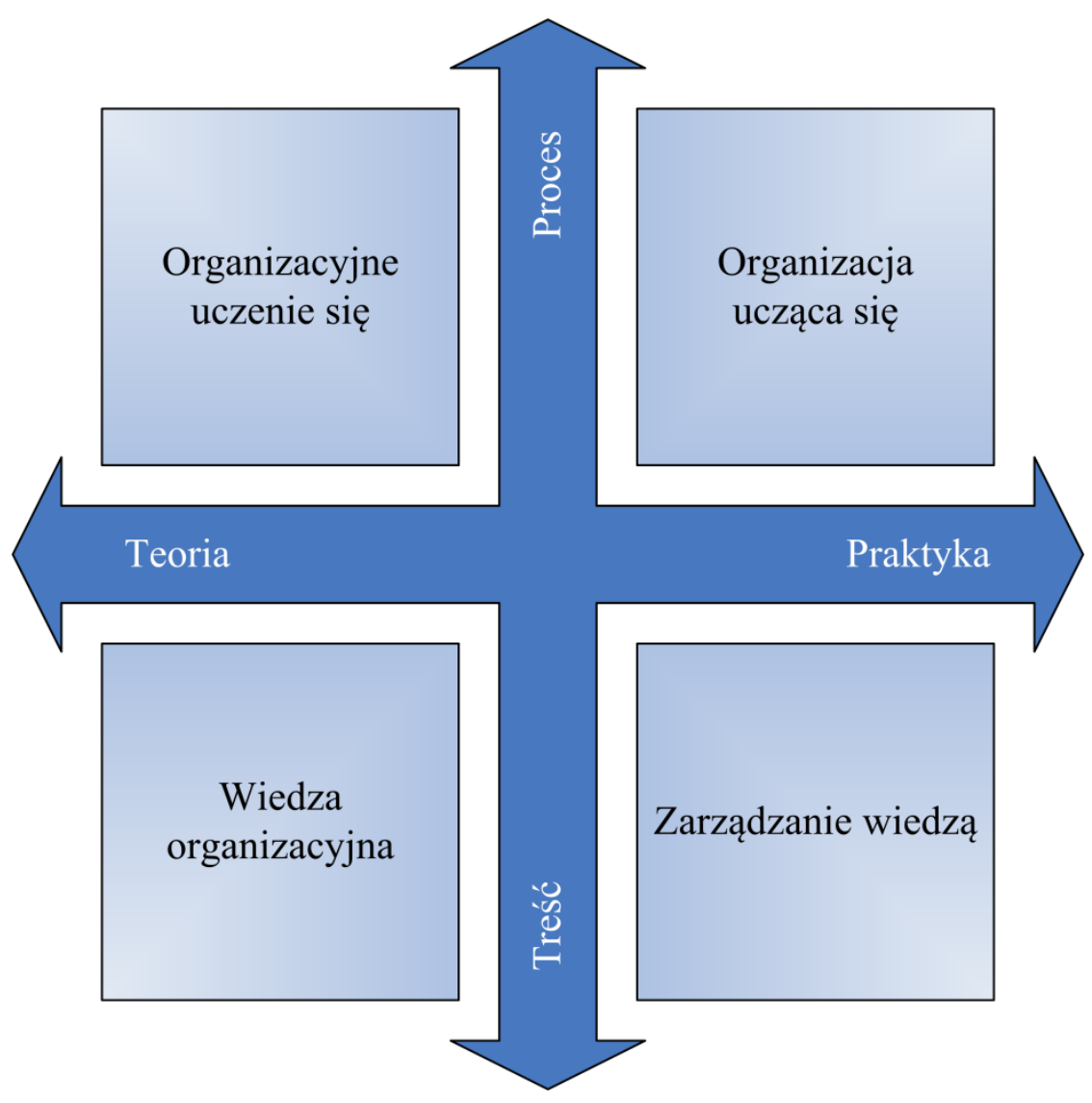

Rysunek 6. Zależność pomiędzy koncepcjami w zakresie wiedzy ${ }^{25}$. Źródło: [Easterby-Smith i Lyles 2006, s. 3].

Przedstawiona na powyższym rysunku została również teoria wiedzy organizacyjnej, która jest kolejną teorią w zakresie wiedzy, niebędącą w centrum zainteresowania niniejszej pracy. Zdaniem Very i Crossana organizacja ucząca się oraz organizacyjne uczenie wywodzą się z różnych nurtów teoretycznych ${ }^{26}$ [Vera i Crossan 2006, s. 124]. Organizacyjne uczenie się wyjaśnia „w jaki sposób organizacja się uczy”, zaś organizacja ucząca się odpowiada na pytanie „W jaki sposób organizacja powinna się uczyć” [Vera i Crossan 2006, s. 124]. Wspomniani autorzy dostrzegają w definicjach zarządzania wiedzą silne wskazówki praktyczne stąd uważają, że można je nawet opisać jako „zarządzanie uczeniem się” [Vera i Crossan 2006, s. 124]. Z rozważań wymienionych autorów wynika, iż podobieństwo koncepcji organizacji uczącej się, jak i zarządzania wiedzą jest konsekwencją ich praktycznej perspektywy, w przeciwieństwie do teoretycznej perspektywy prezentowanej przez teorie

\footnotetext{
${ }^{25}$ Uwaga: pojęcia „proces” na rysunku nie należy mylić w żadnym razie z wcześniej opisanymi w pracy procesami w zakresie wiedzy czy podejściem procesowym do zarządzania wiedzą. Na rysunku proces odwołuje się do aktywności, jaką jest uczenie się.

${ }^{26}$ Z kolei Sitko-Lutek [2009, s. 73] zaznacza, iż większość badaczy definiuje organizacyjne uczenie się jako proces, posiadający kolektywny charakter, który prowadzi do doskonalenia i ma na celu budowę organizacji uczącej się.
} 
organizacyjnego uczenia się oraz wiedzy organizacyjnej. Vera i Crossan postrzegają organizacyjne uczenie się jako proces zmieniający, zarówno indywidualne, jak i grupowe, myślenie i działania, który jest wpleciony oraz warunkowany przez struktury organizacji [Vera i Crossan 2006, s. 123]. Wspomniani autorzy podkreślają również, iż brakuje powszechnie uznanej linii podziału pomiędzy koncepcjami zarządzania wiedzą i organizacyjnego uczenia się [Vera i Crossan 2006, s. 122].

Lamparska-Jasińska [2012, s. 27-28] zauważa, iż zarządzanie wiedzą jako koncepcja interdyscyplinarna posiada określone powiązania z szeregiem innych teorii organizacyjnych. Punktem wspólnym z koncepcją organizacyjnego uczenia się jest teoria, zaś model działań biznesowych koncepcji zarządzania wiedzą stanowi łącznik z teoriami organizacji uczącej się oraz inteligentnej.

Inną interpretacją problemu jest ujęcie Jashapary, który traktuje zarządzanie wiedzą jako działania oraz procesy, zaś organizację uczącą się jako swoisty, określony stan końcowy, do którego podmiot zmierza lub nawet nieosiągalny ideał mający na celu motywowanie firmy do stałych poszukiwań [Jashapara 2006, s. 307].

Należy jednak podkreślić, że istnieje szereg innych prób integracji poszczególnych koncepcji w zakresie wiedzy i uczenia się. Ich podejście jest niejednokrotnie bardzo zróżnicowane, stąd można określić tę kwestie jako niezamkniętą. Nie ulega jednak wątpliwości, iż każda z teorii posiada nieco inny, bardzo cenny dorobek. W związku z tym jednoczesne korzystanie z osiągnięć różnych koncepcji, czego dokonuje niniejsza praca, może prowadzić do lepszego poznania tematyki związanej z wiedzą i uczeniem się.

\subsubsection{Dynamiczne koncepcje w zakresie wiedzy - ujęcie integracyjne}

Obecnie możemy mówić o dominacji koncepcji zarządzania wiedzą dla organizacji działań przedsiębiorstwa $\mathrm{w}$ obszarze informacji i wiedzy. Prowadzi to do efektu kuli śniegowej sprawiając, iż ta teoria rozwija się najbardziej dynamicznie stale wzbogacając swój dorobek teoretyczny, jak i empiryczny. Pozycja zajmowana przez koncepcję zarządzania wiedzą jest w dużej mierze spowodowana określonymi charakterystykami tej teorii, szczególnie przejrzystością, jasnością i zauważonym przez Verę, Crossana [2006, s. 124] praktycyzmem podejścia do zagadnienia.

Podstawą dalszej analizy działań przedsiębiorstwa w zakresie wiedzy jest dorobek literaturowy koncepcji zarządzania wiedzą. Teoria ta jest również trzonem podejścia 
modelowego, należy jednak zaznaczyć, iż dwie pozostałe, omówione wyżej koncepcje w zakresie wiedzy i uczenia się podmiotu są również nieodłącznym elementem modelowego ujęcia stanowiącego trzon niniejszej pracy.

\subsection{Zarządzanie wiedzą $w$ przedsiębiorstwie}

\subsubsection{Modele i strategie zarządzania wiedzą.}

Istnieje szereg modeli (lub podejść do) zarządzania wiedzą. Wybór określonego podejścia może do pewnego stopnia implikować wybór strategii zarządzania wiedzą, a następnie narzędzi realizacji działań. Nie istnieje również jednolita klasyfikacja czy chociaż typologia $\mathrm{w}$ zakresie samych koncepcji zarządzania wiedzą. W opinii części autorów do trzech najbardziej popularnych podejść do zarządzania wiedzą należy zaliczyć (po myślniku podano głównych przedstawicieli danych nurtów, którzy wnieśli do nich najwięcej) [Perechuda 2005, s. 74; Kowalczyk i Nogalski 2007, s. 51; Paliszkiewicz 2007, s. 44-47; Tabaszewska 2012, s. 23-24; Gruszczyńska-Malec i Rutkowska 2013, s. 50]:

- model zasobowy - Leonard-Barton,

- model japoński - Nonaka i Takeuchi,

- model procesowy - Davenport i Prusak; Probst i Raub, Rombhardt; Bukowitz i Williams.

W odniesieniu do przywołanego podziału Paliszkiewicz podkreśla, iż każdy z modeli zarządzania wiedzą posiada zarówno zalety, jak i wady. Niewątpliwą zasługą modelu japońskiego jest wyodrębnienie dwóch typów zasobu wiedzy: jawnej oraz ukrytej, ułomnością zaś niska operacjonalizacja. W modelu zasobowym zaletą jest docenienie znaczenia wiedzy, lecz niestety traktowany jest on jak każdy inny zasób strategicznego znaczenia. Podejście procesowe jest $\mathrm{w}$ dużym stopniu uporządkowane i logiczne. Jego słabością jest jednak postrzeganie wiedzy jako informacji [Paliszkiewicz 2007, s. 49].

Wartym wspomnienia, ze względu na swoją szczegółowość, jest podział szkół zarządzania wiedzą według Earla (Earl's taxonomy), który wyróżnia trzy główne kategorie: ekonomiczną, behawioralną oraz technokratyczną [Handzic i Zhou 2005, s. 4-5].

Opisane różnice często są przyrównywane do podziałów pomiędzy wschodem i zachodem. W opinii Perechudy przyczyną istnienia dwóch wspomnianych nurtów są określone uwarunkowania [Perechuda 2005, s. 54]: 
- indywidualistyczna koncentracja świata zachodniego oraz zespołowy model pracy dominujący na wschodzie,

- popularność informatycznych, ilościowych narzędzi zarządzania wiedzą na zachodzie oraz jakościowych na wschodzie.

Wielość różnego rodzaju spojrzeń i poglądów w zakresie zarządzania wiedzą wymaga doboru jednej perspektywy postrzegania zagadnienia w niniejszej pracy (rysunek 7).

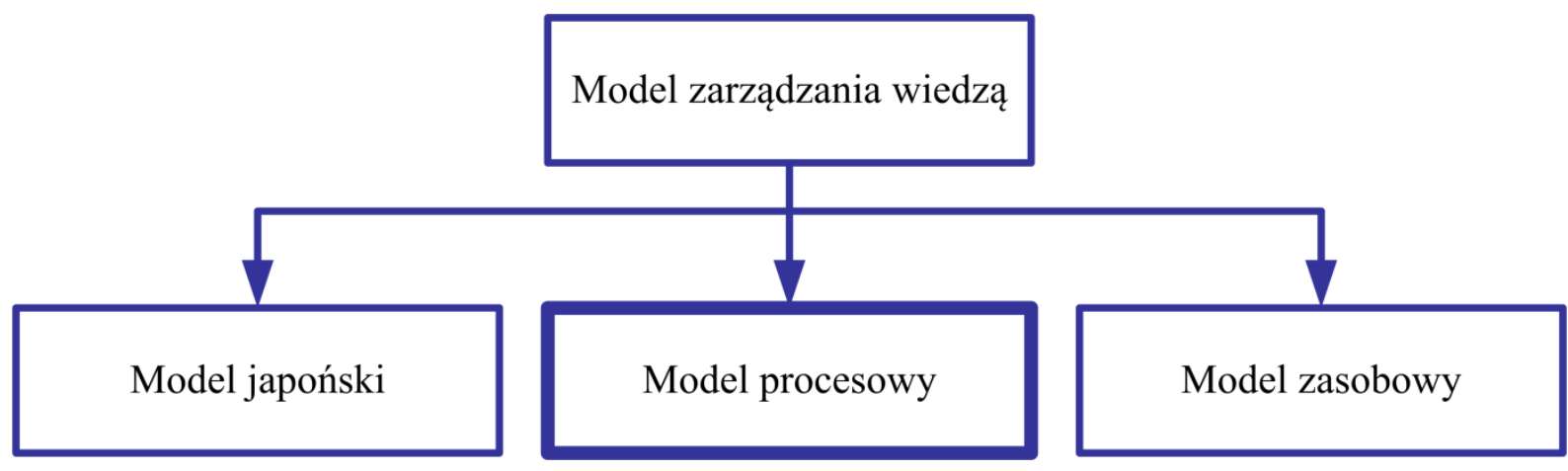

Rysunek 7. Model zarządzania wiedzą.

Źródło: opracowanie własne (koncepcje wyróżnione na podstawie: [Paliszkiewicz 2007, s. 44-47; Kowalczyk i Nogalski 2007, s. 51]).

Wybór podejścia procesowego jako dominującego w niniejszej pracy jest podyktowany kilkoma czynnikami. Po pierwsze, jest on najbardziej dostosowany do uwarunkowań kultury zachodu, do której Polska - kraj, w którym zostanie przeprowadzone badanie empiryczne jest najbardziej zbliżony. Drugim czynnikiem przemawiającym za wyborem tej opcji jest, co podkreśla Paliszkiewicz [2007, s. 49], jego uporządkowanie. Umożliwia ono bowiem podział zarządzania wiedzą na elementy składowe - szczegółowe procesy i relatywnie proste ich zbadanie w różnorodnych typach przedsiębiorstw. Trzecim czynnikiem jest fakt, że pomimo literaturowego utożsamiania podejścia procesowego z koncentracją na wiedzy jawnej (a właściwie brakiem rozróżnienia pomiędzy wiedzą jawną i niejawną) umożliwia ono jednak przynajmniej częściowe wykorzystanie dorobku podejścia japońskiego w kontekście działań w zakresie wiedzy niejawnej. Należy jednak zaznaczyć, iż podejście procesowe $\mathrm{w}$ pewnym stopniu jest sprzeczne $\mathrm{z}$ oryginalną koncepcją Nonaki i Takeuchiego, którzy podkreślają, iż zachodnia kadra zarządzająca powinna skupić się w większym stopniu na mniej usystematyzowanych i formalnych działaniach w zakresie wiedzy [Nonaka i Takeuchi 2000, s. 28]. 
Model zarządzania wiedzą $w$ organizacji jest ściśle powiązany ze strategią zarządzania wiedzą ${ }^{27}$. Należy zaznaczyć, iż wielu autorów nie dokonuje podziału pomiędzy modelami i strategiami zarządzania wiedzą. Jest to spowodowane faktem, iż obie kategorie są bardzo zbliżone i rozróżnienie w tym zakresie nie jest wyraźne. Zdaniem autora, wprowadzenie rozróżnienia pomiędzy tymi kategoriami podziału jest zasadne, w szczególności w przypadku wybranego w niniejszej pracy modelu procesowego. Wskazuje ono bowiem, iż podstawą przyjętego spojrzenia na koncepcję zarządzania wiedzą jest uporządkowane podejście zachodnie. Przykładowo, stosowanie w jego ramach strategii personalizacji, która będzie omówiona w dalszej części pracy, a której idea pochodzi z modelu japońskiego nie oznacza stricte zastosowania tego modelu zaś wyłącznie strategii, która w dużej mierze czerpie z jego dorobku, lecz nie jest z nim tożsama.

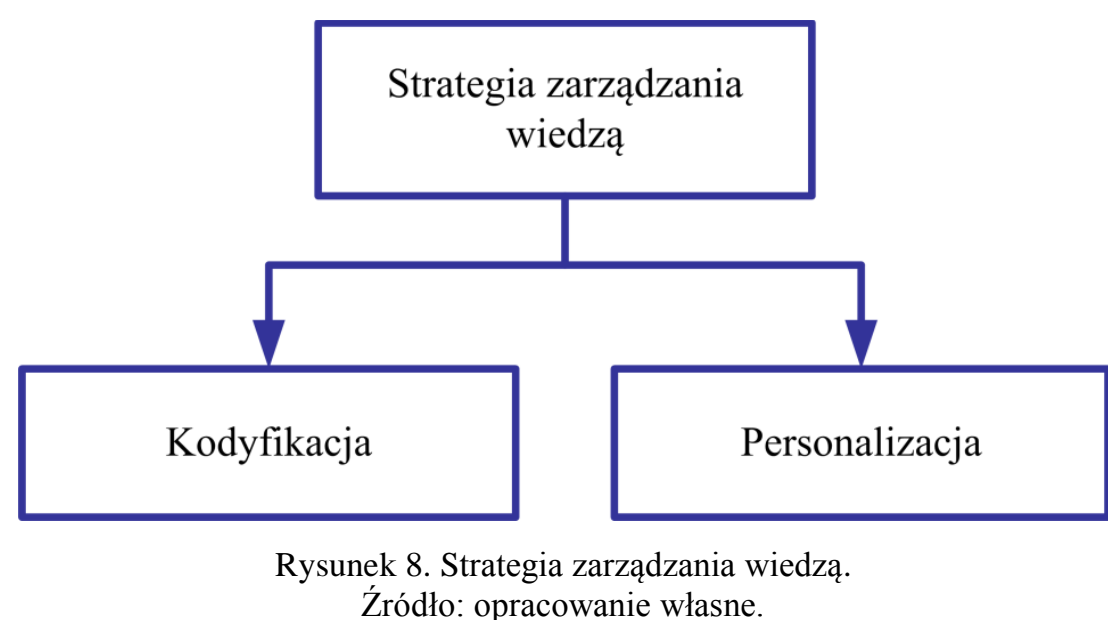

W literaturze istnieją dwie główne strategie zarządzania wiedzą: kodyfikacji i personalizacji (rysunek 8). Strategia kodyfikacji wywodzi się z koncepcji zachodnich, zaś personalizacji z koncepcji japońskiej. Wybór strategii zarządzania wiedzą jest uzależniony od charakteru procesów, jakie mają miejsce w przedsiębiorstwie. W przypadku produktów standardowych zazwyczaj lepsza jest kodyfikacja. W momencie, gdy wykorzystywana jest intuicja i umiejętności indywidualnych pracowników, np. przy produktach niestandardowych dopasowywanych do wymagań poszczególnych klientów, najczęściej sprawdza się personalizacja [Leja 2006, s. 18]. Wprowadzenie systemu zarządzania wiedzą (w tym także narzędzi technologicznych) w przedsiębiorstwie powinno być wykonywane kompleksowo, bazowane na autentycznych potrzebach, a nie np. na krótkotrwałej modzie [Gierszewska

${ }^{27}$ Przykładowo wybór określonego modelu może ograniczać wybór strategii. W przypadku wyboru podejścia japońskiego wykorzystanie niższej kategorii strategii $\mathrm{w}$ takiej samej formie jak w podejściu procesowym mija się z celem. 
2011, s. 173]. Hansen, Nohir i Tierney uważają, że należy konsekwentnie realizować przyjętą na początku strategię (kodyfikacji lub personalizacji) zarządzania wiedzą, gdyż jej zmiana może przynieść więcej kosztów niż korzyści ${ }^{28}$ [Leja 2006, s. 18].

Należy zaznaczyć, że wybór nie musi polegać na selekcji tylko jednej opcji, ale może również być związany z doborem odpowiedniej proporcji dwóch czynników. Jedna z opcji musi jednak dominować, co nie oznacza eliminacji drugiego elementu, który może pełnić rolę wspomagającą. W przypadku omawianych decyzji, należy jednak rozróżnić pomiędzy dominacją danej opcji, a wyłączną koncentracją na niej. Wykorzystanie wyłącznie jednej strategii jest trudne, o ile nie niemożliwe. Potrzebna jest strategia dominująca, ale bardzo przydatna jest również strategia uzupełniająca, np. firma doradcza McKinsey koncentruje się na strategii personalizacji, ale stworzono także bazę dokumentów i mapę wiedzy, co może być postrzegane jako pewnego rodzaju kodyfikacja.

Należy jednak zaznaczyć, że nie są to jedyne ujęcia strategii zarządzania wiedzą. Przykładowo, inaczej do omawianego zagadnienia podeszli Ahmed, Lim i Loh wyróżniając trzy główne strategie zarządzania wiedzą: reaktywną, mechanistyczną, oraz organiczną. $\mathrm{W}$ pierwszej z nich dominują przede wszystkim przekonania techniczne i efektywnościowe realizowane w określonych zakresach i jednostkach przedsiębiorstwa, skoncentrowane w przeważającej mierze na systemach informatycznych. Działania te są przede wszystkim fragmentaryczne i realizowane ad hoc. Kolejne dwie pozostałe strategie - organiczna i mechanistyczna zakładają usystematyzowane działania wdrażane w całej organizacji. Pierwsza z nich zdecydowanie koncentruje się na ludziach uwzględniając m.in. zachęty dla człowieka do dzielenia się wiedzą. Ujęcie mechanistyczne w większym stopniu polega na technologiach informatycznych i jest ukierunkowane z góry na dół [Ahmed, Lim i Loh 2002, s. 20-22].

Martinez wymienia dwa podejścia do strategii: kognitywistyczne oraz pozytywistyczne. Pierwsze $\mathrm{z}$ nich postrzega zarządzanie wiedzą jako pozyskiwanie, gromadzenie oraz rozpowszechnianie informacji, których większa liczba oznacza dokładniejszy opis rzeczywistości. Druga z przytoczonych koncepcji - pozytywistyczna przyjmuje bardziej złożony obraz wiedzy jako zasobu, który nie może być w prosty sposób transferowany ze względu na swoją indywidualną budowę. Zgodnie z tym punktem widzenia

\footnotetext{
28 Pomimo wiodącego w literaturze poglądu, iż jedna ze strategii musi dominować najnowsze badania przeprowadzone $\mathrm{w}$ dość specyficznej grupie firm konsultingowych wskazują, iż niekoniecznie musi to być prawdą. Badania Powell i Ambrosini pokazują, iż brak wyboru dominującej opcji i równoczesne, elastyczne podejście do tematu w zależności od potrzeb jest również skuteczne i jak wskazują wspomniani autorzy nie do końca zbadane [Powell i Ambrosini 2012, s. 209-211, 217, 220-223].
} 
zarządzanie wiedzą powinno skupiać się $\mathrm{w}$ przeważającej mierze na stymulacji interakcji pomiędzy indywidualnymi osobami, zaś działania $\mathrm{w}$ zakresie wiedzy jawnej, takie jak tworzenie repozytoriów wiedzy, powinny zaledwie wspierać te procesy [Martinez 2010, s. 25]. Bardzo podobny podział, jak w omawianej konwencji, stworzyli Bukh, Christensen i Mouritsen. Wyróżniają oni dwie perspektywy zarządzania wiedzą. Pierwsza z nich określana jest przez wymienionych autorów terminem „zorientowanej na artefakty”. Skupia się ona wykorzystaniu technologii informatycznych, czyli w praktyce koncentruje się na działaniach w zakresie informacji. Drugą kategorią zarządzania wiedzą wyróżnioną przez wymienionych autorów jest perspektywa społeczna bazowana na publikacjach Nonaki oraz Nonaki i Takeuchiego [Bukh, Christensen i Mouritsen 2005, s. 16]. Jashapara podkreśla, że mamy obecnie dwie frakcje: pierwszą są specjaliści od zasobów ludzkich, zaś drugą tworzą skoncentrowani na technologiach fachowcy związani $\mathrm{z}$ systemami informatycznymi. Zróżnicowanie poglądów i podejść do tematu tych dwóch grup sprawia, że nie mogą one znaleźć wspólnej płaszczyzny dyskursu [Jashapara 2006, s. 376].

Podsumowując, pomimo istnienia różnorodnych kategoryzacji strategii zarządzania wiedzą, należy zauważyć są one mniej lub bardziej rozbudowanymi wersjami dwóch pierwotnych, a silna linia podziału jest zachowana. Przebiega ona pomiędzy stronnikami postrzegania wiedzy jako czegoś namacalnego - koncentracja na wiedzy jawnej, często nawet utożsamianej z informacją (strategia kodyfikacji) oraz zwolennikami twierdzenia, iż wiedza jest nieodłącznie związana $\mathrm{z}$ umysłem człowieka (strategia personalizacji) ${ }^{29}$. W związku z tym obie z tych strategii wymagają dokładniejszego omówienia.

Celem kodyfikacji jest odpowiednia organizacja posiadanej wiedzy w celu zaprezentowania jej w zrozumiałej i przystępnej dla wszystkich formie [Kowalczyk i Nogalski 2007, s. 54]. Kodyfikacja wydaje się najbardziej oczywistym działaniem w zakresie utrwalania wiedzy. W praktyce jest jednak najczęściej trudna do realizacji [Jemielniak i Koźmiński 2012, s. 82]. Ideę kodyfikacji trafnie prezentują Bukh, Chirstensen i Mouritsen w swojej perspektywie zarządzania wiedzą zorientowanej na artefakty. Zgodnie ze wspomnianą koncepcją, im więcej danych i informacji organizacja jest w stanie zebrać, tym bardziej zmniejsza niepewność swoich działań. Epistemologia zorientowana na artefakty skupia się na spisywaniu wiedzy, która w efekcie może być szybko dostarczona wielu

\footnotetext{
${ }^{29}$ Zachodnie koncepcje zarządzania wiedzą określane są często w literaturze jako koncentrujące się na wiedzy jawnej (utożsamianej nawet $\mathrm{z}$ informacją). Należy jednak zaznaczyć, iż rozróżnienie pomiędzy wiedzą jawną i ukrytą zostało spopularyzowane przez Nonakę i Takeuchiego, a koncepcje zachodnie w swej istocie często nie rozróżniają tych dwóch rodzajów wiedzy, co w praktyce prowadzi do koncentracji na bardziej namacalnym elemencie - wiedzy jawnej.
} 
osobom [Bukh, Christensen i Mouritsen 2005, s. 20-21]. Holsapple i Joshi podkreślają, że przepływ wiedzy z wykorzystaniem form pisanych wymaga ścisłej dyscypliny w zakresie stosowanych opisów czy definicji [Bukh, Christensen i Mouritsen 2005, s. 21-22]. Zdaniem Thomasa i Trevino informacja jest (w przeciwieństwie do wiedzy w formie niejawnej) obiektywnym elementem, stąd jest ważna w procesie podejmowania decyzji [Bukh, Christensen i Mouritsen 2005, s. 20]. Wielu autorów podkreśla również dużą rolę komunikacji i przepływu informacji jako czynników zmniejszających niepewność działania podmiotu. Weiser i Morison podkreślają wagę pamięci projektowej, zaś Malone i inni zwracają uwagę na znaczenie instrukcji oraz innych źródeł pisanych [Bukh, Christensen i Mouritsen 2005, s. 21].

Davenport i Prusak w swojej książce „Working Knowledge” przedstawili doświadczenia dużych firm konsultingowych w zakresie wiedzy. Model zarządzania wiedzą stworzony przez autorów składa się z trzech elementów: poszerzania zasobu wiedzy, kodyfikacji oraz transferu, przy czym najważniejszy jest ten pierwszy [Kowalczyk i Nogalski 2007, s. 53]. Przykładem sukcesu wdrożenia systemu zarządzania wiedzą opartego na kodyfikacji wiedzy jest firma Ernst and Young. Skoncentrowała się ona na zbudowaniu repozytorium wiedzy, które umożliwiło skrócenie jednego z działań z sześciu do dwóch miesięcy. Stało się to dzięki wykorzystywaniu sprawdzonych procedur [Hawryszkiewicz 2010, s. 81-82].

Kodyfikacja ma jednak swoje liczne wady. Nawet jeśli udaje się wyodrębnić poszczególne, ważne elementy wiedzy ukrytej, to ich zapis w formie wiedzy jawnej może przypominać materiał źródłowy w formacie Ultra HD, w którym kluczowe są szczegóły, odzwierciedlony poprzez nośnik, jakim jest VHS. Przekaże on do pewnego stopnia treść, lecz jej wartość będzie znacznie niższa niż oryginału z uwagi na niedoskonałość technologii nośnika.

Zarządzanie wiedzą $\mathrm{w}$ zachodnich przedsiębiorstwach jest skoncentrowane na kodyfikacji omawianego zasobu, co przejawia się $w$ działaniach mających na celu formalizację treści za pomocą odpowiednich narzędzi, jakimi są mapy wiedzy, lecz również tabele, opisy, a także wykresy czy schematy [Perechuda 2005, s. 48]. Problem w tym, że jeżeli przypadek (nawet w niewielkim stopniu) odstaje od schematu może zaistnieć problem z zastosowaniem tej wiedzy. Osoba, która opracowała dany schemat dogłębnie rozumie współzależności i stara się odwzorować je w formie pisemnej, lecz nie jest to z pewnością narzędzie perfekcyjne i nie przenosi całości jej wiedzy w zakresie danego zagadnienia. 
Generalnie, w literaturze można zauważyć bardzo dużo krytyki względem kodyfikacji i podkreślania słabych stron tej koncepcji. Być może jest to związane ze zbytnią oczywistością tej strategii zarządzania wiedzą. Nie zmienia to jednak faktu, że w niektórych przypadkach koncepcja ta może być nieodzowna i bardzo skuteczna.

Strategia personalizacji w zarządzaniu wiedzą bazuje przede wszystkim na wiedzy niejawnej, której jedynymi dysponentami są ludzie. Scheepers, Venkitachalam i Gibbs podkreślają, iż jej podstawą jest kontakt międzyludzki, który umożliwia bezpośredni transfer posiadanej przez osoby wiedzy [Paliszkiewicz 2007, s. 41]. Omawiana koncepcja podkreśla, iż w przypadku wiedzy bardzo duże znaczenie ma zagadnienie kontekstu, gdyż „to co ma sens w jednym kontekście, może go utracić w innym” [Nonaka i Takeuchi 2000, s. 33]. Ten aspekt strategii personalizacji kontrastuje z brakiem przywiązywania szczególnej uwagi do tego zagadnienia w przypadku strategii kodyfikacji.

Popularność personalizacji wyraża fakt, iż wielu autorów publikacji w obszarze zarządzania wiedzą, podkreśla wagę działań nakierowanych na człowieka. Przykładowo Drucker podkreśla, że ogólnie zarządzanie wiedzą koncentruje się na ludziach. Jego zdaniem celem tej koncepcji jest wykorzystanie silnych stron oraz talentów oraz neutralizacja słabości osób [Dąbrowski i Gierszewska 2005, s. 19]. W literaturze podkreśla się również, iż ludzie są najcenniejszym kapitałem organizacji, gdyż ich działania wpływają na każdy element przedsiębiorstwa [Szyjewski, Nowak i Grabara 2004, s. 14]. Nie są oni podmiotami, które uczą się w sposób pasywny, gdyż dokonują interpretacji wiedzy oraz dostosowania jej do swojej perspektywy oraz sytuacji [Nonaka i Takeuchi 2000, s. 33]. Nonaka i Nishiguchi podkreślają znaczenie tworzenia odpowiedniego środowiska, które może sprzyjać kreacji wiedzy [Schmitz 2007, s. 4].

Strategia personalizacji w dużej mierze bazuje na samodzielnych pracach Nonaki oraz wspólnych pracach Nonaki i Takeuchiego. Ogólnie podejście to jest często nazywane japońskim. Kluczowym elementem tego ujęcia zagadnienia zarządzania wiedzą jest podział wiedzy na jawną oraz ukrytą (inaczej nazywaną niejawną). Zakłada ono, iż podstawowym elementem $\mathrm{w}$ tworzeniu wiedzy organizacji jest wiedza poszczególnych jednostek [Kowalczyk i Nogalski 2007, s. 51, 52] czyli wiedza ukryta. W zakresie tworzenia wiedzy, podejście japońskie upatruje wartości w interakcji pomiędzy dwoma typami wiedzy. Została ona ujęta w modelu SECI, którego istota zostanie zaprezentowana w dalszej części podrozdziału. 
Omawiana koncepcja zakłada również mniej ustrukturyzowane podejście do procesów w zakresie wiedzy. Autorzy podkreślają, iż zachodnia kadra zarządzająca powinna skupić się w większym stopniu na mniej usystematyzowanych i mniej formalnych działaniach w zakresie wiedzy [Nonaka i Takeuchi 2000, s. 28]. Nonaka i Takeuchi określają również kadrę zarządzającą jako oderwanych od rzeczywistości romantyków, którzy dążą do ideałów. Pomostem pomiędzy nimi, a rzeczywistością stanowi kadra średniego szczebla [Nonaka i Takeuchi 2000, s. 33].

W ujęciu japońskim często podkreślane jest znaczenie średniego szczebla kierowniczego $\mathrm{w}$ procesach zarządzania wiedzą. Osoby te kontaktują się zarówno z kierownictwem firmy, jak i pracownikami operacyjnymi posiadającymi kontakt z klientami [Bukh, Christensen i Mouritsen 2005, s. 29]. Nonaka i Takeuchi podkreślają, iż to właśnie menedżerowie średniego szczebla dokonują syntezy niejawnej wiedzy kadry zarządzającej i szeregowych pracowników przedsiębiorstwa. Proces ten zdaniem wspomnianych autorów przyczynia się do powstawania, czy też ulepszania nowych technologii, jak i produktów [Nonaka i Takeuchi 2000, s. 34]. Innym ważnym elementem japońskiej koncepcji jest środowisko pracy. Nonaka i Konno podkreślają wagę miejsc społecznych, nazywanych przez nich „Ba”, które umożliwiają nawiązywanie relacji międzyludzkich [Bukh, Christensen i Mouritsen 2005, s. 27].

Dobrą egzemplifikacją japońskiego sposobu myślenia w zakresie strategii zarządzania wiedzą jest przywołany przez Nonakę i Takeuchiego przykład projektowania Hondy City. Sukces tego projektu do pewnego stopnia był wynikiem braku jasnego sformułowania misji, zaś jedynie wytyczenia ogólnego kierunku działań [Nonaka i Takeuchi 2000, s. 31-32]. Przypadek Hondy City pokazuje jak ważne jest zwrócenie uwagi na wiedzę ukrytą przy działaniach kreatywnych.

Zdaniem Nonaki i Takeuchiego wiedza organizacyjna jest tworzona poprzez dynamiczną interakcję pomiędzy dwoma rodzajami wiedzy - dostępną i ukrytą (rysunki 9 i 10) [Nonaka i Takeuchi 2000, s. 95]. 


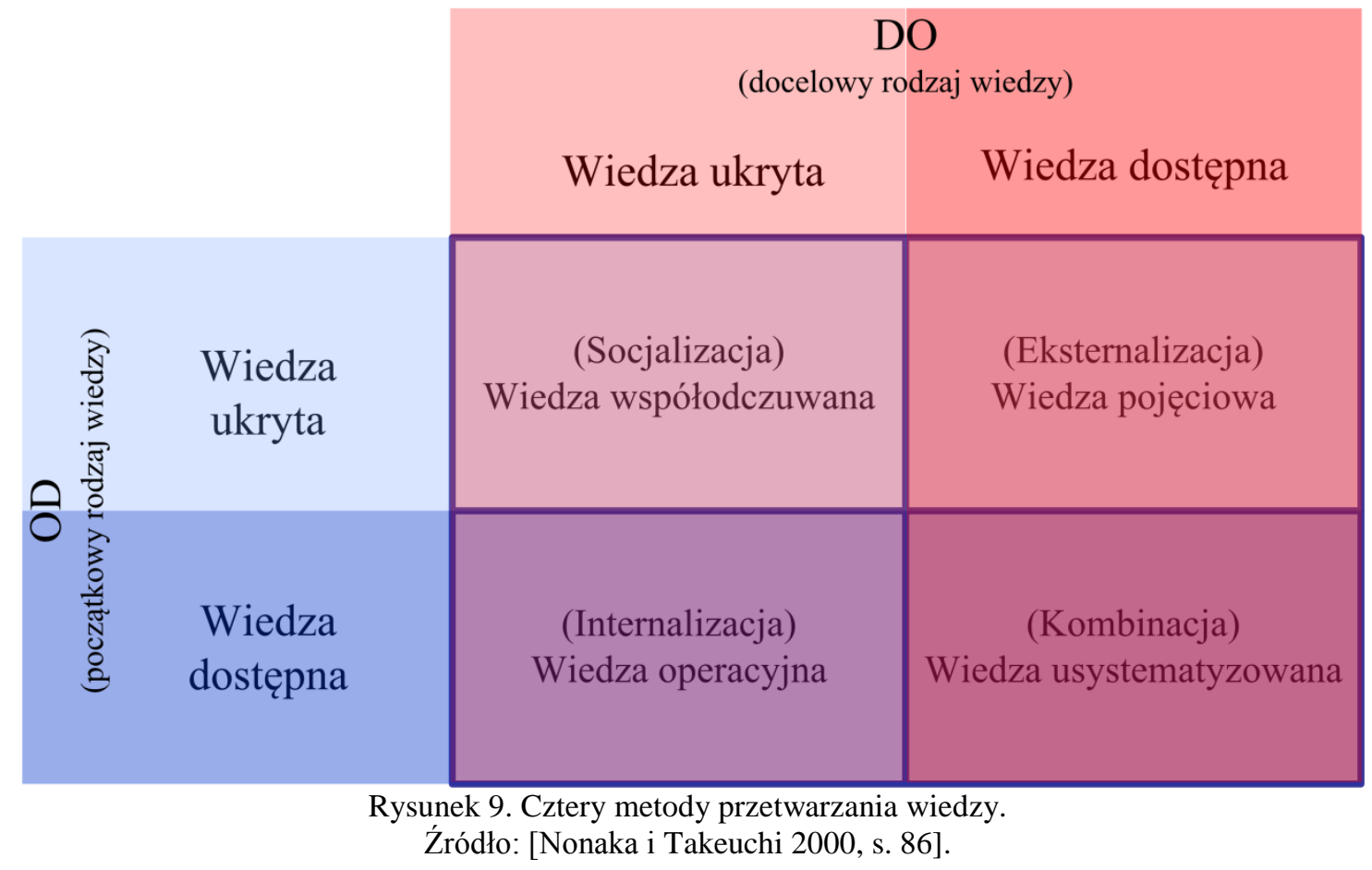

Pierwszym sposobem przetwarzania wiedzy $w$ omawianym modelu jest socjalizacja. Jest to pozyskiwanie przez daną jednostkę wiedzy ukrytej od innych osób. Jak podkreślają Nonaka i Takeuchi - człowiekowi trudno zrozumieć i dostosować się do sposobów myślenia innych ludzi bez spędzenia $\mathrm{z}$ nimi określonego czasu i zdobycia wspólnego doświadczenia [Nonaka i Takeuchi 2000, s. 86]. Proces eksternalizacji jest działaniem, które polega wyrażaniu wiedzy niejawnej przy wykorzystaniu np. metafor, pojęć, czy analogii [Nonaka i Takeuchi 2000, s. 88]. Kombinacja polega na tworzeniu nowych elementów wiedzy jawnej na podstawie już istniejących elementów wiedzy tego typu np. poprzez ujednolicanie, kategoryzację czy selekcjonowanie [Nonaka i Takeuchi 2000, s. 91]. Powiększanie zasobu wiedzy ukrytej poprzez włączanie elementów wiedzy dostępnej jest określane przez Nonakę i Takeuchiego jako internalizacja [Nonaka i Takeuchi 2000, s. 93]. 


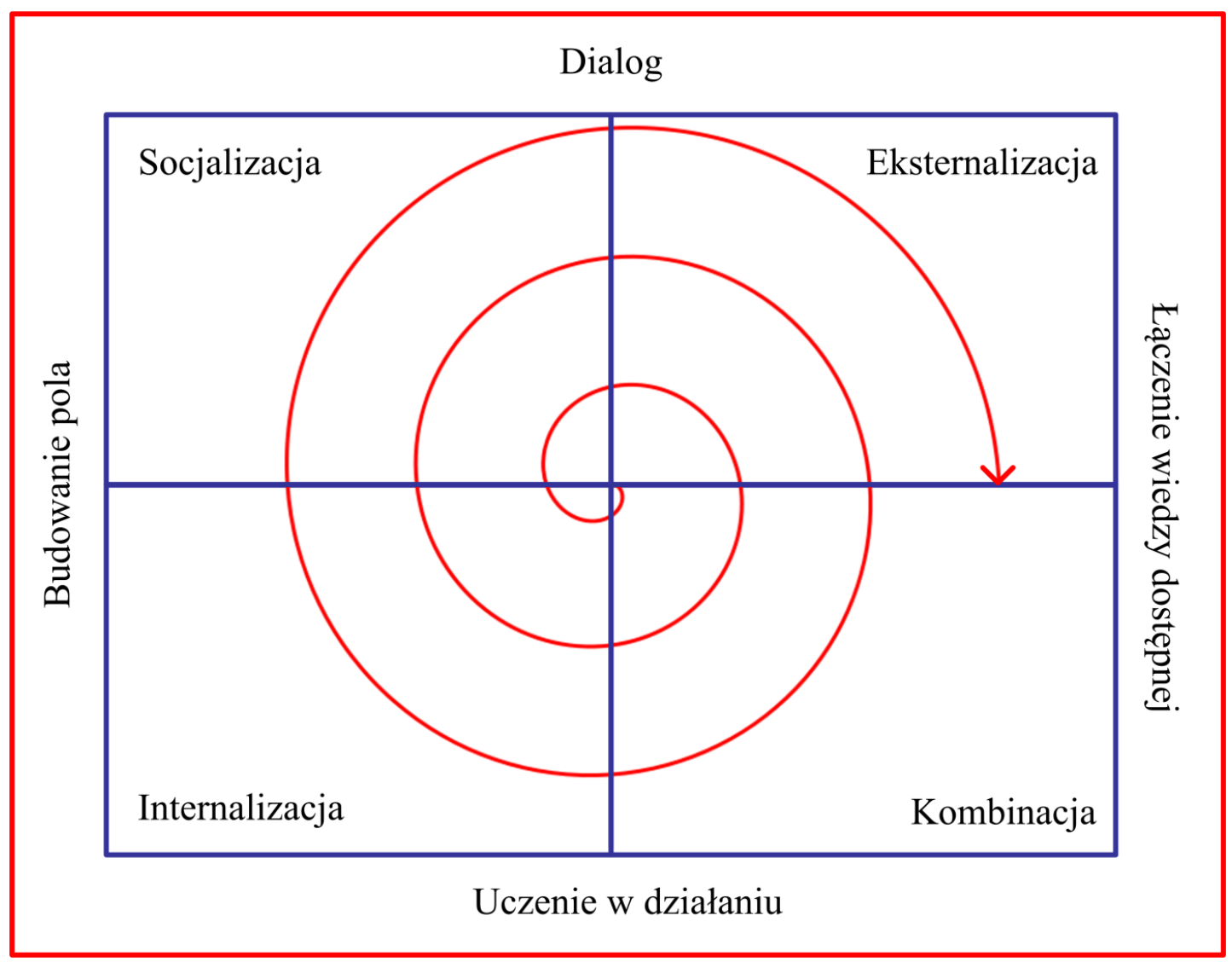

Rysunek 10. Spirala przetwarzania wiedzy.

Źródło: [Nonaka i Takeuchi 2000, s. 96].

W opinii Jashapary największym wkładem Nonaki (i Takeuchiego) jest koncepcja wytwarzania nowej wiedzy za pomocą procesów przekształcania tego zasobu z formy ukrytej w postać jawną oraz odwrotnie [Jashapara 2006, s. 315]. W opinii Kowalczyka i Nogalskiego zagadnienia w zakresie zarządzania wiedzą opisane przez Nonakę i Takeuchiego są w dużej mierze specyficzne. Wynika to $\mathrm{z}$ faktu, iż badania były skupione na japońskich, dużych przedsiębiorstwach posiadających raczej rozbudowane struktury. Po drugie, opisane aspekty są silnie umocowane w kontekście kulturowym Dalekiego Wschodu. W związku z tym, zdaniem wspomnianych autorów, koncepcja Nonaki i Takeuchiego nie wnosi wiele dla szeregu małych i średnich podmiotów poza ogólnym filozoficznym ujęciem zagadnienia [Kowalczyk i Nogalski 2007, s. 56].

Strategia personalizacji jest najczęściej stosowana w podmiotach, które zajmują się wyspecjalizowanymi zagadnieniami. Jednostki te w celu wykonywania swoich zadań potrzebują przede wszystkim wiedzy niejawnej. W przypadku stosowania omawianej koncepcji zarządzania wiedzą jej podstawą są odpowiedni, kreatywni pracownicy oraz dobrze wykształcone sieci kontaktów. Wymienione elementy są równie ważne jak skuteczne systemy zbierania i zapisywania wiedzy $\mathrm{w}$ przypadku stosowania strategii kodyfikacji [Bukh, Christensen i Mouritsen 2005, s. 28]. Poziom przepływu wiedzy w przedsiębiorstwie w dużej 
mierze zależy od jego struktury organizacyjnej. Szansa na wytworzenie nowej wiedzy jest znacznie większa $\mathrm{w}$ przedsiębiorstwie, które bazuje na zespołach projektowych niż w podmiocie z dominacją struktury hierarchicznej [Bukh, Christensen i Mouritsen 2005, s. 28].

Przykładem dużej firmy stosującej strategię personalizacji jest Hewlett-Packard, przedsiębiorstwo zatrudniające 120 tys. pracowników. Ważnym elementem warunkującym istnienie tego podmiotu jest innowacyjność. W związku z tym inżynierowie zatrudnieni w tej firmie regularnie podróżują samolotami służbowymi, aby mieć możliwość osobistych spotkań ze swoimi kolegami pracującymi $\mathrm{w}$ innych lokalizacjach. $\mathrm{Z}$ tego środka transportu może skorzystać każdy pracownik, gdyż kursują one regularnie [Fazlagić 2006, s. 102]. Innym przykładem personalizacji jest firma Xerox. W jej biurach, w celu wspierania spontanicznego tworzenia wiedzy, zdecydowano się zamontować ogólnodostępne tablice wraz z markerami w pobliżu np. automatów z napojami, a nawet klatek schodowych [Cavaleri i Seivert 2005, s. 294]. Firma McKinsey również skupiła się na relacjach międzyludzkich i korzysta ze strategii personalizacji [Hawryszkiewicz 2010, s. 82]. Przedsiębiorstwo tworzy bazy ekspertów, dokonuje transferu pracowników pomiędzy poszczególnymi biurami. Kształtowana w podmiocie kultura organizacyjna sprawia, że na zapytania konsultantów szybko udzielane są odpowiedzi [Fazlagić 2006, s. 101]. W literaturze podaje się przykład organizacji biur firmy Google jako wzoru w zakresie kreatywnej pracy zespołowej [Gierszewska 2011, s. 173].

Kompleksowo omawiając koncepcję zarządzania wiedzą należy również wspomnieć o roli technologii informacyjnych oraz o społeczno-kulturowych aspektach tej teorii, gdyż te obszary są ważnymi elementami omawianego zagadnienia. Zostaną one omówione w kolejnych dwóch sekcjach pracy.

\subsubsection{Społeczno-kulturowe oraz organizacyjne elementy zarządzania wiedzą}

Wszelkie rozważania w zakresie zarządzania, nie tylko wiedzą, muszą uwzględniać również implikacje kulturowe, które w dużym stopniu warunkują możliwości zastosowania poszczególnych działań i koncepcji w praktyce [Paliszkiewicz 2007, s. 59]. Pomimo faktu, iż dzisiejsze publikacje powstające w nurcie zarządzania wiedzą zdecydowanie doceniają i wręcz podkreślają znaczenie czynników społeczno-kulturowych w kontekście zarządzania wiedzą, początkowo obszar ten był nieco zaniedbywany przez autorów [Hislop 2013, s. 135]. 
Kultura organizacji jest obecnie ogólnie uznanym czynnikiem, który ma znaczący wpływ na procesy zarządzania wiedzą. Projekty w tym obszarze mają szansę efektywnie funkcjonować jedynie w przypadku istnienia sprzyjającej kultury organizacyjnej [Handzic i Zhou 2005, s. 33-34]. W literaturze można znaleźć wiele definicji zagadnienia kultury organizacyjnej. Jedną z najbardziej popularnych jest ta sformułowana przez Hofstede, który postrzega kulturę organizacyjną jako zbiorowe programowanie pamięci odróżniające pracowników jednego przedsiębiorstwa od innych [Paliszkiewicz 2007, s. 59].

Ujęcie zagadnienia kultury organizacyjnej jest różnie ujmowane w poszczególnych koncepcjach zarządzania wiedzą. Przede wszystkim można dostrzec różnicę pomiędzy koncepcją japońską (Nonaka i Takeuchi) oraz koncepcją procesową (Davenport i Prusak Stany Zjednoczone, a także Probst, Raub i Romhardt - Szwajcaria). Autorzy japońscy przede wszystkim zakładają pozytywne nastawienie pracowników w kontekście procesów dzielenia się wiedzą, a także tworzenia tego zasobu, stąd omawiane ujęcie koncentruje się na kreacji odpowiedniej atmosfery i autonomii oraz na gwarantowaniu powszechności zasobu wiedzy. Autorzy zachodni podkreślają natomiast potrzebę wytworzenia w przedsiębiorstwie warunków, które umożliwią pracownikom dostrzeżenie indywidualnych korzyści z działań zakresie dzielenia się posiadaną przez siebie wiedzą $\mathrm{z}$ innymi członkami organizacji [Paliszkiewicz 2007, s. 61]. Jest to związane nie tyle z kulturą organizacyjną istniejącą w poszczególnych podmiotach, lecz z różnicami kulturowymi występującymi pomiędzy krajami zachodu, a kulturą japońską (lub nawet wschodnio-azjatycką) ${ }^{30}$.

Ważnym jest podkreślenie roli kadry kierowniczej w zakresie kreowania kultury organizacyjnej przedsiębiorstwa. To właśnie zachowania, postawy oraz normy podzielane przez osoby zarządzające odgrywają zasadniczą rolę w tym procesie [Paliszkiewicz 2007, s. 64]. Koskinen i Pihlanto podkreślają znaczenie działań w zakresie kształtowania odpowiednich nawyków wśród poszczególnych pracowników przedsiębiorstwa w procesach kreacji i wykorzystania wiedzy [Koskinen i Pihlanto 2008, s. 26]. Należy jednak zaznaczyć, iż najczęściej nieefektywnymi są przedsięwzięcia „inżynierii kulturowej”, które nie są zgodne z założeniami, a także wartościami uznanymi w przedsiębiorstwie. Znacznie lepszym rozwiązaniem jest dopasowywanie działań do istniejącej już w przedsiębiorstwie kultury organizacyjnej [Jashapara 2006, s. 256].

\footnotetext{
${ }^{30}$ Jak zaznacza Glińska-Neweś [2007, s. 155] w tym kontekście bardzo duże znaczenie ma postrzeganie istoty wiedzy. Istnieje wyraźna różnica pomiędzy wschodem (Japonia i Chiny) i zachodem (Europa oraz Ameryka Północna) związana z podstawami filozoficznymi cywilizacji. W kulturze zachodniej wiedza jest kreowana przede wszystkim indywidualnie i postrzegana raczej w perspektywie wiedzy jawnej, w przeciwieństwie do kultury wschodu gdzie dominuje wiedza niejawna oraz zbiorowy wkład w jej tworzenie.
} 
Probst, Raub i Rombhardt zaznaczają, iż wielu autorów podkreśla, że dla innowacyjności podmiotu ważnym jest, aby pracownicy firmy mieli możliwość prezentowania nowych pomysłów. Niestety w praktyce gospodarczej, często zdarza się, że kultura organizacyjna blokuje możliwość wprowadzania zmian [Probst, Raub i Romhardt 2004, s. 149].

Innym czynnikiem jest poziom zaufania w przedsiębiorstwie. Od niego w dużej mierze zależy sprawność przepływów wiedzy w podmiocie [Liebowitz 2008, s. 7]. Jest to związane z faktem, iż najważniejszym czynnikiem, decydującym o sukcesie całego procesu zarządzania wiedzą są ludzie, gdyż wszystkie działania w tym zakresie opierają się na chęci pracowników do dzielenia się wiedzą [Martinez 2010, s. 30]. W związku z tym Chen i Huang [2007, s. 113] uważają, iż firmy powinny wspomagać powstawanie relacji społecznych wśród pracowników w celu lepszego wykorzystania ich potencjału. Jak podkreśla Liebowitz [2008, s. 18] największym wyzwaniem w zakresie zarządzania wiedzą jest zmiana przekonań pracowników i odejście od obecnego, powszechnego myślenia, iż „wiedza jest władzą” do myślenia, iż „dzielenie się wiedzą jest władzą”. Niestety istnieje wiele argumentów, z punktu wiedzenia pracowników przedsiębiorstwa, przemawiających przeciwko dzieleniu się przez nich wiedzą, zwłaszcza w momencie, gdy ta wiedza jest unikatowa [Martinez 2010, s. 30]. Politis podkreśla, iż zaufanie nie może w żadnym wypadku być wymuszone. Osoby zarządzające mogą wyłącznie próbować stworzyć sprzyjające środowisko w firmie [Liebowitz 2008, s. 6]. Jedną z możliwości przezwyciężenia tej sytuacji jest stworzenie odpowiedniego systemu wynagradzania pracowników za uczestnictwo w działaniach w zakresie zarządzania wiedzą. Liebowitz uważa, że jednym $\mathrm{z}$ działań, które może spowodować wzrost zaufania wśród pracowników przedsiębiorstwa jest skrócenie czasu odpowiedzi w procesach komunikacji w realizowanych w danym podmiocie [Liebowitz 2008, s. 6].

Handzic i Zhou zwracają również uwagę na znaczenie struktury organizacyjnej przedsiębiorstwa [Handzic i Zhou 2005, s. 33-38]. Organizacje, które wykorzystują m.in. system pracy zespołowej umożliwiają lepszą współpracę i większe zaangażowanie w procesy zarządzania wiedzą w przeciwieństwie do podmiotów posiadających ścisłe hierarchie czy biurokratyczne struktury, które nie zachęcają do innowacji [Handzic i Zhou 2005, s. 38].

Jak podkreśla Hansen, wiele krytyki pojawia się w odniesieniu do działań praktycznych $\mathrm{w}$ przedsiębiorstwach $\mathrm{w}$ obszarze zarządzania wiedzą. Jest ona związana z faktem, iż te działania są najczęściej skoncentrowane na aspektach technologicznych omijając w szczególności społeczne elementy przepływu wiedzy w przedsiębiorstwie 
[Easterby-Smith i Lyles 2006, s. 12]. W związku z tym powstaje pytanie, jaką rolę w procesach zarządzania wiedzą odgrywają szybko rozwijające się w ostatnich latach technologie informacyjne i komunikacyjne?

\subsubsection{Rola technologii informacyjnych i komunikacyjnych w zarządzaniu wiedzą}

Od końca lat 80. przedsiębiorstwa w szybkim tempie zwiększają wykorzystanie technologii komputerowych [Bali, Wickramasinghe i Lahaney 2009, s. 3]. W latach 90-tych XX wieku szybki rozwój informatyki, w szczególności zaś pojawienie się możliwości wykorzystania Internetu dla celów komercyjnych, umożliwił rozkwit w zakresie zaawansowanych narzędzi zarządzania wiedzą [Vera i Crossan 2005, s. 122]. Ogólnie, okres rozwoju technologii internetowych $\mathrm{w}$ dużym stopniu zbiega się rozwojem koncepcji zarządzania wiedzą. Brdulak podkreśla, że nie jest to zależność przypadkowa. Dzięki wspomnianym technologiom ludzie uzyskali dostęp do znacznych ilości informacji i danych. Nie było jednak automatycznie możliwości skapitalizowania tego dostępu. Zdaniem wspomnianego autora zaistniała sytuacja wywołała zapotrzebowanie na rozwój zarządzania wiedzą, które umożliwia skuteczne użycie informacji oraz danych [Brdulak 2005, s. 24]. Podobnego zdania jest Jashapara, który również podkreśla kluczową rolę technologii informacyjnych w rozwoju koncepcji zarządzania wiedzą [Jashapara 2006, s. 363]. Andersson, Curley i Formica podkreślają obustronne powiązania w tym zakresie - w miarę jak podmioty gospodarcze stają się bardziej zależne od technologii informatycznych, stają się również zależne od zasobu, jakim jest wiedza [Andersson, Curley i Formica 2010, s. 29].

Dwudziesty pierwszy wiek przyniósł duże zmiany w zakresie sposobu prowadzenia biznesu. Dalszy, gwałtowny rozwój technologii informacyjnych i komunikacyjnych, zdaniem niektórych autorów, umożliwił znaczne zwiększenie wydajności i efektywności procesów biznesowych [Anantatmula 2008, s. 299]. Obecnie zarządzanie wiedzą jest w dużej mierze postrzegane właśnie w kontekście technologii informatycznych [Evans 2005, s. 11].

Technologie informatyczne są ogólnie postrzegane jako jedna ze skuteczniejszych dźwigni w zakresie zarządzania wiedzą [Kowalczyk i Nogalski 2007, s. 76]. Koskinen i Pihlanto zaznaczają, iż zastosowanie systemów informatycznych w przedsiębiorstwach zdecydowanie uprościło działania w zakresie przepływu wiedzy w przedsiębiorstwie [Koskinen i Pihlanto 2008, s. 25], pozwalając na efektywne gromadzenie, szybkie 
przekształcanie i dostęp do danych i informacji ${ }^{31}$ [Anantatmula 2008, s. 301]. Lee, Kim i Kim [2012, s. 200] prezentują bardzo ryzykowną opinię, iż to właśnie systemy informatyczne są rdzeniem zarządzania wiedzą ${ }^{32}$. Powszechna zgoda występuję za to w zakresie faktu, iż technologie informatyczne są pomocne $\mathrm{w}$ zakresie przetwarzania większych ilości wiedzy ${ }^{33}$ [Busch 2008, s. 33].

Ogólnie, dostępne narzędzia informatyczne w przeważającej mierze koncentrują się na działaniach w obszarze wiedzy jawnej, choć większość autorów zgadza się, iż wiedza ukryta jest w praktyce najważniejsza [Jashapara 2006, s. 120]. Istnieją jednak przykłady skutecznego działania omawianych narzędzi w zakresie wsparcia kontaktów międzyludzkich. Bardzo dobrą ilustracją efektywnego wykorzystania technologii informatycznych w kontekście implementacji strategii personalizacji w zarządzaniu wiedzą jest funkcjonowanie działu eksploracji firmy BP, który wykorzystuje wideokonferencje. Przykładowo, w momencie problemów sprzętowych w Ameryce Południowej organizowane są konferencje specjalistów z Alaski i Włoch, którzy mogą przedyskutować problem wspólnie ze swoimi kolegami rozwiązującymi problem na miejscu, odległym o tysiące kilometrów. Wykorzystanie narzędzi informatycznych umożliwia w praktyce szybkie pokonanie różnych trudności, dzięki wykorzystaniu doświadczenia osób rozrzuconych po całym globie [Handzic i Zhou 2005, s. 62]. Należy jednak podkreślić, że wiele osób ma sceptyczne podejście w zakresie potencjału technologii informatycznych w zakresie wsparcia procesów transferu wiedzy [Handzic i Zhou 2005, s. 61]. Komunikacja elektroniczna, choć użyteczna, jest nadal mniej skuteczna i nie może zastąpić spotkań twarzą twarz [Handzic i Zhou 2005, s. 40-41]. W przypadku przedsiębiorstw, które chcą dążyć do wzrostu interakcji pomiędzy pracownikami (strategia personalizacji) technologie informatyczne mogą przynieść negatywne skutki, gdyż pracownicy mogą np. rezygnować z osobistych spotkań [Busch 2008, s. 24].

Ogólnie w literaturze dotyczącej zarządzania wiedzą można zaobserwować wiele krytyki względem znaczenia technologii informatycznych w tym obszarze. Część autorów uważa, że technologie informatyczne i komunikacyjne (TIK) (Information and Communication Technologies) generalnie sprzyjają procesom zarządzania wiedzą, lecz technologie te służą wyłącznie przetwarzaniu nie tyle wiedzy, co informacji [Busch 2008,

\footnotetext{
${ }^{31}$ Zagadnienie przepływu wiedzy jawnej (utożsamianej z danymi i informacją) w przedsiębiorstwie jest zbadane bardziej szczegółowo w porównaniu z obszarem wiedzy niejawnej [Liebowitz 2008, s. 8].

${ }^{32}$ Skrajność opinii autorów może być spowodowana faktem, iż bazuje ona na badaniu przeprowadzonym w dość specyficznych warunkach Korei Południowej.

${ }^{33}$ Busch [2008, s. 33] używa w tym miejscu terminu „,wiedza”, lecz z kontekstu można wywnioskować, iż ma na myśli wiedzę jawną utożsamianą często $\mathrm{z}$ informacją.
} 
s. 24]. Fazlagić uważa, iż technologie informatyczne są skuteczne w momencie, gdy liczba dostępnych do wyboru opcji jest ograniczona [Fazlagić 2006, s. 44]. Ich zalety są znacznie rzadziej podkreślane. Być może są uznawane za zbyt oczywiste? Jednym z problemów z pewnością jest przecenianie możliwości TIK przez kadrę zarządzającą. Stankiewicz również podkreśla, że nierzadkim jest przekonanie, iż technologie informatyczne są niezawodnym panaceum na każdego rodzaju trudności w zakresie wiedzy. Prawdą jest jednak, że są one wyłącznie narzędziem, które w odpowiednich okolicznościach, może być pomocne [Stankiewicz 2006, s. 146]. Decyzje kierownictwa w zakresie doboru narzędzi informatycznych są kluczowe [Handzic i Zhou 2005, s. 78]. Powszechnym problemem w praktyce wykorzystania TIK w zarządzaniu wiedzą w przedsiębiorstwie jest koncentracja na jednej metodzie lub pojedynczym narzędziu [Probst, Raub i Romhardt 2004, s. 9]. Kadra zarządzająca również często uważa, że inwestycje w systemy zarządzania wiedzą równocześnie stworzą w przedsiębiorstwie kulturę sprzyjającą przepływowi wiedzy. Nie jest to jednak takie proste [Martinez 2010, s. 29].

Częścią kontrowersji w zakresie roli technologii informatycznych w ramach omawianego obszaru $\mathrm{z}$ pewnością jest fakt, że w przeszłości kierowano organizacjami wykorzystując założenie, iż im więcej danych tym więcej informacji. W warunkach dużej rzadkości tego typu zasobu, ta strategia była działaniem skutecznym, lecz w dzisiejszych czasach sytuacja uległa diametralnej zmianie i tego typu podejście prowadzić może do przeładowania danymi, co z kolei może wywołać chaos informacyjny [Drucker 2006, s. 1819]. Boughzala i Ermine zaznaczają, iż przeszliśmy z ery, w której informacje są zasobem rzadkim do czasu, w którym są powszechnie dostępne [Boughzala i Ermine 2006, s. 42]. Przedsiębiorstwa zmagają się obecnie z przytłaczającymi ilościami danych tzw. trend „big data”. Wyzywaniem jest efektywne przekształcanie tych informacji w wiedzę. W przeszłości w Stanach Zjednoczonych można było zaobserwować zjawisko określane „paradoksem produktywności”. Wiązało się ono z coraz większymi inwestycjami w zakresie technologii informatycznych oraz relatywnie słabymi efektami. Przyczyną tego zjawiska są nie tyle same technologie, ale brak odpowiednich procesów w przedsiębiorstwach. Firmy informatyczne najszybciej odpowiedziały na wzrastające potrzeby przedsiębiorstw w zakresie wiedzy i zasobów niematerialnych. Niestety, ich rozwiązania opierały się na budowie złożonych struktur informacyjnych, które nigdy nie zastąpią kompleksowych działań w zakresie zarządzania wiedzą wykraczających poza technologię [Geisler i Wickramasinghe 2009, s. 15].

Drucker uważa, że brak umiejętności rozróżnienia, przez osoby zarządzające firmami, pomiędzy pojęciami informacji i wiedzy sprawił, że przedsiębiorstwa wydawały 
bardzo duże ilości pieniędzy na technologie informatyczne, które w efekcie przyniosły bardzo niewielkie efekty [Ahmed, Lim i Loh 2002, s. 14]. Problem rozróżniania terminów informacji i wiedzy w przedsiębiorstwach podkreślają również Cavaleri i Seivert [2005, s. 3] postulując, aby firmy koncentrowały się na procesach i potencjale ludzi, a nie jak obecnie na technologiach informatycznych. Problem wynika z faktu, iż obecnie 80\% implementacji rozwiązań w zakresie zarządzania wiedzą zakłada, iż wiedza jest relatywnie namacalnym obiektem, który jest możliwy do zapisania i przechowywana w pamięci komputera [Fazlagić 2006, s. 55]. Wiele programów informatycznych, które posiadają w nazwie frazę „zarządzania wiedzą" w praktyce służy tylko do przetwarzania informacji [Probst, Raub i Romhardt 2004, s. 9]. Producenci oprogramowania, w wielu przypadkach, w momencie wzrostu popularności omawianej koncepcji dodali do nazw swoich wcześniej już dostępnych produktów termin „zarządzanie wiedzą” lub po prostu „wiedza” [Jashapara 2006, s. 30]. Zarządzanie wiedzą jest bowiem w wielu przypadkach omyłkowo postrzegane jako rozwinięcie technologii przetwarzania informacji. Jest to ujęcie błędne, gdyż głównym elementem zarządzania wiedzą są działania związane z ludźmi [Andersson, Curley i Formica 2010, s. 29].

W kontekście zarządzania wiedzą można zauważyć funkcjonowanie zasady Pareto. 80 procent działań dotyczy procesów, kultury organizacji oraz ludzi, zaś tylko 20 procent prac związanych jest z obszarem technologii informatycznych [Liebowitz 2008, s. 18]. Zdaniem Jashapary z doświadczeń różnorodnych podmiotów można wywnioskować, iż technologie informatyczne nie powinny pochłaniać więcej niż jednej trzeciej wydatków przeznaczonych na zarządzanie wiedzą [Jashapara 2006, s. 119]. Jak wynika z badania przeprowadzonego przez Anantatmula i Kanungo przedsiębiorstwa powinny rozwijać systemy informatyczne w taki sposób, aby zaspokajały specyficzne potrzeby biznesowe organizacji. Tego rodzaju działanie jest podstawą do przełożenia inwestycji w technologię na wyniki finansowe podmiotu [Anantatmula 2008, s. 301]. Przy projektowaniu programów komputerowych nie zawsze uwzględnia się potrzeby użytkowników ${ }^{34}$ [Probst, Raub i Romhardt 2004, s. 9]. Egzemplifikacją konsekwencji braku strategicznego podejścia do zagadnienia zarządzania wiedzą może być przykład jednej $\mathrm{z}$ dużych izraelskich firm telekomunikacyjnych. Przedsiębiorstwo rozpoczęło działania w tym zakresie od zakupu najnowszego oprogramowania komputerowego, które miało na celu wspierać procesy zarządzania wiedzą.

\footnotetext{
${ }^{34}$ Należy także postrzegać ten element w perspektywie dynamicznej - procesy w każdej organizacji stale się zmieniają, stąd technologie powinny ewoluować wraz z nimi. Nawet, jeśli w danym momencie wykorzystywane narzędzia informatyczne są efektywnymi instrumentami w zakresie omawianych działań, to bez odpowiedniego i systematycznego uaktualniania mogą one po pewnym czasie stać się wręcz barierą w procesach zarządzania wiedzą w przedsiębiorstwie [du Plessis 2008, s. 289].
} 
Niestety, oprogramowanie nie zdało egzaminu i pozostało niewykorzystane, gdyż zabrakło koncentracji na samych procesach, które miało ono wspierać. Brakowało zdefiniowania potrzeb podmiotu w zakresie wiedzy, które miałyby być zaspokojone implementowanym programem [Pasher i Ronen 2011, s. 39]. Kowalczyk i Nogalski przestrzegają, aby działania w zakresie technologii informatycznych $w$ zarządzaniu wiedzą nie były zbytnio skomplikowane i rozbudowane ${ }^{35}$. Przede wszystkim ważnym jest odpowiednie dopasowanie narzędzi do potrzeb podmiotu [Kowalczyk i Nogalski 2007, s. 123-124].

Zarządzanie wiedzą nie polega wyłącznie na działaniach w zakresie technologii, stąd przedsiębiorstwa nie powinny polegać na opinii podmiotów dostarczających oprogramowanie, które najczęściej oferują tzw. kompleksowe rozwiązania w tym zakresie, a w praktyce ograniczają się wyłącznie do technologii. Takie działania prowadzą bowiem wyłącznie do marnotrawstwa pieniędzy. Technologia nie jest elementem, od którego należy rozpoczynać wdrażanie systemów zarządzania wiedzą, jest to narzędzie, które powinno być rozpatrywane na samym końcu projektowania działań w tym zakresie [Geisler i Wickramasinghe 2009, s. 12].

W literaturze można znaleźć nawet skrajnie nieprzychylne technologiom informatycznym opinie odnośnie ich ogólnego znaczenia dla biznesu. Przykładowo Carr twierdzi, iż znaczenie technologii informatycznych dla przewagi konkurencyjnej jest w rzeczywistości coraz mniejsze, gdyż każde posunięcie np. innowacja wprowadzona przez firmę może być w bardzo szybkim czasie skopiowane przez podmioty konkurencyjne [Handzic i Zhou 2005, s. 60]. Podobnego zdania jest Seely-Brown, który ocenia zagadnienie z perspektywy makroekonomicznej. Jego zdaniem w ciągu dwóch ostatnich dekad XX wieku przedsiębiorstwa wydały ponad trylion dolarów amerykańskich na technologie, które miały na celu zwiększenie efektywności działań pracowników umysłowych. Brak efektów w zakresie tych inwestycji był spowodowanych brakiem analizy rzeczywistych procesów tworzenia wiedzy. Nie jest ona bowiem tworzona przez narzędzia informatyczne, lecz powstaje jako rezultat interakcji społecznych. Ważna jest przede wszystkim współpraca międzyludzka, która umożliwia łączenie pomysłów poszczególnych osób w większą całość [Ahmed, Lim i Loh 2002, s. 14-15]. Wielu ekspertów zajmujących się zagadnieniem zarządzania wiedzą podkreśla element ludzki zarządzania wiedzą. Jest to związane

\footnotetext{
35 Przykładem firmy, która zdecydowała wykorzystywać relatywnie proste technologie informatyczne w zarządzaniu wiedzą jest BBC. Początkowo rozpoczęto od wprowadzania m.in. takich narzędzi jak forum czy blog. W późniejszym okresie, gdy pracownicy przywykli do najprostszych technologii, rozszerzono paletę instrumentów o edytowalne strony internetowe (system Wiki), które też nie należą do najbardziej zaawansowanego oprogramowania [Desouza 2011, s. 16].
} 
z możliwościami ludzkiego umysłu, który w przeciwieństwie do technologii informatycznych, posiada ogromny potencjał kojarzenia faktów, które pozornie mogą nie być ze sobą powiązane [Evans 2005, s. 11]. Gierszewska przywołuje badania, w których szukano zależności pomiędzy wpływem inwestycji w technologie informatyczne w przedsiębiorstwach, a stopą zwrotu zainwestowanego w te podmioty kapitału podkreślając, iż nie zaobserwowano pozytywnej korelacji. Niektóre badania wykazywały nawet negatywną korelację [Gierszewska 2011, s. 175]. Jedną z przyczyn opisanej sytuacji może być opisana przez Fazlagića, iż komputery mogą też stworzyć poczucie komfortu i utrudniać faktyczne reformy w zakresie zarządzania wiedzą [Fazlagić 2006, s. 159].

Dużym problemem zarządzania wiedzą jest polaryzacja poglądów różnych grup zajmujących się tym zagadnieniem. Jedni skupiają się na działaniach społecznych skoncentrowanych na zasobach ludzkich, zaś drudzy na technologiach informatycznych. Jashapara podkreśla, iż zwolennicy jednego ujęcia często nie odnoszą się do drugiego. Jest to spowodowane faktem, iż obie grupy przyjmują inne założenia oraz operują praktycznie odmiennym językiem. Zarządzanie wiedzą tymczasem wymaga wykorzystania podejścia interdyscyplinarnego [Jashapara 2006, s. 23, 24]. Przedsiębiorstwa również mają tendencję do popadania w ekstrema. Wcześniej wspominano o podmiotach koncentrujących swoją uwagę na technologiach informatycznych, można jednak odnaleźć organizacje, które popadają w drugą skrajność - minimalizację znaczenia technologii informatycznych, a takie podejście w zakresie zarządzania wiedzą może również nie być wystarczająco skuteczne [Handzic i Zhou 2005, s. 59]. Ważna jest równowaga i balans, gdyż zarządzanie wiedzą jest zagadnieniem interdyscyplinarnym bazującym na szeregu różnorodnych dziedzin takich, jak psychologia, informatyka, filozofia, antropologia, a także zarządzanie przedsiębiorstwem ${ }^{36} 37$ [Jashapara 2006, s. 23]. Ogólnie, jednym z paradoksów roli technologii informatycznych w zarządzaniu wiedzą, jest stwierdzenie, trafnie opisujące ich rolę - nie są one najważniejsze w procesach związanych z wiedzą, lecz w praktyce trudno się bez nich obejść [Dąbrowski i Gierszewska 2005, s. 29]. Paradoks ten można podsumować w następujący sposób - zarządzanie wiedzą, może sprawnie odbywać się bez komputerów, lecz największą zaletą tych urządzeń jest możliwość przyspieszania działań - mimo, że mogłyby one być

\footnotetext{
${ }^{36}$ Kompleksowe i zrównoważone podejście odnośnie technologii informatycznych i działań społecznych $\mathrm{w}$ zarządzaniu wiedzą $\mathrm{w}$ przedsiębiorstwie jest podkreślane $\mathrm{w}$ literaturze przez wielu autorów, w tym m.in. Tabaszewską [2011, s. 65] czy Griffiths i Koukpaki [2012, s. 74-75].

${ }^{37}$ Jak podkreślają Ng, Yip, Din i Bakar [2012, s. 212] przedsiębiorstwa, które zbytnio koncentrują się na „twardych” elementach zarządzania wiedzą kojarzonych z kodyfikacją mogą być mało kreatywne. W przeciwnej sytuacji, gdy w podmiocie zbytnio dominują „miękkie” elementy społeczne, wiedza może zdaniem autorów „wyparować" z uwagi na brak odpowiednich procesów jej zatrzymywania.
} 
wykonywane bez ich pomocy. Biorąc jednak pod uwagę szerszy kontekst - całości gospodarki, konkurencji rynkowej, tempa działania, jak również koszt zasobów ludzkich, wszystko to sprawia, że komputery stają się niezastąpione i stanowią nieodłączony element zarządzania wiedzą ${ }^{38}$.

Tabela 4. Wybrane literaturowe typologie narzędzi informatycznych stosowanych w zarządzaniu wiedzą.

\begin{tabular}{|c|c|}
\hline Typologia & Autor / autorzy \\
\hline $\begin{array}{l}\text { Repozytoria wiedzy, katalogi ekspertów, narzędzia wspierające } \\
\text { współpracę. }\end{array}$ & $\begin{array}{l}\text { Jean-Grégoire } \\
\text { Bernard }\end{array}$ \\
\hline $\begin{array}{l}\text { Business Intelligence, systemy pracy grupowej } \\
\text { (groupware/collaboration), systemy sterowania przepływem pracy } \\
\text { (workflow / Business Process Management), systemy zarządzania } \\
\text { relacjami z klientami (CRM), systemy zarządzania dokumentami } \\
\text { i treściami (document management / content management), portale } \\
\text { korporacyjne (Enterprise Information Portal), systemy wyszukiwawcze } \\
\text { (search and retrieval). }\end{array}$ & K. Klincewicz \\
\hline $\begin{array}{l}\text { Tworzenie wiedzy, konsolidacja wiedzy, rozpowszechnianie wiedzy, } \\
\text { ochrona wiedzy. }\end{array}$ & $\begin{array}{l}\text { Gerjan van } \\
\text { Heijst i inni }\end{array}$ \\
\hline $\begin{array}{l}\text { Narzędzia wspierające: kreowanie, dostęp do wiedzy, dzielenie się } \\
\text { wiedzą } \\
\text { (wśród narzędzi wspierających dostęp i dzielenie się wiedzą wyróżniono: } \\
\text { systemy zarządzania dokumentami, systemy workflow, systemy } \\
\text { wspomagania pracy grupowej, systemy wspomagania decyzji } \\
\text { (eksperckie), intranet, portale korporacyjne, narzędzia e-learningu, } \\
\text { hurtownie danych). }\end{array}$ & J. Paliszkiewicz \\
\hline $\begin{array}{c}\text { Systemy gromadzące informacje, systemy komunikacji wewnętrznej, } \\
\text { systemy komunikacji zewnętrznej, narzędzia wspomagające przyswajanie } \\
\text { wiedzy. }\end{array}$ & M. Walczak \\
\hline
\end{tabular}

Źródło: [Gierszewska 2011, s. 180; Paliszkiewicz 2007, s. 65-67; Jemielniak i Koźmiński 2012, s. 305-307].

${ }^{38}$ Bardzo trafnym, według autora niniejszej pracy, jest stwierdzenie Pinho, Rego i Cunha [2012, s. 233], iż narzędzia informatyczne oraz działania społeczno-organizacyjne $\mathrm{w}$ zakresie zarządzania wiedzą nie powinny być postrzegane rozdzielnie, lecz raczej w kontekście wzajemnych oddziaływań, gdyż tak naprawdę charakterystyka wzajemnych relacji obu tych elementów decyduje o tworzeniu pozytywnych efektów w ramach omawianej koncepcji. 
Zagrożenie odnoszące się do systemów informatycznych jest jednak takie, że nie należy ich roli przeceniać. Pomimo swoich zalet, technologia informatyczna jest tylko narzędziem, które samo nie wykona wielu procesów, jednak w rękach ludzi staje się potężnym instrumentem. Próba kategoryzacji narzędzi w zakresie zarządzania wiedzą jest zagadnieniem dość skomplikowanym. Złożoność problemu polega na różnorodności dostępnych na rynku narzędzi o nieporównywalnej często funkcjonalności. Stworzenie ich spójnej klasyfikacji jest praktycznie niemożliwe. Przykładowo, firma David Skyrme Associates już w 2006 roku zidentyfikowała aż 80 kategorii narzędzi informatycznych wspierających procesy zarządzania wiedzą, które nie są jednak rozłączne [Skyrme 2007]. Wybrane, literaturowe typologie narzędzi informatycznych stosowanych w zarządzaniu wiedzą zostały zaprezentowane w tabeli 4.

W ramach pomiaru poziomu wykorzystania narzędzi informatycznych w zarządzaniu wiedzą W ilościowym badaniu empirycznym, stanowiącym element niniejszej pracy, niemożliwym było zastosowanie żadnej z zaprezentowanych wcześniej typologii z uwagi na charakter wyróżnionych w nich kategorii. W celu przeprowadzenia badania potrzebna była przede wszystkim kompleksowa, nieskomplikowana i zrozumiała dla wszystkich respondentów typologia. Stąd zdecydowano się stworzyć własną, wykorzystując jednak w tym działaniu dorobek literatury (por. tab. 5).

Tabela 5. Typologia systemów informatycznych w zarządzaniu wiedzą.

\begin{tabular}{|c|r|}
\hline Lp. & Kategoria systemów informatycznych w zarządzaniu wiedza \\
\hline $\mathbf{1}$ & $\begin{array}{r}\text { Podstawowe technologie informatyczne } \\
\text { (Internet, e-mail, edytory tekstu, arkusze kalkulacyjne) }\end{array}$ \\
\hline $\mathbf{2}$ & $\begin{array}{r}\text { Systemy magazynowania danych } \\
\text { (np. systemy gromadzące, udostępniające i zarządzające dokumentami oraz innymi } \\
\text { danymi, CRM, hurtownie danych) }\end{array}$ \\
\hline $\mathbf{3}$ & $\begin{array}{r}\text { Informatyczne systemy komunikacyjne } \\
\mathbf{4}\end{array}$ \\
\hline $\mathbf{5}$ & (np. portale korporacyjne, intranet, forum firmowe, grupy dyskusyjne) \\
\hline & $\begin{array}{r}\text { Systemy wspótpracy grupowej (groupware/collaboration) } \\
\text { (kusiness Intelligence, Executive Information Systems) }\end{array}$ \\
\hline
\end{tabular}

Źródło: opracowanie własne na podstawie: [Alavi i Tiwana 2006, s. 113-118; Paliszkiewicz 2007, s. 66; Geisler i Wickramasinghe 2009, s. 13; Gierszewska 2011, s. 180; Jemielniak i Koźmiński 2012, s. 306]. 
Dokonano selekcji kategorii systemów IT i opracowano ich autorski podział. Podczas pracy nad typologią była ona kilkukrotnie konsultowana $\mathrm{z}$ informatykiem badającym zagadnienia zarządzania wiedzą. Najważniejszym celem przyświecającym autorowi była prostota podziału i jego zrozumiałość nawet dla osoby nieobeznanej z technologiami informatycznymi. Autor jest świadomy faktu, iż wyróżnione elementy nie zawsze są rozłączone, co jest kosztem uzyskania wysokiego poziomu przejrzystości podziału. W prowadzonym na szeroką skalę empirycznym badaniu ilościowym przekłada się to jednak na podwyższenie jakości odpowiedzi respondentów. Zintegrowana typologia wykorzystywana w niniejszej pracy została przedstawiona w tabeli 5 .

\subsubsection{Kompleksowe podejście do zarządzania wiedzą}

W kontekście podejścia procesowego każde przedsiębiorstwo musi dokonać przede wszystkim dwóch ważnych wyborów. Pierwszym jest dobór dominującej strategii zarządzania wiedzą oraz zakresu wykorzystania strategii wspierającej. Należy przy tym mieć na względzie, iż strategia dominująca skoncentruje uwagę przedsiębiorstwa na określonym typie wiedzy (rysunek 11). Można jednak do pewnego stopnia zmniejszyć znaczenie tego wyboru wykorzystując w większym stopniu strategie wspierającą, przy czym nadal podstawą będzie strategia dominująca. W tym kontekście Handzic i Zhou opowiadają się za odpowiednim zrównoważeniem wypływającym z m.in. $\mathrm{z}$ charakterystyki działalności podmiotu [Handzic i Zhou 2005, s. 77].

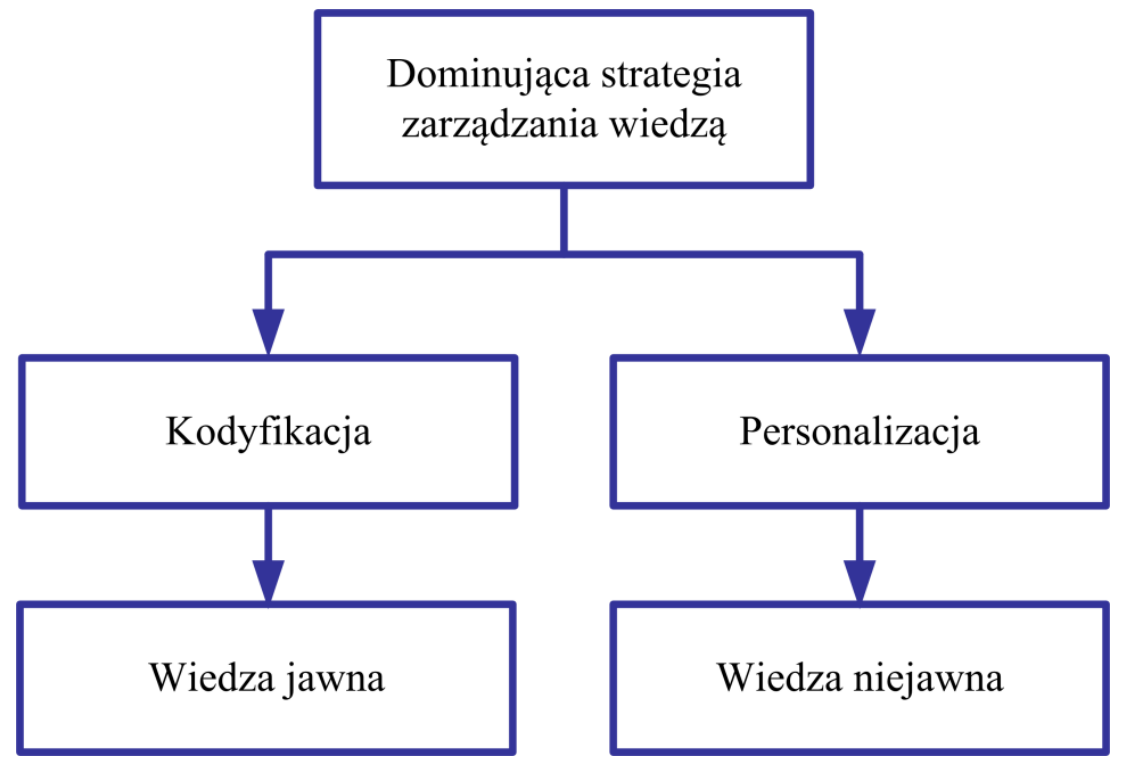

Rysunek 11. Koncentracja na określonym typie wiedzy a dominująca strategia zarządzania wiedzą. Źródło: opracowanie własne. 
Kolejnym ważnym wyborem jest odpowiednia (dopasowana do strategii i potrzeb podmiotu) alokacja zasobów na poziomie narzędziowym. Mamy tutaj do czynienia z dwiema głównymi grupami narzędzi: „twarde” technologie informatyczne oraz „miękkie” działania społeczno-kulturowe (rysunek 12). Ważnym elementem są działania organizacyjne, które trudno zakwalifikować do określonej grupy. Żadna z grup narzędzi nie może być pominięta. Proporcja koncentracji na poszczególnych instrumentach powinna być zależna od przyjętej strategii i indywidualnych uwarunkowań przedsiębiorstwa.

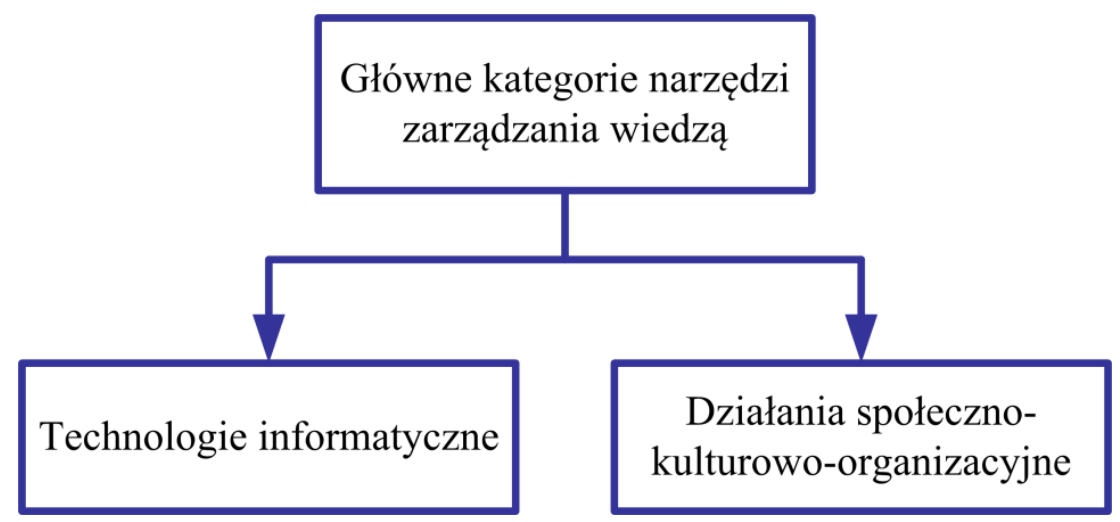

Rysunek 12. Główne kategorie narzędzi zarządzania wiedzą. Źródło: opracowanie własne.

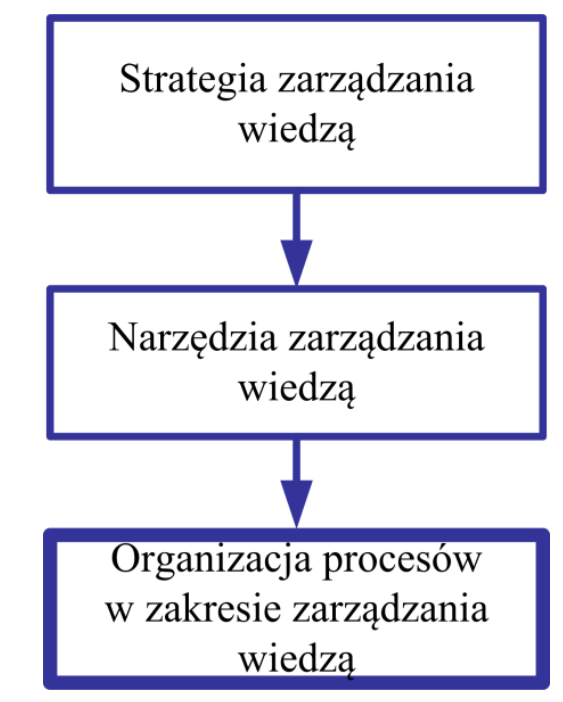

Rysunek 13. Procesy zarządzania wiedzą. Źródło: opracowanie własne.

Przedstawione działania muszą być następnie ujęte w odpowiednio zbalansowane procesy (rysunek 13), które zostaną przedstawione w kolejnym podrozdziale. 


\subsection{Procesy zarządzania wiedzą}

Najważniejszą cechą i jednocześnie zaletą procesowego ujęcia zarządzania wiedzą jest kompleksowe uporządkowanie działań w omawianym obszarze. Należy zaznaczyć, iż $\mathrm{w}$ literaturze $\mathrm{w}$ zakresie podejścia procesowego nie ma zgody, co do jednolitego podziału działań w obszarze zarządzania wiedzą na określone procesy. Podejście poszczególnych autorów do omawianego zagadnienia zostało podsumowane w tabeli 6.

Tabela 6. Podział zakresu procesów zarządzania wiedzą według wybranych autorów.

\begin{tabular}{|c|c|}
\hline Wyróżnione procesy zarządzania wiedzą & $\begin{array}{l}\text { Autor / } \\
\text { autorzy }\end{array}$ \\
\hline Tworzenie, kodyfikacja i rozpowszechnianie wiedzy. & $\begin{array}{l}\text { Davenport } \\
\text { i Prusak }\end{array}$ \\
\hline $\begin{array}{c}\text { Lokalizowanie wiedzy, pozyskiwanie wiedzy, rozwijanie wiedzy, dzielenie } \\
\text { się wiedzą i jej rozpowszechnianie, wykorzystywanie wiedzy, } \\
\text { zachowywanie wiedzy. }\end{array}$ & $\begin{array}{l}\text { G. Probst, } \\
\text { S. Raub, } \\
\text { K. Rombhardt }\end{array}$ \\
\hline Akumulacja, ochrona i wykorzystanie wiedzy. & $\begin{array}{l}\text { B. Chakravarthy, } \\
\text { S. McEvily, Y. } \\
\text { Doz, D. Rau }\end{array}$ \\
\hline $\begin{array}{l}\text { Pozyskiwanie wiedzy z otoczenia, wykorzystywanie wiedzy w organizacji, } \\
\text { szacowanie aktywów wiedzy w organizacji, utrzymanie i rozwijanie } \\
\text { aktywów wiedzy, sprzedaż wiedzy w formie nowych produktów, usług } \\
\text { i technologii. }\end{array}$ & $\begin{array}{l}\text { W. R. } \\
\text { Bukowitz, R. } \\
\text { L. Williams }\end{array}$ \\
\hline $\begin{array}{c}\text { Odkrywanie wiedzy, generowanie wiedzy, wartościowanie wiedzy, } \\
\text { upowszechnianie wiedzy, wykorzystanie wiedzy }{ }^{39}\end{array}$ & A. Jashapara \\
\hline $\begin{array}{l}\text { Lokalizowanie zasobów wiedzy, pozyskiwanie wiedzy, zachowywanie } \\
\text { wiedzy, stosowanie wiedzy. }\end{array}$ & $\begin{array}{l}\text { J. Trajer, } \\
\text { A. Paszek, } \\
\text { S. Iwan }\end{array}$ \\
\hline
\end{tabular}

Źródło: opracowanie własne na podstawie: [Probst, Raub i Romhardt 2004, s. 42; Chakravarthy i in. 2006, s. 305; Jashapara 2006, s. 5-9; Trajer, Paszek i Iwan 2012, s. 59-68].

${ }^{39}$ Podział na podstawie struktury książki autora. 
Autor pracy, na podstawie powyższych klasyfikacji, zdecydował się wyróżnić następujące procesy w zakresie zarządzania wiedzą: pozyskiwanie, kreacja, zachowywanie i rozpowszechnianie, wykorzystanie i ochrona wiedzy. Wybór powyższych procesów jest związany z faktem, iż przy zachowaniu relatywnej ogólności, kompleksowo pokrywają one przestrzeń tematyczną obszaru zarządzania wiedzą. Poniżej każdy z nich został szczegółowo omówiony.

\subsubsection{Pozyskiwanie i kreacja wiedzy}

Obecnie przedsiębiorstwa są w wielu przypadkach zmuszone pozyskiwać wiedzę z zewnątrz, gdyż w związku z ogólną szybkością rozwoju tego zasobu w gospodarce oraz wzrastającą specjalizacją, nie są one w stanie samodzielnie wypracowywać odpowiedniego, potrzebnego do działania know-how [Probst, Raub i Romhardt 2004, s. 118]. W praktyce wiedza pochodząca ze źródeł zewnętrznych zajmuje przeważający udział w zasobie wiedzy podmiotów gospodarczych [Probst, Raub i Romhardt 2004, s. 42]. Simon podkreśla również, że obecnie nawet $\mathrm{w}$ podmiotach badawczych, większość zasobu wiedzy zdobywa się za pomocą studiowania publikacji specjalistycznych, a nie jak można by się spodziewać w procesie samodzielnego prowadzenia badań [Probst, Raub i Romhardt 2004, s. 138]. W literaturze można spotkać opinie, iż nowe pomysły i rozwiązania powinny być przez pracowników pozyskiwane z zewnątrz w sposób ciągły. Zwolennikiem takiego podejścia jest również Jack Welch [Kowalczyk i Nogalski 2007, s. 93].

Kowalczyk i Nogalski podkreślają, również wagę rekrutacji pracowników, którą można postrzegać jako działanie w zakresie pozyskiwania wiedzy. Powinna ona uwzględniać skłonność kandydatów do poszukiwania i dzielenia się zasobem wiedzy [Kowalczyk i Nogalski 2007, s. 94]. Wagę rekrutacji w kontekście zarządzania wiedzą doceniają również Probst, Raub i Rombhardt [2004, s. 122-123].

Probst, Raub i Rombhardt podkreślają, iż rynek wiedzy jest ogólnie bardzo osobliwy w swojej charakterystyce. Jest to związane w dużej mierze $\mathrm{z}$ faktem, iż nabywcy nie są w stanie dokonać kompleksowej oceny przedmiotu zakupu w momencie transakcji, stąd potrzebna jest pewna doza zaufania. Inną specyficzną cechą omawianego rynku jest fakt, iż najcenniejsze dobra najczęściej nie pojawiają się na oficjalnym rynku (np. utalentowani pracownicy czy przełomowe technologie) [Probst, Raub i Romhardt 2004, s. 119]. Wspomniane uwarunkowania nie zawsze muszą być jednak obecne. Przykładowo, 
w przypadku patentów istnieje znacznie większa możliwość oceny nabywanej w jego ramach wiedzy. Zdarzają się także sytuacje, iż przedsiębiorstwo ma kłopoty finansowe i wystawia w ramach publicznej oferty swoje patenty. Taka sytuacja miała miejsce na przełomie lat 2012 i 2013, kiedy firma Kodak wystawiła wiele cennych, posiadanych przez siebie patentów na sprzedaż. Zostały one nabyte głównie przez firmy Apple i Google [Fingas 2013, s. 1; Whittaker 2013, s. 1].

Dużą zaletą pozyskiwania wiedzy z zewnątrz jest, iż tego rodzaju wiedza najczęściej jest już w pewnym stopniu sprawdzona w praktyce oraz istnieje wokół niej mniej niepewności [Kowalczyk i Nogalski 2007, s. 93]. Niestety, wielokrotnie podmioty gospodarcze tracą cenny czas, gdyż poszukują informacji w nieodpowiednich źródłach [Paliszkiewicz 2007, s. 69]. Ponadto, przedsiębiorstwa rzadko efektywnie wykorzystują swoje kontakty z innymi podmiotami w celu pozyskania cennej wiedzy [Probst, Raub i Romhardt 2004, s. 42-43], mimo iż potencjał w tym zakresie jest dość duży. Jednym z cenniejszych, zewnętrznych źródeł wiedzy dla przedsiębiorstw mogą być instytuty badawcze czy uczelnie wyższe. Przykładowo, wiele podmiotów gospodarczych współpracuje Massachusetts Institute of Technology, która należy do najlepszych amerykańskich uczelni technicznych. Przedsiębiorstwa finansują funkcjonowanie ponad 50 katedr istniejących w tym ośrodku akademickim, co z pewnością umożliwia im dostęp do rzadkiej i cennej wiedzy [Probst, Raub i Romhardt 2004, s. 144].

W pozyskiwaniu wiedzy powinno się uwzględniać wszystkie możliwe źródła [Probst, Raub i Romhardt 2004, s. 43]. Jednak jak podkreśla Paliszkiewicz „Zlokalizowanie wszystkich możliwych źródeł wiedzy istotnych dla organizacji jest zadaniem prawie niemożliwym do wykonania..." [Paliszkiewicz 2007, s. 74]. W literaturze można znaleźć różnorodne zestawienia potencjalnych źródeł pozyskiwania wiedzy. Na podstawie literatury została stworzona poniższa typologia (tabela 7) uwzględniająca najważniejsze, zdaniem autora, źródła zewnętrznego pozyskiwania wiedzy.

Pozyskiwanie wiedzy z zewnętrznych źródeł ma też swoje negatywne strony. Zdaniem Paliszkiewicz wiedza ze źródeł ogólnodostępnych nie ma wpływu na wzrost poziomu konkurencyjności przedsiębiorstwa, stąd ważne jest wykorzystywanie źródeł, które są niedostępne dla innych podmiotów i własne tworzenie oraz rozwijanie wiedzy [Paliszkiewicz 2007, s. 74]. Istniejące rynki wiedzy są zdecydowanie niedoskonałe, a związku z praktycznym brakiem przejrzystości nie ma właściwie możliwości porównywania dostępnych na nich dóbr [Probst, Raub i Romhardt 2004, s. 119]. 
Tabela 7. Źródła zewnętrznego pozyskiwania wiedzy.

\begin{tabular}{|c|c|}
\hline$L p$. & Źródto wiedzy \\
\hline 1. & Szkolenia i kursy zewnętrzne \\
\hline 2. & Firmy doradcze (konsultingowe) \\
\hline 3. & Publikacje naukowe, publicystyczne, branżowe \\
\hline 4. & Zamówione ekspertyzy \\
\hline 5. & Badania rynku (własne lub zlecone) \\
\hline 6. & Internet \\
\hline 7. & $\begin{array}{c}\text { Wiedza i wcześniejsze doświadczenia } \\
\text { nowozatrudnionych pracowników }\end{array}$ \\
\hline 8. & $\begin{array}{l}\text { Inne oddziały lub filie przedsiębiorstwa } \\
\text { oraz podmioty powiązane kapitałowo }\end{array}$ \\
\hline 9. & Klienci \\
\hline 10. & Dostawcy i podwykonawcy \\
\hline 11. & Konkurenci \\
\hline 12. & Alianse strategiczne \\
\hline 13. & $\begin{array}{c}\text { Organizacje branżowe/kluby networkingu* } \\
\text { (*kluby networkingu - promują współpracę między } \\
\text { firmami, zazwyczaj z różnych branż) }\end{array}$ \\
\hline 14. & Instytucje badawcze, uczelnie wyższe \\
\hline 15. & Instytucje rządowe i samorządowe \\
\hline 16. & Własne działania w zakresie badań i rozwoju \\
\hline
\end{tabular}

Źródło: opracowanie własne na podstawie: [Davenport i Probst 2002, s. 13; Darroch 2003, s. 45; Probst, Raub i Romhardt 2004, s. 126-133; Kowalczyk i Nogalski 2007, s. 94; Paliszkiewicz 2007, s. 71-73; Mazur, Rószkiewicz i Strzyżewska 2008, s. 151; Sparrow 2010].

Dużym problemem w kontekście importowania zasobu wiedzy z zewnątrz jest znaczne prawdopodobieństwo odrzucenia wiedzy czy też wynalazku związanego z syndromem ,złe bo nie nasze”. Prowadzi to często do nieekonomicznych wyborów własnych, lecz droższych rozwiązań [Probst, Raub i Romhardt 2004, s. 119-120]. Inną trudnością jest również adekwatność danego rozwiązania do warunków panujących w innym podmiocie czy na innym rynku. Dana reguła, a także technologia czy produkt mogą odnosić 
sukces $\mathrm{z}$ uwagi na stosowanie ich w bardzo specyficznych okolicznościach. Wyjęcie ich z określonego kontekstu może sprawić, że staną się bezużyteczne [Probst, Raub i Romhardt 2004, s. 121]. W pierwszej dekadzie XXI wieku duże przedsiębiorstwa z branży nowych technologii m.in. Microsoft i IBM przeprowadziły szereg przejęć mniejszych podmiotów. Dążyły one przede wszystkim do pozyskania utalentowanych zasobów ludzkich, które miały im posłużyć w realizacji ich strategicznych projektów. Niestety, kreatywność, stąd też wartość pracowników przejmowanych firm, w nowych warunkach, znacząco spadła. Niektóre osoby nawet odchodziły z pracy. Przykład ten pokazuje, iż w praktyce przejęcie przez jeden podmiot wiedzy posiadanej przez drugi, jest bardzo trudne, o ile nie niemożliwe. Istnieje bardzo duże ryzyko spadku wartości przejmowanych zasobów wiedzy, w tym przede wszystkim motywacji pracowników [Probst, Raub i Romhardt 2004, s. 127-128].

Wewnętrzny rozwój wiedzy jest działaniem, które uzupełnia pozyskiwanie wiedzy z zewnątrz organizacji [Probst, Raub i Romhardt 2004, s. 43]. Tworzenie wiedzy jest w istocie zagadnieniem rozległym [Kowalczyk i Nogalski 2007, s. 89]. Probst, Raub i Rombhardt, zwracają uwagę, iż w dzisiejszych czasach kreacja nowej wiedzy i innowacji nie jest domeną działu badań i rozwoju przedsiębiorstwa. Działania w tym zakresie powinny istnieć we wszystkich sferach aktywności podmiotu [Probst, Raub i Romhardt 2004, s. 141, 170]. Podobnego zdania są Kowalczyk i Nogalski, którzy podkreślają, iż wszystkie struktury przedsiębiorstwa powinny być zaangażowane w proces rozwoju wiedzy [Kowalczyk i Nogalski 2007, s. 92]. Nowa wiedza może być również wytwarzana podczas tak błahej czynności jak codzienna rozmowa. Jest to związane $\mathrm{z}$ faktem, iż określone informacje w posiadaniu różnych osób mają inną wartość - są ujęte w innym kontekście [Kowalczyk i Nogalski 2007, s. 89, 90].

Samodzielny, wewnętrzny rozwój wiedzy przez przedsiębiorstwo, zamiast zewnętrznego jej pozyskania, może być uzasadniony zarówno argumentami strategicznymi, jak i ekonomicznymi. W pierwszym przypadku, gdy podmiot dąży do utrzymania kontroli w zakresie kluczowych kompetencji, w drugim, gdy samodzielne wytworzenie określonej wiedzy jest mniej kosztowne w porównaniu z jej zakupem [Probst, Raub i Romhardt 2004, s. 142].

Nowa wiedza nie zawsze jest efektem działań ściśle nakierowanych na rozwój tego zasobu. Kontrola nad procesem kreacji wiedzy jest w dużej mierze ograniczona. Zarządzanie powinno koncentrować się raczej na próbie stworzenia sprzyjających rozwojowi tego zasobu warunków, niż na bezpośrednim sterowaniu całym procesem [Probst, Raub i Romhardt 2004, s. 149, 170]. Znaczenie odpowiednich warunków dla pracowników w kontekście kreacji 
nowej wiedzy w przedsiębiorstwie jest również podkreślane przez Kowalczyka i Nogalskiego [2007, s. 92]. Badania firmy Steelcase wykazały, iż powyżej 70 procent wiedzy pracownik zdobywa w miejscu pracy poprzez kontakty i sytuacje nieformalne [Fazlagić 2010, s. 197]. W opinii Handzic i Zhou przestrzeń pracy może być ukształtowana w taki sposób, aby sprzyjała powstawaniu pomysłów poprzez rozmowy i kontakty nieformalne. Działaniami w tym zakresie według wspomnianych autorów może być np. zainstalowanie automatu do kawy, uruchomienie punktu dostępowego do Internetu czy stworzenie pokoju, w którym pracownicy mogą się spotkać i porozmawiać [Handzic i Zhou 2005, s. 41]. Przykładem takich działań może być wspomniana wcześniej firma Xerox, która w wybranych miejscach np. przy automatach z napojami czy klatkach schodowych instaluje w swoich siedzibach tablice z markerami [Cavaleri i Seivert 2005, s. 294]. Firma ICL (obecnie Fujitsu) zrezygnowała z indywidualnych biur na rzecz wspólnych miejsc pracy celem intensyfikacji współpracy [Evans 2005, s. 39-40]. W kontekście bardziej zaawansowanych działań, jakie podejmują przedsiębiorstwa, dla realizacji omawianego celu, należy przede wszystkim wymienić powszechnie znane, z uwagi na swój nietypowy wygląd, biura firmy Google, które pobudzają kreatywność i umożliwiają łatwiejszą współpracę pracowników przedsiębiorstwa. W Polsce najbardziej popularnym jest przykład firmy Allegro, której nowa siedziba w Poznaniu o nazwie Pixel zawiera wiele elementów, które sprzyjają współpracy i przepływowi wiedzy w przedsiębiorstwie.

Choć rozwój wiedzy obejmuje zarówno działania świadome, jak i nieświadome [Kowalczyk i Nogalski 2007, s. 92], należy również podkreślić, że kreacja wiedzy nie jest procesem polegającym wyłącznie na szczęściu czy przypadku. Sam pomysł stanowi wyłącznie 10 procent. Na całą resztę, czyli 90 procent składa się przede wszystkim ciężka, systematyczna praca [Probst, Raub i Romhardt 2004, s. 141].

\subsubsection{Zachowywanie i rozpowszechnianie wiedzy}

Działania dotyczące zachowywania i magazynowania wiedzy są ściśle związane z transferem i rozpowszechnianiem tego zasobu. Mają one na celu ułatwienie późniejszego dostępu do wiedzy, która istnieje w przedsiębiorstwach w różnorodnych miejscach i formach [Choo 2006, s. 2]. Dodatkowo, jak wspomniano wcześniej w pracy, wiedza jest zasobem bardzo ulotnym stąd działania te nie są łatwe. 
W kontekście zachowywania wiedzy przedsiębiorstwo może skoncentrować się, albo na strategii kodyfikacji lub personalizacji. Jest to podejście słuszne, gdyż zarządzanie wiedzą powinno być dopasowane do charakteru działalności przedsiębiorstwa. Pomimo to wielu autorów zaznacza, iż możliwe jest wykorzystywanie drugiej strategii jako uzupełniającej.

Zachowywanie wiedzy implikuje również trzy rodzaje działań: selekcja elementów wiedzy, nadanie im właściwej formy oraz aktualizacja [Paliszkiewicz 2007, s. 83]. Ważnym jest, aby regularnie przeprowadzać procesy m.in. selekcji oraz aktualizacji zasobów informacji i wiedzy. Jest to związane $\mathrm{z}$ faktem, iż posiadana przez podmiot wiedza nie jest dana raz na zawsze [Probst, Raub i Romhardt 2004, s. 44].

Istniejąca $\mathrm{w}$ przedsiębiorstwie wiedza ( $\mathrm{w}$ formie skodyfikowanej czy w umysłach pracowników) jest bezużyteczna bez skutecznego jej rozpowszechnienia wśród pracowników. Rozpowszechnianie wiedzy $\mathrm{w}$ przedsiębiorstwie jest czasem określane również jako wewnętrzny transfer wiedzy. Działanie to umożliwia przekształcanie poszczególnych elementów omawianego zasobu w zasób całej organizacji [Probst, Raub i Romhardt 2004, s. 43]. Celem działań osób zarządzających w przedsiębiorstwie (szczególnie w przypadku strategii personalizacji) powinno stać się wytworzenie sytuacji wspólnej, świadomej odpowiedzialności wszystkich pracowników za zasób wiedzy ich organizacji [Paliszkiewicz 2007, s. 58].

Wagę omawianego procesu podkreśla Gladstone, według którego brak wiedzy jest równie powszechny, jak brak odpowiedniego upowszechnienia tego zasobu, co uniemożliwia jego wykorzystanie [Gladstone 2004, s. 160]. Paliszkiewicz zaznacza, iż dzielenie się wiedzą obecnie powinno się traktować jako warunek skuteczności działań podmiotu, nie zaś tylko jako postulat etyczny [Paliszkiewicz 2007, s. 53]. Jest to związane z obecnymi uwarunkowaniami gospodarczymi, które charakteryzują się m.in. popularyzacją pracy zespołowej względem indywidualnej, wzrastającą kooperacją przedsiębiorstw i coraz powszechniejszym występowaniem organizacji wirtualnych [Probst, Raub i Romhardt 2004, s. 206]. W związku z tym, w opinii Kowalczyka i Nogalskiego, transfer zasobu wiedzy powinien stanowić nawet element życia organizacji i odbywać się w sposób ciągły [Kowalczyk i Nogalski 2007, s. 103].

Transfer wiedzy składa się z dwóch działań: transmisji oraz absorpcji [Paliszkiewicz 2007, s. 78]. Ważnym elementem transferu wiedzy jest jej absorpcja przez odbiorcę. Bez absorpcji nie może dojść do transferu tego zasobu [Perechuda 2005, s. 76]. Właściwa absorpcja wiedzy wymaga, aby zasób ten był dostarczony we właściwej formie oraz pochodził z wiarygodnego źródła [Paliszkiewicz 2007, s. 50]. Gladstone podkreśla, 
że wartość przekazu jest uwarunkowana nie przez nadawcę, lecz odbiorcę [Gladstone 2004, s. 161].

Pierwszym narzędziem, które może być pomocne w omawianym procesie jest technologia informatyczna. Niestety, narzędzia informatyczne nie rozwiążą całości problemu, brak intencji człowieka do dzielenia się wiedzą skutecznie uniemożliwi jakikolwiek wewnętrzny transfer wiedzy. Również Probst, Raub i Rombhardt podkreślają, że należy wystrzegać się dominacji informatyki [Probst, Raub i Romhardt 2004, s. 198]. Paliszkiewicz podkreśla, iż oprócz technologii ważna jest modyfikacja kultury ${ }^{40}$ podmiotu [Paliszkiewicz 2007, s. 83]. Jest to związane faktem, iż „system hybrydowy”, który w odpowiedni sposób łączy zarówno tradycyjne, jak i nowoczesne (technologiczne) działania w zakresie upowszechniania wiedzy $\mathrm{w}$ organizacji jest $\mathrm{z}$ reguły najskuteczniejszy [Probst, Raub i Romhardt 2004, s. 199].

W przypadku kodyfikacji - podstawą jest sprawny system zapisu wiedzy do formy jawnej. Gromadzona wiedza powinna być odpowiednio wyselekcjonowana i dopasowana do potrzeb przedsiębiorstwa, jak również łatwa do wykorzystania przez ostatecznych użytkowników. Ważny jest również czas dostępu do niej. Przede wszystkim kluczowym jest subiektywne postrzeganie pracownika, że warto poszukiwać wiedzy w skodyfikowanych bazach danych przedsiębiorstwa. Wypływa ono z jego przeszłych doświadczeń oraz opinii panującej w przedsiębiorstwie. Paliszkiewicz na podstawie literatury określa szereg warunków akceptacji przez użytkowników przechowywanej, skodyfikowanej wiedzy, wśród których wymienia: istotność, łatwość i wygodę dostępu, wiarygodność i gwarancję wsparcia dla użytkownika w razie problemów [Paliszkiewicz 2007, s. 85].

Wiedza znajdująca się w posiadaniu wielu ekspertów może być przekazana wyłącznie za pomocą kontaktów bezpośrednich [Kowalczyk i Nogalski 2007, s. 96]. Istnieją jednak wyjątki. W pewnych, określonych sytuacjach interakcja elektroniczna może być równie skuteczna - przykładem są wspomniane wcześniej wideokonferencje w firmie BP. Mimo to zdecydowanie należy zgodzić się z faktem, iż podstawą przekazywania wiedzy niejawnej jest interakcja międzyludzka, której kontakty bezpośrednie są podstawową i najpełniejszą formą, zaś interakcja elektroniczna jest w wielu elementach jest ograniczona, stąd nie zawsze jest skuteczna. Interakcja międzyludzka może również nabierać różnorodnego

\footnotetext{
${ }^{40}$ Dobrym przykładem jest firma IKEA, w której tworzenie odpowiedniej, sprzyjającej transferowi wiedzy, kultury organizacyjnej rozpoczyna się $\mathrm{w}$ momencie zatrudnienia pracownika. Jednym z celów pierwszych szkoleń jest uświadomienie wprowadzanej do firmy osobie, wagi dzielenia się wiedzą. Również decyzje dotyczące nagród dla pracowników uwzględniają ich postawę w omawianym obszarze [Paquette i Desouza 2011, s. 196].
} 
charakteru. Przepływ wiedzy w organizacji następuje zarówno kanałami formalnymi, jak i nieformalnymi. Należy pamiętać przede wszystkim o wadze kontaktów interpersonalnych oraz relacji społecznych, gdyż są one bardzo ważne w procesie rozwoju zasobu wiedzy przedsiębiorstwa [Paliszkiewicz 2007, s. 54]. Zdaniem Kowalczyka i Nogalskiego najskuteczniejszą metodą w zakresie przepływu wiedzy ukrytej jest nieformalny transfer tego zasobu [Kowalczyk i Nogalski 2007, s. 103]. Negatywną stroną nieformalnego transferu wiedzy jest fakt, iż wykorzystuje się w tym przypadku fizycznie najbliższe (dostępne), a nie zaś najlepsze źródła wiedzy [Kowalczyk i Nogalski 2007, s. 104].

Interakcja międzyludzka umożliwia znacznie łatwiejsze i pełniejsze przekazywanie treści. Egzemplifikacją skutecznego narzędzia w tym zakresie są opowiadania (storytelling). Umożliwiają one wprowadzenie kontekstu i sprawiają, że informacje i wiedza są łatwiej i szybciej przyswajalne [Busch 2008, s. 27]. Innym przykładem, są wspólnoty praktyków odpowiednie warunki pozwalają na zacieśnianie współpracy osób zainteresowanych określonymi zagadnieniami tworząc grupy wspólnych zainteresowań, które umożliwiają rozwój i późniejsze wykorzystanie wiedzy [Jashapara 2006, s. 257-265].

W literaturze można odnaleźć szereg sposobów i koncepcji umożliwiających stymulację rozpowszechniania tej najcenniejszej wiedzy, czyli niejawnej. Najważniejsze jest umożliwienie interakcji. Stąd efektywnym działaniem może być wprowadzenie zespołowego trybu pracy [Busch 2008, s. 27]. Interakcji może również sprzyjać utrzymywanie wspólnych przestrzeni spotkań, przy czym mogą to być po prostu bary czy stołówki pracownicze lub przestrzenie socjalne [Darroch 2003, s. 46; Wang i in. 2009, s. 119]. Można w tym zakresie iść znacznie dalej stwarzając wspólne przestrzenie pracy [Evans 2005, s. 39-40]. Ponadto, należy również stymulować współpracę pomiędzy poszczególnymi jednostkami organizacyjnymi [Wang i in. 2009, s. 119]. Probst, Raub i Rombhardt podkreślają, iż skutecznym działaniem $\mathrm{w}$ tej sferze może być utworzenie odpowiednich struktur egzystujących poza podziałami funkcjonalnymi czy geograficznymi, które mogą być związane z określonymi zagadnieniami czy obszarami tematycznymi. Tego rodzaju grupy wewnętrznych ekspertów mogą być podstawą sieci informacyjnej i uczenia się podmiotu [Probst, Raub i Romhardt 2004, s. 189].

Nie należy zapominać, że interakcję międzyludzką mogą wspomagać również elektroniczne narzędzia komunikacyjne. Można wśród nich wyróżnić m.in. portale korporacyjne, intranet, forum firmowe, tele- i wideokonferencje, komunikatory (instant messaging), pocztę elektroniczną czy grupy dyskusyjne [Kowalczyk i Nogalski 2007, s. 106107]. 
Liebowitz podkreśla, że szczególnie ważnym działaniem w zakresie implementacji zarządzania wiedzą w podmiocie jest stworzenie skutecznych organizacyjnych przepływów wiedzy wewnątrz organizacji [Busch 2008, s. 23]. Potrzeba skutecznego i szybkiego działania w zakresie rozpowszechniania wiedzy została zauważona w pierwszej kolejności przez firmy doradcze. Jest to związane $\mathrm{z}$ faktem, iż wiedza jest $\mathrm{w}$ samym centrum ich działalności. Przykładowo, McKinsey zdecydował się utworzyć specjalne zespoły zadaniowe specjalizujące się w określonych dziedzinach zarządzania czy sektorach gospodarki. Omawiana firma poszła nawet dalej tworząc tzw. „system szybkiego reagowania”, który okazał się bardzo efektywny. Jego podstawą jest elektroniczny system zarządzania dokumentami wraz z informacjami o specjalizacji poszczególnych ekspertów. Jest zasilany w dane przez dział, w którym dyżurują osoby pomagające w znalezieniu posiadających odpowiednią wiedzę ekspertów oraz zespół zadaniowy wspierający rozwiązywanie skomplikowanych i złożonych przypadków [Probst, Raub i Romhardt 2004, s. 189, 191].

Dobrym przykładem skutecznego działania w zakresie rozpowszechniania wiedzy jest również firma Volkswagen. Świadomość znaczenia dzielenia się i przepływu wiedzy została w tym podmiocie wpleciona do kultury organizacyjnej firmy. Standardem jest system cyklicznych spotkań w ramach komórek organizacyjnych oraz spotkania międzyzespołowe. Ważnym elementem wspomnianych zebrań jest omawianie występujących problemów oraz obowiązek wysłuchania każdego zaproponowanego pomysłu czy sugestii [Perechuda 2005, s. 83,84$]$.

Badania przeprowadzone w Cranfield School of Management sugerują, iż problemy w zakresie przepływu wiedzy można zakwalifikować do trzech grup: metod zarządzania (w tym problemów $\mathrm{z}$ delegowaniem uprawnień lub oddaniem władzy), struktury (m.in. sztywność) lub ludzi (m.in. brak motywacji lub czasu czy opór wobec zmian) [Paliszkiewicz 2007, s. 80]. Trochę inaczej do zagadnienia podchodzą Probst, Raub i Rombhardt, którzy uważają, że omawiane problemy w zakresie dzielenia się wiedzą w przedsiębiorstwie można ująć w dwóch głównych kategoriach: zdolności i chęci [Probst, Raub i Romhardt 2004, s. 202].

W odniesieniu do pierwszego rodzaju problemów należy stwierdzić, iż podstawą wydajnego rozpowszechniania wiedzy są określone struktury organizacji, jak również narzędzia technologiczne. Ich obecność nie jest jednak czynnikiem wystarczającym, lecz koniecznym. Istnieje szereg kulturowych, jak i psychologicznych barier, które mogą nakładać się również z podziałami hierarchicznymi czy funkcjonalnymi, co skutecznie może zablokować przepływ informacji i wiedzy [Probst, Raub i Romhardt 2004, s. 201]. 
Problemem są też ścisłe regulacje. Zdaniem Paliszkiewicz, nie ma możliwości stworzenia efektywnej wymiany wiedzy $\mathrm{w}$ momencie istnienia ścisłych regulacji w zakresie tego, co każdy pracownik powinien wiedzieć [Paliszkiewicz 2007, s. 78].

Dużym problemem w procesie rozpowszechniania wiedzy jest fakt, iż dzielenie się przez człowieka wiedzą jest w dużej mierze nienaturalne [Fazlagić 2006, s. 110]. Jashapara zalicza stąd zagadnienie wspomagania i stymulacji dzielenia się wiedzą do największych obecnych wyzwań w zakresie zarządzania wiedzą w przedsiębiorstwie [Jashapara 2006, s. 377]. Podobnego zdania są Probst, Raub i Rombardt, którzy podkreślają problem barier psychologicznych związanych z dzieleniem się wiedzą wynikających z faktu, iż człowiek najczęściej postrzega swój zasób wiedzy jako prywatną własność, a także element przewagi nad pozostałymi członkami organizacji [Probst, Raub i Romhardt 2004, s. 185]. Tego rodzaju zagrożenie skuteczności działań w zakresie dzielenia się wiedzą w organizacji występuje w momencie, gdy powoduje ono pozbawienie danych pracowników wyłączności w obszarze określonych informacji. Taka sytuacja jest domeną organizacji, w których posiadana wiedza jest równoznaczna z władzą oraz zajmowaną pozycją w hierarchii [Probst, Raub i Romhardt 2004, s. 202].

\subsubsection{Wykorzystywanie wiedzy}

Wykorzystywanie wiedzy jest kluczowym procesem zarządzania wiedzą w przedsiębiorstwie. Decyduje on w praktyce o sensowności wszystkich wcześniejszych działań - poprawne jego przeprowadzenie jest bowiem celem zarządzania wiedzą. Jest to związane z faktem, który podkreślają Ye, Desouza i Paquette [2011, s. 213], iż jednym z ważniejszych wyzwań omawianej koncepcji jest skrócenie drogi pomiędzy tworzeniem (lub pozyskiwaniem) wiedzy, a jej zastosowaniem. Wagę etapu praktycznego wdrażania wspomnianego zasobu podkreślają również Probst, Raub i Rombhardt, zdaniem których zgromadzona wiedza, która nie umożliwia praktycznego jej zastosowania jest tak naprawdę bezużyteczna [Probst, Raub i Romhardt 2004, s. 211].

Kowalczyk i Nogalski podkreślają, iż na omawianym etapie można dostrzec praktyczne wyniki działań $\mathrm{w}$ postaci innowacji opartej na zgromadzonej przez przedsiębiorstwo wiedzy [Kowalczyk i Nogalski 2007, s. 108]. Namacalne efekty widoczne w tym miejscu wiążą się jednak z pewnym zagrożeniem. Agresywna polityka podmiotu w zakresie wykorzystania zgromadzonej wiedzy może zniechęcać do pozyskiwania i kreacji 
nowej wiedzy, gdyż gromadzenie nowych elementów omawianego zasobu nie prowadzi do zwrotu z podjętej inwestycji w krótkim okresie, w przeciwieństwie do działań w zakresie implementacji wiedzy [Chakravarthy i in. 2006, s. 317]. Nie można zbytnio też koncentrować się wyłącznie na tym etapie, trzeba zachować równowagę. Generalnie można przypuszczać, że duża część przedsiębiorstw, szczególnie tych notowanych na giełdzie, zwłaszcza z rozproszonym akcjonariatem może być bardziej skłonna do krótkookresowego działania, koncentracji na wykorzystaniu posiadanej już wiedzy, co utrudnia inne procesy zarządzania wiedzą. Jest to między innymi związane $\mathrm{z}$ niedoskonałością stosowanej obecnie rachunkowości, która głównie postrzega wydatki w zakresie wiedzy jako koszty nie zaś inwestycje.

Zastosowanie wiedzy może również nie być tak proste, jak jej pozyskanie. Zdarza się, że określona wiedza nie jest możliwa do zastosowania w innym miejscu czy przedsiębiorstwie, co jest związane z konkretnym kontekstem jej zastosowania. W takim przypadku mówimy, że wiedza ma charakter lepki [Wiatrak 2007, s. 14]. Wykorzystanie wiedzy może być również utrudnione z uwagi na czynnik ludzki. Dużym problemem mogą być bariery psychologiczne. Mogą one wynikać z różnych czynników w tym m.in. różnego rodzaju obaw czy zbyt wysokiej samooceny. Przykładem takiej sytuacji był długoletni brak zainteresowania japońskimi sposobami wytwarzania w Niemczech, co spowodowało utratę wielu szans wzrostu [Probst, Raub i Romhardt 2004, s. 215]. Bardzo popularnym podejściem jest wspomniany już syndrom, „złe bo nie nasze”. W przezwyciężeniu tego zjawiska i przybliżeniu pracownikom szans, jakie stwarza otwartość na nową wiedzę znaczącą rolę odgrywa kadra zarządzająca [Probst, Raub i Romhardt 2004, s. 216].

\subsubsection{Ochrona wiedzy}

Ostatnim opisywanym elementem zarządzania wiedzą, lecz w praktyce takim, który powinien towarzyszyć wszystkim działaniom w zakresie wiedzy przedsiębiorstwa jest ochrona tego zasobu. Zdaniem autora można wyróżnić dwa główne zagrożenia w tym obszarze. Pierwsze z nich to przejęcie zasobu wiedzy przez konkurencyjne przedsiębiorstwa. Drugie to przypadkowa utrata (np. uszkodzenie nośnika danych w przypadku wiedzy jawnej lub odejście pracownika w przypadku wiedzy niejawnej). Nie ma tu rozwiązania idealnego. Działania dotyczące minimalizacji ryzyka jednego rodzaju najczęściej powodują wzrost ryzyka drugiego rodzaju. Innym negatywnym skutkiem działań zakresie związanych 
z ochroną omawianego zasobu jest możliwość utrudnienia dzielenia się wiedzą wewnątrz podmiotu $^{41}$ [Chakravarthy i in. 2006, s. 314].

Przedsiębiorstwa w wielu przypadkach same pozbywają się bardzo ważnych zasobów wiedzy. Dobrym przykładem tego zjawiska jest nieprzemyślana redukcja etatów ${ }^{42}$, która w długim okresie może spowodować wzrost kosztów z uwagi na konieczność odbudowy utraconych zasobów intelektualnych [Jemielniak i Koźmiński 2012, s. 85]. Przykładowo, w jednej z firm ubezpieczeniowych dokonano redukcji zatrudnienia, co miało zaowocować obniżką kosztów działalności oraz przyspieszeniem obsługi klientów. Po pewnym czasie okazało się, że zwolniono osoby posiadające kluczową wiedzę, w tym przypadku z zakresu likwidacji szkód. W efekcie koszty związane z wprowadzeniem nowych rozwiązań zdecydowanie przewyższyły uzyskane korzyści [Gladstone 2004, s. 156]. Utrata szczególnie ważnej wiedzy może utrudnić działalność całego przedsiębiorstwa [Probst, Raub i Romhardt 2004, s. 229]. Odejście kompetentnego pracownika w mniejszych przedsiębiorstwach może prowadzić nawet do bankructwa podmiotu [Perechuda 2005, s. 66]. Mimo to, wiele firm nie posiada odpowiednich procedur zabezpieczających je przed przypadkową $^{43}$ utratą omawianego zasobu [Paliszkiewicz 2007, s. 90]. Kluczowa wiedza jest w wielu przedsiębiorstwach w posiadaniu jednej osoby i brakuje działań umożliwiających jej rozpowszechnienie. $\mathrm{W}$ momencie odejścia pracownika, taka sytuacja może doprowadzić do (czasem nieodwracalnej) utraty wiedzy ${ }^{44}$ [Geisler i Wickramasinghe 2009, s. 10-11].

Popularne działania w zakresie „odchudzania” struktur organizacji doprowadziły do sytuacji, w której określona wiedza nie jest dublowana. Jest to racjonalne z ekonomicznego punktu widzenia, lecz sprawia, iż wiedza jest trudniej dostępna dla pracowników, którzy jej potrzebują. Ponadto, omawiane działania często zaburzają również nieformalne ciągi

\footnotetext{
41 Według Perechudy przedsiębiorstwo może podejść do zagadnienia ochrony wiedzy w dwojaki sposób stosując strategię udostępniania lub protekcji wiedzy. Stanowią one swoje przeciwieństwo. Ideą pierwszej z nich jest celowe udostępnianie wiedzy otoczeniu, np. aby stała się bardziej wartościowa. Drugą, znacznie trudniejszą do zastosowania opcją, jest strategia protekcji wiedzy [Perechuda 2005, s. 32-33].

${ }^{42} \mathrm{Z}$ badań firmy konsultingowej Delphi wynika, iż 42 procent wiedzy organizacji znajduje się w umysłach pracowników [van Heghe 2011, s. 29].

${ }^{43}$ Martins i Meyer [2012, s. 91-92] postulują implementację w przedsiębiorstwach określonej strategii mającej na celu przeciwdziałanie zjawisku utraty wiedzy. Wspomniani autorzy podkreślają jednak, iż dokładne procedury muszą mieć charakter indywidualny, gdyż każdy podmiot jest inny, a działania powinny skupiać się na elementach ważnych dla określonej firmy.

${ }^{44}$ Ermine [2012, s. 99] przywołuje ryzyko związane z obecną sytuacją demograficzną - starzejącą się populacją. Jego zdaniem masowe przejście na emeryturę dużej liczby pracowników może spowodować masową utratę wiedzy wielu organizacji [Ermine 2012, s. 99]. W efekcie z pewnością nie pozostanie to bez wpływu na długoterminową przewagę konkurencyjną tych podmiotów, chyba że zostaną wprowadzone w przedsiębiorstwach odpowiednie procedury mające na celu powstrzymanie, lub chociaż minimalizację odpływu omawianego zasobu.
} 
komunikacyjne pomiędzy różnymi jednostkami podmiotu [Probst, Raub, Romhardt 2004, s. 85].

W opinii Schmitt, Borzillo i Probsta [2011, s. 67] każde zwolnienia niosą ze sobą zagrożenie uszczuplenia potencjału wiedzy podmiotu. W związku z tym odchudzanie organizacji musi być bardzo dobrze przemyślane. Trzeba być świadomym negatywnych skutków nieostrożnych działań. Nie oznacza to, że nie wolno prowadzić tego procesu, tylko należy robić to rozważnie. Jak zaznacza Mitroff, szczególnie szkodliwe, pod względem utraty wiedzy, mogą być zwolnienia pracowników, których jedynym celem jest redukcja kosztów przedsiębiorstwa [Probst, Raub i Romhardt 2004, s. 250].

Innym rodzajem ryzyka, któremu muszą stawić czoła przedsiębiorstwa, jest przejęcie ich zasobów intelektualnych przez konkurencję. Gladstone podkreśla, iż jednym z ważniejszych wyzwań osób zajmujących się zarządzaniem wiedzą jest powstrzymanie, często bardzo dużych, wycieków wiedzy z przedsiębiorstw, które są efektem braku skutecznego zarządzania tym zasobem [Gladstone 2004, s. 155]. Kłak podkreśla, iż ochrona ważnej dla podmiotu wiedzy stanowi ochronę przewagi konkurencyjnej przedsiębiorstwa [Kłak 2010, s. 83].

Probst, Raub i Rombhardt zaznaczają, iż każde przedsiębiorstwo musi zadecydować, które $\mathrm{z}$ posiadanych przez podmiot zasobów wiedzy należy zabezpieczać przed rozpowszechnianiem, a które szeroko udostępniać m.in. wśród pracowników. Brak decyzji w tym zakresie może prowadzić do zbyt dużej jawności, która może skutkować wykorzystaniem nadarzających się okoliczności przez konkurencję [Probst, Raub i Romhardt 2004, s. 92, 183]. Można sobie również wyobrazić sytuację przeciwną, w której zbyt daleko posunięta niejawność prowadzi do braku efektywnego wykorzystania posiadanej wiedzy.

Ponadto, należy także pamiętać, iż przedsiębiorstwo w praktyce nie zawsze może posiadać całkowite prawa do określonych zasobów wiedzy. Przykładowo pracownik opuszczający jedno miejsce zatrudnienia korzysta ze zdobytej wiedzy u nowego pracodawcy [Fazlagić 2006, s. 58]. Ryzyko utraty wiedzy można tylko ograniczać. Zdaniem Appleyarda trzeba rozważyć szereg działań m.in. ochrony prawnej, umów w zakresie niekonkurowania, oraz instruowania i szkolenia pracowników w zakresie dzielenia się posiadaną wiedzą, w szczególności z osobami spoza organizacji [Chakravarthy i in. 2006, s. 310].

Działaniem, które może w dużej mierze utrudnić skopiowanie wiedzy jest wplecenie jej w złożone procesy interakcji licznej grupy osób lub podmiotów [Chakravarthy i in. 2006, s. 310]. Takie działanie utrudnia zrozumienie całości procesu i może stanowić relatywnie skuteczną ochronę przed konkurentami. Z tym podejściem zgadzają się Chakravarthy, 
McEvily, Doz oraz Rau, którzy sugerują, że większy udział wiedzy niejawnej w całkowitym zasobie wiedzy przedsiębiorstwa pozwala „prościej chronić, zbudowaną na tej wiedzy, pozycję konkurencyjną podmiotu" [Chakravarthy i in. 2006, s. 311].

Popularne patenty są $\mathrm{z}$ reguły skuteczne wyłącznie w niektórych branżach [Chakravarthy i in. 2006, s. 310]. Jest to związane m.in. z faktem, iż mają one określony termin ważności lub wymaga się dokładnego opisania danej wiedzy we wniosku patentowym. Czasem lepiej w inny sposób chronić wiedzę np. w formie wiedzy niejawnej [Jemielniak i Koźmiński 2012, s. 85]. Dobrymi przykładami przedsiębiorstw, które przyjęły politykę wiedzy niejawnej wobec kluczowych elementów swojego zasobu wiedzy, są firmy Heinz czy Coca-Cola. Receptury ich kluczowych produktów są znane wyłącznie kilku osobom.

\subsubsection{Podsumowanie podejścia procesowego}

W podejściu procesowym do zarządzania wiedzą bardzo ważnym zagadnieniem jest zapewnienie równomiernej koncentracji przedsiębiorstwa na każdym z procesów. Brak przywiązywania uwagi do jednego z nich może prędzej lub później prowadzić do zmniejszenia lub nawet zaniku pozytywnych efektów działań w zakresie wiedzy ${ }^{45}$.

Należy też podkreślić, iż sprawna realizacja procesów jest w dużej mierze uzależniona od kadry zarządzającej [Handzic i Zhou 2005, s. 36], która podejmuje kluczowe decyzje w zakresie doboru strategii, a także wykorzystywanych narzędzi. Od poziomu przywództwa jednostek zarządzających zależy również praktyczna implementacja działań i ich faktyczna realizacja $w$ formie opisanych $w$ pracy procesów, a także stałe ich usprawnianie, jak również aktualizacja na wszystkich poziomach (rysunek 14). Jak podkreśla Tabaszewska [2011, s. 67] kadra zarządzająca powinna aktywnie zachęcać pracowników ${ }^{46}$ do odpowiednich działań oraz podkreślać ich istotność. Donate i Guadamillas [2011, s. 906, 907] na podstawie swoich badań, zwracają uwagę, iż postawa wspomnianych osób powinna być przykładem zachęcającym pracowników do zaangażowania w obszarze każdego z procesów. Efekty czynnego zaangażowania kierownictwa podmiotu zostały potwierdzone empiryczne przez Kinga i Marksa Jr. [2008, s. 140] oraz przez Kjærgaard i Kautz [2008, s. 296], którzy z kolei podkreślają negatywne konsekwencje bezczynności kadry zarządzającej tym obszarze.

\footnotetext{
45 Potwierdza to m.in. badanie empiryczne przeprowadzone przez Kraaijenbrink [2012, s. 1090, 1094] na przykładzie firm holenderskich.

${ }^{46}$ Z badań Ajmal, Helo i Kekäle [2010, s. 164] przeprowadzonych w przedsiębiorstwach zorganizowanych projektowo, wynika, iż jedną $\mathrm{z}$ największych barier we wprowadzaniu zarządzania wiedzą jest brak odpowiednich zachęt dla pracowników stymulujących ich udział w przedsięwzięciu.
} 


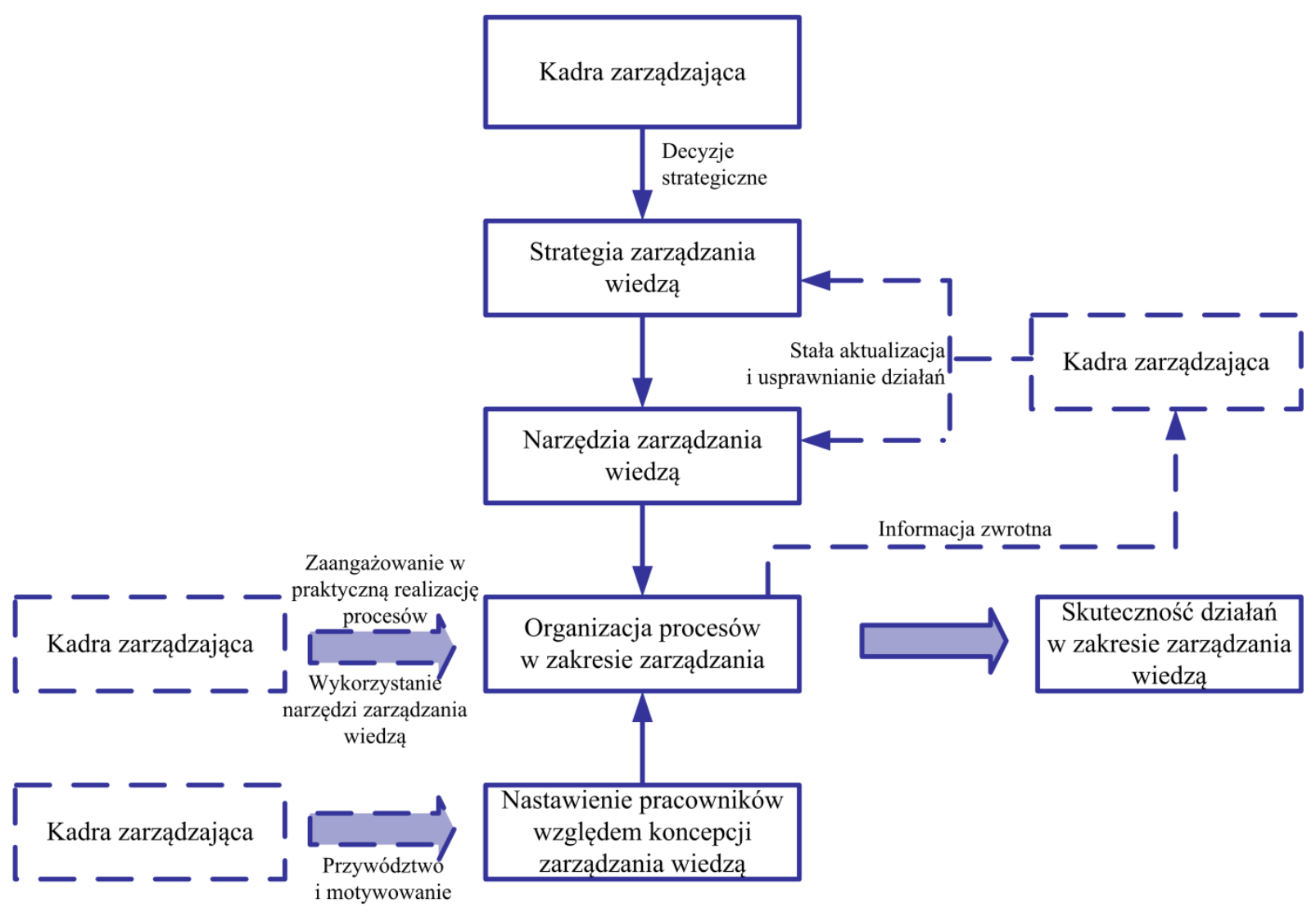

Rysunek 14. Determinanty sukcesu zarządzania wiedzą w przedsiębiorstwie.

Źródło: opracowanie własne.

Podsumowując, strategiczne planowanie i realizacja działań w ramach poszczególnych procesów zarządzania wiedzą (pozyskiwania, kreacji, zachowywania i rozpowszechniania, wykorzystania i ochrony wiedzy) ma wpływ na zarządzanie wiedzą w całym przedsiębiorstwie. Błędy lub niewystarczające zaangażowanie w obrębie jednego z nich powodują powstawanie słabego ogniwa, które może doprowadzić do niewydolności całego systemu zarządzania wiedzą. Należy również podkreślić, iż ostateczne efekty zależą w dużej mierzej od działań kadry zarządzającej z uwagi na wielowymiarowy wpływ tych osób na każdy proces, a także każdy aspekt realizacji koncepcji.

Innym bardzo ważnym elementem, związanym $\mathrm{z}$ omawianym obszarem, jest odpowiednie ukierunkowanie procesów w zakresie wiedzy. Przedsiębiorstwo musi prowadzić szeroką selekcję informacji i wiedzy według określonego kryterium. W niniejszej rozprawie jego rolę spełnia orientacja rynkowa. Zasadność tego podejścia zostanie wyjaśniona w kolejnym rozdziale pracy. 


\subsection{Podsumowanie i wnioski}

W literaturze istnieje szereg dynamicznych podejść do opisywania działania przedsiębiorstw w zakresie wiedzy. Brakuje jednak kompleksowego ujęcia tych działań najczęściej są one analizowane oddzielnie. Trudnym zadaniem jest określenie różnic i relacji pomiędzy poszczególnymi koncepcjami w omawianym obszarze. Jedną z przyczyn problemu jest fakt, iż w literaturze brakuje wyraźnego rozróżnienia pomiędzy wiedzą a uczeniem się [Chakravarthy i in. 2006, s. 306]. Brak istnienia jasnych relacji i zgodności pomiędzy koncepcjami egzemplifikuje stwierdzenie Nonaki i Takeuchiego, którzy podkreślają, że teoria organizacji uczącej się Senge ma „coś wspólnego” z ich koncepcją tworzenia wiedzy, lecz wspomniany autor rzadko posługuje się pojęciem „wiedza” i nie wyjaśnia jak tworzyć ten zasób [Nonaka i Takeuchi 2000, s. 68].

Zdaniem autora każda z koncepcji posiada swój unikalny dorobek, a dodatkowo bardzo rzadka konfrontacja różnorodnych teorii w literaturze, stwarza szansę wykreowania unikalnej wartości dodanej. Rozdział zawiera analizę dorobku poszczególnych dynamicznych koncepcji i jest próbą wyodrębnienia poszczególnych, komplementarnych elementów wartości dodanej omawianych teorii w celu ich późniejszego wykorzystania do wzbogacenia statycznego modelu przedstawionego w pierwszym rozdziale pracy.

Konkluzją rozważań prowadzonych przez autora jest wniosek, iż zarządzanie wiedzą jest koncepcją dominującą, ze względu na swoje cechy praktyczne oraz uporządkowaną strukturę procesów. Pomimo to powinna być ona wzbogacona przez dorobek pozostałych teorii, gdyż zawierają one cenne elementy komplementarne względem zarządzania wiedzą. W opinii autora pracy, organizacyjne uczenie się wnosi bardzo cenną perspektywę uczenia się jedno-, dwu- i trzypętlowego. Z kolei koncepcja organizacji uczącej się, pomimo swojego raczej abstrakcyjnego charakteru, uniemożliwiającego praktyczne wdrożenie tej idei w przedsiębiorstwie, dostarcza cennych wniosków, które mają wpływ na kształt ostatecznego modelu opracowanego w pracy. Przede wszystkim wyznacza ona kierunek, w którym powinno dążyć nowoczesne przedsiębiorstwo. Zakłada także stałe zmiany związane ze zmieniającym się środowiskiem działania podmiotu oraz podkreśla wagę ciągłego uczenia się firmy i doskonalenia procesów związanych z pozyskiwaniem i wykorzystaniem wiedzy, co jest nieodzowne w dzisiejszych warunkach wysokiej konkurencji.

Rozdział koncentruje się jednak przede wszystkim na najważniejszej dynamicznej koncepcji odnośnie działania przedsiębiorstw w zakresie wiedzy - zarządzaniu wiedzą, które jest podstawową teorią wykorzystywaną w omawianym obszarze. Autor porządkuje bogaty 
dorobek literaturowy teorii zarządzania wiedzą, koncentrując się na modelu procesowym. Na podstawie różnorodnych klasyfikacji dostępnych literaturze, zdecydowano się wyróżnić następujące procesy zarządzania wiedzą: pozyskiwanie, kreację, zachowywanie i rozpowszechnianie, wykorzystanie i ochronę wiedzy. Wybór powyższych procesów jest związany z faktem, iż przy zachowaniu relatywnej ogólności, kompleksowo pokrywają one przestrzeń tematyczną zarządzania wiedzą. Ponadto, w ramach prowadzonych rozważań opracowano, na podstawie literatury, autorską typologię narzędzi informatycznych w zarządzaniu wiedzą. 


\section{Orientacja na wiedzę a kształtowanie przewagi konkurencyjnej przedsiębiorstwa}

Zanim termin orientacja na wiedzę zostanie dokładnie zdefiniowany i omówiony w podrozdziale 3.2, należy powrócić do rysunku 4 zaprezentowanego pod koniec rozdziału pierwszego pracy. Został on przywołany poniżej jako rysunek 15 wraz z podziałem na trzy części: A, B i C.

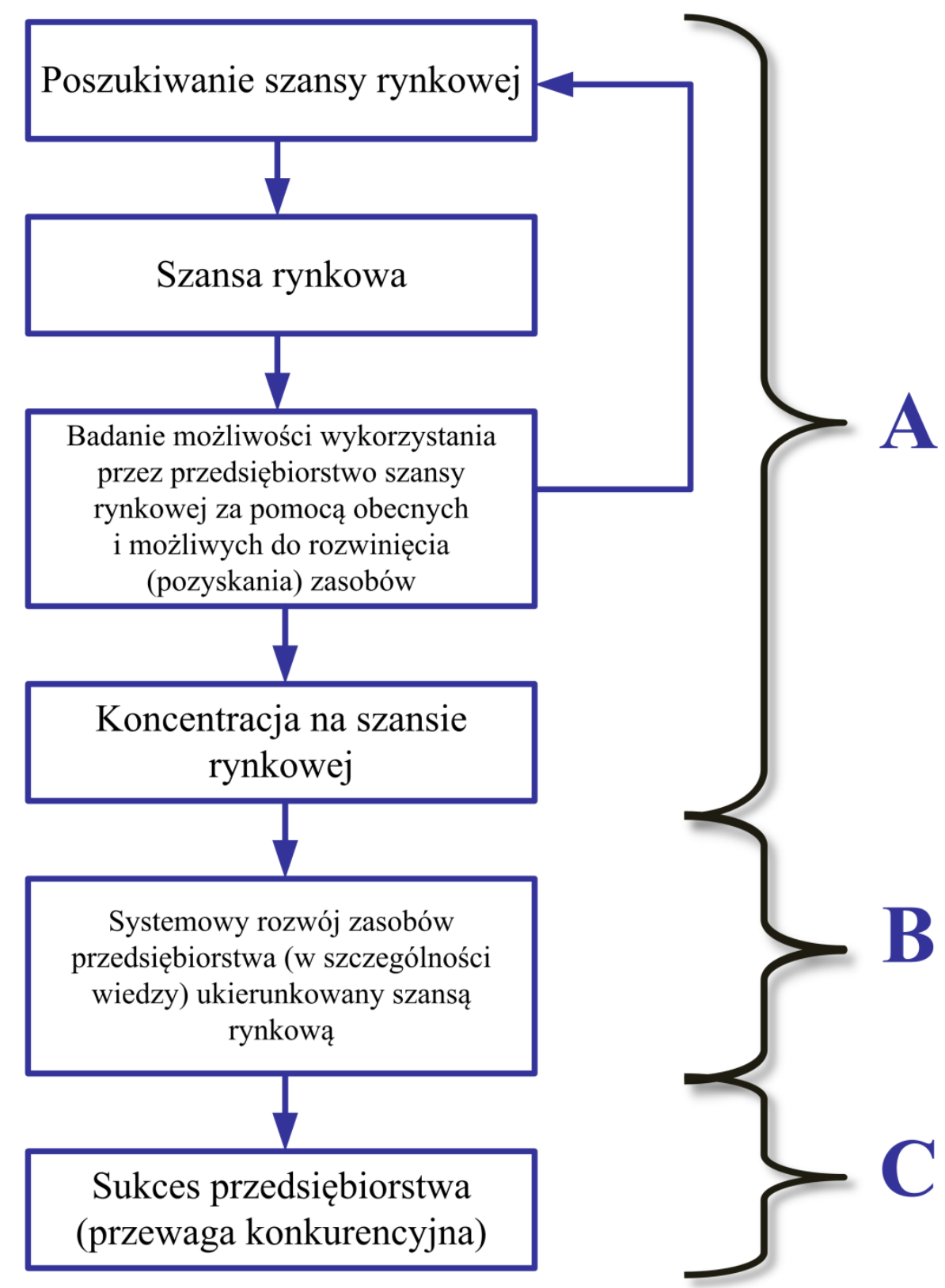

Rysunek 15. Ogólny schemat kształtowania przewagi konkurencyjnej przedsiębiorstwa - z podziałem na trzy główne części.

Źródło: opracowanie własne na podstawie rozważań [Faulknera i Bowmana 1996, s. 30].

W rozdziale drugim niniejszej pracy dokładnie omówiono działania w zakresie wiedzy przedsiębiorstwa (część B na rysunku 15). Należy podkreślić, iż zagadnienie 
ukierunkowania prowadzonych przez przedsiębiorstwo przedsięwzięć w zakresie wiedzy jest kluczowe, gdyż wartość i przełożenie na przewagę konkurencyjną wszystkich późniejszych aktywności będzie zdeterminowane tym, czy ich kierunek jest właściwy. W literaturze dotyczącej koncepcji zarządzania wiedzą można znaleźć wiele przykładów przedsiębiorstw, które inwestując $\mathrm{w}$ tym obszarze nie powiązały działań w zakresie wiedzy z procesami biznesowymi, które miałyby być usprawnione, czy zadaniami biznesowymi, które miałyby być zrealizowane za pomocą tego narzędzia. Najczęściej takie postępowanie sprawiało, iż implementacja przedsięwzięć związanych z wiedzą kończyła się porażką przejawiającą się wyłącznie w poniesieniu kosztów. Rysunek 15 obrazuje fakt, iż czynności w zakresie wiedzy są wyłącznie elementem większego, kompleksowego procesu prowadzącego do ukształtowania przewagi konkurencyjnej przedsiębiorstwa.

W części A przywołano natomiast proces ukierunkowywania działań przedsiębiorstwa poprzez wyszukiwanie i wykorzystywanie szans rynkowych. Zakłada on określoną kolejność działań. Niestety, dokładne zbadanie realizacji przedstawionych procesów nie jest możliwe $\mathrm{w}$ ramach badania ilościowego. $\mathrm{W}$ związku $\mathrm{z}$ tym autor zdecydował się wykorzystać w tym miejscu orientację rynkową, której idea w dużej mierze odpowiada przedstawionym w części A procesom. Zaletą tej koncepcji jest istnienie uznanego w literaturze i przetestowanego narzędzia badawczego do pomiaru poziomu orientacji rynkowej przedsiębiorstwa, którego wykorzystanie jest możliwe w badaniu ilościowym. W związku z tym dalsze rozważania wymagają dokładnego omówienia koncepcji orientacji rynkowej przedsiębiorstwa.

\subsection{Orientacja rynkowa przedsiębiorstwa}

W opinii Noble, Sinha i Kumar [2002, s. 25] orientacja przedsiębiorstwa odzwierciedla jego kulturę, a także metody funkcjonowania w różnych obszarach. Podobnie do zagadnienia podchodzi Pazio [2007, s. 14], w którego opinii sposoby działania podmiotu „..W ramach gry przedsiębiorstwa $\mathrm{z}$ jego otoczeniem można nazwać modelem funkcjonowania, filozofią lub orientacją" [Pazio 2007, s. 14]. W niniejszej pracy, w nawiązaniu do literatury, pojęcie orientacji przedsiębiorstwa będzie rozumiane jako określone charakterystyki działania podmiotu gospodarczego, które są odpowiedzią na zastane przez firmę warunki gospodarowania. 
Tradycyjne orientacje podmiotów gospodarczych skupiały się na wnętrzu przedsiębiorstwa, następnie coraz bardziej były ukierunkowane zewnętrznie. W literaturze najczęściej wyróżnia się następujące orientacje przedsiębiorstwa: produkcyjną, produktową, sprzedażową oraz na nabywcę [Niestrój 2003, s. 18-21; Pazio 2007, s. 14-17; Fonfara 2014, s. 15-25].

Orientacja produkcyjna skupia się na procesie wytwarzania produktu, szczególnie na kwestiach techniczno-organizacyjnych i obniżkach kosztów produkcji, czyniąc cały proces bardziej efektywnym dla podmiotu [Pazio 2007, s. 14-17]. Orientacja produkcyjna jest konsekwencją nadwyżki popytu nad podażą i występowania rynku sprzedawcy [Niestrój 2003, s. 18]. W tym przypadku o pozycji podmiotu na rynku decydują możliwości wytwórcze [Mruk 2012, s. 15].

Orientacja produktowa skoncentrowana jest na ulepszaniu wytwarzanego produktu lub usługi. Jest ona „następcą” orientacji produkcyjnej pojawiającą się w momencie pierwszych problemów ze zbytem towarów. W ramach wcześniejszej orientacji wzrost sprzedaży następował poprzez zwiększenie produkcji bez szczególnej koncentracji na jakości wytwarzanych dóbr. Orientacja produktowa oznacza przede wszystkim koncentrację podmiotu na jakości wykonania wytwarzanych towarów, która ma decydować o rozwoju i pozycji firmy w odniesieniu do innych przedsiębiorstw [Niestrój 2003, s. 18].

Orientacja sprzedażowa (nazywana również dystrybucyjną) jest konsekwencją występowania barier popytowych w masowej skali [Mazurkiewicz i Pizło 2006, s. 19; Niestrój 2003, s. 18]. W ramach tej orientacji przedsiębiorstwo skupia się na wyszukiwaniu rynków zbytu na wytwarzane przez firmę towary. Podmiot wychodzi z założenia, że osoby nieposiadające dostatecznej informacji o ofercie nie będą dokonywać zakupów, stąd ważnym narzędziem w tym przypadku są działania promocyjne i sprzedażowe [Mazurkiewicz i Pizło 2006, s. 20]. Są to jednak najczęściej działania krótkookresowe [Fonfara 2014, s. 16-17].

Orientacja na nabywcę (marketingowa) koncentruje się na potrzebach odbiorców produktów i usług przedsiębiorstwa. W tym przypadku podstawą działań firmy jest badanie preferencji i potrzeb nabywców [Fonfara 2014, s. 17]. W ramach tej koncepcji firma powinna zrozumieć i zaspokoić pojawiające się, wśród potencjalnych odbiorców, potrzeby lepiej niż podmioty konkurencyjne [Pazio 2007, s. 17]. Dobrym przykładem świadomego podkreślania elementu koncentracji na klienta jest firma Google. Według filozofii tej firmy jednym z najważniejszych działań, jakie podejmuje to przedsiębiorstwo, powinna być koncentracja na użytkowniku ,...a reszta przyjdzie sama” [Google 2005]. 
Jak podkreśla K. Fonfara [2014, s. 17, 18, 22] orientacja na nabywcę lub marketingowa, jak sama nazwa wskazuje, jest związana $\mathrm{z}$ koncepcją marketingu. W literaturze można odnaleźć szereg objaśnień i ujęć teorii marketingu. Często przywoływanymi są dwie definicje sformułowane przez Petera Druckera. Według pierwszej z nich „celem marketingu jest wytworzenie takiej sytuacji, w której działania w zakresie sprzedaży nie są w ogóle potrzebne" [Armstrong i Kotler 2011, s. 33]. Drugie ujęcie zauważa, iż marketing jest „postrzeganiem przedsiębiorstwa i jego działalności z punktu widzenia ostatecznego rezultatu, czyli z punktu widzenia nabywcy" [Tajeddini, Trueman i Larsen 2006, s. 533]. Altkorn [2001, s. 3] szczególnie podkreśla element uwypuklony w drugiej przytoczonych definicji, iż marketing nie powinien być ograniczany tylko do pojedynczego podsystemu firmy. Ideą marketingu jest określony sposób myślenia, który powinien być domeną całego przedsiębiorstwa [Altkorn 2001, s. 3]. W podobnej konwencji wyraża się $\mathrm{Ph}$. Kotler, który podkreśla, iż „marketing nie może być obecnie rozumiany w ten sam sposób, co w przeszłości, czyli jako narzędzie zwiększania sprzedaży, tylko w nowym sensie - spełniania potrzeb nabywcy" [Armstrong i Kotler 2011, s. 33].

Jak podkreśla K. Fonfara [2014, s. 22] wyłączna koncentracja przedsiębiorstwa na nabywcy może być niewystarczająca, aby podmiot gospodarczy osiągnął odpowiednią skuteczność działania. Ważne są również kontakty z innymi podmiotami. W tym celu w literaturze wprowadzono pojęcie orientacji rynkowej, będącej rozszerzeniem koncepcji orientacji na nabywcę (marketingowej) firmy ${ }^{47}$ [Fonfara 2014, s. 22].

Jak podkreślają Helfert, Ritter i Walter [2002, s. 1122] w literaturze czasem upatruje się źródeł orientacji na rynkowej w osiemnastowiecznym dziele Adama Smitha „Bogactwo narodów". Szereg artykułów wskazuje również na publikacje Druckera z lat 50. XX wieku [Helfert, Ritter i Walter 2002, s. 1122], jednak wyraźny wzrost zainteresowania omawianą koncepcją nastąpił pod koniec lat osiemdziesiątych XX wieku. Jednym z najbardziej znanych i najczęściej cytowanych do dziś artykułów na temat orientacji rynkowej jest publikacja Shapiro [1988]. Autor przedstawił w niej omawianą teorię przywołując przykład przedsiębiorstwa produkcyjnego Wolverine zlokalizowanego w stanie Indiana w Stanach Zjednoczonych. W artykule podkreśla iż jednym z kluczowym elementów omawianej koncepcji jest zrozumienie sposobu, w jaki klienci używają produktów firmy. Ważnym jest też wykorzystanie tej wiedzy przez wszystkie działy przedsiębiorstwa, które muszą

\footnotetext{
${ }^{47} \mathrm{~W}$ literaturze można również spotkać autorów, którzy traktują orientację marketingową i rynkową jako to samo [Pazio 2007, s. 17], a także publikacje, które postrzegają orientacją rynkową jako operacjonalizację koncepcji marketingu [Kumar i in. 2011, s. 16].
} 
„przenikać każdą funkcję przedsiębiorstwa” [Shapiro 1988, s. 3]. Jest to związane z faktem, iż poszczególne jednostki organizacyjne podmiotu gospodarczego w wielu przypadkach oddzielają bariery - stają się one wyspami, które zamiast działać wspólnie zaczynają rywalizować między sobą, co nie służy realizacji celów firmy [Shapiro 1988, s. 8, 11]. Ostatnim elementem orientacji rynkowej w ujęciu Shapiro, jest analiza poczynań kluczowych konkurentów, która wraz $\mathrm{z}$ informacjami od klientów umożliwia identyfikację szans rynkowych [Shapiro 1988, s. 7, 9].

Duży wkład do koncepcji orientacji rynkowej wniosły dwa zespoły badaczy: Kohli i Jaworski oraz Narver i Slater, którzy również stworzyli dwa ważne narzędzia pomiaru omawianej teorii - MKTOR [Narver i Slater 1990] oraz MARKOR [Kohli, Jaworski i Kumar 1993]. Można nawet zaryzykować stwierdzenie, iż omawiana koncepcja została w dużym stopniu zdominowana w literaturze przez wymienionych autorów.

Kohli i Jaworski [1990, s. 3] swoje rozważania na temat orientacji rynkowej rozpoczynają od koncepcji marketingu i od trzech jej składowych elementów wyniesionych m.in. z przemyśleń Kotlera. Są nimi trzy tzw. „filary” literaturowych definicji marketingu: orientacja na klienta, skoordynowany marketing oraz rentowność. Autorzy dochodzą jednak do wniosku, że koncepcja orientacji rynkowej wymaga przede wszystkim bardziej konkretnego podejścia do dwóch pierwszych elementów, ostatecznie definiując orientację rynkową jako „generowanie, w ramach całej organizacji, wiedzy rynkowej (market intelligence) odnoszącej się do obecnych i przyszłych potrzeb nabywców, rozpowszechnianie jej w ramach wszystkich działów podmiotu oraz reaktywność na nią całej organizacji” [Kohli i Jaworski 1990, s. 3, 6].

Generowanie wiedzy rynkowej, jak podkreślają Kohli i Jaworski, jest czymś więcej niż poznaniem wyartykułowanych potrzeb nabywców. Dotyczy ono również czynników, które wpływają na preferencje i potrzeby kupujących, jak np. działania konkurentów czy regulacje rządowe. Omawiane zagadnienie zwraca również uwagę na inne podmioty biorące udział w sprzedaży np. dystrybutorów czy detalistów [Kohli i Jaworski 1990, s. 4]. Uzyskana wiedza rynkowa musi być następnie odpowiednio rozpowszechniona i zakomunikowana w ramach wszystkich działów przedsiębiorstwa. W tym kontekście Kohli i Jaworski podkreślają znaczenie instrumentów formalnych, ale również nieformalnych, a także komunikacji poziomej w organizacji [Kohli i Jaworski 1990, s. 5, 6]. Ostatnim, lecz kluczowym w kontekście efektów, jest trzeci element orientacji rynkowej - reaktywność organizacji. Kohli i Jaworski przede wszystkim podkreślają, iż reakcja na wiedzę rynkową 
powinna pojawić się we wszystkich działach przedsiębiorstwa, a nie wyłącznie w dziale marketingu, gdyż bez tego efekty mogą nie zostać osiągnięte [Kohli i Jaworski 1990, s. 6].

Kohli i Jaworski [1990, s. 3-4] wyraźnie wyjaśniają również motywy wykorzystania terminu orientacja rynkowa zamiast orientacja marketingowa. Ich zdaniem „marketing” odnosi się do konkretnego działu firmy, a omawiana koncepcja, jak wcześniej podkreślano, do całości przedsiębiorstwa. W związku z tym użycie słowa „marketing” może potencjalnie wprowadzać w błąd. Ponadto, zdaniem autorów, słowo „rynek” jest bardziej poprawne w wykorzystywanym znaczeniu, gdyż podkreśla znaczenie „klientów oraz sił na nich wpływających" [Kohli i Jaworski 1990, s. 3-4] i nadmiernie nie zawyża roli marketingu w organizacji [Kohli i Jaworski 1990, s. 4]. W literaturze można jednak spotkać opinie, iż rozważania Kohliego i Jaworskiego [1990] dotyczą w istocie orientacji marketingowej nie zaś orientacji rynkowej [Wrenn 1997, s. 33].

Drugim z uznanych i ugruntowanych ujęć orientacji rynkowej jest stworzone przez Narvera i Slatera [1990]. Ich perspektywa, jak sami autorzy podkreślają, jest w dużej mierze spójna z rozważaniami Kohliego i Jaworskiego [Narver i Slater 1990, s. 21]. W omawianej publikacji orientacja rynkowa składa się z trzech elementów behawioralnych: orientacji na klienta, orientacji na konkurenta oraz międzyfunkcjonalnej koordynacji ${ }^{48}$ [Narver i Slater 1990, s. 22, 29].

Orientacja na nabywcę w ujęciu autorów polega na zrozumieniu, kim są docelowi kupujący, zarówno obecni, jak i przyszli, oraz w jaki sposób należy im dostarczać możliwie najwyższą wartość. Podkreślają oni, iż wartość można tworzyć zarówno przez zwiększanie korzyści z produktu, jak i obniżając cenę. Czasem, aby zrozumieć sytuację, należy również pogłębić analizę o klientów nabywcy [Narver i Slater 1990, s. 21]. W przeciwieństwie do Kohliego i Jaworskiego [1990], Narver i Slater [1990, s. 21-22] jako jeden z trzech głównych elementów koncepcji uznają orientację na konkurentów. Autorzy podkreślają, iż ważna jest stała analiza nie tylko obecnych konkurentów, ale również potencjalnych podmiotów, które mogą stać się konkurentami [Narver i Slater 1990, s. 21-22]. Ostatnim z kluczowych elementów omawianej koncepcji w podejściu Narvera i Slatera [1990] jest międzyfunkcjonalna koordynacja. Jest to ujęcie problemu nakreślonego przez Shapiro [1988] związanego z tworzeniem barier pomiędzy poszczególnymi działami przedsiębiorstw, które

\footnotetext{
48 Początkowo autorzy uwzględnili również dwa inne komponenty (długoterminowe nastawienie podmiotu oraz orientacja na zysk), lecz zostały one później wyeliminowane ze względu na wyniki testów statystycznych [Narver i Slater 1990, s. 24].
} 
w pewnym momencie stanowią swoiste „wyspy”. Autorzy używają tu bardzo obrazowej analogii - orkiestry symfonicznej, w której liczy się każdy instrument.

Podsumowując, oba ujęcia teoretyczne koncepcji orientacji rynkowej: Kohliego i Jaworskiego [1990] oraz Narvera i Slatera [1990] mają swoje słabe i silne strony. Oba podejścia podkreślają wagę orientacji na nabywcę - zarówno obecnego, jak i przyszłego. Można jednak zauważyć, iż zakres ujęcia omawianego zagadnienia przez Narvera i Slatera [1990] jest do pewnego stopnia zawężony do nabywców i konkurentów. Kohli i Jaworski [1990] podkreślają ważną przecież rolę innych podmiotów rynkowych takich, jak np. detaliści czy dystrybutorzy. Kohli i Jaworski [1990] uwypuklają wagę rozpowszechniania i reakcji całej organizacji na wiedzę rynkową, zaś Narver i Slater [1990] wykorzystują pojęcie międzyfunkcjonalnej koordynacji (interfunctional coordination) używając analogii orkiestry symfonicznej, co wydaje się bardziej trafnym podejściem, zgodnym z ujęciem Shapiro [1988]. Można odnieść wrażenie, iż Kohli i Jaworski [1990] omijają bardzo ważne zagadnienie współpracy poszczególnych działów organizacji, które jest w praktyce bardzo znaczące, gdyż jak wynika z przykładu przedstawionego przez Shapiro [1988], bariery pomiędzy działami bywają realnym problemem w kontekście realizacji orientacji rynkowej.

Poza głównymi, najczęściej cytowanymi ujęciami orientacji rynkowej, w literaturze można znaleźć również rozważania innych autorów. Są one w dużej mierze rozwinięciami podejść przywołanych wcześniej [Greenley 1995, s. 48]. Publikacje te można określić jako dzieła porządkujące, ale niektóre wnoszą również nowe elementy. Przykładem takiej publikacji jest artykuł Deshpande, Farley i Webster [1993]. Autorzy określają w nim orientację rynkową jako ,zestaw przekonań stawiających interes nabywcy na pierwszym miejscu, lecz nie negujący znaczenia innych interesariuszy takich jak właściciele, kierownicy i pracownicy w celu rozwoju zysków przedsiębiorstwa w perspektywie długoterminowej” [Deshpande, Farley i Webster 1993, s. 27]. Definicja Deshpande, Farley i Webster [1993, s. 27] w przeciwieństwie do wcześniej przedstawionych, przykłada duże znaczenie do poszczególnych grup podmiotów wewnętrznych. Eksponowana w niej długoterminowa perspektywa orientacji rynkowej pojawiła się jednak już wcześniej w rozważaniach Narvera i Slatera [1990]. Innym ujęciem omawianego zagadnienia jest to zaprezentowane przez Martin i Grbac [2003, s. 27]. Zwracają oni w swoim artykule uwagę na fakt, iż przedsiębiorstwo zorientowane rynkowo nie tylko powinno odpowiadać na potrzeby rynku, ale także, aby były to działania efektywne, musi reagować szybciej niż robi to konkurencja [Martin i Grbac 2003, s. 27]. W literaturze istnieje również nurt postrzegający orientację 
rynkową z punktu widzenia perspektywy kulturowej. Warto także podkreślić koncepcję Homburga i Pflessera [2000, s. 450], którzy wyróżnili cztery komponenty zorientowanej rynkowo kultury organizacyjnej: podstawowe wartości, normy, artefakty oraz zachowania [Homburg i Pflesser 2000, s. 450].

Przykładem ujęcia porządkującego rozważania poszczególnych badaczy jest artykuł Daya [1994]. Autor na podstawie literatury przedmiotu, uznaje, iż orientacja rynkowa charakteryzuje się zdolnościami przedsiębiorstwa w zakresie identyfikacji oraz spełniania potrzeb klienta i wśród jej cech wyróżnia [Day 1994, s. 37]:

- stawianie potrzeb klienta na pierwszym miejscu [Deshpande, Farley i Webster 1993, s. 27],

- umiejętność pozyskiwania, rozpowszechniania i wykorzystania informacji o klientach i konkurencji [Kohli i Jaworski 1990, s. 4],

- tworzenie wartości dla klienta poprzez skoordynowane wykorzystanie różnorodnych zasobów podmiotu [Narver i Slater 1990, s. 22; Shapiro 1988, s. 5, 6].

Innymi wartościowymi podejściami systematyzującymi dorobek literaturowy w obszarze orientacji rynkowej są publikacje Becker i Homburg [1999, s. 21] oraz Lafferty i Hult [2001, s. 100]. Becker i Homburg [1999, s. 20-21] zauważają, iż w literaturze można wyróżnić trzy różne perspektywy orientacji rynkowej [Becker i Homburg 1999, s. 21; Helfert, Ritter i Walter 2002, s. 1120]:

- behawioralną - Kohli i Jaworski [1990],

- kulturową z wyraźnymi elementami perspektywy behawioralnej - Narver i Slater [1990],

- systemową - Becker i Homburg [1999].

W kontekście rzadko omawianej perspektywy systemowej system zarządzania przedsiębiorstwa jest podzielony na pięć podsystemów: informacja, planowanie, organizacja, kontrola i zasoby ludzkie [Becker i Homburg 1999, s. 17, 22-24; Helfert, Ritter i Walter 2002, s. 1120].

Z kolei Lafferty i Hult [2001, s. 95] wyróżniają pięć perspektyw orientacji rynkowej: [Lafferty i Hult 2001, s. 95]

- perspektywę decyzyjną (the decision-making perspective),

- perspektywę wiedzy rynkowej (the market intelligence perspective),

- perspektywę behawioralną oparta na zagadnieniach kulturowych (the culturally based behavioral perspective),

- perspektywę strategiczną (the strategic perspective), 
- perspektywę orientacji na nabywcę (the customer orientation perspective).

Ponadto, wspomniani autorzy podkreślają, iż wyodrębnione perspektywy obejmują cztery główne obszary [Lafferty i Hult 2001, s. 100]:

- orientacja na nabywców (an emphasis on customers),

- podkreślanie znaczenia dzielenie się informacją i wiedzą (the importance of shared knowledge (information)),

- międzyfunkcjonalna koordynacja działań marketingowych i relacji (interfunctional coordination of marketing activities and relationships),

- podejmowanie odpowiednich działań w momencie pojawienia się określonych sygnałów rynkowych (being responsive to market activities by taking the appropriate action).

Synteza powyższych pięciu perspektyw stworzona przez Lafferty i Hult [2001, s. 95-100] nie stanowi nic więcej niż integrację dwóch dominujących koncepcji orientacji rynkowej: Kohliego i Jaworskiego [1990] oraz Narvera i Slatera [1990]. Jest ona jednak cennym uporządkowaniem zagadnień poruszanych w ramach omawianej tematyki.

W ramach niniejszej pracy orientacja rynkowa jest rozumiana jako: współpraca całej struktury organizacyjnej przedsiębiorstwa w celu ciągłego odkrywania i zaspokajania potrzeb nabywców, a także obserwacja działań konkurentów i innych podmiotów oraz zdarzeń rynkowych. Przedstawiona definicja jest syntezą rozważań literaturowych opartych w przeważającej mierze na publikacjach Narvera i Slatera [1990] i Shapiro [1988], lecz także Kohliego i Jaworskiego [1990] oraz Kohliego, Jawroskiego i Kumara [1993].

Jak wcześniej wspomniano, na początku lat 90. powstały dwie skale pomiaru orientacji rynkowej: MKTOR [Narver i Slater 1990] oraz MARKOR [Kohli, Jaworski i Kumar 1993]. Oba instrumenty są popularnymi narzędziami pomiaru poziomu orientacji rynkowej i są stosowane do dziś praktycznie w niezmienionej formie [Kaur, Sharma i Seli 2013, s. 52]. Bazują one na rozważaniach w zakresie orientacji rynkowej, które zostały przedstawione wcześniej w pracy.

Autor, w celu przeprowadzenia badań empirycznych w ramach niniejszej pracy, zdecydował się wykorzystać narzędzie MKTOR. Decyzja ta została podjęta po analizie opinii $\mathrm{i}$ argumentów dostępnych $\mathrm{w}$ literaturze przedmiotu. Pierwszym $\mathrm{z}$ nich jest fakt, iż wiarygodność statystyczna skali MARKOR jest niższa w porównaniu ze skalą MKTOR [Pelham i Wilson 1996, s. 33]. Jak wspomniano wcześniej, w literaturze istnieją również opinie, iż narzędzie stworzone przez Kohliego i Jaworskiego mierzy raczej orientację marketingową, czyli poziom wdrożenia koncepcji marketingu, nie zaś szersze zagadnienie 
orientacji rynkowej [Wrenn 1997, s. 33; Hooley i in. 2000, s. 274]. Ponadto, w opinii Hooley i in. [2000, s. 274] skala MKTOR jest bardziej interesująca i perspektywiczna, w związku z tym, iż zawiera główne aspekty charakteryzujące skalę Kohliego i Jaworskiego, oceniając równocześnie aspekty kulturowe [Hooley i in. 2000, s. 274]. Dodatkowym argumentem za wyborem MKTOR był fakt, iż została ona sprawdzona w warunkach polskich przez Hooley $\mathrm{i}$ in. [2000], co jest ważnym czynnikiem w kontekście chociażby odpowiedniego, precyzyjnego tłumaczenia pytań oraz poprawnego zrozumienia zastosowanych terminów przez polskich respondentów.

Tabela 8. Pytania MKTOR wykorzystane w celu pomiaru poziomu orientacji rynkowej badanych przedsiębiorstw.

\begin{tabular}{|c|l|}
\hline 1. & Ściśle monitorujemy poziom zaspokojenia potrzeb naszych klientów \\
\hline 2. & $\begin{array}{l}\text { Pracownicy działu sprzedaży dzielą się informacjami o konkurentach } \\
\text { z innymi komórkami naszej firmy }\end{array}$ \\
\hline 3. & $\begin{array}{l}\text { Zadowolenie nabywcy jest głównym wyznacznikiem tworzenia celów } \\
\text { i strategii naszej firmy }\end{array}$ \\
\hline 4. & Szybko reagujemy na działania konkurentów \\
\hline 5. & Przedstawiciele zarządu regularnie odwiedzają ważniejszych klientów \\
\hline 6. & Informacje o klientach są rozpowszechniane w całej firmie \\
\hline 7. & Strategie konkurowania bazują na zrozumieniu potrzeb klienta \\
\hline 8. & $\begin{array}{l}\text { Działania wszystkich komórek firmy są zintegrowane w celu obsługi } \\
\text { potrzeb nabywców }\end{array}$ \\
\hline 9. & $\begin{array}{l}\text { Oferowanie większych korzyści dla klienta związanych z zakupem naszych } \\
\text { produktów i usług stanowi podstawę tworzenia strategii firmy }\end{array}$ \\
\hline 10. & Często badamy poziom zadowolenia klientów \\
\hline 11. & Przywiązujemy dużą uwagę do usług posprzedażowych \\
\hline 12. & Zarząd regularnie omawia silne i słabe strony konkurentów \\
\hline 13. & $\begin{array}{l}\text { Nasi menedżerowie wiedzą, w jaki sposób pracownicy firmy mogą } \\
\text { przyczynić się do wzrostu zadowolenia nabywców }\end{array}$ \\
\hline 14. & $\begin{array}{l}\text { Koncentrujemy się na wybranej grupie lub grupach nabywców, jeśli dzięki } \\
\text { temu możemy osiągnąć przewagę konkurencyjną }\end{array}$ \\
\hline
\end{tabular}

Źródło: [Fonfara 2009, 2012].

Skala MKTOR składa się z czternastu pytań: sześć z nich dotyczy orientacji na nabywcę, cztery orientacji na konkurentów i cztery międzyfunkcjonalnej koordynacji 
w ramach przedsiębiorstwa [Hooley i in. 2000, s. 277]. Dokładna treść pytań została przedstawiona w tabeli 8 .

Jak podkreśla Hooley i in. [2000, s. 277] istnieją dwa sposoby pomiaru orientacji rynkowej. Pierwszy z nich, oryginalny, wykorzystywany przez Narvera i Slatera zakłada kalkulację wyników dla poszczególnych komponentów (orientacja na nabywcę, orientacja na konkurentów, międzyfunkcjonalna koordynacja), a następnie obliczenie średniej arytmetycznej z trzech wartości. Istnieje w tym przypadku również możliwość nadawania wag poszczególnym elementom składowym. Drugim sposobem jest obliczenie średniej arytmetycznej ze wszystkich czternastu pytań. Ta opcja nadaje większą wagę orientacji na klienta $\mathrm{z}$ uwagi na większą liczbę pytań w zakresie tego aspektu orientacji rynkowej [Hooley $\mathrm{i}$ in. 2000, s. 277]. W przeprowadzonym przez autora badaniu zdecydowano się na wykorzystanie drugiego sposobu kalkulacji orientacji rynkowej z uwagi na fakt, iż został on przetestowany w przeszłości w badaniach prowadzonych w Polsce m.in. przez K. Fonfarę [2009, 2012].

Należy podkreślić, iż zarówno MARKOR, jak i MKTOR nie są narzędziami doskonałymi i w literaturze pojawiają się również wątpliwości względem ich wiarygodności [Kaur, Sharma i Seli 2013, s. 52-53]. Jedną z problematycznych kwestii jest dopasowanie instrumentów do określonej kultury, obszaru czy środowiska. Przykładem może być badanie przeprowadzone w Australii, z którego wynika, że zarówno skala MARKOR, jak i MKTOR nie są dopasowane do ,australijskiej kultury biznesowej” [Farrell i Oczkowski 1997, s. 6-7]. Tym bardziej cenne są wspomniane wcześniej doświadczenia Hooley i in. [2000], którzy przetestowali skalę MKTOR w warunkach polskich.

Koncepcja orientacji rynkowej zyskała na popularności pod koniec lat osiemdziesiątych i na początku lat dziewięćdziesiątych XX wieku. Późniejsze zmiany gospodarcze związane ze wzrostem znaczenia zasobu wiedzy, określane gospodarką opartą na wiedzy, nie zanegowały jej znaczenia, a wręcz umożliwiły jej wzbogacenie. Jedne z pierwszych rozważań w tym zakresie przeprowadzili Narver i Slater [1995]. Zauważyli oni i docenili wzrastającą rolę zasobu wiedzy w gospodarce oraz dostrzegli szansę w tym zjawisku na wzbogacenie koncepcji orientacji rynkowej [Narver i Slater 1995, 2000]. Szereg innych autorów również interesowało się tymi zagadnieniami m.in. Baker i Sinkula [1999, s. 425] czy Farell [2000, s. 221].

Był to jednak początkowy okres rozwoju badań nad teoriami w zakresie działań przedsiębiorstw w obszarze wiedzy. Ich kompleksowość i poziom były znacznie mniej 
zaawansowane niż dziś. Wyrazem tego jest fakt, iż Narver i Slater [1995, 2000], podobnie jak i inni wymienieni autorzy bazują w swoich rozważaniach wyłącznie na koncepcjach organizacji uczącej się lub organizacyjnego uczenia się. Są to bardzo wartościowe i cenne teorie, lecz posiadające określone wady. Koncepcja organizacji uczącej się nie posiada kompleksowego, zwartego dorobku [Jashapara 2006, s. 307], zaś organizacyjne uczenie się jest mało konkretne [Jashapara 2006, s. 82]. Zastosowanie wyłącznie tych dwóch teorii, uniemożliwiało stworzenie narzędzi pomiaru działań przedsiębiorstw w zakresie wiedzy o podobnym poziomie i kształcie, jaki reprezentowały skale MKTOR i MARKOR w odniesieniu do orientacji rynkowej.

Przykładowo, pytania stosowane w kwestionariuszach badawczych wykorzystywanych przez Baker i Sinkula [1999, s. 425], Farella [2000, s. 221], Farella i Oczkowskiego [2002, s. 213], dla organizacji uczącej się posiadają wspomniane wcześniej, ogólne wady koncepcji organizacji uczącej się - są mało konkretne. Odnoszą się one raczej do postaw i opinii reprezentowanych przez pracowników i kadrę zarządzającą badanego podmiotu, a w mniejszym stopniu do konkretnych działań podejmowanych w przedsiębiorstwach.

Druga ze wspomnianych koncepcji - organizacyjnego uczenia się, była rzadziej analizowana wraz $\mathrm{z}$ orientacją rynkową. Jednym $\mathrm{z}$ przykładów takich badań jest przeprowadzone przez Morgan, Katsikeas i Appiah-Adu [1998]. Niestety, wadą narzędzia badawczego zastosowanego przez autorów, podobnie jak i całej koncepcji organizacyjnego uczenia się jest fragmentaryczność. Skala pomiaru organizacyjnego uczenia się zastosowana przez Morgan, Katsikeas i Appiah-Adu [1998, s. 364-365] koncentruje się w dużej mierze na kadrze zarządzającej i ogólnych aspektach strategicznych organizacji.

Obecnie, z uwagi na bardzo bogaty dorobek zdecydowanie bardziej kompleksowej teorii zarządzania wiedzą, istnieje możliwość wyróżnienia i zbadania poszczególnych, konkretnych działań przedsiębiorstw w zakresie wiedzy. Dzięki temu, spektrum dostępnych możliwości badawczych jest znacznie większe. Zalety koncepcji zarządzania wiedzą zostały docenione przez wielu autorów. W literaturze podkreśla się nawet, że pojawienie się teorii zarządzania wiedzą spowodowało spadek zainteresowania wcześniejszymi teoriami w zakresie uczenia się [Jashapara 2006, s. 307].

Należy zaznaczyć, iż nie należy porzucać cennego dorobku organizacji uczącej się oraz organizacyjnego uczenia się. Powinien być on również uwzględniany, lecz centralną pozycję w rozważaniach powinna zajmować koncepcja zarządzania wiedzą z uwagi na niekwestionowane zalety tej teorii. 
Kluczowym czynnikiem skłaniającym do kontynuacji pogłębionych badań w omawianym obszarze jest stale wzrastające znaczenie zasobu wiedzy w gospodarce. Sprzyjającą okolicznością jest również dostępność nowych narzędzi badawczych. W związku $\mathrm{z}$ tym analiza teorii orientacji rynkowej wzbogaconej o badania w zakresie zasobu wiedzy, z jednoczesnym wykorzystaniem trzech dominujących koncepcji: zarządzania wiedzą, organizacji uczącej się oraz organizacyjnego uczenia się - może dostarczyć interesujących wniosków.

\subsection{Charakterystyka orientacji przedsiębiorstwa na wiedzę}

Termin „orientacja na wiedzę” w polskich publikacjach został rozpowszechniony przez Mazur, Rószkiewicz i Strzyżewską [2008, 2011]. Autorki definiują to pojęcie jako „...całokształt działań w zakresie wiedzy w przedsiębiorstwie” [Mazur, Rószkiewicz i Strzyżewska 2008, s. 16, 2011, s. 19]. W tym samym znaczeniu, co wcześniej wymienione autorki omawiany termin wykorzystuje również Olszewski [2011, s. 9, 12]. Morawski [2006, s. 1, 2011, s. 13], uważa, że organizacja zorientowana na wiedzę to kolejny etap ewolucji podmiotów gospodarczych. Truch [2004, s. 3, 4] wykorzystuje wspomniane pojęcie w swoich badaniach nad powiązaniem działań w zakresie zarządzania wiedzą oraz celów biznesowych w przedsiębiorstwach.

W literaturze pojawia się także zbliżony termin „orientacja na zarządzanie wiedzą” stosowany m.in. przez Darroch i McNaughton [2003]. Wykorzystuje go również Brdulak [2012, s. 81], który definiuje cztery szczegółowe charakterystyki tego typu przedsiębiorstwa (orientacja procesowa, uczenie się, kultura organizacyjna oraz zarządzanie zmianą). W niniejszej rozprawie, w przeciwieństwie do niektórych publikacji, autor wyraźnie rozgranicza pomiędzy terminami orientacja na wiedzę oraz orientacja na zarządzanie wiedzą. Pierwszy z nich dotyczy wszystkich działań w zakresie wiedzy (z wykorzystaniem różnorodnych koncepcji), drugi z nich jest węższy znaczeniowo i ogranicza się do działań związanych z realizacją koncepcji zarządzania wiedzą. W związku z dominacją dorobku teorii zarządzania wiedzą terminy te, w kontekście praktycznych działań przedsiębiorstwa, mogą być jednak bardzo zbliżone. 


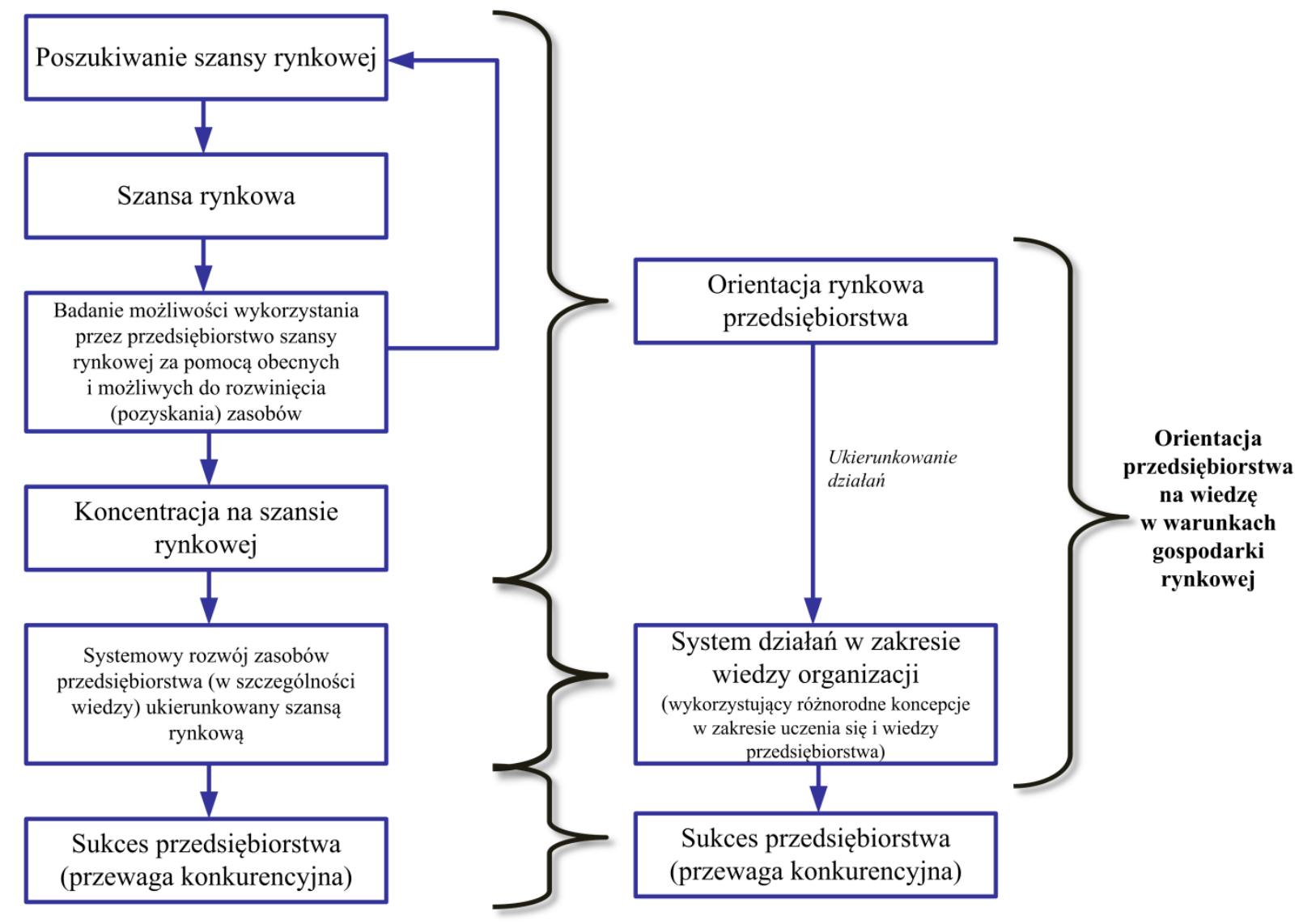

Rysunek 16. Schemat kształtowania przewagi konkurencyjnej przedsiębiorstwa a orientacja na wiedzę. Źródło: opracowanie własne (integracja na podstawie rozważań: [Faulknera i Bowmana 1996, s. 30; Darroch i McNaughton 2003, s. 572-575; Mazur, Rószkiewicz i Strzyżewska 2008, s. 23-24; Wang i in. 2009, s. 99]).

Autor niniejszej pracy zwraca szczególną uwagę na ukierunkowanie prowadzonych przez podmiot działań w zakresie wiedzy. W związku z faktem, iż rozważania dotyczą firm działających w warunkach gospodarki rynkowej, najbardziej odpowiednim „drogowskazem” w tym zakresie jest koncepcja orientacji rynkowej. Zdaniem autora jest to bardzo ważny, lub nawet kluczowy element procesów w zakresie wiedzy w kontekście ich końcowego efektu dla przedsiębiorstwa (rysunek 16). W związku z tym, na podstawie prowadzonych w pracy rozważań wynikających z literatury, w niniejszej rozprawie orientacja na wiedzę została zdefiniowana jako: rynkowo ukierunkowany system działań przedsiębiorstwa w zakresie wiedzy.

Część wymienionych wcześniej autorów w kontekście koncepcji orientacji na wiedzę (czy również bardzo zbliżonego pojęcia orientacji na zarządzanie wiedzą) również podkreśla znaczenie rynkowego ukierunkowania działań w tym zakresie, np. Darroch i McNaughton [2003], Mazur, Rószkiewicz i Strzyżewska [2008, s. 24-25] i do pewnego stopnia Morawski [2006, s. 1]. Wspomniani autorzy uważają, iż w warunkach gospodarki rynkowej 
przedsiębiorstwo $\mathrm{w}$ pełni zorientowane na wiedzę powinno przede wszystkim, z uwagi na cel swojego istnienia, przywiązywać uwagę do wiedzy rynkowej. W przypadku podmiotów działających w takim środowisku wiedza rynkowa jest kluczowa dla ich przetrwania. Nie są one instytucjami badawczymi, które mogą tworzyć, pozyskiwać i rozpowszechniać interesującą wiedzę poznawczą, lecz nieużyteczną w praktyce. W przypadku podmiotów gospodarczych orientacja na wiedzę oznacza koncentrację na wiedzy utylitarnej, gdzie kryterium utylitarności jest rynek i jego potrzeby.

W opinii Mazur, Rószkiewicz i Strzyżewskiej [2008, s. 24-25], które powołują się również na publikację Darroch i McNaughton [2003], z pozycją których zgadza się również Skrzypek [2009, s. 65], przedsiębiorstwa zorientowane na zarządzanie wiedzą (lub wiedzę) w warunkach gospodarki rynkowej są również zorientowane rynkowo. Jest to związane z faktem, iż właściwa realizacja koncepcji związanej z wiedzą, w specyficznych warunkach konkurencji i gospodarki rynkowej automatycznie wymusza realizację teorii orientacji na rynek [Mazur, Rószkiewicz i Strzyżewska 2008, s. 24-25].

Zdaniem autora niniejszej pracy, warto jednak wyraźnie oddzielić, w kontekście badawczym, procesy w zakresie wiedzy i rynku (rysunek 16). Realizacja koncepcji orientacji na wiedzę teoretycznie wymusza realizację koncepcji orientacji rynkowej, gdyż jak zaznaczają Mazur, Rószkiewicz i Strzyżewska [2008] wiedza rynkowa to też pewien rodzaj wiedzy. Niestety, w praktyce w literaturze dotyczącej działań przedsiębiorstw w zakresie omawianego zasobu można odszukać liczne przykłady aktywnych poczynań przedsiębiorstw w obszarze wiedzy, które nie mają powiązania $\mathrm{z}$ rynkiem czy procesami biznesowymi w przedsiębiorstwie. Istnienie wyraźnych, rynkowo ukierunkowanych działań w zakresie wiedzy, zdaniem autora niniejszej pracy (a także innych autorów np. Wang i in. [2009, s. 99]), jest elementem kluczowym w kontekście przełożenia procesów w obszarze omawianego zasobu na ostateczne wyniki i konkurencyjność przedsiębiorstwa. W związku z tym w definicji orientacji na wiedzę stosowanej w niniejszej pracy wyraźnie zaznaczono element ukierunkowania działań przedsiębiorstwa w zakresie wiedzy (rysunek 16). Innymi słowy, ujęcie zagadnienia w rozprawie można scharakteryzować w następujący sposób: przedsiębiorstwo charakteryzujące się wysokim poziomem orientacji na wiedzę w warunkach gospodarki rynkowej musi się odznaczać zarówno dużą intensywnością działań w zakresie wiedzy oraz wysoką orientacją rynkową. Należy jednak zaznaczyć, iż obecność pierwszego z wymienionych czynników (intensywnych procesów w zakresie wiedzy) nie jest gwarantem istnienia drugiego (wysokiej orientacji rynkowej), lecz zagadnieniem, które należy zbadać. 
Ponadto, autor zdecydował się wykorzystać termin „orientacja na wiedzę”, gdyż jest on bardzo obszerny, oraz przede wszystkim relatywnie „neutralny koncepcyjnie”. Jego użycie w pracy nie implikuje koncentracji wyłącznie na jednej określonej teorii, koncepcji czy nurcie teoretycznym w zakresie działań organizacji w obszarze wiedzy czy uczenia się. Jak już wcześniej wspominano, autor jest zdania, iż przedsiębiorstwo, w swoich działaniach, powinno wykorzystywać dorobek różnorodnych koncepcji w zakresie wiedzy czy uczenia się. Nie należy ograniczać się wyłącznie do jednej (nawet najlepszej) teorii. Każda z koncepcji wnosi cenny, różnorodny i unikalny wkład do omawianego zagadnienia. Jest to szczególnie widoczne w przypadku wiedzy i uczenia się. Teorie dotyczące zarządzania tymi elementami w organizacji, w praktyce bardzo rzadko do siebie nawiązują i są mało kompatybilne. Poza negatywnymi skutkami tej sytuacji, próby jednoczesnego wykorzystania dorobku wielu z nich mogą prowadzić do interesujących konkluzji. Będą one widoczne w dalszych rozważaniach dotyczących modeli teoretycznych i badawczych wykorzystywanych w niniejszej pracy. Pomimo faktu, iż głównie stosowaną w pracy koncepcją jest zarządzanie wiedzą to inne teorie też funkcjonują w niej w formie wspierającej.

\subsection{Modelowe ujęcie roli orientacji na wiedzę w kształtowaniu przewagi konkurencyjnej przedsiębiorstwa}

Zagadnienie rynkowo ukierunkowanych procesów w zakresie wiedzy przedsiębiorstwa było już rozpatrywane w literaturze i badane przez szereg autorów. Prawdopodobnie pierwszymi, którzy zainteresowali się niniejszym zagadnieniem byli Darroch i McNaughton [2003]. Autorzy w swoim badaniu wyróżnili cztery typy podmiotów. Pierwszym z nich były podmioty zorientowane na wiedzę naukową (scientific oriented). Wykazywały one cechy przedsiębiorstwa nastawionego na uczenie się bez cech ukierunkowania na rynek. Drugą grupę stanowiły firmy zorientowane zarówno na rynek, jak i na uczenie się (knowledge management oriented). Ten typ podmiotu potrafił pogodzić orientację na rynek $\mathrm{z}$ orientacją na uczenie się. Trzecią grupę firm charakteryzowała orientacja rynkowa, zaś ich działania w zakresie procesów pozyskiwania, kreacji upowszechniania wiedzy były mało intensywne (market oriented). Czwartą grupę stanowiły przedsiębiorstwa, które nie przejawiały orientacji na uczenie się, ani orientacji rynkowej (non adopters). Rezultaty badań przeprowadzonych przez autorów w Nowej Zelandii pokazały, że najlepsze wyniki osiągały przedsiębiorstwa z drugiej grupy, które potrafiły efektywnie łączyć orientację rynkową z orientacją na uczenie się. Darroch i McNaughton podkreślili także, że ich badania przeprowadzone w Nowej Zelandii należałoby 
skonfrontować z analizami przeprowadzanymi w innych krajach [Darroch i McNaughton 2003, s. 573, 583, 590; Mazur, Rószkiewicz i Strzyżewska 2008, s. 25-26].

Zbliżone badanie w Polsce przeprowadziły Mazur, Rószkiewicz i Strzyżewska. Nazwały one wysoką intensywność wszystkich działań przedsiębiorstwa w zakresie wiedzy, podobnie jak autor niniejszej pracy, orientacją na wiedzę. W tym przypadku dokonano jednak założenia, iż podmioty zorientowane na wiedzę działające w gospodarce rynkowej są również zorientowane rynkowo [Mazur, Rószkiewicz i Strzyżewska 2008, s. 24-25]. W ramach narzędzia badawczego pytania dotyczące rynku zostały połączone z pytaniami dotyczącymi działań w zakresie wiedzy. Wyniki badań wykazały średnią zależność pomiędzy orientacją na wiedzę a wynikami przedsiębiorstwa [Mazur, Rószkiewicz i Strzyżewska 2008, s. 93-94]. Wymienione badanie różniło się jednak od studiów przeprowadzonych w ramach niniejszej pracy. Przede wszystkim, podmiotem analiz przeprowadzonych przez wymienione autorki były średnie przedsiębiorstwa funkcjonujące w Polsce, nie zaś firmy działające na rynkach zagranicznych. Pytania mające na celu pomiar orientacji rynkowej, we wspomnianej publikacji, bazowały na mierniku rozwiniętym przez Kohliego, Jaworskiego i Kumara $[1993]^{49}$ nie zaś, jak w niniejszej pracy, na skali Narvera i Slatera [1990]. W niniejszej pracy, zastosowano również inny zestaw, opartych na literaturze przedmiotu, pytań mających na celu zbadanie poziomu działań przedsiębiorstw w zakresie wiedzy. Ostatnią, lecz bardzo ważną różnicą jest zakres czasowy badań - niniejsze badanie zostało przeprowadzone około pięć lat po analizach wykonanych przez Mazur, Rószkiewicz i Strzyżewska [2008]. W związku z ciągłym wzrostem znaczenia zasobu wiedzy w gospodarce różnica zakresu czasowego badań może mieć duży wpływ na ostateczne wyniki.

Bardzo ważnym wkładem do poznania omawianego zagadnienia są analizy przeprowadzone przez Wang i in. [2009]. Rezultaty badań autorów wskazują, iż orientacja rynkowa przedsiębiorstwa jest czynnikiem koniecznym do przełożenia działań w zakresie zarządzania wiedzą ${ }^{50}$ w firmie na wyniki firmy [Wang i in. 2009, s. 99]. W tym badaniu podobnie jak w niniejszej pracy wyraźnie rozdzielono intensywność procesów dotyczących wiedzy w przedsiębiorstwie oraz poziom orientacji rynkowej podmiotu.

Poza autorami, którzy bezpośrednio odwoływali się do zagadnienia rynkowo ukierunkowanych działań przedsiębiorstw w odniesieniu do wiedzy i przeprowadzali badania w tym obszarze, w literaturze można znaleźć również krótkie i najczęściej lakoniczne

\footnotetext{
${ }^{49}$ Por. Mazur, Rószkiewicz i Strzyżewska [2008, s. 29].

${ }^{50}$ Badanie Wang i in. [2009] dotyczyło wyłącznie koncepcji zarządzania wiedzą, nie obejmowało innych teorii w zakresie wiedzy i uczenia się.
} 
odwołania do tej kwestii. Wskazują one na potrzebę odpowiedniego ukierunkowania procesów przedsiębiorstwa w zakresie wiedzy, najczęściej właśnie w kierunku rynku, a także strategii i procesów biznesowych przedsiębiorstwa. Przykładowo, Probst, Raub i Romhardt podkreślają, iż rozwój zasobów wiedzy przedsiębiorstwa musi być odpowiednio ukierunkowany i nie może zostać pozostawiony przypadkowi. W przeciwieństwie do poznawania istniejącego w ludzkiej naturze, zarządzanie wiedzą organizacji musi spełniać warunek użyteczności, gdyż gromadzenie wszelkiego rodzaju wiedzy jest według wymienionych autorów działaniem bezsensownym [Probst, Raub i Romhardt 2004, s. 35]. Probst, Raub i Romhardt podają także przykład firmy Phonak, w której aż 40 procent czasu pracy działu badań i rozwoju przeznacza się „na kontakty z klientami” [Probst, Raub i Romhardt 2004, s. 59]. Kowalczyk i Nogalski podkreślają, iż ważnym jest, aby wiedza była możliwa do wykorzystania w praktyce, gdyż bez tego jest bezużyteczna [Kowalczyk i Nogalski 2007, s. 108]. W podobnej konwencji wypowiada się Szymura-Tyc [2010, s. 183184] zaznaczając potrzebę zbadania zagadnienia wpływu marketingu na proces innowacji. Morawski [2011, s. 16] podkreśla iż, w koncepcji zarządzania wiedzą, ważne jest powiązanie działań z tworzeniem wartości dla klientów oraz celami podmiotu. Z badań Zacka [1999, s. 142] wynika, że uwzględnienie strategii firmy w procesach zarządzania wiedzą jest koniecznością, jeśli działania te mają przynieść pożądane rezultaty. Opinię tę potwierdzają Deng [2012, s. 127-128], a także Kasten [2008, s. 123-124] wychodząc z założenia, iż jednym z warunków efektywności strategii w zakresie wiedzy jest jej zgodność ze strategią biznesową przedsiębiorstwa. Chakravarthy i in. [2006, s. 315] podają przykład firmy Sharp, w której przedstawiciele działu marketingu ściśle współpracują z osobami odpowiedzialnymi za technologie [Chakravarthy $\mathrm{i}$ in. 2006, s. 315].

Niniejsza praca, bazując na wcześniejszym dorobku literaturowym, dąży do rozwoju omawianych zagadnień zarówno w zakresie teoretycznym, jak i empirycznym. Podstawą rozważań prowadzonych w rozprawie jest, przedstawiony wcześniej w pracy, podstawowy model kształtowania przewagi konkurencyjnej przedsiębiorstwa, który w uproszczonej formie zaprezentowano na rysunku 17. 


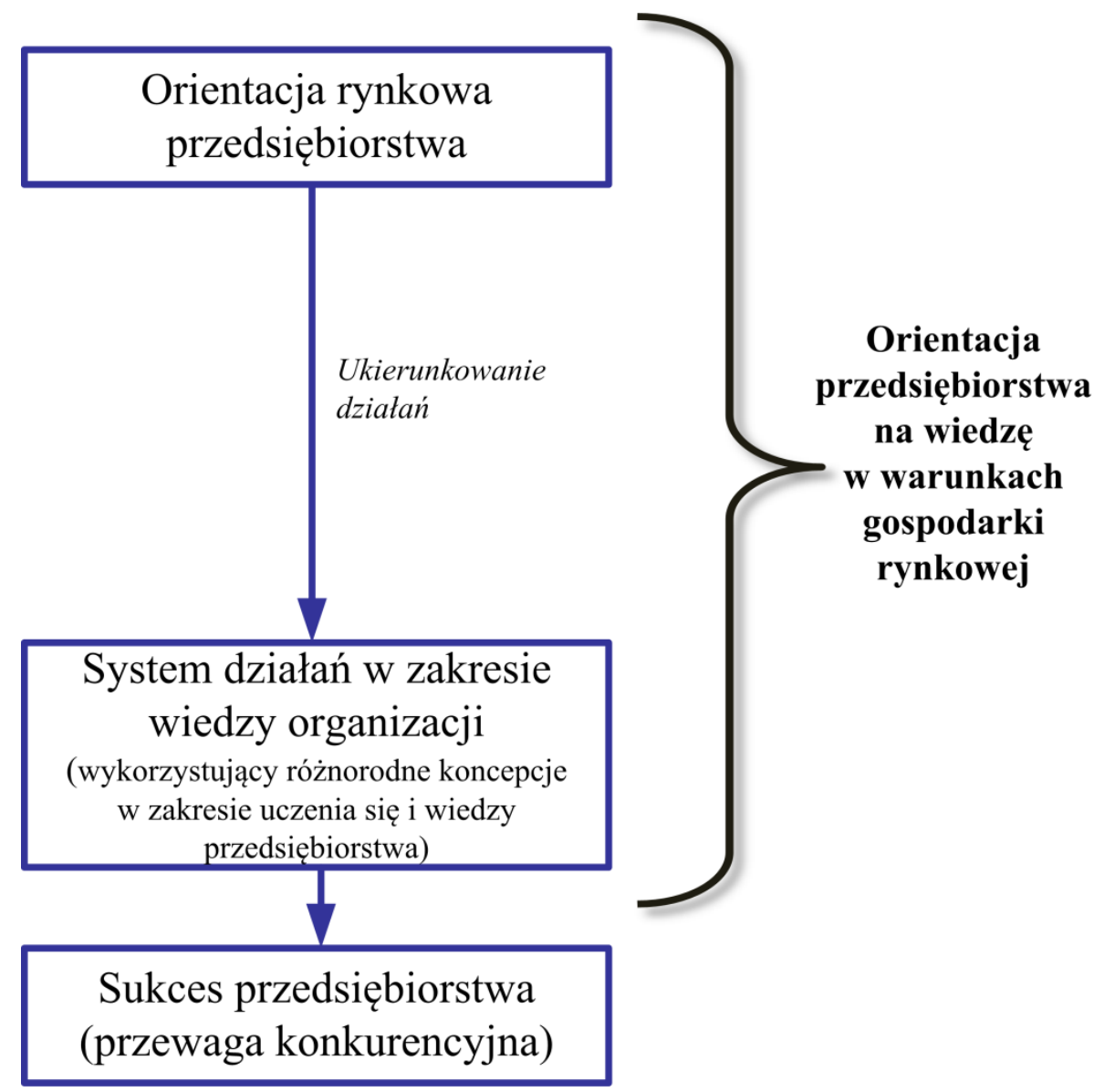

Rysunek 17. Schemat kształtowania przewagi konkurencyjnej przedsiębiorstwa - wersja uproszczona. Źródło: opracowanie własne (integracja na podstawie rozważań: [Faulknera i Bowmana 1996, s. 30; Darroch i McNaughton 2003, s. 572-575; Mazur, Rószkiewicz i Strzyżewska 2008, s. 23-24; Wang i in. 2009, s. 99]).

System działań przedsiębiorstwa w zakresie wiedzy (element środkowy na rysunku 17) rozpatrywany jest w niniejszej pracy zgodnie $z$ dyskusją w rozdziale 2 - poprzez pryzmat poszczególnych procesów, co można ująć w formie graficznej (rysunek 18). Podział działań związanych $\mathrm{z}$ wiedzą $\mathrm{w}$ przedsiębiorstwie na poszczególne procesy jest wykorzystywany w teorii zarządzania wiedzą. Zdaniem autora, organizacja może (a nawet powinna) w realizacji poszczególnych procesów, jak i w całości działań, posługiwać się również cennym dorobkiem innych teorii w tym obszarze. Nie wszystkie elementy opisywanego systemu można ująć w formie procesów, szczególnie problematyczne do zobrazowania w tej postaci są składniki wynikające z dorobku koncepcji organizacyjnego uczenia się i organizacji uczącej się (rysunek 18). 


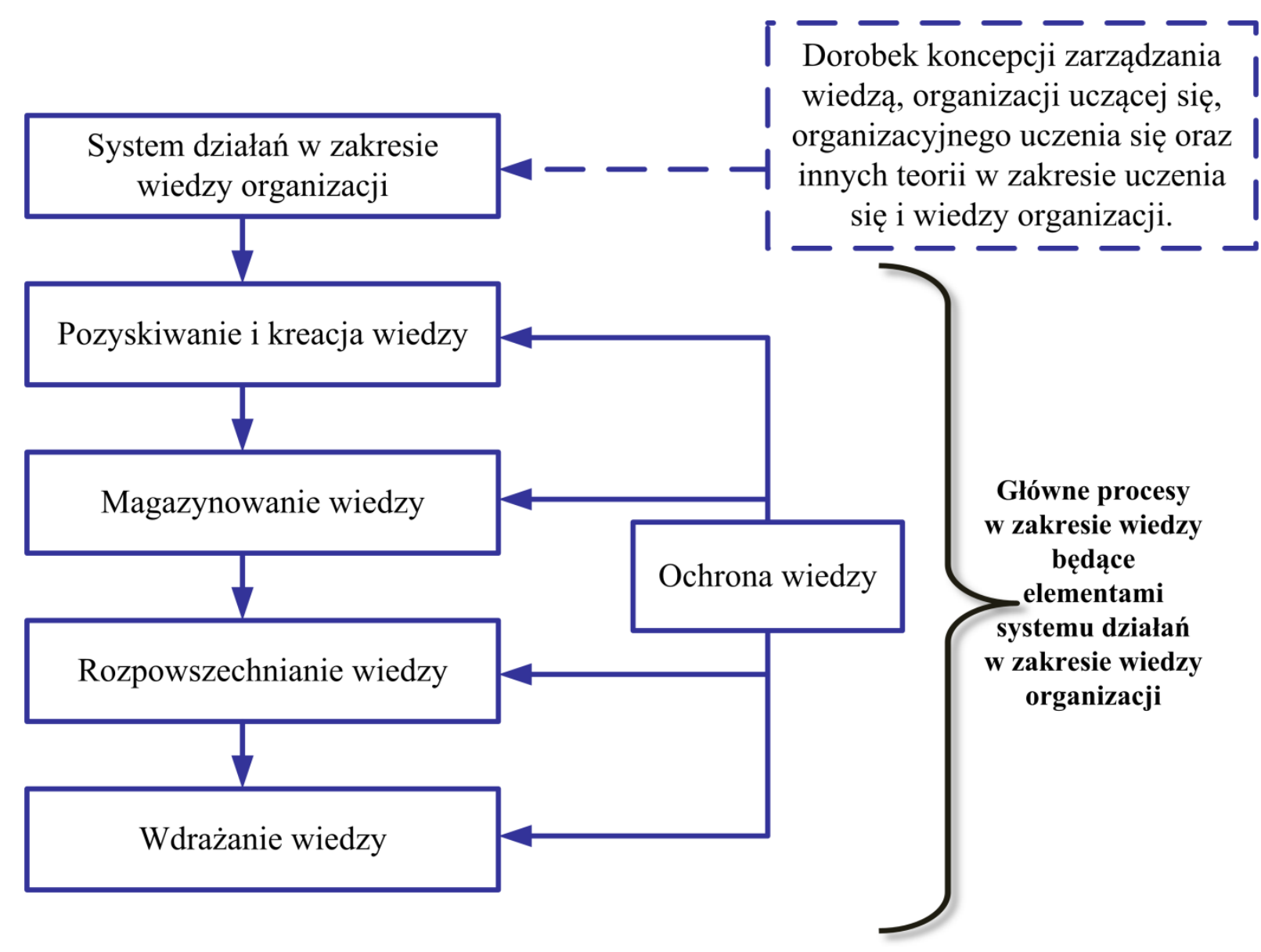

Rysunek 18. Schemat systemu działań w zakresie wiedzy w organizacji. Źródło: opracowanie własne.

Przedstawiony na rysunku 17 trzyetapowy model kształtowania przewagi konkurencyjnej przedsiębiorstwa jest dużym uogólnieniem działań przedsiębiorstwa w relatywnie krótkim okresie. W przeszłości przejście przedsiębiorstwa przez wymieniony łańcuch działań (przy założeniu obfitości pozostałych zasobów) mogło zapewnić firmie przewagę konkurencyjną na lata, niestety w obecnych warunkach nie jest to możliwe. Jest to spowodowane faktem, iż w dzisiejszych czasach nawet najlepszy i najcenniejszy zasób wiedzy szybko się dezaktualizuje. Dodatkowo, nawet gdy jest on perfekcyjnie chroniony to prawie każde rozwiązanie, które jest rezultatem wiedzy może być w dużym stopniu bezkarnie naśladowane. W związku z tym przedsiębiorstwa nie powinny bazować na określonym statycznie zasobie wiedzy, lecz na umiejętności jego stałego rozwoju. Zdaniem autora niniejszej pracy, implikuje to ciągłe wykonywanie przedstawionej na rysunku 17 trzyetapowej sekwencji działań. Jednokrotna, zakończona sukcesem, realizacja w firmie wszystkich etapów wspomnianego diagramu umożliwia wytworzenie określonej, cennej wiedzy operacyjnej, np. w formie nowego produktu. Jego sprzedaż umożliwia firmie 
osiągnięcie zysku przez pewien relatywnie krótki okres. Niestety, po określonym, zależnym od branży i charakteru produktu czasie, stanie się on przestarzały i niekonkurencyjny. Może on również być naśladowany lub skopiowany przez inne podmioty. W związku z tym, firma musi przejść kolejny raz przez wymieniony łańcuch działań podejmując próbę unowocześnienia starego lub rozwoju nowego produktu. Przedstawiony tok myślenia jest zgodny z opinią Kalety [2009, s. 32]. Jego zdaniem w realiach współczesnej gospodarki, przedsiębiorstwa nie mogą kształtować działań konkurencyjnych jedynie w wymiarze operacyjnym. Muszą one posiadać model rozwoju, który umożliwi im kreację długofalowych przewag konkurencyjnych wobec pozostałych podmiotów [Kaleta 2009, s. 32].

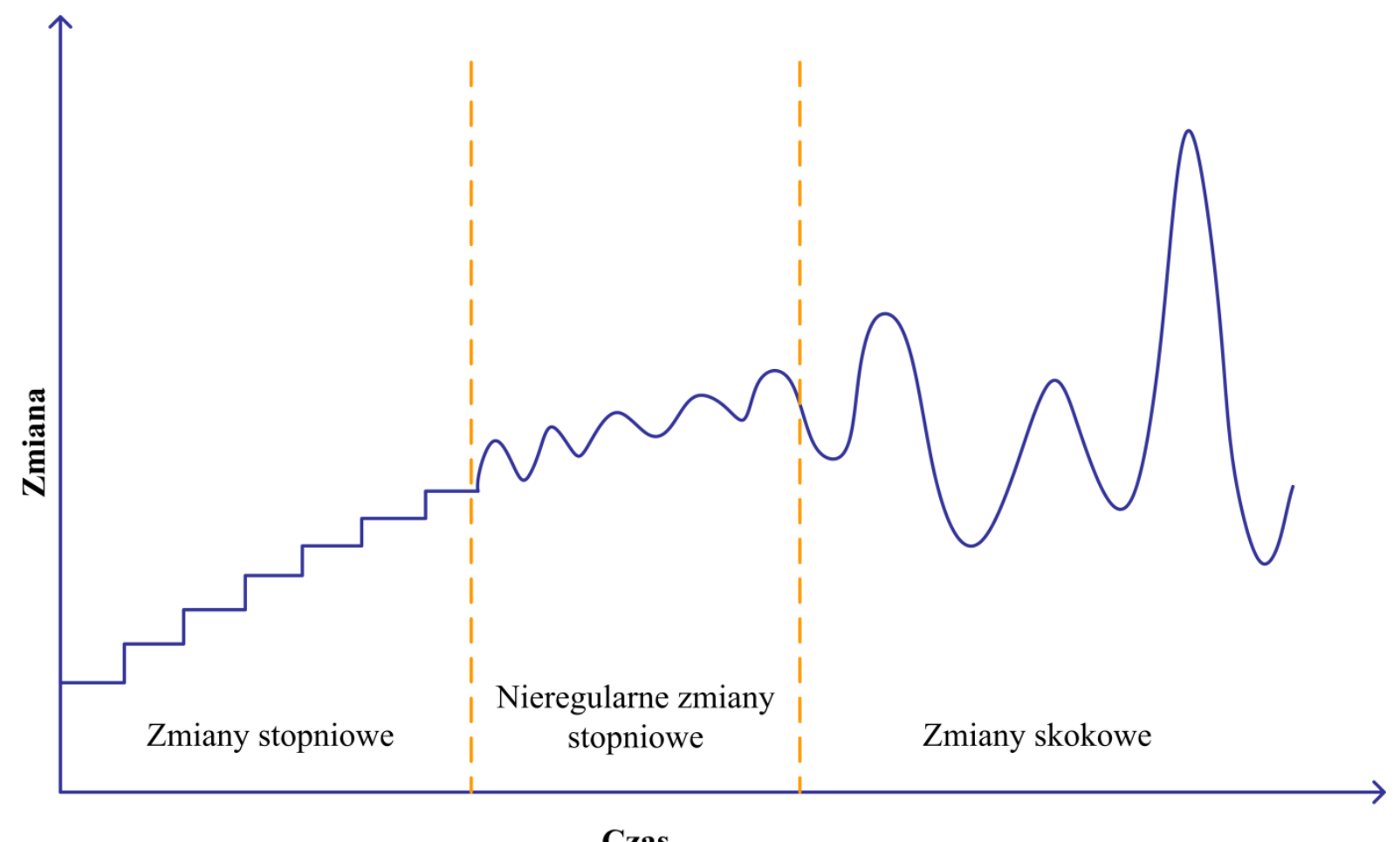

Rysunek 19. Zmiany w przedsiębiorstwie spowodowane przemianami rynku. Źródło: [Jashapara 2006, s. 273].

Bardzo dużym utrudnieniem działań w omawianym zakresie są szybkie zmiany rynkowe, które implikują również zmiany w przedsiębiorstwach (rysunek 19). Obecnie coraz częściej mamy do czynienia ze zmianami skokowymi. Dotyczy to w szczególności podmiotów zaangażowanych na rynkach zagranicznych. Dobrą receptę dla firmy, w perspektywie omawianego zjawiska, dostarcza Foster. Jego zdaniem przedsiębiorstwo powinno zmieniać się w takim samym tempie i kierunku, jak rynek. Zagrożeniem jest przede wszystkim przywiązanie osób zarządzających przedsiębiorstwem do aktualnej oferty 
podmiotu [Jashapara 2006, s. 304]. Zdaniem Evans nie istnieje nic bardziej błędnego, niż przyjęcie założenia, że produkty oraz działania, które w przeszłości umożliwiły sukces przedsiębiorstwu, będą podobnie efektywne jutro [Evans 2005, s. 23]. Zmiany otoczenia stają się obecnie coraz bardziej gwałtowne co sprawia, że potrzeby oraz metody ich zaspokajania również się zmieniają. Wpływa to na szybką dezaktualizację zdobytych w przeszłości doświadczeń i sprawdzonych działań [Dąbrowski i Gierszewska 2005, s. 7].

Przywiązanie do istniejącej wiedzy w organizacji może być uwarunkowane politycznie. Określone grupy osób mogą sprzeciwiać się zmianom ze względu na groźbę utraty wpływów w organizacji. Przykładem takiego działania jest firma IBM, która uzyskała przewagę w obszarze komputerów w latach 60-tych i 70-tych XX wieku, tracąc ją w latach 80-tych XX wieku na rzecz Intela i Microsoftu [Chakravarthy i in. 2006, s. 318]. Ta sama firma kilka dekad później zachowała się jednak inaczej, prawdopodobnie wyciągając wnioski z wcześniejszej lekcji. W pierwszej dekadzie XXI wieku IBM sprzedał swój dział komputerów przenośnych firmie Lenovo oraz skoncentrował się na bardziej perspektywicznych obszarach takich, jak świadczenie usług informatycznych dla podmiotów gospodarczych [Pasher i Ronen 2011, s. 43].

Dużym problemem odnoszącym się do wspomnianych zmian skokowych są ograniczone możliwości ich wcześniejszego przewidywania. W związku z tym tak ważne dla przedsiębiorstwa są zarówno ciągła obserwacja rynku, jak i szybka reakcja na zmiany. Jest to równoznaczne $\mathrm{z}$ ciągłym przechodzeniem przez wszystkie etapy wcześniej zaprezentowanego schematu kształtowania przewagi konkurencyjnej przedsiębiorstwa. Innymi słowy, przedsiębiorstwo w dzisiejszych czasach powinno charakteryzować się nie tylko intensywnymi działaniami w zakresie wiedzy, ale także ich odpowiednim ukierunkowaniem, które powinno stale, odpowiednio się zmieniać, zgodnie ze zmianami potrzeb rynkowych.

W celu kompleksowego ujęcia przedstawionych powyżej rozważań oraz dokładniejszego odwzorowania mechanizmu kształtowania długofalowej przewagi konkurencyjnej przedsiębiorstwa, model przedstawiony na rysunku 17 musi zostać dalej rozwinięty (por. rysunek 20). W myśl podejścia dynamicznego przedsiębiorstwo, aby utrzymać długoterminową przewagę konkurencyjną musi nieustannie, z sukcesem, przechodzić przez wymienione etapy. Jest to zgodne z opiniami Hamela i Prahalada, zdaniem których można wyróżnić dwa źródła przewagi przedsiębiorstwa - zapewniające mu przewagę w krótkim okresie oraz w długim okresie. Źródła krótkookresowej przewagi konkurencyjnej zapewniają chwilową, nietrwałą przewagę nad konkurentami. Mogą być łatwo przejęte 
i skopiowane przez klientów. Długoterminową przewagę tworzą umiejętności dostarczania klientom unikalnej wartości szybciej i taniej niż konkurencja [Adamik 2008, s. 12]. Utrzymanie przewagi konkurencyjnej podmiotu wymaga od przedsiębiorstwa szybszej nauki w porównaniu z konkurencją [Dąbrowski i Gierszewska 2005, s. 14]. Żadna wiedza nie będzie wyróżniała przedsiębiorstwa na zawsze [Chakravarthy i in. 2006, s. 307].

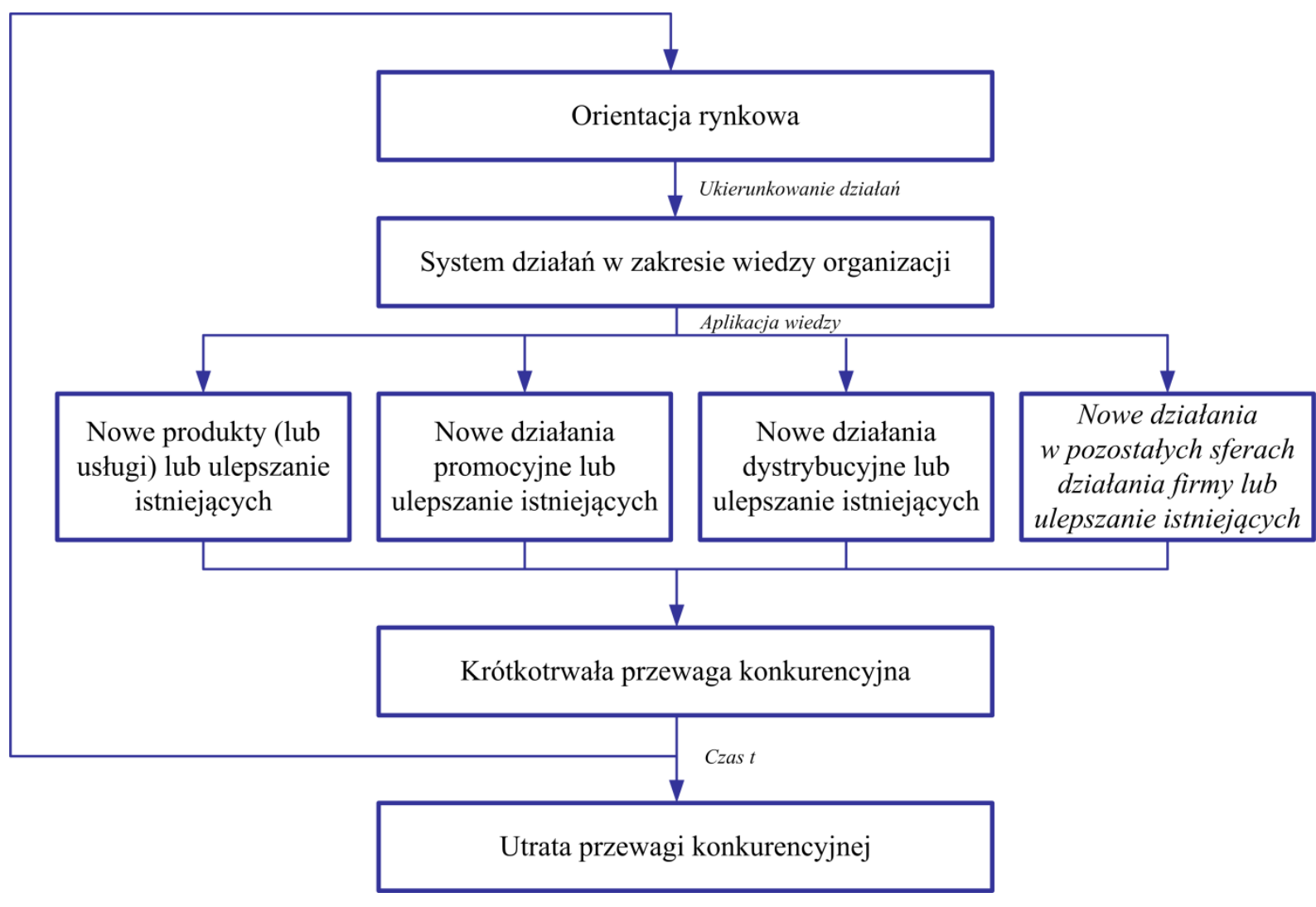

Rysunek 20. Model dynamicznej orientacji na wiedzę.

Źródło: opracowanie własne.

W przeszłości żywotność wiedzy była zdecydowanie dłuższa, stąd niewielka grupa ekspertów była w stanie zaprojektować takie systemy czy działania, które umożliwiały podmiotowi przetrwanie nawet przez dekady, lecz dzisiaj nie jest to wykonalne [Cavaleri i Seivert 2005, s. 12]. Szybki rozwój technologiczny w gospodarce sprawia, iż każdy element tego zasobu szybko się dezaktualizuje. Określone obszary wiedzy, które dziś są ważne dla działalności podmiotu, jutro mogą być bez znaczenia [Probst, Raub i Romhardt 2004, s. 51]. Tę kwestię podsumowują dwa cytaty: Drucker: „Tylko zmiana jest rzeczą stałą” [Dąbrowski i Gierszewska 2005, s. 7] oraz J. D. Thompson: „...zmiana jest metafizyką naszego wieku i sama w sobie też się zmienia" [Dąbrowski i Gierszewska 2005, s. 7]. 
W przypadku proponowanego procesu długoterminowa przewaga konkurencyjna przedsiębiorstwa jest oparta na jego umiejętności sprawnego i ciągłego przechodzenia przez zaproponowany cykl, czyli na rynkowo ukierunkowanym, systematycznym pozyskiwaniu, kreacji, rozpowszechnianiu, magazynowaniu, aplikacji i ochronie wiedzy, a także innych aktywnych działań w zakresie tego zasobu (rysunek 20).

Elementem wyjściowym opisywanego procesu kształtowania przewagi konkurencyjnej przedsiębiorstwa jest rynkowa orientacja podmiotu. Jak podkreśla Adamik, strategia budowania przewagi konkurencyjnej przedsiębiorstwa może być postrzegana jako efektywna wyłącznie w momencie, gdy zostanie pozytywnie zweryfikowana przez odbiorców jego produktów lub usług. To właśnie rynek jest najważniejszym sędzią działań przedsiębiorstwa [Adamik 2008, s. 35]. W związku z tym, każde działanie firmy powinno mieć źródło w potrzebach rynku. W przeciwnym razie przedsiębiorstwo może rozwijać ofertę, która nie jest tak naprawdę potrzebna. Kolejnym i zarazem najważniejszym elementem procesu jest system rozwoju wiedzy (szczegółowo przedstawiony na rysunku 18). Są to systemowe rozwiązania w przedsiębiorstwie mające na celu ciągłą kreację, pozyskiwanie, aplikację i ochronę wiedzy. Rezultatem tych działań jest rozwój i usprawnianie nie tylko produktów czy usług przedsiębiorstwa, lecz wszystkich procesów zachodzących wewnątrz podmiotu. Działania w zakresie stałego, rynkowo ukierunkowanego rozwoju wiedzy są niezbędne, gdyż w obecnych warunkach gospodarki opartej na wiedzy, wymagany poziom zarówno produktów, jak i usług oraz wszystkich procesów zachodzących w przedsiębiorstwie, ze względu na szybki rozwój i dużą konkurencję, stale wzrasta. Wspomniane zjawisko, wraz $\mathrm{z}$ modelem dynamicznej orientacji na wiedzę, zostało przedstawione na rysunku 21. Miernikiem pozycji danego przedsiębiorstwa w ramach graficznej prezentacji modelu są zagregowane subiektywne opinie klientów wyrażane w ich działaniach zakupowych. Nabywanie produktów i usług oferowanych przez firmę przekłada się w efekcie na wyniki finansowe oraz przewagę konkurencyjną podmiotu.

Przykładem przedsiębiorstw, którym nie udało się przejść do kolejnego cyklu w prezentowanym wyżej modelu mogą być japońskie firmy elektroniczne - Sony i Panasonic. Mają one problemy z utrzymaniem przewagi konkurencyjnej, gdyż nie są w stanie wytworzyć nowych i atrakcyjnych dla obecnego rynku produktów. Ich domeną były m.in. telewizory, których ogólna sprzedaż nie jest dziś wysoka w związku z konkurencją innych urządzeń np. tabletów [Motriuk 2012, s. 1]. 


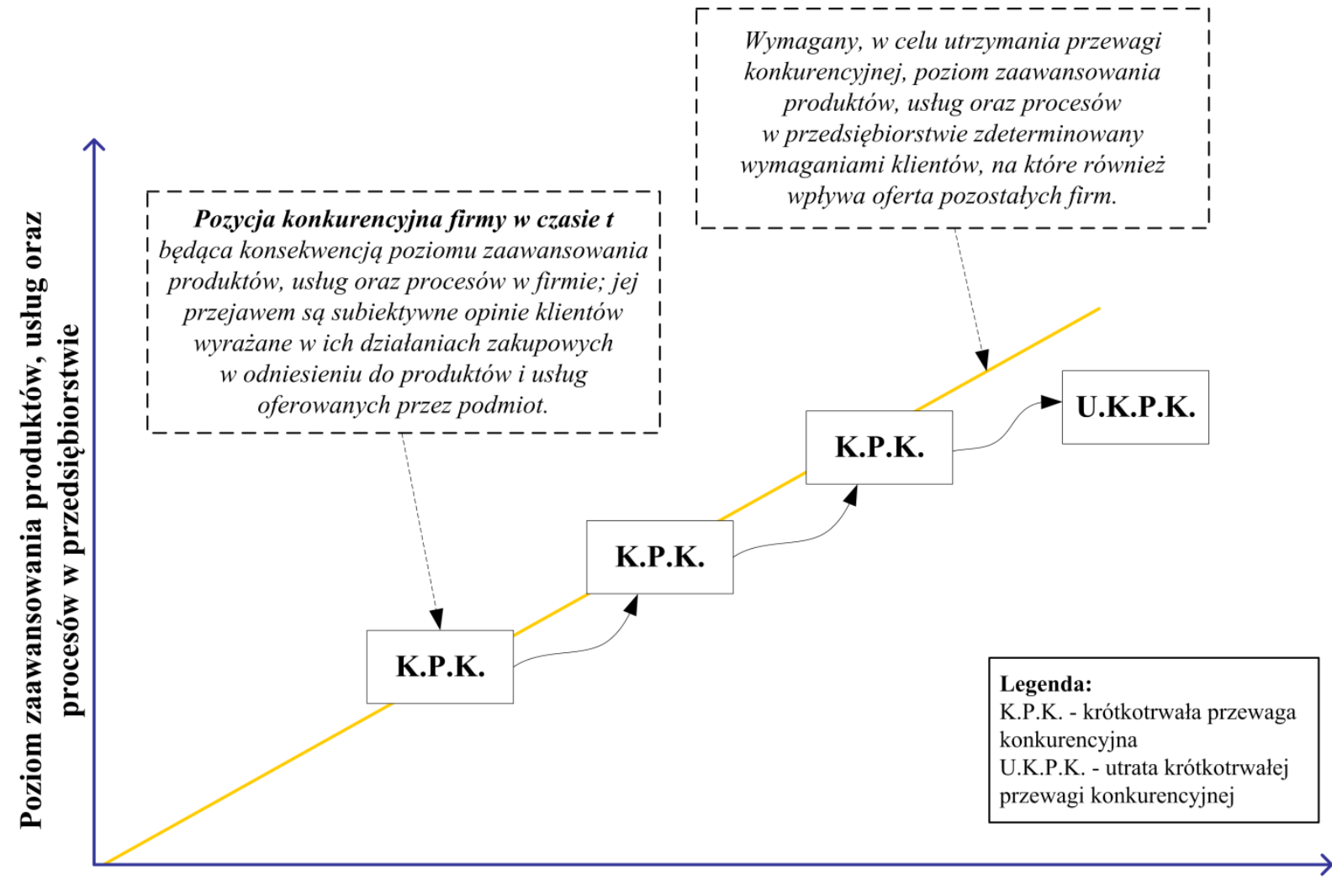

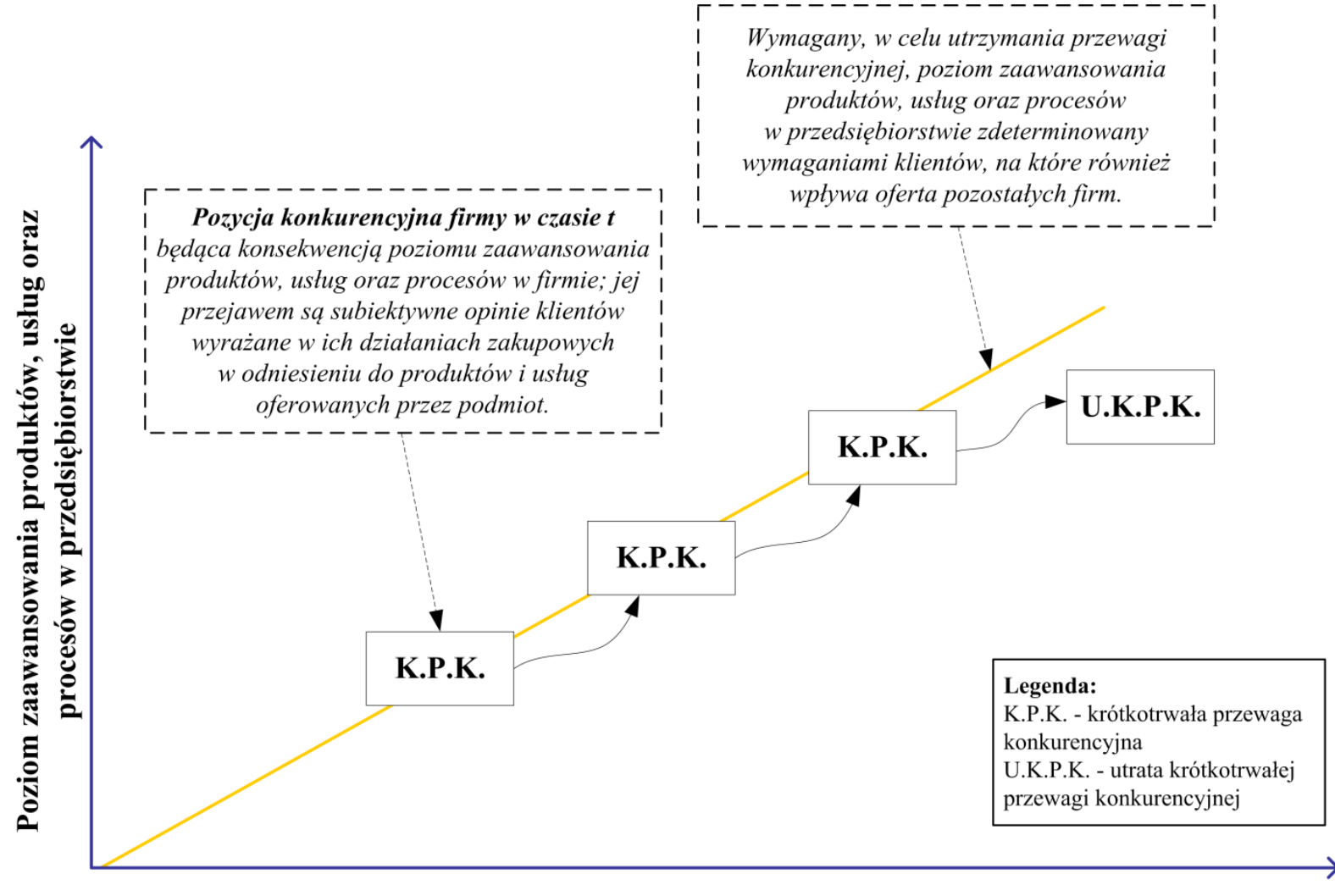

Czas

Rysunek 21. Model dynamicznej orientacji na wiedzę w kształtowaniu przewagi konkurencyjnej przedsiębiorstwa - prezentacja graficzna, długookresowa. Źródło: opracowanie własne.

Podsumowując, zważywszy na realia współczesnej gospodarki, przedsiębiorstwo powinno być stale aktywne w obszarze swojego najważniejszego zasobu - wiedzy. Postrzegając go w formie dynamicznej - procesów prowadzących do powstania coraz to nowej, rynkowo ukierunkowanej wiedzy.

Należy jednak podkreślić, że opisane działania są konsekwencją zewnętrznej sytuacji gospodarczej, w jakiej znajduje się podmiot i są przejawem praktycyzmu - dostosowania do zastanych warunków. Realia funkcjonowania poszczególnych przedsiębiorstw nie są jednak jednorodne i są pochodną wielu czynników. Opisane wcześniej zjawisko powstawania gospodarki opartej na wiedzy nakreśla określony kierunek zmian, lecz tempo ich oddziaływania na poszczególne podmioty gospodarcze jest zróżnicowane. W związku z tym można podejrzewać, że istnieją różnice $\mathrm{w}$ zakresie poziomu intensywności nakreślonych w modelu procesów w zależności od szeregu mniej lub bardziej istotnych czynników determinujących środowisko działania podmiotu gospodarczego. 
Szczególnie interesującym rodzajem podmiotu, w omawianym kontekście, są przedsiębiorstwa w procesie internacjonalizacji. Charakteryzują się one szerokim obszarem działania egzystując jednocześnie na wielu, często różnorodnych rynkach. Można oczekiwać, iż efektywne funkcjonowanie tego typu firm wymaga właściwych, intensywnych i przede wszystkim skutecznych działań w zakresie wiedzy. W celu sprawdzenia słuszności powyższego stwierdzenia, w pierwszej kolejności omówiona zostanie teoria internacjonalizacji przedsiębiorstwa. Następnie zaprezentowany wcześniej model zostanie przedstawiony w sytuacji zaangażowania firmy na rynkach zagranicznych.

\subsection{Podsumowanie i wnioski}

W rozdziale pogłębiono rozważania dotyczące ukierunkowania działań przedsiębiorstwa w zakresie wiedzy. Motywacją do koncentracji na tym zagadnieniu był fakt, iż w literaturze dotyczącej koncepcji zarządzania wiedzą można znaleźć wiele przykładów przedsiębiorstw, które inwestując w tym obszarze, nie powiązały działań dotyczących wiedzy z procesami biznesowymi, które miałyby być usprawnione, czy zadaniami biznesowymi, które miałyby być zrealizowane za pomocą tego narzędzia. Najczęściej takie postępowanie sprawiało, iż implementacja przedsięwzięć w tym zakresie kończyła się porażką przejawiającą się wyłącznie w poniesieniu wysokich kosztów.

$\mathrm{Z}$ uwagi na fakt, że rozpatrywane przedsiębiorstwa funkcjonują w gospodarce rynkowej, w celu ukierunkowania działań podmiotów w zakresie wiedzy zdecydowano się wykorzystać ugruntowaną w literaturze koncepcję orientacji rynkowej. W ramach rozważań teoretycznych rozpatrzono różnorodne podejścia do wymienionej teorii. Spośród dwóch dominujących ujęć orientacji rynkowej: Narvera i Slatera [1990] oraz Kohliego i Jaworskiego [1990], z uwagi na szereg omówionych w pracy przyczyn, zdecydowano się wykorzystać podejście Narvera i Slatera [1990], jak i narzędzie pomiaru orientacji rynkowej MKTOR wypracowane przez tych autorów.

Rozważania w zakresie orientacji rynkowej, a także konkluzje rozdziału drugiego w zakresie dynamicznych koncepcji dotyczących wiedzy, stały się podstawą do zaprojektowania modelu dynamicznej orientacji na wiedzę. Został on zbudowany na podstawie modelu statycznego zaprezentowanego w rozdziale pierwszym.

W opinii autora potrzeba dynamicznego podejścia do zasobu wiedzy jest wywołana m.in. szybkim rozwojem technologicznym w gospodarce, który sprawia, iż każdy element 
tego zasobu szybko się dezaktualizuje. Określone obszary wiedzy, które dziś są ważne dla działalności podmiotu, jutro mogą być bez znaczenia [Probst, Raub i Romhardt 2004, s. 51]. W przypadku proponowanego przez autora modelu, długoterminowa przewaga konkurencyjna przedsiębiorstwa jest oparta na jego umiejętności sprawnego i ciągłego przechodzenia przez zaproponowany cykl działań, czyli do rynkowo ukierunkowanego, systematycznego pozyskiwania, kreacji, rozpowszechniania, magazynowania, aplikacji, ochrony wiedzy, a także innych aktywnych działań w zakresie tego zasobu.

Elementem wyjściowym modelu dynamicznej orientacji na wiedzę jest rynkowa orientacja podmiotu. Jak podkreśla Adamik, strategia budowania przewagi konkurencyjnej przedsiębiorstwa może być postrzegana jako efektywna wyłącznie w momencie, gdy zostanie pozytywnie zweryfikowana przez odbiorców produktów lub usług firmy. To właśnie rynek jest najważniejszym sędzią działań przedsiębiorstwa [Adamik 2008, s. 35]. W związku z tym, każde działanie firmy powinno mieć źródło w potrzebach rynku. W przeciwnym razie przedsiębiorstwo może rozwijać ofertę, która nie jest tak naprawdę potrzebna. Kolejnym i zarazem najważniejszym elementem procesu jest system rozwoju wiedzy. Są to kompleksowe rozwiązania w przedsiębiorstwie mające na celu ciągłą kreację, pozyskiwanie, aplikację i ochronę wiedzy. Rezultatem tych działań jest rozwój i usprawnianie nie tylko produktów czy usług przedsiębiorstwa, lecz wszystkich procesów zachodzących wewnątrz podmiotu. Należy podkreślić, iż działania w zakresie stałego, rynkowo ukierunkowanego rozwoju wiedzy są niezbędne, gdyż w obecnych warunkach gospodarki opartej na wiedzy, wymagany poziom zarówno produktów, jak i usług oraz wszystkich procesów zachodzących w przedsiębiorstwie, ze względu na szybki rozwój i dużą konkurencję, stale wzrasta.

Konkluzją rozdziału jest stwierdzenie, iż szczególnie interesującym rodzajem podmiotów, w omawianym kontekście, są przedsiębiorstwa zaangażowane na rynkach zagranicznych. Jest to związane $\mathrm{z}$ faktem, iż charakteryzują się one szerokim obszarem działania egzystując jednocześnie na wielu, często różnorodnych rynkach. W związku z tym można oczekiwać, iż efektywne funkcjonowanie tego typu firm wymaga odpowiednio ukierunkowanych, intensywnych i przede wszystkim skutecznych działań w zakresie wiedzy. 


\section{Orientacja na wiedzę a przewaga konkurencyjna przedsiębiorstwa $\mathrm{w}$ procesie internacjonalizacji}

$\mathrm{Na}$ końcu poprzedniego rozdziału zasugerowano, iż w przypadku podmiotów gospodarczych $\mathrm{W}$ procesie internacjonalizacji, ze względu na ich charakterystykę i środowisko działania mogą się one cechować przeciętnie wyższym poziomem orientacji na wiedzę w porównaniu do firm funkcjonujących wyłącznie na rynkach lokalnych. Pierwszym elementem kompleksowych rozważań w tym względzie jest poznanie teorii internacjonalizacji przedsiębiorstwa.

\subsection{Proces internacjonalizacji przedsiębiorstwa}

Pierwszych symptomów w zakresie internacjonalizacji przedsiębiorstw w opinii jednych autorów należy szukać nawet w XVII wieku w związku istnieniem kompanii handlowych. Według innych badaczy można wyróżnić trzy historyczne fazy umiędzynarodowienia przedsiębiorstw [Pakulska i Poniatowska-Jaksch 2007, s. 3] (rysunek 22).

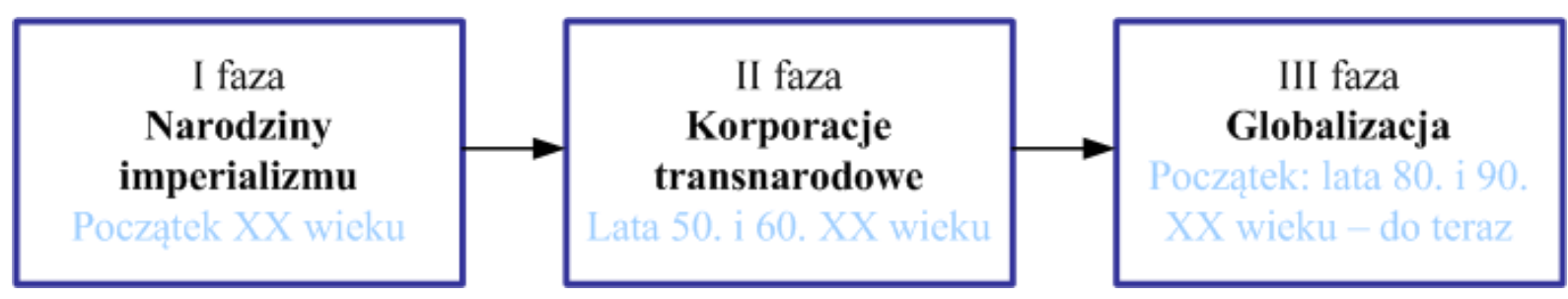

Rysunek 22. Historyczne ujęcie faz umiędzynarodowienia przedsiębiorstw. Źródło: na podstawie: [Pakulska i Poniatowska-Jaksch 2007, s. 3].

Pierwsza faza umiędzynarodowienia określana jako „narodziny imperializmu” miała miejsce na początku XX wieku, przed rozpoczęciem I Wojny Światowej. Jej zaistnienie było związane z rozwojem handlu zagranicznego i wzrostem przepływów kapitału finansowego. Druga faza, datowana na lata pięćdziesiąte i sześćdziesiąte $\mathrm{XX}$ wieku, związana była ze wzrostem bezpośrednich inwestycji zagranicznych i początkiem istnienia korporacji transnarodowych. Początek trzeciej fazy, powszechnie noszącej miano globalizacji umiejscawia się $\mathrm{w}$ latach osiemdziesiątych lub dziewięćdziesiątych XX wieku [Pakulska i Poniatowska-Jaksch 2007, s. 3]. 
Obecnie koncepcja internacjonalizacji jest najczęściej w literaturze ujmowana w trzech płaszczyznach [Otta 1994, s. 46, 47; Gorynia i Owczarzak 2004, s. 15; Karasiewicz 2009, s. 153, 154; Szymura-Tyc 2012, s. 10]:

- makro - dotyczy otwarcia gospodarki w zakresie wymiany międzynarodowej,

- mezo - odnosi się do internacjonalizacji branż - grup przedsiębiorstw wzajemnie konkurujących i posiadających $\mathrm{w}$ ofercie produkty o wysokim poziomie substytucyjności,

- mikro - dotyczy działalności pojedynczego podmiotu na rynkach zagranicznych.

W przeszłości dominującą pozycję zajmowały modele makroekonomiczne [Gorynia i Owczarzak 2004, s. 15]. Koncentrują się one na wyjaśnianiu zakresu i przyczyn międzypaństwowej wymiany gospodarczej [Karasiewicz 2009, s. 154]. Wśród autorów, którzy wnieśli znaczący wkład w ramach omawianego nurtu należy wymienić: A. Smitha, D. Ricardo, W. Taussiga, J. Vinera, G. Haberlera, E. Heckschera, B. Ohlina, P.A. Samuelsona, M.V. Posnera i S.B. Lindera [Gorynia i Owczarzak 2004, s. 15].

Mezoekonomiczne koncepcje internacjonalizacji koncentrują się na zagadnieniach konkurencyjności branż w określonym państwie w układzie globalnym. Prace z tego obszaru wykorzystują modele dotyczące cyklu życia produktu skupiając się na aspekcie branżowym. Konkurencyjność danej branży krajowej w perspektywie międzynarodowej jest uzależniona przez cztery zasadnicze siły: warunki popytowe, warunki produkcji, uwarunkowania występujące $\mathrm{w}$ danej branży oraz wpływ branż wspomagających i pokrewnych [Gorynia i Owczarzak 2004, s. 15; Karasiewicz 2009, s. 155].

Mikroekonomiczne modele internacjonalizacji koncentrują się na objaśnianiu zagadnienia wymiany międzynarodowej, form aktywności i przyczyn działalności na rynkach zagranicznych najważniejszego podmiotu w gospodarce, jakim jest przedsiębiorstwo [Karasiewicz 2009, s. 155]. Modele mikroekonomiczne są w obszarze szczególnego zainteresowania niniejszej pracy, jednak przed ich szczegółowym omówieniem należy dokładnie sprecyzować szeroko wykorzystywane w rozprawie pojęcie internacjonalizacji.

Zarówno Andersen, jak i Daszkiewicz podkreślają, iż w literaturze nie istnieje jedna, powszechnie akceptowana definicja koncepcji internacjonalizacji [Daszkiewicz 2004, s. 15; Andersen 1997, s. 28]. Kozioł-Nadolna zauważa, iż funkcjonuje wiele ujęć tego zagadnienia, które mogą dotyczyć różnorodnych płaszczyzn działalności podmiotu [Kozioł-Nadolna 2013, s. 66]. 
W kontekście makroekonomicznym Kukułka określa internacjonalizację m.in. jako „...rozszerzanie zakresu oraz intensyfikacji wzajemnych oddziaływań poszczególnych państw i narodów” [Kozioł-Nadolna 2013, s. 66].

Pojęcie internacjonalizacji w ujęciu mikroekonomicznym, które jest szczególnie ważne dla niniejszej pracy, zostało zdefiniowane przez szereg badaczy. Wybrane definicje zostały zebrane w tabeli 9.

Tabela 9. Wybrane definicje koncepcji internacjonalizacji w ujęciu mikroekonomicznym.

\begin{tabular}{|c|c|}
\hline Definicja & $\begin{array}{l}\text { Autor / } \\
\text { autorzy }\end{array}$ \\
\hline $\begin{array}{l}\text { Zewnętrzne ukierunkowanie w zakresie międzynarodowych działań } \\
\text { przedsiębiorstwa. }\end{array}$ & P. W. Turnbull \\
\hline $\begin{array}{l}\text { Umiędzynarodowienie działalności przedsiębiorstwa, lecz niekoniecznie } \\
\text { własności podmiotu. }\end{array}$ & M. Gorynia \\
\hline $\begin{array}{c}\text { Każdy typ aktywności gospodarczej, jaki może podejmować } \\
\text { przedsiębiorstwo poza granicami kraju. }\end{array}$ & J. Rymarczyk \\
\hline $\begin{array}{l}\text { Proces internacjonalizacji przedsiębiorstwa, lub inaczej } \\
\text { umiędzynarodowienia jego działalności gospodarczej, oznacza } \\
\text { podejmowanie przez firmę działań w różnorodnych obszarach poza } \\
\text { granicami państwa pochodzenia podmiotu. W tym procesie aktywność } \\
\text { przedsiębiorstwa jest rozszerzana poza krajowe rynki. }\end{array}$ & $\begin{array}{l}\text { K. Kozioł- } \\
\text { Nadolna }\end{array}$ \\
\hline $\begin{array}{l}\text { Internacjonalizacja przedsiębiorstwa jest procesem, w którym podmiot } \\
\text { stopniowo zwiększa swoje zaangażowanie zagraniczne. }\end{array}$ & $\begin{array}{l}\text { J. Johanson, J. E. } \\
\text { Vahlne }\end{array}$ \\
\hline
\end{tabular}

Źródło: opracowanie własne na podstawie:

[Andersen 1997, s. 28; Gorynia 2007, s. 16; Rymarczyk 2004, s. 19; Kozioł-Nadolna 2013, s. 65; Johanson i Vahlne 1977, s. 23].

Wśród przedstawionych powyżej definicji można zauważyć różnice w zakresie pojmowania omawianej koncepcji, a dokładniej jej szczegółowych charakterystyk. Przede wszystkim, jak podkreśla B. Stępień, internacjonalizację firmy można postrzegać statycznie - 
jako stan umiędzynarodowienia charakteryzujący przedsiębiorstwo w danym momencie, lecz także w sposób dynamiczny - w perspektywie procesu, który składa się z etapów [Stępień 2011, s. 99]. Podobnie Duliniec [2009, s. 15] zauważa, iż internacjonalizacja przedsiębiorstwa może być ujmowana jako proces, wynik oraz nastawienie kierownictwa (orientacja). Jak podkreśla K. Fonfara [2009, s. 12] pierwsze z wymienionych podejść - procesowe jest najpowszechniej stosowane w literaturze.

B. Stępień podkreśla, iż umiędzynarodowienie podmiotu gospodarczego charakteryzuje się stopniowalnością, która może być mierzona według szeregu kryteriów, w tym m.in. wielkością zagranicznych obrotów, liczbą obsługiwanych rynków czy majątkiem zagranicznym [Stępień 2011, s. 100]. Ponadto, należy zaznaczyć, iż tylko w ramach płaszczyzny mikro stworzono syntetyczne wskaźniki internacjonalizacji, które opisują stopień internacjonalizacji podmiotu gospodarczego [Karasiewicz 2009, s. 156].

Należy również zauważyć, iż internacjonalizacja przedsiębiorstwa nie musi być koniecznie związana $\mathrm{z}$ działalnością podmiotu na rynkach zagranicznych. Może ona być również skutkiem kontaktów z podmiotami zagranicznym na rynku lokalnym. Przykładowo, może to być związane z prowadzeniem działalności importowej czy też zawarciem umowy franchisingowej, licencyjnej lub joint venture działając jednak w granicach rodzimego rynku. Rozróżnienie tego typu działań jest podstawą klasyfikacji na internacjonalizację czynną (aktywne wychodzenie poza rynek lokalny podmiotu) oraz bierną (współpraca z podmiotami zagranicznym na rynku lokalnym) [Gorynia 2000, s. 16; Stępień 2011, s. 99; Fonfara 2012, s. 23].

W niniejszej pracy przyjmuje się, iż termin internacjonalizacja odnosi się zarówno do internacjonalizacji czynnej, jak i biernej. Oznacza to, iż obejmuje ona każdy rodzaj zaangażowania zagranicznego przedsiębiorstwa, zarówno aktywności firmy poza granicami kraju, jak i kontakt z podmiotami zagranicznymi w ramach rynku lokalnego.

Badacze zajmujący się zagadnieniem internacjonalizacji ujmowali swoje rozważania teoretyczne czy wyniki badań w odpowiednie, różnorodne modele [Gorynia i Jankowska 2008, s. 78]. Jak podkreśla Daszkiewicz pogrupowanie modeli internacjonalizacji według czytelnych i jasnych kryteriów nie jest zadaniem łatwym. Różnią się one poziomem analizy i strukturą. Innym problemem jest także fakt, iż modele te nie mają kompleksowego charakteru [Daszkiewicz 2004, s. 34].

Karasiewicz [2013, s. 109-110] zauważa, iż teorie internacjonalizacji w ujęciu mikro nastawione są przeważnie na wyjaśnienie siedmiu problemów dotyczących działalności 
podmiotu gospodarczego na rynkach zagranicznych, do których zalicza [Karasiewicz 2013, s. 109-110]:

- przyczyny (motywy) internacjonalizacji firmy,

- relacje pomiędzy pomiotami rynkowymi (konkurującymi oraz kooperującymi) w procesie internacjonalizacji,

- zasoby firm potrzebne do procesu internacjonalizacji,

- ścieżki internacjonalizacji podmiotów gospodarczych, w tym oceny atrakcyjności, a także wyboru rynków zagranicznych,

- ścieżki umiędzynaradawiania firmy związanych ze strategią wejścia na rynki zagraniczne,

- przewagi konkurencyjnych podmiotów gospodarczych w procesach internacjonalizacji,

- efekty procesów internacjonalizacji firmy.

Wspomniany autor tworzy kompleksowy przegląd modeli internacjonalizacji, które klasyfikuje w ramach pięciu grup (tabela 10).

Tabela 10. Zestawienie modeli internacjonalizacji przedsiębiorstw.

\begin{tabular}{|c|c|}
\hline Kategoria & Modele w ramach kategorii \\
\hline Ekonomiczne & $\begin{array}{l}\text { - teoria monopolistycznej przewagi } \\
\text { - teoria reakcji oligopolistycznej } \\
\text { - teoria lokalizacji } \\
\text { - teoria internalizacji } \\
\text { - eklektyczna teoria produkcji } \\
\text { międzynarodowej }\end{array}$ \\
\hline Produktowe & $\begin{array}{l}\text { - teoria międzynarodowego cyklu życia } \\
\text { produktu } \\
\text { - teoria zawłaszczenia }\end{array}$ \\
\hline Finansowe & $\begin{array}{l}\text { - teoria obszarów walutowych } \\
\text { - model Hirscha } \\
\text { - teoria dywersyfikacji } \\
\text { - teoria opcji rzeczywistych } \\
\text { - teoria portfela }\end{array}$ \\
\hline Behawioralne & - model uppsalski \\
\hline
\end{tabular}




\begin{tabular}{|l|l|}
\hline & - modele innowacyjne \\
& - podejście strategiczne \\
& - podejście sieciowe \\
\hline Zasobowe & - podejście ewolucyjne \\
& - model przedsiębiorstw ,globalnych \\
& od początku” \\
& - model umiejętności organizacji \\
& - model LLL \\
\hline
\end{tabular}

Źródło: [Karasiewicz 2013, s. 111].

Jest to bardzo szeroka klasyfikacja. Autorzy na ogół koncentrują się jednak wyłącznie na najważniejszych modelach z uwagi na ich charakterystykę i różnorodność. Najczęściej analizowane w literaturze podziały zostały zaprezentowane w tabeli 11 . W niniejszej pracy szczegółowo przeanalizowane zostaną najpowszechniejsze modele internacjonalizacji przedsiębiorstwa: modele etapowe (w tym model Uppsala), paradygmat eklektyczny, modele sieciowe oraz model strategiczny.

Tabela 11. Najczęściej analizowane w literaturze modele internacjonalizacji.

\begin{tabular}{|c|c|c|}
\hline $\begin{array}{l}\text { J. Johanson i J. E. Vahlne } \\
\text { (1990) }\end{array}$ & $\begin{array}{l}\text { K. Fonfara } \\
\text { (2009) }\end{array}$ & $\begin{array}{l}\text { M. Gorynia i B. Jankowska } \\
\text { (2011) }\end{array}$ \\
\hline $\begin{array}{l}\text { - paradygmat eklektyczny, } \\
\text { - model Uppsala (ujęcie } \\
\text { etapowe), } \\
\text { - podejście sieciowe } \\
\text { do procesu } \\
\text { internacjonalizacji. }\end{array}$ & $\begin{array}{l}\text { - model Uppsala, } \\
\text { - paradygmat eklektyczny, } \\
\text { - podejście sieciowe, } \\
\text { - model strategiczny. }\end{array}$ & $\begin{array}{l}\text { - model sekwencyjny } \\
\text { (konwencjonalny, } \\
\text { tradycyjny, ewolucyjny), } \\
\text { - internacjonalizacja } \\
\text { niekonwencjonalna, } \\
\text { internacjonalizacja } \\
\text { symultaniczna, } \\
\text { - internacjonalizacja } \\
\text { w ujęciu podejścia } \\
\text { sieciowego. }\end{array}$ \\
\hline
\end{tabular}

Źródło: [Johanson i Vahlne 1990, s. 11-22; Fonfara 2009, s. 13; Gorynia i Jankowska 2011, s. 44-65; Małys 2012, s. 59].

Jednym $\mathrm{z}$ najbardziej powszechnych w literaturze ujęć umiędzynarodowienia przedsiębiorstwa jest potraktowanie tego zagadnienia jako procesu. Internacjonalizacja firmy 
w perspektywie procesu cechuje się układem fazowym form zaangażowania zagranicznego. Formy te pozostają w quasi-przyczynowej zależności, co oznacza, iż zastosowanie jednej z nich do pewnego stopnia warunkuje przejście do kolejnej [Rymarczyk 2004, s. 20]. Najbardziej popularną koncepcją internacjonalizacji przedsiębiorstwa jest właśnie historycznie pierwszy model etapowy - model uppsalski, stworzony przez J. Johansona, F. Wiedersheim-Paula oraz J. E. Vahlne [Gorynia i Jankowska 2008, s. 78, 2011, s. 44]. Autorzy na podstawie obserwacji szwedzkich przedsiębiorstw doszli do wniosku, że zaangażowanie na rynkach zagranicznych większości podmiotów gospodarczych zwiększa się stopniowo [Johanson i Wiedersheim-Paul 1975, s. 305]. Badacze przyjęli, iż do największych przeszkód utrudniających internacjonalizację przedsiębiorstw należą brak wiedzy i zasobów. Przeszkody te mogą być ograniczane m.in. poprzez nabywanie wiedzy przez przedsiębiorstwo w zakresie sposobów funkcjonowania na rynkach zagranicznych. $\mathrm{W}$ modelu przyjmuje się, iż firma w celu zmniejszenia ryzyka zaczyna internacjonalizację od krajów sąsiednich lub relatywnie lepiej znanych np. pod względem stosowanych w nich praktyk gospodarczych [Johanson i Wiedersheim-Paul 1975, s. 306].

Johnason i Wiedersheim-Paul identyfikują cztery różne etapy internacjonalizacji przedsiębiorstwa [Johanson i Wiedersheim-Paul 1975, s. 307]:

- brak regularnych działań eksportowych,

- eksport przez niezależnych pośredników (agentów),

- własne przedstawicielstwo handlowe,

- własna filia produkcyjna.

Autorzy zaznaczają, iż możliwe są też inne etapy, lecz te wyróżnione przez nich charakteryzują się różnymi poziomami zaangażowania podmiotu na rynku zagranicznym, a także zrozumieniem przez praktyków biznesu [Johanson i Wiedersheim-Paul 1975, s. 307].

Bliskość krajów, w przypadku omawianej koncepcji, jest określana za pomocą dystansu psychicznego, którego poziom charakteryzuje szereg czynników utrudniających przepływ informacji ,z” i „do” danego rynku [Johanson i Wiedersheim-Paul 1975, s. 307308; Johanson i Vahlne 1977, s. 24].

Wzrost internacjonalizacji przedsiębiorstwa według modelu Uppsala może odbywać się W dwojaki sposób: poprzez zwiększanie liczby krajów zaangażowania lub zakresu zaangażowanych zasobów [Malys 2013, s. 62-63] (rysunek 23). 
BIZ (bezpośrednia inwestycja zagraniczna)

\begin{tabular}{|l|l|l|l|l|}
\hline \multicolumn{1}{|c|}{$\begin{array}{c}\text { Rodzaj } \\
\text { działalności }\end{array}$} & $\begin{array}{c}\text { Brak regularnych } \\
\text { działań } \\
\text { eksportowych. }\end{array}$ & $\begin{array}{c}\text { Eksport przez } \\
\text { niezależnych } \\
\text { pośredników } \\
\text { (agentów). }\end{array}$ & $\begin{array}{c}\text { Własne } \\
\text { przedstawicielstwo } \\
\text { handlowe. }\end{array}$ & Własna filia \\
produkcyjna.
\end{tabular}

Rysunek 23. Wzrost internacjonalizacji według modelu Uppsala.

Źródło: [Hollensen 1998, s. 41]

Koncepcja Johansona i Wiedersheim-Paula [1975] została później rozwinięta przez Johansona i Vahlne’a [1977], którzy w ramach swoich rozważań podkreślali znaczenie braku wiedzy o rynkach zagranicznych jako ważnej przeszkody w rozwoju internacjonalizacji przedsiębiorstwa. W ich opinii, ta wiedza jest główną różnicą pomiędzy działalnością podmiotów na rynkach lokalnych i zagranicznych. Swoje rozważania ujęli w spójny model (rysunek 24) [Johanson i Vahlne 1977, s. 26].

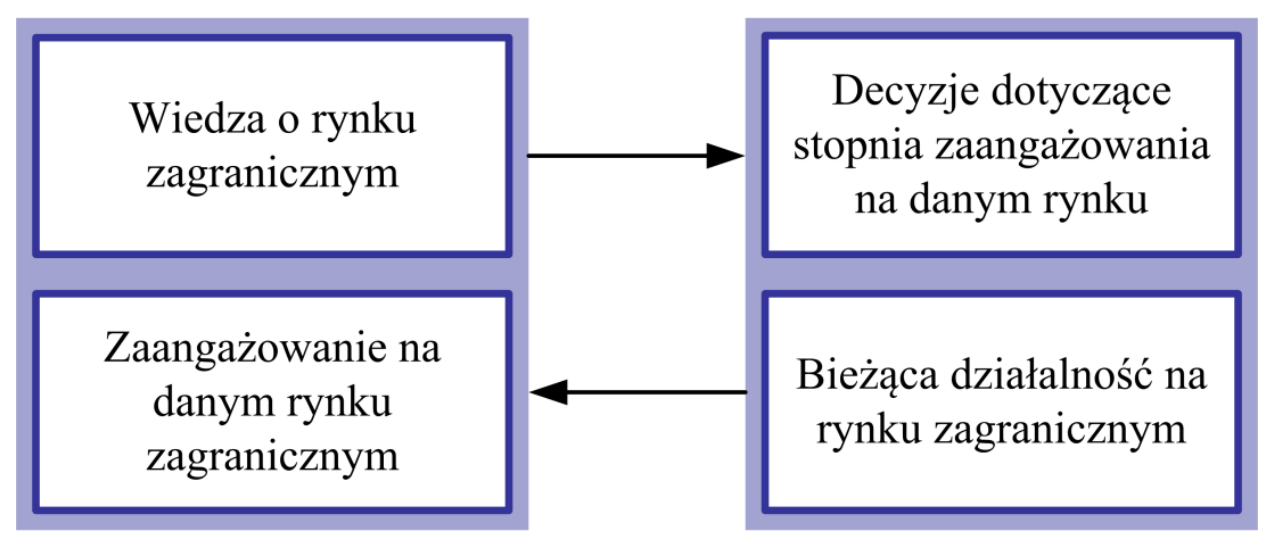

Rysunek 24. Mechanizm procesu internacjonalizacji przedsiębiorstwa z perspektywy oryginalnego modelu uppsalskiego z 1977 roku.

Źródło: [Johanson i Vahlne 1977, s. 26]. 
Wspomniani autorzy wykorzystują podział wiedzy wprowadzony przez Penrose (1966). W jego ramach wyróżnia się dwa rodzaje wiedzy: obiektywną (objective knowledge) oraz doświadczalną (experiential knowledge). Autorzy podkreślają, że w kontekście internacjonalizacji przedsiębiorstwa kluczową jest wiedza drugiego rodzaju. Jest to związane z faktem, iż trudno ją przekazywać, gdyż może być pozyskiwana wyłącznie przez doświadczenie. Ponadto, autorzy wyróżniają wiedzę ogólną (general knowledge) oraz specyficzną dla danego rynku (market-specific knowledge). Pierwsza z nich może być swobodnie przenoszona pomiędzy rynkami, druga zaś jest zdobywana przez doświadczenie na danym rynku [Johanson i Vahlne 1977, s. 28]. Autorzy podkreślają, że istnieją wyjątki od prezentowanego przez nich modelu stopniowej internacjonalizacji. Należą do nich sytuacje, w których firma ma bardzo duże zasoby finansowe, a także gdy warunki gospodarcze są stabilne lub firma posiada szeroką gamę doświadczeń z innych, podobnych rynków [Johanson i Wiedersheim-Paul 1975, s. 307; Johanson i Vahlne 1977, s. 30-31; Johanson i Vahlne 1990, s. 12].

Model Uppsala stał się inspiracją dla kolejnych badaczy. W literaturze pojawiło się wiele modeli, których wspólnym mianownikiem była etapowość procesu internacjonalizacji (tabele 12 i 13). 
Tabela 12. Pozostałe modele etapowe (cz. I).

\begin{tabular}{|c|c|c|c|c|c|c|}
\hline $\begin{array}{c}\text { Pavord i Bogart } \\
{[1975]}\end{array}$ & Bilkey i Tesar [1977] & $\begin{array}{l}\text { Wiedersheim- } \\
\text { Paul i in. [1978] }\end{array}$ & Cavusgil [1980] & Reid [1981] & $\begin{array}{c}\text { Wortzel i Wortzel } \\
\text { [1981] }\end{array}$ & Czinkota [1982] \\
\hline $\begin{array}{lr}\text { 1. Firma nie } & \text { prowadzi } \\
\text { działalności } & \\
\text { eksportowej. } & \\
\text { 2. Firma } & \text { prowadzi } \\
\text { drobną } & \text { (bierną) } \\
\text { działalność } & \text { w } \\
\text { eksportu. } & \\
\begin{array}{l}\text { 3. Firma } \\
\text { agresywną }\end{array} & \text { prowadzi } \\
\text { eksportową. } & \end{array}$ & 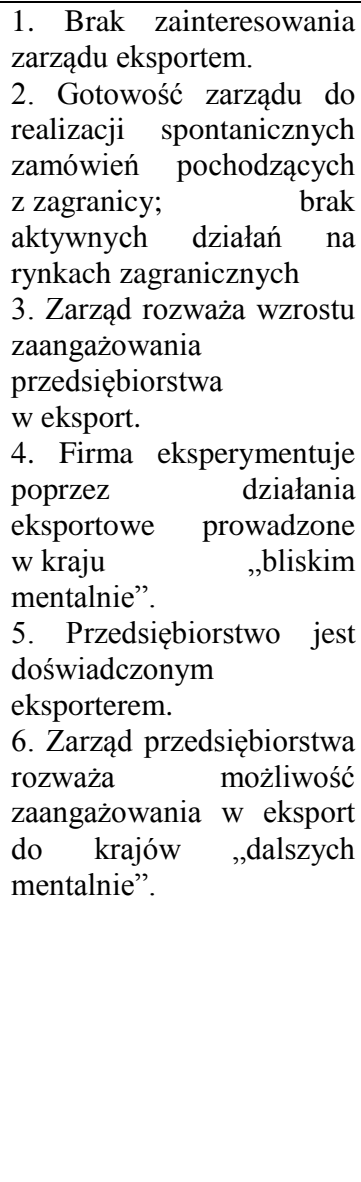 & $\begin{array}{l}\text { 1. Przedsiębiorstwo } \\
\text { jest zorientowane na } \\
\text { krajowy rynek; } \\
\text { posiada nieznaczne } \\
\text { zasoby informacji } \\
\text { oraz transmisji. } \\
\text { 2. Przedsiębiorstwo } \\
\text { posiada nieznaczna } \\
\text { wole rozpoczęcia } \\
\text { eksportu - „bierny } \\
\text { nieeksporter”, lecz } \\
\text { nadal nieznaczne } \\
\text { zasoby informacji } \\
\text { oraz transmisji. } \\
3 . \quad \text { Przedsiębiorstwo } \\
\text { posiada duża wolę } \\
\text { rozpoczęcia eksportu, } \\
\text { a także duże zasoby } \\
\text { informacji oraz } \\
\text { transmisji. }\end{array}$ & 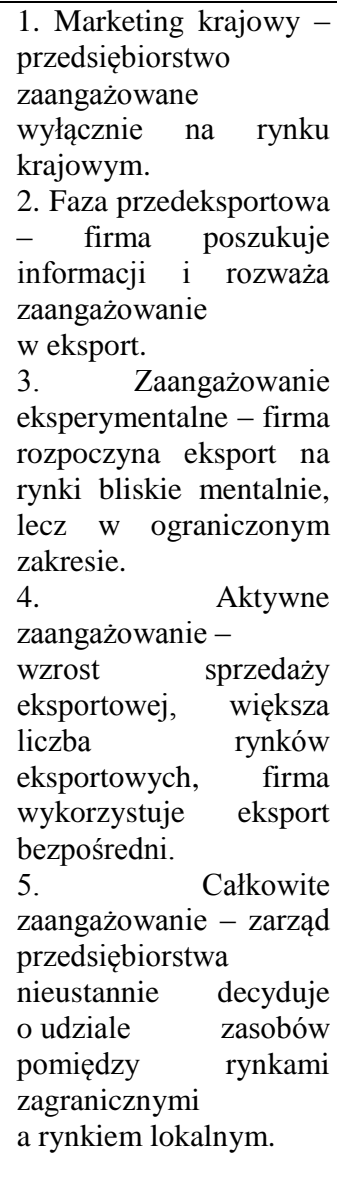 & $\begin{array}{l}\text { 1. W przedsiębiorstwie } \\
\text { istnieje śrwiadomość } \\
\text { eksportu, rosnąca } \\
\text { potrzeba zaistnienia na } \\
\text { rynkach zagranicznych } \\
\text { oraz problem poznania } \\
\text { możliwości sprzedaży } \\
\text { oferty za granicą. } \\
\text { 2. Intencja eksportu - } \\
\text { motywy, postawy oraz } \\
\text { oczekiwania działalności } \\
\text { eksportowej. } \\
\text { 3. Próby eksportu - } \\
\text { zdobywanie przez firmę } \\
\text { doświadczenia } \\
\text { w eksporcie. } \\
\text { 4. Ocena efektów } \\
\text { działalności } \\
\text { eksportowej. } \\
\text { 5. Akceptacja eksportu- } \\
\text { przyjęcie, } \\
\text { odrzucenie } \\
\text { zaangażowania firmy } \\
\text { w eksport. }\end{array}$ & 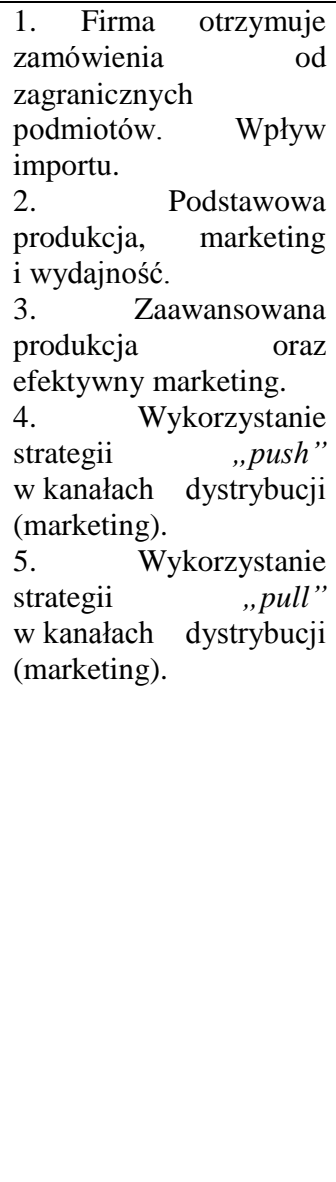 & 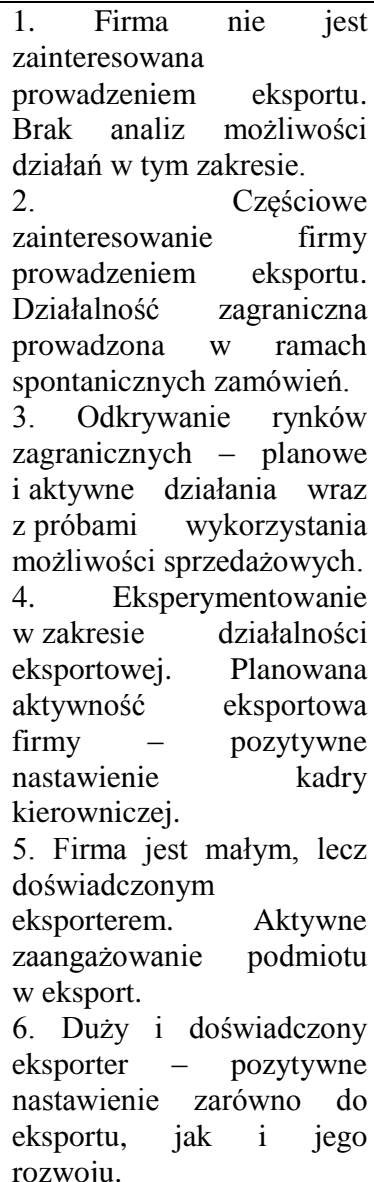 \\
\hline
\end{tabular}

Źródło: na podstawie: [Andersen 1993, s. 213; Morgan i Katsikeas 1997, s. 73-74; Fonfara 2000, s. 101; Daszkiewicz, Wasilczuk i Dominiak 2005, s. 11-12; Gorynia i Jankowska 2007, s. 29; Małys 2012, s. 66-67; Karasiewicz 2013, s. 136-137]. 
Tabela 13. Pozostałe modele etapowe (cz. II).

\begin{tabular}{|c|c|c|c|c|c|}
\hline $\begin{array}{c}\text { Barrett i Wilkinson } \\
{[1986]}\end{array}$ & Moon i Lee [1990] & $\begin{array}{c}\text { Lim, Sharkey i Kim } \\
\text { [1991] }\end{array}$ & Rao i Naidu [1992] & 996] & 2000] \\
\hline $\begin{array}{l}\text { 1. Firma nie jest } \\
\text { zaangażowana } \mathrm{w} \text { eksport } \\
\text { i nigdy nie rozważała } \\
\text { zaangażowania na rynkach } \\
\text { zagranicznych. } \\
\text { 2. Firma nie jest } \\
\text { zaangażowana } \mathrm{w} \text { eksport, } \\
\text { lecz planuje wejście na } \\
\text { rynki zagraniczne. } \\
\text { Podmiot rozpoznaje } \\
\text { możliwości sprzedaży } \\
\text { zagranicznej. } \\
\text { 3. Firma jest eksporterem } \\
\text { - prowadzi działalność } \\
\text { zagraniczną bazując na } \\
\text { eksporcie. }\end{array}$ & $\begin{array}{l}\text { 1. Niski poziom } \\
\text { zaangażowania } \\
\text { przedsiębiorstwa } \\
\text { w działalność } \\
\text { eksportową. } \\
\text { 2. Średni poziom } \\
\text { zaangażowania } \\
\text { przedsiębiorstwa } \\
\text { w działalność } \\
\text { eksportową. } \\
\text { 3. Wysoki poziom } \\
\text { zaangażowania } \\
\text { przedsiębiorstwa } \\
\text { w działalność } \\
\text { eksportową. }\end{array}$ & 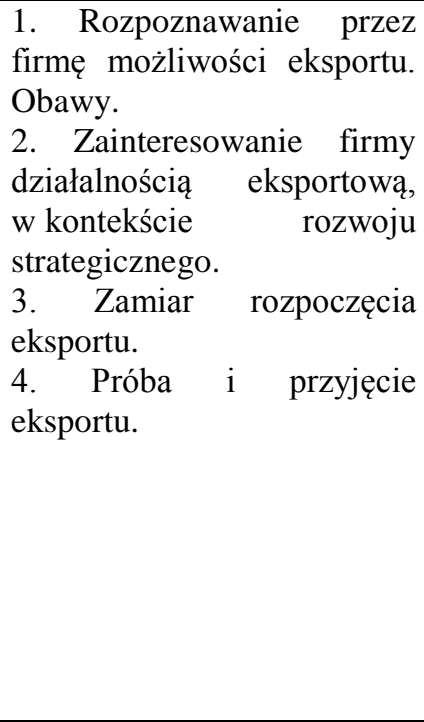 & $\begin{array}{l}\text { 1. Przedsiębiorstwo nie } \\
\text { eksportuje i nie jest } \\
\text { zainteresowane działalnością } \\
\text { na rynkach zagranicznych. } \\
\text { 2. Przedsiębiorstwo nie } \\
\text { eksportuje, ale przejawia } \\
\text { zainteresowanie działalnością } \\
\text { na rynkach zagranicznych. } \\
\text { 3. Przedsiębiorstwo jest } \\
\text { sporadycznie zaangażowane } \\
\text { w działalność eksportową. } \\
\text { 4. Przedsiębiorstwo jest } \\
\text { regularnie zaangażowane } \\
\text { w działalność eksportową. }\end{array}$ & $\begin{array}{l}\text { 1. Brak zainteresowania } \\
\text { przedsiębiorstwa } \\
\text { eksportem } \\
\text { 2. Częściowe zaintere- } \\
\text { sowanie przedsiębiorstwa } \\
\text { eksportem. } \\
\text { 3. Przedsiębiorstwa rozpo- } \\
\text { czyna prowadzenie } \\
\text { regularnego eksportu. } \\
\text { 4. Przedsiębiorstwo } \\
\text { eksperymentuje w zakresie } \\
\text { działalności eksportowej. } \\
\text { 5. Przedsiębiorstwo jest } \\
\text { doświadczonym, lecz } \\
\text { małym eksporterem. } \\
\text { 6. Przedsiębiorstwo jest } \\
\text { dużym i doświadczonym } \\
\text { eksporterem. }\end{array}$ & $\begin{array}{l}\text { I. Strategia } \\
\text { anonimowa: } \\
\text { 1. Poddostawca wielu } \\
\text { odbiorców zagranicz- } \\
\text { nych. } \\
\text { 2. Wyspecjalizowany } \\
\text { poddostawca. } \\
\text { II. Strategia markowa: } \\
\text { 1. Tworzenie } \\
\text { handlowej marki } \\
\text { własnej. } \\
\text { 2. Ulepszenie produktu. } \\
\text { 3. Próby osiągnięcia } \\
\text { pozycji lidera } \\
\text { w ramach rynku } \\
\text { międzynarodowego. }\end{array}$ \\
\hline
\end{tabular}

Źródło: na podstawie: [Andersen 1993, s. 213; Morgan i Katsikeas 1997, s. 73-74; Fonfara 2000, s. 101; Daszkiewicz, Wasilczuk i Dominiak 2005, s. 11-12; Gorynia i Jankowska 2007, s. 29; Małys 2012, s. 66-67; Karasiewicz 2013, s. 136-137]. 
Jednym z autorów, którzy podjęli się próby grupowania modeli etapowych był Andersen [1993]. Autor wyróżnia model uppsalski (U-M) oraz modele innowacyjne (I-M). Do innowacyjnych modeli zaliczane są przede wszystkim modele Bilkey i Tesar (1977), Cavusgil (1980), Czinkota (1982) i Reid (1981). W literaturze można również znaleźć ujęcia (np. Karasiewicz [2013, s. 136-137]), które zaliczają większość z przedstawionych w tabelach 12 i 13 modeli etapowych do grupy modeli innowacyjnych ${ }^{51}$.

Karasiewicz [2013, s. 138] na podstawie analizy porównawczej modeli innowacyjnych wyróżnia (bez względu na liczbę etapów zawartych w poszczególnych modelach) trzy ogólne fazy [Karasiewicz 2013, s. 138]:

- faza krajowa - podmiot nie jest zainteresowany eksportem,

- faza niskiego zaangażowania w działalność na rynkach zagranicznych - próby eksportu czy zbieranie przez firmę doświadczenia,

- faza wysokiego zaangażowania w działalność na rynkach zagranicznych przedsiębiorstwo traktuje swoją obecność zagraniczną jako ważny element swojego rozwoju.

Modele etapowe (zarówno oryginalny model uppsalski, jak i jego modyfikacje) pomimo swoich uznanych walorów poznawczych zostały poddane również znaczącej krytyce. Jest to związane przede wszystkim z faktem, iż w praktyce proces internacjonalizacji nie zawsze musi przebiegać formie sekwencyjnej lecz skokowej - określanej jako leapfrogging. Jak podkreśla B. Stępień najbardziej problematyczne w kontekście modelu uppsalskiego są przedsiębiorstwa „urodzone globalnie”, czyli działające globalnie od początku swojego istnienia [Stępień 2011, s. 110-111]. Pozostałe, najbardziej powszechne zarzuty wobec modelu Uppsala zostały zebrane w tabeli 14.

Tabela 14. Główne argumenty krytyki modelu Uppsala.

\begin{tabular}{|c|c|}
\hline Krytyka modelu Uppsala & Autor \\
\hline Zbyt deterministyczny charakter & S. Reid i P.W. Turnbull \\
\hline Pomija zjawisko born globals & B.M. Oviatt i P.P. McDougall \\
\hline $\begin{array}{c}\text { Nieadekwatny wśród przedsiębiorstw } \\
\text { oferujących niektóre produkty i usługi }\end{array}$ & S. Bridgewater \\
\hline $\begin{array}{c}\text { Model w ogóle nie sprawdza się w branży } \\
\text { usługowej }\end{array}$ & D. D. Sharma i J. Johanson \\
\hline
\end{tabular}

\footnotetext{
${ }^{51}$ Gorynia i Jankowska [2011, s. 51] wyróżniają w ramach modeli etapowych: model uppsalski i pozostałe, które nawiązują do niego i stanowią jego rozwinięcie, a także modele innowacyjne.
} 


\begin{tabular}{|c|c|}
\hline $\begin{array}{c}\text { Dystans psychiczny - w dzisiejszych czasach } \\
\text { nie stanowi już tak dużej bariery }\end{array}$ & K.A. Nordstrom \\
\hline $\begin{array}{c}\text { Brak wyznaczenia jednoznacznych granic } \\
\text { pomiędzy poszczególnymi etapami }\end{array}$ & S. Reid \\
\hline $\begin{array}{c}\text { Implikuje jednokierunkowość } \\
\text { internacjonalizacji }\end{array}$ & A. Jatar \\
\hline $\begin{array}{c}\text { Zakłada systematyczność uczenia się } \\
\text { przedsiębiorstwa }\end{array}$ & S. Hollensen \\
\hline
\end{tabular}

Źródło: na podstawie [Gorynia i Jankowska 2008, s. 86-87, 2011, s. 51-53; Hollensen 1998, s. 43; Malys 2013, s. 71].

Ponadto, poza dotychczas przywołaną krytyką modelu Uppsala, Karasiewicz [2013, s. 135] podkreśla, iż omawiany model nie wyjaśnia motywów internacjonalizacji, a także zależności i relacji przedsiębiorstwa zaangażowanego zagranicznie. Ponadto, pomija on kwestię efektów internacjonalizacji przedsiębiorstwa.

Pomimo krytyki, szczególnie oryginalny model Uppsala zyskał dużą popularność, gdyż sprawdzał się w praktyce skutecznie wyjaśniając wiele rzeczywistych przypadków biznesowych. Podkreśla się, że jest on szczególnie skuteczny w przypadku firm prowadzących eksport, jak również w kontekście zachowań przedsiębiorstw związanych z dystansem kulturowym [Hollensen 1998, s. 44].

Krytyka koncepcji etapowych internacjonalizacji przedsiębiorstwa stała się podstawą do stworzenia modelu internacjonalizacji niekonwencjonalnej. Podważa on założenia o sekwencyjności i kumulatywnym charakterze zaangażowania zagranicznego przedsiębiorstwa. W rzeczywistości gospodarczej istnieje wiele przykładów przedsiębiorstw, których proces internacjonalizacji nie kształtuje się w sposób etapowy. Szczególnie znamienne jest zjawisko leapfrogging. Oznacza ono, iż przedsiębiorstwa na początku swojego zaangażowania zagranicznego postępują zgodnie z modelami etapowymi, zaś po nabyciu doświadczenia międzynarodowego omijają niektóre etapy przechodząc do bardziej zaawansowanych form internacjonalizacji. Zbliżoną koncepcją jest internacjonalizacja symultaniczna, która podkreśla znaczenie zanikania różnic pomiędzy poszczególnymi krajami, konwergencję rynków i ujednolicanie potrzeb nabywców. Przyjęcie tej perspektywy sprzyja równoległej ekspansji na większą liczbę rynków [Gorynia i Jankowska 2008, s. 88-91, 2011, s. 54-57]. 
Innym ważnym modelem internacjonalizacji jest paradygmat eklektyczny, który został opracowany przez J. H. Dunninga pod koniec lat 70. dwudziestego wieku. Teoria ta dotyczy wyłącznie bezpośrednich inwestycji zagranicznych przedsiębiorstw. Jej pojawienie się było związane z zapotrzebowaniem na wyjaśnienie zmian w zakresie produkcji międzynarodowej, które pojawiły się w latach 60-tych i 70-tych [Dunning 1979, s. 271-272]. Koncepcja opiera się na trzech rodzajach zmiennych - przewagach, które warunkują, bezpośrednie inwestycje zagraniczne przedsiębiorstw. Są to przewagi związane z własnością (ownership specific advantages), lokalizacją (location specific advantages), a także internalizacją działalności w ramach struktur podmiotu (internalization specific advantages) [Dunning 1998, s. 45]. Dunning podkreśla, że wszystkie trzy elementy paradygmatu OLI (ownership, location, internalization) są jednakowo ważne i tylko ich łączne zastosowanie może być celowe i skuteczne [Dunning 1998, s. 45].

Pierwsza przewaga związana jest z własnością działalności podmiotu i składa się z określenia trzech części [Dunning 1988, s. 2]:

- dostępu do określonych, wartościowych zasobów,

- przewag posiadanych przez przedsiębiorstwa międzynarodowe w porównaniu z nowymi firmami lokalnymi (dostęp do szeregu zasobów, w tym wiedzy),

- zróżnicowania geograficznego oraz międzynarodowości przedsiębiorstwa.

Kolejnym czynnikiem w ramach paradygmatu eklektycznego jest lokalizacja. Według omawianej koncepcji przedsiębiorstwo będzie bardziej skłonne do uruchomienia produkcji na danym terenie, jeżeli będzie mogło wykorzystać określone czynniki produkcji czy zasoby występujące $\mathrm{w}$ tej lokalizacji. Odrębnym czynnikiem skłaniającym do uruchomienia produkcji zagranicznej mogą być bariery administracyjne w kraju funkcjonowania [Dunning 1980, s. 13, 1988, s. 4].

Przewaga związana z internalizacją jest związana z postrzeganym ryzykiem i kosztami współpracy z obcymi firmami oraz zagrożeniami i nakładami, które towarzyszą uruchomieniu zagranicznej produkcji we własnymi zakresie [Dunning 1988, s. 3]. Poziom kosztów i ryzyk w obu przypadkach zależy od charakterystyki określonego rynku.

Inną perspektywę internacjonalizacji przedsiębiorstwa prezentują modele sieciowe. W przeciwieństwie do wcześniej przedstawionych modeli nie ujmują one przedsiębiorstwa jako całkowicie niezależnego i autonomicznego bytu w kontekście procesu internacjonalizacji. Podejście sieciowe zwraca uwagę na powiązania i relacje biznesowe 
podmiotów gospodarczych z ich otoczeniem [Fonfara 2007, s. 4; Ratajczak-Mrozek 2010, s. 30].

Jednym $\mathrm{z}$ najbardziej znanych $^{52}$ modeli internacjonalizacji $\mathrm{w}$ ramach podejścia sieciowego jest model autorstwa Johansona i Mattssona [1988, s. 287-314]. Wspomniani badacze podkreślają, iż stopień internacjonalizacji firmy zależy nie tylko od powiązań samego podmiotu, ale również od internacjonalizacji sieci, w jakiej on się znajduje. Sieć jest utożsamiana z rynkiem krajowym lub określonym sektorem tegoż rynku [Johanson i Mattsson 1988, s. 287-314; Laine i Kock 2000, s. 3-5].

W kontekście określenia stopnia umiędzynarodowienia przedsiębiorstwa $\mathrm{w}$ ujęciu sieciowym można wyróżnić cztery modelowe sytuacje przedstawione na rysunku 25.

Stopień internacjonalizacji sieci

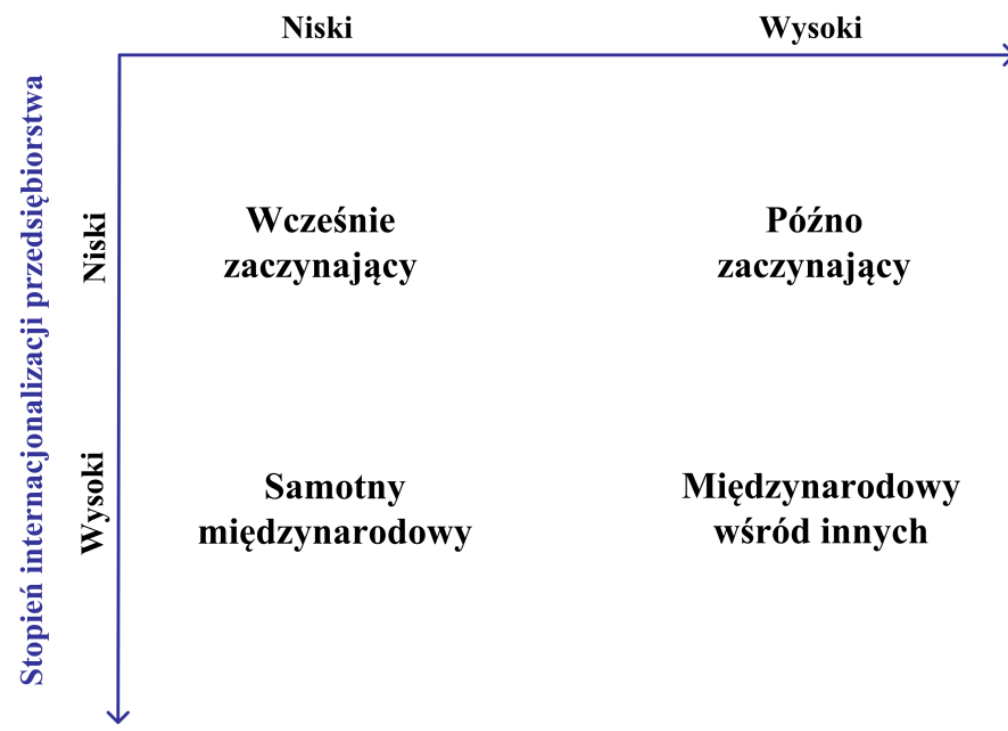

Rysunek 25. Internacjonalizacja przedsiębiorstwa i internacjonalizacja sieci.

Źródło: [Johanson i Mattsson 1988, s. 295; Laine i Kock 2000, s. 4].

Firma kształtuje i rozwija swoją pozycję na rynkach zagranicznych poprzez [Johanson i Mattsson 1988, s. 296]:

- rozszerzenie międzynarodowe (international extension) - rozwój nowych dla firmy więzi w ramach sieci narodowych,

- penetrację (penetration) - rozwoju więzi i zaangażowania zasobów w zagranicznych sieciach biznesowych,

- międzynarodową integrację (international integration) - rozwój koordynacji w ramach istniejących więzi w różnych sieciach narodowych.

\footnotetext{
${ }^{52}$ Wykorzystują go m.in. Johanson i Vahlne [2009, s. 1415].
} 
Znaczenie ujęcia sieciowego zostało również docenione przez Johansona i Vahlne [2009], którzy zmodyfikowali, dostosowując do współczesnych realiów, swój model Uppsala. Uaktualnienie wspomnianego modelu dokonane przez jego autorów było związane z rozwojem myśli teoretycznej oraz zmianami praktyk biznesowych, jakie zaszły od czasu publikacji oryginalnego modelu. Podstawą zmian jest postrzeganie środowiska biznesowego w perspektywie rozległej sieci zależności - sieci biznesowych, w przeciwieństwie do pierwotnego ujęcia zakładającego istnienie wyłącznie niezależnych podmiotów (rysunek 26) [Johanson i Vahlne 2009, s. 1411].

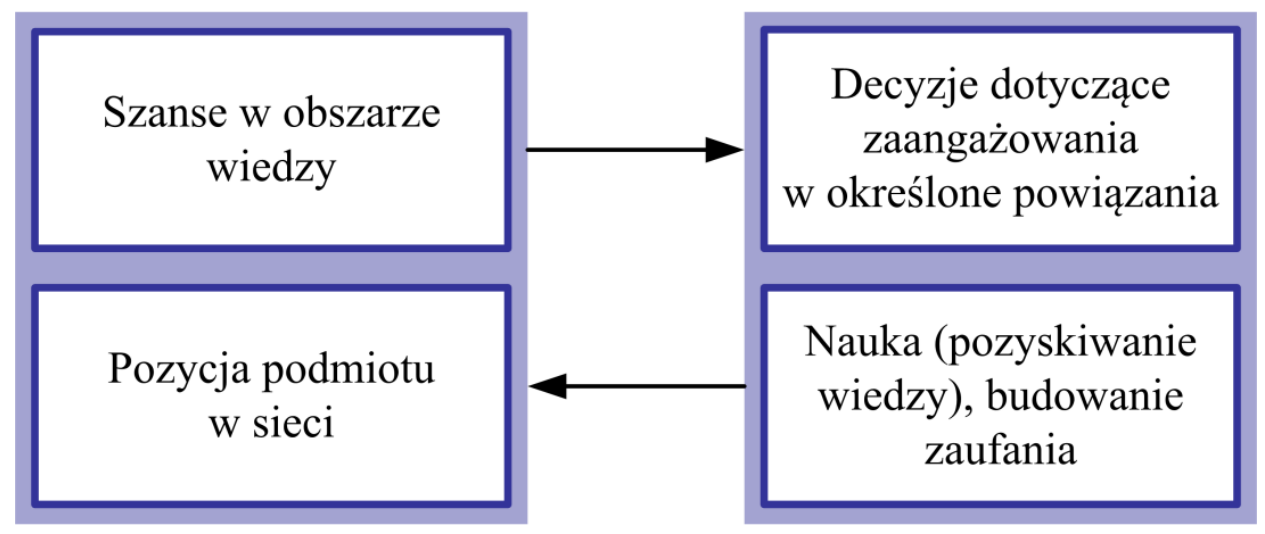

Rysunek 26. Współczesna wersja modelu Johansona i Vahlne - model internacjonalizacji sieci biznesowej z 2009r.

Źródło: [Johanson i Vahlne 2009, s. 1424].

Uwspółcześniona wersja modelu rozwija zagadnienia budowania zaufania, a także tworzenia wiedzy. Bierze ona pod uwagę fakt, iż nowe elementy wiedzy firm są tworzone w ramach ich relacji w sieciach [Johanson i Vahlne 2009, s. 1411]. W ramach omawianego modelu autorzy odpowiadają na krytykę, która pojawiała się w odniesieniu do ich podejścia do wiedzy. Badacze jednak nadal uznają wiedzę pochodzącą $\mathrm{z}$ doświadczenia przedsiębiorstwa za podstawowy element modelu procesu internacjonalizacji, również $w$ jego ujęciu sieciowym [Johanson i Vahlne 2009, s. 1416].

Uaktualniony został również paradygmat eklektyczny internacjonalizacji przedsiębiorstwa. Jego autor - J. H. Dunning uznał, iż z uwagi na przemiany, które nastąpiły w gospodarce współpraca pomiędzy firmami stała się kluczowa [Dunning 1995, s. 481, 1998, s. 48].

Inną perspektywę działalności przedsiębiorstwa na rynkach zagranicznych przedstawia model strategiczny. Powstał on na bazie krytyki teorii etapowej i eklektycznej internacjonalizacji. Omawiany model podkreśla potrzebę spojrzenia na zaangażowanie 
przedsiębiorstwa na rynkach zagranicznych z perspektywy istoty i znaczenia tego działania w kontekście strategii firmy [Witek-Hajduk 2010, s. 67]. Ujęcie to przede wszystkim koncentruje się na dużych firmach międzynarodowych. W tej koncepcji internacjonalizacja przedsiębiorstwa jest efektem przyjęcia przez podmiot określonych strategii działania uwzględniających zasoby firmy, oraz co bardzo ważne, zewnętrzne szanse i zagrożenia [Galan, Galende i Gonazalez-Benito 1999, s. 780; Fonfara 2009, s. 15], a także wielkość przedsiębiorstwa i jego doświadczenie w działalności na rynkach zagranicznych [Young 1987, s. 31, 35; Fonfara 2009, s. 15]. Model strategiczny podkreśla również kluczowe znaczenie kadry zarządzającej przedsiębiorstwa dla zaangażowania podmiotu na rynkach zagranicznych. Sposób myślenia tych osób, ich orientacja, motywacja, doświadczenie międzynarodowe, poziom wykształcenia, a także stan wiedzy o rynkach zagranicznych ma w ramach omawianej koncepcji kluczowe znaczenie dla kształtu internacjonalizacji przedsiębiorstwa. Przejawia się ono w podejściu osób zarządzających do szans rynkowych na rynkach zagranicznych [Reid 1981, s. 109, 1983b, s. 324]. Należy zaznaczyć, iż znaczącym wkładem modelu strategicznego jest uwzględnienie wagi dynamizmu sytuacji rynkowej w kontekście działalności przedsiębiorstwa poza granicami kraju [Reid 1983a, s. 49].

Omówione modele internacjonalizacji przedsiębiorstwa $\mathrm{z}$ odmiennych perspektyw wyjaśniają zachowanie firmy w procesie internacjonalizacji. W różnym stopniu uwzględniają one również zagadnienie wiedzy.

Modele etapowe (w tym w szczególności oryginalny model Uppsala) tworzą teoretyczne podstawy sekwencyjnego ujęcia zagadnienia internacjonalizacji przedsiębiorstwa i wyodrębnienia poszczególnych stadiów zaangażowania firmy na rynkach zagranicznych, które są wykorzystywane w niniejszej pracy. W ramach modeli sekwencyjnych, także w ujęciu sieciowym, ich autorzy podkreślają, iż szczególnie ważna jest wiedza wynikająca z doświadczenia (experiential knowledge) [Johanson i Vahlne 1977, s. 28, 2009, s. 1417].

Paradygmat eklektyczny szczegółowo wyjaśnia uwarunkowania związane z wykorzystaniem bezpośrednich inwestycji zagranicznych i koncentruje się raczej na przedsiębiorstwach produkcyjnych. Model nie uwzględnia zagadnienia działań firmy w obszarze wiedzy. Biorąc pod uwagę założenia tego modelu, implicite przyjmuje się w nim, że przedsiębiorstwo posiada duży potencjał w zakresie pozyskiwania, przetwarzania i wyciągania racjonalnych wniosków z informacji i wiedzy, czyli jej wykorzystywania.

Zagadnienia związane $\mathrm{z}$ wiedzą $\mathrm{w}$ kontekście ujęcia sieciowego dotyczą w przeważającej mierze transferu tego zasobu (jego charakteru i efektywności) pomiędzy uczestnikami sieci biznesowych. Ponadto, podejście sieciowe skupia się w szczególności na 
wiedzy o rynkach zagranicznych, a także wiedzy o relacjach [Hauke 2009; Małys 2013]. W uaktualnionej wersji modelu eklektycznego, podkreśla się znaczenie aktywów niematerialnych, w tym wiedzy, jako ważnego zasobu przedsiębiorstwa [Dunning 1998, s. 59]. Koncepcja ta jednak również skupia się na znaczeniu transferu tego zasobu w ramach sieci biznesowej [Dunning 1995, s. 472], nie koncentrując się przy tym na kompleksowym ujęciu procesów podmiotu w zakresie wiedzy.

Dużym osiągnięciem modelu strategicznego jest uwzględnienie dynamizmu sytuacji rynkowej i jej wpływu na charakter internacjonalizacji przedsiębiorstwa w czasie. Wspomniana koncepcja bierze pod uwagę zagadnienie wiedzy osób zarządzających firmą (liderów), która następnie wpływa na zachowanie podmiotu. W modelu strategicznym brakuje jednak całościowej analizy działań w ramach tego zasobu w odniesieniu do całego przedsiębiorstwa.

Podsumowując, należy stwierdzić, iż zagadnienie wiedzy jest obecne, lecz nie jest kompleksowo i bardzo szczegółowo ujmowane w kontekście przedstawionych modeli internacjonalizacji. Przykładowo, w modelu Uppsala przyjmuje się, iż przedsiębiorstwo egzystujące na danym rynku zagranicznym jest w stanie gromadzić i odnosić korzyści z wiedzy pochodzącej z doświadczenia będącego konsekwencją działalności na tym rynku. Nasuwa się przy tym wiele pytań. Czy każdy podmiot jest w stanie efektywnie gromadzić wiedzę rynkową? Czy poszczególne firmy podczas działalności na obcym rynku lub rynkach przekładają swoje doświadczenia na wiedzę? Czy odpowiednio zachowują wiedzę płynącą z doświadczeń? Czy korzystają ze zgromadzonej wiedzy? Przedsiębiorstwo, w przeciwieństwie do ludzi, jest pewnego rodzaju abstrakcyjnym bytem. Jego skład osobowy nie jest stały. Ponadto, nawet jeśli istnieje koordynacja działań odpowiednich elementów (np. działów czy poszczególnych osób) często nie jest ona perfekcyjna. W celu właściwego, efektywnego funkcjonowania, każda firma potrzebuje strategii zarządzania informacją i wiedzą oraz odpowiednich procesów wdrażających ją w życie. W kontekście informacji i wiedzy rynkowej przedsiębiorstwo musi posiadać odpowiednie zdolności absorpcyjne aktywnie pozyskiwać wiedzę $\mathrm{z}$ różnych źródeł (także $\mathrm{w}$ ramach relacji z innymi podmiotami), wyciągać wnioski z doświadczenia rynkowego, a następnie je zachowywać, rozpowszechniać iw odpowiednim momencie wykorzystywać. Nie są to zadania łatwe, szczególnie w większych przedsiębiorstwach. Można stąd oczekiwać, że nie wszystkie podmioty gospodarcze w równym stopniu będą posiadały zdolności do efektywnych działań w zakresie informacji i wiedzy rynkowej, co może być ważnym czynnikiem wpływającym na poziom ich konkurencyjności. 
Należy także podkreślić, iż prawie wszystkie przedstawione wcześniej modele internacjonalizacji nie biorą również pod uwagę faktu, że rynek lub rynki zagraniczne nieustannie się zmieniają. Wyjątkiem jest model strategiczny, który jednak w bardzo ograniczony sposób uwzględnia z kolei zagadnienie wiedzy.

Ujęcie dynamiczne zagadnienia wiedzy w ramach całego przedsiębiorstwa zostało zawarte w modelu przedstawionym przez autora we wcześniejszym rozdziale pracy. Podkreśla on fakt, iż podmiot, który raz pozna rynek, będzie w stanie wykorzystać swój potencjał wyłącznie przez określony czas, gdyż posiadana wiedza straci w pewnym momencie aktualność. Perspektywa przyjęta w niniejszej pracy zakłada zdobycie stałej, ciągłej, procesowej umiejętności poznawania rynku (a nie jednorazowego poznania), co w dzisiejszych czasach jest szczególnie cenne.

W odniesieniu do internacjonalizacji i uczenia się przedsiębiorstwa główny nacisk w literaturze, np. $\quad \mathrm{w}$ modelu Uppsala, kładziony jest na źródła, $\mathrm{z}$ których przedsiębiorstwa pozyskują wiedzę o rynkach zagranicznych, nie zaś ogólną, procesową i kompleksową umiejętność działań w zakresie wiedzy (nie tylko o rynkach zagranicznych, ale ze wszystkich zakresów działania podmiotu).

Należy również podkreślić, iż rozważania w modelach internacjonalizacji koncentrują się wyłącznie na wiedzy rynkowej. Pomijana jest wiedza o charakterze technicznym ${ }^{53}$. Ważnym jest jednak uwzględnienie również tego rodzaju wiedzy (w tym przede wszystkim jej rozwoju), gdyż samą wiedzą o rynku żaden podmiot gospodarczy nie wykształci przewagi konkurencyjnej. W związku $\mathrm{z}$ tym, w celu efektywnego konkurowania firmy potrzebują zarówno:

- stale aktualizowanej wiedzy o rynku,

- stale aktualizowanej, istotnej rynkowo, wiedzy technicznej.

Podstawowymi narzędziami firmy w tym zakresie są odpowiednio wykształcone, w ramach przedsiębiorstwa, procesy umożliwiające pozyskiwanie, zachowywanie, rozpowszechnianie i wykorzystywanie wiedzy rynkowej i technicznej.

W oryginalnym modelu Uppsala, jego autorzy podkreślają podział na wiedzę specyficzną dla określonego rynku oraz ogólną, która może być wykorzystana na wszystkich rynkach [Johnason i Vahlne 1977, s. 28]. Niniejsza praca dotyczy umiejętności podmiotu składających się na systematyczne, dynamiczne pozyskiwanie wiedzy o potrzebach

\footnotetext{
${ }^{53}$ Wiedzą techniczną, w perspektywie niniejszej pracy, jest wiedza dotycząca specjalizacji przedsiębiorstwa np. w przypadku firmy produkującej beton jest to wiedza dotycząca rozwiązań umożliwiających wzbogacenie oferty, ulepszenie składu produktu, usprawnienie procesów produkcyjnych czy obniżenie ich kosztów.
} 
nabywców oraz zarządzania nią. Umiejętności te polegają na procesowym, umiejętnym i kreatywnym przekształcaniu tej wiedzy w zasób niematerialny przedsiębiorstwa, co wraz z rozwojem wiedzy technicznej, ostatecznie prowadzi do ciągłego powstawania produktów i usług zapewniających firmie przewagę konkurencyjną. Innymi słowy, jest to mistrzostwo w zakresie odpowiednio ukierunkowanych procesów w zakresie wiedzy. Potencjał ten można w dużym stopniu wykorzystać na różnych rynkach. Jest to związane z faktem, iż w dłuższym okresie nie liczy się zasób a proces, gdyż omawiany zasób szybko staje się nieaktualny. W kontekście wiedzy specyficznej, należy również podkreślić, iż sama obecność na rynku czy rynkach zagranicznych może nie wystarczyć do zdobycia o nim (o nich) wiedzy. Podmiot musi posiadać zdolności procesowego pozyskiwania (i absorpcji), kreacji, magazynowania oraz wykorzystania tej wiedzy, gdyż bez tego nie przekształci się ona w przewagę konkurencyjną przedsiębiorstwa.

Podsumowując, modele etapowe, jak również i inne modele internacjonalizacji w kontekście wiedzy praktycznie pomijają zagadnienie ogólnych, procesowych zdolności przedsiębiorstwa do ciągłego przetwarzania tego zasobu w obszarze specjalizacji podmiotu (m.in. pozyskiwania i wdrażania). Modele sekwencyjne w zakresie wiedzy specyficznej, dotyczącej określonego rynku lub rynków uznają, iż w kontekście zdobywanego doświadczenia przedsiębiorstwo zawsze jest w stanie pozyskać wiedzę o danym rynku, zabsorbować ją i wykorzystać. Jest to założenie (określane w j. angielskim jako leap of faith), które zdaniem autora nie zawsze musi być spełnione. Ponadto należy podkreślić, iż poznania rynku i potrzeb nabywców nie można w dzisiejszych czasach uznać za działanie jednorazowe. Czynności w tym zakresie muszą być powtarzane w sposób ciągły z uwagi na dynamizm sytuacji rynkowej, który jest wywołany m.in. szeregiem globalnych uwarunkowań makroekonomicznych.

Powyższe rozważania implikują potrzebę wykształcenia w przedsiębiorstwie odpowiednich procesów w zakresie zarządzania informacją i wiedzą, nie tylko rynkową, ale także techniczną. Są one niezbędne w celu wykształcenia, a także utrzymywania przez przedsiębiorstwo przewagi konkurencyjnej.

Bazując na obecnej w ramach modeli sekwencyjnych, a także sieciowych etapowości zaangażowania zagranicznego przedsiębiorstwa niniejsza praca postrzega internacjonalizację jako proces. Jak podkreślali Johanson i Wiedersheim-Paul [1975, s. 306-307] etapy można definiować w różnorodny sposób. Poszczególne etapy różnicują jednak charakter i skalę zaangażowania przedsiębiorstwa na rynkach zagranicznych. W związku z tym można również 
oczekiwać, że intensywność i charakterystyka orientacji na wiedzę podmiotów na poszczególnych etapach będzie również zróżnicowana.

\subsection{Modelowe ujęcie roli orientacji na wiedzę $w$ kształtowaniu przewagi konkurencyjnej przedsiębiorstwa w procesie internacjonalizacji}

W związku z analizami teoretycznymi przeprowadzonymi w poprzednim podrozdziale (4.1.) można stwierdzić, iż modele internacjonalizacji i inne badania $\mathrm{w}$ tym zakresie nie do końca wyczerpują i wyjaśniają rolę działań w obszarze wiedzy w kontekście zaangażowania przedsiębiorstwa na rynkach zagranicznych. W tym obszarze brakuje przede wszystkim kompleksowych analiz dotyczących intensywności, charakterystyki i ukierunkowania wszystkich procesów w zakresie wiedzy w przedsiębiorstwach działających lokalnie i na poszczególnych etapach internacjonalizacji. Nie została również zbadana rola wspomnianych procesów w kształtowaniu przewagi konkurencyjnej firm działających na rynkach zagranicznych. Sytuacja ta tworzy określoną lukę badawczą.

$\mathrm{W}$ trzecim rozdziale przedstawiono model dynamicznej orientacji na wiedzę. Został on zaprezentowany $\mathrm{w}$ formie, która nie uwzględnia zaangażowania firmy na rynkach zagranicznych. W opinii autora specyficzne charakterystyki podmiotów w procesie internacjonalizacji sprawiają, iż wspomniany model może być szczególnie użyteczny w prowadzeniu działań dążących do wyjaśnienia procesu kształtowania przewagi konkurencyjnej przedsiębiorstw działających na rynkach międzynarodowych. Można przypuszczać, iż warunki środowiska w jakich one funkcjonują wymuszają na tych podmiotach bardziej intensywne działania w zakresie wiedzy w porównaniu z przedsiębiorstwami działającymi lokalnie. Jak zauważa K. Fonfara (a także szereg innych autorów) koncepcja internacjonalizacji przedsiębiorstwa opiera się na założeniu, że funkcjonowanie firmy na rynku zagranicznym zdecydowanie różni się w porównaniu z działalnością na rynku lokalnym [Fonfara 2009, s. 11]. M. Szymura-Tyc szczególnie podkreśla większą złożoność zagranicznych działań rynkowych [Szymura-Tyc 2001, s. 68, 2002, s. 7, 2012, s. 15]. Wybrane różnice w omawianym zakresie zostały zebrane w tabeli 15. 
Tabela 15. Porównanie wybranych charakterystyk działalności przedsiębiorstw działających lokalnie oraz $\mathrm{w}$ procesie internacjonalizacji.

\begin{tabular}{|c|c|c|}
\hline & $\begin{array}{c}\text { Przedsiębiorstwo działające } \\
\text { lokalnie }\end{array}$ & $\begin{array}{c}\text { Przedsiębiorstwo działające } \\
\text { na rynku lub rynkach } \\
\text { zagranicznych }\end{array}$ \\
\hline $\begin{array}{l}\text { Odległość geograficzna } \\
\text { i kulturowa od nabywcy }\end{array}$ & Mała & Duża \\
\hline $\begin{array}{c}\text { Początkowa luka wiedzy } \\
\text { w zakresie potrzeb } \\
\text { nabywców }\end{array}$ & Mała & Relatywnie duża \\
\hline $\begin{array}{l}\text { Liczba rynków (krajów), } \\
\text { na których należy śledzić } \\
\text { zmiany (w tym szczególnie } \\
\text { potrzeby nabywców) }\end{array}$ & 1 & 2 lub więcej \\
\hline Różnorodność nabywców & Najczęściej niewielka & Najczęściej wysoka \\
\hline Warunki funkcjonowania & Relatywnie stabilne & Dynamiczne, niestabilne \\
\hline $\begin{array}{c}\text { Sposób pozyskiwania wiedzy } \\
\text { o potrzebach klienta }\end{array}$ & W dużym stopniu naturalny & $\begin{array}{c}\text { Uwarunkowany procesowo, } \\
\text { utrudniony }\end{array}$ \\
\hline $\begin{array}{c}\text { Znaczenie zasobu wiedzy } \\
\text { jako elementu kształtowania } \\
\text { przewagi konkurencyjnej }\end{array}$ & Niskie - wysokie & Wysokie \\
\hline $\begin{array}{c}\text { Potencjalne tempo reakcji na } \\
\text { zmiany rynkowe }\end{array}$ & Brak większych przeszkód & Utrudniona \\
\hline Działania w zakresie wiedzy & Relatywnie łatwe & Utrudnione \\
\hline $\begin{array}{c}\text { Potencjał budowania } \\
\text { przewagi konkurencyjnej na } \\
\text { wiedzy }\end{array}$ & Mniejszy & Większy \\
\hline $\begin{array}{c}\text { Przeciętny poziom znaczenia } \\
\text { zasobu wiedzy na } \\
\text { obsługiwanych rynkach }\end{array}$ & Najczęściej niższy & Najczęściej wyższy \\
\hline Różnorodność konkurencji & Ograniczona & Najczęściej duża \\
\hline Znajomość środowiska & Najczęściej znaczna & Ograniczona \\
\hline
\end{tabular}




\begin{tabular}{|c|c|c|}
\hline $\begin{array}{c}\text { działania (m.in. kulturowego, } \\
\text { prawnego, ekonomicznego } \\
\text { oraz technicznego) }\end{array}$ & Ograniczona \\
\hline $\begin{array}{c}\text { Znajomość innych } \\
\text { podmiotów występujących } \\
\text { na rynku } \\
\text { (m.in. dystrybutorów } \\
\text { i konkurentów) }\end{array}$ & Najczęściej znaczna & \\
\hline $\begin{array}{c}\text { Komunikacja (i przepływ } \\
\text { wiedzy) }\end{array}$ & Brak większych ograniczeń & Utrudniona \\
\hline $\begin{array}{c}\text { Koszty prowadzenia } \\
\text { działalności }\end{array}$ & Niższe & Wyższe \\
\hline
\end{tabular}

Źródło: opracowanie własne na podstawie: [Fonfara 2000, s. 94-95, 2012, s. 23; Szymura-Tyc 2001, s. 68, 2002, s. 7; Daszkiewicz 2004, s. 35; Wiktor, Oczkowska i Żabikowska 2008, s. 13-14].

Jak podkreśla K. Fonfara [2012, s. 23] przedsiębiorstwo w procesie internacjonalizacji napotyka najczęściej nieznane środowisko działania pod względem ekonomicznym, technicznym, a także ekonomicznym, prawnym i kulturowym. Podobnie wygląda sytuacja w zakresie wszelkich interesariuszy podmiotu takich, jak np. konkurenci czy dystrybutorzy [Fonfara 2012, s. 23]. Organizacyjne zdolności w zakresie procesowego i systematycznego działania w zakresie pozyskiwania potrzebnej wiedzy (oraz jej uaktualniania) są więc w przypadku tych podmiotów szczególnie cenne. W związku z tym pierwszym elementem odróżniającym podmiot $\mathrm{w}$ procesie internacjonalizacji od firmy działającej lokalnie jest znaczna początkowa luka wiedzy w zakresie potrzeb nabywców. Wiedza podmiotu w tym obszarze na wczesnych etapach obecności na danym rynku zagranicznym jest zazwyczaj niewielka. W przypadku przedsiębiorstw działających lokalnie, wiedza o potrzebach nabywców jest zdobywana do pewnego stopnia naturalnie - zarząd oraz pracownicy firmy egzystują $\mathrm{w}$ danym środowisku, społeczeństwie i kulturze najczęściej przez dużą część swojego życia. Posiadają oni pewną podstawową wiedzę na temat nabywców oraz ich potrzeb i preferencji. Jest to wiedza, która najczęściej nie wystarcza całkowicie do działalności przedsiębiorstwa, lecz stanowi pewnego rodzaju ważną podstawę, której nie posiadają firmy pochodzące z zagranicy. W związku z tym muszą one w większym stopniu polegać na odpowiednich i systematycznych procedurach działania mających na celu 
poznanie rynku. Nawet, gdy przedsiębiorstwu w procesie internacjonalizacji uda się zapełnić początkową lukę wiedzy, jego docelowe grupy nabywców oraz co za tym idzie ich potrzeby i wymagania będą stale się zmieniały. Statyczne podejście do tego zagadnienia nie jest w dzisiejszych czasach wystarczające. Podmioty te muszą nadążać za trendami zmian potrzeb i popytu. Biorąc dodatkowo pod uwagę, iż przedsiębiorstwo w procesie internacjonalizacji $\mathrm{z}$ definicji działa przynajmniej na dwóch rynkach, a w wielu przypadkach liczba ta jest znacznie większa, musi ono jednocześnie śledzić zmiany w zakresie potrzeb nabywców w wielu miejscach. Wymaga to odpowiednich procesowych i systemowych rozwiązań oraz odpowiedniego zarządzania i wykorzystania zdobytej wiedzy.

Kolejnym elementem wyróżniającym firmy w procesie internacjonalizacji jest fakt, że egzystują one na styku przynajmniej dwóch gospodarek, co sprawia, że ich warunki funkcjonowania są bardzo dynamiczne i nieprzewidywalne. Jest to spowodowane chociażby różnymi walutami, których kursy mogą w nieprzewidywalny sposób zmieniać się w czasie, co powoduje dodatkowe ryzyko i koszty. Ważnym elementem są też często nietrwałe regulacje administracyjne w poszczególnych krajach, które muszą być stale śledzone, aby przedsiębiorstwo mogło właściwie funkcjonować i odpowiednio planować swoje działania. Nie bez znaczenia są też relacje polityczne, które mogą utrudniać prowadzenie działalności. Rozproszenie geograficzne aktywności przedsiębiorstwa i potrzeba równoczesnych, często zróżnicowanych strategicznych decyzji rynkowych sprawia, iż reakcje na zmiany popytu rynkowego są najczęściej wolniejsze. Jednym z podstawowych problemów utrudniających działalność w obszarze wiedzy są właśnie odległości geograficzne. Procesy w obszarze wiedzy polegają $\mathrm{w}$ dużej mierze na zasobach ludzkich. Technologie informatyczne mogą być pomocne, lecz wyłącznie w bardzo ograniczonych zastosowaniach są one skuteczne w transferze danych, informacji - czyli wiedzy jawnej. Przekazywanie na odległość tej najcenniejszej wiedzy niejawnej, będącej wyłącznie domeną ludzi, jest w dużym stopniu utrudnione. Skuteczne i efektywne zarządzanie tego typu wiedzą w rozproszonych geograficznie firmach wymaga stworzenia odpowiednich procesów i dokładnej ich realizacji.

Należy tu również przywołać zagadnienie dystansu kulturowego czy psychicznego występującego pomiędzy dwoma różnymi rynkami. Zjawiska te utrudniają przepływ informacji zarówno od rynku do firmy, jak i odwrotnie [Gorynia i Jankowska 2008, s. 78-79]. Dystans we wspomnianych zakresach może również występować w przedsiębiorstwach, które nie podejmują działalności zagranicznej. Można jednak przypuszczać, iż przeciętny poziom omawianego zjawiska $w$ podmiotach w procesie internacjonalizacji będzie wyższy, a problemy w tym zakresie większe. 
Przedsiębiorstwa zaangażowane na rynkach zagranicznych mają również większy potencjał w zakresie budowania przewagi konkurencyjnej opartej na wiedzy z uwagi na fakt, iż mogą przenosić część doświadczeń zdobytych na jednych rynkach na inne, o czym m.in. wspomina Dunning [1988, s. 1]. Tego rodzaju firmy najczęściej posiadają dużą wiedzę w zakresie organizacji procesów działania podmiotu gospodarczego (wiedza ogólna) oraz znacznie bardziej dopracowane i bogate w wiedzę produkty. Jak podkreśla Daszkiewicz [2004, s. 35], mogą one częściowo wiedzą ogólną nadrabiać brak znajomości rynków lokalnych. Przenoszenie wiedzy z jednego rynku na drugi nie jest jednak działaniem łatwym i z pewnością nie odbywa się automatycznie - wymaga to wykształcenia odpowiednich procesów i aktywnego działania w tym obszarze. Należy podkreślić, że najczęściej nie jest możliwe wykorzystanie całości wiedzy $\mathrm{z}$ uwagi na różnorodne warunki działania oraz odmienne charakterystyki rynków.

Podmioty gospodarcze zaangażowane na rynkach zagranicznych mają przeciętnie łatwiejszy dostęp do tańszych czynników produkcji, siły roboczej oraz lepsze możliwości pozyskiwania kapitału (obecność na większej liczbie rynków). W celu skutecznego wykorzystania tych potencjalnych korzyści potrzebują one odpowiednich procesów w zakresie wiedzy.

Innym bardzo ważnym aspektem są podmioty konkurencyjne wobec przedsiębiorstw zaangażowanych na rynkach zagranicznych. W wielu przypadkach są one zupełnie inne niż na rynkach lokalnych, często silniejsze, różnorodne i bardziej dynamiczne. W celu efektywnego konkurowania firma musi posiadać silną i stabilną przewagę konkurencyjną. W gospodarce opartej na wiedzy najlepszą jej podstawą jest stale procesowo uaktualniona wiedza firmy.

Daszkiewicz zwraca uwagę na problemy i bariery komunikacyjne oraz związane z nimi koszty pojawiające się w momencie zaangażowania zagranicznego przedsiębiorstwa. Wynikają one m.in. z różnic językowych oraz kulturowych w tym podejścia nabywców do podmiotów zagranicznych. Dodatkowe koszty mogą być również powodowane problemami związanymi z zarządzaniem, brakiem objęcia przedsiębiorstwa rządową infrastrukturą czy innymi podobnymi barierami i problemami operacyjnymi [Daszkiewicz 2004, s. 35].

W związku z przedstawionymi czynnikami charakteryzującymi działalność omawianych podmiotów gospodarczych, firmy w procesie internacjonalizacji muszą aktywnie dostosowywać się do określonych, różnorodnych zastanych na poszczególnych rynkach warunków. W szczególności ważna jest sprawna i skuteczna identyfikacja 
i uzupełnianie braków w obrębie zasobu wiedzy. Znaczenie szybkich i efektywnych działań w obszarze zarządzania zasobem wiedzy jest podstawą codziennej działalności przedsiębiorstw w procesie internacjonalizacji, a przede wszystkim kluczowym elementem utrzymania ich przewagi konkurencyjnej.

Podsumowując, można przypuszczać, iż przedstawione powyżej różnice w znaczący sposób wpływają na działalność przedsiębiorstwa w procesie internacjonalizacji w odniesieniu do działań związanych z wiedzą. Przede wszystkim, należy zaznaczyć, iż rozwój produktu w kontekście zmian potrzeb rynkowych musi być wielotorowy w związku z większą liczbą obsługiwanych rynków (minimum 2). W odniesieniu do modelu dynamicznej orientacji na wiedzę w kształtowaniu przewagi konkurencyjnej przedsiębiorstwa, przedstawionego w poprzednim rozdziale (rysunek 21), powoduje to powstawanie większej liczby spiral (rysunek 27) ${ }^{54}$. Jest to związane z faktem, iż poziom zaawansowania oferty wymagany do utrzymania przewagi konkurencyjnej przedsiębiorstwa na różnych rynkach, a także tempo jego zmian, są inne w zależności od charakterystyk poszczególnych rynków (rysunek 27) ${ }^{55}$. Jak wcześniej wspomniano obecność na wielu rynkach umożliwia jednak transfer wiedzy ogólnej pomiędzy poszczególnymi rynkami. W ostatecznym rozrachunku sytuacja implikuje potrzebę zaawansowanych i skoordynowanych działań w zakresie wiedzy.

Duże znaczenie dla podmiotu zaangażowanego zagranicznie ma jednak wielotorowy i przez to skomplikowany rozwój specyficznej wiedzy lokalnej. Przykładem prób stałego, procesowego pozyskiwania lokalnie ukierunkowanej wiedzy jest firma Toyota. Posiada ona wiele rozproszonych po całym świecie ośrodków badań i rozwoju [Hauke 2008, s. 1], czego efektem jest bardzo dobra (i utrzymywana od lat) pozycja przedsiębiorstwa na rynku motoryzacyjnym charakteryzującym się wysoką konkurencją [USATODAY 2013, s. 1; FT 2013, s. 1]. Innym przykładem sukcesu skutecznych działań w zakresie wiedzy w kontekście internacjonalizacji jest firma McDonald's. Podmiot ten zawdzięcza swoją przewagę konkurencyjną na wielu rynkach odpowiedniemu dostosowaniu oferty do potrzeb nabywców na różnych rynkach, przy równoczesnym globalnym wykorzystaniu i rozwoju wiedzy ogólnej.

\footnotetext{
${ }^{54}$ Graficzna prezentacja koncepcji dynamicznych działań w zakresie wiedzy w kształtowaniu przewagi konkurencyjnej przedsiębiorstwa działającego na jednym rynku została zaprezentowana na rysunku 21.

${ }^{55}$ Zarówno na rysunkach 21 , jak i 27 dla uproszczenia wykorzystano linie proste w celu odzwierciedlenia hipotetycznego, wymaganego w celu utrzymania przewagi konkurencyjnej, poziomu zaawansowania oferty przedsiębiorstwa na poszczególnych rynkach. Z dużym prawdopodobieństwem jednak, w rzeczywistości gospodarczej, kształt tych linii będzie znacznie bardziej nieregularny i urozmaicony.
} 


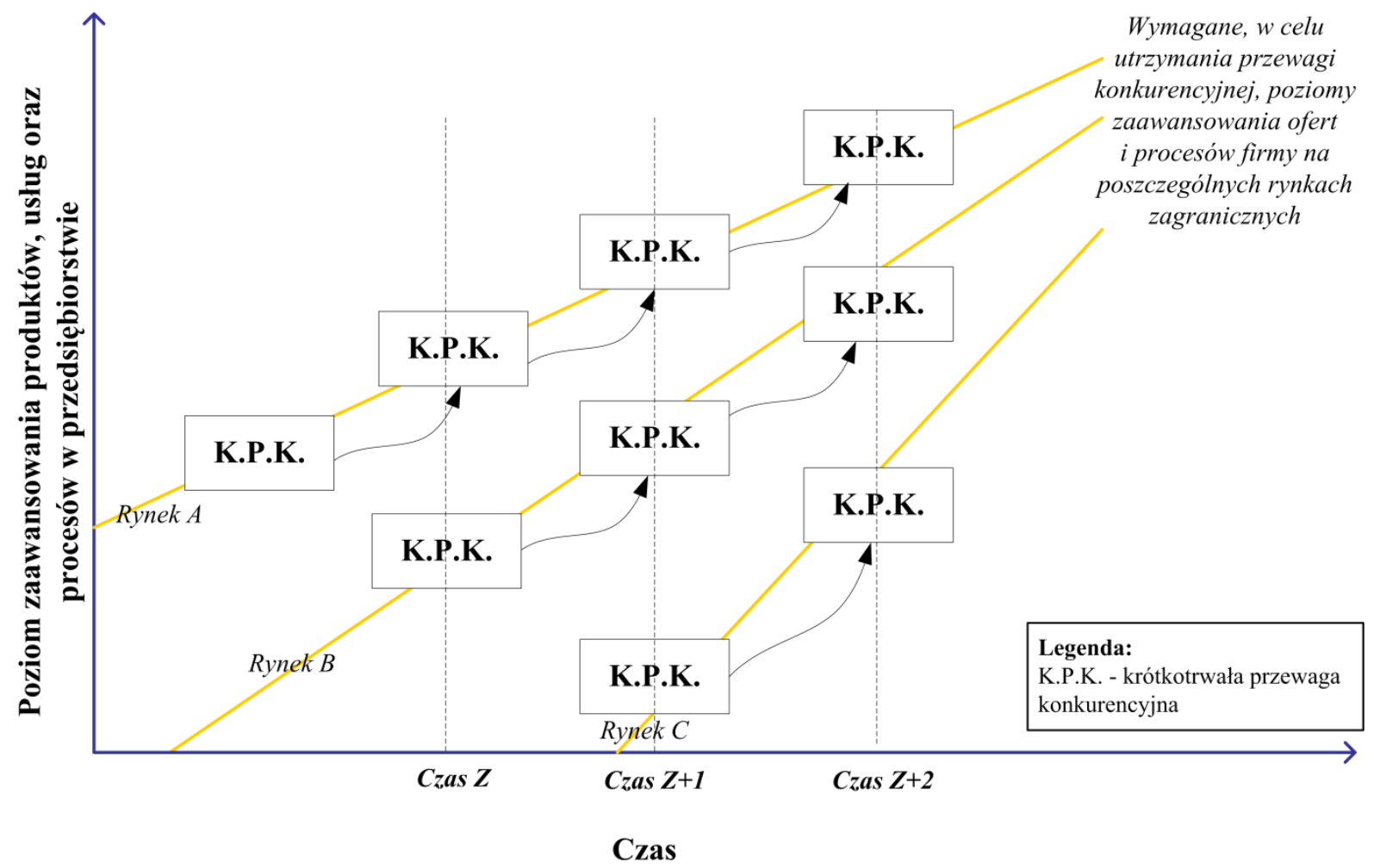

Rysunek 27. Model dynamicznej orientacji na wiedzę - ujęcie długoterminowe dla przedsiębiorstwa działającego na trzech rynkach zagranicznych.

Źródło: opracowanie własne.

Z uwagi na wcześniej zaprezentowane charakterystyki środowiska działania przedsiębiorstwa funkcjonującego na rynkach zagranicznych, procesy w ramach przedstawionego w poprzednim rozdziale modelu w tego typu podmiotach muszą zachodzić szybciej i intensywniej. Jest to związane ze skomplikowanym przebiegiem jednoczesnego kształtowania i utrzymania przewagi konkurencyjnej na wielu różnorodnych rynkach. $\mathrm{W}$ związku $\mathrm{z}$ tym można przypuszczać, iż w szczególności $\mathrm{W}$ firmach $\mathrm{W}$ procesie internacjonalizacji niezbędne są systemowe działania $\mathrm{w}$ zakresie pozyskiwania, kreacji, wykorzystania i ochrony wiedzy, które aby były użyteczne, muszą być ukierunkowane rynkowo (orientacja na wiedzę przedsiębiorstwa działającego w warunkach gospodarki rynkowej). Można więc oczekiwać, że podmioty przejawiające wymienione tendencje na niskim poziomie nie będą $\mathrm{W}$ stanie rozpocząć i utrzymywać działalności na rynkach zagranicznych. $\mathrm{Na}$ tej podstawie można więc przypuszczać, że ważnym czynnikiem w funkcjonowaniu podmiotów prowadzących działalność zagraniczną jest wysoka 
intensywność procesów związanych $\mathrm{z}$ wiedzą - wyższa niż w przypadku podmiotów działających lokalnie, których uwarunkowania działalności są mniej skomplikowane. W związku z powyższymi rozważaniami została sformułowana następująca hipoteza:

H1: Przedsiębiorstwa działajace na rynkach zagranicznych sq przeciętnie bardziej zorientowane na wiedzę w porównaniu do przedsiębiorstw działających lokalnie.

Heterogeniczność form działalności przedsiębiorstwa $\mathrm{w}$ procesie internacjonalizacji wiąże się z różnorodnym zaangażowaniem firmy na rynkach zagranicznych, zróżnicowaną złożonością procesów zachodzących w przedsiębiorstwie, a także potrzebą coraz szybszego przystosowywania do zmieniających się warunków i stawiania czoła coraz groźniejszym konkurentom. Można przypuszczać, że większe zaangażowanie w proces internacjonalizacji (rozumiane w aspekcie czasu, formy, a także udziału sprzedaży zagranicznej w sprzedaży firmy ogółem) może sprzyjać osiąganiu przez podmiot wyższych poziomów orientacji na wiedzę. Dłuższy okres zaangażowania przedsiębiorstwa w proces internacjonalizacji może wpływać na wzrost orientacji przedsiębiorstwa na wiedzę ze względu na większe doświadczenie firmy i świadomość wagi tego czynnika. Można oczekiwać, iż wyższy udział sprzedaży przedsiębiorstwa na rynkach zagranicznych w porównaniu do jego sprzedaży ogółem, implikuje większą koncentrację firmy na procesie internacjonalizacji i stwarza to większe możliwości pozyskiwania i wykorzystywania zasobu wiedzy. Można również podejrzewać, że w zależności od wykorzystania mniej lub bardziej zaawansowanej formy sposobu działalności przedsiębiorstwa na rynku zagranicznym - istnieją różnice w poziomie badanych procesów. W związku z tym została sformułowana poniższa hipoteza:

H2: Przedsiębiorstwa wraz $z$ większym zaangażowaniem $w$ proces internacjonalizacji sa przeciętnie bardziej zorientowane na wiedzę.

Z uwagi na wcześniej przedstawione i omówione charakterystyki przedsiębiorstwa zaangażowanego na rynkach zagranicznych (powszechne luki wiedzy w wielu obszarach, dynamiczne środowisko funkcjonowania, intensywną, najczęściej mniej znaną konkurencję, wzrost znaczenia zasobu wiedzy w procesach gospodarczych) można podejrzewać, że wysoka intensywność rynkowo ukierunkowanych, systemowych działań w zakresie wiedzy (orientacji na wiedzę) może pozytywnie wpływać na pozycję konkurencyjną podmiotu zaangażowanego na rynkach zagranicznych. Stąd została sformułowana hipoteza: 
H3: Wyższy poziom orientacji na wiedzę przedsiębiorstw $w$ procesie internacjonalizacji wpływa pozytywnie na kształtowanie przewagi konkurencyjnej podmiotów zaangażowanych zagranicznie.

Ponadto, coraz powszechniejsze i częstsze zaangażowanie na rynkach zagranicznych różnego rodzaju podmiotów oraz podkreślana przez wielu autorów wzrastająca rola wiedzy i procesów z nią związanych, jako najważniejszego zasobu przedsiębiorstwa, decydującego o jego przewadze konkurencyjnej sprawiają, że warto zbadać zagadnienie orientacji na wiedzę $\mathrm{w}$ przedsiębiorstwach $\mathrm{w}$ procesie internacjonalizacji.

Podsumowując, na podstawie rozważań teoretycznych można oczekiwać, iż przedsiębiorstwa $\mathrm{w}$ procesie internacjonalizacji są bardziej zorientowane na wiedzę niż podmioty działające lokalnie (hipoteza 1). Pozytywna, empiryczna weryfikacja tej hipotezy może być podstawą do dalszych badań. Zakładając potwierdzoną empirycznie zgodność z rzeczywistością hipotezy pierwszej można podejrzewać, że przedsiębiorstwa wraz $\mathrm{z}$ większym zaangażowaniem w proces internacjonalizacji są bardziej zorientowane na wiedzę (hipoteza 2). Ponadto, można również oczekiwać, iż wyższy poziom orientacji na wiedzę przedsiębiorstwa w procesie internacjonalizacji wpływa pozytywnie na kształtowanie jego przewagi konkurencyjnej (hipoteza 3).

Opisane zależności wstępujące pomiędzy hipotezami zostały zaprezentowane graficznie na rysunku 28. 


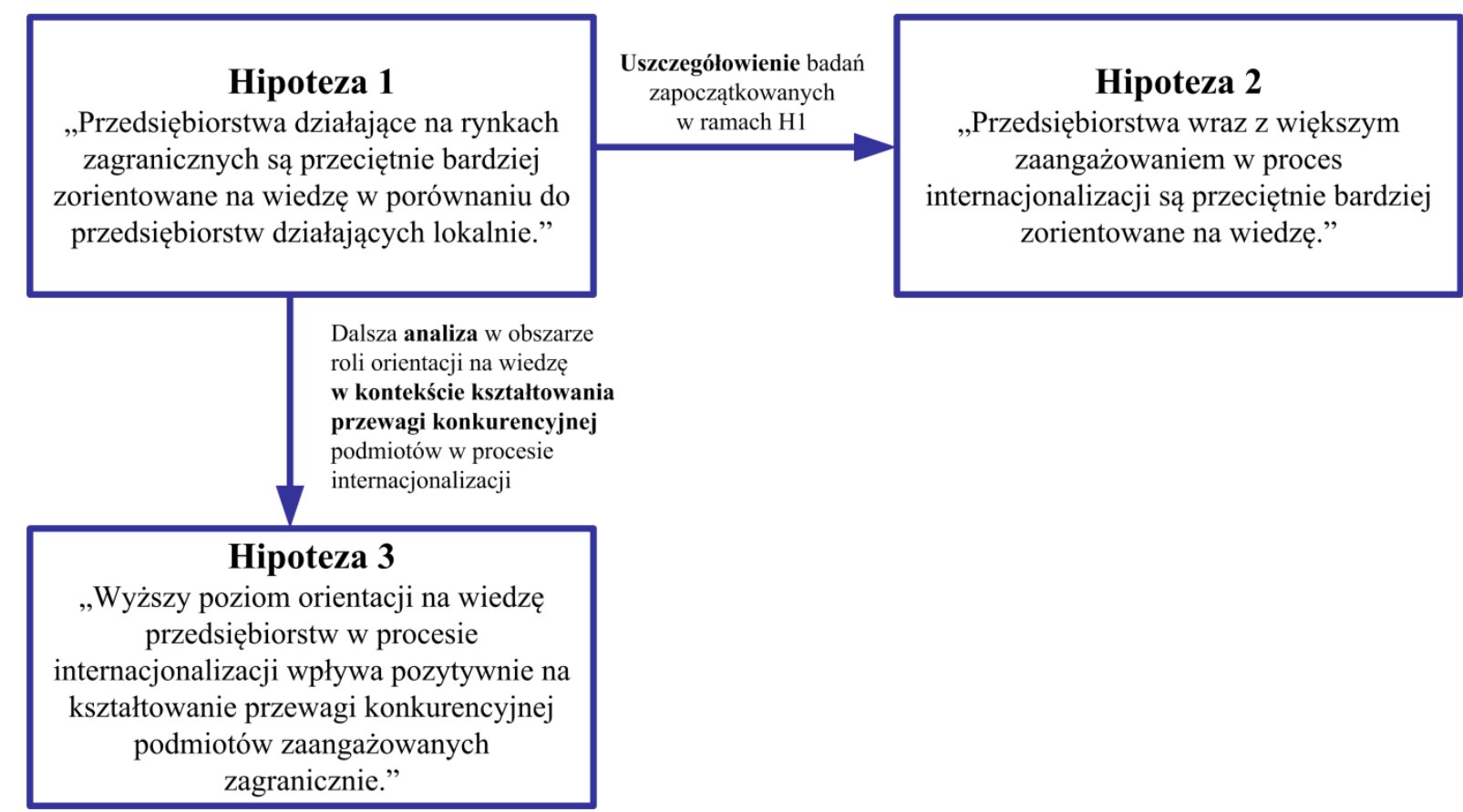

Rysunek 28. Graficzna ilustracja zależności występujących pomiędzy poszczególnymi hipotezami weryfikowanymi w pracy.

Źródło: opracowanie własne.

\subsection{Podsumowanie i wnioski}

W rozdziale czwartym omówiono najpowszechniejsze modele internacjonalizacji przedsiębiorstwa: modele etapowe (w tym model Uppsala), paradygmat eklektyczny, modele sieciowe oraz model strategiczny. Stwierdzono, iż zagadnienie wiedzy jest obecne, lecz nie jest kompleksowo i bardzo szczegółowo ujmowane w kontekście przedstawionych teorii internacjonalizacji. Zauważono, iż prawie wszystkie zaprezentowane wcześniej modele nie biorą pod uwagę faktu, że rynek lub rynki zagraniczne nieustannie się zmieniają. Wyjątkiem jest model strategiczny, który jednak w bardzo ograniczony sposób uwzględnia z kolei zagadnienie wiedzy.

Specyficzne charakterystyki podmiotów w procesie internacjonalizacji sprawiają, iż zaprezentowany, w ramach rozdziału trzeciego pracy, opracowany przez autora model dynamicznej orientacji na wiedzę, może być szczególnie użyteczny w prowadzeniu działań dążących do wyjaśnienia procesu kształtowania przewagi konkurencyjnej przedsiębiorstw zaangażowanych na rynkach zagranicznych. Jest to związane $\mathrm{z}$ warunkami środowiska, w jakim funkcjonują omawiane firmy. Warunki te wymuszają na przedsiębiorstwach bardziej intensywne działania w zakresie wiedzy w porównaniu z tymi, działającymi lokalnie.

$\mathrm{W}$ związku $\mathrm{z}$ tym podjęto działania $\mathrm{w}$ celu przystosowania, zaproponowanego w rozdziale trzecim, dynamicznego modelu orientacji na wiedzę do warunków 
funkcjonowania przedsiębiorstw w procesie internacjonalizacji. Przede wszystkim, należy zaznaczyć, iż rozwój produktu w kontekście zmian potrzeb rynkowych musi być wielotorowy w związku z większą liczbą obsługiwanych rynków. W odniesieniu do zaproponowanego modelu powoduje to powstawanie większej liczby spiral. Jest to związane $\mathrm{z}$ faktem, iż poziom oferty wymagany do utrzymania przewagi konkurencyjnej przedsiębiorstwa na różnych rynkach, a także tempo jego zmian, są inne w zależności od charakterystyk poszczególnych rynków. Innym aspektem jest fakt, iż szeroka obecność międzynarodowa umożliwia transfer wiedzy ogólnej pomiędzy poszczególnymi rynkami. W ostatecznym rozrachunku sytuacja implikuje potrzebę zaawansowanych i skoordynowanych działań w zakresie wiedzy.

Rozważania w ramach rozdziału czwartego stały się podstawą sformułowania trzech hipotez badawczych niniejszej pracy. 


\section{Zależność pomiędzy orientacją na wiedzę przedsiębiorstwa w procesie internacjonalizacji a jego przewagą konkurencyjną - wyniki badań empirycznych}

\subsection{Metodologia}

Celem rozprawy jest wyjaśnienie roli orientacji na wiedzę, czyli rynkowo ukierunkowanych działań $\mathrm{w}$ obszarze tego zasobu, w przedsiębiorstwach $\mathrm{w}$ procesie internacjonalizacji w kształtowaniu ich przewagi konkurencyjnej. W związku ze złożonością celu głównego ustalono trzy cele szczegółowe:

- porównanie intensywności i charakterystyki procesów w zakresie wiedzy oraz poziomu orientacji rynkowej przedsiębiorstw działających lokalnie oraz podmiotów w procesie internacjonalizacji (rysunek 29),

- określenie intensywności i charakterystyki procesów dotyczących wiedzy oraz poziomu orientacji rynkowej przedsiębiorstw na różnych etapach zaangażowania zagranicznego (w aspekcie $\mathrm{czasu}^{56}$, formy internacjonalizacji, a także udziału sprzedaży zagranicznej w sprzedaży firmy ogółem) (rysunek 30),

- ustalenie, w jakim stopniu intensywność procesów w zakresie wiedzy wraz z poziomem orientacji rynkowej przedsiębiorstw zaangażowanych na rynkach zagranicznych wpływają na kształtowanie przewagi konkurencyjnej tego typu podmiotów (rysunek 31).

Dla postawionych celów rozprawy opracowano następujące schematy koncepcyjne badań przedstawione na rysunkach 29, 30 i 31 . 56 Okres działalności przedsiębiorstwa na rynkach zagranicznych - mierzony w latach, sumaryczny okres
zaangażowania podmiotu gospodarczego, w dowolnej formie i zakresie, na rynkach zagranicznych. 


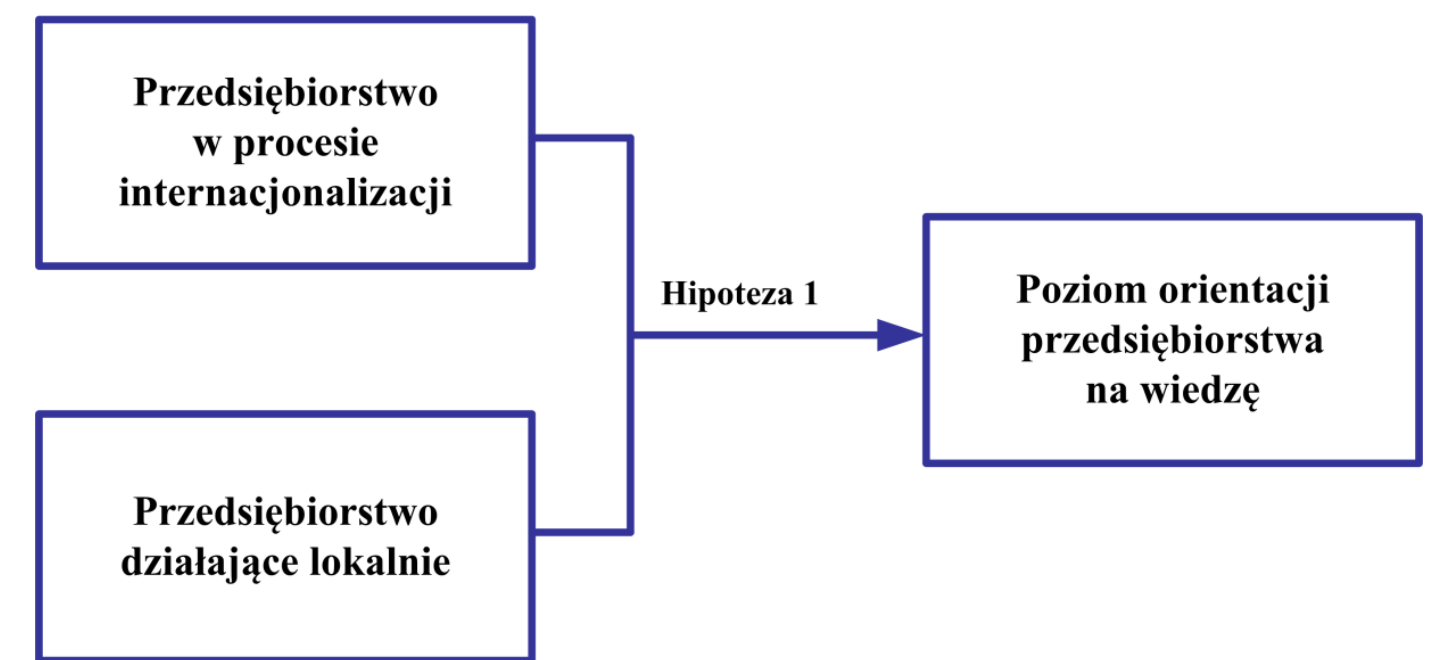

Rysunek 29. Schemat koncepcyjny badań (model badawczy) - porównanie poziomu orientacji na wiedzę przedsiębiorstw działających lokalnie i podmiotów w procesie internacjonalizacji. Źródło: opracowanie własne.

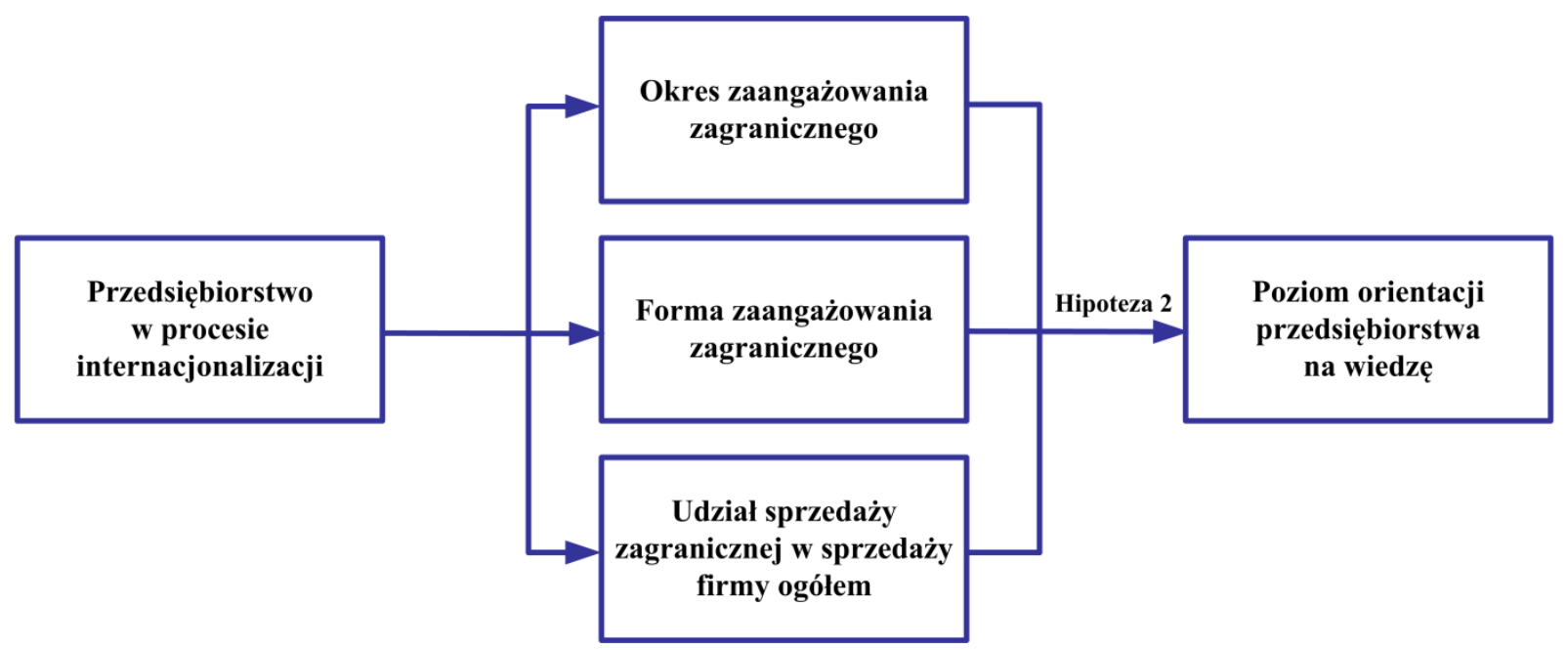

Rysunek 30. Schemat koncepcyjny badań (model badawczy) - porównanie poziomu orientacji na wiedzę przedsiębiorstw na poszczególnych etapach internacjonalizacji z wykorzystaniem trzech kryteriów poziomu zaangażowania zagranicznego.

Źródło: opracowanie własne.

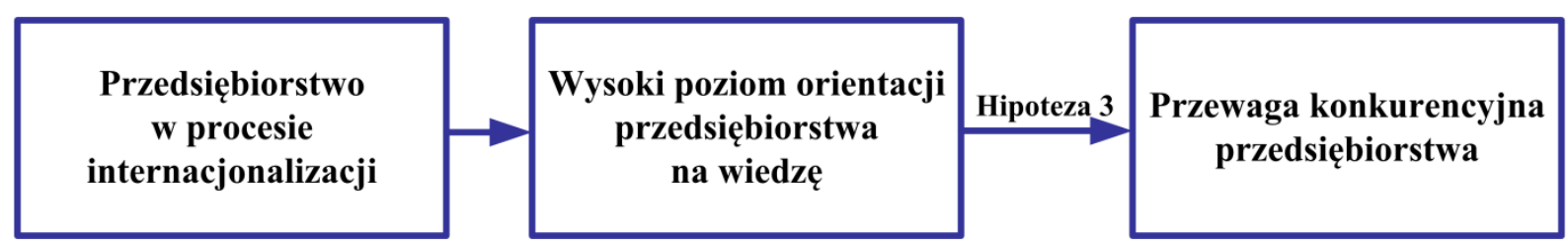

Rysunek 31. Schemat koncepcyjny badań (model badawczy) - rola orientacji na wiedzę w kształtowaniu przewagi konkurencyjnej przedsiębiorstwa w procesie internacjonalizacji.

Źródło: opracowanie własne. 
W celu przetestowania wcześniej zaprezentowanych hipotez i realizacji celów rozprawy, autor zdecydował się na zastosowanie badań ilościowych oraz jakościowych ${ }^{57}$. Analizy ilościowe zostały przeprowadzone za pomocą kwestionariusza ankiety przesyłanego drogą elektroniczną oraz tradycyjną - pocztową. W ramach badań jakościowych zostały wykorzystane studia przypadków.

Przedmiotem wyżej wymienionych analiz były intensywność i charakterystyka działań w zakresie wiedzy przedsiębiorstw, poziom ich orientacji rynkowej, a także wpływ wymienionych czynników na kształtowanie przewagi konkurencyjnej badanych podmiotów. Poziomem analizy empirycznej jest przedsiębiorstwo. Zakres czasowy badań ilościowych obejmował drugi i trzeci kwartał 2012 roku oraz początek 2013 roku. Studia przypadku zostały przeprowadzone w okresie od czerwca do sierpnia 2013 roku. Badania dotyczyły podmiotów gospodarczych $\mathrm{w}$ procesie internacjonalizacji prowadzących działalność na terenie Polski.

W ramach hipotezy pierwszej zmienną niezależną stanowił fakt zaangażowania przedsiębiorstwa $\mathrm{w}$ proces internacjonalizacji, a zmienną zależną poziom orientacji firmy na wiedzę (intensywność procesów w zakresie wiedzy podmiotu oraz poziom jego orientacji rynkowej). W przypadku hipotezy drugiej, która była pogłębieniem hipotezy pierwszej, badano wyłącznie podmioty w procesie internacjonalizacji. Zmienną niezależną stanowił etap procesu internacjonalizacji firmy mierzony za pomocą okresu zaangażowania zagranicznego przedsiębiorstwa, forma internacjonalizacji oraz udział sprzedaży zagranicznej w sprzedaży firmy ogółem. Zmienną zależną, podobnie jak whipotezie pierwszej stanowił poziom orientacji przedsiębiorstwa na wiedzę. W przypadku hipotezy trzeciej analizy również dotyczyły wyłącznie firm zaangażowanych zagranicznie. Zmienną niezależną stanowił poziom orientacji przedsiębiorstwa na wiedzę, zaś zmienną zależną istnienie lub brak przewagi konkurencyjnej podmiotu względem najbliższych konkurentów.

Centralnym elementem niniejszej pracy jest orientacja przedsiębiorstwa na wiedzę. Jak wcześniej wyjaśniono, podmiot charakteryzujący się wysoką orientacją na wiedzę posiada rynkowo ukierunkowane procesy $\mathrm{w}$ zakresie wiedzy. Pojęcie orientacji na wiedzę jest pojęciem eklektycznym, składającym się z dwóch czynników składowych. W związku z tym autor niniejszej pracy nie wykorzystuje jednego miernika tego zjawiska, lecz zakłada

\footnotetext{
${ }^{57}$ Badanie światowych publikacji naukowych z obszaru najpowszechniejszej koncepcji w omawianej tematyce zarządzania wiedzą - przeprowadzone przez Dwivedi i in. [2011, s. 52, 53] pokazuje, że jednoczesne wykorzystanie ilościowych, jak i jakościowych metod badawczych jest powszechnym podejściem w ramach podejmowanej problematyki.
} 
iż podmiot zorientowany na wiedzę charakteryzuje się jednocześnie wysoką orientacją rynkową oraz posiada intensywne działania w zakresie wiedzy. Takie podejście umożliwia wykorzystanie powszechnie uznanego w literaturze miernika orientacji na wiedzę stworzonego przez Narvera i Slatera [1990]. W literaturze nie istnieje jeden powszechnie uznany miernik intensywności działań podmiotu dotyczących wiedzy, lecz po analizie wielu dostępnych pozycji literaturowych było możliwe stworzenie potrzebnego, ugruntowanego w literaturze narzędzia. Opis opracowanego miernika zostanie zaprezentowany w dalszej części pracy.

Kwestionariusz ankiety wykorzystywany w badaniach ilościowych w pracy został opracowany w dwóch wersjach - tradycyjnej (papierowej) oraz elektronicznej. Oba zawierały identyczne pytania. Jego długość (mierzona w formie tradycyjnej) wynosiła sześć stron, na których rozmieszczone zostały pytania pogrupowane w siedem następujących sekcji:

1. Pozyskiwanie wiedzy.

2. Rozpowszechnianie wiedzy - zagadnienia ogólne.

3. Rozpowszechnianie wiedzy - technologie informatyczne.

4. Wdrażanie oraz otwartość przedsiębiorstwa na wiedzę.

5. Orientacja rynkowa.

6. Poziom konkurencyjności przedsiębiorstwa w porównaniu do najbliższych konkurentów.

7. Charakterystyka przedsiębiorstwa.

Omawiany kwestionariusz ankiety został zbudowany przez autora niniejszej pracy ${ }^{58}$ na podstawie źródeł literaturowych, w tym w szczególności Wang i in. [2008, s. 118-122], Mazur, Rószkiewicz i Strzyżewska [2008, s. 150-155], Darroch i McNaughton [2003, s. 581] oraz kwestionariuszy ankiety $\mathrm{z}$ publikacji Fonfara [2009, 2012] (dokładne źródła poszczególnych pytań zostały wyszczególnione w załączniku 5). Szczegółowa charakterystyka poszczególnych sekcji kwestionariusza ankiety wykorzystywanego w badaniach ilościowych została przedstawiona w załączniku 2.

\footnotetext{
${ }^{58} \mathrm{~W}$ literaturze nie ma jednego, powszechnie uznanego, narzędzia wykorzystywanego do badania przejawów czy charakterystyki działań przedsiębiorstw w zakresie wiedzy, nie istnieją też tego typu narzędzia w zakresie poszczególnych teorii w zakresie wiedzy - jak podkreśla Kłak [2010, s. 49]: „Zarządzanie wiedzą to stosunkowo młoda dziedzina zarządzania o bardzo różnorakich korzeniach, która jeszcze nie ma wykrystalizowanej metodologii”. W przypadku orientacji rynkowej przedsiębiorstwa sytuacja wygląda inaczej - istnieją przetestowane i sprawdzone zestawy pytań pozwalające określić poziom rynkowego ukierunkowania podmiotu, w związku $\mathrm{z}$ tym w niniejszej pracy został zastosowany miernik opracowany przez Narvera i Slatera, zaadoptowany przez Hooley i in. [2000, s. 279].
} 
W badaniu w zdecydowanej większości pytań wykorzystano pięciostopniową skalę Likerta $^{59}$ (wyjątkiem była ostatnia sekcja, dotycząca charakterystyki przedsiębiorstwa). Celem harmonizacji skali było ułatwienie respondentom szybkiego zrozumienia sposobu udzielania odpowiedzi, co miało na celu minimalizację efektu zniechęcenia respondenta i przełożenie się na wyższą zwrotność oraz jakość pozyskiwanych informacji. Jak podkreśla Ratajczak-Mrozek przyjęcie takiego sposobu i skali pozwala na porównywanie rezultatów pochodzących od podmiotów o różnorodnej charakterystyce oraz dodatkowo powiększa gotowość w zakresie udzielania przez respondentów odpowiedzi [Ratajczak-Mrozek 2008, s. 219].

W sekcji pierwszej (źródła wiedzy) i trzeciej (technologie informatyczne) respondent miał do wyboru pięć następujących opcji: 1 - brak wykorzystania (źródła wiedzy) lub nie znam lub nie używamy (technologie informatyczne) ${ }^{60}, 2$ - niewielkie wykorzystanie, 3 przeciętne wykorzystanie, 4 - wysokie wykorzystanie, 5 - bardzo wysokie wykorzystanie.

W sekcjach drugiej, czwartej i piątej osoba wypełniająca ankietę wybierała, w jakim stopniu zgadza się przedstawionymi stwierdzeniami odnoszącymi się do swojej firmy: 1 całkowicie się nie zgadzam, 2 - nie zgadzam się, 3 - ani się nie zgadzam, ani się zgadzam, 4 - zgadzam się, 5 - całkowicie się zgadzam.

W sekcji szóstej, dotyczącej oceny przewagi konkurencyjnej przedsiębiorstwa, wykorzystano następującą skalę: 1 - znacznie gorszy, 2 - gorszy, 3 - prawie taki sami, 4 lepszy, 5 - znacznie lepszy.

Znaczącym problemem w zakresie zagadnienia przewagi konkurencyjnej przedsiębiorstwa jest pomiar pozycji konkurencyjnej podmiotu. Jak zaznacza Barney najbardziej popularnym sposobem jej pomiaru są metody księgowe. Wykorzystują one dane finansowe, które są dla wielu firm publicznie dostępne (istnieje obowiązek ich publikowania). Podstawą tego rodzaju metod jest analiza wskaźnikowa. Dostarcza ona wielu informacji o przedsiębiorstwie, lecz posiada także znaczące wady. Przede wszystkim możliwy jest

\footnotetext{
${ }^{59}$ Wybór pięciostopniowej wersji skali Likerta był związany z faktem, iż jest ona najpowszechniej stosowaną w praktyce jej wersją, do której większość osób jest prawdopodobnie przyzwyczajona. 7-stopniowa skala jest bardziej szczegółowa, lecz może być mniej przyjazna dla respondenta.

${ }^{60}$ Opcje do wyboru w sekcjach pierwszej i trzeciej były takie same za wyjątkiem opcji pierwszej. W przypadku sekcji trzeciej (technologie informatyczne) intencją autora była klaryfikacja sytuacji, w której respondent nie wie czy dana technologia informatyczna jest stosowana $\mathrm{w}$ jego przedsiębiorstwie, gdyż może nie być specjalistą w tym zakresie. W związku z tym przy opisie opcji „„” dodano również deskrypcję „nie znam”. Decyzja o jej dodaniu była związana $\mathrm{z}$ potencjalnym zagrożeniem zniechęcenia i porzucenia wypełniania ankiety przez respondenta spowodowanym przez brak wiedzy na temat stosowania danej technologii w organizacji. Ponadto, w momencie gdy respondent nie zna danej technologii, z dużym prawdopodobieństwem nie jest ona powszechnie i efektywnie stosowana w podmiocie, stąd powinien zaznaczyć on pierwszą opcję w danym pytaniu.
} 
wpływ kadry zarządzającej na dostępne wartości finansowe poprzez m.in. wybór różnego rodzaju metod amortyzacji lub liczenia np. zapasów firmy [Barney 2011, s. 18-21]. Inną słabością analizy wskaźnikowej jest możliwość (do pewnego stopnia) manipulowania danymi finansowymi, co przy zastosowaniu standardowych wskaźników może utrudniać wyciągnięcie właściwych wniosków. Tę wadę w dużej mierze można wyeliminować poprzez dokładną i kompleksową analizę danych finansowych przedsiębiorstw, lecz przy badaniu ilościowym obejmującym znaczną próbę przedsiębiorstw jest to praktycznie niemożliwe do wykonania.

Kolejną wadą mierników finansowych jest fakt, że prawie całkowicie omijają one wartości niematerialne i prawne przedsiębiorstwa [Barney 2011, s. 21]. W odniesieniu do dzisiejszych zmian - coraz bardziej powszechnej gospodarki opartej na wiedzy - wartości te stają się, co najmniej, jednymi z ważniejszych elementów tworzenia wartości dodanej.

Przedstawione zalety finansowych mierników skłaniają do ich zastosowania, lecz ich wady wymagają uzupełnienia tych mierników także miernikami niefinansowymi. W związku z tym w niniejszej pracy pozycja konkurencyjna przedsiębiorstwa będzie mierzona w sposób zagregowany za pomocą mierników finansowych, jak i niefinansowych, a dokładniej za pomocą agregatowego „wskaźnika konkurencyjności”61 [Fonfara 2009, 2012]. Składa się on z czterech składowych:

- zysk ogółem w porównaniu z najbliższymi konkurentami,

- stopa zwrotu z nakładów inwestycyjnych (ROI) w porównaniu do najbliższych konkurentów,

- wartość sprzedaży w porównaniu z najbliższymi konkurentami,

- udział w rynku w porównaniu do najbliższych konkurentów.

Respondenci w kwestionariuszu określali pozycję swojego przedsiębiorstwa do pozycji konkurencji w powyższych kwestiach za pomocą (opisanej wcześniej) pięciostopniowej skali Likerta. W badaniu pytano o dane za 2011 rok.

Wykorzystywany w pracy, w celu określenia przewagi konkurencyjnej podmiotu, wskaźnik konkurencyjności jest obliczany na podstawie średniej arytmetycznej czterech składowych, przedstawionych powyżej. Ostateczna wartość opisywanego miernika może przyjmować wartości pomiędzy 1 a 5 . Wyniki interpretowane są w ramach trzech przedziałów:

- $<=2,5$ - podmioty gorsze od najbliższych konkurentów,

${ }^{61} \mathrm{~W}$ literaturze istnieją różnice w kontekście stosowanej nazwy opisywanego narzędzia. Przykładowo M. Ratajczak-Mrozek [2010] używa terminu ,wskaźnik efektów”. 
- $\quad>2,5$ oraz $<3,5$ - podmioty porównywalne z najbliższymi konkurentami,

- >=3,5 - podmioty lepsze od najbliższych konkurentów (przedsiębiorstwa, którym udało się wytworzyć przewagę konkurencyjną względem najbliższych konkurentów).

Koncepcja pomiaru pozycji konkurencyjnej przedsiębiorstwa względem jego najbliższych konkurentów jest zgodna $\mathrm{z}$ podejściem K. Obłoja, który zauważa, iż „,..przewaga konkurencyjna jest podstawą procesu tworzenia i zawłaszczania wartości w większym stopniu, niż się to udaje konkurentom" [Obłój 2007, s. 409]. M. Gorynia [2000, s. 49, 52, 53] również odnotowuje potrzebę odniesienia mierników stosowanych do pomiaru pozycji konkurencyjnej do rywali przedsiębiorstwa. Ponadto, wykorzystywane w niniejszej pracy narzędzie było już stosowane i sprawdzone w przeszłości w badaniach prowadzonych przez Katedrę Marketingu Międzynarodowego Uniwersytetu Ekonomicznego w Poznaniu, w tym m.in. K. Fonfara [2009, 2012], M. Ratajczak-Mrozek [2008, 2010], czy Ł. Małys [2012, 2013].

Szczegółowa charakterystyka systemu ankietowania elektronicznego oraz kształt tradycyjnego kwestionariusza papierowego zostały kompleksowo przedstawione w załącznikach do niniejszej pracy.

Właściwe badania empiryczne były poprzedzone pretestami i badaniami pilotażowymi. Dotyczyły one zarówno kwestionariusza w wersji elektronicznej, jak i w tradycyjnej, drukowanej wersji papierowej. W trakcie pretestów zaprezentowano kwestionariusz znacznej, relatywnie zróżnicowanej grupie osób. Były wśród nich osoby pracujące w podmiotach gospodarczych, w tym studenci programu Master of Business Administration Wielkopolskiej Szkoły Biznesu przy Uniwersytecie Ekonomicznym w Poznaniu, ale także studenci studiów drugiego stopnia oraz pracownicy naukowodydaktyczni uczelni wyższych. Wymienione osoby zostały poproszone o uzupełnienie kwestionariusza oraz o przekazanie krytycznych uwag dotyczących jego konstrukcji.

Podczas budowy kwestionariusza ankiety autor dążył do tego, aby był on jak najbardziej przyjazny dla respondenta. Cel ten miał być osiągnięty poprzez możliwie jak najszerzej zakrojone uproszczenie i skrócenie jego treści, która docelowo miała zawierać wyłącznie niezbędne i zrozumiałe dla każdej osoby pytania. W związku z tym podczas pretestów szereg pytań zostało przeformułowanych, a wiele niepotrzebnych elementów usuniętych. Końcowa forma kwestionariusza ankiety, zdaniem szeregu osób biorących udział w pretestach charakteryzowała się tym, że nie była nadmiernie przepełniona treścią, pytania 
były zrozumiałe i co najważniejsze instrument badawczy był czytelny, a odpowiedzi na pytania łatwe do szybkiego i sprawnego zaznaczania.

Opracowany kwestionariusz ankiety badania ilościowego w obszarze działań przedsiębiorstw w zakresie wiedzy (pierwsze cztery sekcje) miał na celu rozpoznanie ogólnych przejawów aktywności podmiotów w poszczególnych fazach działań w zakresie wiedzy (pozyskiwanie, rozpowszechnianie oraz wdrażanie wiedzy). Z uwagi na szerokie spektrum branż podmiotów biorących udział w niniejszym badaniu niemożliwym było bardzo szczegółowe zbadanie określonych działań w zakresie poszczególnych obszarów działań w zakresie wiedzy. Aktywność w obszarze wiedzy podmiotów gospodarczych jest bardzo trudna do precyzyjnej identyfikacji w badaniu ilościowym. W związku z tym, w celu szczegółowego rozpoznania charakterystyki działań przedsiębiorstw w tym zakresie wzbogacono pracę również o badania jakościowe (studia przypadków).

Ilościowe badanie empiryczne w pracy zostało przeprowadzone w dwóch etapach. Pierwszym było badanie elektroniczne przeprowadzone $\mathrm{z}$ wykorzystaniem opisanego wcześniej elektronicznego systemu ankietowania, drugim było tradycyjne badanie papierowe. Podczas obu badań jako źródła danych kontaktowych respondentów wykorzystywano bazę Kompass Polska, która została zakupiona przez Katedrę Marketingu Międzynarodowego Uniwersytetu Ekonomicznego w Poznaniu. Umowa licencyjna wykorzystania bazy danych oraz sposób zbierania danych kontaktowych przez firmę Kompass Polska umożliwia wykorzystanie wyłącznie określonej części danych z bazy w badaniu elektronicznym. Zdecydowano się więc na podzielenie badania na dwie części - elektroniczną oraz tradycyjną, papierową. Wyniki obu badań były analizowane wspólnie.

Przeprowadzone badania dotyczyły dwóch populacji: przedsiębiorstw działających na rynkach zagranicznych (w procesie internacjonalizacji) oraz firm działających lokalnie (nieuczestniczących $\mathrm{w}$ procesie internacjonalizacji). Jako operat losowania posłużyła baza danych Kompass Polska.

W przypadku badania elektronicznego zdecydowano się wysłać kwestionariusz ankiety do wszystkich podmiotów, które wyraziły zgodę na wysyłanie im informacji drogą elektroniczną (34 039). W procesie doboru przedsiębiorstw do tradycyjnego badania pocztowego $\mathrm{z}$ całkowitej liczby podmiotów w bazie Kompass wyeliminowano firmy uczestniczące w badaniu elektronicznym. Następnie z pozostałej puli podmiotów wybrano 
w sposób losowy 1000 podmiotów gospodarczych (wśród nich 500 w procesie internacjonalizacji oraz 500 działających lokalnie), do których wysłano kwestionariusze ankiety z wykorzystaniem tradycyjnej poczty.

Badanie elektroniczne zostało przeprowadzone jako pierwsze. Po otrzymaniu wyników przeanalizowano strukturę branżową firm, z których otrzymano wypełnione kwestionariusze. Stwierdzono, iż struktura branżowa otrzymanych odpowiedzi jest w przybliżeniu proporcjonalna względem ogólnej struktury branżowej przedsiębiorstw działających w Polsce (według Głównego Urzędu Statystycznego). Wyjątek stanowiła jednak bardzo widoczna nadreprezentacja przedsiębiorstw $\mathrm{z}$ branży przemysłowej. W związku z faktem, iż plan badań zakładał wspólną analizę danych obu badań, z losowania próby do badania tradycyjnego zostały wykluczone przedsiębiorstwa z branży przemysłowej.

Badanie z wykorzystaniem elektronicznego systemu ankietowania zostało przeprowadzone w okresie maj-wrzesień 2012r. W badaniu elektronicznym kwestionariusz ankiety został wysłany do 34039 podmiotów. Otrzymano 1244 wypełnione kwestionariusze. Zwrotność przy założeniu, iż wszystkie ankiety dotarły do adresatów wyniosła 3,7\%. $\mathrm{W}$ związku $\mathrm{z}$ technologią wykorzystywaną w badaniu nie jest możliwe podanie dokładnej liczby kwestionariuszy, które nie dotarły do respondentów na skutek szeregu możliwych okoliczności takich jak likwidacja przedsiębiorstwa, zmiana danych kontaktowych, problemy spowodowane zbyt restrykcyjnymi rozwiązaniami w zakresie niechcianej poczty, problemy z serwerami itp. Ocena reprezentatywności próby pod kątem ogólnopolskiej struktury branżowej przedsiębiorstw została zamieszczona w kolejnej części pracy, w ramach prezentacji charakterystyki badanych podmiotów.

Tradycyjne badanie pocztowe, zostało przeprowadzone w okresie luty-marzec 2013 r. W tym rodzaju badania kwestionariusz ankiety został wysłany do 1000 podmiotów gospodarczych. Otrzymano 90 wypełnionych kwestionariuszy (zwrotność 9\%). 25 kwestionariuszy nie dotarło do adresatów.

W obu rodzajach badań umożliwiono przedsiębiorstwom wypełniającym kwestionariusz, otrzymanie raportu z badań. Siedemdziesiąt trzy ankietowane podmioty wyraziły zainteresowanie wynikami prowadzonych badań.

Autor ma świadomość, iż zastosowany kwestionariusz ankiety wykorzystywany w badaniu ilościowym jest dużym uproszczeniem, w odniesieniu do badania procesów w zakresie wiedzy $\mathrm{w}$ przedsiębiorstwie. Ze względu na ograniczenie zasobów 
przeznaczonych na realizację rozprawy doktorskiej jest on pewnego rodzaju kompromisem, który biorąc pod uwagę cele niniejszej pracy jest jednak narzędziem wystarczającym. Nie bada on strategii zarządzania wiedzą przyjętej w przedsiębiorstwie - tylko przejawy istnienia jakiegokolwiek zainteresowania tym zagadnieniem w poszczególnych zakresach działań podmiotów w obszarze wiedzy. Należy również zwrócić uwagę na duże uogólnienie przyjęte w niniejszej pracy związane $\mathrm{z}$ brakiem podziału badanych przedsiębiorstw na poszczególne branże. Kolejnym ograniczeniem jest operat losowania - baza danych Kompass Poland, która została wykorzystana jako źródło danych kontaktowych do badanych podmiotów. Nie jest ona perfekcyjnym zbiorem kompleksowo odzwierciedlającym populację przedsiębiorstw w Polsce.

W celu weryfikacji statystycznej danych ilościowych w pracy zastosowano szereg testów statystycznych. W przypadku hipotezy pierwszej wykorzystano test Manna-Whitneya, który posiada zastosowanie $\mathrm{w}$ procesie testowania różnic pomiędzy dwoma niezależnymi zbiorami [Bedyńska i Brzezicka 2007, s. 203]. W ramach testu obserwacje z obu grup są porządkowane i nadawane im są odpowiednie rangi [Rószkiewicz 2011, s. 92].

W przypadku hipotezy drugiej wykorzystano trzy kryteria zaangażowania zagranicznego firmy. W procesie weryfikacji statystycznej tej hipotezy w ramach pierwszego i drugiego kryterium: okresu zaangażowania zagranicznego oraz udziału sprzedaży zagranicznej, został wykorzystany współczynnik korelacji rang Spearmana. Jego wykorzystanie jest związane z faktem, iż badane cechy mierzone są na skali porządkowej i możliwe jest nadanie wariantom cech określonych rang [Jóźwiak i Podgórski 2012, s. 351$352]$.

Statystyczne testowanie hipotezy drugiej, w kontekście trzeciego kryterium - formy internacjonalizacji przedsiębiorstwa nie mogło zostać dokonane za pomocą współczynnika korelacji rang Spearmana z uwagi na brak niezależności testowanych zbiorów (pytanie wielokrotnego wyboru). W związku $\mathrm{z}$ tym zastosowano test $\mathrm{t}$ dla średnich kolumnowych z poprawką Bonferroniego (korekta wartości p dla wielokrotnych porównań) ${ }^{62}$ oraz wariancją oszacowaną na podstawie porównywanych kategorii ${ }^{63}$.

W celu weryfikacji hipotezy trzeciej zastosowana została regresja logistyczna. Wykorzystuje się ją w ramach modelowania, a także symulacji wartości prawdopodobieństwa

\footnotetext{
${ }^{62}$ Poprawka Bonferroniego jest najczęściej dokonywana przez podzielenie poziomu istotności alfa $(\alpha)$ przez liczbę przeprowadzanych testów [Statsoft 2011].

${ }^{63} \mathrm{Ze}$ względu na fakt, że respondenci mogli wybrać wiele odpowiedzi z zestawu.
} 
wystąpienia określonego zdarzenia [Rószkiewicz 2011, s. 193]. We wszystkich przeprowadzonych w pracy testach przyjęto $\alpha=0,05^{64}$.

\subsection{Wyniki badań ilościowych}

\subsubsection{Charakterystyka respondentów}

Niniejsze badania skupiały się $\mathrm{W}$ przeważającej mierze na przedsiębiorstwach w procesie internacjonalizacji. Jednakże w celu weryfikacji hipotezy pierwszej, w badaniu wzięły również udział przedsiębiorstwa działające lokalnie. Celem takiego doboru próby było zbadanie różnic $\mathrm{w}$ specyfice działalności, w obszarze wiedzy, przedsiębiorstw zaangażowanych zagranicznie na tle pozostałych podmiotów. W związku z tym, w pierwszej kolejności w ramach charakterystyki próby badawczej, zostanie omówiony podział na przedsiębiorstwa działające lokalnie oraz w procesie internacjonalizacji, z wykorzystaniem trzech różnych kryteriów. Przedstawione grupowanie będzie wykorzystywane do prezentacji pozostałych charakterystyk badanej próby.

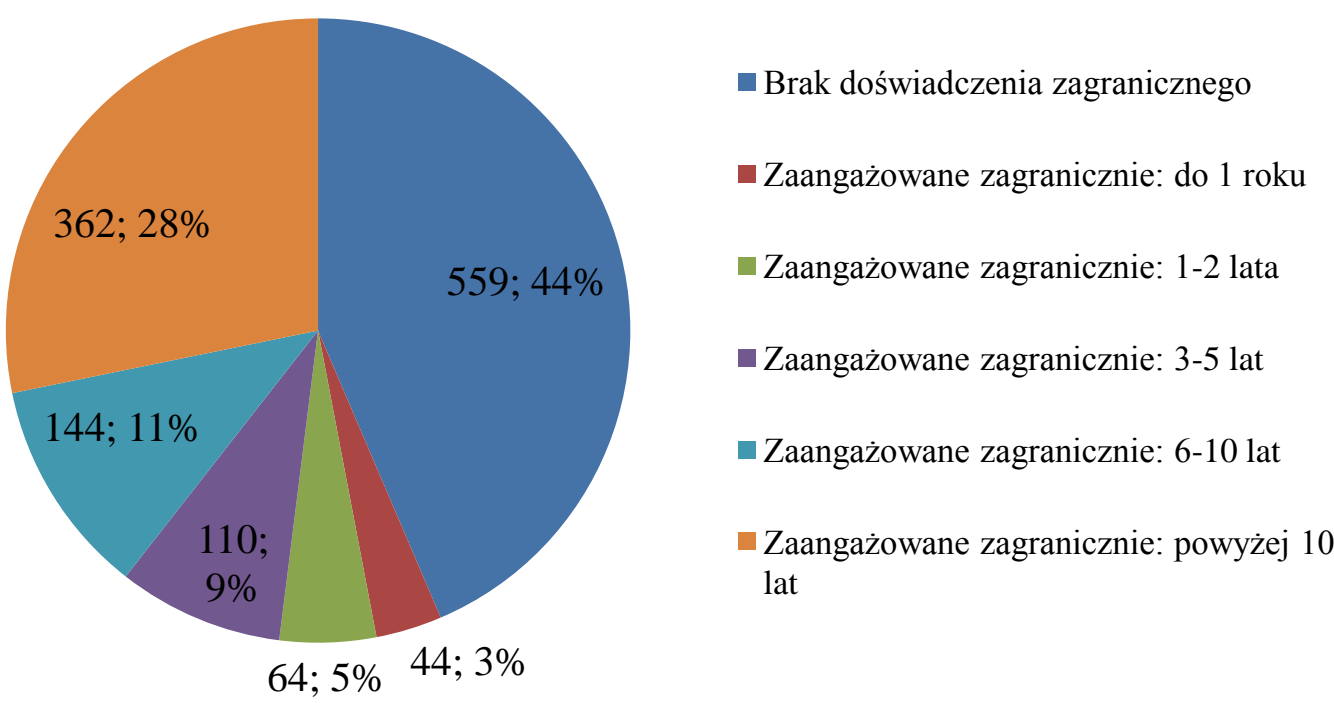

Rysunek 32. Charakterystyka próby badawczej z wykorzystaniem kryterium okresu zaangażowania zagranicznego przedsiębiorstw.

Źródło: opracowanie własne.

Pierwszym kryterium wykorzystywanym w niniejszym badaniu do wyodrębnienia przedsiębiorstw $\mathrm{w}$ procesie internacjonalizacji jest okres zaangażowania zagranicznego (rysunek 32). W badanej próbie dominują przedsiębiorstwa w procesie internacjonalizacji

\footnotetext{
${ }^{64} \alpha$-poziom istotności (prawdopodobieństwo popełnienia błędu I rodzaju tj. odrzucenia prawdziwej hipotezy zerowej).
} 
(56 procent). Podmioty działające lokalne stanowią również bardzo ważny jej element. Co ważne, w grupie podmiotów w procesie internacjonalizacji dominują firmy z bogatszym doświadczeniem zagranicznym - dłuższym niż 3 lata.

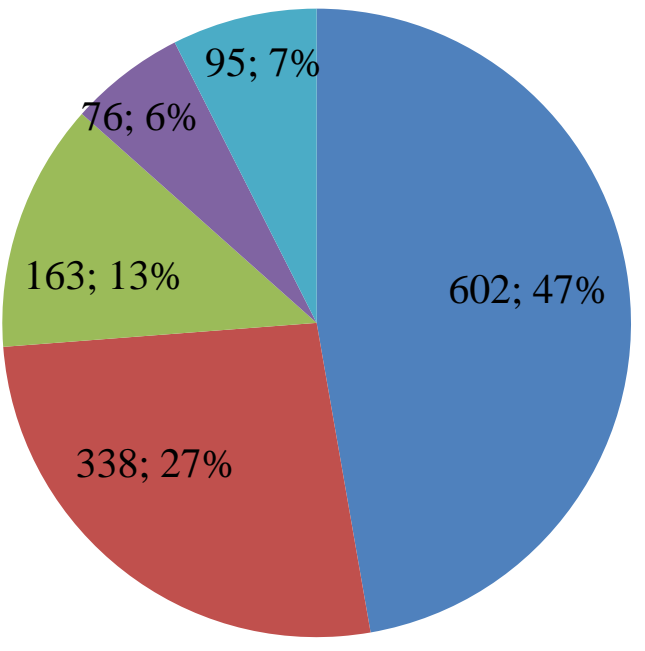

口 0\% sprzedaży zagranicznej w sprzedaży ogółem firmy

-1-10\% sprzedaży zagranicznej w sprzedaży ogółem firmy

-11-30\% sprzedaży zagranicznej w sprzedaży ogółem firmy

• 31-60\% sprzedaży zagranicznej w sprzedaży ogółem firmy

- >60\% sprzedaży zagranicznej w sprzedaży ogółem firmy

Rysunek 33. Charakterystyka próby badawczej z wykorzystaniem kryterium udziału sprzedaży zagranicznej. Źródło: opracowanie własne.

Kolejnym wykorzystywanym kryterium w zakresie internacjonalizacji jest udział sprzedaży zagranicznej przedsiębiorstwa porównaniu do jego sprzedaży ogółem. Udziały podmiotów zaangażowanych zagranicznie i działających lokalnie, w niewielkim stopniu, lecz jednak, są zróżnicowane w porównaniu do wcześniej zaprezentowanego podziału z wykorzystaniem kryterium okresu zaangażowania firmy na rynkach zagranicznych. Jest to związane $\mathrm{z}$ faktem, iż dane przedsiębiorstwo może uczestniczyć w procesie internacjonalizacji, lecz niekoniecznie musi sprzedawać swoje produkty czy usługi poza granicami kraju. Jak wynika z rysunku 33 liczba podmiotów, które nie sprzedają swoich produktów i usług za granicą wynosi $47 \%$ badanej próby. Pozostałe 53\% stanowią firmy dokonujące sprzedaży zagranicznej swoich wyrobów. Dla połowy z nich przychody zagraniczne stanowią znaczący udział - powyżej 30\%. 


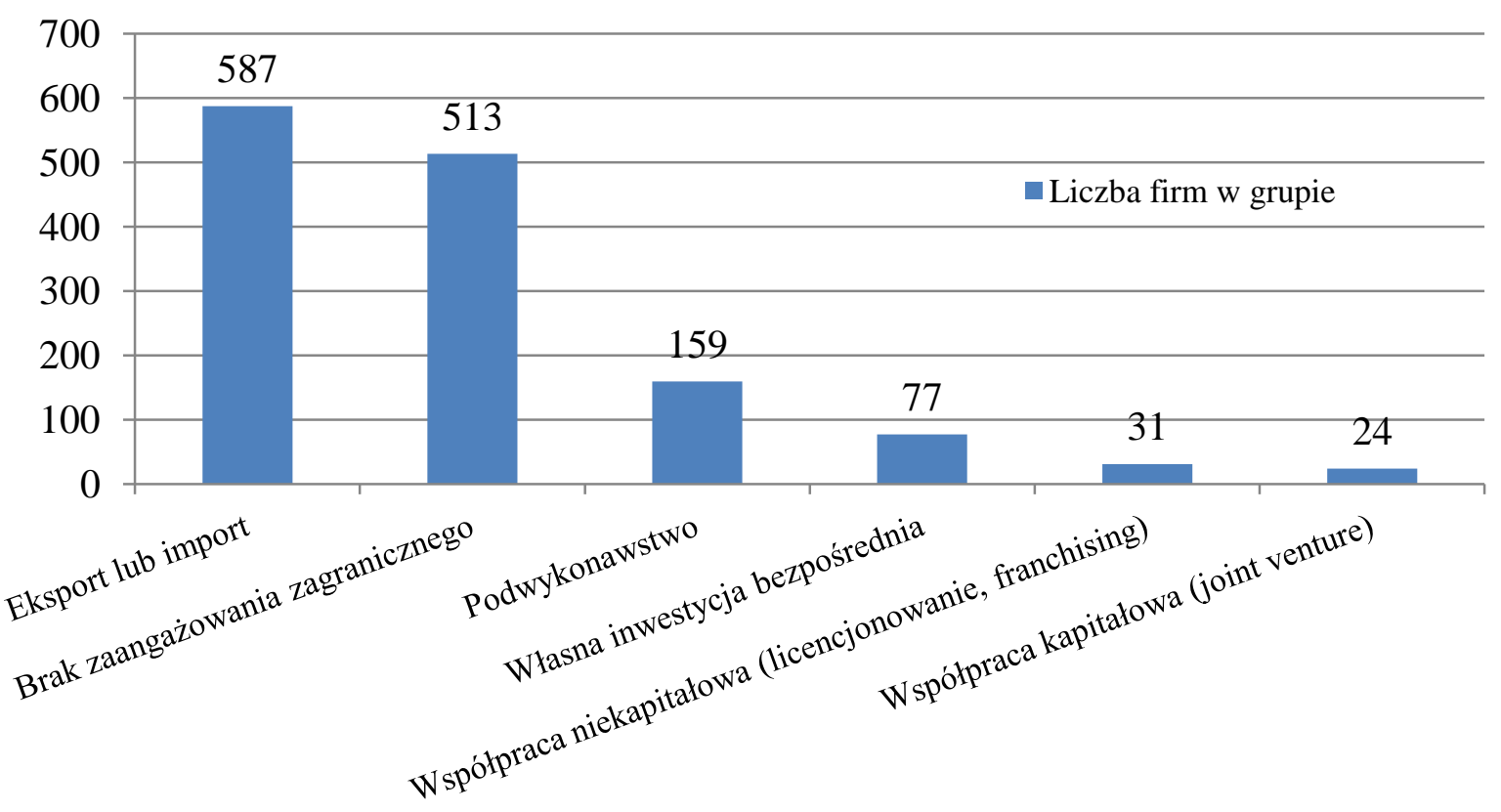

Rysunek 34. Charakterystyka próby badawczej z wykorzystaniem kryterium formy zaangażowania zagranicznego przedsiębiorstw ${ }^{65}$.

Żródło: opracowanie własne.

Innym $\mathrm{z}$ zastosowanych kryteriów była forma zaangażowania zagranicznego przedsiębiorstwa. W tym przypadku respondenci mogli zaznaczyć więcej niż jedną odpowiedź. Z rysunku 34 można wywnioskować, iż zdecydowana większość podmiotów w procesie internacjonalizacji angażuje się w eksport lub import. Licznie reprezentowane jest również podwykonawstwo. Zauważalna jest też grupa podmiotów wykorzystująca własną inwestycję bezpośrednią. Pozostałe formy internacjonalizacji są mniej popularne wśród badanych przedsiębiorstw. Należy jednak zauważyć, iż ze względu na dużą wielkość próby każda forma zaangażowania zagranicznego przedsiębiorstw jest w widoczny sposób reprezentowana.

Z trzech przedstawionych powyżej kryteriów w zakresie internacjonalizacji firm autor niniejszej rozprawy zdecydował się wybrać dominujące, jakim jest okres zaangażowania podmiotu na rynkach zagranicznych. Jest ono głównym wyróżnikiem w kontekście podziału na przedsiębiorstwa działające lokalnie i w procesie internacjonalizacji. Pozostałe kryteria udział sprzedaży zagranicznej i forma zaangażowania zagranicznego są również stosowane w dalszych częściach pracy, lecz w nieco mniejszym zakresie m.in. w celu weryfikacji hipotezy drugiej.

\footnotetext{
${ }^{65}$ Wartości nie sumują się do 100\%, gdyż respondenci mogli zaznaczyć więcej niż jedną formę zaangażowania zagranicznego przedsiębiorstwa.
} 
W badanej próbie (rysunek 35) dominowały małe przedsiębiorstwa (1049 zatrudnionych osób), liczną grupę stanowiły też mikroprzedsiębiorstwa (do 10 zatrudnionych osób). Udział firm średnich wynosił prawie $26 \%$, resztę - ok. $7 \%$ stanowiły przedsiębiorstwa duże i bardzo duże zatrudniające ponad 250 osób.

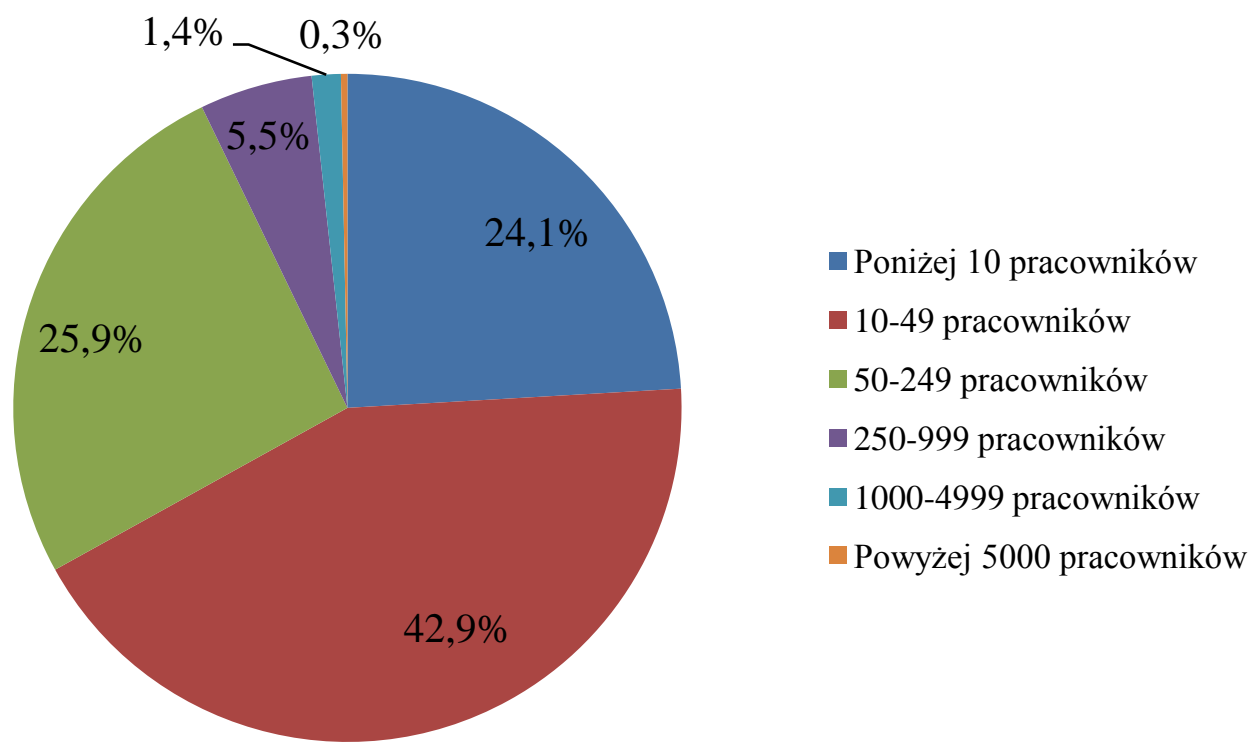

Rysunek 35. Zatrudnienie - całość próby.

Źródło: opracowanie własne.

Profil przedsiębiorstw w procesie internacjonalizacji (rysunek 36), w zakresie zatrudnienia nie różni się znacząco od wcześniej przedstawionej charakterystyki całości próby. Jednak w tym przypadku nieco większy udział mają przedsiębiorstwa średnie (ponad $28 \%$ ) oraz duże i bardzo duże (prawie 10\%). 


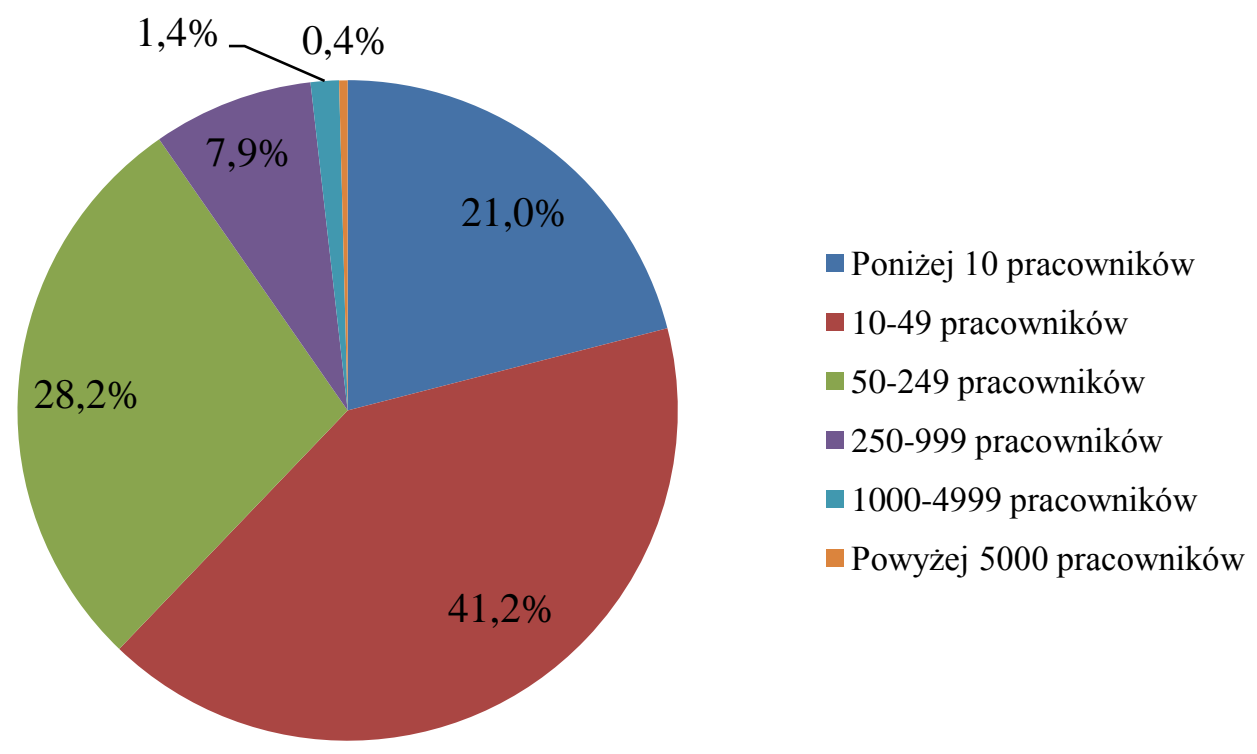

Rysunek 36. Zatrudnienie - przedsiębiorstwa w procesie internacjonalizacji (kryterium: okres zaangażowania w proces internacjonalizacji $>0$ ).

Źródło: opracowanie własne.

W celu określenia poziomu reprezentatywności branżowej badanej próby skonfrontowano udziały podmiotów z poszczególnych branż wśród badanych przedsiębiorstw z kompozycją branżową firm w Polsce na podstawie rejestru REGON. Niestety, kategoryzacja branżowa przyjęta na potrzeby badania w niektórych aspektach różni się od klasyfikacji przyjętej w tym zakresie przez Główny Urząd Statystyczny (GUS). Brak dokładnej zgodności obu kategoryzacji utrudnia, ale nie uniemożliwia ogólnego porównania obu zestawień.

Można stwierdzić, iż badana próba przedsiębiorstw (tabela 16) do pewnego stopnia różni się, pod względem udziału poszczególnych branż od podziału branżowego przedsiębiorstw w gospodarce polskiej publikowanego przez GUS na podstawie rejestru REGON (tabela 18), lecz ogólne proporcje w znacznej części branż zostały zachowane. W badanej próbie można zauważyć mniejszy udział firm zajmujących się handlem hurtowym i detalicznym (19,8\% wobec $27,2 \%)$ oraz znacznie większy udział przemysłu. 
Tabela 16. Liczba podmiotów, poddanych badaniu, reprezentujących poszczególne branże - całkowita próba.

\begin{tabular}{|c|c|c|}
\hline Branza & $\begin{array}{c}\text { Liczba } \\
\text { podmiotów }\end{array}$ & Udzial $\boldsymbol{w} \%$ \\
\hline Handel hurtowy i detaliczny & 254 & $19,8 \%$ \\
\hline Pozostała produkcja & 180 & $14,0 \%$ \\
\hline Inne & 146 & $11,4 \%$ \\
\hline Budownictwo & 130 & $10,1 \%$ \\
\hline Inne usługi & 120 & $9,4 \%$ \\
\hline Produkcja - średnio wysoka technika & 115 & $9,0 \%$ \\
\hline Działalność profesjonalna, naukowa, \\
techniczna & 112 & $8,7 \%$ \\
\hline Usługi informatyczne i telekomunikacyjne & 63 & $4,9 \%$ \\
\hline Produkcja - wysoka technika & 39 & $3,0 \%$ \\
\hline Usługi transportowe & 32 & $2,5 \%$ \\
\hline Przemysł energetyczny & 27 & $2,1 \%$ \\
\hline Usługi hotelarskie i gastronomiczne & 24 & $1,9 \%$ \\
\hline Usługi - rynek nieruchomości & 18 & $1,4 \%$ \\
\hline Usługi finansowe i ubezpieczeniowe & 17 & $1,3 \%$ \\
\hline Przemysł wydobywczy & 5 & $0,4 \%$ \\
\hline Branża nieokreślona & 1 & $0,1 \%$ \\
\hline Suma: & 1283 & $100,0 \%$ \\
\hline
\end{tabular}

Źródło: opracowanie własne.

Klasyfikacja branżowa dotycząca wyłącznie podmiotów zaangażowanych zagranicznie (tabela 17) w badanej próbie różni się nieco od przedstawionej wcześniej ogólnej kategoryzacji w tym zbiorze (tabela 16). W porównaniu do całościowego zestawienia branżowego, w omawianej grupie większy udział mają podmioty zajmujące się produkcją (zarówno w zakresie wysokiej, średniej, jak i niskiej techniki), usługami transportowymi, działalnością profesjonalną, naukową i techniczną oraz handlem. Mniejszy zaś udział w omawianym zbiorze mają firmy $\mathrm{z}$ branż: budownictwo, usługi informatyczne i telekomunikacyjne oraz usługi ubezpieczeniowe. 
Tabela 17. Liczba podmiotów, poddanych badaniu, reprezentujących poszczególne branże - wyłącznie firmy w procesie internacjonalizacji (kryterium: okres zaangażowania zagranicznego $>0$ ).

\begin{tabular}{|c|c|c|}
\hline Branza & $\begin{array}{c}\text { Liczba } \\
\text { podmiotów }\end{array}$ & Udziat $\boldsymbol{w} \%$ \\
\hline Handel hurtowy i detaliczny & 149 & $20,6 \%$ \\
\hline Pozostała produkcja & 133 & $18,4 \%$ \\
\hline Produkcja - średnio wysoka technika & 100 & $13,8 \%$ \\
\hline Inne & 68 & $9,4 \%$ \\
\hline Budownictwo & 62 & $8,6 \%$ \\
\hline Działalność profesjonalna, naukowa, & 47 & $6,5 \%$ \\
\hline techniczna & 46 & $6,4 \%$ \\
\hline Inne usługi & 34 & $4,7 \%$ \\
\hline Usługi informatyczne i telekomunikacyjne & 28 & $3,9 \%$ \\
\hline Usługi transportowe & 25 & $3,5 \%$ \\
\hline Przemysł energetyczny & 14 & $1,9 \%$ \\
\hline Usługi hotelarskie i gastronomiczne & 9 & $1,2 \%$ \\
\hline Usługi finansowe i ubezpieczeniowe & 3 & $0,4 \%$ \\
\hline Usługi - rynek nieruchomości & 3 & $0,4 \%$ \\
\hline Przemysł wydobywczy & 2 & $0,3 \%$ \\
\hline Branża nieokreślona & 1 & $0,1 \%$ \\
\hline Suma: & 724 & $100,0 \%$ \\
\hline
\end{tabular}

Źródło: opracowanie własne.

Tabela 18. Struktura podmiotów w gospodarce polskiej, stan na 30.04.2012 według rejestru REGON.

\begin{tabular}{|c|c|c|}
\hline Branza & $\begin{array}{c}\text { Liczba } \\
\text { podmiotów }\end{array}$ & Udzial $\boldsymbol{w} \%$ \\
\hline Handel hurtowy i detaliczny... & 1054601 & $27,2 \%$ \\
\hline Budownictwo & 463102 & $11,9 \%$ \\
\hline Przetwórstwo przemysłowe & 355206 & $9,2 \%$ \\
\hline Działalność profesjonalna, naukowa i techniczna & 340060 & $8,8 \%$ \\
\hline Transport i gospodarka magazynowa & 251926 & $6,5 \%$ \\
\hline Pozostała działalność usługowa & 237056 & $6,1 \%$ \\
\hline Działalność związana z obsługą rynku & 205231 & $5,3 \%$ \\
\hline nieruchomości & 195820 & $5,0 \%$ \\
\hline Opieka zdrowotna i pomoc społeczna & 126942 & $3,3 \%$ \\
\hline Działalność finansowa i ubezpieczeniowa & 122518 & $3,2 \%$ \\
\hline Działalność związana z zakwaterowaniem... & 118010 & $3,0 \%$ \\
\hline Edukacja & 102544 & $2,6 \%$ \\
\hline Informacja i komunikacja & 97241 & $2,5 \%$ \\
\hline Administracja i działalność wspierająca & 91692 & $2,4 \%$ \\
\hline Rolnictwo, leśnictwo, łowiectwo i rybactwo & 116596 & $3,0 \%$ \\
\hline Pozostałe sekcje & & \\
\hline
\end{tabular}

Źródło: opracowanie własne na podstawie:

[Biuletynu Informacji Publicznej Głównego Urzędu Statystycznego 2012]. 
Zdecydowanie największą grupę podmiotów w całkowitej badanej próbie, prawie 80 procent, stanowiły przedsiębiorstwa będące własnością prywatnych podmiotów krajowych. Udział firm, których właścicielami są podmioty zagraniczne i polski Skarb Państwa był porównywalny i wynosił około 10 procent (rysunek 37).

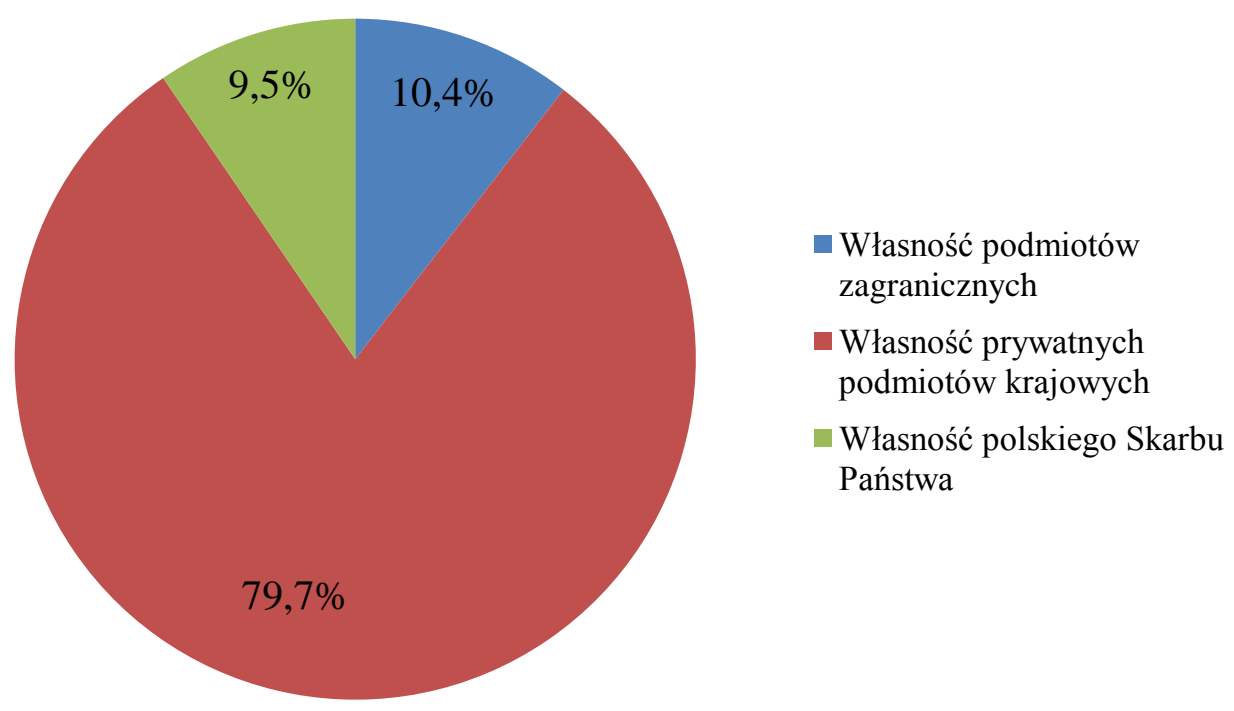

Rysunek 37. Forma własności przedsiębiorstwa - całość próby. Źródło: opracowanie własne.

W podgrupie badanej próby skupiającej przedsiębiorstwa zaangażowane na rynkach zagranicznych, w porównaniu do całości populacji, większy jest udział firm będących własnością podmiotów zagranicznych (prawie piętnaście procent). Udział przedsiębiorstw należących do polskiego Skarbu Państwa jest o około jedną trzecią mniejszy, nieznacznie mniejszy jest również udział firm będących własnością prywatnych podmiotów krajowych (rysunek 38). 


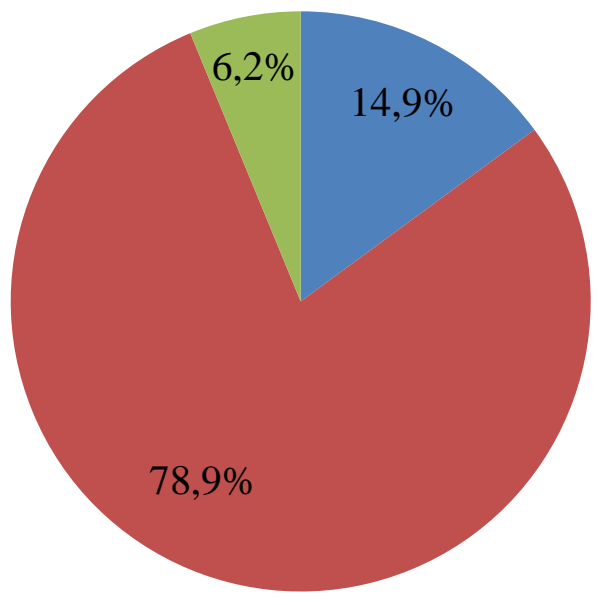

- Własność podmiotów zagranicznych

- Własność prywatnych podmiotów krajowych

Własność polskiego Skarbu Państwa

Rysunek 38. Forma własności przedsiębiorstwa - przedsiębiorstwa w procesie internacjonalizacji (kryterium: okres zaangażowania zagranicznego $>0$ ).

Źródło: opracowanie własne.

Dalsza analiza danych empirycznych zostanie przeprowadzona w poniższej kolejności:

- analiza różnic w zakresie poziomu orientacji na wiedzę przedsiębiorstw działających lokalnie i zaangażowanych na rynkach zagranicznych (weryfikacja hipotezy 1),

- analiza różnic w zakresie poziomu orientacji na wiedzę przedsiębiorstw na poszczególnych etapach internacjonalizacji w kontekście:

○ okresu zaangażowania firmy na rynkach zagranicznych,

○ udziału sprzedaży zagranicznej w sprzedaży firmy ogółem,

○ formy zaangażowania firmy na rynkach zagranicznych, (weryfikacja hipotezy 2),

- analiza roli orientacji na wiedzę w kształtowaniu przewagi konkurencyjnej przedsiębiorstwa w procesie internacjonalizacji (weryfikacja hipotezy 3).

\subsubsection{Poziom orientacji na wiedzę przedsiębiorstw działających lokalnie oraz podmiotów zaangażowanych zagranicznie}

Kwestionariusz ankietowy, jak wspomniano we wcześniejszym rozdziale, został podzielony na siedem sekcji. Pierwsze cztery z nich miały na celu pomiar poziomu działań przedsiębiorstwa w zakresie wiedzy (z podziałem na cztery główne procesy). Kolejne sekcje 
dotyczyły orientacji rynkowej podmiotu, poziomu konkurencyjności i ogólnych charakterystyk przedsiębiorstwa.

W celu weryfikacji hipotez został stworzony zintegrowany wskaźnik intensywności procesów w zakresie wiedzy w przedsiębiorstwie. Jest on średnią arytmetyczną wyników czterech sekcji kwestionariusza ankiety mierzących poszczególne procesy w zakresie wiedzy w przedsiębiorstwie (rysunek 39). W sekcji pierwszej (źródła wiedzy) na potrzeby zintegrowanego miernika intensywności procesów w zakresie wiedzy autor stworzył zbiór kluczowych źródeł pozyskiwania omawianego zasobu ${ }^{66}$. W kolejnych analizach wykorzystywano również inne, zbiorcze kategorie źródeł wiedzy: źródła innowacyjne, źródła eksperckie, źródła rynkowe, źródła branżowe oraz własne badania i rozwój ${ }^{67}$.

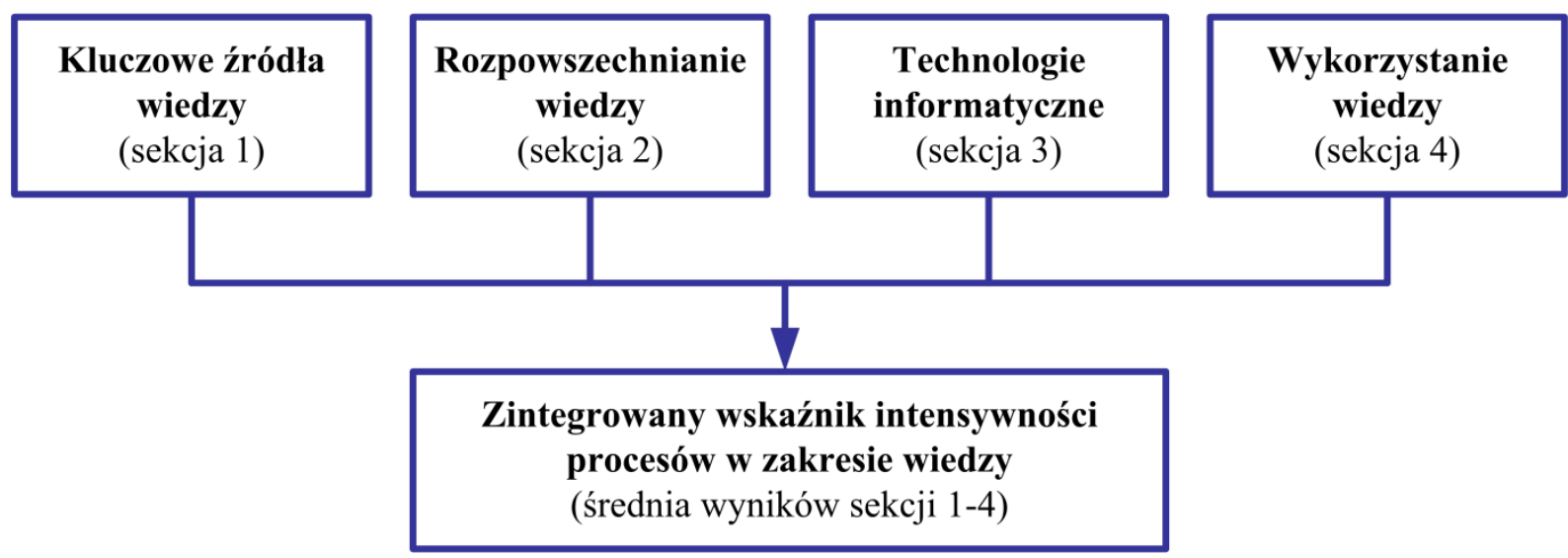

Rysunek 39. Zintegrowany wskaźnik intensywności procesów w zakresie wiedzy w przedsiębiorstwie. Źródło: opracowanie własne.

W celu zbadania poziomu orientacji rynkowej została wykorzystana skala MKTOR opracowana przez Narvera i Slatera [1990]. Zestaw czternastu pytań z zakresu orientacji na nabywcę, orientacji na konkurentów oraz międzyfunkcjonalnej koordynacji został zamieszczony w sekcji 5 kwestionariusza (rysunek 40).

\footnotetext{
${ }^{66}$ Kluczowe źródła wiedzy: szkolenia i kursy zewnętrzne, firmy doradcze (konsultingowe), publikacje naukowe, publicystyczne, branżowe, zamówione ekspertyzy, badania rynku (własne lub zlecone), klienci, dostawcy i podwykonawcy, konkurenci, organizacje branżowe/kluby networkingu, instytucje badawcze, uczelnie wyższe, własne działania w zakresie badań i rozwoju.

${ }^{67}$ Skład pozostałych, wykorzystywanych w pracy kategorii źródeł wiedzy:

- źródła innowacyjne: publikacje naukowe, publicystyczne, branżowe; instytucje badawcze, uczelnie wyższe; własne działania w zakresie badań i rozwoju;

- źródła eksperckie: szkolenia i kursy zewnętrzne; firmy doradcze (konsultingowe); zamówione ekspertyzy;

- źródła rynkowe: badania rynku (własne lub zlecone); klienci;

- źródła branżowe: publikacje naukowe, publicystyczne, branżowe; dostawcy i podwykonawcy; konkurenci; organizacje branżowe/kluby networkingu;

- własne badania i rozwój: własne działania w zakresie badań i rozwoju.
} 


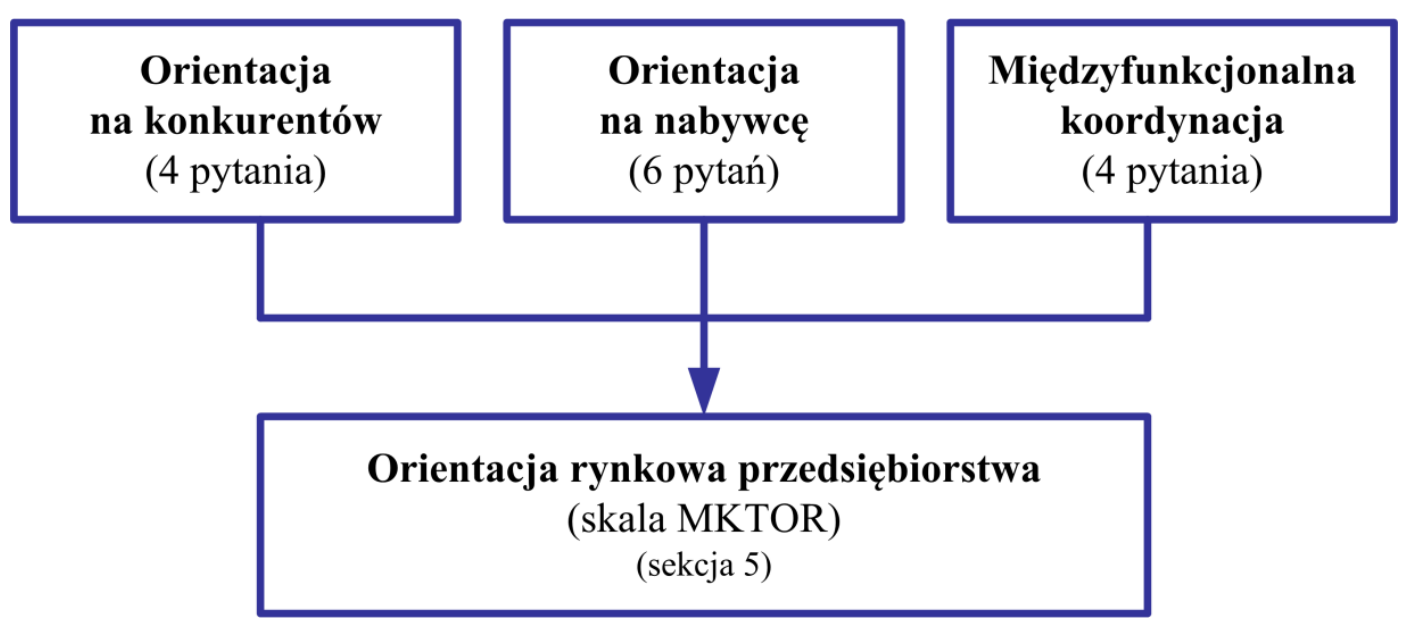

Rysunek 40. Elementy składowe skali MKTOR.

Źródło: opracowanie własne na podstawie [Hooley i in. 2000, s. 277].

W celu zbadania rzetelności zestawów pytań składających się na poszczególne mierniki wykorzystano współczynnik rzetelności skali Alfa Cronbacha (tabela 19).

Tabela 19. Współczynnik rzetelności skali Alfa Cronacha.

\begin{tabular}{|l|c|}
\hline \multicolumn{1}{|c|}{ Sekcja } & $\begin{array}{c}\text { Wartość Alfa } \\
\text { Cronbacha }\end{array}$ \\
\hline Sekcja 5 - orientacja rynkowa & 0,913 \\
\hline Wskaźnik konkurencyjności & 0,908 \\
\hline Sekcja 4 - wdrażanie wiedzy & 0,861 \\
\hline Sekcja 2 - rozpowszechnianie wiedzy & 0,838 \\
\hline $\begin{array}{l}\text { Zintegrowany wskaźnik intensywności procesów w zakresie } \\
\text { wiedzy (średnia artymetyczna sekcji 1-4) }\end{array}$ & 0,783 \\
\hline Kluczowe źródła wiedzy (sekcja 1) & 0,781 \\
\hline Sekcja 3 - technologie informatyczne & 0,774 \\
\hline
\end{tabular}

Źródło: opracowanie własne z wykorzystaniem programu SPSS.

Statystyka Alfa Cronbacha przyjmuje wartości od 0 do 1. Wartość bliska 1 wskazuje na wysoką rzetelność skali. Najczęściej za rzetelną określa się skalę, dla której wartość omawianej statystyki wynosi przynajmniej 0,7 [Bedyńska i Brzezicka 2007, s. 154, 156]. Jak wynika z tabeli 13 warunek rzetelności wyrażony przez wartość współczynnika jest spełniony dla wszystkich sekcji. 
Weryfikacja hipotezy 1:

H1: Przedsiębiorstwa działajace na rynkach zagranicznych sa przeciętnie bardziej zorientowane na wiedze w porównaniu do przedsiębiorstw działajacych lokalnie.

W tabeli 20 zaprezentowano udziały podmiotów, w ramach dwóch analizowanych grup przedsiębiorstw, charakteryzujących się orientacją na wiedzę oraz cechami będącymi jej elementami składowymi.

Tabela 20. Udziały firm charakteryzujących się wysoką orientacją na wiedzę w grupach przedsiębiorstw działających lokalnie oraz w procesie internacjonalizacji.

\begin{tabular}{|c|c|c|c|c|c|}
\hline $\begin{array}{l}\text { Liczba } \\
\text { firm } \\
\qquad w \\
\text { grupie }\end{array}$ & $\begin{array}{c}\text { Zakres przestrzenny } \\
\text { działalności podmiotu }\end{array}$ & $\begin{array}{c}\text { Wysoki poziom } \\
\text { orientacji na } \\
\text { wiedze } \\
\text { Intensywne dziatania } \\
\text { w zakresie wiedzy, } \\
\text { jak } \text { i wysoka orientacja } \\
\text { rynkowa }(>3,5) \\
\end{array}$ & $\begin{array}{l}\text { Intensywne } \\
\text { działania } \\
\text { w zakresie } \\
\text { wiedzy }(>3,5)\end{array}$ & $\begin{array}{l}\text { Wysoka } \\
\text { orientacja } \\
\text { rynkowa } \\
(>3,5)\end{array}$ & $\begin{array}{c}\frac{\text { Brak orientacji }}{\text { na }} \text { wiedze } \\
\text { Brak intensywnych } \\
\text { działan w zakresie } \\
\text { wiedzy, } \\
\text { jak i niska orientacja } \\
\text { rynkowa (oba <3,5) }\end{array}$ \\
\hline 550 & $\begin{array}{c}\text { Działajacy } \\
\text { lokalnie }\end{array}$ & $19,5 \%$ & $22,7 \%$ & $53,6 \%$ & $43,1 \%$ \\
\hline \multirow[t]{2}{*}{724} & $\begin{array}{c}\text { W procesie } \\
\text { internacjonalizacji }\end{array}$ & $28,6 \%$ & $32,3 \%$ & $60,5 \%$ & $35,8 \%$ \\
\hline & $\begin{array}{c}\text { Różnica: firmy } \\
\text { w procesie } \\
\text { internacjonalizacji } \\
\text { a działajace lokalnie }\end{array}$ & $9,1 \%$ & $9,6 \%$ & $6,9 \%$ & $-7,3 \%$ \\
\hline
\end{tabular}

Źródło: opracowanie własne.

W tabeli 20 można zauważyć, iż większość z obu typów przedsiębiorstw posiada wysoką orientację rynkową, choć przodują w tym obszarze firmy w procesie internacjonalizacji. Nieco większe różnice występują w zakresie aktywności badanych podmiotów w obszarze wiedzy.

Najważniejszym miernikiem w niniejszym badaniu jest liczba podmiotów charakteryzujących się wysoką orientacją na wiedzę (intensywnymi, rynkowo ukierunkowanymi działaniami w zakresie wiedzy). Można zauważyć relatywnie znaczące różnice pomiędzy udziałami podmiotów posiadających tę cechę $\mathrm{w}$ omawianych grupach. Różnice w tym zakresie są zbliżone do przedstawionego wcześniej porównania udziałów firm posiadających wysoki poziom intensywności procesów w zakresie wiedzy, aczkolwiek 
udziały przedsiębiorstw charakteryzujących się wysoką orientacją na wiedzę w obu omawianych grupach firm są nieco niższe.

W celu uszczegółowienia analizy, w tabeli 21 zaprezentowane zostało zestawienie poziomu orientacji rynkowej oraz intensywności działań w zakresie poszczególnych procesów w obszarze wiedzy $\mathrm{W}$ przedsiębiorstwach $\mathrm{w}$ procesie internacjonalizacji w porównaniu do podmiotów działających lokalnie. Dane zostały zaprezentowane z wykorzystaniem dwóch czynników składowych orientacji na wiedzę: poziomu zintegrowanego miernika intensywności procesów w zakresie wiedzy (średnia sekcji 1-4) oraz poziomu orientacji rynkowej (sekcja 5). Dla obu czynników uznano, iż wysoki poziom działań w danym obszarze zachodzi w momencie, gdy średnia ocena podmiotu w zakresie określonych procesów jest większa od 3,5 (zakres skali 1-5). W przeciwnym razie mówimy o niskim poziomie działań w danym obszarze.

Tabela 21. Poziom procesów w zakresie wiedzy oraz orientacji rynkowej w przedsiębiorstwach działających lokalnie oraz $\mathrm{w}$ procesie internacjonalizacji.

\begin{tabular}{|c|c|c|c|c|c|c|c|}
\hline $\begin{array}{l}\text { Liczba } \\
\text { firm } \\
w \\
\text { grupie }\end{array}$ & $\begin{array}{c}\text { Zakres } \\
\text { przestrzenny } \\
\text { dziatalności } \\
\text { podmiotu }\end{array}$ & $\begin{array}{c}\text { Kluczowe } \\
\text { źródła } \\
\text { wiedzy } \\
\text { (sekcja 1) }\end{array}$ & $\begin{array}{c}\text { Rozpowsze- } \\
\text { chnianie } \\
\text { wiedzy } \\
\text { (sekcja 2) }\end{array}$ & $\begin{array}{c}\text { Technologie } \\
\text { informatyczne } \\
\text { (sekcja 3) }\end{array}$ & $\begin{array}{c}\text { Wykorzysta- } \\
\text { nie } \\
\text { wiedzy } \\
\text { (sekcja 4) }\end{array}$ & $\begin{array}{c}\text { Zintegrowany } \\
\text { wskaźnik } \\
\text { intensywności } \\
\text { procesów } \\
\text { w zakresie } \\
\text { wiedzy } \\
\text { (srednia } \\
\text { sekcji } 1-4) \\
\end{array}$ & $\begin{array}{c}\text { Orientacja } \\
\text { rynkowa } \\
\text { (sekcja 5) }\end{array}$ \\
\hline 550 & $\begin{array}{l}\text { Działajacy } \\
\text { lokalnie }\end{array}$ & 2,39 & 3,68 & 2,82 & 3,53 & 3,10 & 3,52 \\
\hline \multirow[t]{2}{*}{724} & $\begin{array}{c}\text { W procesie } \\
\text { internacjonalizacji }\end{array}$ & 2,60 & 3,76 & 2,99 & 3,63 & 3,25 & 3,68 \\
\hline & $\begin{array}{c}\text { Różnica: firmy } \\
\text { w procesie } \\
\text { internacjonalizacji } \\
\text { a działajace } \\
\text { lokalnie }\end{array}$ & 0,21 & 0,09 & 0,17 & 0,10 & 0,14 & 0,15 \\
\hline
\end{tabular}

Źródło: opracowanie własne.

Przedstawione w tabeli 21 różnice pomiędzy przedsiębiorstwami działającymi lokalnie, a zaangażowanymi zagranicznie nie są duże, lecz należy zauważyć, że utrzymują one ten sam kierunek dla wszystkich sekcji. Podobna tendencja utrzymuje się również w przypadku poszczególnych pytań zawartych w kwestionariuszu ankiety, na które składają się wyróżnione sekcje. Największe różnice można zauważyć w zakresie rodzaju źródeł wykorzystywanych przez poszczególne kategorie przedsiębiorstw. Ważnym aspektem, 
w kontekście interpretacji otrzymanych wyników jest relatywnie duży rozmiar próby badawczej - liczy ona 1274 firmy.

Jak wcześniej wspomniano, wartości zaprezentowane w tabeli 21 sugerują dość znaczne różnice w odniesieniu do źródeł wiedzy, z jakich korzystają grupy przedsiębiorstw. W związku z tym kwestia ta została dokładniej przestawiona w tabeli 22.

Tabela 22. Poziom wykorzystania określonych kategorii źródeł wiedzy przez przedsiębiorstwa działające lokalnie oraz $\mathrm{w}$ procesie internacjonalizacji.

\begin{tabular}{|c|c|c|c|c|c|c|c|}
\hline $\begin{array}{c}\text { Liczba } \\
\text { firm } \\
w \\
\text { grupie }\end{array}$ & $\begin{array}{c}\text { Zakres } \\
\text { przestrzenny } \\
\text { działalności } \\
\text { podmiotu }\end{array}$ & $\begin{array}{c}\text { Źródta } \\
\text { innowacyjne }\end{array}$ & $\begin{array}{c}\text { Źródta } \\
\text { eksperckie }\end{array}$ & $\begin{array}{c}\text { Źródta } \\
\text { rynkowe }\end{array}$ & $\begin{array}{c}\text { Źródta } \\
\text { branżowe }\end{array}$ & $\begin{array}{c}\text { Wtasne } \\
\text { badania } \\
\text { i rozwój }\end{array}$ & $\begin{array}{c}\text { Kluczowe } \\
\text { źródta } \\
\text { wiedzy }\end{array}$ \\
\hline 550 & $\begin{array}{c}\text { Działajacy } \\
\text { lokalnie }\end{array}$ & 2,52 & 2,07 & 2,57 & 2,46 & 2,59 & 2,39 \\
\hline $\begin{array}{c}\text { W procesie } \\
\text { internacjonalizacji }\end{array}$ & 2,73 & 2,13 & 2,98 & 2,69 & 2,99 & 2,60 \\
\hline $\begin{array}{c}\text { Różnica: firmy } \\
\text { w procesie } \\
\text { internacjonalizacji } \\
\text { a działające } \\
\text { lokalnie }\end{array}$ & 0,21 & 0,06 & 0,41 & 0,23 & 0,40 & 0,21 \\
\hline
\end{tabular}

Źródło: opracowanie własne.

Jak wynika z tabeli 22, największe różnice pomiędzy poziomem wykorzystania poszczególnych typów źródeł wiedzy przez omawiane rodzaje podmiotów, występują w zakresie źródeł rynkowych oraz badań i rozwoju. Pomimo widocznych, lecz relatywnie mniejszych różnic $\mathrm{w}$ zakresie orientacji rynkowej pomiędzy obiema grupami przedsiębiorstw (tabela 22), firmy działające lokalnie zdecydowanie w mniejszym stopniu korzystają z rynkowych źródeł wiedzy. Jest to zgodne z wcześniejszymi rozważaniami teoretycznymi zawartymi w pracy, z których wynika, iż część działań związanych z pozyskiwaniem wiedzy o rynku, w przypadku przedsiębiorstw działających lokalnie, odbywa się naturalnie i nieświadomie oraz nie wymaga formalnych systemowych oraz procesowych przedsięwzięć podmiotu.

Widoczne różnice w zakresie większego wykorzystania poszczególnych wyróżnionych kategorii występują również w przypadku źródeł innowacyjnych, branżowych oraz kluczowych. Należy również zaznaczyć, iż w przypadku wszystkich kategorii źródeł występuje wyższy poziom ich wykorzystania przez podmioty w procesie internacjonalizacji. 
W celu weryfikacji statystycznej istotności różnic $\mathrm{w}$ zakresie dwóch elementów składowych orientacji na wiedzę, pomiędzy grupami przedsiębiorstw działających lokalnie oraz podmiotów funkcjonujących na rynkach zagranicznych wykorzystany zostanie test Manna-Whitneya.

$\mathrm{H}_{0}: \mathrm{F}_{1}(\mathrm{x})=\mathrm{F}_{2}(\mathrm{x})$

$\mathrm{H}_{1}: \mathrm{F}_{1}(\mathrm{x}) \neq \mathrm{F}_{2}(\mathrm{x})$

$F_{1}(x), F_{2}(x)$ - rozkład analizowanej cechy w wyróżnionych grupach.

Tabela 23. Weryfikacja hipotezy pierwszej - analizy statystyczne z wykorzystaniem testu Manna-Whitneya.

\begin{tabular}{|c|c|c|}
\hline Zmienna & $\begin{array}{c}\text { Orientacja } \\
\text { rynkowa }\end{array}$ & $\begin{array}{c}\text { Działania } \\
\text { w zakresie } \\
\text { wiedzy }\end{array}$ \\
\hline $\begin{array}{c}\text { U Manna- } \\
\text { Whitneya }\end{array}$ & 185440,000 & 182070,500 \\
\hline Z & $-2,453$ & $-2,708$ \\
\hline $\begin{array}{c}\text { Istotność } \\
\text { asymptotyczna } \\
\text { (dwustronna) } \\
\text { (p-value) }\end{array}$ & $\mathbf{0 , 0 1 4}$ & $\mathbf{0 , 0 0 7}$ \\
\hline
\end{tabular}

Źródło: opracowanie własne, tabela wygenerowana za pomocą systemu SPSS.

Istotność asymptotyczna (dwustronna) - wartość p.

U Manna-Whitneya - wartość statystyki testowej.

$Z$ - statystyka testująca w sytuacji dwustronnej hipotezy alternatywnej. 
Tabela 24. Weryfikacja hipotezy pierwszej - rangi w ramach testu Manna-Whitneya.

\begin{tabular}{|c|c|c|c|}
\hline \multicolumn{2}{|c|}{ (a) } & $\begin{array}{c}\text { Średnia } \\
\text { ranga }\end{array}$ & Suma rang \\
\hline \multirow{2}{*}{$\begin{array}{l}\text { Orientacja } \\
\text { rynkowa }\end{array}$} & $\begin{array}{c}\text { Podmioty } w \\
\text { procesie } \\
\text { internacjonalizacji }\end{array}$ & 656,37 & 475210,00 \\
\hline & $\begin{array}{l}\text { Podmioty } \\
\text { działające } \\
\text { lokalnie }\end{array}$ & 612,66 & 336965,00 \\
\hline \multirow{2}{*}{$\begin{array}{c}\text { Działania } \\
\text { w } \\
\text { zakresie } \\
\text { wiedzy }\end{array}$} & $\begin{array}{c}\text { Podmioty } \mathrm{w} \\
\text { procesie } \\
\text { internacjonalizacji }\end{array}$ & 661,02 & 478579,50 \\
\hline & $\begin{array}{l}\text { Podmioty } \\
\text { działające } \\
\text { lokalnie }\end{array}$ & 606,54 & 333595,50 \\
\hline
\end{tabular}

Źródło: opracowanie własne, tabela wygenerowana za pomocą systemu SPSS.

Z tabeli 23 możemy odczytać, iż istotność asymptotyczna jest mniejsza od założonego współczynnika $\alpha=0,05(p<\alpha)$, stąd należy odrzucić hipotezę zerową. Różnice pomiędzy grupami przedsiębiorstw $\mathrm{W}$ procesie internacjonalizacji oraz podmiotami działającymi lokalnie są istotne.

W związku z faktem, iż zarówno średnie, jak i sumy rang w zakresie obu czynników składowych orientacji na wiedzę, wśród podmiotów zaangażowanych na rynkach zagranicznych są wyższe, można stąd wnioskować, iż to właśnie te przedsiębiorstwa są bardziej zorientowane na wiedzę.

Na podstawie testu Manna-Whitneya można stwierdzić, iż różnice poziomu orientacji na wiedzę ${ }^{68}$ pomiędzy grupami przedsiębiorstw działających lokalnie oraz $\mathrm{w}$ procesie internacjonalizacji są istotne statystycznie na poziomie istotności $\alpha=0,05$.

Przedstawione analizy i testy statystyczne pokazują widoczne różnice w zakresie poziomu orientacji na wiedzę pomiędzy przedsiębiorstwami działającymi lokalnie

\footnotetext{
${ }^{68} \mathrm{Na}$ którą składają się orientacja rynkowa i działania w zakresie wiedzy.
} 
a zaangażowanymi zagranicznie, a także wyższy poziom badanego zjawiska wśród podmiotów $\mathrm{w}$ drugiej $\mathrm{z}$ badanych grup. Należy podkreślić, iż zaobserwowane różnice są stabilne w zakresie wszystkich czynników składowych.

Biorąc pod uwagę powyższe rozstrzygnięcia, w tym przede wszystkim rezultat wykorzystanego testu statystycznego, otrzymane wyniki są podstawą do pozytywnej weryfikacji postawionej hipotezy pierwszej zakładającej, iż przedsiębiorstwa działające na rynkach zagranicznych sa przeciętnie bardziej zorientowane na wiedzę w porównaniu do przedsiębiorstw działających lokalnie.

\subsubsection{Poziom orientacji na wiedzę przedsiębiorstw na poszczególnych etapach procesu internacjonalizacji.}

Dotychczasowe analizy miały na celu porównanie przedsiębiorstw działających lokalnie oraz firm zaangażowanych na rynkach zagranicznych. Traktowały one drugi rodzaj podmiotów jako jednolitą grupę. Dalsze analizy, dokonywane w celu weryfikacji hipotezy drugiej (H2), która jest uszczegółowieniem hipotezy pierwszej, będą wyróżniać poszczególne etapy i formy procesu internacjonalizacji w celu jeszcze dokładniejszego poznania charakteru działań w zakresie orientacji rynkowej oraz intensywności działań w zakresie wiedzy w poszczególnych wyróżnionych kategoriach. Dokładna treść hipotezy drugiej została przytoczona poniżej.

H2: Przedsiębiorstwa wraz $z$ większym zaangażowaniem $w$ proces internacjonalizacji sa przeciętnie bardziej zorientowane na wiedzę.

Weryfikacja powyższej hipotezy zostanie przeprowadzenia $\mathrm{z}$ wykorzystaniem trzech grup analiz:

a) porównania poziomu rynkowo ukierunkowanych procesów w zakresie wiedzy

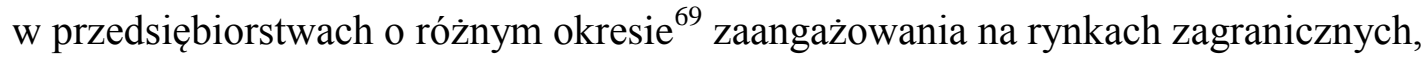

b) porównania poziomu rynkowo ukierunkowanych procesów w zakresie wiedzy w przedsiębiorstwach o różnym udziale sprzedaży na rynkach zagranicznych w porównaniu do sprzedaży ogółem,

\footnotetext{
${ }^{69}$ Okres działalności przedsiębiorstwa na rynkach zagranicznych - mierzony w latach, sumaryczny okres zaangażowania podmiotu gospodarczego, w dowolnej formie i zakresie, na rynkach zagranicznych.
} 
c) porównania poziomu rynkowo ukierunkowanych procesów w zakresie wiedzy w przedsiębiorstwach wykorzystujących poszczególne formy zaangażowania zagranicznego.

Pierwsza z przeprowadzonych serii analiz, w ramach weryfikacji hipotezy drugiej, ma na celu porównanie poziomu orientacji na wiedzę przedsiębiorstw $\mathrm{z}$ określonym doświadczeniem na rynkach zagranicznych. Udziały przedsiębiorstw charakteryzujących się wysokim poziomem badanego zjawiska, oraz jego czynników składowych, w wyróżnionych grupach firm zostały zaprezentowane w tabeli 25 .

Tabela 25. Udziały firm charakteryzujących się wysoką orientacją na wiedzę grupach podmiotów z określonymi okresami doświadczenia w procesie internacjonalizacji.

\begin{tabular}{|c|c|c|c|c|c|}
\hline $\begin{array}{l}\text { Liczba } \\
\text { firm } \\
\text { w grupie }\end{array}$ & $\begin{array}{c}\text { Okres zaangażowania } \\
\text { zagranicznego } \\
\text { przedsiębiorstwa }\end{array}$ & $\begin{array}{c}\text { Wysoki poziom } \\
\text { orientacji na } \\
\text { wiedze } \\
\text { Intensywne } \\
\text { dziatania } \\
\text { w zakresie wiedzy, } \\
\text { jak i wysoka } \\
\text { orientacja rynkowa } \\
(>3,5) \\
\end{array}$ & $\begin{array}{c}\text { Intensywne } \\
\text { działania } \\
\text { w zakresie } \\
\text { wiedzy } \\
(>3,5)\end{array}$ & $\begin{array}{c}\text { Wysoka } \\
\text { orientacja } \\
\text { rynkowa } \\
(>3,5)\end{array}$ & $\begin{array}{c}\frac{\text { Brak orientacji }}{\text { na wiedze }} \\
\text { Brak intensywnych } \\
\text { dziatań w zakresie } \\
\text { wiedzy, } \\
\text { jak i niska } \\
\text { orientacja rynkowa } \\
\text { (oba }<3,5)\end{array}$ \\
\hline 44 & $\begin{array}{l}\text { Zaangażowany } \\
\text { zagranicznie: do } 1 \text { roku }\end{array}$ & $25,0 \%$ & $34,1 \%$ & $54,5 \%$ & $36,4 \%$ \\
\hline 64 & $\begin{array}{l}\text { Zaangażowany } \\
\text { zagranicznie: } 1 \text {-2 lata }\end{array}$ & $28,1 \%$ & $31,3 \%$ & $60,9 \%$ & $35,9 \%$ \\
\hline 110 & $\begin{array}{c}\text { Zaangażowany } \\
\text { zagranicznie: } 3-5 \text { lat }\end{array}$ & $25,5 \%$ & $28,2 \%$ & $58,2 \%$ & $39,1 \%$ \\
\hline 144 & $\begin{array}{c}\text { Zaangażowany } \\
\text { zagranicznie: } 6-10 \text { lat }\end{array}$ & $25,7 \%$ & $29,9 \%$ & $56,9 \%$ & $38,9 \%$ \\
\hline 361 & $\begin{array}{c}\text { Zaangażowany } \\
\text { zagranicznie: powyżej } 10 \\
\text { lat }\end{array}$ & $31,3 \%$ & $34,6 \%$ & $63,2 \%$ & $33,5 \%$ \\
\hline
\end{tabular}

Źródło: opracowanie własne.

Z zestawienia zawartego w tabeli 25 można wywnioskować, iż poziom orientacji na wiedzę w podmiotach posiadających doświadczenie zagraniczne od roku do dwóch lat jest relatywnie wysoki, wyższy niż w przedsiębiorstwach na początku zaangażowania na rynkach zagranicznych. W przypadku firm nieco dłużej obecnych w procesie internacjonalizacji od trzech do dziesięciu lat - poziom orientacji na wiedzę jest niższy w porównaniu z firmami zaangażowanymi poza granicami kraju od roku do dwóch lat. Bardzo wyraźna jest jednak wysoka intensywność rynkowo ukierunkowanych działań najbardziej doświadczonych 
w procesie internacjonalizacji przedsiębiorstw (działających na rynkach zagranicznych powyżej 10 lat).

Tabela 26 pokazuje w bardziej szczegółowy sposób poziom poszczególnych badanych procesów w wyróżnionych grupach przedsiębiorstw.

Tabela 26. Poziom orientacji rynkowej oraz intensywność działań w zakresie wiedzy (z podziałem na poszczególne procesy) w przedsiębiorstwach z określonym doświadczeniem w procesie internacjonalizacji.

\begin{tabular}{|c|c|c|c|c|c|c|c|}
\hline $\begin{array}{l}\text { Liczba } \\
\text { firm } \\
\quad w \\
\text { grupie }\end{array}$ & $\begin{array}{c}\text { Okres } \\
\text { zaangażowania } \\
\text { zagranicznego } \\
\text { przedsiębiorstwa }\end{array}$ & $\begin{array}{l}\text { Kluczowe } \\
\text { źródła } \\
\text { wiedzy } \\
\text { (sekcja 1) }\end{array}$ & $\begin{array}{c}\text { Rozpowsze- } \\
\text { chnianie } \\
\text { wiedzy } \\
\text { (sekcja 2) }\end{array}$ & $\begin{array}{c}\text { Technologie } \\
\text { informatyczne } \\
\text { (sekcja 3) }\end{array}$ & $\begin{array}{c}\text { Wykorzysta- } \\
\text { nie } \\
\text { wiedzy } \\
\text { (sekcja 4) }\end{array}$ & \begin{tabular}{|c} 
Zintegrowany \\
wskaźnik \\
intensywności \\
procesów \\
w zakresie \\
wiedzy \\
(średnia \\
sekcji 1-4)
\end{tabular} & $\begin{array}{c}\text { Orientacja } \\
\text { rynkowa } \\
\text { (sekcja 5) }\end{array}$ \\
\hline 44 & $\begin{array}{c}\text { Zaangażowany } \\
\text { zagranicznie: do } \\
1 \text { roku }\end{array}$ & 2,60 & 3,82 & 3,04 & 3,76 & 3,31 & 3,69 \\
\hline 64 & $\begin{array}{c}\text { Zaangażowany } \\
\text { zagranicznie: } 1-2 \\
\text { lata }\end{array}$ & 2,63 & 3,82 & 2,92 & 3,67 & 3,26 & 3,66 \\
\hline 110 & $\begin{array}{c}\text { Zaangażowany } \\
\text { zagranicznie: } 3-5 \\
\text { lat }\end{array}$ & 2,52 & 3,76 & 2,90 & 3,62 & 3,20 & 3,69 \\
\hline 144 & $\begin{array}{c}\text { Zaangażowany } \\
\text { zagranicznie: } 6- \\
10 \text { lat }\end{array}$ & 2,59 & 3,71 & 2,91 & 3,61 & 3,20 & 3,63 \\
\hline 361 & $\begin{array}{l}\text { Zaangażowany } \\
\text { zagranicznie: } \\
\text { powyżej } 10 \text { lat }\end{array}$ & 2,63 & 3,77 & 3,05 & 3,63 & 3,27 & 3,69 \\
\hline
\end{tabular}

Źródło: opracowanie własne.

Z tabeli 26 wynika, iż intensywność działań w zakresie wiedzy jest relatywnie wysoka w firmach na początku procesu internacjonalizacji (do jednego roku). Jest to prawdopodobnie spowodowane faktem, że podmiot rozpoczynając działalność zagraniczną nie jest zaznajomiony z nową sytuacją, nowymi nabywcami i nowym otoczeniem. Wymusza to zwiększenie intensywności działań poznawczych oraz odpowiednie przetwarzanie uzyskanej wiedzy prowadzące do wprowadzenia odpowiednich zmian w przedsiębiorstwie. Działania w zakresie wiedzy w podmiotach znajdujących się na kolejnych, wyróżnionych etapach internacjonalizacji są mniej intensywne. Wyjątkiem jest ostatnia kategoria. Skupia ona podmioty uczestniczące w procesie internacjonalizacji powyżej dziesięciu lat, wśród których przeciętny poziom działań w zakresie wiedzy jest relatywnie wysoki. Najważniejszym wnioskiem jest jednak fakt, iż otrzymane dane empiryczne nie pokazują wyższej intensywności działań w zakresie wiedzy wśród przedsiębiorstw charakteryzujących się dłuższym okresem zaangażowania na rynkach zagranicznych. 
Poziom orientacji rynkowej w niewielkim zakresie różni się w obrębie wyróżnionych grup przedsiębiorstw, co może być spowodowane niedoskonałością narzędzia badawczego brakiem wysokiej dokładności pomiaru w momencie, gdy różnice są niewielkie. Nieduże różnice między otrzymanymi wartościami sugerują, iż poziom orientacji rynkowej jest podobny w wyróżnionych grupach podmiotów.

Kolejna analiza, której wyniki zostały zaprezentowane w tabeli 27 ma na celu poznanie źródeł wiedzy, z jakich korzystają wyróżnione grupy podmiotów.

Tabela 27. Poziom wykorzystania poszczególnych kategorii źródeł wiedzy przez przedsiębiorstwa z określonym doświadczeniem $\mathrm{w}$ procesie internacjonalizacji.

\begin{tabular}{|c|c|c|c|c|c|c|c|}
\hline $\begin{array}{c}\text { Liczba } \\
\text { firm } \\
\text { w grupie }\end{array}$ & $\begin{array}{c}\text { Okres } \\
\text { zaangażowania } \\
\text { zagranicznego } \\
\text { przedsiębiorstwa } \\
\text { Zaangażowany } \\
\text { zagranicznie: } \text { do } \\
\text { I roku }\end{array}$ & $\begin{array}{c}\text { Źródta } \\
\text { innowacyjne }\end{array}$ & $\begin{array}{c}\text { Źródta } \\
\text { eksperckie }\end{array}$ & $\begin{array}{c}\text { Źródta } \\
\text { rynkowe }\end{array}$ & $\begin{array}{c}\text { Źródta } \\
\text { branżowe }\end{array}$ & $\begin{array}{c}\text { Wtasne } \\
\text { badania } \\
\text { i rozwój }\end{array}$ & $\begin{array}{c}\text { Kluczowe } \\
\text { źódta } \\
\text { wiedzy }\end{array}$ \\
\hline 64 & $\begin{array}{c}\text { Zaangażowany } \\
\text { zagranicznie: } 1- \\
\text { 2 lata }\end{array}$ & 2,70 & 2,16 & 3,04 & 2,74 & 2,83 & 2,63 \\
\hline 110 & $\begin{array}{c}\text { Zaangażowany } \\
\text { zagranicznie: } 3- \\
\text { 5 lat }\end{array}$ & 2,61 & 2,01 & 2,90 & 2,68 & 2,88 & 2,52 \\
\hline 361 & $\begin{array}{c}\text { Zaangażowany } \\
\text { zagranicznie: 6- } \\
\text { 10 lat }\end{array}$ & 2,79 & 2,12 & 2,93 & 2,64 & 3,02 & 2,59 \\
\hline $\begin{array}{c}\text { Zaangażowany } \\
\text { zagranicznie: } \\
\text { powyżej 10 lat }\end{array}$ & 2,76 & 2,17 & 3,00 & 2,70 & 3,07 & 2,63 \\
\hline
\end{tabular}

Źródło: opracowanie własne.

W odniesieniu do źródeł wiedzy, $\mathrm{z}$ jakich korzystają przedsiębiorstwa na poszczególnych etapach internacjonalizacji, mierzonych kryterium długości zaangażowania podmiotu na rynkach zagranicznych, można zaobserwować podobną tendencję jak we wcześniejszych analizach. Występuje niższa intensywność wykorzystania poszczególnych grup źródeł wiedzy wśród podmiotów z doświadczeniem 3-10 lat. Wyjątkiem są własne działania w zakresie badań i rozwoju. Zaangażowanie podmiotów w tym obszarze jest wyższe w firmach dłużej zaangażowanych w proces internacjonalizacji (tabela 27).

W celu sprawdzenia korelacji pomiędzy intensywnością orientacji przedsiębiorstwa na wiedzę a okresem jego zaangażowania zagranicznego zostanie zastosowany współczynnik korelacji rang Spearmana (tabela 28). 
$\rho_{S}$ - współczynnik korelacji rang w populacji [Jóźwiak i Podgórski 2012, s. 352].
$\mathrm{H}_{0}: \rho_{S}=0$
$\mathrm{H}_{1}: \rho_{S} \neq 0$

Tabela 28. Weryfikacja hipotezy drugiej - okres zaangażowania zagranicznego przedsiębiorstwa - korelacja rang Spearmana.

\begin{tabular}{|c|c|c|c|}
\hline \multicolumn{2}{|c|}{} & $\begin{array}{c}\text { Orientacja } \\
\text { rynkowa }\end{array}$ & $\begin{array}{c}\text { Działania } \\
\text { w zakresie } \\
\text { wiedzy }\end{array}$ \\
\hline \multirow{2}{*}{ rho Spearmana } & $\begin{array}{c}\text { Współczynnik } \\
\text { korelacji }\end{array}$ & 0,041 & 0,036 \\
\cline { 2 - 4 } & $\begin{array}{c}\text { Istotność } \\
\text { (dwustronna) } \\
\text { p-value }\end{array}$ & 0,267 & 0,338 \\
\hline Zródło: opracowanie własne, tabela wygenerowana za pomocą systemu SPSS.
\end{tabular}

Wartość współczynnika p dla obu czynników składowych orientacji na wiedzę jest większa od 0,05, stąd nie ma podstaw do odrzucenia hipotezy zerowej.

Analiza statystyczna z wykorzystaniem korelacji rang Spearmana dowodzi, iż nie istnieje statystycznie istotna korelacja pomiędzy okresem zaangażowania zagranicznego przedsiębiorstwa, a poziomem jego orientacji na wiedzę (tabela 28).

Można jednak zauważyć określone, aczkolwiek niewielkie, prawidłowości. Całkowite i kompleksowe działania przedsiębiorstw dotyczące wiedzy są najbardziej intensywne w początkowych okresach internacjonalizacji (pierwsze dwa lata) oraz w bardzo doświadczonych podmiotach. W przypadku przedsiębiorstw w początkowym okresie internacjonalizacji prawdopodobnie jest to związane z faktem, iż są to przedsiębiorstwa, które znalazły się w nowej sytuacji i są świadome swoich braków w zasobie wiedzy. W związku z tym intensyfikują one swoje działania w zakresie odpowiedniego poznania rynków zagranicznych, rozwoju nowych produktów i ogólnego usprawniania działania przedsiębiorstwa w celu sprostania nowemu wyzwaniu. Po okresie stabilizacji, działania te najwyraźniej tracą impet. Wyższa orientacja na wiedzę $\mathrm{w}$ przypadku podmiotów z doświadczeniem zagranicznym powyżej 10 lat może być związana $\mathrm{z}$ faktem, 
iż prawdopodobnie ta kategoria $\mathrm{w}$ dużej mierze skupia podmioty obecne na rynkach zagranicznych znacznie dłużej niż dziesięć lat. Mogą one posiadać rozwinięte procedury działania i świadomość znaczenia rynkowo ukierunkowanych procesów w zakresie wiedzy.

Ważnym i interesującym wnioskiem jest również fakt, iż tworzenie i wykorzystanie wiedzy $z$ pomocą własnych działań badawczych i rozwojowych jest wyższe w przedsiębiorstwach charakteryzujących się dłuższym okresem zaangażowania zagranicznego.

Druga seria analiz, w ramach weryfikacji hipotezy drugiej, ma na celu porównanie poziomu orientacji na wiedzę przedsiębiorstw z określonymi udziałami sprzedaży firmy na rynkach zagranicznych w porównaniu do jej sprzedaży ogółem. Udziały przedsiębiorstw charakteryzujących się wysokim poziomem badanego zjawiska, oraz jego czynników składowych, w wyróżnionych grupach firm zostały zaprezentowane w tabeli 29, zaś bardziej szczegółowe dane przedstawiono w tabeli 30.

Tabela 29. Udziały firm charakteryzujących się wysoką orientacją na wiedzę grupach podmiotów z określonym udziałem sprzedaży na rynkach zagranicznych w porównaniu do sprzedaży ogółem.

\begin{tabular}{|c|c|c|c|c|c|}
\hline $\begin{array}{c}\text { Liczba } \\
\text { firm } \\
\text { w } \\
\text { grupie }\end{array}$ & $\begin{array}{l}\text { Przybliżony udziat } \\
\text { wielkości sprzedaży } \\
\text { zagranicznej firmy } \\
\text { w porównaniu do } \\
\text { sprzedaży ogótem }\end{array}$ & $\begin{array}{c}\text { Wysoki poziom } \\
\text { orientacji na } \\
\text { wiedze } \\
\text { Intensywne dziatania } \\
\text { w zakresie wiedzy, } \\
\text { jak } i \text { wysoka } \\
\text { orientacja rynkowa } \\
(>3,5)\end{array}$ & $\begin{array}{c}\text { Intensywne } \\
\text { działania } \\
\text { w zakresie } \\
\text { wiedzy } \\
(>3,5)\end{array}$ & $\begin{array}{c}\text { Wysoka } \\
\text { orientacja } \\
\text { rynkowa } \\
(>3,5)\end{array}$ & $\begin{array}{c}\frac{\text { Brak orientacji }}{\text { na }} \text { wiedze } \\
\text { Brak intensywnych } \\
\text { dziatan w zakresie } \\
\text { wiedzy, } \\
\text { jak i niska orientacja } \\
\text { rynkowa }(\text { oba }<3,5)\end{array}$ \\
\hline 338 & $1-10 \%$ & $24,9 \%$ & $27,2 \%$ & $61,2 \%$ & $36,4 \%$ \\
\hline 163 & $11-30 \%$ & $35,6 \%$ & $38,7 \%$ & $66,3 \%$ & $30,7 \%$ \\
\hline 76 & $31-60 \%$ & $32,9 \%$ & $35,5 \%$ & $63,2 \%$ & $34,2 \%$ \\
\hline 95 & $>60 \%$ & $29,5 \%$ & $36,8 \%$ & $49,5 \%$ & $43,2 \%$ \\
\hline
\end{tabular}

Źródło: opracowanie własne. 
Tabela 30. Intensywność działań w zakresie wiedzy (z podziałem na poszczególne procesy) oraz poziom orientacji rynkowej w przedsiębiorstwach z określonym udziałem sprzedaży na rynkach zagranicznych

\begin{tabular}{|c|c|c|c|c|c|c|c|}
\hline $\begin{array}{l}\text { Liczba } \\
\text { firm } \\
\quad w \\
\text { grupie }\end{array}$ & $\begin{array}{l}\text { Przybliżony udziat } \\
\text { wielkości sprzedaży } \\
\text { zagranicznej firmy } \\
\text { w porównaniu do } \\
\text { sprzedaży ogółem }\end{array}$ & $\begin{array}{l}\text { Kluczowe } \\
\text { źródta } \\
\text { wiedzy } \\
\text { (sekcja 1) }\end{array}$ & $\begin{array}{l}\text { Rozpowsze- } \\
\text { chnianie } \\
\text { wiedzy } \\
\text { (sekcja 2) }\end{array}$ & $\begin{array}{c}\text { Technologie } \\
\text { informatyczne } \\
\text { (sekcja 3) }\end{array}$ & $\begin{array}{c}\text { Wykorzysta- } \\
\text { nie } \\
\text { wiedzy } \\
\text { (sekcja 4) }\end{array}$ & $\begin{array}{c}\text { Zintegrowany } \\
\text { wskaźnik } \\
\text { intensywności } \\
\text { procesów } \\
\text { w zakresie } \\
\text { wiedzy } \\
\text { ('srednia } \\
\text { arytmetyczna } \\
\text { sekcji 1-4) }\end{array}$ & $\begin{array}{c}\text { Orientacja } \\
\text { rynkowa } \\
(\text { sekcja 5) }\end{array}$ \\
\hline 338 & $1-10 \%$ & 2,55 & 3,77 & 2,88 & 3,62 & 3,20 & 3,68 \\
\hline 163 & $11-30 \%$ & 2,65 & 3,75 & 3,09 & 3,66 & 3,29 & 3,73 \\
\hline 76 & $31-60 \%$ & 2,71 & 3,81 & 3,11 & 3,69 & 3,33 & 3,66 \\
\hline 95 & $>60 \%$ & 2,60 & 3,75 & 3,10 & 3,61 & 3,21 & 3,58 \\
\hline
\end{tabular}

Źródło: opracowanie własne.

Pierwszym wnioskiem, jaki można zaobserwować na podstawie tabeli 30 są niewielkie różnice pomiędzy wyszczególnionymi zbiorami podmiotów $\mathrm{W}$ zakresie intensywności badanych procesów w przedsiębiorstwach. W tabeli 29 można jednak zauważyć, iż udział firm charakteryzujących się wysoką orientacją na wiedzę w poszczególnych grupach jest wyższy $\mathrm{w}$ przypadku podmiotów $\mathrm{z}$ większym udziałem sprzedaży zagranicznej, niestety prawidłowość ta występuje tylko w grupach firm charakteryzujących się relatywnie niskimi poziomami sprzedaży zagranicznej (do 30\%). Pewnym zaskoczeniem są niższe niż spodziewane wartości poziomu analizowanych działań w grupach podmiotów, które przekroczyły wspomnianą granicę, szczególnie w ostatniej z nich. Jednym z powodów otrzymania takich wyników może być fakt, iż dwie ostatnie wyróżnione grupy mogą skupiać specyficzne typy podmiotów np. określonych poddostawców zorientowanych na produkcję konkretnych komponentów zamówionych przez odbiorców zagranicznych. Może to ograniczać intensywność ich działań w badanych obszarach, gdyż część analizowanych procesów może być realizowana poza tymi firmami. Jest to prawdopodobne szczególnie z uwagi na fakt, iż liczba przedsiębiorstw w dwóch ostatnich grupach jest zdecydowanie mniejsza niż w pozostałych zbiorach.

W przypadku kryterium źródeł wiedzy (tabela 31) można zauważyć, iż podmioty z wyższym udziałem sprzedaży zagranicznej nieco bardziej intensywnie wykorzystują źródła eksperckie. Poza wspomnianą prawidłowością w kontekście źródeł pozyskiwania wiedzy nie można zaobserwować żadnej innej określonej prawidłowości. 
Tabela 31. Poziom wykorzystania poszczególnych kategorii źródeł wiedzy przez przedsiębiorstwa z określonym udziałem sprzedaży na rynkach zagranicznych w porównaniu do sprzedaży ogółem.

\begin{tabular}{|c|c|c|c|c|c|c|c|}
\hline $\begin{array}{c}\text { Liczba } \\
\text { firm } \\
\text { w } \\
\text { grupie }\end{array}$ & $\begin{array}{c}\text { Przybliżony udziat } \\
\text { wielkości sprzedaży } \\
\text { zagranicznej firmy } \\
\text { w porównaniu do } \\
\text { sprzedaży ogótem }\end{array}$ & $\begin{array}{c}\text { Źródła } \\
\text { innowa- } \\
\text { cyjne }\end{array}$ & $\begin{array}{c}\text { Źródta } \\
\text { eksperckie }\end{array}$ & $\begin{array}{c}\text { Źródta } \\
\text { rynkowe }\end{array}$ & $\begin{array}{c}\text { Źródta } \\
\text { branżowe }\end{array}$ & $\begin{array}{c}\text { Własne } \\
\text { badania } \\
\text { i rozwój }\end{array}$ & $\begin{array}{c}\text { Kluczowe } \\
\text { źódta } \\
\text { wiedzy }\end{array}$ \\
\hline 338 & $1-10 \%$ & 2,69 & 2,03 & 2,98 & 2,68 & 2,95 & 2,55 \\
\hline 163 & $11-30 \%$ & 2,77 & 2,21 & 2,85 & 2,72 & 2,99 & 2,65 \\
\hline 76 & $31-60 \%$ & 2,82 & 2,21 & 2,85 & 2,83 & 3,11 & 2,71 \\
\hline 95 & $>60 \%$ & 2,78 & 2,24 & 2,94 & 2,53 & 3,05 & 2,60 \\
\hline
\end{tabular}

Źródło: opracowanie własne.

W celu sprawdzenia korelacji pomiędzy intensywnością orientacji przedsiębiorstwa na wiedzę, a udziałem jego sprzedaży zagranicznej w porównaniu do sprzedaży ogółem zostanie zastosowany współczynnik korelacji rang Spearmana (tabela 32).

$\rho_{S}$ - współczynnik korelacji rang w populacji [Jóźwiak i Podgórski 2012, s. 352].

$\mathrm{H}_{0}: \rho_{S}=0$

$\mathrm{H}_{1}: \rho_{S} \neq 0$

Tabela 32. Weryfikacja hipotezy drugiej - udział sprzedaży zagranicznej przedsiębiorstwa - korelacja rang Spearmana.

\begin{tabular}{|c|c|c|c|}
\hline \multicolumn{2}{|c|}{} & $\begin{array}{c}\text { Orientacja } \\
\text { rynkowa }\end{array}$ & $\begin{array}{c}\text { Działania } \\
\text { w zakresie } \\
\text { wiedzy }\end{array}$ \\
\hline rho Spearmana & $\begin{array}{c}\text { Współczynnik } \\
\text { korelacji }\end{array}$ & $-0,028$ & $0,086^{*}$ \\
\cline { 2 - 4 } & $\begin{array}{c}\text { Istotność } \\
\text { (dwustronna) } \\
\text { p-value }\end{array}$ & 0,474 & 0,025 \\
\hline Z. Korelacja jest istotna na poziomie 0.05 (dwustronnie). \\
\hline Zródracowanie własne, tabela wygenerowana za pomocą systemu SPSS.
\end{tabular}

Wartość współczynnika p w przypadku działań w zakresie wiedzy jest mniejsza od 0,05 , stąd istnieje korelacja pomiędzy badanymi czynnikami i należy odrzucić hipotezę 
zerową. W kontekście orientacji rynkowej wartość współczynnika p jest większa od 0,05 i nie ma podstaw do odrzucenia hipotezy zerowej.

Analiza statystyczna z wykorzystaniem korelacji rang Spearmana pokazuje, iż istnieje bardzo słaba, lecz statystycznie istotna $(p=0,025)$ korelacja pomiędzy udziałem sprzedaży zagranicznej przedsiębiorstwa, a intensywnością jego działań w zakresie wiedzy. Podobnej korelacji nie można jednak dostrzec w kontekście orientacji rynkowej. W związku z faktem, iż orientacja na wiedzę zakłada jednoczesne występowanie obu badanych czynników należy stwierdzić, iż nie istnieje statystycznie istotna korelacja pomiędzy udziałem sprzedaży przedsiębiorstwa na rynkach zagranicznych, a poziomem jego orientacji na wiedzę (tabela $32)$.

Podsumowując, kryterium udziału sprzedaży zagranicznej ujawnia dwie grupy podmiotów zaangażowanych zagranicznie. Pierwsza - w miarę wzrostu sprzedaży zagranicznej nieznacznie zwiększa również swoją orientację na wiedzę. Prawdopodobnie jednak w związku z faktem, iż Polska jest relatywnie dużym rynkiem w przypadku tego typu podmiotów udział sprzedaży zagranicznej rzadko przekracza 30 procent.

W przedsiębiorstwach z udziałem sprzedaży zagranicznej: $31-60 \%$ oraz $>60 \%$ mamy, $\mathrm{z}$ dużym prawdopodobieństwem, do czynienia $\mathrm{w}$ przeważającej mierze $\mathrm{z}$ firmami ściśle współpracującymi z partnerami zagranicznymi. Prawdopodobnie w wielu przypadkach zajmują się oni działaniami rynkowymi w imieniu badanych podmiotów i częściowo dostarczają im również potrzebną wiedzę. W związku z tym firmy należące do omawianych grup są przypuszczalnie podmiotami wyspecjalizowanymi w określonych działaniach, stąd poziom badanych procesów związanych szczególnie z rynkiem, ale też i z wiedzą może być w ich przypadku niższy.

Ostatnią grupą analiz przeprowadzanych w ramach weryfikacji hipotezy drugiej, jest porównanie poziomu orientacji na wiedzę $\mathrm{w}$ przedsiębiorstwach wykorzystujących poszczególne formy zaangażowania zagranicznego. Udziały firm charakteryzujących się wysokim poziomem badanego zjawiska, oraz jego czynników składowych, w wyróżnionych grupach, zostały zaprezentowane w tabeli 33, zaś bardziej szczegółowe dane przedstawiono w tabeli 34. Należy pamiętać, iż respondenci w przypadku tego pytania mogli zaznaczyć więcej niż jedną odpowiedź. 
Tabela 33. Udziały firm charakteryzujących się wysoką orientacją na wiedzę grupach podmiotów wykorzystujących określone formy internacjonalizacji.

\begin{tabular}{|c|c|c|c|c|c|}
\hline $\begin{array}{c}\text { Liczba } \\
\text { firm } \\
\text { w grupie }\end{array}$ & $\begin{array}{c}\text { Forma } \\
\text { zaangażowania } \\
\text { zagranicznego }\end{array}$ & $\begin{array}{c}\text { Wysoki poziom } \\
\text { orientacji na } \\
\text { wiedze } \\
\text { Intensywne działania } \\
\text { w zakresie wiedzy, } \\
\text { jak } \text { i wysoka } \\
\text { orientacja rynkowa } \\
(>3,5) \\
\end{array}$ & $\begin{array}{c}\text { Intensywne } \\
\text { działania } \\
\text { w zakresie } \\
\text { wiedzy } \\
(>3,5)\end{array}$ & $\begin{array}{l}\text { Wysoka } \\
\text { orientacja } \\
\text { rynkowa } \\
(>3,5)\end{array}$ & $\begin{array}{c}\frac{\text { Brak orientacji }}{\text { na wiedze }} \\
\text { Brak intensywnych } \\
\text { działań w zakresie } \\
\text { wiedzy, } \\
\text { jak i niska orientacja } \\
\text { rynkowa (oba <3,5) }\end{array}$ \\
\hline 590 & Eksport lub import & $27,5 \%$ & $30,5 \%$ & $60,0 \%$ & $36,9 \%$ \\
\hline 31 & $\begin{array}{c}\text { Wspótpraca } \\
\text { niekapitałowa } \\
\text { (licencjonowanie, } \\
\text { franchising) }\end{array}$ & $41,9 \%$ & $48,4 \%$ & $61,3 \%$ & $32,3 \%$ \\
\hline 24 & $\begin{array}{c}\text { Wspótpraca kapitałowa } \\
\text { (joint venture) }\end{array}$ & $45,8 \%$ & $50,0 \%$ & $66,7 \%$ & $29,2 \%$ \\
\hline 159 & Podwykonawstwo & $30,8 \%$ & $34,6 \%$ & $66,0 \%$ & $30,2 \%$ \\
\hline 77 & $\begin{array}{c}\text { Wtasna inwestycja } \\
\text { bezpośrednia }\end{array}$ & $37,7 \%$ & $39,0 \%$ & $63,6 \%$ & $35,1 \%$ \\
\hline
\end{tabular}

Źródło: opracowanie własne.

Tabela 33 pokazuje, iż znaczna część firm zaangażowanych w kapitałową oraz niekapitałową współpracę z podmiotami zagranicznymi charakteryzuje się wysokim poziomem orientacji na wiedzę. Omawiana tabela uwypukla również niską intensywność działań w zakresie wiedzy podmiotów wykorzystujących import lub eksport. Szczególnie interesującym jest jednak zestawienie dwóch form - podwykonawstwa oraz własnej inwestycji bezpośredniej (WIB). Z tabeli 34 wynika, że podwykonawstwo przeciętnie charakteryzuje się praktycznie porównywalną lub nawet nieco wyższą intensywnością działań w zakresie wiedzy w zestawieniu $\mathrm{z}$ WIB. Mimo to, udział podmiotów o wysokiej intensywności działań w zakresie wiedzy w przypadku WIB jest wyższy niż w przypadku podwykonawstwa (tabela 33). Może to świadczyć o dużej polaryzacji podmiotów zajmujących się podwykonawstwem - np. występowaniu w tej grupie niewielkiej liczby podmiotów o bardzo wysokiej intensywności omawianych działań przy pozostałych firmach charakteryzujących się niskim lub średnim poziomem aktywności w badanych obszarach. 
Tabela 34. Intensywność działań w zakresie wiedzy (z podziałem na poszczególne procesy) oraz poziom orientacji rynkowej w przedsiębiorstwach wykorzystaniem określone formy internacjonalizacji.

\begin{tabular}{|c|c|c|c|c|c|c|c|}
\hline $\begin{array}{l}\text { Liczba } \\
\text { firm } \\
\quad w \\
\text { grupie }\end{array}$ & $\begin{array}{c}\text { Forma } \\
\text { zaangażowania } \\
\text { zagranicznego }\end{array}$ & $\begin{array}{l}\text { Kluczowe } \\
\text { źródta } \\
\text { wiedzy } \\
\text { (sekcja 1) }\end{array}$ & $\begin{array}{c}\text { Rozpowsze- } \\
\text { chnianie } \\
\text { wiedzy } \\
\text { (sekcja 2) }\end{array}$ & $\begin{array}{c}\text { Technologie } \\
\text { informatyczne } \\
\text { (sekcja 3) }\end{array}$ & $\begin{array}{l}\text { Wykorzy- } \\
\text { stanie } \\
\text { wiedzy } \\
\text { (sekcja 4) }\end{array}$ & $\begin{array}{c}\text { Zintegrowany } \\
\text { wskaźnik } \\
\text { intensywności } \\
\text { procesów } \\
\text { w zakresie } \\
\text { wiedzy } \\
\text { ('srednia } \\
\text { arytmetyczna } \\
\text { sekcji 1-4) } \\
\end{array}$ & $\begin{array}{c}\text { Orientacja } \\
\text { rynkowa } \\
(\text { sekcja 5) }\end{array}$ \\
\hline 590 & Eksport lub import & 2,58 & 3,74 & 2,92 & 3,62 & 3,21 & 3,67 \\
\hline 31 & $\begin{array}{c}\text { Wspótpraca } \\
\text { niekapitałowa } \\
\text { (licencjonowanie, } \\
\text { franchising) }\end{array}$ & 2,93 & 3,90 & 3,39 & 3,74 & 3,49 & 3,65 \\
\hline 24 & $\begin{array}{c}\text { Wspótpraca } \\
\text { kapitałowa } \\
\text { (joint venture) } \\
\end{array}$ & 2,88 & 3,83 & 3,43 & 3,86 & 3,50 & 3,84 \\
\hline 159 & Podwykonawstwo & 2,67 & 3,85 & 3,06 & 3,67 & 3,31 & 3,70 \\
\hline 77 & $\begin{array}{l}\text { Wtasna inwestycja } \\
\text { bezpośrednia }\end{array}$ & 2,72 & 3,65 & 3,19 & 3,63 & 3,30 & 3,65 \\
\hline
\end{tabular}

Źródło: opracowanie własne.

Jak wynika z tabeli 34 najliczniejszą grupą w badanej próbie, w kontekście formy internacjonalizacji, były przedsiębiorstwa zaangażowane w eksport lub import. Ich działania w zakresie wiedzy są relatywnie mało intensywne. Najbardziej aktywnymi w zakresie wiedzy są podmioty zaangażowane we współpracę $\mathrm{z}$ podmiotami zagranicznymi (zarówno kapitałową, jak i niekapitałową). W przypadku poziomu orientacji rynkowej najwyższą wartością dla tego kryterium charakteryzuje się współpraca kapitałowa. Należy jednak podkreślić, iż powyższa tabela zawiera wyłącznie średnie wartości dla danych grup. Warto je skonfrontować i analizować wspólnie z wcześniejszą tabelą (33) przedstawiającą, w ramach wykorzystywanych form internacjonalizacji, udziały podmiotów posiadających wysoką intensywność poszczególnych procesów. W tabeli 33 różnice pomiędzy poszczególnymi formami są bardziej wyraźne w porównaniu $\mathrm{z}$ tabela 34 . Jest to związane $\mathrm{z}$ faktem, iż w przedsiębiorstwach wykorzystujących określone formy internacjonalizacji częściej obserwowane jest równoczesne występowanie intensywnych działań w zakresie wiedzy oraz wysokiej orientacji rynkowej.

W celu dokładniejszego zrozumienia omawianego zagadnienia w tabeli 35 została przedstawiona charakterystyka badanych form zaangażowania zagranicznego pod kątem wykorzystania określonych źródeł wiedzy. 
Tabela 35. Poziom wykorzystania poszczególnych kategorii źródeł wiedzy przez przedsiębiorstwa wykorzystujące określone formy internacjonalizacji.

\begin{tabular}{|c|c|c|c|c|c|c|c|}
\hline $\begin{array}{c}\text { Liczba } \\
\text { firm } \\
\text { grupie }\end{array}$ & $\begin{array}{c}\text { Forma } \\
\text { zaangażowania } \\
\text { zagranicznego }\end{array}$ & $\begin{array}{c}\text { Źródta } \\
\text { innowacyjne }\end{array}$ & $\begin{array}{c}\text { Źródta } \\
\text { eksperckie }\end{array}$ & $\begin{array}{c}\text { Źródła } \\
\text { rynkowe }\end{array}$ & $\begin{array}{c}\text { Źródła } \\
\text { branżowe }\end{array}$ & $\begin{array}{c}\text { Własne } \\
\text { badania } \\
\text { i rozwój }\end{array}$ & $\begin{array}{c}\text { Kluczowe } \\
\text { źródta } \\
\text { wiedzy }\end{array}$ \\
\hline 590 & $\begin{array}{c}\text { Eksport lub } \\
\text { import }\end{array}$ & 2,71 & 2,10 & 2,95 & 2,69 & 2,98 & 2,58 \\
\hline 24 & $\begin{array}{c}\text { Wspótpraca } \\
\text { niekapitatowa } \\
\text { (licencjonowanie, } \\
\text { franchising) }\end{array}$ & 3,13 & 2,32 & 3,35 & 3,04 & 3,32 & 2,93 \\
\hline 159 & $\begin{array}{c}\text { Wspótpraca } \\
\text { kapitatowa } \\
\text { (joint venture) }\end{array}$ & 2,97 & 2,67 & 3,25 & 2,76 & 3,38 & 2,88 \\
\hline $\begin{array}{c}\text { Podwykonawstwo } \\
77\end{array}$ & 2,88 & 2,21 & 2,56 & 2,73 & 3,13 & 2,67 \\
\hline $\begin{array}{c}\text { Wtasna } \\
\text { inwestycja } \\
\text { bezpośrednia }\end{array}$ & 2,91 & 2,35 & 3,03 & 2,69 & 3,34 & 2,72 \\
\hline
\end{tabular}

Źródło: opracowanie własne.

Tabela 35 ujawnia relatywnie wysokie wykorzystanie szerokiej gamy źródeł wiedzy przez przedsiębiorstwa zaangażowane we współpracę zagraniczną. Przedsiębiorstwa wykorzystujące współpracę kapitałową lub niekapitałową dominują szczególnie w zakresie wykorzystania źródeł rynkowych, innowacyjnych oraz własnych badań i rozwoju. Należy jednak zaznaczyć, iż bardzo wysoki poziom utylizacji własnych działań badawczych występuje również wśród podmiotów wykorzystujących w procesie internacjonalizacji form własnej inwestycji bezpośredniej.

W przypadku kryterium formy zaangażowania zagranicznego przedsiębiorstwa nie jest możliwe zastosowanie „,klasycznych” miar współzależności, gdyż respondenci w tym pytaniu mogli wybrać kilka odpowiedzi (zastosowano test wielokrotnego wyboru) stąd badane populacje nie są niezależne. W związku $\mathrm{z}$ tym utworzono w programie SPSS zestaw wielokrotnych odpowiedzi i przeprowadzono test $\mathrm{t}$ dla średnich kolumnowych z poprawką Bonferroniego (jest to korekta wartości p dla porównań wielokrotnych) oraz wariancją, która jest oszacowana na podstawie porównywanych kategorii. 
$\mathrm{H}_{0}: \mu_{1}=\mu_{2}$

$\mathrm{H}_{1}: \mu_{1} \neq \mu_{2}$

Tabela 36. Weryfikacja hipotezy drugiej - średnie wartości orientacji na wiedzę i liczebności poszczególnych form zaangażowania zagranicznego przedsiębiorstw.

\begin{tabular}{|c|c|c|c|c|c|c|}
\hline & \multicolumn{5}{|c|}{ Forma zaangażowania zagranicznego } \\
\hline & & $\begin{array}{l}\text { Eksport } \\
\text { lub import }\end{array}$ & $\begin{array}{c}\text { Współpraca } \\
\text { niekapitałowa } \\
\text { (licencjonowanie, } \\
\text { franchising) }\end{array}$ & $\begin{array}{c}\text { Współpraca } \\
\text { kapitałowa } \\
\text { (joint } \\
\text { venture) }\end{array}$ & Podwykonawstwo & $\begin{array}{c}\text { Własna } \\
\text { inwestycja } \\
\text { bezpośrednia }\end{array}$ \\
\hline $\begin{array}{c}\text { Zintegr. } \\
\text { wsk. } \\
\text { intens. } \\
\text { proc. }\end{array}$ & Średnia & 3,21 & 3,49 & 3,50 & 3,31 & 3,30 \\
\hline $\begin{array}{c}\text { w zakresie } \\
\text { wiedzy } \\
\text { (średnia } \\
\text { arytmet. } \\
\text { sekcji 1-4) }\end{array}$ & Liczebność & 590 & 31 & 24 & 159 & 77 \\
\hline & Średnia & 3,67 & 3,65 & 3,84 & 3,70 & 3,65 \\
\hline & Liczebność & 590 & 31 & 24 & 159 & 77 \\
\hline
\end{tabular}

Źródło: opracowanie własne, tabela wygenerowana za pomocą systemu SPSS.

Z tabeli 37 będącej tabelą wynikową programu IBM SPSS, otrzymaną w ramach wykorzystywanego testu $\mathrm{t}^{70}$ wynika, iż istnieje tylko jedna statystycznie istotna różnica - pomiędzy intensywnością działań w zakresie wiedzy w przedsiębiorstwach eksportujących lub importujących w porównaniu do podmiotów prowadzących współpracę niekapitałową. Pomiędzy pozostałymi wyróżnionymi grupami przedsiębiorstw nie można zaobserwować różnic istotnych statystycznie w zakresie działań w obszarze wiedzy. ${ }^{70}$ Dokładna nazwa wykorzystywanego testu: test $\mathrm{t}$ dla średnich kolumnowych $\mathrm{z}$ poprawką Bonferroniego
oraz wariancją, która jest oszacowana na podstawie porównywanych kategorii. 
W przypadku poziomu orientacji rynkowej nie zostały zauważone żadne istotne statystycznie różnice w ramach badanych grup podmiotów.

Tabela 37. Porównanie średnich w kolumnach - poszczególne formy zaangażowania zagranicznego przedsiębiorstw.

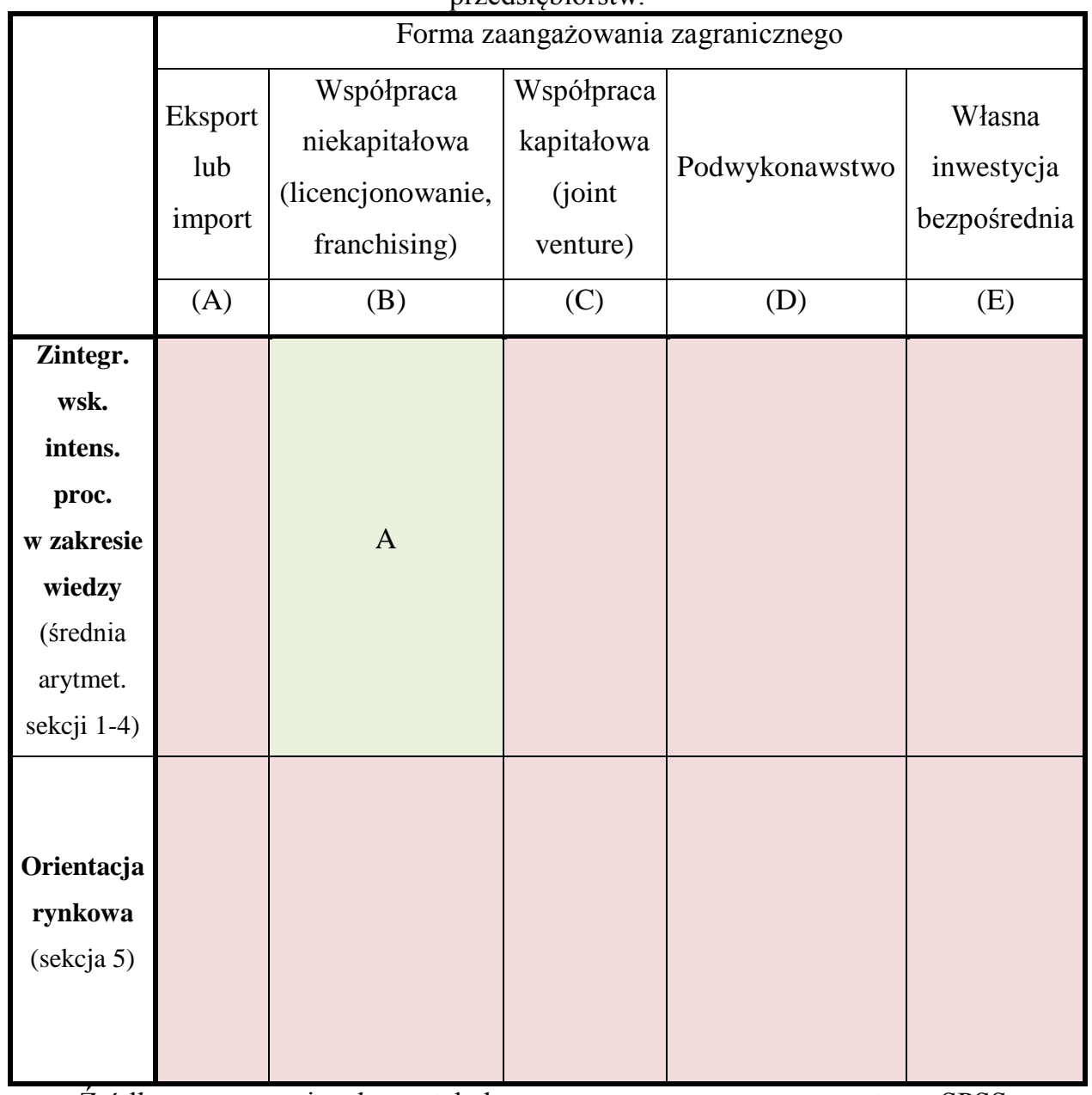

Źródło: opracowanie własne, tabela wygenerowana za pomocą systemu SPSS.

Analiza statystyczna z wykorzystaniem testu t dla średnich kolumnowych z poprawką Bonferroniego oraz wariancją, która jest oszacowana na podstawie porównywanych kategorii, wykazała, iż (poza jednym wyjątkiem) nie istnieją statystycznie istotne różnice pomiędzy formą zaangażowania zagranicznego przedsiębiorstwa, a poziomem jego orientacji na wiedzę.

Wśród trzech wykorzystywanych w pracy kryteriów poziomu internacjonalizacji przedsiębiorstwa najbardziej widoczne różnice $\mathrm{w}$ zakresie poziomu orientacji na wiedzę można zaobserwować posługując się kryterium formy zaangażowania zagranicznego podmiotu. Należy jednak podkreślić, że różnice w poziomie badanego zjawiska nawet w tym przypadku nie są duże. Ponadto, w przeciwieństwie do założeń hipotezy drugiej grupa firm 
wykorzystująca najbardziej zaawansowaną formę internacjonalizacji - własną inwestycję bezpośrednią, nie charakteryzuje się przeciętnie najwyższym poziomem orientacji na wiedzę. Najbardziej zorientowane na wiedzę w tym względzie są podmioty wykorzystujące formy internacjonalizacji postrzegane jako pośrednie - współpraca kapitałowa i niekapitałowa. W przypadku najmniej zaawansowanych form internacjonalizacji, jakimi są import i eksport, gdy kontakt z rynkiem zagranicznym jest ograniczony, intensywność badanych procesów, tak jak się spodziewano, jest najniższa.

W związku $\mathrm{z}$ tym $\mathrm{w}$ ramach przeprowadzonych analiz nie znaleziono dowodów, iż bardziej zaawansowana forma zaangażowania zagranicznego przedsiębiorstwa jest powiązana z wyższą orientacją podmiotu na wiedzę. Ponadto, różnice w poziomie badanego zjawiska wśród firm wykorzystujących poszczególne formy zaangażowania zagranicznego, poza jednym wyjątkiem, nie są istotne statystycznie.

Podsumowując, wyniki przeprowadzonych analiz statystycznych wskazują, iż nie występują większe i spójne różnice w zakresie przeciętnego poziomu orientacji na wiedzę wśród przedsiębiorstw na poszczególnych etapach internacjonalizacji z wykorzystaniem kryteriów okresu zaangażowania zagranicznego i udziału sprzedaży zagranicznej przedsiębiorstwa w jego sprzedaży ogółem. W przypadku kryterium formy internacjonalizacji podmiotu zaobserwowane różnice są widoczne, lecz również niewielkie.

Przeprowadzone testy statystyczne nie wykazują istotnych statystycznie różnic pomiędzy poziomami przeciętnej orientacji na wiedzę przedsiębiorstw na różnych etapach procesu internacjonalizacji $\mathrm{z}$ wykorzystaniem kryterium okresu zaangażowania zagranicznego. W przypadku kryteriów udziału sprzedaży zagranicznej przedsiębiorstwa w jego sprzedaży ogółem oraz formy internacjonalizacji podmiotu zaobserwowano niewielkie, lecz istotne statystycznie różnice wyłącznie w ramach niektórych czynników składowych orientacji na wiedzę.

W związku z tym, na bazie przeprowadzonych analiz nie istnieja podstawy do pozytywnej weryfikacji hipotezy drugiej, zakładającej iż przedsiębiorstwa wraz z większym zaangażowaniem $w$ proces internacjonalizacji saprzeciętnie bardziej zorientowane na wiedzę. 


\subsubsection{Rola orientacji na wiedzę $w$ procesie kształtowania przewagi konkurencyjnej przedsiębiorstwa w procesie internacjonalizacji.}

Pierwsze dwie hipotezy weryfikowane w niniejszej pracy dotyczyły poziomu orientacji na wiedzę przedsiębiorstw działających lokalnie oraz na poszczególnych etapach procesu internacjonalizacji. Dotychczasowe analizy wykazały, że istnieją wyraźne różnice w poziomie orientacji na wiedzę przedsiębiorstw działających lokalnie oraz tych w procesie internacjonalizacji.

Fakt, iż przedsiębiorstwa $\mathrm{w}$ procesie internacjonalizacji, $\mathrm{w}$ porównaniu do firm działających lokalnie, są bardziej zorientowane na wiedzę stanowi potwierdzenie przypuszczeń formułowanych we wcześniejszych, teoretycznych częściach pracy. Wysoka intensywność procesów dotyczących wiedzy w omawianej grupie podmiotów sprawia, iż można oczekiwać, iż wysoki poziom orientacji na wiedzę wpływa na kształtowanie przewagi konkurencyjnej tego typu przedsiębiorstw. Stąd ważnym i interesującym zadaniem będzie weryfikacja hipotezy trzeciej o następującej treści:

H3: Wyższy poziom orientacji na wiedze przedsiębiorstw $w$ procesie internacjonalizacji wplywa pozytywnie na ksztaltowanie przewagi konkurencyjnej podmiotów zaangażowanych zagranicznie.

Szczegółowy proces weryfikacji hipotezy 3 został zaprezentowany na rysunku 41.

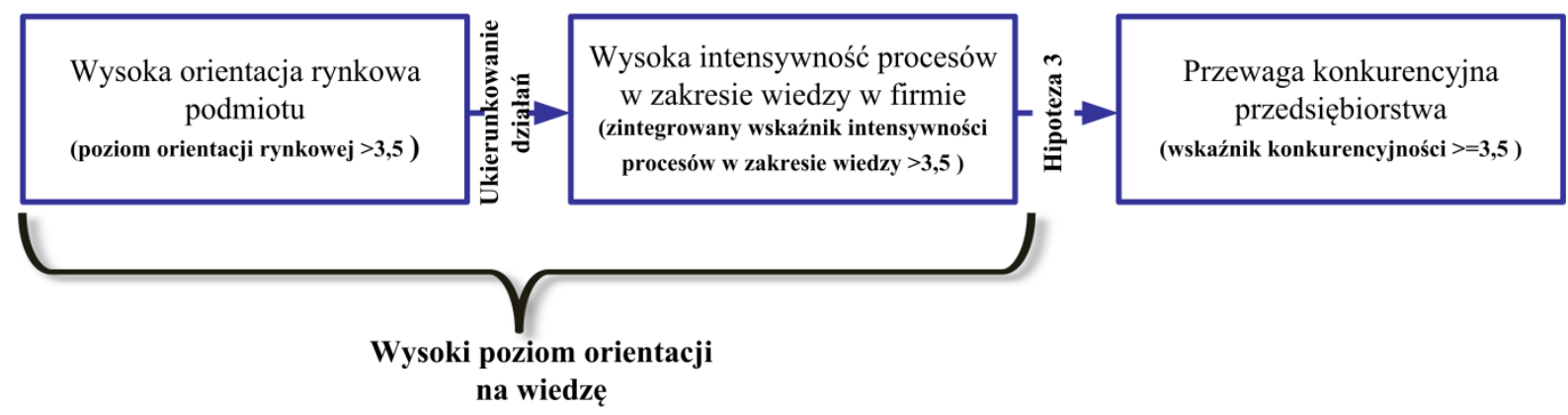

Rysunek 41. Szczegółowy proces weryfikacji hipotezy 3.

Źródło: opracowanie własne. 
Analizowane podmioty, na podstawie ilościowych danych empirycznych, podzielono na trzy kategorie:

- podmioty o wysokiej intensywności procesów w zakresie wiedzy (zintegrowany wskaźnik procesów w zakresie wiedzy >3,5) oraz jednocześnie wysokiej orientacji rynkowej $(>3,5)$ - wysoki poziom orientacji na wiedzę,

- podmioty o wysokiej $(>3,5)$ intensywności działań w zakresie jednego z wymienionych obszarów i niskiej $(<=3,5)$ w odniesieniu do drugiego - średni poziom orientacji na wiedzę,

- podmioty o niskiej intensywności działań w obu obszarach $(<=3,5)$ - niski poziom orientacji na wiedzę.

W każdej z wyróżnionych grup wyszczególniono następnie udziały przedsiębiorstw posiadających przewagę konkurencyjną względem najbliższych konkurentów (wskaźnik konkurencyjności $>=3,5$ ) oraz nieposiadających przewagi konkurencyjnej (wskaźnik konkurencyjności $<3,5)$. Wyniki zostały zaprezentowane w tabeli 38 .

Tabela 38. Poziom konkurencyjności podmiotów charakteryzujących się określonymi poziomami orientacji na wiedzę (I).

\begin{tabular}{|c|c|c|c|}
\hline $\begin{array}{c}\text { Liczba } \\
\text { firm } \\
\text { w grupie }\end{array}$ & $\begin{array}{c}\text { Intensywność procesów } \\
\text { w zakresie wiedzy i poziom } \\
\text { orientacji rynkowej } \\
\text { (Dwa komponenty orientacji na wiedze) }\end{array}$ & $\begin{array}{c}\text { Udziat firm lepszych } \\
\text { od najbliższych } \\
\text { konkurentów }(>=3,5) \\
\text { Przewaga konkurencyjna } \\
\text { względem najbliższych } \\
\text { konkurentów }\end{array}$ & $\begin{array}{c}\text { Udziat firm gorszych } \\
\text { lub równych } \\
\text { względem najbliższych } \\
\text { konkurentów }(<3,5) \\
\text { Brak przewagi konkurencyjnej } \\
\text { względem najbliższych } \\
\text { konkurentów }\end{array}$ \\
\hline 207 & $\begin{array}{l}\text { Wysoki poziom orientacji na wiedzę: } \\
\text { Przedsiębiorstwa, które jednocześnie } \\
\text { reprezentuja intensywne działania } \\
\text { w zakresie wiedzy, jak } i \text { wysokq } \\
\text { orientację rynkowa }(>3,5)\end{array}$ & $61,8 \%$ & $38,2 \%$ \\
\hline 258 & $\begin{array}{c}\text { Średni poziom orientacji na wiedze } \\
\text { Przedsiębiorstwa, które reprezentuja } \\
\text { intensywne dziatania w zakresie jednego } \\
\text { komponentu }(>3,5) \text { oraz } \\
\text { niska w zakresie drugiego }(<=3,5)\end{array}$ & $41,5 \%$ & $58,5 \%$ \\
\hline 259 & $\begin{array}{c}\text { Niski poziom orientacji na wiedzę } \\
\text { Przedsiębiorstwa, które jednocześnie } \\
\text { reprezentuja niska intensywność dziatań } \\
\text { w zakresie wiedzy, jak i niska orientację } \\
\text { rynkowa }(<3,5) \\
\end{array}$ & $24,7 \%$ & $75,3 \%$ \\
\hline
\end{tabular}

Źródło: opracowanie własne.

Wyniki przedstawione $\mathrm{w}$ tabeli 38 pokazują, iż wśród przedsiębiorstw reprezentujących wysoki poziom orientacji na wiedzę zdecydowanie najwięcej jest przedsiębiorstw charakteryzujących się przewagą konkurencyjną względem najbliższych konkurentów. Można również zauważyć, iż jedynie jedna czwarta przedsiębiorstw z niską 
orientacją na wiedzę jest w stanie wytworzyć przewagę konkurencyjną. Wśród podmiotów charakteryzujących się średnim poziomem orientacji na wiedzę udział fïm posiadających przewagę konkurencyjną jest również widocznie wyższy w porównaniu do firm całkowicie nieposiadających badanych cech. Jednakże dopiero równoczesne występowanie wysokiego poziomu orientacji rynkowej oraz intensywnych działań firmy w zakresie wiedzy umożliwia wytworzenie synergii w ramach tych procesów, które sprawiają, że liczba przedsiębiorstw, które są w stanie wykształcić przewagę konkurencyjną znacząco rośnie. Jest to również jedyna $\mathrm{z}$ wyróżnionych grup, w której udział przedsiębiorstw posiadających przewagę konkurencyjną wynosi ponad 50\%.

Tabela 39. Poziom konkurencyjności podmiotów charakteryzujących się określonymi poziomami orientacji na wiedzę (II).

\begin{tabular}{|c|c|c|c|c|}
\hline $\begin{array}{c}\text { Liczba } \\
\text { firm } \\
w \\
\text { grupie }\end{array}$ & $\begin{array}{c}\text { Intensywność procesów } \\
\text { w zakresie wiedzy i poziom } \\
\text { orientacji rynkowej } \\
\text { (Dwa komponenty orientacji na wiedze) }\end{array}$ & $\begin{array}{c}\text { Udział firm } \\
\text { lepszych } \\
\text { od najbliższych } \\
\text { konkurentów } \\
(>=3,5) \\
\text { Przewaga konkurencyjna } \\
\text { względem najbliższych } \\
\text { konkurentów }\end{array}$ & $\begin{array}{c}\text { Udziat firm } \\
\text { równych względem } \\
\text { najbliższych } \\
\text { konkurentów } \\
(>2,5 ;<3,5) \\
\text { Brak przewagi } \\
\text { konkurencyjnej względem } \\
\text { najbliżsych konkurentów }\end{array}$ & $\begin{array}{c}\text { Udziat firm } \\
\text { gorszych } \\
\text { od najbliższych } \\
\text { konkurentów } \\
(<=2,5) \\
\text { Brak przewagi } \\
\text { konkurencyjnej względem } \\
\text { najbliżsych konkurentów }\end{array}$ \\
\hline 207 & $\begin{array}{l}\text { Wysoki poziom orientacji na wiedzę } \\
\text { Przedsiębiorstwa, które jednocześnie } \\
\text { reprezentuja intensywne działania } \\
\text { w zakresie wiedzy, jak } i \text { wysokq } \\
\text { orientację rynkowa }(>3,5)\end{array}$ & $61,8 \%$ & $31,9 \%$ & $6,3 \%$ \\
\hline 258 & $\begin{array}{c}\text { Średni poziom orientacji na wiedze } \\
\text { Przedsiębiorstwa, które reprezentuja } \\
\text { intensywne działania w zakresie jednego } \\
\text { komponentu }(>3,5) \text { oraz } \\
\text { niską w zakresie drugiego }(<=3,5)\end{array}$ & $41,5 \%$ & $38,4 \%$ & $20,2 \%$ \\
\hline 259 & $\begin{array}{l}\text { Niski poziom orientacji na wiedzę } \\
\text { Przedsiębiorstwa, które jednocześnie } \\
\text { reprezentuja niska intensywność dziatań } \\
\text { w zakresie wiedzy, jak i niska orientacje } \\
\text { rynkowa }(<3,5)\end{array}$ & $24,7 \%$ & $43,2 \%$ & $32,0 \%$ \\
\hline
\end{tabular}

Źródło: opracowanie własne.

Tabela 38 pokazuje wyniki przeprowadzonych badań relatywnie ogólnie z podziałem na dwie grupy przedsiębiorstw w kontekście przewagi konkurencyjnej posiadające przewagę konkurencyjną oraz nieposiadające przewagi konkurencyjnej. W celu dokładniejszej analizy w tabeli 39 wyniki zostały przedstawione na większym poziomie szczegółowości, z podziałem na przedsiębiorstwa: lepsze (przewaga konkurencyjna) wskaźnik konkurencyjności: >=3,5, średnie (brak przewagi konkurencyjnej) - wskaźnik konkurencyjności: $>2,5$ oraz $<3,5$, gorsze (brak przewagi konkurencyjnej) - wskaźnik konkurencyjności: $<2,5$. 
Tabela 39 pokazuje, iż w grupie podmiotów charakteryzujących się wysoką orientacją na wiedzę, liczba podmiotów lepszych jest prawie dziesięć razy większa niż firm gorszych, resztę stanowią przedsiębiorstwa średnie. Wśród podmiotów o przeciwnych charakterystykach, które nie są w wysokim stopniu zorientowane rynkowo oraz w ramach, których nie zachodzą intensywne procesy w obszarze wiedzy (ostatni wiersz - tabela 39) można zaobserwować więcej przedsiębiorstw gorszych niż lepszych, a dominującą grupą są firmy średnie. Wśród podmiotów charakteryzujących się wyłącznie jednym z badanych działań na wysokim poziomie - orientacją rynkową lub działaniami w zakresie wiedzy (przedostatni wiersz - tabela 39), można zauważyć, iż udział przedsiębiorstw lepszych jest dość wysoki, lecz jest on bardzo zbliżony do liczby firm średnich. Innym ważnym aspektem jest fakt, iż w tej grupie udział podmiotów gorszych jest także znaczący.

W celu statystycznej weryfikacji roli orientacji na wiedzę w kształtowaniu przewagi konkurencyjnej przedsiębiorstw zaangażowanych zagranicznie zostanie zastosowana regresja logistyczna (tabela 40). Jako punkt odniesienia zostały przyjęte przedsiębiorstwa, które nie charakteryzują się orientacją na wiedzę.

$\mathrm{H}_{0}: \beta_{\mathrm{i}}=0$

$\mathrm{H}_{1}: \beta_{\mathrm{i}} \neq 0$

Tabela 40. Weryfikacja hipotezy trzeciej - wyniki analizy statystycznej z wykorzystaniem regresji logistycznej.

\begin{tabular}{|c|c|c|c|c|}
\hline $\begin{array}{c}\text { Poziom orientacji przedsiębiorstwa } \\
\text { na wiedzę }\end{array}$ & $\beta$ & $\begin{array}{c}\text { Błąd } \\
\text { standardowy }\end{array}$ & $\begin{array}{c}\text { Wartość } \\
\mathrm{p} \\
\text { (p-value) }\end{array}$ & $\psi$ \\
\hline $\begin{array}{c}\text { Wysoki poziomi orientacji } \\
\text { na wiedzę }\end{array}$ & 1,597 & 0,203 & 0,000 & 4,937 \\
\hline $\begin{array}{c}\text { Średni poziom orientacji } \\
\text { na wiedzę }\end{array}$ & 0,770 & 0,192 & 0,000 & 2,159 \\
\hline Wyraz wolny & $-1,114$ & 0,144 & 0,000 & 0,328 \\
\hline
\end{tabular}

Źródło: opracowanie własne, tabela wygenerowana za pomocą systemu SPSS.

$\beta$ - parametry modelu.

Błą standardowy - średnie błędy szacunków parametrów modelu. 
Wartość $p$ - najmniejszy poziom istotności, przy którym należy odrzucić hipotezę zerową (prawdopodobieństwo testowe).

$\psi$ - jednostkowy iloraz szans.

Z tabeli 40 możemy odczytać, iż wartości wszystkich statystyk p są bardzo małe, stąd należy odrzucić hipotezę zerową - współczynnik regresji logistycznej w każdym przypadku był istotnie różny od zera.

Analiza statystyczna z wykorzystaniem regresji logistycznej (tabela 40) dowodzi, iż różnice w zakresie poziomu przewagi konkurencyjnej w ramach wyróżnionych grup są istotne statystycznie. Ponadto, wykonana analiza pokazuje, iż:

- przedsiębiorstwo charakteryzujące się wysokim poziomem orientacji na wiedzę ma, o blisko 5 razy większą szansę uzyskania przewagi konkurencyjnej względem najbliższych konkurentów, w porównaniu do podmiotu, który cechuje się niskim poziomem orientacji na wiedzę,

- przedsiębiorstwo charakteryzujące się średnim poziomem orientacji na wiedzę ma o ponad 2 razy większą szansę uzyskania przewagi konkurencyjnej względem najbliższych konkurentów, w porównaniu do podmiotu, który cechuje się niskim poziomem orientacji na wiedzę.

Autor niniejszej pracy jest świadomy, iż badane procesy stanowią jedynie jeden z elementów wpływających na kształtowanie przewagi konkurencyjnej przedsiębiorstw, lecz biorąc pod uwagę dane empiryczne będące efektem badań, które zostały przeprowadzone na relatywnie dużej liczbie przedsiębiorstw, można stwierdzić, iż badane czynniki są w tym kontekście bardzo ważne. W związku z tym otrzymane rezultaty są podstawą do pozytywnej weryfikacji postawionej hipotezy trzeciej zakładającej, iż wyższy poziom orientacji na wiedze przedsiębiorstw $w$ procesie internacjonalizacji wpływa pozytywnie na kształtowanie przewagi konkurencyjnej podmiotów zaangażowanych zagranicznie. 


\subsection{Wyniki badań jakościowych - studia przypadku}

\subsubsection{Netguru Sp. z o.o.}

\section{Charakterystyka firmy}

Firma Netguru została założona w Poznaniu w 2008 roku przez trzy osoby Jakuba Filipowskiego, Wiktora Schmidta oraz Adama Zygadlewicza. Głównym obszarem działalności przedsiębiorstwa jest tworzenie aplikacji i stron internetowych z wykorzystaniem środowiska Ruby on Rails. Równocześnie ważnym elementem oferty firmy jest konsulting informatyczny. Obecnie Netguru zatrudnia 60 pracowników, lecz planowane jest podwojenie zatrudnienia. Firma posiada bardzo płaską strukturę organizacyjną. Zdecydowaną większość pracowników stanowią deweloperzy (programiści), poza nimi podmiot zatrudnia siedem osób pełniących funkcje wspierające. Zarząd składa się z dwóch osób (założycieli firmy). Większość pracowników pracuje w biurze w Poznaniu, 7 osób w Warszawie, 2 w Gdańsku oraz kilka osób zatrudnionych jest w innych lokalizacjach, także zagranicznych (praca na odległość). Firma stara się unikać formalnej hierarchii. Schemat struktury organizacyjnej podmiotu przedstawiono na rysunku 42.

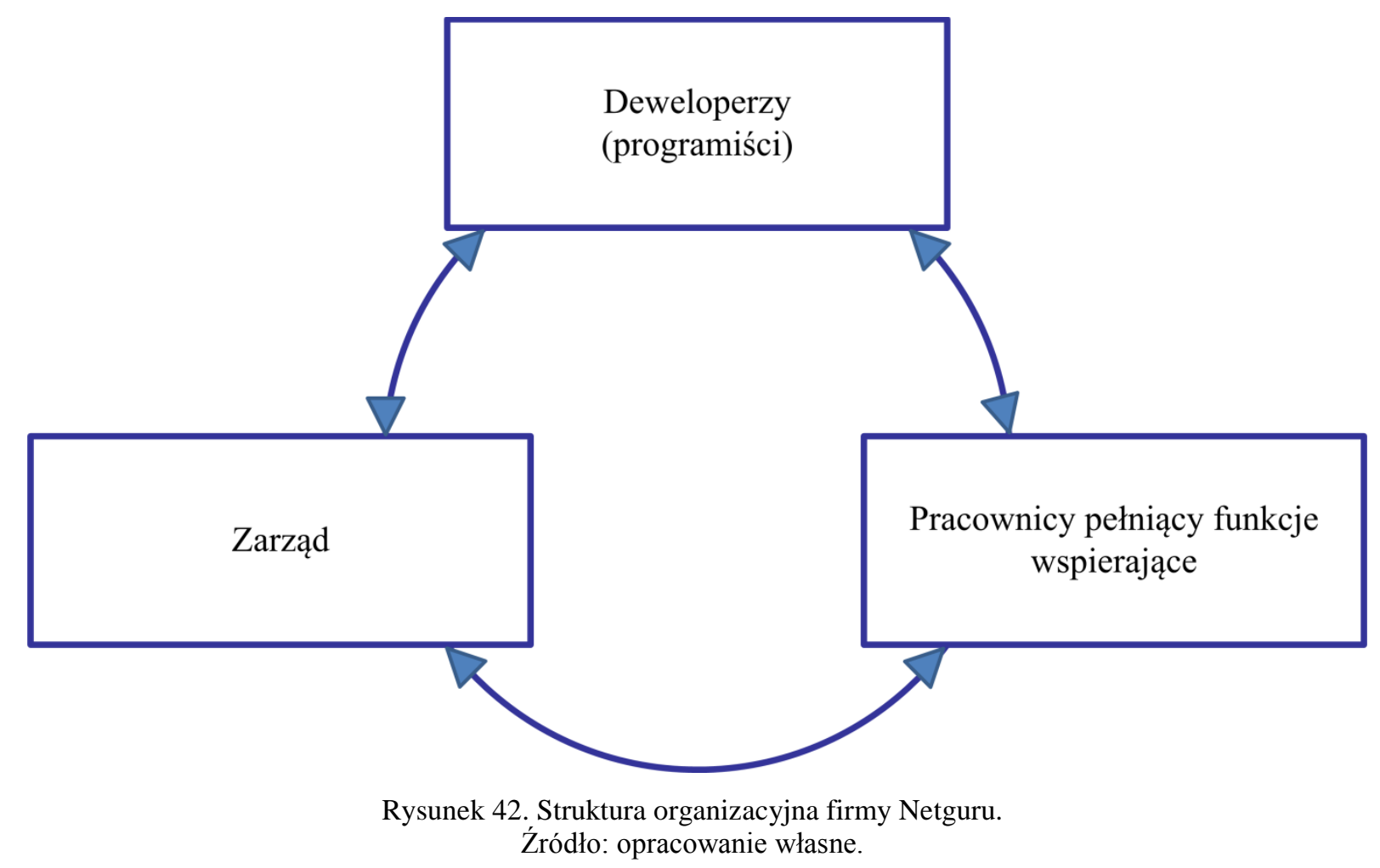




\section{Proces internacjonalizacji podmiotu}

Netguru na początku swojego istnienia skupiało się na rynku krajowym. Jednym z czynników, który okazał się przełomowy w kontekście internacjonalizacji przedsiębiorstwa był roczny wyjazd jednego z współzałożycieli do Dublina, gdzie nawiązał on kontakty i zauważył możliwości kierowania oferty firmy do podmiotów zagranicznych.

Podmiot obecnie konkuruje z podobnymi przedsiębiorstwami z całego świata. Jest to związane z charakterem oferowanych produktów, które nie wymuszają fizycznej obecności klienta $\mathrm{w}$ trakcie prac nad produktem, w momencie jego dostarczenia, jak i działań posprzedażowych. Największym problemem w tym zakresie są bariery psychiczne klientów, które jednak stopniowo stają się coraz mniejsze. W 2013 roku udział sprzedaży zagranicznej firmy w porównaniu do sprzedaży ogółem wynosił ok. 95\%, w 2012 było to zaledwie ok. 50\%, a dwa lata wcześniej praktycznie wszystkimi klientami przedsiębiorstwa były podmioty krajowe. Obecnie wśród klientów Netguru są firmy z wielu krajów świata m.in. z Niemiec, Wielkiej Brytanii, Irlandii i Stanów Zjednoczonych, a także z Bliskiego Wschodu.

Adres strony internetowej firmy (https://netguru.co) nie sugeruje jej związku z żadnym określonym krajem. Na początku istnienia przedsiębiorstwa strona była dostępna wyłącznie w języku polskim, następnie stopniowo pojawiały się elementy anglojęzyczne. Obecnie jedynym wykorzystywanym językiem na netguru.co jest język angielski. Poziom umiędzynarodowienia podmiotu dopełnia również fakt, iż firma zaczyna obecnie zatrudniać pracowników nie tylko z Polski, ale także z innych państw.

\section{Orientacja przedsiębiorstwa na wiedzę}

Netguru jest świadome znaczenia wartości swoich działań w zakresie wiedzy. W związku z tym firma stale aktywnie wprowadza różnorodne rozwiązania w tym obszarze. Aktywność w aspekcie wiedzy jest szczególnie ważna z uwagi na branżę, w jakiej działa przedsiębiorstwo. Środowiska programowania podlegają ciągłej ewolucji, co sprawia, że czas żywotności danego produktu czy rozwiązania jest bardzo krótki. Ponadto, istnieje wiele podmiotów konkurencyjnych, które wywodzą się z różnych części świata.

Podmiot od samego początku ma swoją siedzibę w Poznaniu. Jak wspomniano wcześniej część pracowników pracuje na odległość w innych miastach Polski, a także w innych krajach. Co nietypowe, jeden z współzałożycieli już od trzech lat pracuje zdalnie 
z Warszawy, a drugi, pełniący również rolę dyrektora zarządzającego (Chief Executive Officer), pracował przez rok z Dublina. Brak stałej, fizycznej obecności tak ważnych osób wymusza na wszystkich pracownikach zatrudnionych w przedsiębiorstwie wypracowanie procesów i wykształcenie zdolności komunikacyjnych umożliwiających skuteczny przepływ informacji i wiedzy. Wspomniana sytuacja stanowi ważny czynnik utrudniający kompleksową realizację działań w obszarze zarządzania wiedzą w firmie, stąd procedury w tym zakresie muszą być w takiej sytuacji szczególnie przemyślane.

Ważnym elementem omawianych działań jest fakt, iż w przedsiębiorstwie przywiązuje się również uwagę do kształtowania odpowiedniej kultury organizacji, która sprzyja współpracy oraz wymianie informacji i wiedzy.

Pomimo intensywnego wykorzystywania metod pracy na odległość, częścią sukcesu w zakresie zarządzania wiedzą firmy Netguru jest docenienie wartości osobistego kontaktu pomiędzy pracownikami. W tym celu organizowane są cykliczne spotkania zespołu m.in. w formie comiesięcznych kolacji, a także regularnych wyjazdów integracyjnych odbywających się trzy razy do roku, na których frekwencja, szczególnie wśród osób pracujących na co dzień na odległość, jest bardzo wysoka. Tego rodzaju spotkania zawsze odbywają się w dniach wolnych od pracy, ale już w tygodniu poprzedzającym wyjazd do poznańskiego biura przyjeżdżają osoby pracujące w innych lokalizacjach.

Bardzo ważnym elementem działań w zakresie zarządzania wiedzą w Netguru jest poznańskie biuro firmy. Pomimo, iż część osób pracuje w innych lokalizacjach, większość zatrudnionych na co dzień przebywa w siedzibie firmy. Przestrzeń biurowa jest zorganizowana w taki sposób, aby pobudzać kreatywność oraz ułatwiać przepływ wiedzy pomiędzy pracownikami. Firma projektując przestrzeń pracy starała się wyciągnąć wnioski ze swoich wcześniejszych doświadczeń w tym zakresie. Poprzednie biuro Netguru składało się z dwóch mniejszych pomieszczeń. Efektem tej sytuacji lokalowej był podział pracowników na tych $\mathrm{z}$ jednego pokoju i na tych $\mathrm{z}$ drugiego. W obecnym biurze istnieje szereg standardowych narzędzi i obszarów integracyjnych: kuchnia, automat do kawy czy gry.

Bardzo ważnym procesem $\mathrm{w}$ firmie, stymulującym przepływ wiedzy, jest obligatoryjne, wzajemne sprawdzanie przez pracowników fragmentów programów napisanych przez kolegów (code review). Każdy element kodu źródłowego aplikacji jest obowiązkowo przeglądany przez przynajmniej dwóch członków zespołu przed integracją go z pozostałymi elementami programu. Umożliwia to $\mathrm{w}$ praktyce wzajemne uczenie się w ramach zespołu poprzez obserwację rozwiązań i pomysłów stosowanych przez innych 
pracowników firmy. Działanie to zapewnia również upowszechnianie dobrych praktyk i jest katalizatorem dyskusji na temat określonych rozwiązań.

Kolejnym działaniem w ramach zarządzania wiedzą w firmie jest systematyzacja i stałe usprawnianie rutynowych procesów. Służą temu listy kontrolne (checklist), które w dużej mierze umożliwiają automatyzację powtarzalnych procesów zapobiegając efektowi ciągłego, ponownego wynajdywania tego, co już istnieje (reinventing the wheel). Zawierają one wykaz czynności, które należy wykonać w celu realizacji określonego, większego zadania. Ich kluczową charakterystyką jest fakt, iż nie są one dokumentami zakończonymi. Istnieje zalecenie lub wręcz obowiązek, aby podczas każdego wykonywania określonego zadania próbować usprawnić i zoptymalizować jego przebieg. Jest to dokonywane poprzez modyfikacje listy prowadzonych czynności, co skutkuje ciągłym usprawnianiem działań i uczeniem się organizacji. W celu technicznego i organizacyjnego usprawnienia pracy nad dokumentem (checklista) podmiot wykorzystuje narzędzia z pakietu Google Docs, które umożliwiają grupową i co najważniejsze jednoczesną pracę nad jednym dokumentem wielu osobom.

Poza przedstawionymi wcześniej działaniami organizacyjnymi firma stosuje szereg narzędzi informatycznych wspierających działania w zakresie zarządzania wiedzą. Jednym $\mathrm{z}$ nich jest Hipchat. Jest to komunikator internetowy. W przeszłości pracownicy firmy używali popularnej aplikacji Skype, lecz z biegiem czasu zdecydowano się wykorzystać narzędzie bardziej zaawansowane i lepiej dostosowane do indywidualnych potrzeb podmiotu. W ramach komunikatora wyodrębnionych jest szereg „pokoi rozmów”. Centralnym i najważniejszym z nich jest oczywiście ten, który skupia wszystkich pracowników firmy. Istnieją jednak inne, bardziej wyspecjalizowane „pomieszczenia”. Każdy z projektów realizowanych przez podmiot posiada swój ,pokój rozmów” skupiający wyłącznie osoby zaangażowane $\mathrm{w}$ dane przedsięwzięcie czy pokój bardziej doświadczonych programistów (seniors' room). Jedną z najważniejszych cech omawianego narzędzia jest możliwość dołączania do ,pokoi rozmów” i innych konwersacji tzw. botów. Przypominają one zwykłego użytkownika, lecz są w praktyce programami, które mogą dostarczać różnego rodzaju informacji po wydaniu im określonych komend. Są one również w stanie inicjować rozmaite działania w ramach systemów informatycznych firmy. W przypadku Netguru w ramach każdej konwersacji obecny jest Hipbot, który może np. wykonać zadanie wyszukiwania danej informacji w ramach firmowych e-maili i wyświetlić wyniki w określonym pokoju rozmów.

Podstawowymi narzędziami tworzeniu produktów firmy są GitHub oraz Pivotal Tracker. Ułatwiają one realizację zadań, ale także przepływ informacji i wiedzy w firmie, 
oraz pomiędzy firmą, a jej klientem. Pierwszy z nich (GitHub) stanowi centrum zarządzania tworzonym kodem programistycznym. Jego kluczową cechą jest „wersjonowanie” czyli zachowywanie kolejnych wersji kodu w miarę wprowadzanych zmian. Jest to bardzo ważnym elementem w kontekście efektywności tworzenia produktu, gdyż zawsze można wrócić do wszystkich wcześniejszych etapów. Charakter narzędzia umożliwia również wszystkim pracownikom bezproblemowy dostęp do poszczególnych fragmentów kodu. Innym kluczowym programem jest Pivotal Tracker. Ułatwia on zarządzanie całymi projektami oraz składającymi się na nie pojedynczymi zadaniami, które muszą być zrealizowane. Jego funkcje pozwalają też na łatwą współpracę z klientem podczas procesu „zwinnego” rozwoju aplikacji. Omawiany program jest bezpośrednim przekaźnikiem szczegółowych zadań od klienta do programistów.

\section{Rynkowe ukierunkowanie działań przedsiębiorstwa w zakresie wiedzy}

Intensywne działania w zakresie wiedzy firmy Netguru są w dużej mierze efektywne $\mathrm{z}$ uwagi na ich rynkowe ukierunkowane. Firma jest świadoma faktu, iż zrozumienie i zaspokojenie potrzeb klienta jest naczelnym celem jej istnienia i determinantą sukcesu. W kontekście branży, w jakiej działa przedsiębiorstwo nie jest to zadaniem łatwym. Często podczas tworzenia produktów ich dokładne specyfikacje nie są określone przez klienta. Najczęściej znany jest jedynie ogólny opis czy kierunek działań, a szczegóły są wypracowywane w trakcie prac nad produktem. Stanowi to dodatkowe wyzwanie i wymusza jeszcze silniejszą kooperację z klientem. W działalności podmiotu można zaobserwować szereg aktywności mających na celu ułatwienie współpracy z nabywcą i dokładne poznanie jego wymagań w celu uzyskania odpowiedniego efektu. Firma w wielu miejscach podkreśla, iż właściwa komunikacja z klientem stanowi podstawę efektywności działań.

Jedną z ważnych charakterystyk firmy Netguru, ułatwiającą współpracę z klientem i podkreślającą silną orientację rynkową podmiotu, jest sposób tworzenia oprogramowania. Podmiot wykorzystuje w tym celu określone podejście, tzw. zwinne zarządzanie projektami (Agile Project Management). Polega ona na tworzeniu produktu w najbardziej podstawowej formie (Minimum Viable Product), a następnie etapowym wzbogacaniu funkcjonalności tworzonego oprogramowania (development stage) poprzez sekwencyjne dodawanie kolejnych fragmentów kodu programistycznego. Działanie to odbywa się przy stałej współpracy z klientem, który ma nawet dostęp do „pokoju rozmów” projektu w ramach opisanego 
wcześniej narzędzia komunikacyjnego Hipchat. Umożliwia to sprawną komunikację z odbiorcą i szybkie wyjaśnianie wszelkich niejasności.

Innym ważnym działaniem firmy jest dostarczanie klientowi cotygodniowych raportów informujących go o zaawansowaniu prac nad jego projektem. Odbiorca może również w każdym momencie przetestować najnowszą wersję produktu, wraz z aktualnymi, wprowadzanymi na bieżąco funkcjami, która w trakcie prac zawsze znajduje się na specjalnym serwerze firmy (staging server). Umożliwia to zmianę kierunku działań, jeżeli obrana przez programistów droga nie jest zgodna z wizją klienta.

Jak podkreśla Włochowicz [2008, s. 1] metoda „zwinnego zarządzania projektem” jest odpowiedzią na potrzebę realizacji przedsięwzięć w niepewnym i nieprzewidywalnym środowisku. Model ten pozwala na duże zaangażowanie klienta. Umożliwia on również dokładne zrozumienie jego potrzeb i skupienie energii zespołu na wartości dodanej przede wszystkim z perspektywy odbiorcy, co w ostatecznym rozrachunku skutkuje dostarczaniem klientowi wyłącznie użytecznych i rzeczywiście potrzebnych mu elementów.

Działania rynkowe Netguru uzupełnia prowadzenie bloga firmowego oraz duża aktywność w sieciach społecznościowych (Facebook, Twitter, Google+). Pozwala to na przybliżenie klientom procesów zachodzących w przedsiębiorstwie, w ramach których powstają oferowane przez firmę produkty. Podobną rolę spełniają również wydawane przez podmiot newslettery, które są subskrybowane przez bardzo wielu odbiorców na praktycznie wszystkich kontynentach.

Rynkowo ukierunkowane działania w zakresie wiedzy przejawiają się również w wartościach przedsiębiorstwa (core values). Pojawiają się tam elementy ciągłego ulepszania procesów, co można utożsamiać z modelem organizacji uczącej się Senge. Widoczna jest także koncentracja na komunikacji i poznaniu potrzeb klienta w celu stworzenia zgodnego z jego wizją produktu.

Firma bardzo intensywnie współpracuje ze swoimi konkurentami, w tym również zleca wykonanie określonych zadań zaprzyjaźnionym firmom konkurencyjnym, a także przyjmuje od nich zlecenia. Główną motywacją dla tej współpracy jest optymalizacja zasobów w kontekście nieregularności zleceń.

\section{Przewaga konkurencyjna firmy}

Firma Netguru stara się konkurować na rynku przede wszystkim jakością tworzonych przez siebie produktów informatycznych, jak i dopasowaniem ich kształtu do specyficznych 
potrzeb klienta. W związku $\mathrm{z}$ tym wysoki poziom orientacji na wiedzę jest podstawą konkurencyjności przedsiębiorstwa. Wśród klientów firmy można znaleźć podmioty z wielu krajów świata. Do aplikacji i serwisów internetowych stworzonych przez Netguru należą m.in.: ratemyarea.com, benchify.com, citysocializer.com, cdp.pl, bankpomyslow.bzwbk.pl, a także Multibaza PWN.

Najbliższymi konkurentami przedsiębiorstwa są firmy o podobnym profilu z całego świata, ale także programiści pracujący samodzielnie, jak i informatycy na stałe zatrudniani przez potencjalnych klientów. Firma zdołała wytworzyć dość unikalną przewagę konkurencyjną wobec wymienionych podmiotów i jednostek. Jej wyniki finansowe są lepsze $\mathrm{w}$ porównaniu do najbliższych przedsiębiorstw konkurencyjnych ${ }^{71}$. Jednym z czynników leżących u podstaw obecnej pozycji konkurencyjnej i wyników firmy Netguru jest jej relatywnie duża, w stosunku do większości podmiotów konkurencyjnych, wielkość. W branży, w której działa przedsiębiorstwo często potrzebne jest szybkie sformowanie kilku lub kilkunastoosobowego zespołu programistów do realizacji określonego projektu. W tym przypadku dodatkowym atutem podmiotu jest fakt, iż nie tylko dysponuje on odpowiednimi pracownikami, ale są oni doświadczeni we wspólnej realizacji zadań. Przy tym osoby te znają i operują tymi samymi narzędziami programowania, ale także instrumentami komunikacji oraz przepływu informacji i wiedzy. Dzięki temu ich współpraca jako zespołu jest efektywna, co przekłada się na realną wartość dla nabywcy i ugruntowuje przewagę konkurencyjną przedsiębiorstwa.

\section{Podsumowanie}

Działania w zakresie wiedzy nabierają szczególnego znaczenia w przypadku firmy Netguru z kilku powodów. Przede wszystkim zmiany w obszarze działania podmiotu są bardzo szybkie. Przedsiębiorstwo działa w branży, w której konkurencja jest bardzo intensywna, ponadto firma, $\mathrm{z}$ uwagi na globalny charakter działalności, bezpośrednio konkuruje z podmiotami z całego świata.

W związku charakterem działalności przedsiębiorstwa, bardzo ważnym elementem jest orientacja rynkowa procesów w zakresie wiedzy. Kluczowy jest przede wszystkim element ciągłej komunikacji z klientem - utrzymywanie z nim stałej łączności wraz

\footnotetext{
${ }^{71}$ Nie jest możliwe porównanie wyników przedsiębiorstwa z zarobkami indywidualnych informatyków pracujących na etatach.
} 
z poznawaniem jego potrzeb na różnych poziomach realizacji projektu. Jest to związane z faktem, iż klient na początku realizacji przedsięwzięcia ma wyłącznie ogólny zamysł produktu, a szczegóły są wykształcane i zmieniane w trakcie powstawania strony czy aplikacji. Jest to skuteczne podejście do rozwiązania ogólnego problemu związanego z poznaniem potrzeb klienta, gdyż najczęściej posiada on określone preferencje, lecz nie potrafi ich wyrazić. Zrozumienie jego punktu widzenia musi, w przypadku branży, w jakiej działa przedsiębiorstwo, zająć określony czas i potrzebne są odpowiednie narzędzia współpracy wspomagające ten proces - w tym przypadku ciągła komunikacja (chat), raporty tygodniowe oraz możliwość testowania przez klienta kolejnych elementów powstającego produktu w dowolnym momencie.

Działania w zakresie rynkowo ukierunkowanych procesów w zakresie wiedzy firmy Netguru są bardzo intensywne na poziomie operacyjnym. Jedyną słabością tego przedsiębiorstwa jest obszar strategiczny. Zgodnie z modelem zaprezentowanym w rozdziale trzecim, gospodarka oparta na wiedzy, poza wzrostem znaczenia kluczowego zasobu wiedzy, charakteryzuje się również wzrostem jego nietrwałości. Wiedza operacyjna szybko staje się nieaktualna, stąd przede wszystkim liczą się procesy jej pozyskiwania, kreacji, a także wdrażanie uzyskanych elementów. Podobny efekt można zaobserwować na poziomie strategicznym. Firma Netguru posiada ogromną wiedzę i potencjał w zakresie programowania aplikacji oraz stron internetowych w środowisku Ruby on Rails. Wiedza ta będzie cenna do momentu pojawienia się nowego środowiska lub $\mathrm{np}$. zmiany trendów $\mathrm{W}$ zakresie wykorzystywania Internetu (przykładowo mogą to być technologie mobilne), co może sprawić, iż obszar, na którym koncentruje się firma będzie mniej dochodowy. Innym problemem może być utrata występującej obecnie przewagi kosztowej, w związku ze wzrostem płac informatyków w Polsce oraz wzrastającym potencjałem Azji południowowschodniej.

W związku z tym, w celu wykształcenia długoterminowej przewagi konkurencyjnej, zgodnie $\mathrm{z}$ modelem, potrzebna jest stała obserwacja rynku i badanie kierunków występujących na nim trendów, wyszukiwanie dochodowych segmentów i nisz rynkowych, a następnie rozwój wiedzy firmy w celu wykształcenia dopasowanej oferty do występujących w danym momencie potrzeb. Należy pamiętać, iż żaden operacyjny obszar działalności firmy nie będzie dochodowy na zawsze i firma powinna zauważyć, kiedy należy się z danego obszaru wycofać i zaangażować się w nowy, bardziej perspektywiczny. Dobrym przykładem w tym zakresie jest firma IBM, która istnieje od XIX wieku. W połowie i pod koniec XX wieku zajmowała się ona produkcją sprzętu komputerowego, a obecnie koncentruje się na 
oprogramowaniu i usługach informatycznych. Innym podobnym przykładem jest Apple, którego największa część obecnych przychodów nie pochodzi, jak w przeszłości, z produkcji komputerów, lecz ze sprzedaży telefonów i innych urządzeń mobilnych [Dillet 2013, s. 1].

\subsubsection{Trepko Sp. z o.o.}

\section{Charakterystyka firmy}

Trepko Sp. z o.o. zajmuje się produkcją maszyn pakujących dla podmiotów z przemysłu spożywczego. Firma posiada swoją siedzibę w Gnieźnie (Wielkopolska). W przeszłości podmiot był członkiem Zjednoczenia Maszyn Producentów Przemysłu Spożywczego „SPOMASZ”. W 1993 roku po prywatyzacji powstała firma Unipak Sp. z o.o., która W 2000 roku została przejęta przez Duńską firmę Trepko A/S. Obecnie przedsiębiorstwo $^{72}$ jest częścią międzynarodowego koncernu „Trepko” posiadającego swoją główną siedzibę w Taastrup blisko Kopenhagi, a także oddziały w Wielkiej Brytanii, Stanach Zjednoczonych, Szwecji, Norwegii oraz biuro handlowe w Egipcie. Koncern posiada odbiorców w 65 krajach świata.

Oddział grupy Trepko w Polsce zatrudnia 328 osób, w swojej ofercie posiada m.in. maszyny do napełniania i zamykania gotowych pojemników czy formowania opakowań, systemy dozujące, a także systemy pakowania zbiorczego. Podmiot zapewnia również opiekę techniczną i oferuje szkolenia odnośnie obsługi i napraw produkowanych urządzeń. Firma zajmuje się także produkcją części na zamówienie wytwarzanych według projektu klienta.

Trepko Sp. z o.o. zajmuje się sprzedażą swoich produktów oraz wyrobów wytwarzanych przez inne oddziały koncernu na terenie Europy Środkowo-Wschodniej, krajów byłego ZSRR, w Niemczech, a także na obszarze półwyspu bałkańskiego i części kontynentu afrykańskiego. Sprzedaż produktów firmy nabywcom z innych części świata odbywa się za pośrednictwem innych podmiotów koncernu. Poza tym ograniczeniem przedsiębiorstwo posiada relatywnie dużą autonomię w zakresie prowadzonych działań, w tym strategii i organizacji procesów biznesowych.

\footnotetext{
${ }^{72} \mathrm{~W}$ niniejszym studium przypadku podmiotem badania jest firma „Trepko Sp. z o.o.”, której właścicielem jest duńska firma Trepko A/S.
} 


\section{Proces internacjonalizacji podmiotu}

Przynależność Trepko Sp. z o.o. do międzynarodowego koncernu implikuje wysoki poziom internacjonalizacji podmiotu. Obecnie $88 \%$ procent produkcji przedsiębiorstwa jest sprzedawane poza granicami Polski. Firma intensywnie współpracuje z podmiotami powiązanymi. W ramach koncernu odbywa się również przepływ wiedzy - zarówno technicznej, jak i rynkowej. Kluczowym elementem jest drugi z wymienionych typów wiedzy - wiedza o rynku. W branży, w jakiej działa przedsiębiorstwo, znajomość nabywców oraz ich potrzeb jest podstawą możliwości zaoferowania odpowiedniego produktu (w tym przypadku maszyny), która spełni potrzeby odbiorcy. Nabywcy - przedsiębiorstwa z branży spożywczej, są najczęściej zobligowani określonymi lokalnymi normami, przepisami prawa, a także wymaganiami narzuconymi przez swoich klientów. Znajomość tych uwarunkowań stanowi podstawę sformułowania odpowiedniej oferty, stąd przynależność firmy do koncernu jest kluczowym elementem procesu właściwego projektowania i sprzedaży produktów firmy na odległych rynkach.

\section{Orientacja przedsiębiorstwa na wiedzę}

Trepko Sp. z o.o. przywiązuje dużą wagę do działań w zakresie wiedzy. Z perspektywy zarządu kluczowymi i w praktyce najtrudniejszymi w realizacji są procesy magazynowania i przekazywania wspomnianego zasobu.

Osoby zarządzające przedsiębiorstwem przede wszystkim doceniają znaczenie wiedzy ukrytej. W ich opinii konkurent firmy, który zdobyłby jeden z egzemplarzy maszyn, które są produkowane przez przedsiębiorstwo nie zdołałby przejąć kluczowej wiedzy związanej z jej powstaniem. Maszyna jest do pewnego stopnia nośnikiem wiedzy, lecz przede wszystkim jest efektem procesów, które zachodzą wewnątrz przedsiębiorstwa. Szczegółowa wiedza na temat konstrukcji maszyny, przyczyn zastosowanych rozwiązań znajduje się w głowach konstruktorów i nie może być $\mathrm{w}$ łatwy sposób przekazana. $\mathrm{W}$ związku $\mathrm{z}$ tym Trepko Sp. z o.o. przywiązuje szczególną wagę do działań mających na celu transfer wiedzy niejawnej. Implikuje to działania związane z przekazywaniem wiedzy pomiędzy ludźmi, w modelu Nonaki określanymi jako procesy socjalizacji.

Jednym $\mathrm{z}$ narzędzi stosowanych $\mathrm{w}$ przedsiębiorstwie jest mentoring. Młodsi pracownicy mają przypisanego opiekuna, który na początku pomaga im we wdrożeniu się 
w działalność przedsiębiorstwa. Wyjaśnia im on, jak przebiegają poszczególne procesy i przekazuje niezbędną, unikalną dla podmiotu wiedzę. Dzięki opisanemu systemowi mentoringu młodszy stażem pracownik wie, do kogo może się zwrócić w momencie, gdy spotka się z sytuacją, w której jego wiedza jest niewystarczająca.

Bardzo ważnym elementem działań przedsiębiorstwa w zakresie wiedzy jest postulowana przez zarząd określona kultura organizacyjna. Jej podstawowym atrybutem jest akcentowanie potrzeby stałego rozwoju komunikacji $\mathrm{w}$ przedsiębiorstwie, $\mathrm{w}$ tym przede wszystkim zachęcanie do zadawania pytań oraz podkreślanie potrzeby i znaczenia uważnego słuchania drugiej osoby. W omawianej organizacji zadawanie pytań jest bardzo pozytywnie postrzegane i pożądane, gdyż wpływa to również na rozwój osoby pytanej.

Firma Trepko w zakresie technologii informacyjnych i komunikacyjnych w zarządzaniu wiedzą bazuje raczej na podstawowych narzędziach i prostych rozwiązaniach. Jest to częściowo związane z koncentracją podmiotu na wiedzy niejawnej, w przypadku której najlepiej sprawdzają się narzędzia społeczne i organizacyjne. Ponadto, w firmie występuje raczej przekonanie o efektywności prostszych rozwiązań technologicznych. Tego rodzaju podejście nie jest rzadkością również wśród większych podmiotów.

\section{Ukierunkowanie rynkowe działań przedsiębiorstwa w zakresie wiedzy}

Zarząd przedsiębiorstwa jest zdania, iż rozwój wiedzy bez ukierunkowania jej na potrzeby nabywców jest najczęściej bezcelowy. Jak już wspomniano w odniesieniu do internacjonalizacji przedsiębiorstwa, w przypadku omawianego podmiotu bardzo ważnym jest dokładne poznanie charakterystyki nie tylko nabywców firmy, ale również szersze rozpoznanie warunków ich działalności. Jest to związane z faktem, iż w obszarze produkcji spożywczej istnieje szereg regulacji prawnych, które są zróżnicowane w zależności od lokalizacji wytwórcy. Ponadto, nabywcy towarów spożywczych, produkowanych przez klientów firmy Trepko Sp. z o.o. (np. hurtownie spożywcze czy supermarkety), z reguły narzucają określone wymagania, które najczęściej muszą być uwzględnione już na poziomie projektowania urządzeń. Opisane uwarunkowania implikują potrzebę kompleksowej implementacji koncepcji orientacji rynkowej. Trepko Sp. z o.o. w celu prowadzenia efektywnej walki konkurencyjnej musi posiadać kompleksową wiedzę dotyczącą wszelkich uwarunkowań działalności w swojej branży, w tym szczególnie dobrze znać swoich konkurentów, a także śledzić zmiany w obszarze działalności swoich nabywców. 
Podstawą działań rynkowych przedsiębiorstwa jest przede wszystkim częsty kontakt z klientem. Kluczową aktywnością są regularne rozmowy $\mathrm{z}$ przedstawicielami grupy docelowej firmy, które umożliwiają poznanie trendów występujących w branży, oraz zrozumienie stale zmieniających się potrzeb użytkowników maszyn produkowanych przez firmę. Poza indywidualnymi kontaktami z nabywcami, firma jest zaangażowana w szereg innych aktywności. Trepko Sp. z o.o. regularnie organizuje w swojej siedzibie targi. Przedstawiciele grupy Trepko są również obecni na najważniejszych zewnętrznych wydarzeniach targowych na całym świecie. W gnieźnieńskiej siedzibie firmy organizowane są również cykliczne szkolenia dla klientów firmy. Działania te mają na celu utrzymanie kontaktu z grupą docelową, a także utrwalenie w świadomości nabywców skali oferty przedsiębiorstwa.

\section{Przewaga konkurencyjna firmy}

Efektem opisanych wcześniej działań przedsiębiorstwa jest jego wysoka przewaga konkurencyjna, która przekłada się na wyższe zyski i sprzedaż firmy w porównaniu do najbliższych konkurentów. Jednym z kluczowych czynników sprawczych, które umożliwiły firmie uzyskanie obecnej pozycji konkurencyjnej jest koncentracja podmiotu na dwóch ważnych obszarach: orientacji rynkowej (w szczególności potrzebach nabywcy) oraz intensywnych działaniach w zakresie wiedzy. Przedsiębiorstwo jest świadome, iż każda szansa rynkowa kiedyś zostanie wyeksploatowana i trzeba wcześniej poszukiwać nowego obszaru zaangażowania. Podobnie, każdego rodzaju wiedza - czy to techniczna czy rynkowa szybko staje się nieaktualna. Uwarunkowania rynkowe zmieniają się, stąd produkty, które dziś spełniają potrzeby nabywców, jutro mogą być nieprzydatne. Dodatkowo, tak jak praktycznie w każdej branży, w obszarze działania firmy trwa walka o klienta, stąd podmioty konkurencyjne stale wprowadzają usprawnienia techniczne do swojej oferty, co nie może pozostać bez odpowiedzi firmy. W związku z tym Trepko konkuruje nie tyle wiedzą, co wypracowanymi, odpowiednio ukierunkowanymi procesami, które mają na celu stałe pozyskiwanie nowej, aktualnej wiedzy oraz aktywne jej wykorzystywanie (rysunek 43). 


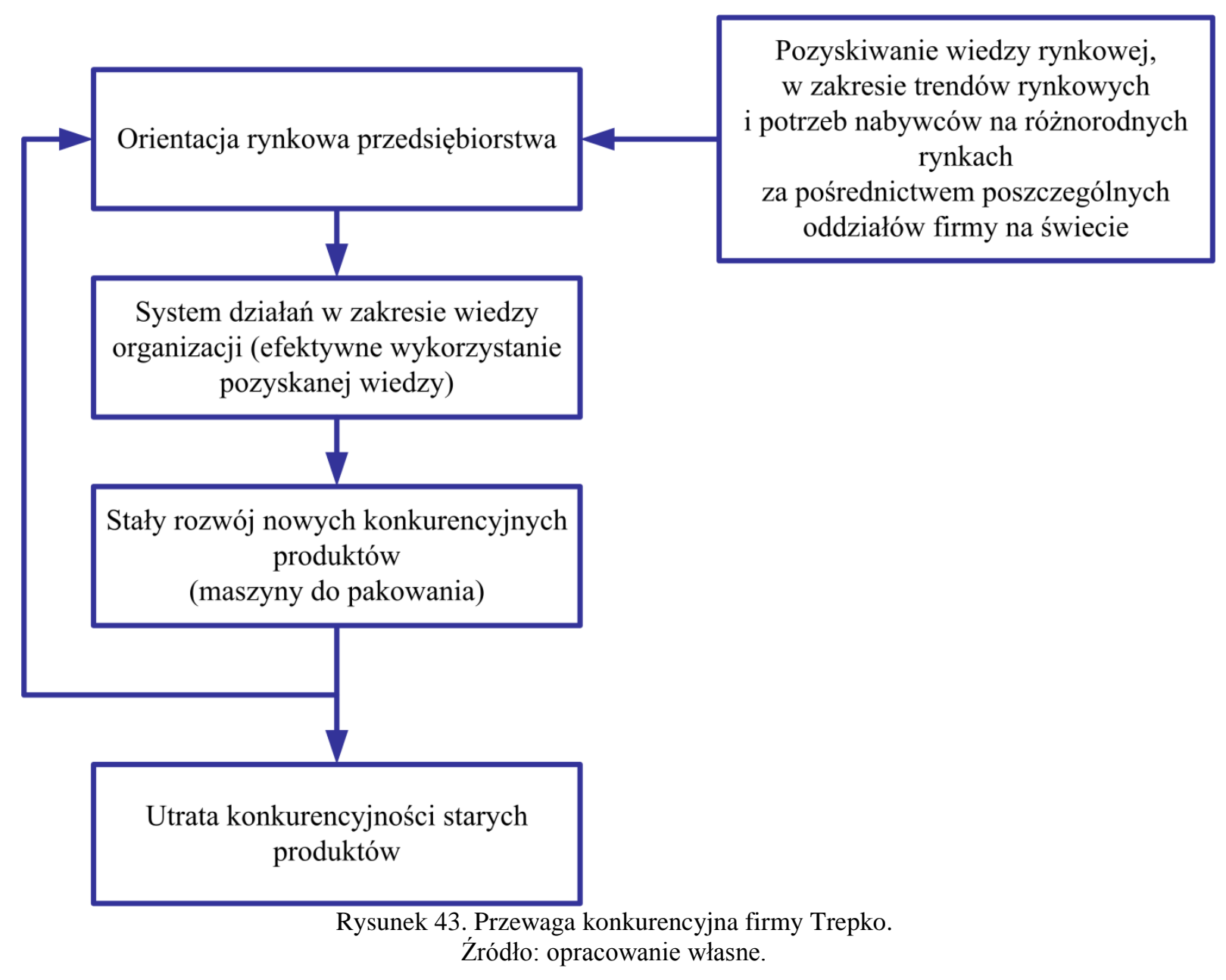

\section{Podsumowanie}

Najważniejszą cechą omawianego przedsiębiorstwa umożliwiającą mu utrzymanie przewagi konkurencyjnej jest świadomość znaczenia działań w zakresie wiedzy oraz roli orientacji rynkowej dla określania ich kierunku. W firmie istnieje jednak niewykorzystany potencjał w odniesieniu do rozwoju procesów oraz narzędzi rozpowszechniania i magazynowania wiedzy, które mogłyby zoptymalizować wysiłki pracowników przedsiębiorstwa. Kluczowym czynnikiem $\mathrm{w}$ ramach badanych procesów jest jednak istniejąca już w podmiocie świadomość potrzeby ciągłego usprawniania działań w zakresie wiedzy oraz stałego poszukiwania i wykorzystywania nowych szans rynkowych szybciej niż konkurenci. 


\subsection{Podsumowanie i wnioski}

Przedmiotem rozważań $\mathrm{w}$ prezentowanym rozdziale było empiryczne sprawdzenie teoretycznych zależności postulowanych we wcześniejszych częściach pracy. W celu weryfikacji postawionych hipotez opracowano trzy modele badawcze. Analizy przeprowadzono na podstawie danych pochodzących $\mathrm{z}$ dwóch badań empirycznych: ilościowego i jakościowego. W ramach badania ilościowego, dzięki wykorzystaniu specjalnie opracowanego, przy współpracy z informatykiem, systemu ankietowania elektronicznego, otrzymano ponad 1300 wypełnionych kwestionariuszy. W przypadku badania jakościowego przeprowadzono dwa szczegółowe studia przypadków w firmach zaangażowanych na rynkach zagranicznych.

Zaprezentowane analizy wykazały widoczne różnice w zakresie poziomu orientacji na wiedzę pomiędzy przedsiębiorstwami działającymi lokalnie a zaangażowanymi zagranicznie, a także wyższy poziom badanego zjawiska wśród podmiotów w drugiej z badanych grup. Należy podkreślić, iż zaobserwowane tendencje charakteryzowały się stabilnością w zakresie wszystkich czynników składowych. Z wykorzystaniem testu Manna-Whitneya stwierdzono, iż wspomniane różnice są istotne statystycznie na poziomie istotności $\alpha=0,05$. Otrzymane wyniki umożliwiły pozytywna weryfikację postawionej we wstępie hipotezy pierwszej zakładającej, iż przedsiębiorstwa działające na rynkach zagranicznych sa przeciętnie bardziej zorientowane na wiedze w porównaniu do przedsiębiorstw działających lokalnie.

Analizy ujawniły również, iż wysoki poziom orientacji rynkowej jest relatywnie powszechny w obu rodzajach podmiotów, znacznie rzadszym jest jednak występowanie intensywnych działań w zakresie wiedzy. Zaobserwowano również duże różnice w sferze źródeł, z jakich czerpią wiedzę podmioty działające lokalnie, w porównaniu z firmami zaangażowanymi na rynkach zagranicznych. Te drugie bardziej intensywnie korzystają z poszczególnych źródeł wiedzy, a także wykorzystują szersze ich spektrum.

$\mathrm{W}$ odniesieniu do drugiej $\mathrm{z}$ postawionych hipotez, przeprowadzone analizy nie wykazały większych i spójnych różnic w zakresie przeciętnego poziomu orientacji na wiedzę wśród podmiotów na poszczególnych etapach internacjonalizacji z wykorzystaniem kryteriów okresu zaangażowania zagranicznego i udziału sprzedaży zagranicznej przedsiębiorstwa w jego sprzedaży ogółem. W przypadku kryterium formy internacjonalizacji podmiotu zaobserwowano widoczne, lecz również małe różnice $\mathrm{w}$ poziomie badanych procesów. Przeprowadzone testy statystyczne wykazały niewielkie, istotne statystycznie różnice wyłącznie dla niektórych czynników składowych orientacji na wiedzę, a także tylko dla 
wybranych kryteriów internacjonalizacji. W związku z tym, na bazie przeprowadzonych analiz nie znaleziono podstaw do pozytywnej weryfikacji hipotezy drugiej, zakładającej iż przedsiębiorstwa wraz $z$ większym zaangażowaniem $w$ proces internacjonalizacji sa przeciętnie bardziej zorientowane na wiedzę.

Bardzo ważnym elementem prezentowanego rozdziału była weryfikacja, na podstawie danych ilościowych, wpływu orientacji na wiedzę przedsiębiorstwa na przewagę konkurencyjną firmy w procesie internacjonalizacji. Analizy danych $\mathrm{z}$ wykorzystaniem regresji logistycznej ujawniły silny, istotny statystycznie wpływ badanego zjawiska na poziom przewagi konkurencyjnej podmiotów zaangażowanych na rynkach zagranicznych. W badanej grupie przedsiębiorstw, wśród podmiotów reprezentujących wysoki poziom orientacji na wiedzę, najwięcej zidentyfikowano firm charakteryzujących się przewagą konkurencyjną wobec najbliższych konkurentów $(61,8 \%)$. Wśród firm charakteryzujących się niską orientacją na wiedzę jedynie jedna czwarta $(24,7 \%)$ była w stanie wykształcić przewagę konkurencyjną wobec najbliższych konkurentów. Ponadto, zauważono, iż przedsiębiorstwo charakteryzujące się wysokim poziomem orientacji na wiedzę ma o blisko 5 razy większą szansę uzyskania przewagi konkurencyjnej względem najbliższych konkurentów, w porównaniu do podmiotu, który cechuje się niskim poziomem orientacji na wiedzę. Przedsiębiorstwo charakteryzujące się średnim poziomem orientacji na wiedzę ma o ponad 2 razy większą szansę uzyskania przewagi konkurencyjnej względem najbliższych konkurentów, w porównaniu do podmiotu, który cechuje się niskim poziomem orientacji na wiedzę.

W związku z tym otrzymane rezultaty były podstawą do pozytywnej weryfikacji, postawionej we wstępie, hipotezy trzeciej zakładającej, iż wyższy poziom orientacji na wiedzę przedsiębiorstw $w$ procesie internacjonalizacji wpływa pozytywnie na ksztaltowanie przewagi konkurencyjnej podmiotów zaangażowanych zagranicznie.

W celu szczegółowej analizy zaobserwowanych zależności przeprowadzono empiryczne badania jakościowe $\mathrm{w}$ formie dwóch studiów przypadku w firmach Netguru i Trepko. Szczególnie obrazowym przykładem przedstawiającym charakterystykę badanych procesów okazał się być przykład firmy Trepko. W tym przedsiębiorstwie wiedza rynkowa jest kluczowym elementem ciągłego rozwoju produktów firmy, czyli również wiedzy technicznej. Firma sprzedaje swoje produkty na całym świecie i każdy z nich musi dostosować do lokalnych wymagań i regulacji. Firma wykorzystuje w tym celu potencjał międzynarodowej grupy, do której należy. Sprawność tego typu działań wymaga jednak odpowiedniej koordynacji i istnienia skutecznych procesów w zakresie wiedzy. Firma Trepko 
mimo iż jest producentem produktów fizycznych, to zarząd postrzega ją jako organizację opartą na wiedzy, w równym stopniu rynkowej, jak i technicznej. 


\section{Zakończenie}

Globalne otoczenie podmiotów gospodarczych zmienia się obecnie w bardzo szybkim tempie. W obliczu szeregu trendów, które pojawiają się i błyskawicznie zanikają jeden z nich wydaje się być relatywnie stały i stabilny. Jest nim wzrost znaczenia zasobu wiedzy w procesie kreowania wartości dodanej w gospodarce. Zjawisko to wymaga odpowiednich reakcji ze strony przedsiębiorstw $\mathrm{w}$ formie podjęcia właściwych działań strategicznych w tym zakresie.

Inną cechą charakterystyczną obecnych czasów jest coraz większa międzynarodowa aktywność gospodarcza przedsiębiorstw. Różnorodne formy zaangażowania firm na rynkach zagranicznych stają się coraz bardziej powszechne. Środowisko gospodarcze, technologie oraz coraz większa integracja kulturowa niewątpliwie sprzyjają tym procesom. Jednak część barier i trudności nadal istnieje. Przedsiębiorstwa decydujące się na zaangażowanie w proces internacjonalizacji w celu wykształcenia przewagi konkurencyjnej muszą być szczególnie aktywne, we wcześniej wspomnianym, kluczowym w dzisiejszych czasach obszarze kreacji wartości dodanej - wiedzy. Wysoka skuteczność działania w omawianym zakresie jest szczególnie potrzebna tego rodzaju podmiotom z uwagi na specyfikę ich funkcjonowania. Napotykają one bowiem różnorodnych, mniej znanych konkurentów, egzystują w zróżnicowanym, dynamicznym oraz rozproszonym geograficznie środowisku, a także mają najczęściej do czynienia z szerokim spektrum odmiennych i stale zmieniających się (w różnorodnym tempie) nabywców.

Potrzebę stałych działań w omawianym zakresie wymusza przede wszystkim charakterystyka zasobu, jakim jest wiedza. Jej nietrwały charakter sprawia, iż jej elementy muszą być ciągle uaktualniane by były użyteczne w prowadzeniu działalności. W związku z tym koniecznym jest ustanowienie określonych grup procesów mających na celu stałe pozyskiwanie, kreację, magazynowanie, rozpowszechnianie oraz wdrażanie wiedzy. Ponadto, często pomijanym w literaturze zagadnieniem jest właściwe ukierunkowanie działań i procesów w zakresie wiedzy. Celowość i określenie strategicznego kierunku powinny być podstawą każdego działania w tym obszarze. W związku z faktem, iż przedsiębiorstwa będące podmiotem badań niniejszej pracy egzystują w środowisku gospodarki rynkowej najwłaściwszą decyzją w tym zakresie jest rynkowa orientacja działań w obszarze wiedzy. Nawiązując do literatury przedmiotu [Darroch i McNaughton 2003; Mazur i in. 2008, 2011] posłużono się w tym kontekście eklektyczną kategorią orientacji na wiedzę, która oznacza rynkowo ukierunkowane działania przedsiębiorstwa w zakresie wiedzy. 
Brak badań w zakresie wpływu rynkowo ukierunkowanych działań w zakresie wiedzy na przewagę konkurencyjną podmiotów zaangażowanych na rynkach zagranicznych tworzy lukę badawczą. Jej wypełnienie było motywacją dla podjęcia tematu prezentowanej pracy. W związku z tym celem rozprawy było wyjaśnienie roli orientacji na wiedzę, czyli rynkowo ukierunkowanych działań w obszarze zasobu wiedzy, w przedsiębiorstwach w procesie internacjonalizacji w kontekście kształtowania ich przewagi konkurencyjnej.

W części teoretycznej pracy opracowano model dynamicznej orientacji na wiedzę. Jego celem było wyjaśnienie charakterystyki kształtowania długoterminowej przewagi konkurencyjnej przedsiębiorstw działających na rynkach zagranicznych, w warunkach współczesnych procesów gospodarczych. Wynika to z faktu, iż obecne realia ekonomiczne charakteryzują się przede wszystkim częstymi zmianami oraz ich niewielką przewidywalnością, a także stałym wzrostem znaczenia zasobu wiedzy. Model jest rozwinięciem rozważań prowadzonych w literaturze. Realizacja działań w ramach zaproponowanej koncepcji wymaga stałej, charakteryzującej się wysoką jakością, aktywności procesowej przedsiębiorstwa. Prezentowane ujęcie zakłada istnienie w przedsiębiorstwie proceduralnych reakcji na zmiany zachodzące na rynku. Odpowiedź na pojawiające się przemiany musi zaś koncentrować się na kluczowym elemencie w zakresie tworzenia wartości dodanej we współczesnej gospodarce, jakim jest obecnie wiedza. Model podkreśla również wagę określonej kolejności omawianych działań. Jest to związane z faktem, iż nawet najbardziej zaawansowane przedsięwzięcia w zakresie wiedzy bez ich właściwego ukierunkowania są bardzo ryzykowne. Mogą one nie odpowiadać potrzebom rynku, którego reakcja w formie popytu na efekty podejmowanych działań jest główną determinantą przewagi konkurencyjnej przedsiębiorstwa.

Rozważania teoretyczne były podstawą do przeprowadzenia badań empirycznych. W celu weryfikacji postawionych w pracy hipotez opracowano odpowiednie modele badawcze. Na ich podstawie przygotowano główne narzędzie badawcze - kwestionariusz ankiety, z wykorzystaniem którego opracowano badanie ilościowe. Ponadto, stworzono schemat wywiadu, który został zastosowany przy prowadzeniu badań jakościowych.

Dla celów badania ilościowego, specjalnie opracowano, we współpracy z informatykiem, system ankietowania elektronicznego. Dzięki wykorzystaniu tego narzędzia oraz tradycyjnej ankiety pocztowej w badaniu uczestniczyło ponad 1300 przedsiębiorstw.

Prowadzone w rozprawie analizy danych empirycznych wykazały, iż uzasadnionym było przypuszczenie, będące jednym $\mathrm{z}$ wyników rozważań prowadzonych $\mathrm{w}$ części teoretycznej niniejszej pracy, iż przedsiębiorstwa zaangażowane na rynkach zagranicznych są 
bardziej zorientowane na wiedzę niż podmioty działające lokalnie. Różnice te okazały się istotne statystycznie. Otrzymane wyniki umożliwiły pozytywną weryfikację hipotezy pierwszej zakładającej, iż przedsiębiorstwa działające na rynkach zagranicznych sa przeciętnie bardziej zorientowane na wiedzę w porównaniu do przedsiębiorstw działajacych lokalnie. Analizy również pokazały, iż wysoki poziom orientacji rynkowej jest relatywnie powszechny $\mathrm{w}$ obu rodzajach podmiotów, znacznie rzadszym jest występowanie intensywnych działań w zakresie wiedzy. Zaobserwowano również duże różnice w sferze źródeł, z jakich czerpią wiedzę podmioty działające lokalnie, w porównaniu z firmami zaangażowanymi na rynkach zagranicznych. Te drugie bardziej intensywnie korzystają z poszczególnych źródeł wiedzy, a także wykorzystują szersze ich spektrum.

Kolejne analizy miały na celu kontynuację wnioskowania zapoczątkowanego w ramach weryfikacji hipotezy 1 . Koncentrowały się one na dokładnym zbadaniu przedsiębiorstw zaangażowanych na rynkach zagranicznych. W tym celu wykorzystano kryterium stopnia (etapu) zaawansowania procesu internacjonalizacji. Etap definiowano z wykorzystaniem trzech kryteriów: okresu zaangażowania zagranicznego przedsiębiorstwa, udziału sprzedaży zagranicznej w porównaniu do sprzedaży firmy ogółem oraz formy zaangażowania zagranicznego przedsiębiorstwa. Próbowano znaleźć dowody, iż w przedsiębiorstwa wraz $\mathrm{z}$ większym zaangażowaniem na rynkach zagranicznych charakteryzują się również wyższym poziomem orientacji na wiedzę. Przeprowadzone analizy, w tym testy statystyczne, z wykorzystaniem trzech wspomnianych kryteriów, nie potwierdziły jednak tego przypuszczenia.

W kontekście okresu zaangażowania badanych podmiotów na rynkach zagranicznych zauważono, iż najbardziej zorientowane na wiedzę są podmioty na początku procesu internacjonalizacji (do 2 lat), a także działające na rynkach zagranicznych powyżej 10 lat.

W zakresie udziału sprzedaży zagranicznej przedsiębiorstw w ich sprzedaży ogółem analizy wykazały, iż najbardziej zorientowane na wiedzę są podmioty z udziałem w zakresie 11-60 procent sprzedaży na rynkach zagranicznych w sprzedaży ogółem. Podmioty z udziałem sprzedaży na rynkach zagranicznych w zakresie 1-10 procent oraz powyżej 60 procent nie wykazywały tak wysokiego poziomu orientacji na wiedzę. Przyczyną tego może być fakt, iż dla pierwszej z wymienionych grup rynki zagraniczne mają przypuszczalnie niewielkie znaczenie, stąd też z ich perspektywy istnieje mniejsza presja w zakresie rozwoju badanych działań. Druga grupa prawdopodobnie w dużej mierze skupiała podmioty zajmujące się podwykonawstwem, które znaczącą część potrzebnej wiedzy otrzymują od swoich zagranicznych zleceniodawców. 
W przypadku wykorzystania kryterium formy zaangażowania zagranicznego przedsiębiorstwa jako miernika etapu internacjonalizacji, najbardziej zorientowane na wiedzę okazały się być firmy posługujące się takimi formami internacjonalizacji, jak współpraca kapitałowa i niekapitałowa. Nieco mniejszym, lecz również wysokim poziomem intensywności badanego zjawiska charakteryzowały się firmy wykorzystujące formę własnej inwestycji bezpośredniej. Zdecydowanie niższym poziomem orientacji na wiedzę odznaczały się przedsiębiorstwa posługujące się $\mathrm{w}$ procesie internacjonalizacji formami organizacyjnymi takimi, jak eksport i import, a także podwykonawstwo.

Wyniki przeprowadzonych badań wykazały, iż poziom orientacji na wiedzę wśród przedsiębiorstw $\mathrm{w}$ różnym stopniu zaangażowanych zagranicznie, $\mathrm{z}$ wykorzystaniem trzech kryteriów internacjonalizacji, jest do pewnego stopnia zróżnicowany. Badane procesy nie są jednak bardziej intensywne w podmiotach znajdujących się na coraz wyższych etapach internacjonalizacji. W związku $\mathrm{z}$ tym nie znaleziono empirycznych dowodów potwierdzających słuszność hipotezy zakładającej, iż przedsiębiorstwa wraz z większym zaangażowaniem $w$ proces internacjonalizacji sqprzeciętnie bardziej zorientowane na wiedzę.

Ostatnim i najważniejszym szczegółowym celem niniejszej rozprawy było poznanie wpływu orientacji przedsiębiorstwa na wiedzę na przewagę konkurencyjną firmy w procesie internacjonalizacji. Analiza danych empirycznych wykazała silny, istotny statystycznie wpływ poziomu orientacji na wiedzę na poziom przewagi konkurencyjnej przedsiębiorstw zaangażowanych na rynkach zagranicznych. W badanej grupie przedsiębiorstw, wśród podmiotów reprezentujących wysoki poziom orientacji na wiedzę, najwięcej było firm charakteryzujących się przewagą konkurencyjną wobec najbliższych konkurentów $(61,8 \%)$. Wśród firm charakteryzujących się niską orientacją na wiedzę jedynie jedna czwarta $(24,7 \%)$ była w stanie wykształcić przewagę konkurencyjną wobec najbliższych konkurentów. Ponadto, wykonane analizy statystyczne z wykorzystaniem regresji logistycznej pokazały, iż:

- przedsiębiorstwo charakteryzujące się wysokim poziomem orientacji na wiedzę ma, o blisko 5 razy większą szansę uzyskania przewagi konkurencyjnej względem najbliższych konkurentów, w porównaniu do podmiotu, który cechuje się niskim poziomem orientacji na wiedzę,

- przedsiębiorstwo charakteryzujące się średnim poziomem orientacji na wiedzę ma o ponad 2 razy większą szansę uzyskania przewagi konkurencyjnej względem najbliższych konkurentów, w porównaniu do podmiotu, który cechuje się niskim poziomem orientacji na wiedzę. 
Otrzymane wyniki umożliwiły pozytywną weryfikację najważniejszej hipotezy w pracy zakładającej, iżwyższy poziom orientacji na wiedze przedsiębiorstw $w$ procesie internacjonalizacji wpływa pozytywnie na kształtowanie przewagi konkurencyjnej podmiotów zaangażowanych zagranicznie.

Efektem niniejszej pracy jest poznanie i opisanie szeregu zjawisk na granicy następujących obszarów: aktywności przedsiębiorstwa w zakresie zasobu wiedzy, orientacji rynkowej, kształtowania przewagi konkurencyjnej podmiotu, a także internacjonalizacji firmy. Rezultatem teoretycznym niniejszej pracy jest powstanie kompleksowego, eklektycznego modelu orientacji na wiedzę na podstawie dorobku literaturowego następujących teorii: zarządzania wiedzą, organizacji uczącej, organizacyjnego uczenia się, a także orientacji rynkowej. Podstawowym efektem poznawczym jest empiryczna weryfikacja różnic w zakresie intensywności i charakterystyki orientacji na wiedzę przedsiębiorstw działających lokalnie i zaangażowanych na rynkach zagranicznych, a także wśród samych firm w procesie internacjonalizacji. Kluczowym efektem poznawczym jest jednak pozytywna weryfikacja empiryczna znaczenia rynkowo ukierunkowanych procesów w zakresie wiedzy w kształtowaniu przewagi konkurencyjnej przedsiębiorstwa $\mathrm{w}$ procesie internacjonalizacji. Niestety, ilościowe badanie empiryczne nie pozwala na szczegółową analizę tego zjawiska. W związku z tym, w celu dokładniejszego zrozumienia odkrytej zależności, która jest najważniejszym rezultatem poznawczym niniejszej pracy, przeprowadzono jakościowe badanie empiryczne w formie dwóch studiów przypadku. Szczególnie interesującym okazał się być przykład firmy Trepko. Wspomniane przedsiębiorstwo zajmuje się produkcją maszyn pakujących dla podmiotów z branży spożywczej. Swoje produkty sprzedaje na całym świecie. Kluczowym elementem przewagi konkurencyjnej tej firmy jest wiedza o potrzebach jej klientów, gdyż najczęściej muszą oni spełnić różnego rodzaju wymagania w zakresie charakterystyki opakowań swoich produktów. W przypadku klientów zagranicznych podmiotu pozyskanie tej wiedzy jest zdecydowanie trudniejsze. W firmie Trepko istnieje jednak duża świadomość znaczenia szczegółowej i aktualnej wiedzy o potrzebach klientów dla przewagi konkurencyjnej przedsiębiorstwa. W związku $\mathrm{z}$ tym podejmowane są intensywne działania w celu jej pozyskania, także z wykorzystaniem potencjału całej grupy Trepko. Wiedza o potrzebach klienta jest potem podstawą rozwoju wiedzy technicznej, a następnie dopasowanych do potrzeb klientów produktów. Sprawność tego typu działań wymaga jednak odpowiedniej koordynacji i istnienia skutecznych procesów w zakresie zarządzania omawianym zasobem. Trepko wytwarza produkty fizyczne, lecz osoby 
zarządzające podmiotem postrzegają firmę jako organizację opartą na wiedzy, w równym stopniu rynkowej, jak i technicznej.

Przeprowadzone badania umożliwiają sformułowanie rekomendacji dla praktyki gospodarczej. Wyniki analiz wskazują, iż osoby zarządzające przedsiębiorstwami zaangażowanymi na rynkach zagranicznych powinny zwracać szczególną uwagę na zagadnienia związane $\mathrm{z}$ działaniami organizacji w zakresie wiedzy. Ważne jest przyjęcie odpowiedniej, ogólnopodmiotowej strategii w tym zakresie, która umożliwi sprawne pozyskiwanie, magazynowanie, rozpowszechnianie, wdrażanie i ochronę tego zasobu. Należy zaznaczyć, iż skuteczna strategia w kontekście działań firmy w obszarze wiedzy nie jest elementem wystarczającym, aczkolwiek koniecznym.

Drugim, dopełniającym komponentem, który umożliwia właściwe wykorzystanie sprawnych procesów podmiotu w zakresie wiedzy jest ich odpowiednie ukierunkowanie. Przedsiębiorstwo powinno stale mieć na uwadze zagadnienie celowości swoich działań. Procesy w zakresie wiedzy muszą służyć realizacji odpowiednich celów firmy co sprawia, że powinny być one odpowiednio ukierunkowane. Rozpatrywane przedsiębiorstwa egzystują w warunkach gospodarki rynkowej, stąd najlepszym drogowskazem w tym zakresie są potrzeby rynku. W związku z tym ważna jest stała systemowa, procesowa obserwacja i prowadzenie analiz rynku. Kluczowym czynnikiem jest również istnienie w ramach podmiotu świadomości ciągłych i trudnych do przewidzenia zmian nieustannie zachodzących w obecnej gospodarce. Należy podkreślić, iż przedsiębiorstwo nie powinno koncentrować się wyłącznie na wiedzy rynkowej, lecz również technicznej. Ważnym jest, aby stale uaktualniana wiedza rynkowa ukierunkowywała ciągły rozwój wiedzy technicznej przedsiębiorstwa. Jednoczesna obecność w przedsiębiorstwie wysokiej orientacji rynkowej oraz intensywnych procesów w zakresie wiedzy prowadzi do powstania efektu synergii. Jak wykazały przeprowadzone badania - przedsiębiorstwa w procesie internacjonalizacji, które równocześnie charakteryzują się intensywnymi działaniami w zakresie wiedzy, jak i wysoką orientacją rynkową, cechują się przeciętnie wyższą przewagą konkurencyjną wobec najbliższych konkurentów.

Autor ma świadomość istnienia określonych ograniczeń zastosowanych $\mathrm{w}$ pracy metod badawczych. Kwestionariusz ankiety wykorzystany w ramach badań ilościowych umożliwił jedynie ogólne poznanie złożonych procesów w zakresie wiedzy. Uzyskano znaczną liczbę wypełnionych kwestionariuszy, lecz kosztem szczegółowości danych. 
Ograniczenie to próbowano zniwelować poprzez przeprowadzenie badań jakościowych, których skala była jednak relatywnie niewielka. Innym ograniczeniem jest wykorzystany w badaniu operat losowania - baza danych Kompass Poland, która nie jest perfekcyjnym zbiorem kompleksowo odzwierciedlającym populację przedsiębiorstw w Polsce.

W przyszłości, w związku z obserwowanymi trendami gospodarczymi, należy spodziewać się dalszego wzrostu znaczenia zasobu wiedzy, a także intensyfikacji konkurencji międzynarodowej, choćby z uwagi na postęp globalizacji przejawiający się przykładowo w procesach tworzenia największej na świecie, europejsko-amerykańskiej strefy wolnego handlu. W związku z tym podmioty gospodarcze będą musiały innowacyjnie reagować na zmieniające się potrzeby rynku szczególnie w obszarze kluczowego, w tworzeniu wartości dodanej zasobu, zasobu wiedzy. Implikuje to potrzebę rozwoju w firmach, stałych, systemowych i rynkowo ukierunkowanych działań w obszarze wiedzy, których skuteczność będzie musiała stale wzrastać. W związku z tym zauważone w pracy prawidłowości powinny być stale obserwowane, a ogólne i szczegółowe analizy w tym zakresie intensyfikowane. Dalsze badania w tematyce rynkowo ukierunkowanych działań przedsiębiorstw w zakresie wiedzy powinny być skoncentrowane na określonych branżach, ich specyfice, wymaganiach i potrzebach w zakresie efektywnej organizacji działań w obszarze wiedzy. 


\section{Bibliografia}

1. Adamik, A., 2008, Creating of Competitive Advantage Based on Cooperation, Wydawnictwo Politechniki Łódzkiej, Lodz.

2. Adamkiewicz-Drwiłło, H.G., 2010, Konkurencyjność przedsiębiorstw w świetle uwarunkowań współczesnej gospodarki, Dom Organizatora, Toruń.

3. Ahmed, P.K., Lim, K.K., Loh, A.Y.E., 2002, Learning Through Knowledge Management, Butterworth-Heinemann, Oxford.

4. Ajmal, M., Helo, P., Kekäle, T., 2010, Critical factors for knowledge management in project business. Journal of Knowledge Management, no. 1, vol. 14, s. 156-168.

5. Alavi, M., Tiwana, A., 2006, Knowledge Management: The Information Technology Dimension [in:] Easterby-Smith, M., Lyles, M.A., 2006, The Blackwell Handbook of Organizational Learning and Knowledge Management, Blackwell Publishing, Oxford, s. 104-120.

6. Altkorn, J., 2001, Orientacje Marketingowe Polskich Przedsiębiorstw, Kongres Ekonomistów Polskich, Polskie Towarzystwo Ekonomiczne (7). Sesja IV, Warszawa.

7. Anantatmula, V.S., 2008, Knowledge Management Success: Roles of Management and Leadership [w:] O’Sullivan, K., 2008, Strategic Knowledge Management in Multinational Organizations, IGI Global, London, s. 299-310.

8. Andersen, O., 1993, On the Internationalization Process of Firms: A Critical Analysis, Journal of International Business Studies, vol. 24, no. 2, $2^{\text {nd }}$ Qtr., s. 209-231.

9. Andersen, O., 1997, Internationalization and Market Entry Mode: A Review of Theories and Conceptual Frameworks, Management International Review 37, Internationalization Processes - New Perspectives for a Classical Field of International Management, s. 27-42.

10. Andersson, T., Curley, M.G., Formica, P., 2010, Knowledge-Driven Entrepreneurship. The Key to Social and Economic Transformation, Springer, New York.

11. Armstrong, G., Kotler, Ph., 2011, Marketing. An Introduction, Pearson, Upper Saddle River.

12. Baker, W.E., Sinkula, J.M., 1999, The Synergistic Effect of Market Orientation and Learning Orientation on Organizational Performance, Journal of Academy of Marketing Science, vol. 27, no. 4, s. 411-427. 
13. Bali, R.K., Wickramasinghe, N., Lahaney, B., 2009, Knowledge Management Primer, Routledge, London.

14. Baloh, P., Desouza, K.C., Paquette, S., 2011, The Concept of Knowledge [in:] Desouza, K.C., Paquette, S., 2011, Knowledge Management. An Introduction, NealSchumann Publishers, Inc., New York, s. 35-72.

15. Barney, J.B., 2011, Gaining and Sustaining Competitive Advantage, Pearson Education, New Jersey.

16. Baruk, J., 2006, Zarzadzanie wiedza i innowacjami, Wydawnictwo Adam Marszałek, Toruń.

17. Becker, J., Homburg, C., 1999, Market-Oriented Management: A Systems-Based Perspective. Journal of Market-Focused Management, vol. 4, no. 1, s. 17-41.

18. Bedyńska, S., Brzezicka, A., 2007, Statystyczny drogowskaz. Praktyczny poradnik danych w naukach społecznych na przykladach z psychologii, Wydawnictwo Szkoły Wyższej Psychologii Społecznej „Academica”, Warszawa.

19. Bieliński, J., 2005, Konkurencyjność przedsiębiorstw w świetle Strategii Lizbońskiej, CeDeWu, Warszawa.

20. Boughzala, I., Ermine, J.L., 2006, Trends in Enterprise Knowledge Management, ISTE Ltd., London.

21. Bratianu, C., Dinca, V.M., 2010, Knowledge Economy Dimensions. Review of International Comparative Management, 11(2), s. 210-221.

22. Brdulak, J., 2012, Wiedza w zarządzaniu przedsiębiorstwem, Szkoła Główna Handlowa w Warszawie - Oficyna Wydawnicza, Warszawa.

23. Brdulak, J.J., 2005, Zarządzanie wiedza a proces innowacji produktu, Szkoła Główna Handlowa - Oficyna Wydawnicza, Warszawa.

24. Brinkley, I., 2006, Defining the knowledge economy, The Work Foundation, London.

25. Brinkley, I., 2008, The Knowledge Economy: How Knowledge is Reshaping the Economic Life of Nations, The Work Foundation, London.

26. Brinkley, I., 2009, Manufacturing and the Knowledge Economy, The Work Foundation, London.

27. Brinkley, I., Lee, N., 2007, The knowledge economy in Europe. A report prepared forthe 2007 EU Spring Council, dostępny: http://www.theworkfoundation.com/assets/docs/publications/80_Knowledge\%20 Economy\%20EU\% 20Spring \%20Council.pdf [dostęp: 22.01.2014r.]. 
28. Bukh, P.N., Christensen, K.S., Mouritsen, J., 2005, Knowledge Management and Intellectual Capital - Establishing a Field of Practice, Palgrave Macmillan, New York.

29. Busch, P., 2008, Tacit Knowledge in Organizational Learning, IGI Publishing, New York.

30. Cavaleri, S., Seivert, S., 2005, Knowledge Leadership. The Art and Science of Knowledge-Based Organization, Elsevier Butterworth-Heinemann, Oxford.

31. Chakravarthy, B., McEvily, S., Doz, Y., Rau, D., 2006, Knowledge Management and Competitive Advantage [in:] Easterby-Smith, M., Lyles, M.A., 2006, The Blackwell Handbook of Organizational Learning and Knowledge Management. Blackwell Publishing, Oxford, s. 305-322.

32. Chen, Ch.J., Huang, J.W., 2007, How organizational climate and structure affect knowledge management - The social interaction perspective. International Journal of Information Management, no. 27, s. 104-118.

33. Choo, C.W., 2006, The Knowing Organization. How Organizations Use Information to Construct Meaning, Create Knowledge, and Make Decisions, Oxford University Press, Oxford.

34. Clarke, T., 2001, The knowledge economy, Education + Training, no. 4/5, vol. 43.

35. Collis, D.J., Montgomery C. A., 2008, Competing on Resources, Harvard Business Review, July-August, s. 140-150.

36. Cook, P., 2002, Knowledge economies: clusters, learning and cooperative advantage, Routledge, New York.

37. Cooke, P., Leydesdorff, L., 2006, Regional Development in the Knowledge-Based Economy: The Construction of Advantage, Journal of Technology Transfer, no. 31.

38. Dąbrowski, J., Gierszewska, G., 2005, Strategie Przedsiębiorstw a Zarzadzanie Wiedza, Wydawnictwo Wyższej Szkoły Przedsiębiorczości i Zarządzania im. Leona Koźmińskiego, Warszawa.

39. Darroch, J., 2003, Developing a measure of knowledge management behaviors and practices. Journal of Knowledge Management, no. 7, iss. 5, s. 41-54.

40. Darroch, J., McNaughton, R., 2003, Beyond Market Orientation. Knowledge Management and the Innvativeness of New Zealand Firms, European Journal of Marketing 37 (3/4), s. 572-593.

41. Daszkiewicz, N., 2004, Internacjonalizacja Matych $i$ Średnich Przedsiębiorstw we Współczesnej Gospodarce, Scientific Publishing Group, Gdańsk. 
42. Daszkiewicz, N., Wasilczuk, J., Dominiak, P., 2005, Małe i średnie przedsiębiorstwa wobec procesów integracji gospodarki światowej - teoria i metodologia badań [w:] Dominiak, P., Wasilczuk, J., Daszkiewicz, N., 2005, Małe i średnie przedsiębiorstwa w obliczu internacjonalizacji i integracji gospodarek europejskich: przykłady Włoch, Francji, Polski i Czech, Scientific Publishing Group, Gdańsk.

43. Davenport, H.D., Prusak, L., 1998, Working Knowledge, Harvard Business Scholl Press, Boston.

44. Davenport, T.H., Probst, G.J.B., 2002, Siemens' Knowledge Journey [in:] Davenport, T.H., Probst, G.J.B., 2002, Knowledge Management Case Book, Publicis Corporate Publishing and John Wiley and Sons (joint publication), Berlin and Munich, s. 10-23.

45. Day, G.S., 1994, The Capabilities of Market-Driven Organizations, Journal of Marketing 58, October, s. 37-52.

46. Deng, H.A., 2012, Conceptual Framework for Effective Knowledge Management Using Information and Communication Technologies [in:] Lee, W.B., 2012, Systems Approaches to Knowledge Management, Transfer, and Resource Development, Information Science Reference, Hershey, s. 117-131.

47. Deshpande, R., Farley, J.U., Webster, Jr., F.E., 1993, Corporate Culture, Customer Orientation, and Innovativeness in Japanese Firms: A Quadrad Analysis, Journal of Marketing, vol. 57, January, s. 23-27.

48. Desouza, K.C., 2011, An Introduction to Knowledge Management [in:] Desouza, K.C., Paquette, S., 2011, Knowledge Management. An Introduction, Neal-Schumann Publishers, Inc., New York, s. 3-34.

49. Dillet, R., 2013, Apple Beats In Q3 2013 With \$35.3B In Revenue, \$6.9B In Profit, \$7.47 EPS, But Posts Another YOY Earnings Decline, Techcrunch, dostępny: http://techcrunch.com/2013/07/23/apple-q3-2013/ [dostęp: 12.09.2013r.].

50. Dobija, D., Rosolińska, A., 2008, New Challenges for Financing Business in the Knowledge-Based Economy, [w:] Runiewicz-Wardyn, M., 2008, Knowledge-Based Economy as Factor of Competitiveness and Economic Growth, Wydawnictwa Akademickie i Profesjonalne, Warszawa.

51. Donate, M.J., Guadamillas, F., 2011, Organizational factors to support knowledge management and innovation, Journal of Knowledge Management, vol. 15, no. 6, s. $890-914$.

52. Drucker, P.F., 1999, Społeczeństwo postkapitalistyczne, Wydawnictwo Naukowe PWN, Warszawa. 
53. Drucker, P.F., 2006, Nadchodzi Nowa Organizacja [w:] Drucker, P.F, 2006, Zarzadzanie Wiedza, Helion, Gliwice.

54. Du Plessis, M., 2008, What bars organisations from managing knowledge successfully?, International Journal of Information Management, no. 28, s. 285-292.

55. Duliniec, E., 2009, Marketing międzynarodowy, Polskie Wydawnictwo Ekonomiczne, Warszawa.

56. Dunning, J.H., 1979, Explaining Changing Patterns of Production: in Defence of the Electic Theory, Oxford Bulletin of Economics and Statistics, vol. 41, iss. 4, s. 269295.

57. Dunning, J.H., 1980, Toward and Electic Theory of International Production: Some Empirical Examples, Journal of International Business Studies, Vol. 11, No. 1, SpringSummer, s. 9-31.

58. Dunning, J.H., 1988, The Eclectic Paradigm of International Production: A Restatement and Some Possible Extensions, Journal of International Business Studies, vol. 19, no. 1, s. 1-31.

59. Dunning, J.H., 1995, Reappraising the Eclectic Paradigm in an Age of Alliance Capitalism, Journal of Intenational Business Studies, vol. 26, no. 3, s. 461-491.

60. Dunning, J.H., 1998, Location and the Multinational Enterprise: A Neglected Factor?, Journal of International Business Studies, vol. 29, no. 1, s. 45-66.

61. Dunning, J.H., 2000, Regions, Globalization and the Knowledge-based Economy, Oxford Univeristy Press, New York.

62. Dwivedi, Y.K., Venkitachalam, K., Sharif, A.M., Al-Karaghouli, W., Weerakkody, V., 2011, Research Trends in Knowledge Management: Analyzing the Past and Predicting the Future, Information Systems Management, no. 28, s. 43-56.

63. Dzikowska, M., Gorynia, M., 2012, Teoretyczne aspekty konkurencyjności przedsiębiorstwa - w kierunku koncepcji eklektycznej?, Gospodarka Narodowa, $\mathrm{nr} 4$, s. 1-30.

64. Easterby-Smith, M., Lyles, M.A., 2006, Introduction: Watersheds of Organizational Learning and Knowledge Management [in:] Easterby-Smith, M., Lyles, M.A., 2006, The Blackwell Handbook of Organizational Learning and Knowledge Management, Blackwell Publishing, Oxford, s. 1-15.

65. Ermine, J.L., 2012, Knowledge Crash and Knowledge Management [in:] Lee, W.B., 2012, Systems Approaches to Knowledge Management, Transfer, and Resource Development, Information Science Reference, Hershey, s. 99-116. 
66. Evans, Ch., 2005, Zarządzanie Wiedza, Polskie Wydawnictwo Ekonomiczne, Warszawa.

67. Farell, M.A., 2000, Developing a Market-Oriented Learning Organisation, Australian Journal of Management, vol. 25, no. 2, September, s. 201-222.

68. Farell, M.A., Oczkowski, E., 2002, Are Market Orientation and Learning Orientation Necessary for Superior Organizational Performance?, Journal of Market-Focused Management, no. 5, s. 197-217.

69. Farrell, M.A., Oczkowski, E., 1997, An analysis of the MKTOR and MARKOR measures of market orientation: An Australian perspective, Marketing Bulletin, no. 8, s. $30-40$.

70. Faulkner, D., Bowman, C., 1996, Strategie konkurencji, Gebethner i Ska, Warszawa.

71. Fazlagić, A.J., 2004, Co to jest organizacja uczaca się?, http://www.fazlagic.egov.pl/artykul.php?artykul=65\&zakladka=4 [dostęp: 25.06.2013r.]

72. Fazlagić, A.J., 2006, Zarządzanie wiedza. Szansa na sukces w biznesie, Gnieźnieńska Wyższa Szkoła Humanistyczno-Menedżerska, Gniezno.

73. Fazlagić, J., 2010, Know-how w działaniu! Jak zdobyć przewagę konkurencyjna dzięki zarządzaniu wiedza, Helion, Gliwice.

74. Financial Times, 2013, Toyota forecasts further gains as net profit triples, http://www.ft.com/intl/cms/s/0/deb2332a-b7ac-11e2-9f1a00144feabdc0.html\#axzz2Su5DgN85 [dostęp: 1.07.2013r.]

75. Fingas, G., 2013, Kodak closes its digital imaging patent sale, settles disputes, Engadget, $1^{\text {st }}$ February 2013, http://www.engadget.com/2013/02/01/kodak-closes-itsdigital-imaging-patent-sale/ [dostęp: 01.07.2013r.].

76. Fonfara, K., 2000, Strategie marketingowe $w$ biznesie międzynarodowym [w:] Fonfara, K., Gorynia, M. (red.), Najlepszy, E., Schroeder, J., 2000, Strategie przedsiębiorstw wbiznesie międzynarodowym, Wydawnictwo Akademii Ekonomicznej w Poznaniu, Poznań, s. 89-128.

77. Fonfara, K., 2007, Zachowanie przedsiębiorstw w procesie internacjonalizacji próba poszukiwania teorii marketingu międzynarodowego, Marketing i Rynek, 1/2007, s. $2-7$.

78. Fonfara, K., 2009, Istota i zakres procesu internacjonalizacji firmy [w:] Fonfara, K., 2009, Zachowanie przedsiębiorstwa w procesie internacjonalizacji - podejście sieciowe, Polskie Wydawnictwo Ekonomiczne, Warszawa, s. 11-25. 
79. Fonfara, K., 2012, The Development of Business Networks in the Company Internationalisation Process, Poznań University of Economics Press, Poznań.

80. Fonfara, K., 2014, Marketing partnerski na rynku przedsiębiorstw, wydanie III zmienione, Polskie Wydawnictwo Ekonomiczne, Warszawa.

81. Fryzeł, B., 2004, Kultura a konkurencyjność przedsiębiorstwa, Wydawnictwo "Dom Organizatora", Toruń.

82. Gaczek, W.M., 2009, Gospodarka oparta na wiedzy w regionach europejskich, Komitet Przestrzennego Zagospodarowania Kraju PAN, Warszawa.

83. Galan, J.I., Galende, J., Gonzalez-Benito, J., 1999, Determinant factors of international development: some empirical evidence, Management Decision, 37/10, s. $778-785$.

84. Geisler, E., Wickramasinghe, N., 2009, Principles of Knowledge Management. Theory, Practice, and Cases, M.E. Sharpe, London.

85. Gierszewska, G., 2011, Zarządzanie Wiedza w Przedsiębiorstwie-Modele, Podejścia, Praktyka, Oficyna Wydawnicza Politechniki Warszawskiej, Warszawa.

86. Gladstone, B., 2004, Zarzadzanie Wiedza, Petit, Warszawa.

87. Glińska-Neweś, A., 2007, Kulturowe uwarunkowania zarządzania wiedza w przedsiębiorstwie, Wydawnictwo „Dom Organizatora”, Toruń.

88. Główny Urząd Statystyczny, 2012, Miesięczna informacja o podmiotach gospodarki narodowej $w$ rejestrze REGON, Biuletyn Informacji Publicznej, 30 kwietnia, http://www.stat.gov.pl/cps/rde/xbcr/bip/BIP_tablice_regon_3004.zip [dostęp: 22.08.2013r.].

89. Google, ca 2005, Dziesięć prawd potwierdzonych przez Google, http://www.google.pl/intl/pl/about/ [dostęp: 22.01.2014r.].

90. Gorynia, M., 2000, Luka konkurencyjna $w$ przedsiębiorstwach a przystapienie Polski do Unii Europejskiej, Gospodarka Narodowa, nr 10, s. 48-67.

91. Gorynia, M., 2007, Studia Nad Transformacja i Internacjonalizacja Gospodarki Polskiej, Difin, Warszawa.

92. Gorynia, M., Jankowska, B., 2007, Teorie internacjonalizacji, Gospodarka Narodowa, nr 10, s. 21-44.

93. Gorynia, M., Jankowska, B., 2008, Klastry a Międzynarodowa Konkurencyjność i Internacjonalizacja Przedsiębiorstwa, Difin, Warszawa.

94. Gorynia, M., Jankowska, B., 2011, Główne koncepcje internacjonalizacji przedsiębiorstwa [w:] Gorynia, M., Jankowska, B., 2011, Wejście Polski do strefy 
EURO a międzynarodowa konkurencyjność $i$ internacjonalizacja polskich przedsiębiorstw, Difin, Warszawa.

95. Gorynia, M., Owczarzak, R., 2004, Podstawy teorii internacjonalizacji i globalizacji działalności przedsiębiorstw, Gospodarka Narodowa, styczeń-luty, s. 1-21.

96. Greenley, G.E, 1995, Forms of Market Orientation In UK Companies. Journal of Management Studies, no. 32, iss. 1, January, s. 47-66.

97. Griffiths, D., Koukpaki, S., 2012, Are We Stuck With Knowledge Management? A Case of Strategic Knowledge Resource Development [in:] Lee, W.B., 2012, Systems Approaches to Knowledge Management, Transfer, and Resource Development, Information Science Reference, Hershey, s. 61-82.

98. Grudzewski, W.M., Merski, J., 2004, Zarządzanie wiedza istota współczesnych organizacji inteligentnych, Wyższa Szkoła Ekonomiczna w Warszawie, Warszawa.

99. Gruszczyńska-Malec, G., Rutkowska, M., 2013, Strategie zarządzania wiedza, Polskie Wydawnictwo Ekonomiczne, Warszawa.

100. Hameed, I., 2009, Sources of Business Competitive Advantage: A Review, Journal of Business \& Economics, vol. 1, iss. 2, s. 222-233.

101. Handzic, M., Zhou, A.Z., 2005, Knowledge Management. An Integrative Approach, Chandos Publishing, Oxford.

102. Hatzichronoglou, T., 1997, Revision of the HighTechnology Sector and Product Classification, OECD Science, Technology and Industry Working Papers, 1997/02, OECD Publishing, http://dx.doi.org/10.1787/134337307632 [dostęp: 26.03.2012r.].

103. Hauke, A., 2008, Toyota Motor Corporation, case study, materiały nieopublikowane.

104. Hauke, A., 2009, Wptyw transferu wiedzy na sukces rynkowy przedsiębiorstwa w procesie internacjonalizacji [w:] Fonfara, K., 2009, Zachowanie przedsiębiorstwa $w$ procesie internacjonalizacji - podejście sieciowe, Polskie Wydawnictwo Ekonomiczne, Warszawa, s. 84-101.

105. Hawryszkiewicz, I., 2010, Knowledge Management. Organizing Knowledge Based Enterprises, Palgrave Macmillan, London.

106. Helfert, G., Ritter, T., Walter, A., 2002, Redefining market orientation from a relationship perspective. Theoretical considerations and empirical results, European Journal of Marketing, vol. 36, no. 9/10, s. 1119-1139.

107. Hislop, D., 2013, Knowledge Management in Organizations. A Critical Introduction, Oxford University Press, Oxford. 
108. Hollensen, S., 1998, Global marketing: a market-responsive approach, Prentice Hall, London.

109. Homburg, Ch., Pflesser, Ch., 2000, A Multiple-Layer Model of Market-Oriented Organizational Culture: Measurement Issues and Performance Outcomes, Journal of Marketing Research, vol. 37, November, s. 449-462.

110. Hooley, G., Cox, T., Fahy, J., Shipley, D., Beracs, J., Fonfara, K., Snoj, B., 2000, Market Orientation in the Transition Economies of Central Europe, Journal of Business Research 50, s. 273-285.

111. Hooley, G., Fahy, J., Greenley, G., Beracs, J., Fonfara, K., Snoj, B., 2003, Market orientation in the service sector of transition economies in Central Europe, European Journal of Marketing, 37 (1/2), s. 86-106.

112. Hsu, G.J.Y., Lin, Y.H., Wei, Z.Y., 2008, Competition policy for technological innovation in an era of knowledge-based economy, Knowledge-Based Systems 21, s. $826-832$.

113. Jackson, S.E., Hitt, M.A., DeNisi, A.S., 2003, Managing Knowledge for Sustained Competitive Advantage - Designing Strategies for Effective Human Resource Management, Jossey-Bass, San Francisco.

114. Jashapara, A., 2006, Zarzadzanie wiedza, Polskie Wydawnictwo Ekonomiczne, Warszawa.

115. Jemielniak, D., Koźmiński, A.K., 2008, Zarzq̨dzanie wiedza, Wydawnictwa Akademickie i Profesjonalne, Warszawa.

116. Jemielniak, D., Koźmiński, A.K., 2012, Zarządzanie wiedza, Wolters Kulwer Polska, Warszawa.

117. Johanson, J., Mattsson, L.G., 1988, Internationalization in Industrial Systems A Network Approach, Strategies in Global Competition, Croom-Helm, New York, s. 287-314.

118. Johanson, J., Vahlne, J.E., 1977, The Internationalization Process of the Firm A Model of Knowledge Development and Increasing Foreign Market Commitments., Journal of International Business Studies, vol. 8, no. 1, Spring-Summer, s. 23-32.

119. Johanson, J., Vahlne, J.E., 1990, The Mechanism of Internationalisation, International Marketing Review, vol. 7, iss. 4, s. 11-24.

120. Johanson, J., Vahlne, J.E., 2009, The Uppsala internationalization process model revisited: From liability of foreignness to liability of outsidership, Journal of International Business Studies, no. 40, s. 1411-1431. 
121. Johanson, J., Wiedersheim-Paul, F., 1975, The Internationalization of Firm Swedish Cases, The Journal of Management Studies, October, s. 305-322.

122. Jóźwiak, J., Podgórski, J., 2012, Statystyka do podstaw, Polskie Wydawnictwo Ekonomiczne, Warszawa.

123. Kahin, B., Foray, D., 2006, Advancing Knowledge and the Knowledge Economy, Massachusetts Institute of Technology, Cambridge.

124. Kąkol, U., 2012, Knowledge and its types. Fundamentals of Knowledge Management. [in:] Żuber, R., 2012, Innovation and Knowledge Management. Select Theoretical and Practical Issues, Difin, Warsaw, s. 17-31.

125. Kaleta, A., 2009, Strategie konkurencji współczesnych przedsiębiorstw [w]: Lachiewicz, S., Matejun, M., 2009, Konkurencyjność jako determinanta rozwoju przedsiębiorstwa, Politechnika Łódzka, Łódź.

126. Karasiewicz, G., 2009, Stopień internacjonalizacji gospodarki polskiej - określenie pozycji i trajektorii zmian w okresie transformacji [w:] Nowak, A.Z., 2009, Ekonomia - etyka - organizacja, Wydawnictwo Naukowe Wydziału Zarządzania Uniwersytetu Warszawskiego, Warszawa, s. 153-180.

127. Karasiewicz, G., 2013, Marketingowe strategie internacjonalizacji polskich przedsiębiorstw, Wolters Kluwer Polska S.A., Warszawa.

128. Karlsson, Ch., Johansson, B., Sough, R.R., 2006, Entrepreneurship and Dynamics in the Knowledge Economy, Routledge, New York.

129. Kasten, J., 2008, Knowledge Strategy: The Linkage Between Business Strategy and Knowledge Management [in:] Srikantaiah, T.K., Koenig M.E.D., 2008, Knowledge Management in Practice. Connections and Context., American Society for Information Science and Technology, Medford, s. 115-124.

130. Kaur, G., Sharma, R.D., Seli, N., 2013, A Balanced Approach towards Market Orientation, Vikalpa, vol. 38, no. 3, July-September, s. 51-65.

131. Kijewska, A., 2005, Systemy informatyczne $w$ zarzadzaniu, Wydawnictwo Politechniki Śląskiej, Gliwice.

132. King, W.R., Marks Jr., P.V., 2008, Motivating knowledge sharing through a knowledge management system, Omega - The International Journal of Management Science, no. 36, s. 131-146.

133. Kjærgaard, A., Kautz, K., 2008, A process model of establishing knowledge management: Insights from a longitudinal field study, Omega - The International Journal of Management Science, no. 36, s. 282-297. 
134. Kłak, M., 2010, Zarządzanie wiedza we wspótczesnym przedsiębiorstwie, Wydawnictwo Wyższej Szkoły Ekonomii i Prawa im. prof. Edwarda Lipińskiego w Kielcach, Kielce.

135. Kleer, J., 2009, Gospodarka oparta na wiedzy a globalizacja: zwiazki czasowe czy przyczynkowe [w:] Kotowicz-Jawor, J., 2009, GOW - wyzwanie dla Polski, Polskie Wydawnictwo Ekonomiczne, Warszawa.

136. Kohli, A.K., Jaworski, B.J., 1990, Market Orientation: The Construct, Research Propositions, and Managerial Implications, Journal of Marketing, April, s. 1-18.

137. Kohli, A.K., Jaworski, B.J., Kumar, A., 1993, MARKOR: A Measure of Market Orientation, Journal of Marketing Research, vol. 30, November, s. 467-477.

138. Koskinen, K.U., Pihlanto, P., 2008, Knowledge Management in Project-Based Companies, An Organic Perspective, Palgrave Macmillan, London.

139. Kowalczyk, A., Nogalski, B., 2007, Zarządzanie wiedzą. Koncepcja i Narzędzia, Difin, Warszawa.

140. Kowalik, F., 2011, Piraci patentowani, Forbes, sierpień.

141. Kozioł-Nadolna, K., 2013, Internacjonalizacja Działalności Badawczo-rozwojowej w Kształtowaniu Procesów Innowacyjnych Przedsiębiorstw w Polsce, CeDeWu Warszawa.

142. Kraaijenbrink, J., 2012, Integrating Knowledge and Knowledge Processes: A Critical Incident Study of Product Development Projects, Journal of Product Innovation Management, no. 29, vol. 6, s. 1082-1096.

143. Kukliński, A., 2003, Gospodarka oparta na wiedzy. Perspektywy Banku Światowego, Biuro Banku Światowego w Polsce, Warszawa.

144. Kumar, V., Jones, E., Venkatesan, R., Leone, R.P., 2011, Is Market Orientation a Source of Sustainable Competitive Advantage or Simply the Cost of Competing?, Journal of Marketing 75, January, s. 16-30.

145. Lafferty, B.A., Hult, G.T.M., 2001, A synthesis of contemporary market orientation perspectives, European Journal of Marketing, vol. 35, no. 1/2, s. 92-109.

146. Laine, A., Kock, S., 2000, A Process Model of Internationalization - New Times Deamnds New Patterns, 16th IMP-conference in Bath, United Kingdom, http://impgroup.org/uploads/papers/83.pdf [dostęp: 16.01.2014r.].

147. Lechner, Ch., 2001, The Competitiveness of Firm Networks, Europäischer Verlag der Wissenschaften, Frankfurt am Main. 
148. Lee, S., Kim, B.G., Kim, H., 2012, An integrated view of knowledge management for performance, Journal of Knowledge Management, vol. 16, no. 2, s. 183-203.

149. Leja, K., 2006, Zarzadzanie Wiedzą. Wybrane Problemy, Zakład Zarządzania Wiedzą i Informacją Naukowo-Techniczną, Wydział Zarządzania i Ekonomii Politechniki Gdańskiej, Gdańsk.

150. Leydesdorff, L., Dolfsma, W., Soete, L., 2005, The Knowledge-Based Economy and the Triple Helix Model, Reading the Dynamics of a Knowledge Economy, Edward Elgar, Cheltenham.

151. Liebowitz, J., 2008, Making Cents Out of Knowledge Management, The Scarecrow Press, inc., Laham.

152. Lockett, A., Thompson, S., Morgenstern, U., 2009, The development of resourcebased view of the firm: A critical appraisal, International Journal of Management Reviews, 11(1), s. 9-28.

153. Loveman, G., 2004, Baza danych o klientach może stać się kopalnia diamentów, Harvard Business Review Polska, luty.

154. Małys, Ł., 2012, Wpływ powiązań sieciowych $w$ procesie internacjonalizacji na wyniki przedsiębiorstwa, Rozprawa doktorska, Uniwersytet Ekonomiczny w Poznaniu, Wydział Gospodarki Międzynarodowej, Poznań.

155. Małys, Ł., 2013, Siła powiąań sieciowych $w$ procesie internacjonalizacji a wyniki przedsiębiorstwa, Difin, Warszawa.

156. Mantura, W., 2009, Znaczenie i ogólne zagadnienia konkurencyjności przedsiębiorstw [w:] Lachiewicz, S., Matejun, M., 2009, Konkurencyjność jako determinanta rozwoju przedsiębiorstwa, Politechnika Łódzka, Łódź.

157. Markowski, B., Uwarunkowania i zróżnicowanie procesów organizacyjnego uczenia się [w:] Sitko-Lutek, A., Skrzypek, E., 2009, Organizacyjne uczenie się w rozwoju kompetencji przedsiębiorstw, C.H. Beck, Warszawa, s. 97-111.

158. Martin, J.H., Grbac, B., 2003, Using supply chain management to leverage a firm's market orientation, Industrial Marketing Management, no. 32, s. 25-38.

159. Martinez, A.R.M., 2010, Micro-Bargaining as Enhancer of Knowledge Management. A Comparison Between Mexico and Germany, Rainer Hamp Verlag, Munchen und Mering.

160. Martins, E.C., Meyer, H.W.J., 2012, Organizational and behavioral factors that influence knowledge retention, Journal of Knowledge Management, vol. 16, no. 1, s. 77-96. 
161. Materska, K., 2007, Informacja w organizacjach społeczeństwa wiedzy, Wydawnictwo Stowarzyszenia Bibliotekarzy Polskich, Warszawa.

162. Mazur, J., Rószkiewicz, M., Strzyżewska, M., 2008, Orientacja na wiedzę a wyniki przedsiębiorstwa. Wyniki badań średnich przedsiębiorstw funkcjonujacych $w$ Polsce, Szkoła Główna Handlowa w Warszawie, Warszawa.

163. Mazur, J., Rószkiewicz, M., Strzyżewska, M., 2011, Kompozycja działań zwiąanych zwiedza a wyniki ekonomiczne przedsiębiorstwa: wyniki badań średnich przedsiębiorstw funkcjonujących $w$ Polsce, Szkoła Główna Handlowa - Oficyna Wydawnicza, Warszawa.

164. Mazurkiewicz, A., Pizło, W., 2006, Podstawy marketingu, Wydawnictwo Prywatnej Wyższej Szkoły Businessu i Administracji, Warszawa.

165. McClave, J.T., Dietrich, F.H., 1988, Statistics, Dellen Publishing Company, San Francisco.

166. McDermott, R., 1999, Why Information Technology Inspired But Cannot Deliver Knowledge Management, California Management Review, $\mathrm{Nr} 4$.

167. McInerney, C.R., Koenig, M.E.D., 2011, Knowledge Management (KM) Processes in Organizations. Theoretical Foundations and Practice, Morgan \& Claypool, Chapel Hill.

168. Morawski, M., 2006, Przedsiębiorstwo zorientowane na wiedzę, E-mentor, http://www.e-mentor.edu.pl/artykul/index/numer/16/id/338 [dostęp: 1.07.2013r.].

169. Morawski, M., 2011, Koncepcja zarzadzania wiedza w przedsiębiorstwie [w:] Morawski, M., Prudzienica, M., 2011, Zarządzanie wiedza w kreowaniu innowacji zarządczych, Wydawnictwo Uniwersytetu Ekonomicznego we Wrocławiu, Wrocław, s. 11-21.

170. Morgan, R.E., Katsikeas, C.S., 1997, Theories of international trade, foreign direct investment and firm internationalization: a critique, Management Decision, vol. 35, iss. 1 , s. $68-78$.

171. Morgan, R.E., Katsikeas, C.S., Appiah-Adu, K., 1998, Market Orientation and Organizational Learning Capabilities, Journal of Marketing Management, no. 14, s. 353-381.

172. Moszkowicz, M., 2000, Strategia przedsiębiorstwa okresu przemian, Polskie Wydawnictwo Ekonomiczne, Warszawa.

173. Moszkowicz, M., Kubiński, P., 2010, Edukacja akademicka a tworzenie w Polsce gospodarki opartej na wiedzy [w:] Hopej, M., Moszkowicz, M., Skalik, J., 2010, 
Wiedza w gospodarce i gospodarka oparta na wiedzy. Edukacja w gospodarce opartej na wiedzy, Wydawnictwo Uniwersytetu Ekonomicznego we Wrocławiu, Wrocław.

174. Motriuk, R., 2012, Japońscy giganci elektroniki w tarapatach, Bankier.pl, s. 1, http://www.bankier.pl/wiadomosc/Japonskie-giganty-elektroniki-w-tarapatach2669723.html [dostęp: 1.07.2013r.].

175. Mruk, H., 2012, Marketing. Satysfakcja klienta i rozwój przedsiębiorstwa, Wydawnictwo Naukowe PWN, Warszawa.

176. Narver, J.C., Slater, S.F., 1990, The Effect of a Market Orientation on Business Profitability. Journal of Marketing, vol. 54, no. 4, October, s. 20-35.

177. Neef, D., Siesfeld, G.A., Cefola, J., 1998, The Economic Impact of Knowledge, Butterworth-Heinemann, Boston.

178. Ng, A.H.H., Yip, M.W., Din, S.B., Bakar, N.A., 2012, Integrated Knowledge Management Strategy: A Preliminary Literature Review, Procedia - Social and Behavioral Sciences, no. 57, s. 209-214.

179. Niestrój, R., 2003, Istota i znaczenie marketingu [w:] Altkorn, J., 2003, Podstawy marketingu, Instytut Marketingu, Kraków, s. 13-44.

180. Nijkamp, P., Siedschlag I., 2011, Innovation, Growth and Competitiveness. Dynamic Regions in the Knowldge-Based World Economy, Springer, Berlin.

181. Noble, Ch.H., Sinha, R.K., Kumar, A., 2002, Market Orientation and Alternative Strategic Orientations: A Longitudinal Assessment of Performance Implications, Journal of Marketing, vol. 66, October, s. 25-39.

182. Nonaka, I., Takeuchi, H., 2000, Kreowanie wiedzy w organizacji, Poltext, Warszawa.

183. Nowakowska, A., Przygodzki, Z., Sokołowicz, M.E., 2011, Region w gospodarce opartej na wiedzy, Difin, Warszawa.

184. Oakes, G., 2000, Introduction: On the Theory of Competitive Advantage [in:] Boronico, J.S., 2000, Studies in the Strategy and Tactics of Competitive Advantage: Management in the New Millennium, The Edwin Mellen Press, Lewiston.

185. Obłój, K., 2001, Logika przewagi konkurencyjnej, Przegląd Organizacji, nr. 9.

186. Obłój, K., 2002, Tworzywo skutecznych strategii. Na styku starych i nowych regut konkurencji, Polskie Wydawnictwo Ekonomiczne, Warszawa.

187. Obłój, K., 2007, Strategia organizacji. W poszukiwaniu trwałej przewagi konkurencyjnej, Polskie Wydawnictwo Ekonomiczne, Warszawa.

188. OECD, 1996, The Knowledge-Based Economy, OECD report, Paris. 
189. Olszewski, M., 2011, Zarzadzanie wiedza w procesie konkurowania przez jakość na rynku hotelarskim, Rozprawa doktorska nieopublikowana, Uniwersytet Ekonomiczny w Poznaniu, Wydział Gospodarki Międzynarodowej, Poznań.

190. Omerzel, D.G., Gulev, R.E., 2011, Knowledge Resources and Competitive Advantage, Managing Global Transitions: International Research Journal, vol. 9, no. 4 , s. 335-354.

191. Otta, W.J., 1994, Strategia przedsiębiorstwa na rynkach zagranicznych [w:] Gołębiowski, T., 1994, Przedsiębiorstwo na rynku międzynarodowym, Wydawnictwo Naukowe PWN, Warszawa, s. 46-76.

192. Pakulska, T., Poniatowska-Jaksch, M., 2007, Global resourcing jako wyzwanie badawcze, http://www.sgh.waw.pl/katedry/kge/mdp/atomnewsitem.2007-0505.0652955173/Global\%20resourcing.pdf [dostęp: 25 kwietnia 2013].

193. Paliszkiewicz, J.O., 2007, Zarzadzanie wiedza $w$ małych $i$ średnich przedsiębiorstwach - koncepcja oceny i modele, Wydawnictwo SGGW, Warszawa.

194. Paquette, S., Desouza, K.C., 2011, Knowledge Transfer [in:] Desouza, K.C., Paquette, S., 2011, Knowledge Management. An Introduction, Neal-Schumann Publishers, Inc., New York, s. 179-212.

195. Pasher, E., Ronen, T., 2011, The Complete Guide to Knowledge Management. A strategic Plan to Leverage Your Company's Intellectual Capital, John Wiley \& Sons, Inc, Hoboken.

196. Pazio, N.M., 2007, Podstawy marketingu, Oficyna Wydawnicza Politechniki Warszawskiej, Warszawa.

197. Pelham, A.M., Wilson, D.T., 1996, A Longitudinal Study of the Impact of Market Structure, Firm Structure, Strategy, and Market Orientation Culture on Dimensions of Small-Firm Performance, Journal of the Academy of Marketing Science, vol. 24, no. 1 , s. $27-43$

198. Perechuda, K., 2005, Zarzadzanie Wiedza w Przedsiębiorstwie, Wydawnictwo Naukowe PWN, Warszawa.

199. Piech, K., 2009, Wiedza i innowacje w rozwoju gospodarczym: w kierunku pomiaru współczesnej roli państwa, Instytut Wiedzy i Innowacji, Warszawa.

200. Pinho, I., Rego, A., Cunha, M.P., 2012, Improving knowledge management processes: a hybrid positive approach, Journal of Knowledge Management, vol. 16, no. 2 , s. $215-242$. 
201. PKD 2007, http://www.stat.gov.pl/klasyfikacje/pkd_07/pdf/2_PKD-2007-

schemat_2.pdf [dostęp: 26.03.2012r.].

202. Porter, M.E., 2006, Przewaga konkurencyjna, Helion, Gliwice.

203. Powell, T.H., Ambrosini, V., 2012, A Pluralistic Approach to Knowledge Management Practices: Evidence from Consultancy Companies, Long Range Planning, no. 45, s. 209-226.

204. Powell, W.W., Snellman, K., 2004, The Knowledge Economy, Annual Review of Sociology 30, s. 199-220.

205. Probst, G., Raub, S., Romhardt, K., 2004, Zarzadzanie Wiedza w Organizacji, Oficyna Ekonomiczna, Kraków.

206. Quest Means Business, 2011, Podcast, CNN, 17 sierpnia 2011, http://itunes.apple.com/us/podcast/quest-means-business/id427213834 [dostęp: 30.08.2011r.]

207. Ratajczak-Mrozek, M., 2008, Sieci biznesowe $w$ procesie kształtowania przewagi konkurencyjnej przedsiębiorstw zaawansowanych technologii na rynkach zagranicznych, rozprawa doktorska, Akademia Ekonomiczna w Poznaniu, Wydział Zarządzania, Poznań.

208. Ratajczak-Mrozek, M., 2010, Sieci biznesowe a przewaga konkurencyjna przedsiębiorstw zaawansowanych technologii na rynkach zagranicznych, Wydawnictwo Uniwersytetu Ekonomicznego w Poznaniu, Poznań.

209. Reid, S., 1983a, Firm Internationalization, Transaction Costs, and Strategic Choice, International Marketing Review, vol. 1, iss. 2, Winter, s. 44-56.

210. Reid, S.D., 1981, The Decision-Maker and Export Entry and Expansion, Journal of International Business Studies, vol. 12, no. 2, s. 101-112.

211. Reid, S.D., 1983b, Managerial and Firm Influences on Export Behavior, Academy of Marketing Science, vol. 11, no. 3, s. 323-332.

212. Rooney, D., Hearn, G., Ninan, A., 2005, Handbook on the Knowledge Economy, Edward Elgar Publishing, Cheltenham.

213. Rosati, D., 2007, Gospodarka Oparta na Wiedzy. Aspekty Międzynarodowe, Wyższa Szkoła Handlu i Prawa im. Ryszarda Łazarskiego w Warszawie, Warszawa.

214. Rószkiewicz, M., 2011, Analiza klienta, SPSS Polska, Kraków.

215. Rothberg, H.N., Erickson, G.S., 2005, From Knowledge to Intelligence - Creating Competitive Advantage in the Next Economy, Elsevier Butterworth-Heinemann, Oxford. 
216. Runiewicz-Wardyn, M., 2008, Knowledge-Based Economy as Factor of Competitiveness and Economic Growth, Wydawnictwa Akademickie i Profesjonalne, Warszawa.

217. Rymarczyk, J., 2004, Internacjonalizacja i Globalizacja Przedsiębiorstwa, Polskie Wydawnictwo Ekonomiczne, Warszawa.

218. Schmitt, A., Borzillo, S., Probst, G., 2011, Don't let knowledge walk away: Knowledge retention during employee downsizing, Management Learning, no. 43, vol. 1, s. 53-74.

219. Schmitz, Ch., 2007, Self-Organized Collaborative Knowledge Management, Kassel University Press, Kassel.

220. Seebacher, U.G., 2002, Cyber Commerce Reframing: The End of Business Process Reengineering?, Springer, Berlin.

221. Senge, P.M., 2012, Piąta Dyscyplina - Teoria i Praktyka Organizacji Uczacych Się, Wolters Kulwer Polska, Warszawa.

222. Shapiro, B.P., 1988, What the Hell is 'Market Oriented'?, Harvard Business Review, vol. 66, s. 119-125.

223. Sidor-Rządkowska, M., 2008, Zarządzanie kompetencjami-teoria i praktyka, Zarządzanie Zmianami - Biuletyn POU, nr 9, wrzesień, http://www.wszpou.edu.pl/biuletyn/index_test.php?strona=biul_akt20_rzad\&nr=20\&p= [dostęp: 10.01.2012r.].

224. Simone, C., Ackerman, M., Wulf, V., 2012, Knowledge Management in Practice: A Special Issue, Computer Supported Cooperative Work, no. 21, s. 109-110.

225. Sitko-Lutek, A., 2009, Organizacyjne uczenie się a kompetencje organizacji [w:] Sitko-Lutek, A., Skrzypek, E., 2009, Organizacyjne uczenie się $w$ rozwoju kompetencji przedsiębiorstw, C.H. Beck, Warszawa, s. 72-84.

226. Skrzypek, E., 2009, Nowe podejście do wiedzy w organizacji [w:] Sitko-Lutek, A., Skrzypek, E., 2009, Organizacyjne uczenie się $w$ rozwoju kompetencji przedsiębiorstw, C.H. Beck, Warszawa, s. 58-71.

227. Skyrme, D.J., 2007, KM Basics, http://www.skyrme.com/resource/kmbasics.htm [dostęp: 1.06.2013r.].

228. Slater, S.F, Narver, J.C., 1995, Market Orientation and the Learning Organization, Journal of Marketing, vol. 59, no. 3, July, s. 63-74.

229. Slater, S.F., Narver, J.C., 2000, Intelligence Generation and Superior Customer Value, Journal of the Academy of Marketing Science, vol. 28, no. 1, s. 120-127. 
230. Śmigielska, G., 2013, Uwarunkowania roli przedsiębiorstw handlowych we współczesnej gospodarce [w:] Śmigielska, G., 2013, Źródła konkurencyjności przedsiębiorstw handlowych $w$ gospodarce opartej na wiedzy, Difin, Warszawa, s. 1351.

231. Sopińska, A., 2010, Wiedza jako strategiczny zasób przedsiębiorstwa, Szkoła Główna Handlowa - Oficyna Wydawnicza, Warszawa.

232. Sparrow, J., 2010, On-line initial self assessment of Knowledge Management, http://interactive-audit.bcu.ac.uk/kmaudit/ [dostęp: 18.03.2012r.].

233. Stankiewicz, M.J., 1999, Budowanie potencjału konkurencyjności przedsiębiorstwa Stan $i$ kierunki rozwoju potencjału konkurencyjności polskich przedsiębiorstw wkontekście dostosowywania gospodarki do wymogów Unii Europejskiej, Towarzystwo Naukowe Organizacji i Kierownictwa "Dom Organizatora”, Torun.

234. Stankiewicz, M.J., 2006, Zarzadzanie Wiedza Jako Kluczowy Czynnik Międzynarodowej Konkurencyjności Przedsiębiorstwa, Wydawnictwo "Dom Organizatora", Torun.

235. Statsoft, 2011, Poprawka Bonferroniego,

http://www.statsoft.pl/textbook/glosfra_stat.html?http\%3A\%2F\%2Fwww.statsoft.pl\% 2Ftextbook\%2Fglosp.html [dostęp: 29.09.2013r.].

236. Stępień, B., 2011, Międzynarodowa kooperacja gospodarcza - przyczyny i uwarunkowania instytucjonalne i kulturowe [w:] Stępień, B., 2011, Międzynarodowa kooperacja gospodarcza z polskiej perspektywy, Polskie Wydawnictwo Ekonomiczne, Warszawa, s. 90-130.

237. Sunassee, N.N., Haumant, V., 2004, Organisational Learning versus the Learning Organisation, Proceedings of SAICSIT 2004, s. 264-268.

238. Sundać, D., Krmpotić, I.F., 2011, Knowledge Economy Factors and the Development of Knowledge-based Economy, Croatian Economic Survey, 13 (1), s. 105-141.

239. Świtalski, W., 2005, Innowacje i konkurencyjność, Wydawnictwa Uniwersytetu Warszawskiego, Warszawa.

240. Szromnik, A., 2013, Wstęp [w:] Śmigielska, G., 2013, Źródła konkurencyjności przedsiębiorstw handlowych $w$ gospodarce opartej na wiedzy, Difin, Warszawa, s. 912.

241. Szyjewski, Z., Nowak, J.S., Grabara, J.K., 2004, Strategie Informatyzacji i Zarzadzania Wiedza, Wydawnictwa Naukowo-Techniczne, Warszawa. 
242. Szymura-Tyc, M., 2001, Nowe paradygmaty konkurencji i marketing a budowa przewagi konkurencyjnej przedsiębiorstw na rynku europejskim, Organizacja i Kierowanie, nr 1, s. 49-70.

243. Szymura-Tyc, M., 2002, Zasoby oparte na wiedzy $w$ procesie budowy przewagi konkurencyjnej przedsiębiorstw, Przegląd Organizacji, nr 3, s. 7-10.

244. Szymura-Tyc, M., 2010, Marketing $w$ gospodarce sieciowej opartej na wiedzy [w:] Figiel, Sz., 2010, Marketing w realiach współczesnego rynku. Implikacje otoczenia rynkowego., Polskie Wydawnictwo Ekonomiczne, Warszawa, s. 178-185.

245. Szymura-Tyc, M., 2010, Marketing we współczesnych procesach tworzenia wartości dla klienta i przedsiębiorstwa, Wydawnictwo Akademii Ekonomicznej w Katowicach, Katowice.

246. Szymura-Tyc, M., 2012, The European perspective in international marketing [in:] Szymura-Tyc, M., 2012, International Marketing in Europe, University of Economics in Katowice Publ., Katowice, s. 9-26.

247. Tabaszewska, E., 2011, Implementacja systemów zarządzania wiedza [w:] Morawski, M., Prudzienica, M., 2011, Zarzadzanie wiedza w kreowaniu innowacji zarządczych, Wydawnictwo Uniwersytetu Ekonomicznego we Wrocławiu, Wrocław, s. 59-69.

248. Tabaszewska, E., 2012, Wprowadzanie i funkcjonowanie systemów zarządzania wiedza w przedsiębiorstwach, Uniwersytet Ekonomiczny we Wrocławiu, Wrocław.

249. Tajeddini, K., Trueman, M., Larsen, G., 2006, Examining the Effect of Market Orientation On Innovativeness, Journal of Marketing Management, vol. 22 (5-6), s. $529-551$.

250. Tiwana, A., 2003, Przewodnik po zarzadzaniu wiedza, e biznes i zastosowania CRM, Wydawnictwo PLACET, Warszawa.

251. Trajer, J., Paszek, A., Iwan, S., 2012, Zarzadzanie wiedza, Polskie Wydawnictwo Ekonomiczne, Warszawa.

252. Tranfield, D., Young, M., Partington, D., Bessant, J., Sapsed, J., 2012, Knowledge Management Routines for Innovation Projects: Developing a Hierarchical Process Model [in:] Tidd, J., 2012, From Knowledge Management to Strategic Competence. Assessing Technological. Market and Organizational Innovation, Imperial College Press, London, s. 113-133.

253. Truch, E., 2004, Knowledge orientation in organizations, Ashgate, Aldershot. 
254. USATODAY, 2013, Toyota profit more than doubles, http://www.usatoday.com/story/money/cars/2013/05/08/toyota-profit-more-thandoubles-on-yen-costcuts/2143481/?utm_source=feedburner\&utm_medium=feed\&utm_campaign=Feed $\% 3$ A+UsatodaycomMoney-Waggoner+(Money+-+Waggoner) [dostęp: 1.07.2013r.]. 255. van Heghe, H., 2011, Knowledge Centric Management, Ecademy Press, St Albans. 256. Vera, D., Crossan, M., 2006, Organizational Learning and Knowledge Management: toward an Integrative Framework [in:] Easterby-Smith, M., Lyles, M.A., 2006, The Blackwell Handbook of Organizational Learning and Knowledge Management, Blackwell Publishing, Oxford, s. 122-141.

257. Wang, C.L., Hult, G.T.M., Ketchen, D.J., Ahmed, P.K., 2009, Knowledge management orientation, market orientation, and firm performance: an integration and empirical examination, Journal of Strategic Marketing, vol. 17, no. 2, s. 99-122.

258. Wang, H.C., He, J., Mahoney, J.T., 2009, Firm-Specific Knowledge Resources and Competitive Advantage: the Roles of Economic- and Relationship-Based Employee Governance Mechanisms, Strategic Management Journal, vol. 30, iss. 12, s. 12651285.

259. Welfe, W., 2007, Gospodarka oparta na wiedzy, Polskie Wydawnictwo Ekonomiczne, Warszawa.

260. Whittaker, Z., 2013, Judge approves Kodak patent sale to Apple, Google, others, ZDNet, 11.01.2013r., http://www.zdnet.com/judge-approves-kodak-patent-sale-toapple-google-others-7000009717/ [dostęp: 01.07.2013r.].

261. Wiatrak, A.P., 2007, Zarzadzanie wiedza w przedsiębiorstwie - istota, zakres i korzyści [w:] Bogdanienka, J., Kuzela, M., Sobczak, I., 2007, Zarządzanie Wiedza w Warunkach Globalnej Wspótpracy Przedsiębiorstw, Adam Marszałek, Toruń.

262. Wielka Encyklopedia PWN, 2005, Wydawnictwo Naukowe PWN, Warszawa.

263. Wiktor, J.W., Oczkowska, R., Żabikowska, A., 2008, Marketing Międzynarodowy. Zarys problematyki, Polskie Wydawnictwo Ekonomiczne, Warszawa.

264. Witek-Hajduk, M.K., 2010, Strategie internacjonalizacji polskich przedsiębiorstw w warunkach akcji polski do Unii Europejskiej, Szkoła Główna Handlowa w Warszawie, Waszawa.

265. Włochowicz, Sz., 2008, Co to jest to Agile Project Management?, http://www.wlochowicz.com/blog/2008/04/co-to-jest-to-agile-projectmanagement.html [dostęp: 12.09.2013r.]. 
266. Wojnicka, E., Klimczak, P., Wojnicka, M., Dąbkowski, J., 2006, Perspektywy rozwoju matych i średnich Przedsiębiorstw wysokich technologii w Polsce do 2020 roku, PARP, Warszawa, http://www.parp.gov.pl/files/74/75/76/perspektywy_rozwoju_msp.pdf [dostęp: 26.03.2012r.].

267. Woodall, J., Lee, M., Stewart, J., 2004, The knowledge revolution and the knowledge economy: the challenge for HRD. New Frontiers in HRD, Routledge, London.

268. Wrenn, B., 1997, The Market Orientation Construct: Measurement and Scaling Issues, Journal of Marketing Theory and Practice, vol. 5, no. 3, Summer, s. 31-54.

269. Wysocki, J., 2002, Przewaga konkurencyjna a sukces rynkowy przedsiębiorstwa [w:] Jurek-Stępień S., 2002, Konkurencyjność - Marketing - Informacja, Szkoła Główna Handlowa w Warszawie - Oficyna Wydawnicza, Warszawa.

270. Ye, Ch., Desouza, K.C., Paquette, S., 2011, Knowledge Application [in:] Desouza, K.C., Paquette, S., 2011, Knowledge Management. An Introduction, Neal-Schumann Publishers, Inc., New York, s. 213-246.

271. Young, S., 1987, Business Strategy and the Internationalization of Business: Recent Approaches, Managerial and Decision Economics, vol. 8, s. 31-40.

272. Zack, M.H., 1999, Developing a Knowledge Strategy, California Management Review, vol. 41, no. 3, Spring, s. 125-145. 


\section{Spis tabel}

TABELA 1. PORÓWNANIE CHARAKTERYSTYK WIEDZY JAWNEJ I UKRYTEJ.___ 18

TABELA 2. DEFINICJE KONCEPCJI ZARZĄ_DZANIA WIEDZĄ.

TABELA 3. PIĘĆ DYSCYPLIN ORGANIZACJI UCZACCEJ SIĘ PETERA SENGE.

TABELA 4. WYBRANE LITERATUROWE TYPOLOGIE NARZĘDZI INFORMATYCZNYCH STOSOWANYCH W ZARZĄDZANIU WIEDZĄ.

TABELA 5. TYPOLOGIA SYSTEMÓW INFORMATYCZNYCH W ZARZĄ̨DZANIU WIEDZĄ. ___ 84

TABELA 6. PODZIAŁ ZAKRESU PROCESÓW ZARZĄDZANIA WIEDZĄ WEDŁUG WYBRANYCH AUTORÓW.

TABELA 7. ŹRÓDŁA ZEWNĘTRZNEGO POZYSKIWANIA WIEDZY.

TABELA 8. PYTANIA MKTOR WYKORZYSTANE W CELU POMIARU POZIOMU ORIENTACJI RYNKOWEJ BADANYCH PRZEDSIĘBIORSTW.

$$
\text { RYNKOWEJ BADANYCH PRZEDSIĘBIORSTW. }
$$

TABELA 9. WYBRANE DEFINICJE KONCEPCJI INTERNACJONALIZACJI W UJĘCIU MIKROEKONOMICZNYM.

TABELA 10. ZESTAWIENIE MODELI INTERNACJONALIZACJI PRZEDSIĘBIORSTW. 136

TABELA 11. NAJCZĘŚCIEJ ANALIZOWANE W LITERATURZE MODELE INTERNACJONALIZACJI.

TABELA 12. POZOSTAŁE MODELE ETAPOWE (CZ. I).

TABELA 13. POZOSTALE MODELE ETAPOWE (CZ. II).

TABELA 14. GLÓWNE ARGUMENTY KRYTYKI MODELU UPPSALA.

TABELA 15. PORÓWNANIE WYBRANYCH CHARAKTERYSTYK DZIAŁALNOŚCI PRZEDSIĘBIORSTW DZIAŁAJĄCYCH LOKALNIE ORAZ W PROCESIE INTERNACJONALIZACJI.

TABELA 16. LICZBA PODMIOTÓW, PODDANYCH BADANIU, REPREZENTUJĄCYCH POSZCZEGÓLNE BRANŻE - CAŁKOWITA PRÓBA.

TABELA 17. LICZBA PODMIOTÓW, PODDANYCH BADANIU, REPREZENTUJĄCYCH POSZCZEGÓLNE BRANŻE - WYŁACZZNIE FIRMY W PROCESIE INTERNACJONALIZACJI (KRYTERIUM: OKRES ZAANGAŻOWANIA ZAGRANICZNEGO > 0).

TABELA 18. STRUKTURA PODMIOTÓW W GOSPODARCE POLSKIEJ, STAN NA 30.04.2012 WEDŁUG REJESTRU REGON.

TABELA 19. WSPÓ£CZYNNIK RZETELNOŚCI SKALI ALFA CRONACHA. 183

TABELA 20. UDZIAŁY FIRM CHARAKTERYZUJĄCYCH SIĘ WYSOKĄ ORIENTACJĄ NA WIEDZĘ W GRUPACH PRZEDSIĘBIORSTW DZIAŁAJĄCYCH LOKALNIE ORAZ W PROCESIE INTERNACJONALIZACJI.

TABELA 21. POZIOM PROCESÓW W ZAKRESIE WIEDZY ORAZ ORIENTACJI RYNKOWEJ W PRZEDSIĘBIORSTWACH DZIAŁAJĄCYCH LOKALNIE ORAZ W PROCESIE INTERNACJONALIZACJI.

TABELA 22. POZIOM WYKORZYSTANIA OKREŚLONYCH KATEGORII ŹRÓDEŁ WIEDZY PRZEZ PRZEDSIĘBIORSTWA DZIAŁAJĄCE LOKALNIE ORAZ W PROCESIE INTERNACJONALIZACJI.

TABELA 23. WERYFIKACJA HIPOTEZY PIERWSZEJ - ANALIZY STATYSTYCZNE Z WYKORZYSTANIEM TESTU MANNA-WHITNEYA.

TABELA 24. WERYFIKACJA HIPOTEZY PIERWSZEJ - RANGI W RAMACH TESTU MANNA187 WHITNEYA.

TABELA 25. UDZIAŁY FIRM CHARAKTERYZUJĄCYCH SIĘ WYSOKĄ ORIENTACJĄ NA WIEDZĘ GRUPACH PODMIOTÓW Z OKREŚLONYMI OKRESAMI DOŚWIADCZENIA W PROCESIE INTERNACJONALIZACJI.

TABELA 26. POZIOM ORIENTACJI RYNKOWEJ ORAZ INTENSYWNOŚĆ DZIAŁAŃ W ZAKRESIE WIEDZY (Z PODZIAŁEM NA POSZCZEGÓLNE PROCESY) W PRZEDSIĘBIORSTWACH Z OKREŚLONYM DOŚWIADCZENIEM W PROCESIE INTERNACJONALIZACJI.

TABELA 27. POZIOM WYKORZYSTANIA POSZCZEGÓLNYCH KATEGORII ŹRÓDEŁ WIEDZY
PRZEZ PRZEDSIĘBIORSTWA Z OKREŚLONYM DOŚWIADCZENIEM W PROCESIE INTERNACJONALIZACJI.

TABELA 28. WERYFIKACJA HIPOTEZY DRUGIEJ - OKRES ZAANGAŻOWANIA ZAGRANICZNEGO PRZEDSIĘBIORSTWA - KORELACJA RANG SPEARMANA.

TABELA 29. UDZIAŁY FIRM CHARAKTERYZUJĄCYCH SIĘ WYSOKĄ ORIENTACJĄ NA WIEDZĘ GRUPACH PODMIOTÓW Z OKREŚLONYM UDZIAŁEM SPRZEDAŻY NA RYNKACH ZAGRANICZNYCH W PORÓWNANIU DO SPRZEDAŻY OGÓŁEM. 
TABELA 30. INTENSYWNOŚĆ DZIAŁAŃ W ZAKRESIE WIEDZY (Z PODZIAŁEM NA POSZCZEGÓLNE PROCESY) ORAZ POZIOM ORIENTACJI RYNKOWEJ W PRZEDSIĘBIORSTWACH Z OKREŚLONYM UDZIAŁEM SPRZEDAŻY NA RYNKACH ZAGRANICZNYCH W PORÓWNANIU DO SPRZEDAŻY OGÓŁEM. 195

TABELA 31. POZIOM WYKORZYSTANIA POSZCZEGÓLNYCH KATEGORII ŹRÓDEŁ WIEDZY PRZEZ PRZEDSIĘBIORSTWA Z OKREŚLONYM UDZIAŁEM SPRZEDAŻY NA RYNKACH ZAGRANICZNYCH W PORÓWNANIU DO SPRZEDAŻY OGÓŁEM. 196

TABELA 32. WERYFIKACJA HIPOTEZY DRUGIEJ - UDZIAŁ SPRZEDAŻY ZAGRANICZNEJ PRZEDSIĘBIORSTWA - KORELACJA RANG SPEARMANA. 196

TABELA 33. UDZIALY FIRM CHARAKTERYZUJĄCYCH SIĘ WYSOKĄ ORIENTACJĄ NA WIEDZE GRUPACH PODMIOTÓW WYKORZYSTUJĄCYCH OKREŚLONE FORMY INTERNACJONALIZACJI.

TABELA 34. INTENSYWNOŚĆ DZIAŁAŃ W ZAKRESIE WIEDZY (Z PODZIAŁEM NA POSZCZEGÓLNE PROCESY) ORAZ POZIOM ORIENTACJI RYNKOWEJ W PRZEDSIĘBIORSTWACH WYKORZYSTANIEM OKREŚLONE FORMY INTERNACJONALIZACJI.

TABELA 35. POZIOM WYKORZYSTANIA POSZCZEGÓLNYCH KATEGORII ŹRÓDEŁ WIEDZY PRZEZ PRZEDSIĘBIORSTWA WYKORZYSTUJĄCE OKREŚLONE FORMY INTERNACJONALIZACJI. 198

TABELA 36. WERYFIKACJA HIPOTEZY DRUGIEJ - ŚREDNIE WARTOŚCI ORIENTACJI NA WIEDZE I LICZEBNOŚCI POSZCZEGÓLNYCH FORM ZAANGAŻOWANIA ZAGRANICZNEGO PRZEDSIĘBIORSTW. 201

TABELA 37. PORÓWNANIE ŚREDNICH W KOLUMNACH - POSZCZEGÓLNE FORMY ZAANGAŻOWANIA ZAGRANICZNEGO PRZEDSIĘBIORSTW.

TABELA 38. POZIOM KONKURENCYJNOŚCI PODMIOTÓW CHARAKTERYZUJĄCYCH SIĘ OKREŚLONYMI POZIOMAMI ORIENTACJI NA WIEDZE (I). 199

TABELA 39. POZIOM KONKURENCYJNOŚCI PODMIOTÓW CHARAKTERYZUJĄCYCH SIĘ OKREŚLONYMI POZIOMAMI ORIENTACJI NA WIEDZE (II). 202 ELA 40. WERYFIKACJA HIPOTEZY TRZECIEJ - WYNIKI ANALIZY STATYSTYCZNEJ Z 205

TABELA 40. WERYFIKACJA HIPOTEZY TRZECIEJ - W
WYKORZYSTANIEM REGRESJI LOGISTYCZNEJ. 206 WYKORZYSTANIEM REGREJILOGISTYCZNEJ. 207 


\section{Spis rysunków}

RYSUNEK 1. CZYNNIKI KSZTAŁTUJACE GOSPODARKE WIEDZY. .26

RYSUNEK 2. OGÓLNY SCHEMAT TWORZENIA, PRZEPEYWU I WYKORZYSTANIA WIEDZY W GOSPODARCE.

RYSUNEK 3. STRATEGIE OGÓLNE BUDOWANIA PRZEWAGI KONKURENCYJNEJ PRZEDSIĘBIORSTWA.

RYSUNEK 4. OGÓLNY SCHEMAT KSZTAŁTOWANIA PRZEWAGI KONKURENCYJNEJ

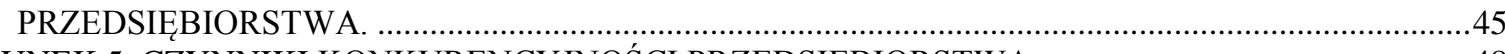

RYSUNEK 5. CZYNNIKI KONKURENCYJNOŚCI PRZEDSIĘBIORSTWA...............................................48

RYSUNEK 6. ZALEŻNOŚĆ POMIĘDZY KONCEPCJAMI W ZAKRESIE WIEDZY. ...................................62

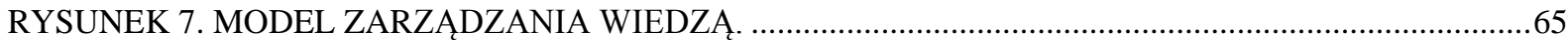

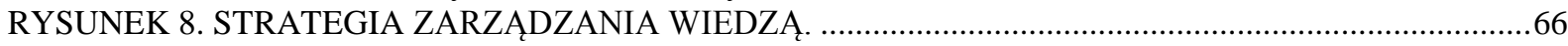

RYSUNEK 9. CZTERY METODY PRZETWARZANIA WIEDZY ………………….................................72

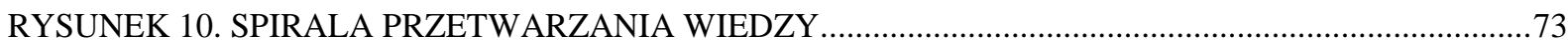

RYSUNEK 11. KONCENTRACJA NA OKREŚLONYM TYPIE WIEDZY A DOMINUJĄCA STRATEGIA ZARZĄDZANIA WIEDZĄ.

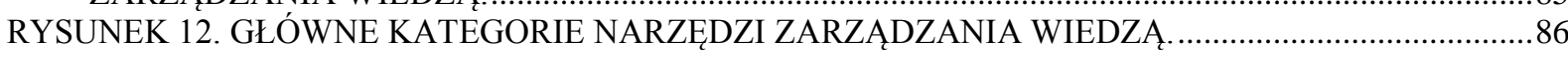

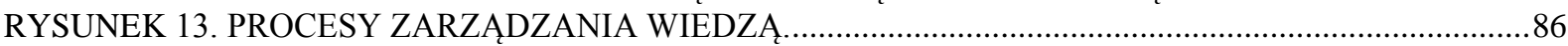

RYSUNEK 14. DETERMINANTY SUKCESU ZARZĄDZANIA WIEDZĄ W PRZEDSIĘBIORSTWIE.....102

RYSUNEK 15. OGÓLNY SCHEMAT KSZTAŁTOWANIA PRZEWAGI KONKURENCYJNEJ

PRZEDSIĘBIORSTWA - Z PODZIAŁEM NA TRZY GŁÓWNE CZĘŚCI. ...........................................105

RYSUNEK 16. SCHEMAT KSZTAŁTOWANIA PRZEWAGI KONKURENCYJNEJ PRZEDSIĘBIORSTWA A ORIENTACJA NA WIEDZĘ.

RYSUNEK 17. SCHEMAT KSZTAŁTOWANIA PRZEWAGI KONKURENCYJNEJ PRZEDSIĘBIORSTWA - WERSJA UPROSZCZONA.

RYSUNEK 18. SCHEMAT SYSTEMU DZIAŁAŃ W ZAKRESIE WIEDZY W ORGANIZACJI...................124

RYSUNEK 19. ZMIANY W PRZEDSIĘBIORSTWIE SPOWODOWANE PRZEMIANAMI RYNKU. ........125

RYSUNEK 20. MODEL DYNAMICZNEJ ORIENTACJI NA WIEDZĘ. ....................................................127

RYSUNEK 21. MODEL DYNAMICZNEJ ORIENTACJI NA WIEDZE W KSZTAŁTOWANIU PRZEWAGI KONKURENCYJNEJ PRZEDSIĘBIORSTWA - PREZENTACJA GRAFICZNA, DŁUGOOKRESOWA.

RYSUNEK 22. HISTORYCZNE UJĘCIE FAZ UMIĘDZYNARODOWIENIA PRZEDSIĘBIORSTW.........132

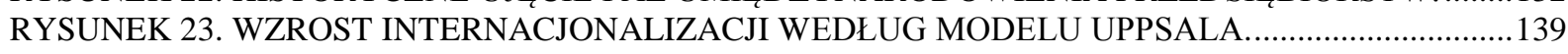

RYSUNEK 24. MECHANIZM PROCESU INTERNACJONALIZACJI PRZEDSIĘBIORSTWA Z PERSPEKTYWY ORYGINALNEGO MODELU UPPSALSKIEGO Z 1977 ROKU.

RYSUNEK 25. INTERNACJONALIZACJA PRZEDSIĘBIORSTWA I INTERNACJONALIZACJA SIECI.146 RYSUNEK 26. WSPÓŁCZESNA WERSJA MODELU JOHANSONA I VAHLNE - MODEL INTERNACJONALIZACJI SIECI BIZNESOWEJ Z 2009R.

RYSUNEK 27. MODEL DYNAMICZNEJ ORIENTACJI NA WIEDZE - UJĘCIE D UGGOTERMINOWE DLA PRZEDSIĘBIORSTWA DZIAŁAJĄCEGO NA TRZECH RYNKACH ZAGRANICZNYCH. ....158 RYSUNEK 28. GRAFICZNA ILUSTRACJA ZALEŻNOŚCI WYSTĘPUJĄCYCH POMIĘDZY POSZCZEGÓLNYMI HIPOTEZAMI WERYFIKOWANYMI W PRACY.

RYSUNEK 29. SCHEMAT KONCEPCYJNY BADAŃ (MODEL BADAWCZY) - PORÓWNANIE POZIOMU ORIENTACJI NA WIEDZĘ PRZEDSIĘBIORSTW DZIAŁAJĄCYCH LOKALNIE I PODMIOTÓW W PROCESIE INTERNACJONALIZACJI..

RYSUNEK 30. SCHEMAT KONCEPCYJNY BADAŃ (MODEL BADAWCZY) - PORÓWNANIE POZIOMU ORIENTACJI NA WIEDZĘ PRZEDSIĘBIORSTW NA POSZCZEGÓLNYCH ETAPACH INTERNACJONALIZACJI Z WYKORZYSTANIEM TRZECH KRYTERIÓW POZIOMU ZAANGAŻOWANIA ZAGRANICZNEGO.

RYSUNEK 31. SCHEMAT KONCEPCYJNY BADAŃ (MODEL BADAWCZY) - ROLA ORIENTACJI NA WIEDZE W KSZTAŁTOWANIU PRZEWAGI KONKURENCYJNEJ PRZEDSIĘBIORSTWA W

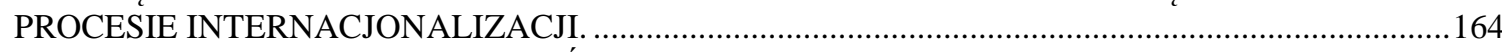

RYSUNEK 32. CHARAKTERYSTYKA PRÓBY BADAWCZEJ Z WYKORZYSTANIEM KRYTERIUM OKRESU ZAANGAŻOWANIA ZAGRANICZNEGO PRZEDSIĘBIORSTW.

RYSUNEK 33. CHARAKTERYSTYKA PRÓBY BADAWCZEJ Z WYKORZYSTANIEM KRYTERIUM UDZIAŁU SPRZEDAŻY ZAGRANICZNEJ.

RYSUNEK 34. CHARAKTERYSTYKA PRÓBY BADAWCZEJ Z WYKORZYSTANIEM KRYTERIUM FORMY ZAANGAŻOWANIA ZAGRANICZNEGO PRZEDSIĘBIORSTW. 
RYSUNEK 35. ZATRUDNIENIE - CAŁOŚĆ PRÓBY.

RYSUNEK 36. ZATRUDNIENIE - PRZEDSIĘBIORSTWA W PROCESIE INTERNACJONALIZACJI

(KRYTERIUM: OKRES ZAANGAŻOWANIA W PROCES INTERNACJONALIZACJI > 0) ...........177

RYSUNEK 37. FORMA WŁASNOŚCI PRZEDSIĘBIORSTWA - CAŁOŚĆ PRÓBY.

RYSUNEK 38. FORMA WŁASNOŚCI PRZEDSIĘBIORSTWA - PRZEDSIĘBIORSTWA W PROCESIE INTERNACJONALIZACJI (KRYTERIUM: OKRES ZAANGAŻOWANIA ZAGRANICZNEGO > 0).

181

RYSUNEK 39. ZINTEGROWANY WSKAŹNIK INTENSYWNOŚCI PROCESÓW W ZAKRESIE WIEDZY

W PRZEDSIĘBIORSTWIE.

RYSUNEK 40. ELEMENTY SKŁADOWE SKALI MKTOR .............................................................. 183

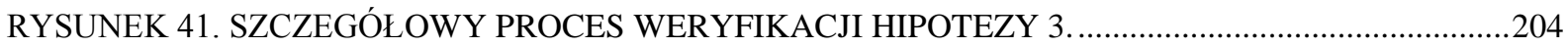

RYSUNEK 42. STRUKTURA ORGANIZACYJNA FIRMY NETGURU..............................................209

RYSUNEK 43. PRZEWAGA KONKURENCYJNA FIRMY TREPKO. ....................................................221

RYSUNEK 44. ZAZNACZANIE ODPOWIEDZI W WERSJI PAPIEROWEJ KWESTIONARIUSZA ANKIETY.

RYSUNEK 45. ZAZNACZANIE ODPOWIEDZI W WERSJI ELEKTRONICZNEJ KWESTIONARIUSZA ANKIETY. 


\section{Aneks \\ Załącznik 1. Wyjaśnienie najważniejszych terminów i kategorii wykorzystywanych w pracy.}

Firma, przedsiębiorstwo, podmiot gospodarczy, organizacja - wymienione terminy są używane zamiennie w celu uniknięcia powtórzeń.

Orientacja przedsiębiorstwa na wiedze - rynkowo ukierunkowany system działań przedsiębiorstwa w zakresie wiedzy.

Termin został dokładnie scharakteryzowany w podrozdziale 3.2.

Model dynamicznej orientacji na wiedzę - model został wypracowany przez autora niniejszej pracy na podstawie teorii: zarządzania wiedzą, organizacyjnego uczenia się, organizacji uczącej się oraz orientacji rynkowej. Koncepcja ta ma na celu przedstawienie (w ujęciu modelowym) roli odpowiednio ukierunkowanych, dynamicznych działań zakresie wiedzy w procesie kształtowania przewagi konkurencyjnej przedsiębiorstwa zaangażowanego na rynkach zagranicznych..

Zagadnienie zostało kompleksowo zaprezentowane w podrozdziale 3.3. oraz w podrozdziale 4.2. w kontekście procesu internacjonalizacji.

Zarządzanie wiedza, organizacyjne uczenie się, organizacja ucząa się - poszczególne koncepcje związane $\mathrm{z}$ aktywnymi działaniami $\mathrm{w}$ zakresie wiedzy $\mathrm{i}$ uczenia się przedsiębiorstwa wykorzystane do stworzenia ujęcia modelowego niniejszej pracy. Pierwsza z nich jest dla niniejszej pracy najważniejsza i stanowi podstawę prezentowanych rozważań w obrębie dynamicznych działań w zakresie wiedzy.

Szczegółowe omówienie poszczególnych koncepcji zostało zamieszczone w rozdziale 2.

Orientacja rynkowa przedsiębiorstwa - współpraca całej struktury organizacyjnej przedsiębiorstwa w celu ciągłego odkrywania i zaspokajania potrzeb nabywców, a także obserwacja działań konkurentów i innych podmiotów oraz zdarzeń rynkowych. (Definicja opracowana na podstawie: Shapiro [1988], Kohli i Jaworski [1990], Kohli, Jaworski i Kumar [1993], Narver i Slater [1990])

Termin został dokładnie scharakteryzowany w podrozdziale 3.1. 
Przedsiębiorstwo $w$ procesie internacjonalizacji (lub zaangażowane na rynkach zagranicznych) - podmiot gospodarczy zaangażowany w każdego rodzaju działalność zagraniczną [Rymarczyk 2004, s. 19]. Definicja ta w kontekście badań empirycznych przeprowadzonych w niniejszej pracy podlega uszczegółowieniu. W kwestionariuszu ankiety (będącym podstawowym instrumentem badawczym pracy) wykorzystano trzy szczegółowe kryteria: okres zaangażowania na rynkach zagranicznych (kryterium główne, domyślne), udział sprzedaży na rynkach zagranicznych oraz forma zaangażowania na rynkach zagranicznych.

Przewaga konkurencyjna przedsiębiorstwa - relatywna różnica wyników firmy, wyrażona zarówno miernikami finansowymi, jak i niefinansowymi, w porównaniu do najbliższych konkurentów podmiotu [Fonfara 2007, s. 3-4].

Gospodarka oparta na wiedzy, gospodarka wiedzy - szczegółowe omówienie obu terminów zostało przedstawione na początku rozdziału 2.

Skład poszczególnych, wykorzystywanych $w$ ilościowym badaniu empirycznym, kategorii źródet wiedzy:

- źródła innowacyjne: publikacje naukowe, publicystyczne, branżowe; instytucje badawcze, uczelnie wyższe; własne działania w zakresie badań i rozwoju;

- źródła eksperckie: szkolenia i kursy zewnętrzne; firmy doradcze (konsultingowe); zamówione ekspertyzy;

- źródła rynkowe: badania rynku (własne lub zlecone); klienci;

- źródła branżowe: publikacje naukowe, publicystyczne, branżowe; dostawcy i podwykonawcy; konkurenci; organizacje branżowe/kluby networkingu;

- własne badania i rozwój: własne działania w zakresie badań i rozwoju;

- kluczowe źródta wiedzy: szkolenia i kursy zewnętrzne; firmy doradcze (konsultingowe); publikacje naukowe, publicystyczne, branżowe; zamówione ekspertyzy; badania rynku (własne lub zlecone); klienci; dostawcy i podwykonawcy; konkurenci; organizacje branżowe/kluby networkingu; instytucje badawcze, uczelnie wyższe; własne działania w zakresie badań i rozwoju. 
Model - pojęcie „model” jest rozumiane w niniejszej pracy jako uproszczenie rzeczywistości.

Wartość p (p-value) - poziom istotności dla określonego testu statystycznego jest prawdopodobieństwem, przy założeniu prawdziwości hipotezy zerowej, otrzymania statystyki testowej, która jest przynajmniej tak sprzeczna $\mathrm{z}$ hipotezą zerową i zgodna z hipotezą alternatywną, jak wartość wyliczona na podstawie próby [McClave i Dietrich 1988, s. 358].

$\alpha$ - poziom istotności (prawdopodobieństwo popełnienia błędu I rodzaju tj. odrzucenia prawdziwej hipotezy zerowej). 


\section{Załącznik 2. Szczegółowa charakterystyka poszczególnych sekcji kwestionariusza ankiety wykorzystywanego $\mathrm{w}$ badaniach ilościowych}

Sekcja „pozyskiwanie wiedzy” skupia szereg źródeł, z jakich przedsiębiorstwo może pozyskiwać wiedzę. Zdecydowana większość wymienionych w sekcji opcji pozyskiwania wiedzy obejmuje źródła zewnętrzne, lecz jedna z możliwych do wyboru opcji dotyczy wewnętrznej kreacji wiedzy (własne działania w zakresie badań i rozwoju). Wykaz ten z pewnością nie jest kompleksowy, również z uwagi na ograniczenia instrumentu badawczego - lista nie może być zbyt długa, aby nie zniechęcać respondenta do udzielania odpowiedzi. Naczelną zasadą przyświecającą autorowi przy tworzeniu niniejszego wykazu było zebranie najważniejszych źródeł, z jakich podmioty gospodarcze mogą czerpać wiedzę, aby sprawdzić poziom ich zaangażowania $\mathrm{w}$ tym zakresie. Wykaz wymienionych źródeł wiedzy został opracowany przez autora z wykorzystaniem szeregu pozycji literaturowych (załącznik 5).

Sekcja „rozpowszechnianie wiedzy” została podzielona na dwie części: ogólną oraz dotyczącą technologii informatycznych. Część ogólna zawiera siedem pytań mających na celu rozpoznanie generalnych, organizacyjnych działań w zakresie rozpowszechniania wiedzy wewnątrz przedsiębiorstwa. Koncentruje się ona na działaniach w zakresie wiedzy niejawnej, gdyż na wiedzy jawnej skupia się część dotycząca narzędzi informatycznych. Sekcja dotycząca technologii informatycznych została dołączona do sekcji dotyczącej rozpowszechniania wiedzy w przedsiębiorstwie. Należy jednak zaznaczyć, iż możliwości i wykorzystanie tego rodzaju narzędzi nie ograniczają się wyłącznie do tego obszaru. Jednak w praktyce ważną (o ile nie najważniejszą) funkcjonalnością dużej części dzisiejszych narzędzi informatycznych służących do zarządzania informacją i wiedzą jest właśnie wspomaganie przepływu i rozpowszechniania wiedzy w przedsiębiorstwie. Omawiana sekcja wyróżnia pięć kategorii systemów informatycznych. Jest to autorska typologia, która została opracowana na podstawie odpowiednich źródeł literaturowych (załącznik 5). Pierwsza jej wersja, określana jako robocza, została skonsultowana $\mathrm{z}$ informatykiem zajmującym się zagadnieniami zarządzania wiedzą $\mathrm{z}$ wykorzystaniem technologii informatycznych. Po otrzymaniu uwag autor wprowadził odpowiednie poprawki i zmiany. Głównym celem wykorzystanej typologii technologii informatycznych $\mathrm{w}$ zarządzaniu wiedzą było przedstawienie zagadnienia w jak najbardziej przystępnej dla respondenta formie - aby osoba, która nie jest szczegółowo obeznana $\mathrm{z}$ zagadnieniami informatycznymi była $\mathrm{w}$ stanie odpowiedzieć na pytania, czy w jej firmie dane kategorie narzędzi są wykorzystywane 
w praktyce oraz w jakim stopniu. Omawiana typologia z pewnością nie wyczerpuje całego spektrum dostępnych technologii informatycznych związanych $\mathrm{z}$ zarządzaniem wiedzą, a ponadto autor jest świadom, że poszczególne wyróżnione kategorie mogą do pewnego stopnia nie być rozłączne. Jest to jednak koszt, jaki musiał być poniesiony z uwagi na niedoskonałość instrumentu badawczego i chęć pozyskania jak najlepszej jakości odpowiedzi od respondentów. Literatura przedmiotu dysponuje wieloma typologiami w tym zakresie, lecz w większości są one bardzo złożone i niezrozumiałe dla osób nieobeznanych z tematem.

Sekcja „wdrażanie oraz otwartość przedsiębiorstwa na wiedzę” dotyczy bardzo ważnego działania w zakresie wiedzy - jej praktycznej implementacji w przedsiębiorstwie. Aktywność podmiotu w tym obszarze jest bardzo ważna, lecz jej efektywność jest uwarunkowana postępowaniem firmy na wcześniejszych etapach działań w zakresie wiedzy.

Sekcja „orientacja rynkowa” ma na celu zbadanie poziomu rynkowego ukierunkowania podmiotu. $\mathrm{Z}$ perspektywy modelu rozwiniętego $\mathrm{w}$ ramach niniejszej pracy działania przedsiębiorstwa w zakresie wiedzy nie będą skuteczne w momencie, gdy ich charakter nie będzie ukierunkowany na potrzeby rynku. W tej sekcji wykorzystano zestaw pytań mających na celu określenie poziomu rynkowej orientacji podmiotu. Został on przetestowany przez Hooley $\mathrm{i}$ in. [2000, s. 279], a także jest stosowany w badaniach Katedry Marketingu Międzynarodowego Uniwersytetu Ekonomicznego w Poznaniu [Fonfara 2009, 2012].

Pytania w sekcji ,poziom konkurencyjności przedsiębiorstwa w porównaniu do najbliższych konkurentów" również zostały oparte na wspomnianych doświadczeniach badawczych Katedry Marketingu Międzynarodowego [Fonfara 2009, 2012]. Omawiana część ankiety zawiera cztery pytania, na które składają się czynniki finansowe i niefinansowe. Mają one na celu, za pomocą agregatowego „wskaźnika konkurencyjności”, określenie poziomu konkurencyjności badanego podmiotu względem jego najbliższych konkurentów.

Ostatnia sekcja „charakterystyka przedsiębiorstwa” ma na celu przybliżenie profilu badanego przedsiębiorstwa. Ta część ankiety w znacznym stopniu wzorowana jest na instrumentach badawczych Katedry Marketingu Międzynarodowego Uniwersytetu Ekonomicznego w Poznaniu, autor niniejszej pracy wprowadził jednak ważne modyfikacje. Jedną z nich jest podział branżowy, według którego respondent może zaklasyfikować swoje przedsiębiorstwo. Został on opracowany na podstawie PKD 2007 oraz Fonfara [2008. 2012]. Klasyfikacja produkcji została uszczegółowiona według kryteriów OECD - przy czym wyróżniono trzy kategorie: wysoka technika, średnio wysoka technika oraz pozostała 
technika $^{73}$. Bardzo ważnym elementem w omawianej sekcji jest też pytanie ostatnie. Ma ono na celu zbadanie dynamizmu procesu internacjonalizacji w danym podmiocie. Umożliwia ono pozyskanie informacji dotyczącej nie tylko obecnych, ale także przeszłych oraz przyszłych form zaangażowania przedsiębiorstwa $\mathrm{w}$ proces internacjonalizacji. Niniejsza sekcja zawiera również szereg innych pytań mających na celu określenie natury i zakresu działalności badanego przedsiębiorstwa oraz charakterystyki jego działań w domenie procesu internacjonalizacji.

${ }^{73}$ Oryginalny podział OECD produkcji wykorzystuje cztery kategorie:

- wysoka technika,

- średnio-wysoka technika,

- średnio-niska technika,

- niska technika [Hatzichronoglou 1997].

Integracja dwóch ostatnich kategorii w niniejszym badaniu nastąpiła z szeregu powodów. Po pierwsze termin „niska technika”, a nawet „średnio-niska technika” mogą, w opinii niektórych osób, mieć wydźwięk pejoratywny. Dodatkowo, autor niniejszej pracy również starał się dążyć do minimalizacji długości kwestionariusza w celu uczynienia go jak najbardziej przystępnym dla respondenta. Ponadto, podział na tak szczegółowe kategorie, zdaniem autora, w tym miejscu nie jest nieodzowny. 


\section{Załącznik 3. Charakterystyka systemu ankietowania elektronicznego oraz tradycyjnego kwestionariusza papierowego.}

W ramach badania został zastosowany system ankietowania elektronicznego (z wykorzystaniem technologii Web 2.0). Narzędzia ankietowania elektronicznego były już używane podczas dwóch badań przeprowadzanych przez Katedrę Marketingu Międzynarodowego: Ekspertyza dla Ministerstwa Gospodarki „Kooperacja polskich przedsiębiorstw” w 2010 roku (kierownik dr Milena Ratajczak-Mrozek) oraz badanie „Kształtowanie powiązań sieciowych w procesie internacjonalizacji przedsiębiorstwa” w 2011 roku (kierownik: prof. dr hab. Krzysztof Fonfara, prof. zw. UEP). Autor niniejszej pracy brał udział w obu badaniach. Narzędzie wykorzystywane w obecnym przedsięwzięciu zostało zbudowane na podstawie systemów używanych we wcześniejszych projektach oraz z wykorzystaniem doświadczeń płynących z wcześniejszych badań.

System od początku charakteryzował się wieloma innowacyjnymi cechami. Jego podstawową cechą była możliwość wysyłki elektronicznej wersji kwestionariuszy ankiety do znacznej liczby respondentów za pomocą poczty elektronicznej. Otrzymany przez odbiorcę w wiadomości indywidualny link umożliwiał mu jednorazowe wypełnienie ankiety. System pozwalał również na wysyłkę przypomnień wyłącznie osobom, które do danego momentu nie wypełniły kwestionariusza, a także możliwość zapisu częściowo wypełnionej ankiety.

System ze względu na swoją innowacyjność i niewielkie przetestowanie praktyczne posiadał niestety również szereg niedociągnięć, które prowadziły do jego ograniczonego wykorzystania podczas niektórych z wcześniejszych badań (ograniczona zwrotność). Był to potencjał do rozwoju, który został wykorzystany w niniejszym badaniu. Pierwszym z nich był fakt, iż pytania były rozmieszczone na wielu stronach, co spowalniało wypełnianie kwestionariusza oraz zniechęcało respondenta z uwagi na fakt braku możliwości oceny przybliżonego czasu, jaki byłby potrzebny na odpowiedź na wszystkie pytania. W prowadzonym przez autora badaniu pytania rozmieszczono na jednej stronie, co dawało respondentowi możliwość oceny długości kwestionariusza przed przystąpieniem do jego wypełniania oraz przyspieszyło proces udzielania odpowiedzi.

Od początku istnienia narzędzia bardzo ważnym jego elementem był rozbudowany system przypomnień. Został on $\mathrm{w}$ ramach niniejszego projektu usystematyzowany i usprawniony. Respondent otrzymywał maksymalnie dwa przypomnienia o zróżnicowanej treści w zależności od tego czy rozpoczął wypełnianie ankiety czy nie. Osoby, które do 
momentu wysyłania przypomnień wypełniły ankietę nie otrzymywały wiadomości z przypomnieniem.

Kolejnym dużym problemem i ograniczeniem wcześniejszych wersji było przeprowadzanie badań przy większych próbach badawczych. System nie był w stanie poradzić sobie z jednorazową wysyłką większej liczby listów elektronicznych, gdyż wysłanie większej liczby wiadomości do respondentów było klasyfikowane przez serwery pocztowe jako wysyłka niepożądana (spam). W związku z tym wprowadzono system wysyłania pakietowego - po uruchomieniu jakiejkolwiek wysyłki (pierwszego zaproszenia do wypełniania ankiety czy przypomnień) system wysyłał dziesięć listów co dziesięć minut. Umożliwiło to minimalizację ryzyka klasyfikacji wysyłki jako poczta niepożądana.

Innym elementem wprowadzonym w niniejszym projekcie do omawianego systemu była funkcja informowania respondenta o nieudzieleniu odpowiedzi na określone pytania. Jeżeli respondent pominął jedno lub więcej z pytań na końcu kwestionariusza oraz przy każdym z pominiętych punktów wyświetlała się odpowiednia informacja.

Kolejnym udogodnieniem było wprowadzenie różnych wersji formatowania treści listów elektronicznych (za pomocą, których wysyłano pierwsze zaproszenie do wypełnienia ankiety oraz przypomnienia). Wyeliminowało to problemy nieprawidłowego wyświetlania listów nawet na mniej standardowych urządzeniach elektronicznych oraz prostszych klientach pocztowych (np. Squirrel Mail, który jest dość powszechnie stosowany w podmiotach gospodarczych).

System ankietowania elektronicznego zarówno podczas wcześniejszych projektów, jak i obecnego był rozwijany we współpracy z firmą informatyczną. W kontekście niniejszego badania ścisła współpraca $\mathrm{z}$ programistą umożliwiła autorowi koncentrację na warstwie koncepcyjnej narzędzia badawczego pozostawiając zagadnienia techniczne wykwalifikowanej osobie, która dokonywała odpowiednich, wskazanych przez autora niniejszej pracy, zmian w funkcjonowaniu i kształcie narzędzia.

Ostateczny wygląd kwestionariusza w wersji elektronicznej został przedstawiony na zdjęciach w załączniku 6.

Kwestionariusz w tradycyjnej, drukowanej wersji papierowej został opracowany w celu przeprowadzenia uzupełniającego badania z wykorzystaniem tradycyjnej poczty. Treść pytań w nim zawartych była praktycznie identyczna w porównaniu do jego odpowiednika elektronicznego. Jedyną różnicą było pytanie o wyniki przedsiębiorstwa zarówno w roku 2011, jak i w roku 2012. Badanie elektroniczne przeprowadzane było przed końcem roku 2012 stąd pytano tylko o wyniki w roku kalendarzowym 2011. W związku z faktem, iż dane 
z obu kwestionariuszy były analizowane wspólnie brano pod uwagę wyłącznie wyniki firm $\mathrm{z}$ roku 2011. Ostateczny wygląd kwestionariusza w tradycyjnej, drukowanej wersji papierowej został przedstawiony w załączniku $4 \mathrm{~b}$.

W przypadku kwestionariusza ankiety należy również zwrócić uwagę na zastosowane konwencje zaznaczania odpowiedzi. W drukowanej wersji instrumentu badawczego respondent zakreślał odpowiednią cyfrę przy każdym pytaniu (rysunek 44). W przypadku badania elektronicznego system był jeszcze prostszy, gdyż wystarczyło, aby osoba wypełniająca ankietę, w celu odpowiedzi na pytanie wykonała zaledwie jedno kliknięcie myszką na ekranie lub w przypadku urządzenia z ekranem dotykowym - dotknęła ekranu w odpowiednim miejscu (rysunek 45).

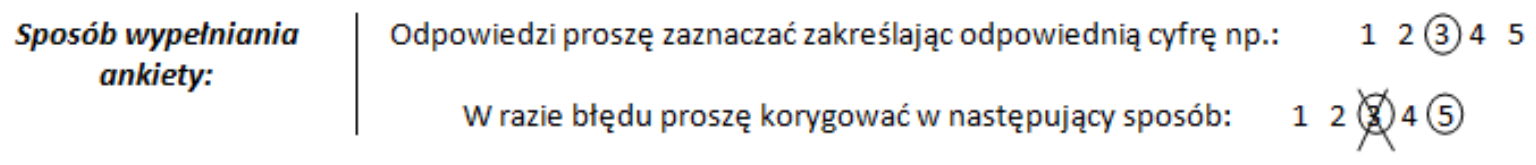

Rysunek 44. Zaznaczanie odpowiedzi w wersji papierowej kwestionariusza ankiety. Źródło: opracowanie własne.

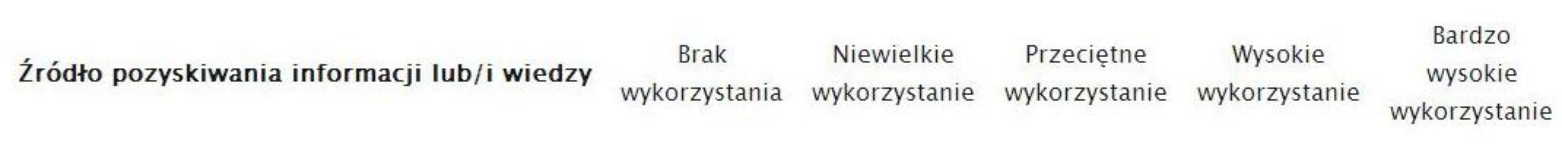

\begin{tabular}{|c|c|c|c|c|c|}
\hline Szkolenia i kursy zewnętrzne & 0 & 0 & 0 & 0 & 0 \\
\hline Firmy doradcze (konsultingowe) & (0) & O & (-) & 0 & - \\
\hline Publikacje naukowe, publicystyczne, branżowe & 0 & 0 & 0 & 0 & (O) \\
\hline Zamówione ekspertyzy & O & 0 & 0 & ( & ○ \\
\hline
\end{tabular}

Rysunek 45. Zaznaczanie odpowiedzi w wersji elektronicznej kwestionariusza ankiety. Źródło: opracowanie własne.

Do każdego kwestionariusza ankiety dołączony był list wprowadzający (załącznik 4a) w krótki sposób wyjaśniający istotę badania oraz zawierający informacje kontaktowe do autora badania, z których respondent mógł skorzystać w razie problemów z wypełnianiem kwestionariusza. W przypadku badania elektronicznego wspomniane wprowadzenie było zawarte $\mathrm{w}$ treści listu elektronicznego (zawierającego również indywidualny link do strony z kwestionariuszem). W przypadku tradycyjnego badania pocztowego, było ono umieszczone na osobnym arkuszu papieru przesyłanym do respondenta razem z kwestionariuszem. 


\section{Załącznik 4a. List wprowadzający do kwestionariusza ankiety.}

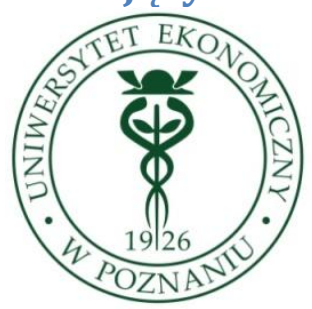

Uniwersytet Ekonomiczny w Poznaniu

Katedra Marketingu Międzynarodowego

Projekt badawczy

Finansowany przez Narodowe Centrum Nauki (www.ncn.gov.pl)

Rola orientacji na wiedzę w procesie kształtowania przewagi konkurencyjnej przedsiębiorstwa w procesie internacjonalizacji

Szanowni Państwo,

Rozwój gospodarki opartej na wiedzy niesie ze sobą potrzebę przystosowania przedsiębiorstw do nowych realiów funkcjonowania. Poniższy kwestionariusz ankiety jest instrumentem badawczym projektu mającego na celu zbadanie roli jaką odgrywa orientacja na wiedzę w poszczególnych, działających w różnych warunkach, przedsiębiorstwach.

Zwracam się z prośbą o wypełnienie załączonego kwestionariusza, najpóźniej do 15 marca br. Jest on całkowicie anonimowy, a odpowiedzi będą przetwarzane tylko w formie zagregowanej. Jeżeli są Państwo zainteresowani poznaniem wyników badania proszę o kontakt pod adresem e-mail: marcin.soniewicki@ue.poznan.pl.

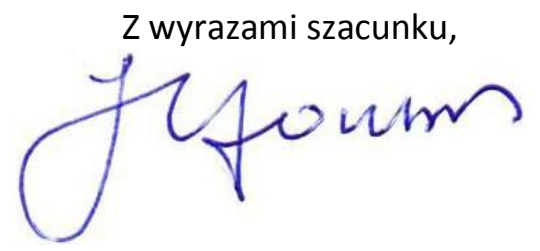

prof. dr hab. Krzysztof Fonfara, prof. zw. UEP Kierownik Katedry Marketingu Międzynarodowego Uniwersytet Ekonomiczny w Poznaniu

\section{Osoba odpowiedzialna za badanie}

mgr Marcin Soniewicki

marcin.soniewicki@ue.poznan.pl

tel. $+48696 * * * * * *$

\section{Kontakt}

Uniwersytet Ekonomiczny w Poznaniu

Katedra Marketingu Międzynarodowego

al. Niepodległości 10

61-875 Poznań 


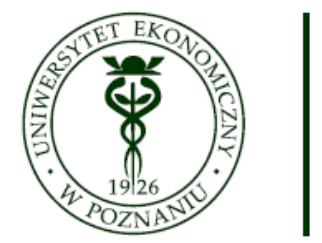

\title{
UNIWERSYTET EKONOMICZNY W POZNANIU
}

\section{Rola orientacji na wiedzę w procesie kształtowania przewagi konkurencyjnej przedsiębiorstwa w procesie internacjonalizacji}

\author{
Projekt badawczy \\ Finansowany przez Narodowe Centrum Nauki (www.ncn.gov.pl)
}

Kwestionariusz ankiety

Żadna z odpowiedzi nie jest ani dobra, ani zła. Zapewniamy całkowitą anonimowość.

Rezultaty badań będą przetwarzane wyłącznie w postaci zagregowanej.

W razie pytań lub wątpliwości prosimy o kontakt pod nr tel. 696

lub marcin.soniewicki@ue.poznan.pl

Ankiete prosimy przesłać na adres:

Uniwersytet Ekonomiczny w Poznaniu

Katedra Marketingu Międzynarodowego

al. Niepodległości 10

61-875 Poznań 
Sposób wypełniania

ankiety:
Odpowiedzi proszę zaznaczać zakreślając odpowiednią cyfrę np.: 1 2(3) 45

W razie błędu proszę korygować w następujący sposób: 12

\section{Pozyskiwanie wiedzy}

Proszę określić w jakim stopniu Pana/Pani przedsiębiorstwo wykorzystuje różnego rodzaju źródła pozyskiwania informacji i wiedzy według następującej skali:

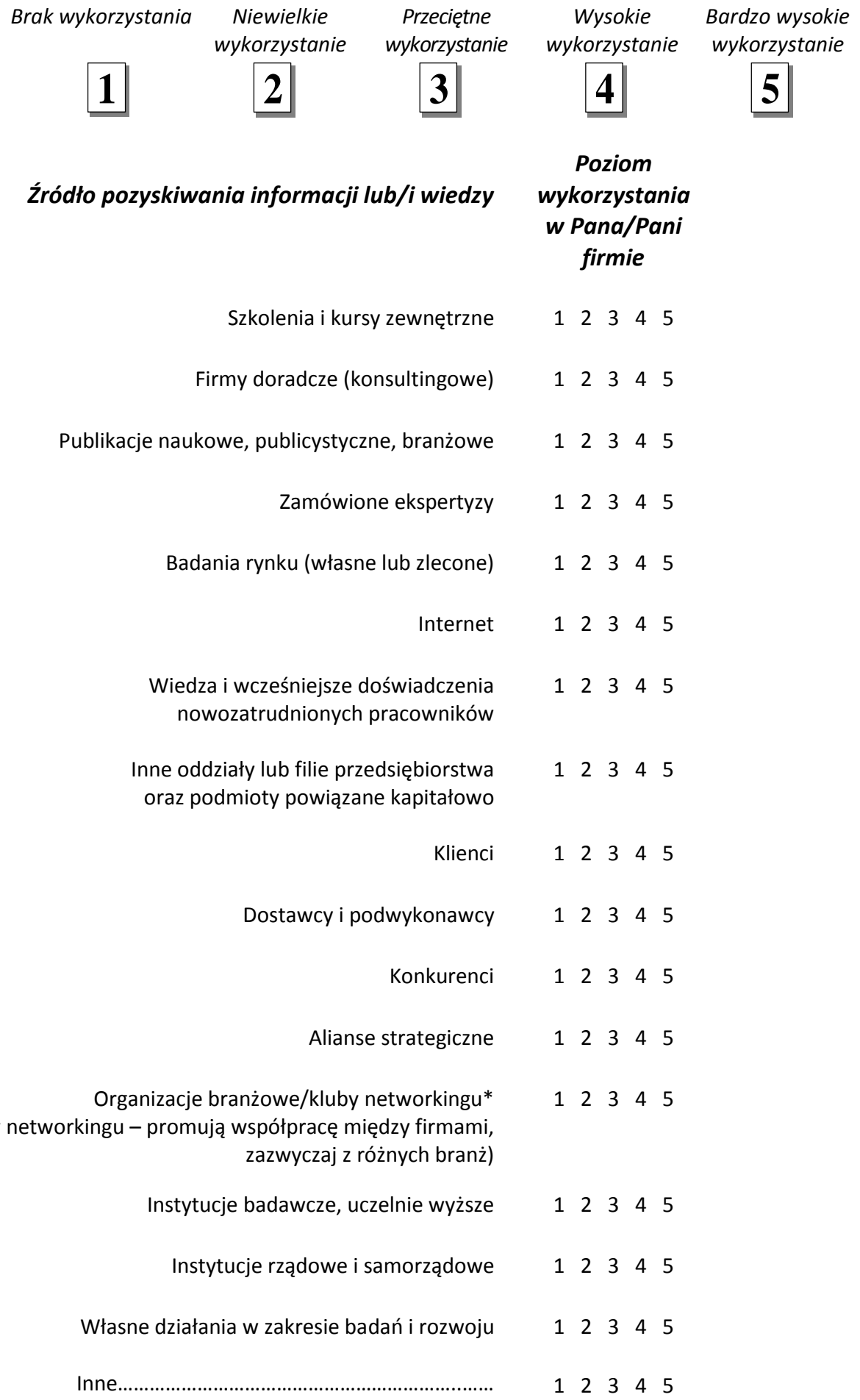

(*kluby networkingu - promują współpracę między firmami, 


\section{Rozpowszechnianie wiedzy-zagadnienia ogólne}

Jak dalece zgodziłby/zgodziłaby się Pan/Pani z poniższymi stwierdzeniami dotyczącymi rozpowszechniania wiedzy w Pana/Pani przedsiębiorstwie. Proszę zastosować następującą skalę:

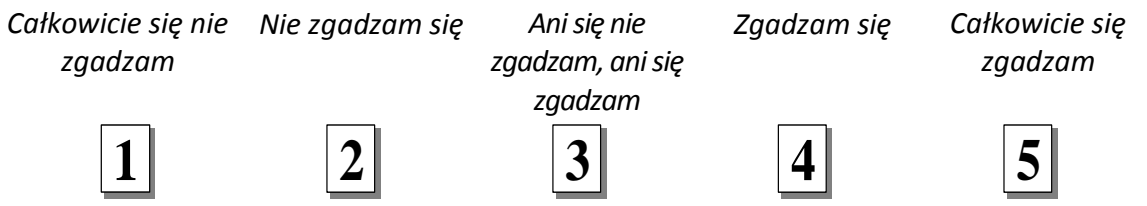

W naszym przedsiębiorstwie istnieją warunki do wspólnych spotkań i wymiany doświadczeń np. przestrzenie socjalne lub stołówki

Pracownicy różnych działów naszej firmy często współpracują ze sobą (nieformalnie lub formalnie)

Wszyscy pracownicy naszej firmy oraz zarząd najczęściej nie mają problemów z uzyskaniem, potrzebnych im w danym momencie, informacji oraz wiedzy

Najlepsze praktyki innych firm (np. konkurentów) są regularnie upowszechniane w naszym przedsiębiorstwie

Osoby zarządzające w naszym przedsiębiorstwie (indywidualnie lub grupowo) często spotykają się z pracownikami

W naszym przedsiębiorstwie, w miarę możliwości, wprowadzamy zespołowy tryb pracy

W naszej firmie podejmowane są ciągłe działania mające na celu udoskonalenie przepływu informacji i wiedzy

\section{Rozpowszechnianie wiedzy - technologie informatyczne}

Proszę ocenić poziom wykorzystania poszczególnych technologii informatycznych w Pana/Pani przedsiębiorstwie wg następującej skali:

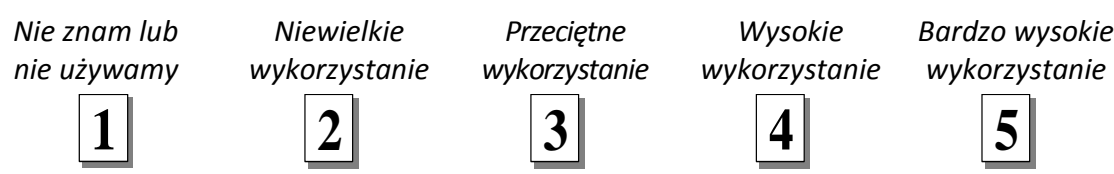

Systemy magazynowania danych (np. systemy gromadzące, udostępniające i zarządzające dokumentami oraz innymi danymi, CRM, hurtownie danych)

Informatyczne systemy komunikacyjne (np. portale korporacyjne, Intranet, forum firmowe, grupy dyskusyjne)

Systemy współpracy grupowej (groupware/collaboration) (kompleksowe systemy wspierające wspólną pracę)

Systemy wspierania decyzji, systemy eksperckie (Business Intelligence, Executive Information Systems) $\begin{array}{lllll}1 & 2 & 3 & 4 & 5\end{array}$

$\begin{array}{lllll}1 & 2 & 3 & 4 & 5\end{array}$

$\begin{array}{lllll}1 & 2 & 3 & 4 & 5\end{array}$

$\begin{array}{lllll}1 & 2 & 3 & 4 & 5\end{array}$ 


\section{Wdrażanie oraz otwartość przedsiębiorstwa na wiedzę}

Jak dalece zgodziłby/zgodziłaby się Pan/Pani z poniższymi stwierdzeniami dotyczącymi wdrażania i otwartości na wiedzę, w odniesieniu do swojej firmy. Proszę zastosować następującą skalę:

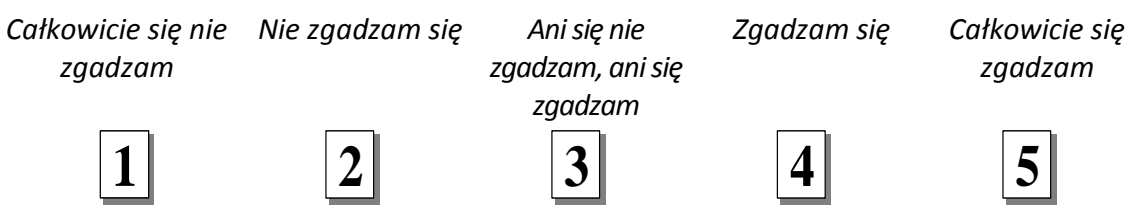

Nasze przedsiębiorstwo ma określone cele i plany na najbliższe lata ujęte pisemnie oraz znane pracownikom

Z punktu widzenia strategii naszego przedsiębiorstwa ciągły rozwój nowej wiedzy jest najważniejszym elementem konkurowania

Nasze przedsiębiorstwo stale pracuje nad nowymi produktami lub/i usługami oraz usprawnieniami organizacyjnymi

Nasze przedsiębiorstwo na bieżąco identyfikuje swoje braki i potrzeby w zakresie informacji i wiedzy

Gromadzone w naszym przedsiębiorstwie informacje i wiedza są aktywnie wykorzystywane w codziennej działalności przedsiębiorstwa, zwłaszcza przy podejmowaniu decyzji

Wiele pomysłów, inicjatyw lub usprawnień powstaje w naszej firmie dzięki sprawnemu przepływowi informacji i wiedzy w przedsiębiorstwie

Pracownicy naszej firmy często zgłaszają różnego rodzaju pomysły

$\begin{array}{lllll}1 & 2 & 3 & 4 & 5\end{array}$

Proces oceny (oraz ewentualnego wdrażania) pomysłów zgłaszanych przez pracowników najczęściej sprawnie przebiega w naszym przedsiębiorstwie 


\section{Orientacja rynkowa}

Jak dalece zgodziłby/zgodziłaby się Pan/Pani z poniższymi stwierdzeniami dotyczącymi marketingu i sprzedaży, w odniesieniu do swojej firmy. Proszę zastosować następującą skalę:

\begin{tabular}{cccc}
$\begin{array}{c}\text { Całkowicie się } \\
\text { nie zgadzam }\end{array}$ & $\begin{array}{c}\text { Nie zgadzam } \\
\text { się }\end{array}$ & $\begin{array}{c}\text { Ani się nie } \\
\text { zgadzam,ani } \\
\text { się zgadzam }\end{array}$ & $\begin{array}{c}\text { Zgadzam się } \\
\text { Całkowicie się } \\
\text { zgadzam }\end{array}$ \\
\hline 2 & $\mathbf{3}$ & $\mathbf{4}$ & $\mathbf{5}$
\end{tabular}

Ściśle monitorujemy poziom zaspokojenia potrzeb naszych klientów

$\begin{array}{llllll}1 & 2 & 3 & 4 & 5\end{array}$

Pracownicy działu sprzedaży dzielą się informacjami o konkurentach z innymi komórkami naszej firmy

Zadowolenie nabywcy jest głównym wyznacznikiem tworzenia celów i strategii naszej firmy

$\begin{array}{llllll}1 & 2 & 3 & 4 & 5\end{array}$

$\begin{array}{llllll}1 & 2 & 3 & 4 & 5\end{array}$

Szybko reagujemy na działania konkurentów

$\begin{array}{lllll}1 & 2 & 3 & 4 & 5\end{array}$

Przedstawiciele zarządu regularnie odwiedzają ważniejszych klientów

$\begin{array}{lllll}1 & 2 & 3 & 4 & 5\end{array}$

Informacje o klientach są rozpowszechniane w całej firmie

1223045

Strategie konkurowania bazują na zrozumieniu potrzeb klienta

$\begin{array}{lllll}1 & 2 & 3 & 4 & 5\end{array}$

Działania wszystkich komórek firmy są zintegrowane w celu obsługi potrzeb nabywców

Oferowanie większych korzyści dla klienta związanych z zakupem naszych produktów i usług stanowi podstawę tworzenia strategii firmy

Często badamy poziom zadowolenia klientów

$\begin{array}{lllll}1 & 2 & 3 & 4 & 5\end{array}$

$\begin{array}{lllll}1 & 2 & 3 & 4 & 5\end{array}$

1223445

Przywiązujemy dużą uwagę do usług posprzedażowych

$\begin{array}{lllll}1 & 2 & 3 & 4 & 5\end{array}$

Zarząd regularnie omawia silne i słabe strony konkurentów

$\begin{array}{lllll}1 & 2 & 3 & 4 & 5\end{array}$

Nasi menedżerowie wiedzą, w jaki sposób pracownicy firmy mogą przyczynić się

$\begin{array}{lllll}1 & 2 & 3 & 4 & 5\end{array}$

do wzrostu zadowolenia nabywców

Koncentrujemy się na wybranej grupie lub grupach nabywców, jeśli dzięki temu możemy

$\begin{array}{lllll}1 & 2 & 3 & 4 & 5\end{array}$ osiągnąć przewagę konkurencyjną 


\section{Poziom konkurencyjności w porównaniu do najbliższych konkurentów w latach 2011 i 2012}

Proszę ocenić wyniki Pana/Pani przedsiębiorstwa $\underline{w}$ porównaniu do najbliższych konkurentów w poszczególnych latach według następującej skali:

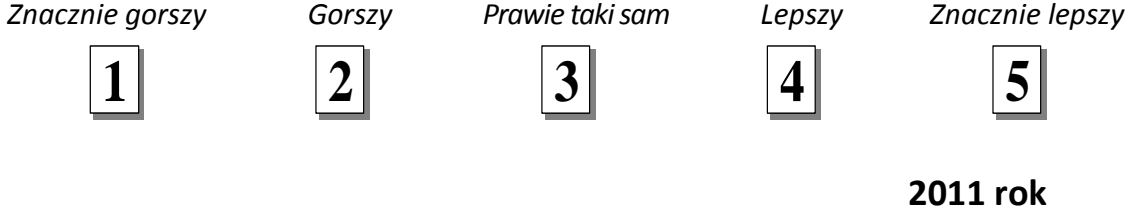

Zysk ogółem w porównaniu z najbliższymi konkurentami

Stopa zwrotu z nakładów inwestycyjnych (ROI) w porównaniu z najbliższymi konkurentami

Wartość sprzedaży w porównaniu z najbliższymi konkurentami

Udział w rynku w porównaniu z najbliższymi konkurentami

\author{
$123 \quad 4 \quad 5$
}

1223445

1223045

1223345 $\begin{array}{lllll}1 & 2 & 3 & 4 & 5\end{array}$

2012 rok

1223345

1223454

1223345

\section{Charakterystyka przedsiębiorstwa}

Proszę o podanie kilku podstawowych informacji o firmie (proszę wskazać jedną branżę w jakiej działa Państwa przedsiębiorstwo (proszę zaznaczyć tylko jedną):

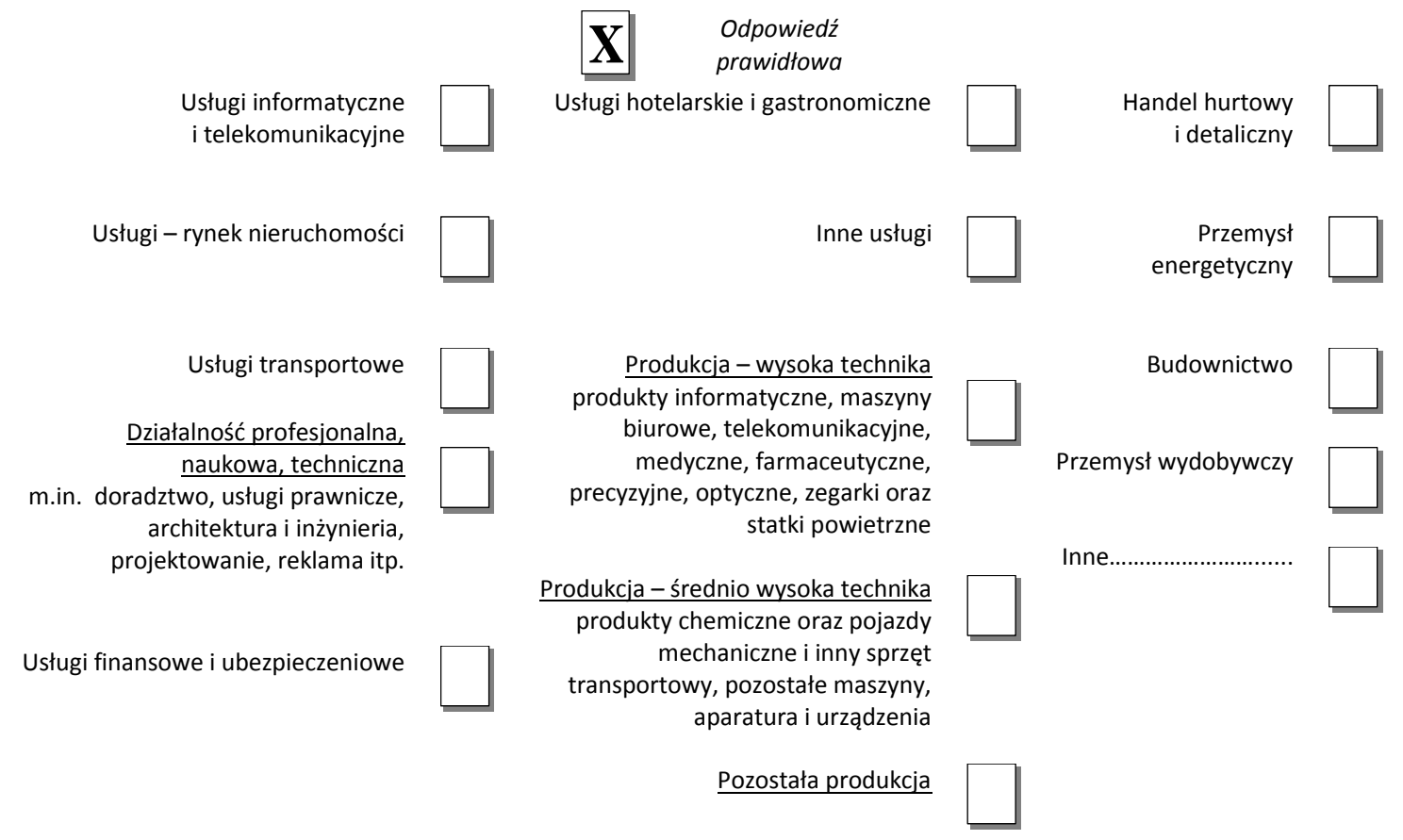

- Proszę określić przybliżoną wielkość faktycznego zatrudnienia w Państwa przedsiębiorstwie (wraz z umowami zlecenie, czasowymi i o dzieło):

Poniżej 10

250-999

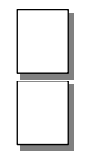

10-49

1000-4999

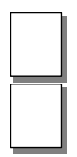

50-249

Powyżej 5000 
- Proszę wybrać opcję, która najlepiej odzwierciedla formę własności Państwa firmy (dominujący udział):

Własność podmiotów zagranicznych

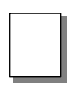

Własność prywatnych podmiotów krajowych

- Państwa przedsiębiorstwo można określić jako:

Przedsiębiorstwo nieposiadające oddziałów za granicą

Centrala przedsiębiorstwa posiadającego oddziały zagraniczne

Oddział/filia przedsiębiorstwa zagranicznego

Własność polskiego Skarbu Państwa

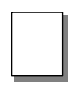

$0 \%$

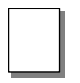

$1-10 \%$

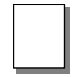

$11-30 \%$

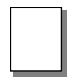

$31-60 \%$

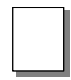

$>60 \%$

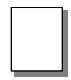

- Proszę wskazać łaczny okres zaangażowania firmy w działalność na rynkach zagranicznych:
Brak
do 1 roku
1-2 lata
3-5 lat
6-10 lat
powyżej 10 lat
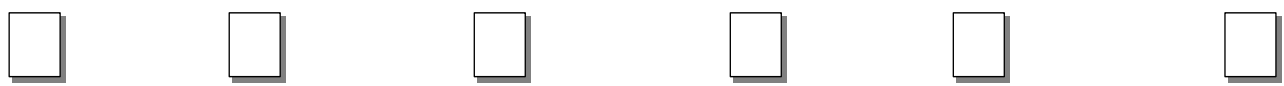

- $\quad$ Proszę wskazać przeszłe, realizowane i planowane przez Pana/Pani firmę formy ekspansji zagranicznej w procesie internacjonalizacji.

\begin{tabular}{|c|c|c|c|c|c|c|c|}
\hline & Import & $\begin{array}{c}\text { Eksport } \\
\text { pośredni } \\
\text { (przez } \\
\text { pośredników } \\
\text { krajowych) }\end{array}$ & $\begin{array}{c}\text { Eksport } \\
\text { bezpośredni }\end{array}$ & $\begin{array}{c}\text { Współpraca } \\
\text { niekapitałowa } \\
\text { (licencjonowanie, } \\
\text { franchising) }\end{array}$ & $\begin{array}{l}\text { Współpraca } \\
\text { kapitałowa } \\
\text { (joint } \\
\text { venture) }\end{array}$ & $\begin{array}{l}\text { Podwyko- } \\
\text { nawstwo }\end{array}$ & $\begin{array}{c}\text { Własna } \\
\text { inwestycja } \\
\text { bezpośrednia }\end{array}$ \\
\hline \multicolumn{8}{|l|}{$\begin{array}{r}\text { Początek } \\
\text { internacjonalizacji } \\
\text { (w przeszłości) }\end{array}$} \\
\hline \multicolumn{8}{|l|}{ Obecnie } \\
\hline \multicolumn{8}{|l|}{$\begin{array}{r}\text { Planowane formy } \\
\text { internacjonalizacji } \\
\text { (w przyszłości) }\end{array}$} \\
\hline & & & & $\begin{array}{c}\text { Brak } \\
\text { zaangażowania } \\
\text { zagranicznego }\end{array}$ & & & \\
\hline
\end{tabular}




\section{Załącznik 5. Źródłła pytań wykorzystanych w kwestionariuszu ankiety.}

\section{Pozyskiwanie wiedzy}

Pytanie

Proszę określić w jakim stopniu Pana/Pani przedsiębiorstwo wykorzystuje różnego rodzaju źródła pozyskiwania informacji i wiedzy wg następującej skali:
Źródło

Opracowanie własne na podstawie: Sparrow [2010], Mazur, Rószkiewicz i Strzyżewska [2008, s. 151], Darroch [2003, s. 45], Kowalczyk i Nogalski [2007, s. 94], Probst, Raub i Romhardt [2004, s. 126-133], Paliszkiewicz [2007, s. 71-73], Davenport i Probst [2002, s. 13].

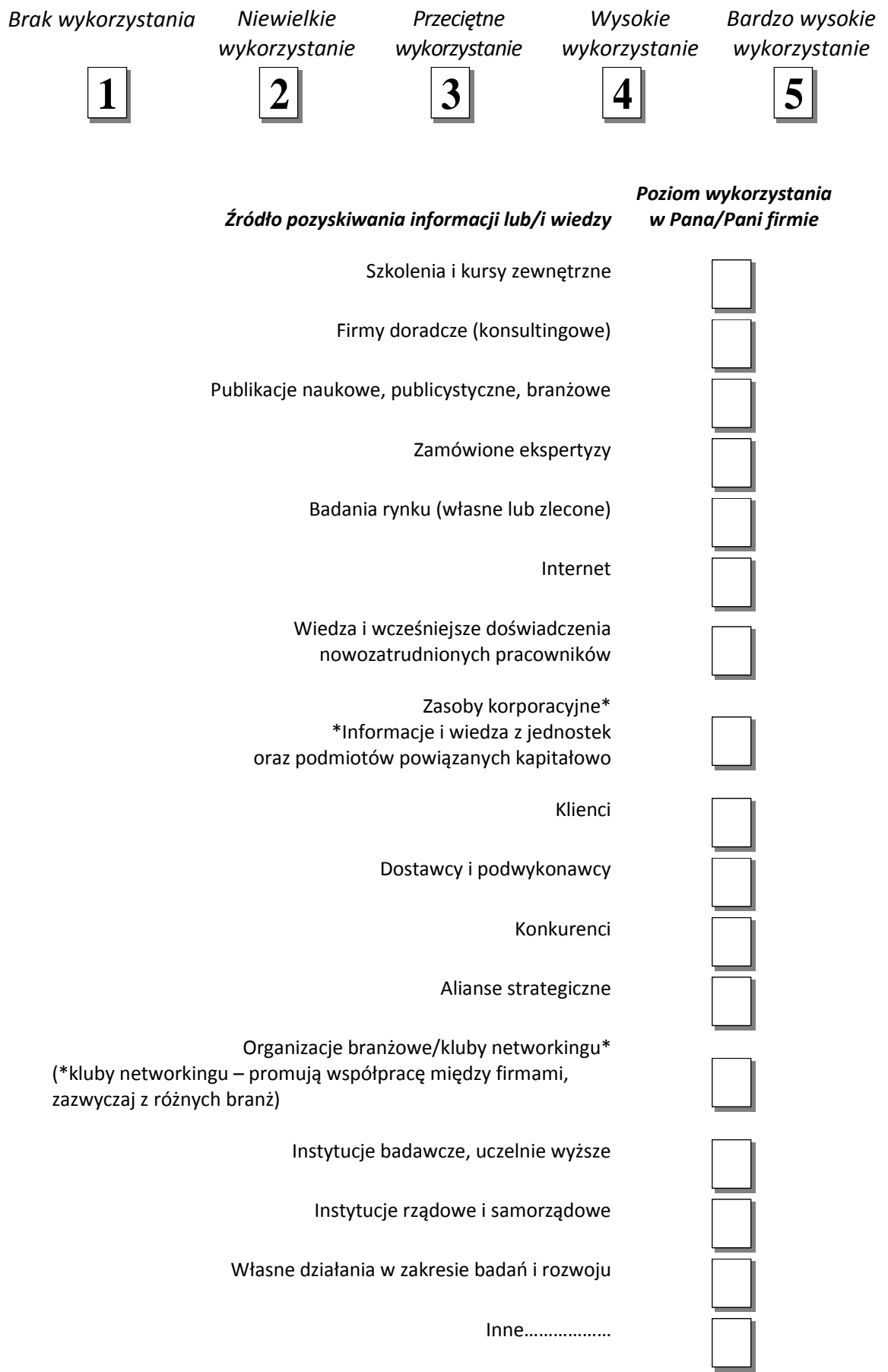




\section{Rozpowszechnianie wiedzy-zagadnienia ogólne}

Jak dalece zgodziłby/zgodziłaby się Pan/Pani z poniższymi stwierdzeniami dotyczącymi rozpowszechniania wiedzy w Pana/Pani przedsiębiorstwie. Proszę zastosować następującą skalę:

\begin{tabular}{|c|c|c|c|}
\hline $\begin{array}{c}\text { Catkowicie się nie } \\
\text { zgadzam }\end{array}$ & Nie zgadzam się & $\begin{array}{c}\text { Ani się nie } \\
\text { zgadzam, ani się }\end{array}$ & Zgadzam się \\
\hline
\end{tabular}

\begin{tabular}{|l|l|l|}
\hline 2 & 4 & 5 \\
\hline
\end{tabular}

\begin{tabular}{|c|c|c|}
\hline & Odp. & Źródło \\
\hline $\begin{array}{l}\text { W naszym przedsiębiorstwie istnieją warunki do wspólnych spotkań i wymiany doświadczeń } \\
\text { np. przestrzenie socjalne, stołówki itp. }\end{array}$ & & $\begin{array}{l}\text { Na podstawie: Wang i in. } \\
\text { [2009, s. 119], Darroch } \\
{[2003, \text { s. 46]. }}\end{array}$ \\
\hline $\begin{array}{l}\text { Pracownicy różnych działów naszej firmy często współpracują ze sobą (nieformalnie lub } \\
\text { formalnie) }\end{array}$ & & $\begin{array}{l}\text { Na podstawie: Wang i in. } \\
{[2009, \text { s. } 119] .}\end{array}$ \\
\hline $\begin{array}{l}\text { Wszyscy pracownicy naszej firmy oraz zarząd najczęściej nie mają problemów z uzyskaniem, } \\
\text { potrzebnych im w danym momencie, informacji oraz wiedzy }\end{array}$ & & $\begin{array}{l}\text { Na podstawie: Wang i in. } \\
\text { [2009, s. 119], Mazur, } \\
\text { Rószkiewicz i Strzyżewska } \\
{[2008, \text { s. } 152] .}\end{array}$ \\
\hline $\begin{array}{l}\text { Najlepsze praktyki innych firm (np. konkurentów) są regularnie upowszechniane w naszym } \\
\text { przedsiębiorstwie }\end{array}$ & & $\begin{array}{l}\text { Mazur, Rószkiewicz } \\
\text { i Strzyżewska [2008, s. 152]. }\end{array}$ \\
\hline $\begin{array}{l}\text { Osoby zarządzające w naszym przedsiębiorstwie (indywidualnie lub grupowo) często spotykają } \\
\text { się z pracownikami }\end{array}$ & & $\begin{array}{l}\text { Na podstawie: Darroch } \\
\text { [2003, s. 45], Mazur, } \\
\text { Rószkiewicz i Strzyżewska } \\
{[2008, \text { s. } 152] .}\end{array}$ \\
\hline W naszym przedsiębiorstwie, w miarę możliwości, wprowadzamy zespołowy tryb pracy & & $\begin{array}{l}\text { Na podstawie: Busch [2008, } \\
\text { s. 27]. }\end{array}$ \\
\hline $\begin{array}{l}\text { W naszej firmie podejmowane są ciągłe działania mające na celu udoskonalenie przepływu } \\
\text { informacji i wiedzy }\end{array}$ & & $\begin{array}{l}\text { Geisler i Wickramasinghe } \\
\text { [2009, s. 13]. }\end{array}$ \\
\hline
\end{tabular}

\section{Rozpowszechnianie wiedzy - technologie informatyczne}

Pytanie

Proszę ocenić poziom wykorzystania poszczególnych technologii informatycznych w Pana/Pani przedsiębiorstwie wg następującej skali:

\section{Źródło}

Opracowanie własne na podstawie: Alavi i Tiwana [2006, s. 113118], Jemielniak i Koźmiński [2012, s. 306], Paliszkiewicz [2007, s. 66], Gierszewska [2011, s. 180], Geisler i Wickramasinghe [2009, s. 13].

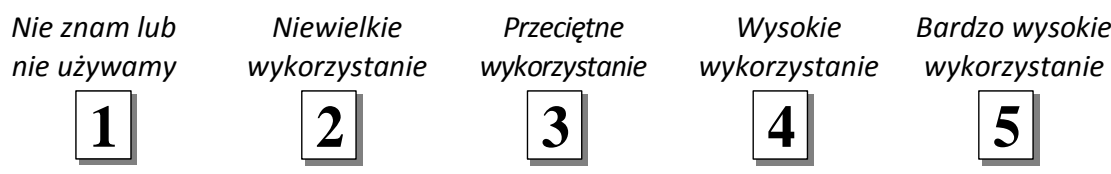

Podstawowe technologie informatyczne (Internet, e-mail, edytory tekstu, arkusze kalkulacyjne) 


\section{Wdrażanie oraz otwartość przedsiębiorstwa na wiedzę}

Jak dalece zgodziłby/zgodziłaby się Pan/Pani z poniższymi stwierdzeniami dotyczącymi wdrażania i otwartości na wiedzę, w odniesieniu do swojej firmy. Proszę zastosować następującą skalę:

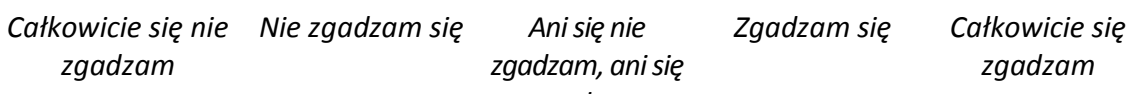

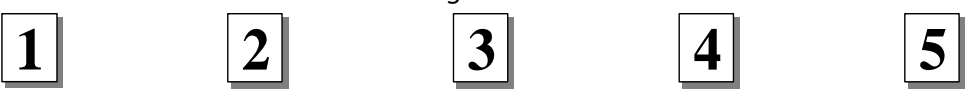

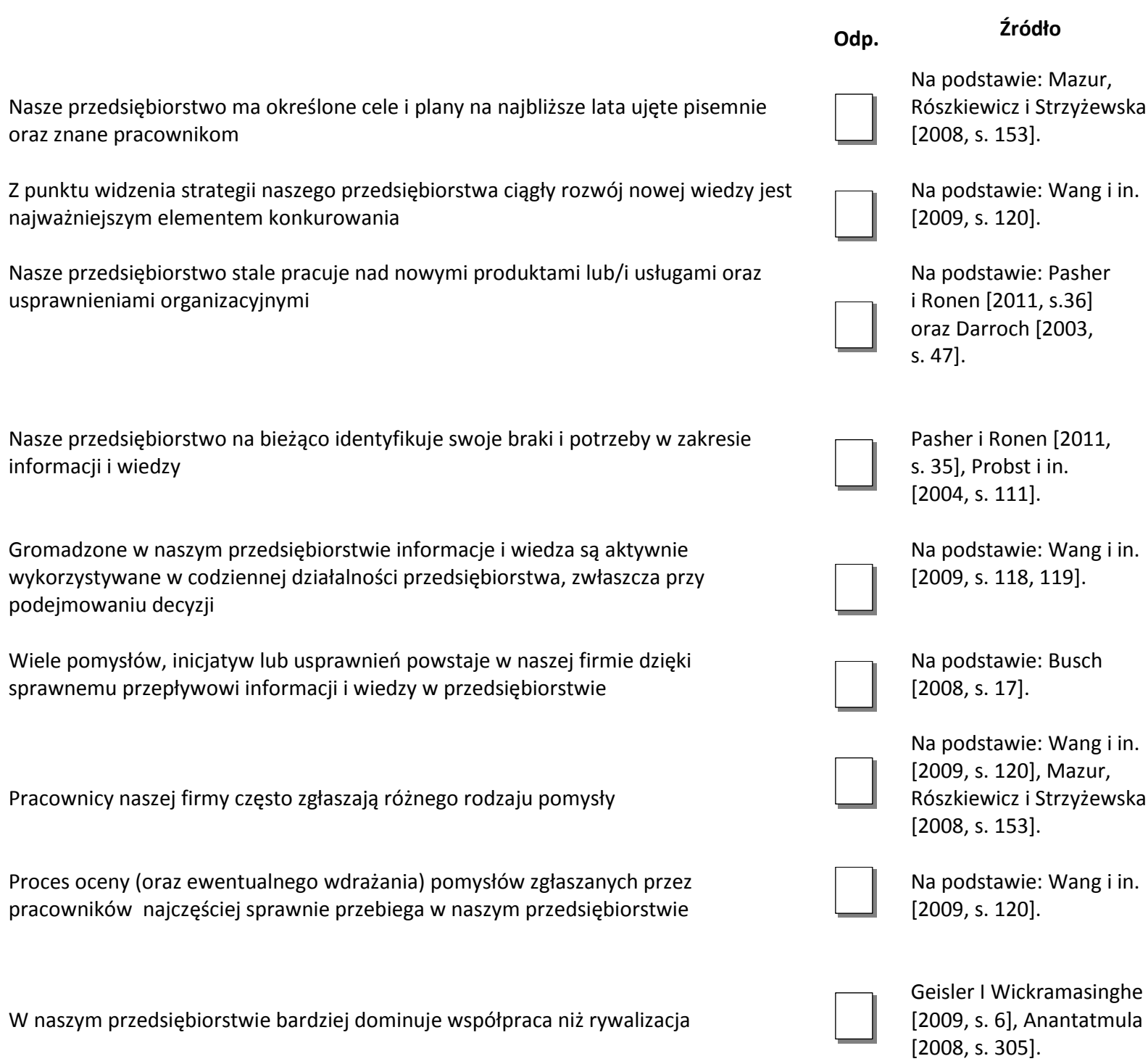


Dokładnie analizujemy każde nasze niepowodzenie w celu zapobiegania podobnym zdarzeniom w przyszłości

Na podstawie: Wang i in. [2009, s. 118], Darroch [2003, s. 46].

\section{Orientacja rynkowa}

\section{Pytanie}

Jak dalece zgodziłby/zgodziłaby się Pan/Pani z poniższymi stwierdzeniami dotyczącymi marketingu i sprzedaży, w odniesieniu do swojej firmy. Proszę zastosować następującą skalę:

$\begin{array}{cc}\text { Całkowicie się } & \text { Nie zgadzam } \\ \text { nie zgadzam } & \text { się }\end{array}$
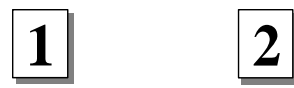
Ani się nie zgadzam, ani się zgadzam

Źródło

Hooley i in. [2000, s. 279], Hooley i in. [2003, s. 97].

Ściśle monitorujemy poziom zaspokojenia potrzeb naszych klientów

Pracownicy działu sprzedaży dzielą się informacjami o konkurentach z innymi komórkami naszej firmy

Zadowolenie nabywcy jest głównym wyznacznikiem tworzenia celów i strategii naszej firmy

Szybko reagujemy na działania konkurentów

Przedstawiciele zarządu regularnie odwiedzają ważniejszych klientów

Informacje o klientach są rozpowszechniane w całej firmie

Strategie konkurowania bazują na zrozumieniu potrzeb klienta

Działania wszystkich komórek firmy są zintegrowane w celu obsługi potrzeb nabywców

Oferowanie większych korzyści dla klienta związanych z zakupem naszych produktów i usług stanowi podstawę tworzenia strategii firmy

Często badamy poziom zadowolenia klientów

Przywiązujemy dużą uwagę do usług posprzedażowych

Zarząd regularnie omawia silne i słabe strony konkurentów

Nasi menedżerowie wiedzą, w jaki sposób pracownicy firmy mogą przyczynić się do wzrostu zadowolenia nabywców

Koncentrujemy się na wybranej grupie lub grupach nabywców, jeśli dzięki temu możemy osiągnąć przewagę konkurencyjna 


\section{Poziom konkurencyjności przedsiębiorstwa w roku 2011 i 2012}

Proszę ocenić wyniki Pana/Pani przedsiębiorstwa w 2011 i 2012 roku w porównaniu do najbliższych konkurentów według następującej skali:

\begin{tabular}{ccccc|} 
Znacznie gorszy & Gorszy & Prawie takisam & Lepszy & Znacznie lepszy \\
\hline $\mathbf{1}$ & $\mathbf{2}$ & $\mathbf{3}$ & $\mathbf{4}$ & $\mathbf{5}$ \\
\hline
\end{tabular}

2011r. 2012r. Źródło

Zysk ogółem w porównaniu z najbliższymi konkurentami

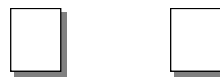

Na podstawie: Fonfara [2009].

\section{Stopa zwrotu z nakładów inwestycyjnych (ROI) w} porównaniu z najbliższymi konkurentami
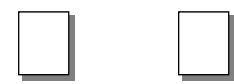

Na podstawie: Fonfara [2009].

Wartość sprzedaży w porównaniu z najbliższymi konkurentami
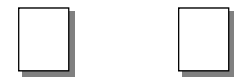

Na podstawie: Fonfara [2009].

Udział w rynku w porównaniu z najbliższymi konkurentami
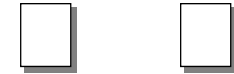

Na podstawie: Fonfara [2009].

\section{Charakterystyka przedsiębiorstwa}

\section{Pytanie}

Proszę o podanie kilku podstawowych informacji o firmie:

\section{Źródło}

Na podstawie: Fonfara [2009, 2012], Hatzichronoglou [1997] Wojnicka i in. [2006, s. 9], PKD 2007 [2007].

$$
\text { X } \begin{gathered}
\text { Odpowiedź } \\
\text { prawidłowa }
\end{gathered}
$$

Usługi informatyczne i telekomunikacyjne

Usługi - rynek nieruchomości

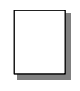

Usługi transportowe

Działalność profesjonalna naukowa, techniczn m.in. doradztwo, usługi prawnicze, architektura i inżynieria, projektowanie, reklama itp.

Usługi finansowe i ubezpieczeniowe

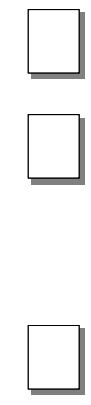

Usługi hotelarskie i gastronomiczne

Inne usługi

Produkcja - wysoka technika produkty informatyczne, maszyny biurowe, telekomunikacyjne, medyczne, farmaceutyczne, precyzyjne, optyczne, zegarki oraz statki powietrzne

Produkcja - średnio wysoka technika produkty chemiczne oraz pojazdy mechaniczne i inny sprzęt transportowy, pozostałe maszyny, aparatura i urządzenia

Pozostała produkcja
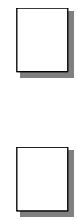

\section{Handel hurtowy} i detaliczny

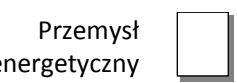

Budownictwo

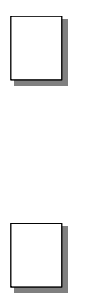

Przemysł wydobywczy

Inne
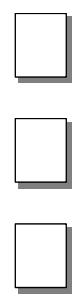
- Proszę określić przybliżoną wielkość faktycznego zatrudnienia w Państwa przedsiębiorstwie (wraz z umowami zlecenie, czasowymi i o dzieło):

Poniżej 10

250-999

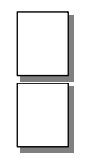

$10-49$

1000-4999

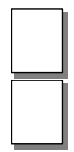

$50-249$

Powyżej 5000

- Proszę wybrać opcję, która najlepiej odzwierciedla formę własności Państwa firmy (dominujący udział):

Własność podmiotów zagranicznych

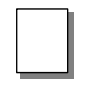

Własność prywatnych podmiotów

krajowych

- Państwa przedsiębiorstwo można określić jako:

Przedsiębiorstwo nieposiadające oddziałów za granicą

Centrala przedsiębiorstwa posiadającego oddziały zagraniczne

Oddział/filia przedsiębiorstwa zagranicznego

Własność polskiego Skarbu Państwa
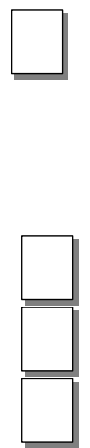

- Przybliżony udział wielkości sprzedaży na rynkach zagranicznych w stosunku do sprzedaży firmy ogółem:

$0 \%$

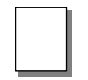

$1-10 \%$

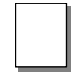

$11-30 \%$

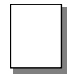

$31-60 \%$

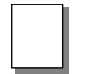

$>60 \%$

- Proszę wskazać łączny okres zaangażowania firmy w działalność na rynkach zagranicznych:
Brak
do 1 roku
1-2 lata
3-5 lat
6-10 lat
powyżej 10 lat
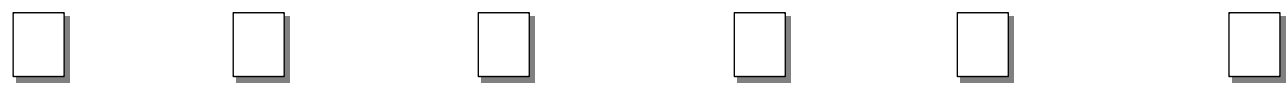

- Proszę wskazać przeszłe, realizowane i planowane przez Pana/Pani firmę formy ekspansji zagranicznej w procesie internacjonalizacji.

\begin{tabular}{|c|c|c|c|c|c|c|c|}
\hline & Import & $\begin{array}{c}\text { Eksport } \\
\text { pośredni } \\
\text { (przez } \\
\text { pośredników } \\
\text { krajowych) }\end{array}$ & $\begin{array}{c}\text { Eksport } \\
\text { bezpośredni }\end{array}$ & $\begin{array}{c}\text { Współpraca } \\
\text { niekapitałowa } \\
\text { (licencjonowanie, } \\
\text { franchising) }\end{array}$ & $\begin{array}{c}\text { Współpraca } \\
\text { kapitałowa } \\
\text { (joint } \\
\text { venture) }\end{array}$ & $\begin{array}{l}\text { Podwyko- } \\
\text { nawstwo }\end{array}$ & $\begin{array}{c}\text { Własna } \\
\text { inwestycja } \\
\text { bezpośrednia }\end{array}$ \\
\hline \multicolumn{8}{|l|}{$\begin{array}{r}\text { Początek } \\
\text { internacjonalizacji } \\
\text { (w przeszłości) }\end{array}$} \\
\hline \multicolumn{8}{|l|}{ Obecnie } \\
\hline $\begin{array}{r}\text { Planowane formy } \\
\text { internacjonalizacji } \\
\text { (w przyszłości) }\end{array}$ & & & & & & & \\
\hline
\end{tabular}


7 Ankieta - Kooperacja pols $\times \square$

C www.orientacjanawiedze.pl/1/survey/welcome/672883fe696a4ca0ca0dd5c9c3064095bbd8a60e

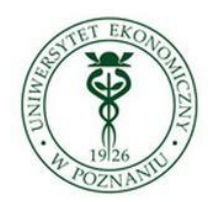

Uniwersytet Ekonomiczny w Poznaniu Katedra Marketingu Międzynarodowego

Projekt badawczy

Rynkowo ukierunkowane procesy zarządzania wiedzą w kształtowaniu przewagi konkurencyjnej

przedsiebiorstwa

w procesie internacjonalizacji

Żadna z odpowiedzi nie jest ani dobra, ani zła.

Przejdż do ankiety

$\square$ Ankieta - Kooperacaj pols $\times$

$\leftarrow \rightarrow$ C [ www.orientacjanawiedze.pl/1/survey/q/11/672883fe696a4ca0ca0dd5c9c3064095bbd8a60e

\section{Pozyskiwanie wiedzy}

Proszę określić w jakim stopniu Pana/Pani przedsiębiorstwo wykorzystuje różnego rodzaju ́ródła pozyskiwania informacji lub/i wiedzy:

\begin{tabular}{|c|c|c|c|c|c|}
\hline Źródło pozyskiwania informacji lub/i wiedzy & $\begin{array}{c}\text { Brak } \\
\text { wykorzystania }\end{array}$ & $\begin{array}{c}\text { Niewielkie } \\
\text { wykorzystanie }\end{array}$ & $\begin{array}{c}\text { Przeciẹtne } \\
\text { wykorzystanie }\end{array}$ & $\begin{array}{c}\text { Wysokie } \\
\text { wykorzystanie }\end{array}$ & $\begin{array}{c}\text { Bardzo } \\
\text { wysokie } \\
\text { wykorzystanie }\end{array}$ \\
\hline Szkolenia i kursy zewnętrzne & 0 & (0) & 0 & 0 & 0 \\
\hline Publikacje naukowe, publicystyczne, branżowe & 0 & 0 & ○ & 0 & 0 \\
\hline Zamówione ekspertyzy & 0 & 0 & (-) & 0 & 0 \\
\hline Badania rynku (własne lub zlecone) & 0 & - & o & 0 & 0 \\
\hline
\end{tabular}


$\leftarrow \rightarrow$ C [ www.orientacjanawiedze.pl/1/survey/q/1/672883fe696a4ca0ca0dd5c9c3064095bbd8a60e

\section{Rozpowszechnianie wiedzy - zagadnienia ogólne}

\$) Jak dalece zgodziłby/zgodziłaby się Pan/Pani z poniższymi stwierdzeniami dotyczącymi rozpowszechniania wiedzy w Pana/Pani przedsiębiorstwie.

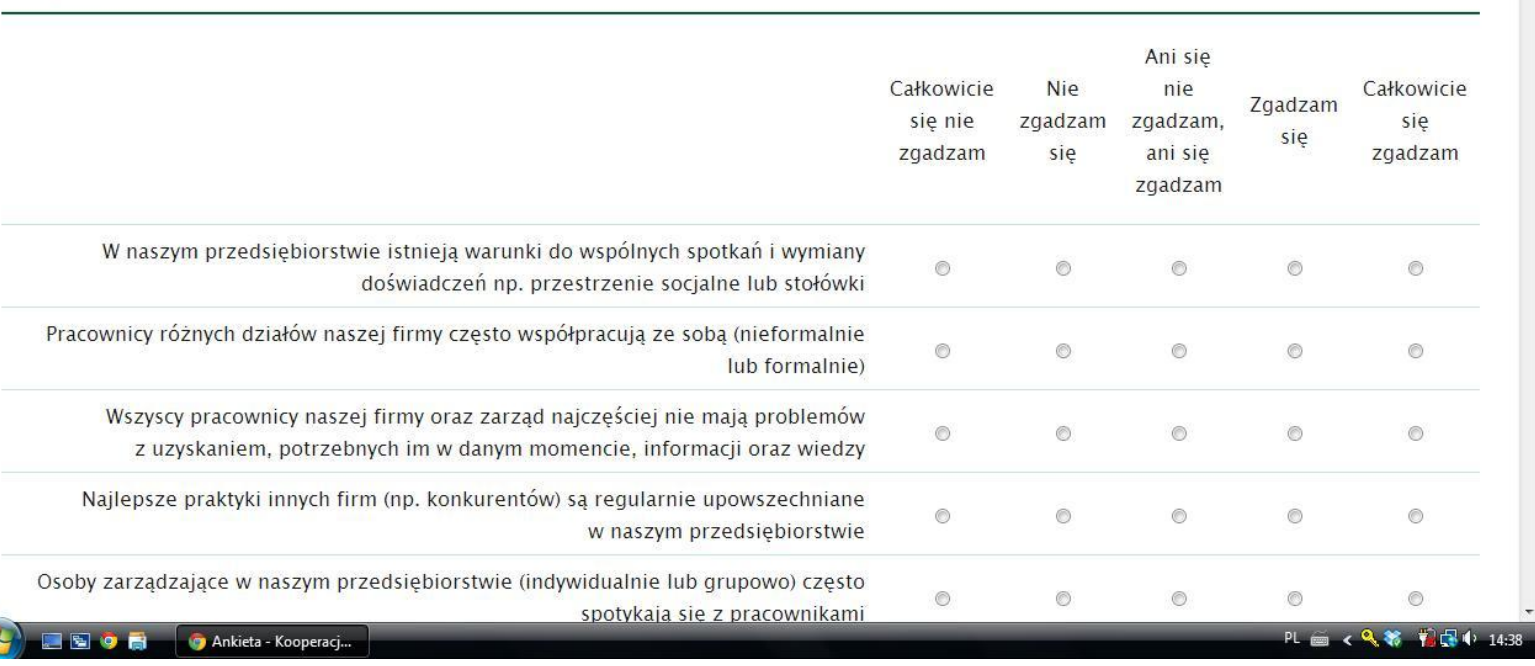

$\square$ Ankieta - Kooperacja pols $\times$

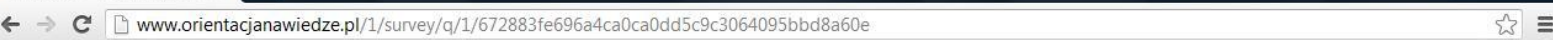

3. Rozpowszechnianie wiedzy - technologie informatyczne

Proszę ocenić poziom wykorzystania poszczególnych technologii informatycznych w Pana/Pani przedsiębiorstwie

\begin{tabular}{|c|c|c|c|c|c|}
\hline & $\begin{array}{c}\text { Nie } \\
\text { znam } \\
\text { lub nie } \\
\text { używamy }\end{array}$ & $\begin{array}{l}\text { Niewielkie } \\
\text { wykorzystanie }\end{array}$ & $\begin{array}{c}\text { Przeciętne } \\
\text { wykorzystanie }\end{array}$ & $\begin{array}{l}\text { Wysokie } \\
\text { wykorzystanie }\end{array}$ & $\begin{array}{c}\text { Bardzo } \\
\text { wysokie } \\
\text { wykorzystanie }\end{array}$ \\
\hline $\begin{array}{l}\text { Podstawowe technologie informatyczne } \\
\text { (Internet, e-mail, edytory tekstu, arkusze kalkulacyjne) }\end{array}$ & 0 & 0 & 0 & 0 & 0 \\
\hline $\begin{array}{l}\text { (np. systemy gromadzace, udosteppniajace i zarzadzajace } \\
\text { dokumentami oraz innymi danymi, CRM, hurtownie danych) }\end{array}$ & 0 & (2) & 0 & (0) & 0 \\
\hline $\begin{array}{r}\text { Informatyczne systemy komunikacyjne } \\
\text { (np. portale korporacyjne, Intranet, forum firmowe, grupy dyskusyjne) }\end{array}$ & 0 & 0 & 0 & 0 & 0 \\
\hline $\begin{array}{r}\text { Systemy współpracy grupowej (groupware/collaboration) } \\
\text { (kompleksowe systemy wspierające wspólnạ pracẹ) }\end{array}$ & 0 & 0 & 0 & 0 & 0 \\
\hline
\end{tabular}




\section{Wdrażanie oraz otwartość przedsiębiorstwa na wiedzę}

\$ै. Jak dalece zgodziłby/zgodziłaby się Pan/Pani z poniższymi stwierdzeniami dotyczącymi wdrażania i otwartości na wiedzę, w odniesieniu do swojej firmy.

\begin{tabular}{|c|c|c|c|c|c|}
\hline & $\begin{array}{l}\text { Całkowicie } \\
\text { się nie } \\
\text { zgadzam }\end{array}$ & $\begin{array}{c}\text { Nie } \\
\text { zgadzam } \\
\text { się }\end{array}$ & $\begin{array}{l}\text { Ani się } \\
\text { nie } \\
\text { zgadzam, } \\
\text { ani się } \\
\text { zgadzam }\end{array}$ & $\begin{array}{l}\text { Zgadzam } \\
\text { się }\end{array}$ & $\begin{array}{c}\text { Całkowicie } \\
\text { się } \\
\text { zgadzam }\end{array}$ \\
\hline $\begin{array}{r}\text { Nasze przedsiębiorstwo ma określone cele i plany na najbliższe lata ujęte pisemnie } \\
\text { oraz znane pracownikom }\end{array}$ & ○ & 0 & 0 & $\odot$ & 0 \\
\hline $\begin{array}{r}\text { Z punktu widzenia strategii naszego przedsiębiorstwa ciągły rozwój nowej wiedzy jest } \\
\text { najważniejszym elementem konkurowania }\end{array}$ & 0 & ○ & 0 & ○ & 0 \\
\hline $\begin{array}{r}\text { Nasze przedsiębiorstwo stale pracuje nad nowymi produktami lub/i usługami oraz } \\
\text { usprawnieniami organizacyjnymi }\end{array}$ & 0 & ○ & 0 & $\odot$ & 0 \\
\hline Nasze przedsiębiorstwo na bieżąco identyfikuje swoje braki i potrzeby w zakresie & & & & & \\
\hline $\begin{array}{r}\text { informacji } \\
\text { i wiedzy }\end{array}$ & 0 & ○ & 0 & ○ & 0 \\
\hline
\end{tabular}

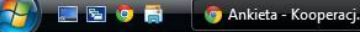

Ankieta - Kooperacja pols $\times \square$

$\leftarrow \Rightarrow$ C Www.orientacjanawiedze.pl/1/survey/q/1/672883fe696a4ca0ca0dd5c9c3064095bbd8a60e

\begin{tabular}{l}
\hline Własność podmiotów zagranicznych \\
Własność prywatnych podmiotów krajowych \\
\hline Własność polskiego Skarbu Państwa $\quad \bigcirc$
\end{tabular}

Państwa przedsiębiorstwo można określić jako 
Przykład komunikatu dla respondenta, który nie udzielił wszystkich wymaganych odpowiedzi:

Ankieta - Kooperacja pols $\times \square$

$\leftarrow \rightarrow$ C $\square$ www.orientacjanawiedze.pl/1/survey/q/1/672883fe696a4ca0ca0dd5c9c3064095bbd8a60e internacjonalizacji.

\begin{tabular}{|c|c|c|c|c|c|c|c|}
\hline & Import & $\begin{array}{l}\text { Eksport } \\
\text { pośredni } \\
\text { (przez } \\
\text { pośredników } \\
\text { krajowych) }\end{array}$ & $\begin{array}{c}\text { Eksport } \\
\text { bezpośredni }\end{array}$ & $\begin{array}{c}\text { Współpraca } \\
\text { niekapitałowa } \\
\text { (licencjonowanie, } \\
\text { franchising) }\end{array}$ & $\begin{array}{l}\text { Współpraca } \\
\text { kapitałowa } \\
\text { (joint } \\
\text { venture) }\end{array}$ & $\begin{array}{l}\text { Podwyko- } \\
\text { nawstwo }\end{array}$ & $\begin{array}{c}\text { Własna } \\
\text { inwestycja } \\
\text { bezpośrednia }\end{array}$ \\
\hline \multicolumn{8}{|c|}{ odpowiedż na to pytanie jest wymagana. } \\
\hline Początek internacjonalizacji (w przeszłości) & $\square$ & $\square$ & $\square$ & 回 & $\square$ & $\square$ & $\square$ \\
\hline Obecnie & $\square$ & $\square$ & $\square$ & $\square$ & 四 & 田 & $\square$ \\
\hline Planowane formy internacjonalizacji & 回 & 回 & 回 & 回 & 回 & 回 & 回 \\
\hline
\end{tabular}

Nie wszystkie obowiązkowe pola zostały wypełnione. Niewypełnione pytania zostały oznaczone na czerwono.

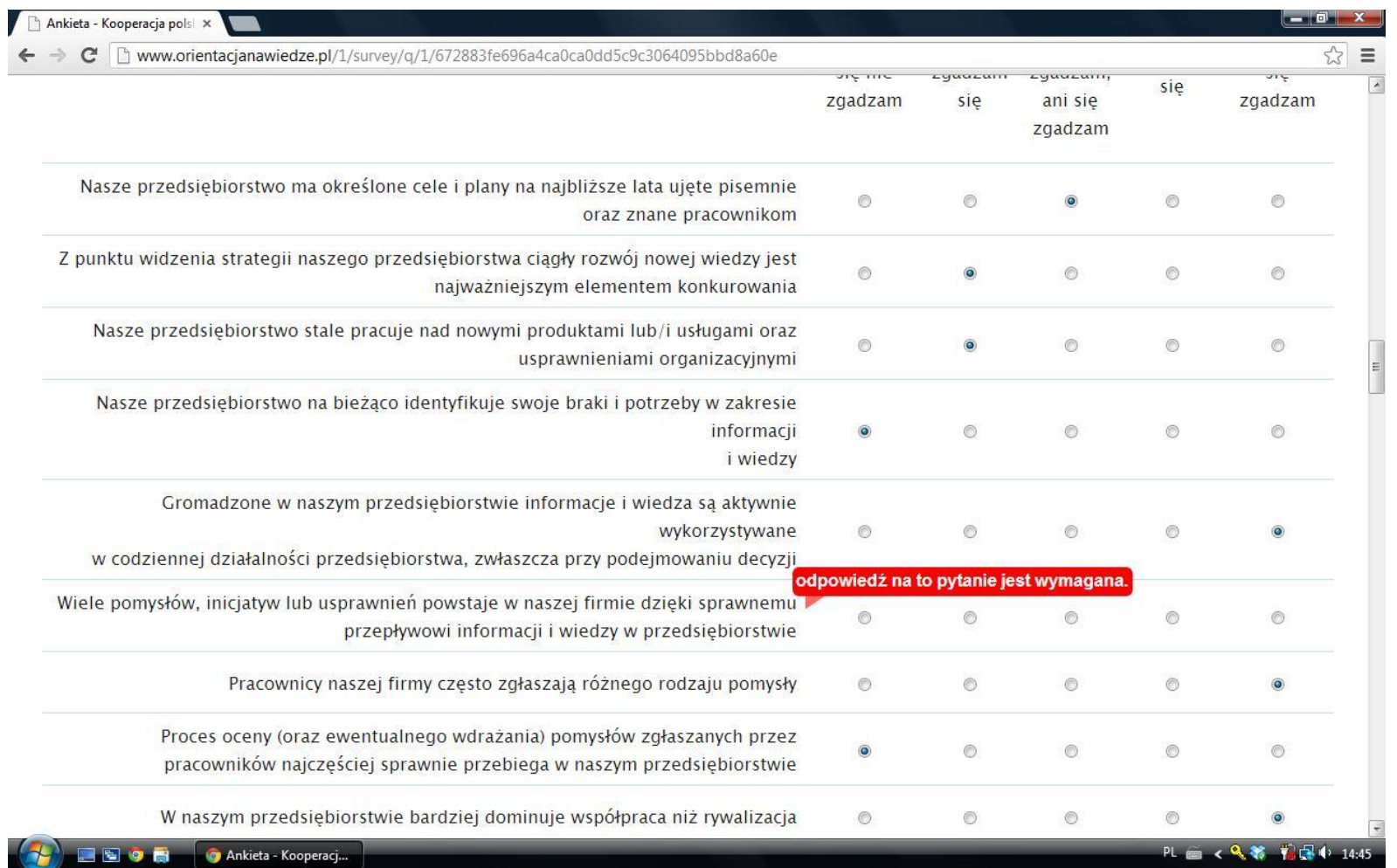

